UNIVERSIDADE DE SÃO PAULO

FACULDADE DE FILOSOFIA, LETRAS E CIÊNCIAS HUMANAS

DEPARTAMENTO DE SOCIOLOGIA

PROGRAMA DE PÓS-GRADUAÇÃO EM SOCIOLOGIA

FÁBIO PIMENTEL DE MARIA DA SILVA

CRÍTICA DA AUTORIDADE: DOMINAÇÃO E EMANCIPAÇÃO NA OBRA DE MAX HORKHEIMER

São Paulo

2018 
UNIVERSIDADE DE SÃO PAULO

FACULDADE DE FILOSOFIA, LETRAS E CIÊNCIAS HUMANAS

DEPARTAMENTO DE SOCIOLOGIA

PROGRAMA DE PÓS-GRADUAÇÃO EM SOCIOLOGIA

\title{
CRÍTICA DA AUTORIDADE: DOMINAÇÃO E EMANCIPAÇÃO NA OBRA DE MAX HORKHEIMER
}

\author{
FÁBIO PIMENTEL DE MARIA DA SILVA
}

Tese apresentada à Faculdade de Filosofia, Letras e Ciências

Humanas da Universidade de São Paulo, como requisito parcial para a obtenção do título de Doutor em Ciências.

Área de concentração: Sociologia. Orientador: Prof. Associado Ricardo Musse.

São Paulo Versão corrigida 2018

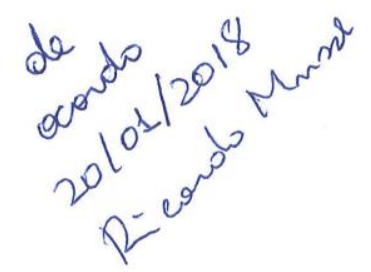


Autorizo a reprodução e divulgação total ou parcial deste trabalho, por qualquer meio convencional ou eletrônico, para fins de estudo e pesquisa, desde que citada a fonte.

1. marxismo. 2. teoria crítica. 3. Max Horkheimer. 4. dominação. 5. ideologia. I. Musse, Ricardo, orient. II. Título. 


\section{FOLHA DE APROVAÇÃO}

Nome: Fábio Pimentel De Maria da Silva

Título: Crítica da autoridade: dominação e emancipação na obra de Max Horkheimer

Tese apresentada à Faculdade de Filosofia, Letras e Ciências Humanas da Universidade de São Paulo, como requisito parcial para a obtenção do título de Doutor em Ciências. Área de concentração: Sociologia. Orientador: Prof. Associado Ricardo Musse.

\section{Banca examinadora:}

Membros externos:

Prof. Titular Wolfgang Leo Maar - Instituição: Centro de Educação e Ciências Humanas da Universidade Federal de São Carlos - Departamento de Filosofia e Metodologia das Ciências

Prof. Titular Afrânio Mendes Catani - Instituição: Faculdade de Educação da Universidade de São Paulo - Departamento de Administração Escolar e Economia da Educação

$\underline{\text { Membros internos: }}$

Prof ${ }^{\mathrm{a}}$ Titular Olgária Chain Feres Matos - Instituição: Faculdade de Filosofia, Letras e Ciências Humanas da Universidade de São Paulo - Departamento de Filosofia

Prof. Associado Ruy Gomes Braga Neto - Instituição: Faculdade de Filosofia, Letras e Ciências Humanas da Universidade de São Paulo - Departamento de Sociologia

Prof. Associado Ricardo Musse (orientador) - Instituição: Faculdade de Filosofia, Letras e Ciências Humanas da Universidade de São Paulo - Departamento de Sociologia 
Para a Carol. 


\section{$\underline{\text { Agradecimentos }}$}

Agradeço ao meu orientador, Prof. Ricardo Musse, pelo apoio e estímulo ao longo dos anos, por dividir sua experiência no processo de orientação e em suas aulas, assim como pela paciência e, também, pela impaciência necessária.

Gostaria também de manifestar meu reconhecimento à Prof ${ }^{\mathrm{a}}$ Vera da Silva Telles, pelo apoio quando do ingresso no curso de doutorado, e ao Prof. Sérgio Miceli, pelas observações desafiadoras. Aos colegas do "Seminário de Projetos" de 2013 e à Prof ${ }^{a}$ Sylvia Gemignani Garcia sou grato pelo aprendizado em conjunto.

Os Professores José Leon Crochik e Sílvio César Camargo foram extremamente atenciosos quando do exame de qualificação, e me alertaram sobre o perigo de o trabalho se perder em caminhos pouco promissores.

Ao longo dos últimos anos recebi em diversos momentos o incentivo e auxílio dos Professores Ruy Braga, Brasílio João Sallum Jr. e Helmut Galle, com os quais espero continuar aprendendo.

Aos Professores Alex Demirović e Jürgen Ritsert, da Universidade de Frankfurt, agradeço a acolhida gentil e receptiva durante o período de doutorado-sanduíche. Christian Oehlke, Emanuel Kapfinger e Sarah Stuckhardt tornaram a estadia na Alemanha a mais agradável e proveitosa possível.

Pela dedicação que tanto facilita a vida dos alunos, agradeço aos funcionários da PósGraduação em Sociologia, Gustavo Mascarenhas e Evânia Guilhon e Sá, aos funcionários da Biblioteca Florestan Fernandes e da FFLCH em geral, e também a André Lania Tosar e seus funcionários da Copiadora L\&M.

Nos amigos e companheiros de orientação com quem tenho, no mínimo, aprendido há bastante tempo, pude sempre encontrar apoio e amizade: Vladimir Puzone, Caio Vasconcellos, Carlos Pissardo, Bruna Della Torre, Edu Altheman, Luiz Enrique Vieira de Souza, Ilan Lapyda, Anouch Kurkdjian, Ugo Rivetti, Stefan Klein e Ricardo Regatieri. A Fernando Neves e Francisco Pereira, que se juntaram há pouco ao grupo, agradeço as indicações que tornaram a escrita do penúltimo capítulo mais fluida. Bruno Carvalho e Daniel Nagase me estimularam na abordagem dada a alguns dos problemas tratados aqui.

Incentivo para iniciar e terminar o doutorado têm me dado, ao longo dos últimos anos, Vicente Sampaio, Danilo Nunes do Carmo, Ricardo Crissiuma, Maria Carlotto, Rafaela Pannain, Tatiana Lima Faria, Ricardo Borrmann, Daniel Garroux, Gabriela Bittencourt, Fabio Franco, Edu Fernandes e Leo Masaro. 
Contribuíram de maneira essencial para a realização deste trabalho Rita Sperandeo, Marília Amaro, Carla Giacomelli e Luciana Gregori.

Com minha família, sempre acolhedora, tenho podido contar em todas ocasiões.

E a Carol, a quem tenho oferecido várias ausências, tem me presenteado com o mais decisivo.

Agradeço também à Prof ${ }^{-}$Olgária Chain Feres Matos e aos Profs. Wolfgang Leo Maar, Afrânio Mendes Catani e Ruy Braga, pela disposição em participar da banca de defesa.

Indispensáveis para a realização desta pesquisa foram as bolsas de doutorado da CAPES e de doutorado-sanduíche do CNPq. 
Mas quem não quer falar sobre o capitalismo devia se calar também sobre o fascismo.

Max Horkheimer 


\section{$\underline{\text { Resumo }}$}

A sujeição ao existente foi o tema central do programa de pesquisas organizado por Max Horkheimer no âmbito do Instituto de Pesquisa Social, ao longo da década de trinta. As diversas formas de subjetivação da dominação - psíquica, política e ideológica - foram objeto da reflexão de Horkheimer e de seus colaboradores, ao longo de um período que correspondeu, aproximadamente, ao da edição da Revista de Pesquisa Social, publicada entre 1932 e 1941. A "autoridade" foi o tema que vinculou a obra de Horkheimer à de seus colegas no Instituto, nesta tese representados por Fromm, Pollock e Neumann, autores que compreendiam o problema da dominação sob diferentes prismas, e cuja apropriação do marxismo seguia a cada vez um curso próprio. Tenta-se mostrar como Max Horkheimer, a partir de sua compreensão da ideologia e da ciência contemporâneas, formulou uma concepção de "autoridade" que influiu decisivamente sobre a apropriação crítica feita pelo autor, em seus ensaios, das contribuições daqueles membros do Instituto. Ao incorporá-las em sua obra, Horkheimer modificava a estrutura de seus principais conceitos e lhes conferia novas funções, o que incluía a busca por potenciais de emancipação. Nesse processo, o autor examinava a imbricação entre o fetichismo presente nas diversas esferas sociais, a violência psíquica e política e a luta de classes. 


\begin{abstract}
$\underline{\text { Abstract }}$
Subjection to the existing was the central theme of the research program organized by Max Horkheimer in the scope of the Frankfurt Institute for Social Research, during the thirties. The various forms of subjectivation of domination - psychic, political, and ideological - were the object of Horkheimer and his collaborators' reflection over a period that corresponded approximately to that of the edition of the Journal of Social Research, published between 1932 and 1941. The issue of "authority" linked Horkheimer's work to that of his colleagues at the Institute, in this doctoral thesis represented by Erich Fromm, Friedrich Pollock and Franz Neumann, authors who understood the problem of domination under different prisms, and whose appropriation of marxism followed each time a specific course. The aim here is to show how Max Horkheimer, starting from his understanding of contemporary ideology and science, formulated a conception of "authority" that decisively influenced the author's critical incorporation in his essays of the contributions of those members of the Institute. In assimilating them in his work, Horkheimer modified the structure of their main concepts and gave them new functions, which included the search for emancipation potentials. In this process, the author examined the imbrication between fetishism present in the various social spheres, psychic and political violence and class struggle.
\end{abstract}




\section{$\underline{\text { Zusammenfassung }}$}

Die Unterwerfung unters Bestehende war das zentrale Thema des von Max Horkheimer in den dreißiger Jahren im Rahmen des Frankfurter Instituts für Sozialforschung geplanten Forschungsprogramms. Die verschiedenen (psychischen, politischen und ideologischen) Formen der Subjektivierung von Herrschaft waren Gegenstand der Reflexion Horkheimers und seiner Mitarbeiter während einer Periode, die ungefähr der der Herausgabe der zwischen 1932 und 1941 veröffentlichten Zeitschrift für Sozialforschung entsprach. Die Frage der "Autorität" hat Horkheimers Werk an dasjenige seiner Kollegen im Institut geknüpft, die in dieser Dissertation durch Erich Fromm, Friedrich Pollock und Franz Neumann dargestellt werden Autoren, die das Problem der Herrschaft jeweils unter verschiedenen Prismen verstanden haben, und deren Aneignung des Marxismus jeweils seinen eigenen Weg gegangen ist. Hier wird versucht zu zeigen, wie Max Horkheimer von seinem Verständnis der zeitgenössischen Ideologie und Wissenschaft ausgehend eine Auffassung von "Autorität" formuliert hat, die entscheidend auf die kritische Einverleibung durch den Autor (in seinen Aufsätzen) der Beiträge derjenigen Institutsmitglieder wirkte. Indem Horkheimer sich diese Beiträge in seinem Werk aneignete, veränderte er die Strukturen ihrer Hauptbegriffe und verlieh ihnen neue Funktionen, was die Suche nach Emanzipationspotentialen mit eingeschlossen hat. In diesem Prozess untersuchte der Autor die Verflechtung des in den verschiedenen gesellschaftlichen Sphären vorliegenden Fetischismus mit der physischen und psychischen Gewalt und den Klassenkämpfen. 


\section{SUMÁRIO}

Introdução.

p. 13

\section{PARTE I}

Capítulo 1 - Os primeiros passos do programa de pesquisas

1.1 - Max Horkheimer e o marxismo de sua época.

p. 26

1.2 - Revolução perdida, marxismo e psicanálise: a integração do proletariado e as perguntas do Instituto de Pesquisa Social. p. 40

1.3 - As pesquisas sobre autoridade e família. p. 50

Capítulo 2 - A contribuição de Erich Fromm

2.1 - A teoria do caráter autoritário e a fusão entre marxismo e psicanálise .p. 79

2.2 - O programa de pesquisas dos anos trinta: entre Fromm e Horkheimer. .p. 107

\section{PARTE II}

Capítulo 3 - A crítica de Horkheimer à ideologia contemporânea

3.1 - Ciência e metafísica. p. 116

3.2 - A reificação dos conceitos filosóficos p. 131

Capítulo 4 - Da ideologia contemporânea à história, da ciência contemporânea à teoria crítica

4.1 - A forma contemporânea da ideologia. p. 153

4.2 - "Autoridade" .p. 164

4.3 - A fetichização da ciência.. p.171

4.4 - "Exposição" e "pesquisa". .p. 179 


\section{PARTE III}

Capítulo 5 - O Estado como "estrutura de comandantes e comandados"

5.1 - Economia e política na "fase mais recente" do capitalismo monopolista .p. 185 5.2 - O "Estado autoritário" de Horkheimer: diferenças e semelhanças em relação às teses de Pollock e Neumann .p. 202

5.2.1 - Imperialismo e classes sociais .p. 211

5.2.2 - Estado, burguesia monopolista e a forma autoritária da dominação p. 221

Capítulo 6 - Para além do Estado autoritário: o indivíduo e a emancipação p. 230

6.1 - Historicizando o conceito frommiano de "caráter": alguns elementos da "antropologia da era burguesa" de Horkheimer. p.234

6.2 - A massa, o indivíduo e os "pequenos grupos" p. 242

6.3 - Mudanças no conceito de classes sociais: das cliques aos rackets..... p. 246

6.4 - Os novos rumos da crítica: do indivíduo isolado ao indivíduo nãoidêntico p. 256 



\section{Introdução}

A obra escrita por Horkheimer nos anos trinta e quarenta costuma ser objeto da seguinte divisão: ao assumir a direção do Instituto de Pesquisa Social de Frankfurt, em 1931, o autor teria concebido e posto em prática um programa de "pesquisa social" que, pautado pela ideia da incorporação das ciências especializadas (principalmente a psicologia, a sociologia e a economia) sob a orientação geral de uma teoria marxista da história, e estimulado pela expectativa de uma revolução proletária, concretizou-se tanto nas edições da Revista de Pesquisa Social quanto nas pesquisas coletivas do Instituto. Esse programa, denominado pela recepção de sua obra ocorrida desde fins da década de 1970 de "materialismo interdisciplinar", teria durado até 1936/37 - a partir de então, e até 1941/42, a obra de Horkheimer teria passado por um momento de transição, marcado pela perda da esperança de uma revolução proletária e pelo abandono progressivo do programa de pesquisas que havia sido apresentado em seu discurso de posse como diretor do Instituto: nesse período, sob a influência da tese de Pollock de um "capitalismo de Estado" e sob o peso da situação de guerra e de antissemitismo, Horkheimer progressivamente teria se afastado do marxismo. Esse afastamento teria se caracterizado pelo abandono do programa inicial da teoria crítica em favor de uma filosofia da história na qual a crença nos potenciais emancipatórios da razão (uma crença cultivada, nos anos trinta, sob o signo de um marxismo "ortodoxo" ou "tradicional") teria cedido lugar a uma “crítica da razão instrumental”, que teria caracterizado a obra de Horkheimer a partir de 1942 e cuja maior expressão teria sido a Dialética do Esclarecimento escrita em parceria com Adorno ${ }^{1}$.

Essa interpretação considerou grosso modo que a primeira parte da obra de Horkheimer seria representativa de um marxismo que derivava, da contradição crescente entre as forças produtivas e as relações sociais de produção, a crença no potencial revolucionário do proletariado: a verificação empírica desse potencial, por meio da conjugação da psicologia à teoria marxista da história, bastaria para lhe confiar a ruptura com o modo de produção

\footnotetext{
${ }^{1}$ Convergem nessa interpretação, dentre outros, Cf. Helmut Dubiel, Wissenschaftsorganisation und politische Erfahrung - Studien zur frühen kritischen Theorie. Frankfurt am Main: Suhrkamp, 1978; Alfons Söllner, Geschichte und Herrschaft - Studien zur materialistischen Sozialwissenschaft: 1929-1942. Frankfurt am Main: Suhrkamp, 1979; Seyla Benhabib, “A crítica da razão instrumental”. In: Slavoj Zizek (Org.). Um Mapa da Ideologia. Rio de Janeiro: Contraponto, 1996; Wolfgang Bonß e Norbert Schindler, "Kritische Theorie als interdisziplinärer Materialismus". In: Wolfgang Bonß e Axel Honneth. Sozialforschung als Kritik - zum sozialwissenschaftlichen Potential der kritischen Theorie. Frankfurt, Suhrkamp, 1982. Também partilham das linhas gerais dessa interpretação, ainda que com pequenas divergências quanto à segmentação das fases do autor, intérpretes que estendem a primeira fase da obra de Horkheimer até o início dos anos quarenta: cf. Alfred Schmidt, "Max Horkheimer's Intelellectual Physiognomy" e Jürgen Habermas, "Remarks on the Development of Hotkheimer's Work“, ambos em: Seyla Benhabib; Wolfgang Bonß; John McCole. On Max Horkheimer - new perspectives. Cambridge, Massachussets e Londres, 1993; além de, mais recentemente, John Abromeit, Max Horkheimer and the Foundations of the Frankfurt School. Nova York: Cambridge University Press, 2011.
} 
capitalista; a partir do momento, porém, em que a adesão dos trabalhadores europeus ao fascismo não permitia restarem dúvidas sobre a integração do proletariado, sua obra teria ingressado em uma nova fase e posto em descrédito não apenas o marxismo, mas também a própria razão e, em consequência, o recurso às disciplinas acadêmicas. Daí em diante Horkheimer e Adorno teriam passado a uma "filosofia pessimista da história", cultivada a partir dos anos quarenta. Nas palavras de Habermas,

\begin{abstract}
"Os princípios do materialismo histórico, que enfocam a relação dialética entre as forças produtivas e as relações de produção, tinham-se transformado em proposições pseudonormativas sobre uma teleologia objetiva da história. Esta passou a ser tida como força impulsionadora da realização de uma razão que se manifesta de modo ambíguo nos ideais burgueses. E para se assegurar de seus fundamentos normativos a Teoria Crítica não tinha outra saída a não ser uma filosofia da história. Ora, esse terreno era impróprio para um programa de pesquisa empírico"2.
\end{abstract}

Papel decisivo nessa segmentação entre fases distintas na obra do autor tem a interpretação da Dialética do Esclarecimento como um livro em que Horkheimer, sob o peso de uma situação histórica marcada pela guerra, pelo antissemitismo e pela adesão em peso do proletariado ao fascismo, teria abandonado a crítica do capitalismo que, orientada pelo conceito de "totalidade", se debruçara sobre os problemas da ideologia, da luta de classes e também das transformações econômicas pelas quais passava o modo de produção capitalista, por uma crítica do processo civilizatório e da "razão instrumental". Supostamente elaborada sob a influência da tese de Pollock de um "capitalismo de Estado", a obra escrita em conjunto com Adorno seria calcada em uma "filosofia pessimista da história", segundo a qual a dominação da natureza redundaria na dominação do próprio sujeito e não traria consigo, portanto, possibilidades de emancipação ${ }^{3}$. Ao mesmo tempo, a vinculação da mudança de rumos por que passou o pensamento de Horkheimer nos anos quarenta ao acolhimento, pelo autor, da tese de Pollock, assim como à influência sofrida de Adorno, foi acompanhada do crescimento do interesse pela primeira fase da obra do autor: tanto as reflexões de caráter programático elaboradas por

\footnotetext{
${ }^{2}$ Jürgen Habermas, Teoria do Agir Comunicativo, vol. 2: sobre a crítica da razão funcionalista. Tradução de Paulo Astor Soethe. São Paulo: Editora WMF Martins Fontes, 2012, pp. 687-8.

${ }^{3} \mathrm{Na}$ interpretação de Habermas, a crítica feita na Dialética do Esclarecimento seria fundamentalmente aporética, pois consistiria em uma "contradição performativa" resultante da tentativa de se fazer uma crítica da razão a partir da própria razão. Cf. Jürgen Habermas, O Discurso Filosófico da Modernidade. Tradução de Luiz Sérgio Repa e Rodnei Nascimento. São Paulo: Martins Fontes, 2000, pp. 153-186. Cf. também, do mesmo autor, o posfácio a uma das edições da Dialética do Esclarecimento: "Nachwort". In: Max Horkheimer e Theodor W. Adorno. Dialektik der Aufklärung - Philosophische Fragmente. Frankfurt am Main: Fischer, 1986. p. 281. Cf. ainda, para esse interpretação, Helmut Dubiel, Wissenschaftsorganisation und politische Erfahrung, op. cit., pp. 97-100; e John Abromeit, Max Horkheimer and the Foundations of the Frankfurt School,. op. cit., p. 410 ss.
} 
Horkheimer nos trinta ${ }^{4}$ quanto as pesquisas empíricas que, tendo naquelas reflexões sua diretriz "filosófica", foram desenvolvidas sob sua direção ${ }^{5}$, são vistas como um legado que, tendo atingido seu fim menos de dez anos após o seu começo, estaria por ser recuperado e desenvolvido. Malgrado as inconsistências internas que o programa pudesse ter apresentado ${ }^{6}$, ele seria um modelo crítico mais promissor do que o posterior, a saber, aquela "filosofia pessimista da história" que estaria no núcleo da Dialética do Esclarecimento. A recuperação do "materialismo interdisciplinar" do início da década de 1930 deveria, por isso, ser feita de maneira tanto a preservar a ideia inicial de Horkheimer da conjugação entre pesquisa empírica e reflexão filosófica quanto a evitar os supostos erros em que o projeto teria se enredado ao longo de sua concretização ${ }^{7}$.

De fato, a proposta de uma "interpenetração e desenvolvimento dialéticos e contínuos da teoria filosófica e da prática científica especializada" ${ }^{\text {, }}$, feita por Horkheimer em seu discurso de posse como diretor, deu fôlego ao trabalho realizado no âmbito do Instituto de Pesquisa Social entre os anos de 1931 e 1941 e rendeu frutos notáveis naquele período, que cobriu tanto a formação, ainda na Alemanha, do círculo de autores que viria a ser conhecido como a "primeira geração" da Escola de Frankfurt, quanto o prosseguimento de suas atividades no exílio norte-americano. A ênfase dada ao caráter "interdisciplinar" do programa concebido por Horkheimer para o Instituto, contudo, parece ter obscurecido alguns de seus elementos mais importantes. $\mathrm{Na}$ interpretação que viu nele um "materialismo interdisciplinar", o marxismo tendeu a ser identificado seja a uma fonte das supostas deficiências do programa, seja à mera função regulativa de fornecer uma orientação filosófica voltada à superação da alienação (no caso, a concepção de "materialismo" de Horkheimer). Essa orientação filosófica indicaria os rumos a serem tomados pelas investigações conduzidas pelos representantes das diversas

\footnotetext{
${ }^{4}$ Tem-se em mente aqui não apenas o discurso de posse de 1930, mas também, principalmente, os textos "Observações sobre ciência e crise", "História e Psicologia", "Materialismo e Metafísica", "Materialismo e Moral" e "Teoria Tradicional e Teoria Crítica", dos quais se extraem concepções acerca do papel da teoria crítica, assim como da necessidade da integração da psicanálise ao marxismo.

${ }^{5}$ Pode-se situar nesse âmbito não apenas os "Estudos sobre Autoridade e Família" (Studien über Autorität und Familie), coordenados por Horkheimer, mas também as contribuições, sobre uma ampla diversidade de temas, feitas pelos demais membros do Instituto, cujos textos eram publicados na "Revista de Pesquisa Social" (Zeitschrift für Sozialforschung).

${ }^{6}$ Trata-se aí, argumenta-se, do caráter assumido pelo programa de pesquisas, que seria meramente organizativo e careceria de uma integração real entre a o marxismo e as ciências especializadas. Cf., dentre outros, Wolfgang Bonß e Norbert Schindler, "Kritische Theorie als interdisziplinärer Materialismus", op. cit..

${ }^{7}$ Alfons Söllner, por exemplo, atribui ao programa de pesquisa da primeira metade dos anos trinta um "potencial bastante atual, pois ainda não realizado ao longo da história das ciências". Cf. Alfons Söllner. Geschichte und Herrschaft - Studien zur materialistischen Sozialwissenschaft: 1929-1942. Frankfurt am Main: Suhrkamp, 1979, p. 220.

${ }^{8}$ Max Horkheimer, "Die gegenwärtige Lage der Sozialphilosophie und die Aufgaben eines Instituts für Sozialforschung". In: Max Horkheimer, Gesammelte Schriften. Alfred Schmidt e Gunzelin Schmid Noerr (Orgs.). Frankfurt am Main: Fischer, 1985, vol. 3, p. 29.
} 
disciplinas especializadas, de maneira a propiciar sua integração e evitar o recurso das pesquisas específicas a pressupostos teóricos considerados problemáticos ${ }^{9}$.

Um primeiro ponto a se ressaltar, nesse sentido, nos parece ser o estatuto conferido por Horkheimer às disciplinas especializadas: elas seriam "níveis de abstração"10, dotados de "legalidade própria” em virtude do processo de abstração do trabalho, incidente também sobre a atividade científica e responsável por reduzir o processo de conhecimento a uma série de ciências específicas, contraditórias entre si e atravessadas internamente por contradições internas. A ciência empirista, argumentava Horkheimer, se caracterizava pelo conhecimento preciso dos fenômenos individuais e, ao mesmo tempo, pela incapacidade de conhecer a totalidade social e o sentido da própria atividade científica ${ }^{11}$. A fragmentação dessa nos moldes da divisão social do trabalho exprimiria por isso não apenas o isolamento dos conhecimentos particulares das finalidades históricas e coletivas às quais eles poderiam servir, mas também uma crise interna:

\begin{abstract}
"O fato de a ciência se fechar a um tratamento adequado dos problemas vinculados ao processo social produziu um aplainamento [Verflachung] metódico e conteudístico que não apenas se exprime na desconsideração das relações dinâmicas entre as áreas temáticas específicas, mas se faz sentir de diversas maneiras no funcionamento das disciplinas. A esse isolamento está ligado o fato de que uma série de conceitos não esclarecidos, fixos e fetichistas possam continuar a desempenhar o seu papel, ao passo que eles deveriam ser iluminados por meio de sua inclusão da dinâmica do acontecer" ${ }^{\prime 2}$.
\end{abstract}

A redução da atividade científica ao método típico das ciências naturais tornava a ciência incapaz de apreender o processo histórico e as mudanças que abrangiam o conjunto das esferas sociais, e a fetichização dos conceitos - tomados como entidades fixas e isoladas, desvinculadas do movimento histórico que os originou - resultava em limitações de sua capacidade explicativa, o que se expressava na divisão entre disciplinas científicas com

\footnotetext{
${ }^{9}$ Essa orientação seria necessária por exercer os seguintes papéis no âmbito do programa: evitar os erros nos quais o marxismo da época corria o risco de se enredar (o idealismo de Lukács e o positivismo de algumas correntes da Segunda Internacional) e organizar a atividade científica dos membros do Instituto, dando um sentido coerente a investigações parciais constantemente sob o risco de sucumbir à fragmentação disciplinar. Cf. Helmut Dubiel, Wissenschaftsorganisation und politische Erfahrung, op. cit., pp. 47-55 e p.172; e também John McCole, Seyla Habib e Wolfgang Bonß, "Introduction". In: Idem, On Max Horkheimer - new perspectives. Cambridge, Massachussets: The MIT Press, 1993, pp. 1-2. .

${ }^{10} \mathrm{Cf}$. o prefácio escrito pelo autor para o primeiro número da Revista de Pesquisa Social: Max Horkheimer, "Vorwort [zu Heft 1/2 des I. Jahrgangs der Zeitschrift für Sozialforschung]". In: Max Horkheimer, Gesammelte Schriften, op. cit., vol. 3, p. 36.

${ }^{11}$ Cf. Max Horkheimer, "Bemerkungen über Wissenschaft und Krise". In: Max Horkheimer, Gesammelte Schriften, op. cit., vol. 3, p. 45.

${ }^{12}$ Max Horkheimer, "Bemerkungen über Wissenschaft und Krise", op. cit., p. 43.
} 
frequência incapazes de explicar os próprios fenômenos que se propunham compreender. $\mathrm{O}$ método científico dominante, incapaz de compreender o movimento histórico, deixava fora de seu campo de visão o todo social do qual depende a própria definição das tarefas da ciência, e dessa maneira acatava sem crítica uma divisão estática entre sujeito e objeto. Ao fazê-lo, a ciência entrava em contradição com os elementos de racionalidade do próprio pensamento científico:

\begin{abstract}
"Também na ciência aparece uma dupla contradição. Em primeiro lugar, vale como princípio que cada um de seus passos tenha um fundamento no conhecimento, mas o passo mais importante, isto é, a própria definição de suas tarefas, prescinde da fundamentação teórica e parece estar entregue ao arbítrio. Em segundo lugar, a ciência se ocupa do conhecimento de conexões abrangentes; ela é incapaz, contudo, de compreender em sua vida efetiva a abrangente conexão da qual depende sua própria existência e a direção de seu trabalho, isto é, a sociedade"13.
\end{abstract}

Nessa consideração, Horkheimer seguia a tese de Lukács de que, no capitalismo, a experiência seria reduzida à apercepção de fatos que, em virtude da própria estrutura social, apareceriam necessariamente como unidades isoladas, a aparente adequação do método científico tradicional sendo, portanto, resultado da reificação das relações sociais, um processo a atingir também a ciência ${ }^{14}$. As respostas dadas por Horkheimer a esse diagnóstico seriam, contudo, diferentes daquelas presentes em História e Consciência de Classe. Lukács havia oposto à ciência burguesa o marxismo, considerado como ciência revolucionária assentada na identidade entre sujeito e objeto possibilitada pelo ponto de vista do proletariado. Os fatos apreendidos pela ciência burguesa exprimiriam uma mera necessidade fatalista, e em vez dela apenas poderia apreender a totalidade social a consciência de classe, capaz de efetivar a unidade entre teoria e prática. Horkheimer, por sua vez, considerava que a teoria crítica poderia estabelecer uma relação com a teoria tradicional: as conexões que essa estabelece entre a teoria e os fatos teriam uma validade objetiva e poderiam servir à teoria crítica como "ponto de

\footnotetext{
${ }^{13}$ Max Horkheimer, "Bemerkungen über Wissenschaft und Krise", op. cit., p. 45. Cf. ainda, no mesmo texto, pp. 42-43.

${ }^{14}$ Cf. Georg Lukács. História e consciência de classe: estudos sobre a dialética marxista. Tradução de Rodnei Nascimento. São Paulo: Martins Fontes, 2003, pp. 71-73. Helmut Dubiel também ressaltou o caráter "abstrato" do conhecimento produzido segundo o método analítico da ciência empirista, mas o associou à especialização crescente das disciplinas, sem considerar a vinculação desse processo com o fenômeno da reificação. Cf. Helmut Dubiel, Wissenschaftsorganisation und politische Erfahrung - Studien zur frühen kritischen Theorie. Frankfurt am Main: Suhrkamp, 1978, pp. 167-169.
} 
partida" para a eliminação da parcialidade resultante do isolamento da prática científica em relação à práxis social da qual ela se originou ${ }^{15}$.

De acordo com essa perspectiva, a obra de Horkheimer se exprimiu, desde o início dos anos trinta, em uma espécie de crítica do fetichismo inerente à própria atividade científica, e expresso nos dualismos característicos da teoria tradiciona ${ }^{16}$. Orientado pelo método da crítica da Economia Política, o programa tinha por finalidade empreender uma "exposição" do todo concreto:

\begin{abstract}
"Os elementos conceituais abstratos e suas relações rígidas, examinadas nas pesquisas das ciências individualmente consideradas, constituem o material à disposição da reconstrução teórica de processos vivos. (...) Aqui se trata de conhecer, em suas tendências dominantes, processos ainda não concluídos e que se dão uma única vez [ao contrário dos processos de caráter mecânico investigados pelas ciências naturais]. Para isso, é verdade que o saber analítico tem de ser incorporado, mas o empreendimento no qual ele deve colaborar não coincide de modo algum com ele. Modo de pesquisa e modo de exposição são aqui fundamentalmente diferentes"17.
\end{abstract}

Mas a exposição não tinha, como na obra de Marx, a ciência econômica como um objeto de crítica específica, e embora ao autor e a seus colaboradores do Instituto tenha sido central a consideração dos aspectos econômicos relativos às transformações ocorridas na passagem do capitalismo liberal ao monopolista, o seu objeto primordial foram as formas fetichizadas das esferas do psiquismo, da política e do conhecimento (a ciência e a filosofia), que abrigavam contradições análogas àquelas que Marx havia identificado a partir da análise da mercadoria ${ }^{18}$.

\footnotetext{
${ }^{15}$ Cf. Max Horkheimer, "Teoria tradicional e teoria crítica”. In: Walter Benjamin; Max Horkheimer; Theodor W. Adorno; Jürgen Habermas, Textos escolhidos. Traduções de José Lino Grünewald et al. São Paulo: Abril Cultural, 1980 (Coleção Os Pensadores), p. 124. Sobre esse assunto, e especialmente sobre as diferenças entre Lukács e Horkheimer a esse respeito, cf. Ricardo Musse, "A dialética como discurso do método". Tempo Social. São Paulo, vol. 17, número 1, junho de 2005, pp. 384-386.

${ }^{16}$ E é talvez por isso que o ensaio "Teoria tradicional e teoria crítica" seja capaz de iluminar o programa de pesquisas conduzido nos anos anteriores. A esse respeito, cf. Ricardo Musse, Do Socialismo Científico à Teoria Crítica - modificações na autocompreensão do marxismo entre 1878 e 1937. Tese de doutorado. FFLCH-USP. São Paulo, 1997, p. 70.

${ }^{17}$ Max Horkheimer, “Zum Rationalismusstreit in der gegenwärtigen Philosophie”. In: Max Horkheimer, Gesammelte Schriften, op. cit., vol. 3, pp. 186-187.

${ }^{18}$ Outra é a interpretação de Seyla Benhabib, que considerou que a obra de Horkheimer e dos membros do Instituto de Pesquisa Social teria consistido, na década de trinta, em uma "crítica da Economia Política". Cf. Seyla Benhabib, “A crítica da razão instrumental”. In: Slavoj Zizek (Org.). Um Mapa da Ideologia. Tradução de Vera Ribeiro. Rio de Janeiro: Contraponto, 1996, p. 78. Helmut Dubiel, por sua vez, enfatizou detalhadamente, em sua obra pioneira, o caráter metodológico do recurso feito por Horkheimer à crítica da Economia Política. Cf. Helmut Dubiel, Wissenschaftsorganisation und politische Erfahrung, op. cit., pp. 168-169. Essa avaliação corre o risco, contudo, de negligenciar o caráter de crítica do capitalismo contido naquela obra: se o recurso ao método dialético
} 
A obra de Horkheimer tinha portanto afinidade com a tese de Lukács segundo a qual o fetichismo seria no capitalismo um fenômeno pertencente não apenas à esfera econômica e à ciência que a legitimava, mas também às demais esferas sociais: “(...) pode-se descobrir na estrutura da relação mercantil o protótipo de todas as formas de objetividade e todas as suas

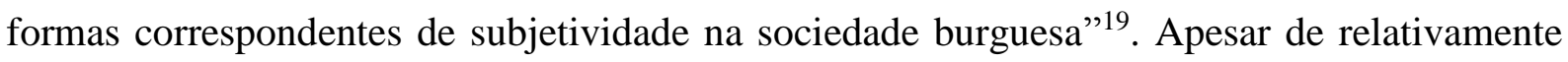
independentes da esfera econômica, aquelas instâncias reforçavam a exploração de classe e a permanência da ordem burguesa, em meio ao processo contrarrevolucionário no qual constituíram-se o regime de produção taylorista-fordista e os regimes fascistas na Europa, em um período - para usar uma expressão de Lukács - de "guerra aberta entre as classes"20. Em consonância a essa ideia de Lukács, Horkheimer julgava terem as esferas da política e da constituição psíquica assumido a primazia do processo histórico na fase mais recente do capitalismo monopolista, o período posterior à primeira guerra mundial: elas contribuiriam, nas palavras do autor, para "manter latentes as tensões que suscitam a eclosão de conflitos com base na situação econômica" ${ }^{21}$.

De acordo com essa ideia, Horkheimer parecia considerar a sua teoria crítica como uma extensão da crítica da Economia Política de Marx para as demais esferas sociais ${ }^{22}$. O autor pretendia, tal qual previsto no prefácio ao primeiro volume da Revista de Pesquisa Social, elaborar uma "teoria do curso histórico" que contemplasse as relações assumidas entre as esferas sociais naquela quadra do capitalismo monopolista ${ }^{23}$. A expressão fora empregada por Engels para se referir à crítica da Economia Política de Marx:

"Onde essa história [da ciência econômica e do modo capitalista de produção] começa, o raciocínio também tem de começar, e sua continuação não há de ser nada além da imagem do curso histórico, em

\footnotetext{
era central, tratava-se sempre de examinar as diferentes esferas sociais em sua conexão com o desenvolvimento do capitalismo.

${ }^{19}$ Cf. Georg Lukács. História e consciência de classe, op. cit., p. 193.

${ }^{20}$ Cf. Lukács, História e consciência de classe, op. cit, p. 449 (trata-se do ensaio "Sobre a mudança de função do materialismo histórico").

${ }^{21}$ Max Horkheimer, "História e Psicologia". In: Max Horkheimer, Teoria Crítica I - uma documentação. Tradução de Hilde Cohn. São Paulo: Perspectiva, 1990, p. 22. Em um dos textos de História e Consciência de Classe, escrito em 1919, Lukács afirmava que o fim da primeira guerra, a revolução na Rússia e suas tentativas na Europa teriam dado início a uma "guerra aberta entre as classes", na qual o fetichismo da mercadoria não seria mais suficiente para garantir a dominação de uma classe por outra e a "violência" ocuparia, por isso, o primeiro plano do processo histórico. Disso deveria ocorrer uma "mudança de função do materialismo histórico", e as formas extraeconômicas de dominação, embora sem dúvida em relação com a exploração, deveriam passar ao primeiro plano de suas preocupações. Cf. Lukács, História e consciência de classe, op. cit., p. 449.

${ }^{22}$ Essa ideia foi formulada em carta escrita a Henryk Grossmann de de 20 de janeiro de 1943, na qual o autor tratava da necessidade de uma reelaboração do conceito marxista de classes sociais. Esse assunto específico será objeto de análise mais adiante. Cf. Max Horkheimer, Gesammelte Schriften, op. cit.., vol. 17, p. 399.

${ }^{23}$ Cf. Max Horkheimer, "Vorwort [zu Heft 1/2 des I. Jahrgangs der Zeitschrift für Sozialforschung]". In: Max Horkheimer, Gesammelte Schriften, vol. 3, p. 38.
} 
forma abstrata e teoricamente consequente; uma imagem corrigida, mas corrigida segundo leis que o próprio curso histórico real nos dá, na medida em que cada momento pode ser considerado no ponto de desenvolvimento de sua plena maturidade, em sua forma clássica" 24 .

Nessa espécie de atualização do marxismo, se fazia necessário considerar que as mudanças concomitantes à passagem do capitalismo liberal à fase monopolista dotaram o fenômeno do fetichismo de novas características. Ainda que continuasse a vigorar sob a forma geral analisada por Marx, o fetichismo teria assumido novas determinações e se tornado mais complexo: no capitalismo liberal, o fetichismo da mercadoria ocultava a contradição entre a aparente racionalidade da troca e a irracionalidade da dominação no âmbito da produção, e dessa maneira legitimava a ordem social com base nas ideias da "troca justa" e da liberdade de contrato; no capitalismo monopolista, desapareciam os elementos de autonomia anteriormente ligados à constituição da esfera da circulação, e a aceitação da dominação pelos indivíduos assumia novas formas, que reforçavam a sua dominação e a exploração de seu trabalho, ao mesmo tempo em que relegavam a um plano secundário aquela aparente racionalidade da esfera da circulação ${ }^{25}$.

Uma ideia presente ao longo dos ensaios do autor pode jogar luz sobre a nova configuração assumida pelo fetichismo especialmente na fase do entreguerras ou, como a chamavam Horkheimer e outros membros do Instituto, na "fase mais recente do capitalismo monopolista". À essa época, julgava Horkheimer, o fetichismo teria se tornado mais complexo com o aplainamento dos dualismos característicos do capitalismo liberal. Como argumentaria o autor no prefácio ao último volume da Revista de Pesquisa Social, "com o advento do fascismo, os dualismo típicos da era liberal, como indivíduo e sociedade, vida pública e privada,

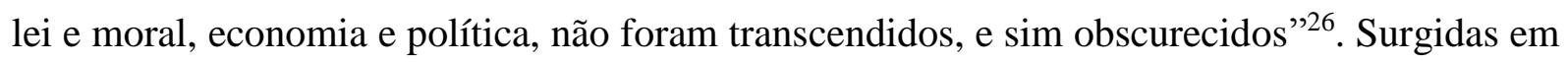
meio ao processo de desaparecimento do indivíduo, tema desenvolvido pelo autor em seus ensaios dos anos trinta e quarenta e cujas bases históricas eram o declínio da função socializadora da família e a perda da autonomia da esfera da circulação, as novas formas autoritárias de dominação foram, em suas expressões ideológica, política e psíquica, analisadas no âmbito do programa de pesquisas de Horkheimer e tornaram-se objeto dos ensaios do próprio autor, por meio da incorporação crítica de contribuições provindas das disciplinas científicas

\footnotetext{
${ }^{24}$ Friedrich Engels, "Karl Marx, 'Zur Kritik der Politischen Ökonomie" " [resenha da "Contribuição à crítica da Economia Política" de 1859]. In: Karl Marx; Friedrich Engels. Werke. vol. 13. Berlim: Dietz, 1971. p. 475. Disponível em www.mlwerke.de.

${ }^{25}$ Cf. Max Horkheimer, "Autoridade e família". In: Max Horkheimer, Teoria Crítica I - uma documentação, op. cit., p. 208.

${ }^{26}$ Max Horkheimer, "Preface”. In: Studies in Philosophy and Social Sciences, vol. 9, 1941, p. 195.
} 
particulares representadas no Instituto de Pesquisa Social, dentre outros, pelo psicanalista Erich Fromm, pelo economista Friedrich Pollock e pelo cientista político Franz Neumann.

Diferentemente do que ocorrera no período do capitalismo concorrencial, a "coerção muda das relações econômicas" 27 não seria mais suficiente para garantir a dominação, e concomitantemente a ideologia, o Estado e a moral burguesa passavam por uma mudança de função. A ideologia perdia seus elementos de oposição à realidade e assumia cada vez mais a forma de uma afirmação do existente. O Estado autoritário se firmava como uma forma de dominação em que desaparecia o traço essencial do Estado liberal, a existência de um conjunto de normas universais que mediavam a dominação de classe, ocorrendo à época, pelo menos aparentemente, um retorno a formas diretas de dominação, como a intensificação do recurso à violência física e à identificação emocional dos indivíduos com o $\operatorname{líder}^{28}$. A moral burguesa, que no período do capitalismo liberal se afirmara como uma instância dotada de relativa autonomia frente às necessidades da produção, assim como caracterizada pela coexistência de elementos emancipatórios e repressivos, no capitalismo monopolista perdia sua função crítica e em seu lugar se firmavam seus elementos meramente repressivos, desvinculando-se dos traços emancipatórios que assumira o individualismo no período da ascensão social da burguesia e se convertendo em mera "autoconservação" 29 . Nesse sentido, a teoria crítica desenvolvida por Horkheimer nos anos trinta antecipou aquela concepção de ideologia como "duplicação da realidade" que haveria de caracterizar as análises da Dialética do Esclarecimento e seria formulada de maneira bastante detida nos textos escritos por Adorno a partir de fins dos anos quarenta ${ }^{30}$.

\footnotetext{
${ }^{27}$ Cf. o capítulo sobre "A assim chamada acumulação primitiva”: Karl Marx, O Capital - crítica da Economia Política. Tradução de Regis Barbosa e Flávio Kothe. São Paulo: Abril Cultural, 1983, volume 1 - tomo 2, p. 277. ${ }^{28}$ Cf. Max Horkheimer, "Aus Vorlesungen über Autorität und Gesellschaft". In: Max Horkheimer, Gesammelte Schriften, op. cit., vol. 12, p. 62.

${ }^{29}$ Cf., por exemplo, Max Horkheimer, "Zum Rationalismusstreit in der gegenwärtigen Philosophie", op. cit., pp. 168-169, e também Herbert Marcuse, "Some social implications of modern technology", vol. 9 da Zeitschrift für Sozialforschung, 1941, p. 421 e p. 428.

${ }^{30}$ No capítulo sobre indústria cultural da Dialética do Esclarecimento, os autores afirmariam que a ideologia contemporânea teria por função "reduplicar" uma "realidade compacta e fechada". Cf. Theodor W. Adorno e Max Horkheimer, Dialética do Esclarecimento. Tradução de Guido A. de Almeida. Rio de Janeiro: Jorge Zahar Editor, 1985, p.142. Pouco antes, à p. 138, os autores afirmavam: "A indústria cultural derruba a objeção que lhe é feita com a mesma facilidade com que derruba a objeção ao mundo que ela duplica com imparcialidade. (...) A nova ideologia tem por objeto o mundo enquanto tal. Ela recorre ao culto do fato, limitando-se a elevar - graças a uma representação tão precisa quanto possível - a existência ruim ao reino dos fatos. Essa transferência converte a própria existência num sucedâneo do sentido e do direito". Segundo Adorno, "a tradicional crítica transcendente da ideologia e obsoleta. (...) Não há mais ideologia no sentido próprio de falsa consciência, mas somente propaganda a favor do mundo, mediante sua duplicação e a mentira provocadora, que não pretende ser acreditada, mas que pede o silêncio". In: Theodor Adorno, "Crítica cultural e sociedade". In: Theodor Adorno, Prismas crítica cultural e sociedade. Tradução de Augustin Wernet e Jorge Mattos Brito de Almeida. São Paulo: Editora Ática, 1998, p. 25.
} 
No âmbito do Instituto de Pesquisa Social, esses diferentes aspectos do processo histórico eram analisados por Fromm, Pollock, Adorno, Neumann, Marcuse, Löwenthal e outros. Entretanto, não obstante a ambição do diretor de elaborar uma "teoria do curso histórico" capaz de contemplar a especificidade daquela quadra do capitalismo (cf. acima), empreendendo dessa maneira, como pretendemos se torne claro mais adiante, uma espécie de atualização da teoria marxista, o programa de pesquisas de Horkheimer tendeu a ser interpretado como se houvesse tido caráter meramente organizativo e institucional ${ }^{31}$. Essa interpretação não deixa de ter alguma razão, na medida em que a prática de pesquisa dos autores do Instituto seguiu a cada vez um curso próprio, dado pela própria autonomização das disciplinas científicas, assim como pela respectiva tradição teórica à qual estava vinculado cada um deles, o que implicava relações específicas com o marxismo, estabelecidas a cada caso.

Nossa hipótese, entretanto, é que os ensaios do próprio Horkheimer constituem o fio capaz de conferir sentido ao programa, na medida em que neles se encontra formulada com mais clareza aquela configuração contemporânea do fetichismo, à qual nos referimos acima.

Cremos, ao contrário da interpretação dominante cujos traços principais tentamos esboçar, não apenas que o programa de investigações obteve resultados consideráveis, mas também que foram justamente elementos da teoria marxista que permitiram o seu êxito: em seus próprios ensaios, Horkheimer empreendeu uma "dialetização" das contribuições de pesquisa fornecidas por seus colegas do Instituto, de maneira a historicizar os seus principais conceitos e a destituir o saber disciplinar de seu caráter fetichizado de produto isolado e subsistente por si mesmo. Os membros do Instituto analisavam o problema da dominação em suas expressões principalmente psíquica e política: o "caráter autoritário" (Fromm), o “capitalismo de Estado" (Pollock) e o "capitalismo monopolista autoritário" (Neumann) corresponderiam às formas contemporâneas de dominação. Horkheimer incorporava essas contribuições de maneira a superar suas unilateralidades originais e a lhes conferir novas funções, por meio de sua historicização. Ao fazê-lo, o autor refletia sobre o problema da "autoridade" de maneira a evitar algumas das aporias em que se enredavam as teorias de seus

\footnotetext{
${ }^{31}$ Wolfgang Bonß e Norbert Schindler consideraram não ter havido uma integração real entre o marxismo e as ciências especializadas. Cf., dos autores, "Kritische Theorie als interdisziplinärer Materialismus". In: In: Wolfgang Bonß e Axel Honneth. Sozialforschung als Kritik - zum sozialwissenschaftlichen Potential der kritischen Theorie. Frankfurt, Suhrkamp, 1982, passim. Helmut Dubiel considerou que dificuldades institucionais (dentre elas a centralização do comando sobre o programa na pessoa do diretor) impediram a concretização da "teoria do curso histórico" e dela fizeram uma promessa não cumprida por Horkheimer, tendo sido apenas esboçada em seus ensaios dos anos trinta. Cf. Helmut Dubiel, Wissenschaftsorganisation und politische Erfahrung, op. cit., pp. 170185 .
} 
colaboradores, e também a indicar possibilidades de emancipação, ainda que exíguas e carentes de elaboração mais sistemática no âmbito da teoria.

A dialetização mencionada permitiu ainda a obtenção de algumas das noções fundamentais que haveriam mais tarde de balizar as análises da Dialética do Esclarecimento, e que aqui mencionamos devido à importância da obra, e ainda que ela própria não seja objeto de análise nesta tese: a centralidade da autopreservação na constituição do sujeito moderno (tema presente na "antropologia da era burguesa" desenvolvida por Horkheimer sob o influxo de elementos da psicologia social de Fromm), o Estado autoritário (concepção de Horkheimer bastante próxima à noção de "capitalismo de Estado" de Pollock, mas que não pode ser confundida com ela, apesar de ter se constituído sob seu influxo), e a teoria dos rackets (que pode ser vista, como tentamos argumentar, como uma ampliação da abrangência das reflexões de Neumann sobre o "não-Estado" e a pulverização do poder em meio às cliques). Nesse sentido, a integração entre as disciplinas foi feita de uma maneira que a recepção dominante parece negligenciar ${ }^{32}$.

A especificidade da dominação contemporânea, caracterizada pela subordinação à realidade em suas formas dadas e pelo declínio dos elementos de oposição ainda presentes nas formas de sociabilidade do capitalismo concorrencial, levou Horkheimer a elaborar um conceito de "autoridade", por meio do qual fosse possível compreender a subjetivação da dominação, em suas formas ideológica, psíquica e política. Central para sua concepção de "autoridade" era a extensão do fetichismo da mercadoria para as demais esferas sociais, assim como uma imbricação entre o fetichismo e processos concretos de dominação, como a luta de classes (em seu sentido econômico, relativo à disputa pela mais-valia), a violência psíquica no âmbito da formação do indivíduo, e o emprego da violência política direta. Daí o lugar ocupado, nos ensaios do autor, por temas como as mudanças na estrutura familiar ao longo do capitalismo monopolista, a substituição da concorrência econômica interna pela disputa imperialista, e a integração social do proletariado em meio à "guerra aberta entre as classes" (a expressão é de

\footnotetext{
${ }^{32}$ A esse respeito, é curioso o rumo tomado pelo comentário clássico de Helmut Dubiel, Wissenschaftsorganisation und politische Erfahrung, op. cit.. Na segunda parte de seu livro, é apresentada detalhadamente e de modo bastante esclarecedor a concepção de "exposição dialética" de Horkheimer, tal qual o autor a havia desenvolvido em seus ensaios dos anos trinta, a partir de Marx e Hegel e em contraposição à concepção tradicional de conhecimento, orientadora da ciência moderna. Dessa maneira, o comentário de Dubiel joga luz sobre uma parte central das reflexões de Horkheimer, com frequência desprezada na recepção (cf. a avaliação feita por John Abromeit acerca dessas reflexões: Max Horkheimer and the foundations of the Frankfurt School, op. cit., p. 334). Ao final de seu comentário, contudo, Dubiel conclui ter sido mal-sucedida a proposta de Horkheimer de uma integração dialética dos saberes disciplinares na 'teoria do curso histórico". É de se imaginar se Dubiel deu pouca importância aos ensaios de Horkheimer e, de acordo com sua ênfase na interdisciplinaridade, tinha em mente que o programa de pesquisas concebido pelo autor deveria se concretizar em uma obra coletiva, tal qual haviam sido os "Estudos sobre autoridade e família" de 1936.
} 
Lukács) ocorrida em sequência aos ensaios de revolução imediatamente após a primeira guerra mundial.

\section{$* * *$}

A tese está dividida em três partes. A primeira delas está estruturada da seguinte maneira: no primeiro capítulo, são apresentados alguns elementos da obra de Horkheimer que conferiram o impulso inicial ao programa, a partir da crítica feita pelo autor a algumas tendências dominantes no marxismo da época, e também são analisadas as pesquisas sobre autoridade e família, elemento nuclear da produção do Instituto de Pesquisa Social, dirigido naqueles anos pelo autor. No segundo capítulo é analisada, então, a obra de Erich Fromm, responsável pela realização da pesquisa com trabalhadores e funcionários alemães e por uma "teoria do caráter autoritário" que foi determinante para a realização daquelas pesquisas. Na segunda parte da tese, pretendemos mostrar como a obra de Horkheimer seguia um curso próprio e passava por modificações ao longo dos anos trinta: as críticas feitas pelo autor às correntes filosóficas contemporâneas (capítulo 3), assim como à ciência produzida sob o modo de produção capitalista (capítulo 4), são expressões de sua compreensão da especificidade assumida pelo fenômeno da ideologia naquela fase do capitalismo. Em consonância a essa compreensão, o autor esboçou uma teoria da história, baseada no conceito de "autoridade" (capítulo 4). O tratamento em separado das pesquisas empíricas do Instituto e da contribuição de Fromm, de um lado (Parte I), e da obra escrita por Horkheimer, de outro (Parte II), exprime portanto uma certa assimetria existente no âmbito do programa de pesquisas dos anos trinta, como veremos ao longo da tese. Na terceira parte, veremos como os elementos centrais das reflexões de Fromm, Pollock e Neumann foram incorporadas nos ensaios de Horkheimer, nos quais passavam a adquirir novas funções e se desprendiam das limitações decorrentes do caráter "tradicional" de suas teorias. As teses desenvolvidas por esses membros do Instituto iluminavam, para Horkheimer, as formas políticas e psicológicas assumidas pela dominação no capitalismo contemporâneo. Horkheimer não deixava, ao mesmo tempo, de buscar sob essas formas contradições capazes de se traduzir em possibilidades de emancipação. 
PARTE I 


\section{Capítulo 1 - Os primeiros passos do programa de pesquisas}

\section{$\underline{1.1 \text { - Max Horkheimer e o marxismo de sua época }}$}

A consideração da sociedade como uma totalidade de fenômenos econômicos, políticos, individuais e ideológicos permitira a Lukács romper com o materialismo mecanicista que considerava ser a base econômica detentora de um primado na explicação dos demais fenômenos: "não é o predomínio de motivos econômicos na explicação da história que distingue de maneira decisiva o marxismo da ciência burguesa, mas o ponto de vista da totalidade" ${ }^{33}$. A própria divisão da ciência burguesa em diversas disciplinas era concebida pelo autor de História e Consciência de Classe como expressão do fenômeno da reificação - apoiando-se no conceito de totalidade, o marxismo por sua vez seria, em oposição à especialização disciplinar, uma "ciência histórico-dialética, única e unitária, do desenvolvimento da sociedade como totalidade" 34 . A possibilidade de considerar a autonomia dos fenômenos ideológicos e sua irredutibilidade a um reflexo da base econômica está na origem da influência exercida pelo livro sobre os autores do chamado "marxismo ocidental" - essa influência, contudo, se deu sob condições históricas diferentes, e por isso haveria de consistir em uma recepção refratada de suas principais teses, pois se Lukács havia, em uma época de revoluções (os anos entre o final da década de 1910 e o início dos anos vinte), afirmado ser a dialética materialista a "expressão pensada do próprio processo revolucionário", Horkheimer não poderia, em um momento no qual a prática revolucionária estava em recesso na Europa, afirmá-lo sem incorrer em dogmatismo ${ }^{35}$.

Se, por um lado, a obra de Max Horkheimer e seus colaboradores do Instituto de Pesquisa Social de Frankfurt foi parte do movimento de valorização dos elementos hegelianos presentes no pensamento de Marx e atribuiu, assim como Lukács, à categoria de totalidade uma posição central na teoria marxista, por outro lado, a versão dada pelos frankfurtianos a esse conceito haveria de ser fundamentalmente outra, pois não esteve imune à crítica o vínculo entre teoria e prática presente em História e Consciência de Classe, não tendo sido acolhida por aquele conjunto de autores a ideia segundo a qual o "ponto de vista do proletariado" garantiria a consciência da totalidade social e, por meio dessa, a passagem da mera contemplação à ação

\footnotetext{
${ }^{33}$ Georg Lukács, História e Consciência de Classe, op. cit., p. 105.

${ }^{34}$ Georg Lukács, História e Consciência de Classe, op. cit., p. 107.

${ }^{35}$ Sobre esse assunto, cf. Ricardo Musse, “A dialética como discurso do método”. Tempo Social. São Paulo, vol. 17, número 1 , junho de 2005, p. 370 e pp. 385-388.
} 
e a superação, pela consciência revolucionária do proletariado, do caráter reificado que as relações sociais assumem no capitalismo ${ }^{36}$.

A concepção de dialética como expressão pensada do processo revolucionário baseavase no postulado de uma unidade entre ser e pensar que, em História e Consciência de Classe, orientava a crítica de Lukács à cientificização do método de Marx por Engels e pelo marxismo da Segunda Internacional, que daquele método teriam excluído o "vínculo dialético entre sujeito e objeto". O postulado daquela unidade, que permitiu a Lukács a concepção do proletariado como "sujeito-objeto" da história, tinha contudo um caráter idealista que Horkheimer se esforçou em acusar, embora não o tenha feito diretamente: como objeção às teses de Lukács, Horkheimer empreendeu uma crítica da filosofia de Hegel. Se era verdade que dela seria possível reter o método dialético e a categoria da totalidade, eles não poderiam, contudo, ser mantidos no mesmo sentido que a eles atribuíra Lukács.

Em suas considerações sobre a filosofia de Hegel, Horkheimer criticou a "transfiguração" [Verklärung] a que sua teoria idealista da história submeteria os processos históricos materiais. Hegel partilharia com os autores do Iluminismo francês da convicção segundo a qual o conhecimento deve dizer respeito à realidade sensível - nesse sentido, sua filosofia mantém o elemento materialista do pensamento iluminista em geral, que no âmbito do processo de emancipação burguês pretendia superar a religião e a metafísica que a sustentava. Hegel teria por isso reconhecido, afirmava Horkheimer, que a ação individual e os fatos constatados empiricamente são o "motor imediato da história". Entretanto, os interesses dos indivíduos e suas paixões seriam para Hegel elementos da existência meramente casual, e embora os indivíduos da massa e os grandes homens fossem movidos por seus impulsos, “(...) reconstituir a estrutura psíquica de tais pessoas, segundo Hegel, em contraposição ao Iluminismo, não é importante, é até subalterno (...)"37.

Para superar o caráter necessariamente fragmentário do conhecimento empírico e preservar as pretensões de conhecimento absoluto que a filosofia kantiana banira para as esferas da moral, da religião e da arte (não condicionadas pelas formas da sensibilidade do espaço e do tempo) Hegel teria sido levado a empreender uma combinação de história empírica e filosofia

\footnotetext{
${ }^{36}$ Cf. Georg Lukács, História e Consciência de Classe, op. cit., pp. 64-70.

${ }^{37}$ Max Horkheimer, "História e Psicologia". In: Max Horkheimer, Teoria Crítica I - uma documentação. Tradução de Hilde Cohn. São Paulo: Hucitec, 1990, p. 16. As críticas a Hegel foram feitas principalmente no ensaio "Hegel e o problema da metafísica", mas também no discurso de posse como diretor do Instituto e, de maneira mais esparsa, em alguns dos ensaios publicados na Revista de Pesquisa Social entre 1932 e 1935 (como o mencionado ensaio sobre "História e psicologia"). Cf., de Horkheimer, "Hegel und das Problem der Metaphysik". In: Max Horkheimer, Gesammelte Schriften. Alfred Schmidt e Gunzelin Schmid Noerr (Orgs.). Frankfurt am Main: Fischer, 1985, vol. 2, pp. 295-308; e "A presente situação da filosofia social e as tarefas de um instituto de pesquisa sociais”. Vários tradutores. Revista praga, n. 7. São Paulo, Hucitec, 1999, pp. 121-132.
} 
da história e a conceber o conhecimento como autoconhecimento do espírito absoluto, um sujeito infinito e idêntico a si mesmo, "que tudo abrange e tudo é"38. É no âmbito desse sujeito absoluto que se relacionariam o indivíduo e a universalidade, e é graças à "astúcia da razão" que adquiriria sentido a pluralidade desordenada de existências e ações individuais no âmbito da história empírica, justificando-se assim também o sofrimento e a existência aparentemente sem sentido, "transfigurados" pela concepção hegeliana de história universal. Dessa maneira, sua filosofia, crítica dos sistemas metafísicos anteriores, teria adquirido ela própria um caráter metafísico. Ao transfigurar a realidade empírica e integrá-la ao sistema do conhecimento absoluto, Hegel teria construído uma teoria metafísica: embora recusasse a ideia de uma intuição intelectual que fosse independente do saber empírico, a sua filosofia, ao aspirar à condição de saber absoluto, tornou-se um sistema metafísico, que decretava a racionalidade de tudo o que existe. Nas palavras de Horkheimer:

“ 'O que é racional é real; e o que é real é racional'. A famosa frase do prólogo à Filosofia do Direito remete a dois lados muito diferentes do pensar hegeliano. A primeira parte enuncia que um incondicionado que existisse apenas na ideia ou fosse 'apenas conceito, princípio do espírito e do coração' não diferiria de uma quimera. (...) A segunda parte daquela frase formula de maneira clássica o sancionamento do curso do mundo pelo puro pensamento: pois o fato de que tudo o que é efetivo seja racional significa que ele, o efetivo, estaria em ordem. Ao limitar a revelação à efetividade experienciável, Hegel amplia a dadidade e a torna uma revelação: ao secularizar o divino, ele diviniza, ao mesmo tempo, o mundo" 39 .

O fundamental na história seria a realidade efetiva, caracterizada pelo desenvolvimento progressivo da Ideia, de suas figuras mais abstratas a suas figuras mais concretas ${ }^{40}$. Da mesma maneira que Hegel havia desprezado a importância das "existências baixas e não-verdadeiras" para a realidade efetiva do todo a se realizar na história, Lukács teria subestimado a importância da consciência psicológica, empírica, para o processo revolucionário, e Horkheimer

\footnotetext{
${ }^{38}$ Cf. Max Horkheimer, "Hegel und das Problem der Metaphysik”, op. cit., p. 297.

${ }^{39}$ Cf. Max Horkheimer, "Hegel und das Problem der Metaphysik". In: Max Horkheimer, Gesammelte Schriften. Vol. 2. pp. 296-298. A citação é da página p. 296. Aqui nos interessa apenas a interpretação que Horkheimer fez de Hegel. Extravasaria os limites deste trabaho saber se, e em que medida, essa interpretação é ou não simplifcadora, e se ela desconsidera os traços materialistas presentes no pensamento hegeliano (que para Horkheimer perdem todo o seu sentido quando desvinculados da ideia de um sistema e da pretensão de conhecimento absoluto).

${ }^{40}$ A crítica de Horkheimer à "transfiguração" hegeliana recapitulava, dessa maneira, a crítica já feita, de maneira resumida, por Marx, no posfácio a $O$ Capital: "Para Hegel, o processo depensamento, que ele, sob o nome de ideia, transforma num sujeito autônomo, é o demiurgo do real, real que constitui apenas a sua manifestação externa". Cf. Karl Marx, O Capital - Crítica da Economia Política. Vol. 1 - O Processo de Produção do Capital. Tradução de Regis Barbosa e Flávio Kothe. São Paulo: Abril Cultural, 1983, p. 20.
} 
considerava o conceito lukácsiano de consciência de classe "análogo ao "espírito absoluto". Marx e Engels haviam criticado os jovens hegelianos por hipostasiarem suas concepções filosóficas e não considerarem as condições históricas reais (o "atraso alemão"), Horkheimer criticava Lukács por hipostasiar seu conceito de consciência de classe e não considerar a situação empírica da classe operária europeia das primeiras décadas do século $\mathrm{XX}^{41}$.

A crítica ao caráter metafísico da obra de Hegel tem uma feição semelhante à crítica feita por Horkheimer à sociologia do conhecimento de Mannheim. Ao examinar a interpretação dada por Mannheim à teoria da ideologia, Horkheimer argumentou que em Ideologia e Utopia o conceito marxiano teria sido esvaziado de seu caráter negativo e posto a serviço de uma finalidade metafísica, justamente na direção contrária da crítica feita por Marx e Engels à filosofia da história dos jovens hegelianos. Mannheim, em sua crítica ao marxismo e a uma suposta unilateralidade de seu conceito de ideologia, que segundo o autor teria sido aplicado unicamente às limitações do pensamento burguês, defendera a necessidade de o marxismo reconhecer ser, ele próprio, uma ideologia. A pretensão da sociologia de Mannheim era transformar a teoria da ideologia de aparato de luta do proletariado em uma história sociológica das ideias, de caráter suprapartidário e escrita por uma "intelligentsia livremente flutuante": segundo essa perspectiva, as ideologias seriam investigadas em relação com as bases sociais que as condicionam, o que não implicaria entretanto relativismo algum, pois a distinção entre o conhecimento verdadeiro e o falso seria aferida com base na adequação ou não entre a ideologia em questão e a situação social em relação à qual ela pretende ter validade. Da situação social seria possível derivar um "sujeito de imputação", uma postura cognoscente ideal que corresponderia à situação social de um determinado grupo ${ }^{42}$. Nessa formulação, a sociologia de Mannheim abandonou o caráter crítico do conceito ("consciência invertida da realidade") e o positivou mas isso, segundo Horkheimer, teria sido feito a serviço de uma finalidade metafísica, pois Mannheim haveria tentado conciliar a relativização das ideologias (por meio de sua vinculação a situações sociais determinadas) com a ideia da correspondência entre a sucessão

\footnotetext{
${ }^{41}$ Se os textos publicados por Horkheimer criticaram o pensamento hegeliano e não abordaram diretamente a obra de Lukács, um manuscrito póstumo sugere que eram principalmente as formulações de História e Consciência de Classe que Horkheimer tinha em mente ao criticar a filosofia hegeliana. Uma das partes do manuscrito consistia em um trecho originalmente pertencente a "Hegel e o problema da metafísica", mas que Horkheimer excluiu da versão final do artigo: “também Lukács afirma que só pode ver a 'verdade concreta do presente' quem 'for capaz de criar o futuro', também ele vincula o conhecimento da 'totalidade' a um 'sujeito-objeto', ainda que, diferentemente do espírito absoluto, à 'consciência de classe do proletariado, que se tornou prática', também ele se agarra à identidade [entre ser e pensar] e faz de uma tal unidade supra-individual a portadora ao mesmo tempo do saber e do acontecer". Cf. Max Horkheimer, "[Subjektivismus und Positivismus als Erben der Hegelschen Metaphysik. Vorbemerkungen zu einer empirischen Erkenntnislehre (Fragment)]". In: Max Hokheimer, Gesammelte Schriften, op. cit., vol. 11, p. 223.

${ }^{42}$ Cf. Max Horkheimer, “Ein neuer Ideologiebegriff?”. In: Gesammelte Schriften, op. cit., vol. 2, pp. 271-276.
} 
histórica das ideologias e o devir da própria essência do homem. A sociologia do conhecimento de Mannheim empreenderia, portanto, uma "transfiguração" das condições históricas reais ao postular um sentido transcendente da história:

\begin{abstract}
"Como nenhum outro filósofo, Mannheim contestou a possibilidade de uma essência eterna e transcendente, que repousasse em si mesma; segundo ele, todo o sentido está imbricado no acontecer. Mas, quando o teor divino é trazido ao mundo dessa maneira, a referência a um pano de fundo metafísico é conservada não apenas na linguagem; pois a teoria demolidora segundo a qual não poderíamos a partir de nenhuma posição ter a certeza de que nossa crença sobreviveria diante da eternidade é amenizada pela afirmação de que as decisões ontológicas em conformidade às quais vivenciamos e estruturamos os fatos põem paulatinamente a descoberto um sentido que abarca todas elas. (...) A afirmação de um sentido unitário da história, que seria ao mesmo tempo passível de ser avaliado de maneira positiva, atua decisivamente na coloração dos conceitos essenciais de Mannheim e vincula a sua perspectiva à filosofia contemporânea - essa afirmação é, contudo, assim como essa, fundada sobre a doutrina cristã da existência de Deus"43.
\end{abstract}

Se a crítica da filosofia hegeliana era dirigida a Lukács, há razão para crer que a crítica a Mannheim tinha por alvo, na verdade, o materialismo dialético de Lênin e seu conceito de "ideologia proletária": Lukács e Lênin eram os teóricos mais influentes do Partido Comunista Alemão (KPD), e Horkheimer dessa maneira examinava em sua obra as posições dominantes no marxismo da época. Examinemos a crítica de Horkheimer a Materialismo $e$ Empiriocriticismo ${ }^{44}$.

O líder da Revolução de Outubro criticara os discípulos russos de Mach que, pertencentes ao movimento socialista, recorriam ao empiriocriticismo e à sua tese de que as sensações seriam o fundamento último do mundo, dela fazendo um instrumento de combate às concepções místicas e religiosas das massas camponesas. Lênin teria oposto ao empiriocriticismo de Mach, segundo Horkheimer, uma concepção errônea de materialismo: se os discípulos russos de Mach incorreram em idealismo subjetivo ao tomar as sensações como o fundamento último do mundo, tão distante quanto essa tese estaria, do pensamento marxista,

\footnotetext{
${ }^{43}$ Max Horkheimer, "Ein neuer Ideologiebegriff?", op. cit., pp. 280-281. Sobre as críticas de Horkheimer a Hegel/Lukács e a Mannheim, cf. o artigo de Vladimir Puzone, "Filosofia da história ou reprodução da vida dos indivíduos? A crítica de Max Horkheimer a Georg Lukács e a reformulação do marxismo". Rio de Janeiro, Sociologia e antropologia, vol. 7, número 1, abril de 2017, pp. 239-265.

${ }^{44} \mathrm{O}$ ensaio de crítica a Mannheim foi publicado em 1930 na revista do Instituto de Pesquisa Social, quando esse ainda estava sob a direção de Grünberg (tratava-se do número 15 do Archiv für die Geschichte des Sozialismus und der Arbeiterbewegung). A edição, a partir de 1985, de obras de Horkheimer até então inéditas permitiu virem a público as reflexões do autor sobre Lênin, feitas em um texto escrito entre 1928 e 1929 que Horkheimer terminou por não divulgar, e no qual tentou revelar os pressupostos metafísicos da concepção de materialismo de Lênin: Max Horkheimer, "[Über Lenins Materialismus und Empiriokritizismus]". In: Gesammelte Schriften, op. cit., vol. 11, pp.171-188.
} 
a teoria que considera a realidade material como esse fundamento, do qual as sensações e as ideias em geral seriam um mero reflexo. Ambas as teses seriam, segundo Horkheimer, igualmente metafísicas: "visto de modo puramente lógico, a tese segundo a qual a sensação refletiria uma realidade exterior à consciência não está nenhum passo além da religião do que a afirmação de Mach de que a própria sensação seria o real originário" 45 . Seguindo a interpretação do "último Engels" de que as ideias seriam "imagens mais ou menos abstratas das coisas e dos fenômenos da realidade"46, Lênin contrapunha o marxismo ao idealismo e defendia o "materialismo dialético" na interpretação cientificizante que lhe dera Engels, isto é, como o único método capaz de refletir uma realidade natural e histórica que seria dialética em si mesma. Em consonância a essa concepção de materialismo, Lênin também reduziu as ideologias a concepções de mundo que exprimem interesses e valores próprios a cada classe social, e dessa maneira empreendeu uma positivação do conceito de ideologia, empreendendo uma operação que teria traços em comum com aquela de Mannheim ${ }^{47}$. Segundo Lênin, o idealismo, do qual o empiriocriticismo seria uma das versões, seria uma mera ideologia burguesa à qual, na luta de classes, caberia opor a ideologia proletária ${ }^{48}$.

Essa seria superior à ideologia burguesa porque, se essa última representou a seu tempo um progresso no conhecimento, a ideologia proletária teria acrescentado a ela novos elementos e se aproximado mais ainda da verdade: Lênin argumentava que as sensações e as ideias seriam cópias de uma realidade material delas independente e, apesar de sempre relativas a ela, se aproximariam progressivamente de uma verdade absoluta ${ }^{49}$. A tese de uma realidade material última apartada da consciência, contudo, seria segundo Horkheimer representativa do dogmatismo metafísico já superado por Kant em sua defesa do papel constitutivo desempenhado pelo sujeito no conhecimento, e Lênin desconsideraria por extensão também as

\footnotetext{
${ }^{45}$ Max Horkheimer, “[Über Lenins Materialismus und Empiriokritizismus]”, op. cit., pp. 185-186.

46 Cf. a "Introdução" de Friedrich Engels, Anti-Dühring. Tradução: Grupo Acrópolis. Disponível em: www.marxists.org

${ }^{47}$ Cf. Michel Löwy, As Aventuras de Karl Marx contra o Barão de Münchhausen: marxismo e positivismo na sociologia do conhecimento. $9^{a}$ edição. São Paulo: Cortez, 2009, pp. 12-13.

${ }^{48}$ Cf. o prefácio e a introdução de Lênin a Materialismo e empiriocriticismo, op. cit.. Na conclusão da obra, Lênin escreveu que "não é possível deixar de ver, sob a escolástica gnoseológica do empirocriticismo, a luta dos partidos em filosofia, luta que exprime, no fundo, as correntes e a ideologia das classes inimigas da sociedade contemporânea". A concepção de ideologia como elaboração intelectual caudatária da luta de classes é claramente enunciada na seguinte passagem de "Que Fazer", em que Lênin combatia o espontaneísmo do movimento operário e defendia o papel organizador do partido: “(...) o problema põe-se unicamente assim: ideologia burguesa ou ideologia socialista. Não há meio termo (...) na sociedade dilacerada pelas contradições de classe, não pode existir uma ideologia à margem das classes ou acima das classes". Vladimir I. Lênin, "Que Fazer". Obras Escolhidas. Tomo 1. $3^{\mathrm{a}}$ edição. São Paulo: Alfa-Ômega, 1986, pp. 107-108.

${ }^{49}$ Cf., no livro de Lênin, o capítulo 2, subitem 11 ("Da verdade absoluta e relativa, ou o ecletismo de Engels descoberto por Bogdanov"). Essa tese era criticada por Horkheimer como mera transfiguração: cf. seu manuscrito "[Über Lenins Materialismus und Empiriokritizismus]", op. cit., pp. 183-184.
} 
contribuições feitas por Hegel, Feuerbach, Marx e Engels para uma teoria do conhecimento que fosse dialética, isto é, apoiada na ação recíproca entre sujeito e objeto: como ressaltado por Horkheimer, o conceito de "práxis" teria permitido a Lênin, em vez de opor ao empiriocriticismo a tese metafísica de um materialismo dialético, fazer uma crítica da filosofia de Mach que vinculasse a gênese do dualismo entre sujeito e objeto ao modo de produção capitalista $^{50}$.

A leitura de A Ideologia Alemã ${ }^{51}$ serviu a Horkheimer de referência para criticar a filosofia da história subjacente às obras de Lukács e Lênin e, por consequência, seus conceitos de "consciência de classe" e de "ideologia proletária". No livro inacabado e não destinado à publicação, em que o acerto de contas com a "consciência filosófica anterior" dos autores conduzira à crítica da filosofia da história e de qualquer tentativa de se estabelecer a priori uma história universal, a ideologia nem é considerada como um reflexo que exprimisse os interesses e os valores de cada classe social, e nem se postula que alguma das classes detivesse um ponto de vista privilegiado para a obtenção do conhecimento do todo: os autores da obra entregue "à crítica roedora dos ratos" criticaram a ideologia como falsa consciência (ou "consciência invertida"), e Horkheimer opôs essa concepção tanto à contraposição entre ideologia proletária e ideologia burguesa, feita por Lênin, quanto à ideia segundo a qual, da situação objetiva do proletariado, poderia ser extraída uma "consciência adjudicada", tese defendida por Lukács.

A influência da Ideologia Alemã sobre Horkheimer pode ser percebida já em seus estudos sobre a filosofia moderna, feitos no âmbito de um curso oferecido em 1927 na Universidade de Frankfurt. Nessas aulas, o professor chamava a atenção dos alunos para a necessidade de ler a obra de autores canônicos como Descartes, Bacon, Maquiavel e Hobbes à

\footnotetext{
${ }^{50}$ Em seu posfácio ao volume em que se encontra o texto póstumo de Horkheimer sobre o livro de Lênin, Gunzelin Schmied Noerr afirmou que Horkheimer teria defendido Mach contra Lênin em virtude de afinidades com o empiriocriticismo. Cf. Gunzelin Schmied Noerr, "Nachwort des Herausgebers", vol. 11 das Gesammelte Schriften, p. 417. Horkheimer de fato criticou as insuficiências da leitura de Mach feita por Lênin e mostrou como a crítica de Lênin não conseguia atingir a fundo os pressupostos do empiriocriticismo, mas a essa época Horkheimer já havia se afastado das afinidades que, na primeira metade da década de 1920, cultivara com o empirismo. Como ressaltado por Abromeit, a crítica feita por Horkheimer a Mach, iniciada em 1926, se tornou mais intesa em 1928 (ano de redação do manuscrito de crítica a Lênin) em virtude do afastamento de Horkheimer da filosofia cultivada por seu orientador, Cornelius, em cujo pensamento a teoria de Mach teria desempenhado um papel importante. Cf. John Abromeit, Max Horkheimer and the foundations of the Frankfurt School. Nova York: Cambridge University Press, 2011, p. 129. Uma leitura precisa e que examina o essencial da crítica de Horkheimer a Lênin pode ser encontrada no comentário de Alfred Schmidt sobre o assunto: "Unter welchen Aspekten Horkheimer Lenins Streitschrift gegen den 'machistischen' Revisionismus beurteilt”, no mesmo volume 11 das Gesammelte Schriften de Horkheimer, pp. 418-425. Em "Materialismo e Metafísica", publicado em 1933, Horkheimer não deixaria dúvidas quanto à sua posição sobre o assunto: "ao pressupor um sujeito independente do tempo, também o empiriocriticismo se afina com a metafísica" (Max Horkheimer, "Materialismus und Metaphysik", Gesammelte Schriften, vol. 3, p. 96).

${ }^{51}$ A obra estava disponível aos membros do Instituto de Pesquisa Social desde 1926, em virtude de sua cooperação com o Instituto Marx-Engels de Moscou.
} 
luz do contexto histórico de seu surgimento. O curso tinha um caráter experimental, pois o próprio Horkheimer estava a essa época se aproximando do marxismo, e por isso os alunos eram advertidos de que as exposições tinham o caráter de esboços de um "programa futuro" ainda a ser plenamente realizado ${ }^{52}$. Mas Horkheimer já defendia sem reservas, em oposição à leitura interna das obras, a ideia de que um "modo de abordagem propriamente científico" deveria relacionar a filosofia à história. $\mathrm{O}$ autor rejeitava, ao mesmo tempo, qualquer determinismo econômico:

\begin{abstract}
"Nos modernos manuais de filosofia é possível ler, digamos, que não foram as necessidades [Bedürfnisse] reais da vida econômica que teriam possibilitado o humanismo, a nova ciência natural, as descobertas e invenções e, sim, que deveriam ser vistos como fundamento e ocasião para esses fenômenos espirituais principalmente as relevantes invenções surgidas àquela época, ou antes. Bem, é verdade que não podemos meramente virar ao avesso afirmações falsas desse tipo, a fim de torná-las verdadeiras. As coisas com certeza não são tão simples assim, e quem alguma vez fez estudos sobre aquela época sabe como complicadas essas relações de fato são" 53
\end{abstract}

No curso de 1927, Horkheimer explicava o desenvolvimento da filosofia moderna a partir da dissolução do mundo feudal e como expressão das mudanças econômicas de então: a expansão da economia mercantil e tudo o que estava ligado a ela - o renascimento das cidades ao longo da baixa idade média, a formação do Estado absolutista em aliança com a burguesia nascente e em oposição à nobreza feudal e, por fim, as inovações técnicas que prepararam o caminho para a revolução científica dos séculos XVI e XVII - tudo isso teria exigido uma ruptura com a autoridade eclesiástica e o pensamento aristotélico-tomista, que haveria de ceder lugar às ciências naturais e à recuperação humanista da cultura clássica ${ }^{54}$. Esse argumento era respaldado por considerações muito semelhantes àquelas feitas por Marx e Engels na Ideologia Alemã:

\footnotetext{
"Os homens, ao transformarem as suas relações, as condições reais em que vivem, mudam também as suas concepções metafísicas, suas ideias religiosas e filosóficas. Temos de considerar como o originário, como a história propriamente dita o processo real de vida da humanidade, ou seja, a maneira pela qual os homens ganham e conservam a sua vida, assim como as formas do intercâmbio condicionadas imediatamente pela respectiva maneira desse processo real da vida, e de modo algum as ideias que os homens a cada época fizeram acerca desse seu ser real. É também totalmente errado crer que essas ideias, tomadas em separado da história da sociedade humana, deveriam ter um

${ }^{52}$ Max Horkheimer, "Vorlesungen über die Geschichte der neueren Philosophie". In: Gesammelte Schriften, op. cit., vol. 9, p. 18.

${ }^{53}$ Max Horkheimer, "Vorlesungen über die Geschichte der neueren Philosophie", op. cit., p. 30 infra-p. 31.

${ }^{54}$ Max Horkheimer, "Vorlesungen über die Geschichte der neueren Philosophie", op. cit., pp. 28-30.
} 
sentido interno que as perpassasse, e que se poderia explicitar esse sentido 'nos limites internos da filosofia' ${ }^{55}$.

Horkheimer explicava o surgimento da filosofia moderna recorrendo a essas ideias e se valendo de enunciados que pareciam transcritos da Ideologia Alemã: “(...) a produção das ideias, das representações de tipo jurídico, político, moral, religioso, metafísico emanam do intercâmbio material dos homens reais e estão imbricadas em seu comportamento real" ${ }^{\text {"56 }}$. O autor mostrava como a luta entre a burguesia e a nobreza feudal se dava, no plano ideal, como a luta entre a escolástica medieval e a filosofia do sujeito que haveria de assumir suas formas mais elaboradas na França e na Inglaterra, respectivamente em suas versões racionalista e empirista. O autor reverberava, assim, a fórmula de Marx e Engels segundo a qual a ideologia dominante seria a "expressão ideal das relações materiais dominantes" 57 . Tal qual na Ideologia Alemã, a apresentação da história era feita de maneira "externa" às categorias filosóficas criticadas como ideológicas: Horkheimer tomava como "pressupostos econômicos"58 do surgimento da filosofia moderna a dissolução do modo de produção feudal, isto é, o desenvolvimento das forças produtivas próprias à economia mercantil e a concomitante luta de classes entre a burguesia e a nobreza. A análise desses pressupostos era feita previamente ao exame dos conceitos centrais pertencentes à obra dos autores estudados (por exemplo, o conceito maquiaveliano de virtù e o conceito hobbesiano de "razão natural"), de maneira que era a partir da práxis histórica (considerada como o conjunto de elementos econômicos, políticos, jurídicos e ideológicos) que Horkheimer criticava a transfiguração efetivada por aqueles conceitos, que alçavam à condição de conceitos universais as características particulares da classe burguesa ${ }^{59}$.

\footnotetext{
${ }^{55}$ Max Horkheimer, "Vorlesungen über die Geschichte der neueren Philosophie", op. cit., p. 17.

${ }^{56}$ Max Horkheimer, "Vorlesungen über die Geschichte der neueren Philosophie", op. cit., p.22.

${ }^{57}$ Karl Marx e Friedrich Engels, A Ideologia Alemã. Tradução de Luiz Claudio de Castro e Costa. São Paulo: Martins Fontes, 2001, p. 48.

${ }^{58}$ Esse era o título do primeiro "ponto" desenvolvido nas aulas de seu curso de 1927. Cf. Max Horkheimer, "Vorlesungen über die Geschichte der neueren Philosophie", op. cit., p. 27.

${ }^{59}$ Sobre os modelos de apresentação marxista da história, cf. a distinção feita por Ruy Fausto entre o modelo das obras da década de 1840 e aquele adotado por Marx em $O$ Capital: "No primeiro modelo, o do "Manifesto Comunista' e da 'Ideologia Alemã', o tempo domina o conceito. Não é o conceito que põe o tempo, mas o tempo que põe o conceito. Há por isso mesmo um primado da prática, que vai até o ponto de diluir as significações teóricas”. Cf. Ruy Fausto, Marx: Lógica e Política - Investigações para uma reconstituição do sentido da dialética, tomo III. 1ª edição. São Paulo: Editora 34, 2002, p. 92. Uma outra leitura do tipo de crítica empreendido por Marx e Engels na obra inacabada de 1845/46 pode ser encontrado em um comentário de Marilena Chauí sobre o problema da ideologia: segundo a autora, a leitura isolada dos capítulos iniciais da primeira parte da obra (a parte sobre Feuerbach) poderia levar à conclusão de que Marx e Engels tinham uma concepção de ideologia como mera representação imaginária. Os capítulos seguintes, por sua vez (cuja publicação, aliás, foi dispersa ao longo do tempo), conteriam uma análise interna dos discursos filosóficos dominantes e exprimiriam com mais clareza a necessária imbricação entre a prática social e pensamento. Cf., da autora, "Apresentação", in: Marilena Chauí; Maria Sylvia de Carvalho Franco. Ideologia e mobilização popular. Rio de Janeiro: Paz e Terra; CEDEC, 1978,
} 
A passagem do modo de produção feudal ao modo de produção capitalista havia ocorrido a partir da contradição entre as relações sociais de produção vigentes (caracterizadas pelo predomínio da propriedade fundiária e pelas restrições à circulação de mercadorias) e o desenvolvimento das forças produtivas próprias à economia mercantil. Surgida dessa contradição, a filosofia moderna seria a expressão ideal da luta de classes entre a burguesia e a nobreza feudal, e só viria a se tornar ideologia dominante quando o modo de produção capitalista já tivesse se estabelecido e elevado, a um nível superior, os elementos do modo de produção anterior, negado pelo devir histórico:

"Resulta nítido que ao modo pelo qual os homens ganham a sua vida em uma
determinada etapa histórica corresponde o grau de seu conhecimento teórico.
(...) Isso não quer dizer que em uma determinada etapa já não se encontrem
elementos de um conhecimento superior, que mais tarde suplante o antigo
conhecimento dominante. Mas enquanto esses não ganharem em poder,
enquanto a sociedade produzir a sua vida e instituir a sua organização com
recurso às antigas concepções sobre a natureza, a antiga forma de consciência
permanecerá a dominante, e principalmente irão defender essa etapa tradicional
do conhecimento aquelas camadas da sociedade que têm um interesse na
continuação da antiga ordem social e econômica a ela vinculada"60.

Entretanto, para Horkheimer apenas seria possível falar desse tipo de contradição dialética para a transição do modo feudal ao modo capitalista de produção. Segundo o autor, a teoria da história elaborada por Marx e Engels examinou as "estruturas e tendências supraindividuais e dinâmicas na evolução histórica" e concluiu que, pelo menos até o capitalismo, os modos de produção tinham se sucedido uns aos outros em virtude da contradição entre o desenvolvimento das forças produtivas e as relações sociais de produção, tendo conseguido estabelecer "como motor da história a dialética entre as formas sociais antiquadas e as diversas

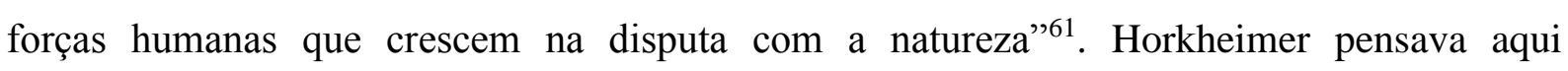
provavelmente nas formulações que Marx e Engels haviam desenvolvido na Ideologia Alemã sobre a sucessão de modos de produção ao longo da história, uma sucessão retomada por Marx no "Prefácio à Contribuição à Crítica da Economia Política", de 1859: da contradição entre o desenvolvimento das forças produtivas e as relações de produção teriam resultado a cada vez novos modos de produção, com seus respectivos aparatos jurídico-políticos e ideologias

pp. 9-10. Independente, porém, do que valha para a Ideologia Alemã, na fase inicial da obra de Horkheimer parecia haver, para empregarmos a caracterização de Ruy Fausto, uma sobreposição do "discurso posto" ao "discurso pressuposto".

${ }^{60}$ Max Horkheimer, "Vorlesungen über die Geschichte der neueren Philosophie", op. cit., p. 22.

${ }^{61}$ Max Horkheimer, "História e psicologia". In: Max Horkheimer, Teoria Crítica I — uma documentação, op. cit., p. 18. 
dominantes. Essa apresentação, contudo, foi feita a exemplo do caso concreto da história europeia e por meio da investigação do processo de transição de um modo de produção a outro, sem supor que houvesse uma conexão interna necessária entre eles e que esse desenvolvimento, portanto, tivesse que ocorrer sempre nessa sequência: “(...) segundo Marx nenhum conhecimento lógico prescrito da história fornece a chave para sua compreensão" ${ }^{62}$. Isso, aliás, contrariaria a crítica feita por Marx e Engels à filosofia da história dos jovens hegelianos.

A recusa a qualquer construção apriorística que pretendesse prever o desenrolar histórico é uma constante dos ensaios de Horkheimer. O fato de Marx e Engels terem analisado as épocas históricas pretéritas como totalidades (modos de produção) que se substituíram uns aos outros em decorrência da contradição entre forças produtivas e relações sociais de produção não significa que essa contradição seja sempre o motor da história, ainda que essa "até agora" tenha sido a história da luta de classes. Eternizar essa tese, contudo, equivaleria a defender um dogma, e o marxismo estaria em permanente risco de transformar o pensamento de Marx e Engels em "mito", em mera ideologia. Dessa maneira, se uma dialética entre forças produtivas e relações sociais de produção havia caracterizado a passagem revolucionária do modo de produção feudal para o modo de produção capitalista, ela não poderia ser transformada em lei universal: como advertiu Horkheimer, isso faria dela uma metafísica tão criticável como as filosofias burguesas da história, e o caráter científico da teoria da história de Marx e Engels se perderia caso fosse transformada em um modelo universal:

\footnotetext{
"Quando o antagonismo entre as forças humanas crescentes e a estrutura social, que neste contexto mostra ser o motor da história, substitui as análises concretas como esquema de construção universal, ou quando ele é alçado a um poder necessário à formação do futuro, então o conceito de história ora esboçado pode converter-se numa metafísica dogmática definitiva" ${ }^{63}$.
}

Daí decorreria também a necessidade de se considerar a "legalidade própria" das esferas sociais e o caráter historicamente mutável do sentido da determinação entre elas: a própria situação do presente (no caso, das primeiras décadas do século XX) mostrava ser falsa a ideia de que haveria uma relação de determinação unívoca entre economia e cultura, pois os homens

\footnotetext{
${ }^{62}$ Max Horkheimer, "História e psicologia", op. cit., p. 18.

${ }^{63}$ Max Horkheimer, "História e psicologia", op. cit., p. 196. Uma crítica semelhante a essa havia sido feita por Horkheimer no artigo em que examina o conceito de ideologia de Mannheim, escrito dois anos antes. Ali, Horkheimer chamava a atenção para a recepção deturpada da obra de Marx, que a identificava a uma tentativa de estabelecer uma verdade a-temporal sobre a história, reduzindo-a ao conjunto de mudanças provocadas mecanicamente pela luta de classes, economicamente condicionada: Marx, afirmava Horkheimer, criticara a filosofia, mas “(...) não é posta uma nova metafísica no lugar da antiga”. Cf. a página 271 do já citado "Ein neuer Ideologiebegriff”.
} 
agiriam no sentido de manter relações sociais de produção que não mais correspondiam a suas forças e necessidades ${ }^{64}$. A ideia de uma sociedade emancipada não poderia, portanto, repousar na suposição de que as próprias características intrínsecas ao modo de produção capitalista conduziriam ao socialismo por meio de uma luta de classes que brotasse, por assim dizer, do solo das contradições econômicas, e qualquer determinismo deveria ser rejeitado em favor da pesquisa das mediações que existem entre as diferentes esferas sociais (dentre elas, as mediações psicológicas). A própria possibilidade de que algum dia a economia não escravize as necessidades culturais e políticas, ocorrendo antes o contrário, seria logicamente dependente da recusa do economicismo:

“A revelação das mediações psíquicas entre o desenvolvimento econômico e os outros
desenvolvimentos culturais há, é verdade, de deixar de pé a afirmação segundo a qual,
a mudanças econômicas radicais, seguiram-se mudanças culturais também radicais, mas
ela pode, sob certas circunstâncias, não apenas conduzir a uma crítica da concepção das
relações funcionais entre ambas as séries, mas também fortalecer a suposição de que a
ordem causal, em algum momento do futuro, se alterará ou se inverterá”"

Uma tese desenvolvida por Lukács pouco depois da revolução na Rússia é capaz de iluminar os argumentos de Horkheimer sobre a relação entre as esferas sociais naquela quadra histórica. Em um dos textos de História e Consciência de Classe, escrito em 1919, Lukács afirmava que o fim da primeira guerra, a revolução na Rússia e suas tentativas na Europa teriam dado início a uma "guerra aberta entre as classes", na qual o fetichismo da mercadoria não seria mais suficiente para garantir a dominação de uma classe por outra e por isso a "violência" ocuparia o primeiro plano do processo histórico. Disso deveria ocorrer uma "mudança de função do materialismo histórico" (título de um dos ensaios de História e Consciência de Classe): em uma época revolucionária, perderia a relevância principal o aspecto estritamente econômico da luta de classes, entendida como disputa pela mais-valia, e a política assumiria a primazia do processo histórico. Em oposição aos períodos de estabilidade do modo de produção capitalista, em que as leis econômicas garantiriam seu funcionamento regular a ponto de adquirir - na compreensão fetichizada que delas tem a economia política - a aparência de leis “eternas", a crise em curso em fins da década de 1910 seria um momento de "ponto morto" do capitalismo, no qual a violência extra-econômica ganharia uma relevância incomparável em relação às épocas passadas: segundo Lukács, no mencionado ensaio, “aquelas medidas com as quais a burguesia intenta superar o ponto morto da crise (...) tornam-se o palco da guerra aberta

\footnotetext{
${ }^{64}$ Max Horkheimer, "História e psicologia", op. cit., pp. 21-22.

${ }^{65}$ Max Horkheimer, "Geschichte und Psychologie”. In: Gesammelte Schriften, vol. 3, p. 58.
} 
entre as classes. A violência torna-se uma potência econômica decisiva da situação"66. Essa situação, na qual a violência direta ocupava o primeiro plano do acontecer histórico, havia sido ela própria engendrada pela crise econômica: “[a primazia da violência] é apenas uma aparência. Pois a violência nunca é e nunca pode ser um princípio autônomo"67. Naquele momento de crise econômica que abria a possibilidade de superação do capitalismo, contudo, a violência direta adquiria uma primazia tal que Lukács esperava que o proletariado, em sua condição de sujeito-objeto da história, pudesse dar o "salto" revolucionário e extinguir o papel que a economia até então exercera na história humana e subordiná-la, por meio da violência do processo revolucionário, à abolição da sua própria classe.

À tese de Lukács, ainda que a revolução não tenha se concretizado na Europa ocidental e embora o argumento de Lukács tenha sido em geral criticado em virtude de seu idealismo ${ }^{68}$, recorremos por ver na ideia de que o capitalismo não poderia mais se manter à base apenas da violência econômica uma grande afinidade também com a centralidade que assumiu, no âmbito do Instituto, o estudo dos fenômenos psíquicos e ideológicos típicos do capitalismo monopolista e atuantes no impedimento de uma política revolucionária. A importância dessa correlação reside no fato de que, para Horkheimer, a esfera que poderíamos grosso modo denominar de “subjetiva" representava à época o mais relevante fator de manutenção das relações sociais: os fenômenos psíquicos e a ideologia atuariam retroativamente sobre o processo de produção da vida social que as havia engendrado, e contribuiriam para a conservação das relações sociais ainda quando as forças produtivas tivessem se desenvolvido a ponto de dispensar a propriedade privada dos meios de produção, e ainda que o modo de produção engendrasse sucessivas crises. O autor considerava que, no período que se seguiu aos ensaios de revolução na Alemanha e na Europa central, as esferas da cultura e da constituição psíquica (autoritária) dos indivíduos teriam assumido a primazia histórica e contribuiriam para "manter latentes entre as classes sociais as tensões que suscitam a eclosão de conflitos com base na situação econômica", exercendo o papel de obstáculos à luta de classes ${ }^{69}$.

Consoante a essas preocupações, a crescente integração social da classe trabalhadora foi objeto do programa intelectual dirigido por Horkheimer e se exprimiu nas pesquisas sobre

\footnotetext{
${ }^{66}$ Georg Lukács, "História e Consciência de Classe”, op. cit., p. 449.

${ }^{67}$ Georg Lukács, "História e Consciência de Classe", op. cit., p. 460.

${ }^{68}$ Cf. Istvan Meszaros, Para Além do Capital: rumo a uma teoria da transição. Tradução de Paulo Cesar Castanheira e Sérgio Lessa. São Paulo: Boitempo Editorial, 2002, pp. 451-452.

${ }^{69}$ Max Horkheimer, "História e Psicologia", op. cit. p. 22. No ano seguinte, Pollock sustentava, ao analisar as relações entre o Estado e a economia monopolista, que "(...) os chamados fatores políticos brotam das condições econômicas e sociais do capitalismo e surgem como forças aparentemente autônomas com tanto mais frequência quanto mais o sistema capitalista se torna rígido e quanto mais crescem as duas tensões internas". Cf. Friedrich Pollock, "Bemerkungen zur Wirtschaftskrise”. Zeitschrift für Sozialforschung, vol. 2, 1933, p. 328.
} 
autoridade e família, já em curso desde 1929. A incorporação da psicanálise e de contribuições provindas das disciplinas acadêmicas tradicionais permitiria afastar da interpretação marxista qualquer traço de dogmatismo, evitando o recurso a uma filosofia da identidade entre sujeito e objeto (assumisse essa um caráter economicista ou idealista, diferença entendida por Horkheimer como duas versões da mesma tese metafísica) e proporcionando a consideração das mediações representadas pelas esferas sociais específicas (a política, o psiquismo, a economia e a cultura em sentido estrito), impossíveis de redução a uma dinâmica histórica determinada de antemão ${ }^{70}$. Essa consideração seria a contraparte positiva da crítica feita por Horkheimer às filosofias da história de Lukács e Lênin, e nela se manifestava a influência exercida sobre Horkheimer pela Ideologia Alemã, em sua recomendação de que o conhecimento deveria partir dos "indivíduos reais, sua ação e suas condições materiais de existência"71. $\mathrm{O}$ indivíduo seria uma mediação imprescindível para a compreensão das relações entre a economia, a política e a cultura, não podendo ser reduzido a mera função de nenhuma delas, e a psicanálise, ao revelar os fatores inconscientes da ação, ofereceria segundo Horkheimer contribuições férteis para se explicar a maneira como os homens agem no sentido da conservação de uma ordem social que os oprime e não corresponde a seus interesses e possibilidades $^{72}$. Em seu discurso de posse como diretor do Instituto, o autor formulava da seguinte maneira a questão que haveria de ocupar a partir de então uma posição central em seu programa:

"quais conexões é possível apurar - num determinado grupo social, num período determinado, em determinados países - entre o papel desse grupo no processo econômico, a transformação ocorrida na estrutura psíquica dos seus membros singulares e os pensamentos e as instituições que agem sobre esse mesmo grupo, como totalidade menor no todo da sociedade, e que são por sua vez o seu produto?"73.

A seguir nos ocuparemos das primeiras respostas dadas a essa pergunta.

\footnotetext{
${ }^{70} \mathrm{Cf}$. o já mencionado discurso de posse, "A presente situação da filosofia social e as tarefas de um instituto de pesquisa sociais", op. cit., , pp. 130-131, e também o ensaio sobre "História e psicologia", op. cit., p. 20. Sobre isso, Horkheimer escreveria em "Hegel e o problema da metafísica": "A pesquisa não permite nenhuma decisão definitiva entre uma dinâmica individual e uma dinâmica integral daquilo que acontece, como bem se pode exigila de uma filosofia orientada metafisicamente, e sim carece de análises concretas para a determinação tanto dos fatores abrangentes a cada caso atuantes, quanto dos fatores relativamente individuais" (pp. 301-302 do volume 2 das Gesammelte Schriften).

${ }^{71}$ Karl Marx e Friedrich Engels, A Ideologia Alemã, op. cit., p. 10.

${ }^{72}$ Max Horkheimer, "História e psicologia", op. cit., p. 21 e pp. 24-25.

${ }^{73}$ Cf. Max Horkheimer, "A presente situação da filosofia social e as tarefas de um instituto de pesquisa sociais", op. cit., p. 131.
} 


\section{2 - Revolução perdida, marxismo e psicanálise: a integração do proletariado e as perguntas} do Instituto de Pesquisa Social

Nas Europa das primeiras décadas do século XX, o ascenso que no lugar da aguardada revolução teve o nazi-fascismo impôs aos marxistas a seguinte pergunta: como um proletariado numeroso, bastante organizado em sindicatos e partidos (do que o caso do Partido SocialDemocrata Alemão, o SPD, foi paradigmático) podia assimilar ideologias conservadoras que favoreciam partidos vinculados ao grande capital monopolista e redundavam na maior exploração de sua própria classe? A integração social do proletariado, um processo que explica tanto o fracasso dos ensaios de revolução empreendidos na Europa central durante as décadas de dez e vinte quanto a adesão crescente dos membros dessa classe aos movimentos fascistas, foi um tema que acompanhou as indagações dos membros da teoria crítica ao longo das mais diversas fases pelas quais passou a "Escola de Frankfurt".

Por um lado havia se revelado falso o evolucionismo mecanicista de uma teoria da história que a reduzia a uma sucessão de modos de produção, todos eles resultantes da contradição entre o desenvolvimento das forças produtivas e as relações sociais vigentes a cada época histórica. Dessa teleologia seria possível inferir a inevitabilidade da eclosão de uma revolução proletária na Europa, em virtude da concentração crescente do capital e da tendência à pauperização dos trabalhadores. Entretanto, não só a integração do proletariado europeu, mas a própria Revolução Russa haviam desacreditado essa concepção de passagem ao socialismo, elaborada na esteira da tese de Engels de que a revolução seria o resultado inexorável do desenvolvimento que a "grande indústria" proporcionou às forças produtivas, "até convertê-las em antagonismos sociais tão clamorosos, que já se pode - se é possível dizer-se - tocar com as mãos a derrota deste regime de produção" ${ }^{\text {74 }}$.

Por outro lado, o ocaso do processo revolucionário na Europa também parecia desautorizar a tese de Lukács de que o "ponto de vista do proletariado" permitiria a superação pela consciência revolucionária do caráter fetichizado que as relações sociais assumem no capitalismo. Essa superação, que Lukács concebeu como a passagem da mera contemplação à

\footnotetext{
${ }^{74}$ Friedrich Engels, Anti-Dühring, op. cit. Cf. a "Introdução" e o cap. I, “Traços Históricos”, da Parte III Socialismo.
} 
ação, teria por pressuposto suficiente a consciência da totalidade social pelo proletariado, possível em virtude da situação especial em que essa classe se encontraria, quando comparado à burguesia: enquanto os membros da classe dominante, por não tomarem parte no processo de produção capitalista como objetos, poderiam cultivar a ilusão de que haveria sujeitos autônomos da história, os trabalhadores, por outro lado, participam daquele processo de produção como forças produtivas. Sendo expressão do fenômeno da reificação de uma maneira específica, a sua própria atividade sendo convertida em objeto submetido ao processo social de abstração do trabalho, a classe trabalhadora seria capaz de reconhecer na forma da mercadoria uma categoria universal, estruturante da totalidade social ${ }^{75}$.

O novo momento histórico, por sua vez, demandava para a elucidação teórica do problema da consciência de classe um referencial que permitisse a investigação dos processos sociais em que se davam a luta de classes e a constituição das ideologias, em suas formas históricas específicas: para tanto, nem o mecanicismo da Segunda Internacional, nem as formulações de História e Consciência de Classe forneciam um ponto de partida. Fazia-se necessária uma renovação da teoria marxista da história, que permitisse a interpretação dos fenômenos subjetivos (isto é, ideológicos e políticos) em sua especificidade e não como meros epifenômenos da produção econômica, e conservasse as conquistas trazidas pela ênfase dada por Lukács e Korsch aos vínculos do marxismo com a dialética hegeliana, mas sem, ao mesmo tempo, abrigar qualquer concepção idealista da formação da consciência de classe ${ }^{76}$.

A incorporação da ideologia e do psiquismo como objetos de investigação é expressão inequívoca da alteração de rota por que passou a prática intelectual do Instituto de Pesquisa Social, após uma década de 1920 marcada pelo privilégio de temas de Economia Política, sob

\footnotetext{
${ }^{75}$ Em História e Consciência de Classe, Lukács havia escrito: "a negatividade puramente abstrata na existência do trabalhador [isto é, a conversão de sua atividade em mera força de trabalho] constitui objetivamente não apenas a forma mais típica de manifestação da reificação, o modelo estrutural para a socialização capitalista; é também, subjetivamente e por essa razão, o ponto em que essa estrutura pode ser elevada à consciência e, dessa maneira, rompida na prática". Cf. Georg Lukács, História e Consciência de Classe, op. cit., p. 347. Segundo Ricardo Musse, "a âncora da teoria na época de Lukács e Korsch, um sólido proletariado organizado e poderoso que parecia ensaiar seus movimentos na direção da revolução social, subitamente desmanchou-se no ar". Cf., do autor, Do Socialismo Científico à Teoria Crítica - modificações na autocompreensão do marxismo entre 1878 e 1937. Tese de doutorado. FFLCH-USP. São Paulo, 1997, p. 198.

${ }^{76}$ Ter aproximado a consciência revolucionária a um processo de conhecimento, desconsiderando os processos históricos em que transcorre a luta de classes, acarretou ao livro de Lukács a acusação de idealismo. Sua preocupação predominante com as características do método marxista o teria desviado da atenção aos processos históricos reais em que a luta de classes se dava. É de se imaginar também que, para o tom quase panfletário e dogmático de muitas de suas formulações tenha contribuído o momento histórico em que os textos do livro foram escritos - um momento que testemunhava diversos processos revolucionários em curso -, assim como a necessidade de afastar as teses social-democratas que, em meio a esses processos, diminuam o papel da consciência na história e confiavam na lenta e gradativa passagem ao socialismo. Sobre os problemas da tese de Lukács do sujeito-objeto, cf. István Meszáros, Para Além do Capital, op. cit., pp. 445-447.
} 
o signo do marxismo da II Internacional. Em consonância a essa mudança, ocupou uma posiçãochave no programa de pesquisas dos anos trinta o sociólogo e psicanalista Erich Fromm, membro da "esquerda freudiana" responsável por empreender uma aproximação entre o pensamento de Marx e o de Freud. As condições para uma revolução aparentemente dadas, a presença de um elemento à primeira vista irracional na consciência de classe do proletariado levava alguns intelectuais a buscar na psicanálise um referencial teórico que, ao iluminar os processos psíquicos, poderia fornecer o auxílio indispensável para se compreender aquilo de que não conseguiam dar conta nem a concepção mecanicista de passagem ao socialismo, nem a tese de Lukács segundo a qual o proletariado seria o "sujeito-objeto" da história: como explicar a adesão da classe trabalhadora a regimes políticos que favoreciam a sua exploração e repressão ${ }^{77}$

Grosso modo se pode afirmar que, na visão de autores como Fromm, Reich, Fenichel e Bernfeld, a teoria de Freud, ao enfatizar o papel do inconsciente na formação do indivíduo, se revelava capaz de contribuir para a resposta, e as seguintes credenciais a habilitavam para uma conjugação com a teoria marxista: na medida em que postulava a existência de relações recíprocas entre os impulsos inconscientes e os fenômenos da consciência (os últimos tomados em sua expressão tanto individual quanto social), se apresentava como uma ciência de base materialista; ao remeter a formação psíquica do indivíduo à sociedade, a psicanálise se caracterizava pela presença de elementos dialéticos, embora não elaborasse uma reflexão sistemática e de caráter histórico sobre essa relação. "Ambas as teorias derrubam a consciência do trono a partir do qual ela parecia conduzir as ações dos homens e representar os seus sentimentos", afirmava Fromm em relação aos pontos de contato entre a psicanálise o materialismo histórico ${ }^{78}$. As deficiências "burguesas" da psicanálise, isto é, a permanência, tanto na letra dos textos de Freud quanto no uso social da técnica psicanalítica, de limitações dualistas incoerentes com o sentido geral de sua teoria, poderia ser sanada por meio de sua integração a uma teoria da história capaz de aproveitar os elementos dialéticos que a própria psicanálise já trazia consigo ${ }^{79}$.

Em linhas gerais, foram esses o contexto histórico e o raciocínio que explicavam a aproximação entre o marxismo e a psicanálise nas décadas de 1920 e 1930, uma aproximação

\footnotetext{
77 Sigo aqui os argumentos de Sérgio Paulo Rouanet, Teoria Crítica e Psicanálise. Rio de Janeiro: Tempo Brasileiro, 1983.

${ }^{78}$ Erich Fromm, "Politik und Psychoanalyse". In: Erich Fromm, Gesamtausgabe. Stuttgart: DVA, 1999, vol. 1, pp. 31-36 (o trecho citado se encontra à p. 32).

${ }^{79}$ Essas limitações são abordadas mais adiante, na interpretação que fazemos do pensamento de Fromm e na breve indicação do modo pelo qual o autor se apropriou criticamente da obra de Freud.
} 
que tomou corpo na obra dos "freudo-marxistas" e que representava o distanciamento, em primeiro lugar, de uma prática clínica que, ao não vincular o trabalho analítico ao todo social, se revelava socialmente conservadora e, ao mesmo tempo, limitada do ponto de vista teórico; em segundo lugar, essa aproximação representava um distanciamento dos dogmatismos que, seja na concepção evolucionista e mecanicista de marxismo da Segunda Internacional, seja no idealismo da concepção do proletariado como "sujeito-objeto" da história, por Lukács, desconsideravam as mediações necessárias à eclosão do processo revolucionário ${ }^{80}$. Na situação histórica mais imediata, o recurso à obra de Freud também exprimia uma relevante tomada de posição teórica frente aos partidos comunistas: a psicanálise, que nos anos imediatamente posteriores à Revolução Russa havia obtido ali uma recepção que, apesar de permeada de diversas controvérsias, lhe foi em larga medida favorável (do que é exemplo a sua defesa por Trotsky), foi excluída por Stálin do elenco das ciências materialistas, e em seu lugar adotada como principal referência para o estudo do psiquismo a teoria dos reflexos condicionados de Pavlov - a "versão russa do behaviorismo" que se conjugava convenientemente com o esquema mecanicista de uma totalidade social entendida como a união de infra- e superestrutura ${ }^{81}$.

Tendo ocupado a direção da "seção sociopsicológica" do Instituto entre 1930 e 1938, Fromm, durante esse tempo responsável pela conjunção entre o marxismo e a psicanálise no âmbito do programa de pesquisas de Max Horkheimer, coordenou as pesquisas empíricas com trabalhadores e funcionários: a ideia central era que o conjunto de representações designadas genericamente por "autoritárias" - por exemplo, a crença na eterna necessidade da existência de uma ordem hierárquica e na irrelevância da ação individual frente aos poderes da sociedade - exerceriam um papel fundamental na conservação da ordem social, ao serem aceitas pelos membros do proletariado que se integrava. Estudar a disseminação de tendências autoritárias

\footnotetext{
${ }^{80}$ Bernard Görlich, seguindo a opinião de Alfred Lorenzer, critica o uso indiscriminado da expressão "freudomarxismo", pois ela encobriria diferenças de pensamento entre autores que erroneamente se supõe pertencerem a uma mesma "escola". O autor reserva, contudo, seguindo o uso do próprio Fromm, o termo "esquerda psicanalítica" para o grupo de autores independentes que distavam tanto da apropriação "eclética" do pensamento de Freud pelos social-democratas quanto do Partido Comunista, após a rejeição da psicanálise por Stálin. A esse grupo da "esquerda psicanalítica" teriam pertencido Erich Fromm, Otto Fenichel, Sigfried Bernfeld e Wilhelm Reich. Cf., de Bernard Görlich, Individuum und Gesellschaft - zum Versuch der Synthese von Freud und Marx im Frommschen Gesamtwerk. Tese de doutorado. Universidade de Frankfurt, 1979, pp. 3-15.

${ }^{81}$ Cf. Alfred Schmidt, "Die 'Zeitschrift für Sozialforschung' " [introdução à reedição dos volumes da Revista de Pesquisa Social]. Munique: DTV, 1980. pp. 31-32. A necessidade de esconjurar as acusações de idealismo (notese que Reich foi expulso do Partido Comunista Alemão, o KPD, em 1934) explicaria, segundo Bernard Görlich, o porquê de Fromm e Reich, em seus textos do início dos anos trinta, enfatizarem a condição de "ciência natural" da psicanálise. Cf. Bernard Görlich, Individuum und Gesellschaft, op. cit., p. 14. Note-se, além disso, que a psicanálise enfrentava fortes resistências também no âmbito acadêmico, de maneira que os membros do Instituto foram pioneiros em introduzir a obra de Freud na universidade.
} 
entre os trabalhadores alemães se afigurava tanto a Fromm quanto a Horkheimer como uma tarefa de pesquisa sumamente importante ${ }^{82}$.

Publicados em 1936 pela editora Felix Alcan de Paris, num momento em que os principais membros do Instituto estavam no exílio, os "Estudos sobre Autoridade e Família" [Studien über Autorität und Familie] foram um conjunto de textos teóricos e relatórios de pesquisa, com farta documentação relativa à coleta de dados por meio de questionários, e que, segundo Horkheimer, seu principal organizador, tinham a finalidade de apresentar as pesquisas mais recentes do Instituto e indicar o caminho que elas deveriam seguir a partir de então ${ }^{83}$. A pesquisa, já tendo sido iniciada previamente à nomeação de Horkheimer como diretor do Instituto, adquiriu consistência sob o influxo de suas reflexões programáticas, e para sua execução contribuiu o fornecimento de dados pela Organização Internacional do Trabalho, o que parece ter sido decisivo para a escolha de Genebra como localização da sucursal do Instituto inaugurada na cidade suíça já em 1931, em virtude do agravamento da situação política alemã ${ }^{84}$.

A escolha do tema da "autoridade" se devia às tendências sociais, políticas e culturais características da fase monopolista do capitalismo, tais como a ascensão dos movimentos e regimes fascistas (que assumiram o poder na Itália em 1922, e na Alemanha em 1933), a difusão de ideias autoritárias e irracionalistas tanto na filosofia quanto na arte, e o predomínio, em comparação com o período imediatamente posterior à primeira guerra mundial, de padrões conservadores nos âmbitos da família e da sexualidade. Como afirmava Horkheimer no prefácio:

\footnotetext{
${ }^{82}$ Cf. as considerações feitas por Fromm posteriormente à realização da pesquisa: Erich Fromm, "Arbeiter und Angestellte am Vorabend des Dritten Reichs - eine sozialpsychologische Untersuchung” [1980]. In: Erich Fromm, Gesamtausgabe, op. cit., vol. 3, p. 3 (trata-se do manuscrito redigido provavelmente ainda na década de 1930, e que Wolfgang Bonß haveria de publicar após a morte de Fromm).

${ }^{83}$ Cf. o prefácio de Horkheimer à obra: "Vorwort". In: Max Horkheimer; Erich Fromm; Herbert Marcuse (Orgs.). Studien über Autorität und Familie. Forschungsberichte aus dem Institut für Sozialforschung. Lüneburg: Dietrich zu Klampen, 1987, pp. VIII-XII. Fromm já se ocupava do tema e realizava pesquisas empíricas sobre ele desde 1929, ou seja, anteriormente ao ingresso de Horkheimer como diretor do Instituto, mas em uma época na qual Horkheimer ao que tudo indica já detinha considerávek influência sobre os rumos do Instituto. Sobre o papel de Horkheimer no planejamento e execução das pesquisas reina, contudo, pouca clareza. Cf. John Abromeit, Max Horkheimer and the foundations of the Frankfurt School, op. cit., pp. 194-195 e pp. 211-212. Além dos três, outros membros do Instituto, especialmente Löwenthal, também contribuíram para a reunião das pesquisas e a organização do volume. Cf., além do prefácio de Horkheimer, o pequeno texto de Ludwig von Friedeburg, escrito para a republicação da obra, feita em 1987 ("Vorbemerkung").

${ }^{84}$ Cf. Martin Jay, A Imaginação dialética, op. cit., p. 64. Ao afirmar que os tema da autoridade e da família são merecedores de uma maior atenção do que aquela que até então lhes havia sido concedida, ainda que não ocupem "uma posição central da teoria [marxista] da sociedade", Horkheimer exprime a mudança que, a partir de seu ingresso como diretor, sofreu a orientação programática do Instituto. Cf. Max Horkheimer, "Vorwort". In: Max Horkheimer et al.. Studien über Autorität und Familie, op. cit., p. XII. Embora a pesquisa tenha sido iniciada antes da nomeação de Horkheimer como diretor, a sua influência no Instituto aparentemente era grande já em fins dos anos vinte, e é provável que o autor tenha contribuído para a decisão do Instituto de empreender as pesquisas.
} 
“À medida que analisávamos o significado que as concepções políticas, morais e religiosas da época recente têm para a sociedade, mais claramente a autoridade aparecia como um fator decisivo. O fortalecimento da crença de que sempre deve haver um 'acima' e um 'abaixo', e de que a obediência é necessária, é uma das funções mais importantes da cultura, tal qual ela se constituiu até agora. É impossível compreender a interação entre as esferas culturais específicas sem considerar em detalhe esse momento" $"$.

A família atraiu a atenção dos pesquisadores por ser uma instituição que, ao mesmo tempo em que cumpria a função de "tornar os indivíduos receptivos à autoridade" 86 , havia sido diagnosticada como em crise: a crescente perda de seu papel de unidade de produção econômica, a concorrência de outras instituições na educação dos jovens (como o rádio e a própria escolarização, que apenas a partir de fins do século XIX passou a ser vista como uma tarefa do Estado), o atendimento, pelo Estado, de funções que antes cabiam exclusivamente à família (além da educação, sejam citadas também a previdência social e a saúde), e por fím, no período posterior à primeira guerra, a crise econômica e o desemprego haviam conduzido a um declínio da autoridade paterna, no qual os autores viam a fonte de mudanças na socialização familiar e no comportamento dos indivíduos: principalmente no período posterior à primeira guerra mundial, teria havido uma relativa suavização da moral repressora (uma mudança expressa, por exemplo, em certa liberalização dos costumes sexuais e no aumento das possibilidades de participação da mulher em esferas até então reservadas exclusivamente aos homens). Essa mudança teria sido acompanhada, entretanto, de um paradoxal reforço de traços autoritários nas diversas esferas culturais.

A perda pelo pai de seu papel de fonte praticamente exclusiva da autoridade familiar era um fenômeno vinculado ao capitalismo monopolista. Durante o capitalismo liberal que vigorou na maior parte do século XIX, a relação social de produção básica predominante nos âmbitos da indústria e do comércio, e que progressivamente se difundia para outros setores (como a agricultura, a educação, a arte etc.), era a relação entre indivíduos que se defrontavam no mercado na condição de vendedores ou compradores da força de trabalho, e apareciam como sujeitos econômicos independentes que perseguiam seu próprio interesse racional por meio do contrato. Nesse período, em que a concorrência ainda era um mecanismo fundamental, predominava o empreendimento econômico individual, sob o comando direto de seus proprietários, e o desempenho das empresas pequenas e médias dependia em grande parte da

\footnotetext{
${ }^{85}$ Max Horkheimer, "Vorwort”. In: Max Horkheimer et al.. Studien über Autorität und Familie, op. cit., p. VIII. ${ }^{86}$ Cf. o prefácio de Horkheimer à obra: Max Horkheimer, "Vorwort". In: Max Horkheimer et al.. Studien über Autorität und Familie, op. cit., p. VIII.
} 
solidariedade familiar: a família ainda conservava, portanto, parte das funções que havia exercido nos modos de produção anteriores, quando correspondia a uma unidade de produção econômica a congregar não apenas os parentes unidos por laços consanguíneos, mas também os servos ou escravos (familia no sentido próprio à Antiguidade). Dessa maneira, era comum que, pelo menos nos negócios de pequeno e médio porte, os membros da família desempenhassem nele um papel importante, principalmente os filhos homens que trabalhavam junto com o pai e cujo destino profissional preferencial seria herdar a empresa, e também, ainda que em menor medida, as filhas mulheres, antes do casamento. Além disso, no âmbito doméstico as diversas necessidades (de alimentação, vestuário, educação dos filhos etc.) ainda dependia em boa parte do trabalho realizado por membros da família ou, ressoando ainda aquele antigo sentido do termo, agregados e empregados domésticos. Essa situação inteira conferia ao pai, na condição de chefe da família, uma posição ímpar de autoridade sobre seus membros. Ela foi, entretanto, radicalmente alterada com o desenvolvimento do capitalismo monopolista: na era dos grandes conglomerados e das sociedades por ações em que a propriedade das empresas se tornou distinta de seu comando, o empresário individual, transformado em acionista, deixou de ser a figura dominante do capitalista, de maneira que tornava-se menos factível a relação entre o desempenho econômico das empresas e as suas habilidades pessoais. Por sua vez, a expansão do capital a setores econômicos cada vez mais amplos, que resultou por exemplo na formação das grandes casas comerciais (ancestrais de nossos supermercados e lojas de departamento), dispensou o lar do provimento de algumas das necessidades básicas de vida e conduziu à da perda do papel da família como unidade de produção econômica e também à perda em muitos casos mesmo da importância da herança, em uma sociedade em que a relação de trabalho assalariado se tornou predominante e se difundiu por antigas parcelas da burguesia. Disso tudo decorreu um significativo declínio da autoridade paterna ${ }^{87}$.

Mas a constatação, nos anos imediatamente anteriores à pesquisa, de uma revitalização de modelos conservadores de família e de padrões tradicionais de comportamento, em consonância com a disseminação de ideologias autoritárias e da ascensão dos movimentos fascistas, punha os autores diante de um paradoxo: a coexistência entre, de um lado, o declínio da autoridade paterna que se verificava sob o capitalismo monopolista em geral e, de outro, o reforço de modelos tradicionais de família nas décadas de vinte e trinta, período em que a

\footnotetext{
${ }^{87}$ Cf. Max Horkheimer, "Autorität und Familie in der Gegenwart”. In: Max Horkheimer, Gesammelte Schriften, vol. 5, pp. 378-379. Harry Braverman forneceu um relato pormenorizado da ampliação da relação assalariada de trabalho em seu Trabalho e Capital Monopolista - a degradação do trabalho no século XX. Tradução de Nathanael C. Caixeiro. Rio de Janeiro: LTC, 1987. Sobre esse ponto, especialmente pp. 231-236.
} 
Europa vivia um período de crise. Além da tarefa de averiguar o grau de difusão do "caráter autoritário" entre os trabalhadores, as pesquisas deveriam contribuir para a explicação desse $\operatorname{paradoxo}^{88}$.

A primeira seção da obra contém três textos. Em primeiro lugar, a "Parte Geral"89, escrita pelo diretor do Instituto: nela, Horkheimer faz considerações sobre o conceito marxista de história e as relações entre economia e cultura, de maneira a distinguir o marxismo de qualquer determinismo econômico e, ao mesmo tempo, defender a consideração, pela teoria social, dos fenômenos psíquicos que se dão ao nível dos indivíduos. Horkheimer ressalta também a importância dos temas da autoridade e da família, estreitamente vinculados: o primeiro se refere à aceitação da dominação social pelos indivíduos - um fenômeno que, se por um lado se estende por toda a história ao longo da qual se pode falar de alienação, teria assumido um significado específico no capitalismo, dada a separação entre os produtores diretos e os meios de produção - o segundo, ao papel da socialização familiar na internalização dessa dominação, no âmbito do processo de formação psíquica do indivíduo. Em segundo lugar, temse a "Parte sociopsicológica" 90 , em que Fromm, em um interesse conjunto ao de Horkheimer, embora com diferenças que examinaremos posteriormente, apresenta elementos gerais de psicanálise, mostra como a constituição social da "autoridade" tem seu equivalente individual no "supereu" e desenvolve sua teoria do "caráter autoritário", entendido como o conjunto de traços de personalidade que, com origem nos impulsos psíquicos sadomasoquistas, constituemse predominantemente a partir do fato de a relação de autoridade ser fonte de gratificação pulsional, resultando em indivíduos suscetíveis a associar prazer e relações sociais de autoridade caracterizadas pela opressão dos mais fracos ou subordinados, a par da submissão aos superiores. Esse conceito desempenhou um papel central nas pesquisas feitas entre 1929 e 1936, orientando a formulação das perguntas contidas nos questionários e a avaliação das

\footnotetext{
${ }^{88}$ Cf. Max Horkheimer, "Vorwort", op. cit., p. X. Sobre a avaliação acerca das oscialações da moral sexual no período do entre-guerras, cf. a segunda seção dos Studien über Autorität und Familie, op. cit., p. 272. Na avaliação feita pelos organizadores, concorreram também as pesquisas acerca da instituição familiar feitas, no período, pela sociologia alemã e europeia em geral. Cf. Herbert Marcuse, "Autorität und Familie in der deutschen Soziologie bis 1933". In: Max Horkheimer et al.. Studien über Autorität und Familie, op. cit., pp. 739-752, especialmente, para esse ponto. pp. 751-752. Cf. também Alfred Meusel, "Deutsche Gesellschaftsauffassung seit 1933", no mesmo livro, pp. 753-770. Sobre os modelos tradicionias de família, cf. a contribuição de Alfred Meusel ao volume: "Die Familie in der deutschen Gesellschaftsauffassung seit 1933". In: Max Horkheimer et al.. Studien über Autorität und Familie, op. cit.. pp. 753-770. Sobre o mesmo assunto se deteve Wirttfogel, nas passagens finais de sua contribuição: Karl August Wittfogel, "Wirtschaftsgeschichtliche Grundlagen der Entwicklung der Familienautorität", op. cit., p. 521. As questões da pesquisa nem sempre são enunciadas com clareza: a essas indicações esparsas some-se o trabalho interpretativo dos comentadores.

${ }^{89}$ Max Horkheimer, “Allgemeiner Teil”. In: Max Horkheimer et al.. Studien über Autorität und Familie, op. cit., pp. 3-75.

${ }^{90}$ Erich Fromm, "Sozialpsychologischer Teil”. In: Max Horkheimer et al. Studien über Autorität und Familie, op. cit., pp. 77-135.
} 
respostas a elas. O terceiro texto é o de Marcuse, a "Parte de história das ideias"91 , que apresenta o modo como o tema da autoridade foi tratado por Lutero, Calvino, Kant, Hegel, Marx, pensadores da contrarrevolução aristocrática (como Burke) e do autoritarismo contemporâneo (Pareto). A segunda seção continha amostras de questionários, informações sobre sua aplicação e os interesses temáticos específicos que nortearam cada um dos levantamentos, descrições dos grupos de respondentes, as próprias perguntas e avaliações mais ou menos extensas acerca do material recolhido. A terceira seção continha contribuições individuais sobre o tema que, escritas seja por membros ou colaboradores ocasionais do Instituto, tinham um caráter extremamente variado, o mais das vezes destoando bastante das formulações dos organizadores (que eram também os autores dos textos da primeira seção), fosse pelo ponto de vista teórico adotado (como no caso do texto de Wittfogel, que se aproxima muito mais do marxismo economicista que havia sido cultivado no Instituto à época em que Grünberg era seu diretor ${ }^{92}$ ), fosse pelo tema (como os estudos sobre a moral sexual dos jovens, feitos por Fritz Jungmann e Marie Jahoda-Lazarsfeld ${ }^{93}$ ), fosse pela própria vinculação disciplinar do estudo (como é o caso do estudo de Ernst Schachtel sobre os aspectos jurídicos do fenômeno da autoridade família contemporânea ${ }^{94}$, ou do texto sobre "o significado da biologia para a sociologia, relativamente ao problema da autoridade", escrito por Kurt Goldstein, psiquiatra que Horkheimer havia conhecido em Frankfurt, quando de seu interesse pela teoria da Gestalt ${ }^{95}$ ).

Além de inacabada (dado o fato de que as informações recolhidas por meio dos questionários não foram elaboradas, sendo apresentadas apenas algumas amostras dos "dados brutos") e de caráter programático (dadas as suas funções de fornecer uma amostra do trabalho feito pelo Instituto até então, assim como de apresentar a temática a que se pretendia que as pesquisas futuras dessem continuidade), os estudos contidos na publicação eram também experimentais, pois ali os organizadores se aventuravam no emprego de técnicas de pesquisa

\footnotetext{
${ }^{91}$ Herbert Marcuse, "Ideengeschichtlicher Teil”. In: Max Horkheimer et al. Studien über Autorität und Familie, op. cit., pp. 136-228.

${ }^{92}$ Karl August Wittfogel, "Wirtschaftsgeschichtliche Grundlagen der Entwicklung der Familienautorität”. In: Max Horkheimer et al. Studien über Autorität und Familie, op. cit., pp. 473-522.

${ }^{93}$ Fritz Jungmann, “Autorität und Sexualmoral in der freien bürgerlichen Jugendbewegung”. In: Max Horkheimer et al. Studien über Autorität und Familie, op. cit., pp. 669-705; Marie Jahoda-Lazarsfeld, “Autorität und Erziehung in der Familie, Schule und Jugendbewegung Oesterreichs”. In: Max Horkheimer et al. Studien über Autorität und Familie, op. cit., pp. 706-725.

${ }^{94}$ Ernst Schachtel, "Das Recht der Gegenwart und die Autorität in der Familie". In: Max Horkheimer et al.., Studien über Autorität und Familie, op. cit., pp. 587-642.

${ }^{95}$ Kurt Goldstein, "Bemerkungen über die Bedeutung der Biologie für die Soziologie anlässlich des Autoritätsproblems”. In: Max Horkheimer et al.. Studien über Autorität und Familie, op. cit., pp. 656-668.
} 
típicas da pesquisa social norte-americana, como questionários e entrevistas ${ }^{96}$. Com elas não tinham familiaridade quase alguma não apenas os filósofos Horkheimer e Marcuse, mas também o sociólogo Fromm, que havia se doutorado sob a orientação de Alfred Weber em Heidelberg, na tradição da sociologia alemã da cultura, e apesar de Horkheimer assegurar ${ }^{97}$ que as exposições teóricas da primeira seção (os textos escritos, respectivamente, por ele, Fromm e Marcuse) foram desenvolvidas a partir do material da segunda e da terceira seções, de feição eminentemente empírica, é certeiro o comentário feito por Ludwig von Friedeburg quando da republicação da obra: "os esboços teóricos [ele se refere aos textos da primeira seção] têm, cada um, o seu lugar nas obras de Horkheimer, Fromm e Marcuse" 98 .

Extravasando essa discrepância entre as duas partes principais da obra (a parte "teórica" e a "empírica") do âmbito restrito do volume coletivo para o âmbito mais amplo do programa de pesquisas do Instituto, isso poderia levar à suposição de que a intenção de Horkheimer de promover uma "interpenetração e desenvolvimento dialéticos e contínuos da teoria filosófica e da prática científica especializada" 99 teria falhado. Voltaremos a essa questão mais adiante na tese, quando examinarmos os ensaios de Horkheimer. É preciso, antes de tudo, uma análise das pesquisas empíricas conduzidas pelo Instituto.

\footnotetext{
${ }^{96}$ Horkheimer ressaltava, por isso, a importância que teve para essa decisão o seu contato com a famosa pesquisa de campo que deu origem à obra Middletown, de Robert e Helen Lynd. Cf. Max Horkheimer et al.., Studien über Autorität und Familie, op. cit., p. X.

97 Cf. Max Horkheimer, "Vorwort", op. cit., p. IX.

${ }^{98}$ Ludwig von Friedeburg, "Vorbemerkung". In: Max Horkheimer et al. Studien über Autorität und Familie, op. cit., p. XIII.

99 Max Horkheimer, "Die gegenwärtige Lage der Sozialphilosophie und die Aufgaben eines Instituts für Sozialforschung”. In: Max Horkheimer, Gesammelte Schriften. Alfred Schmidt e Gunzelin Schmid Noerr (Orgs.). vol. 3. Frankfurt am Main: Fischer, 1985 [1931], p. 29.
} 
$\underline{1.3-\text { As pesquisas sobre autoridade e família }}$

A ideia fundamental da pesquisa com trabalhadores e funcionários era, segundo o seu coordenador, Erich Fromm, prever em que medida a classe trabalhadora alemã estaria disposta a resistir ou, por outro lado, aderir ao nazismo. Eram bastante expressivos os partidos e sindicatos social-democratas e comunistas, e o partido social-democrata (SPD) havia vencido várias eleições entre os anos de 1926 e 1931 - ainda assim, entretanto, esse número elevado e a força dessas organizações não seriam suficientes para garantir qual rumo tomariam mesmo os indivíduos a elas filiados, como a história veio depois a demonstrar ${ }^{100}$. Para aferir com maior precisão a tendência a se esperar seria imperioso conhecer as motivações psíquicas que poderiam conduzir o proletariado seja a um movimento de resistência da esquerda, seja ao encontro do fascismo:

"O ponto de partida da investigação é a suposição teórica de que opiniões que são defendidas em um determinado momento do tempo se mostram pouco confiáveis quando as circunstâncias mudam drasticamente. Em si, uma opinião é nada mais do que a aceitação de modelos de pensamento, que a sociedade em geral compartilha ou são defendidos por um grupo particular, no caso pelos trabalhadores e funcionários alemães. Presumimos que apenas representam motivações fortes para o agir aquelas opiniões que estão enraizadas na estrutura de caráter dos homens (...) Inferimos dessa suposição que apenas quando conhecêssemos com precisão a estrutura de caráter dos trabalhadores e funcionários alemães seria possível prever a sua provável reação a uma vitória do nacional-socialismo" 101 .

\footnotetext{
100 Segundo informação do próprio Fromm, em 1930 os social-democratas ocupavam 193 dos 577 assentos do parlamento alemão, e os comunistas, 77. Cf. Erich Fromm, "Arbeiter und Angestellte am Vorabend des Dritten Reichs", op. cit., p. 41.

${ }^{101}$ Erich Fromm, "Arbeiter und Angestellte am Vorabend des Dritten Reichs", op. cit., p. 3. A inclusão dos funcionários foi feita a par da tese de que a "classe média baixa" à qual eles pertenciam seria um ponto de apoio fundamental para o fascismo (p. 126) . Essa tese já fora defendida por Wilhelm Reich no mesmo período da realização da pesquisa e da publicação dos "Estudos sobre Autoridade e Família". Em seu livro Psicologia de Massas do Fascismo, publicado pela primeira vez em 1933, Reich afirmava: “(...) não devemos esquecer que o movimento nacional-socialista, na sua primeira arrancada vitoriosa, apoiou-se em largas camadas das chamadas classes médias, isto é, os milhões de funcionários públicos e privados, comerciantes de classe média e agricultores de classe média e baixa. Do ponto de vista da base social, o nacional-scoialismo foi sempre um movimento da classe média baixa (...)". Cf. Reich, Psicologia de Massas do Fascismo. $2^{a}$ edição. Tradução de Maria da Graça Macedo. São Paulo: Martins Fontes, 1988, p. 52 (itálico do autor).
} 
A indicação de Horkheimer ${ }^{102}$ acerca da construção dos "tipos" como o alvo dos esforços teóricos da pesquisa confirma a relevância da tipologia caracterológica desenvolvida por Fromm, responsável por fornecer os conceitos fundamentais para a averiguação de qual seria a estrutura psíquica predominante entre os indivíduos que responderam aos questionários: na segunda seção da obra, os registros dos levantamentos são cotejados com os conceitos de: a) "caráter autoritário", no qual a submissão à autoridade exerceria o papel de principal fonte de gratificação pulsional; b) "caráter revolucionário", no qual essa fonte desapareceria e o indivíduo seria por isso tendencialmente antiautoritário; e c) "caráter ambivalente", que seria uma manifestação específica do caráter autoritário, mas na qual os traços autoritários da personalidade se encontrariam de maneira menos extremada e quase sempre misturados a posturas ,progressistas. A expectativa de Fromm, que havia iniciado a pesquisa em 1929 (ou seja, quatro anos antes da ascensão do nazismo), era de que os indivíduos pertencentes ao proletariado estariam mais propensos a ter uma estrutura antiautoritária de caráter, em virtude de não terem passado pelo mesmo processo de interiorização psíquica da coerção social que fez parte da história da ascensão da burguesia e se exprimiu na ética do trabalho e do dever cultivada por esse última ${ }^{103}$.

\footnotetext{
${ }^{102}$ Max Horkheimer, "Vorwort". In: Max Horkheimer et al.., Studien über Autorität und Familie, op. cit., p. X. 103 Cf. Erich Fromm, "Die sozialpsychologische Bedeutung der Mutterrechtstheorie". In: Erich Fromm, Gesamtausgabe, op. cit., vol. 1. p. 107 infra. Se Fromm deu bastante atenção ao tipo autoritário de caráter (cf. o item deste capítulo sobre a teoria do caráter autoritário de Fromm), o mesmo não sucedeu com os dois outros tipos. $\mathrm{O}$ "caráter revolucionário" era definido como aquele em que os impulsos sado-masoquistas estariam diminuídos em grau considerável ou mesmo desapareceriam: o desaparecimento da autoridade enquanto traço fundamental da estrutura de caráter seria uma "revolução em sentido psicológico", que tornaria esses indivíduos mais dispostos do que outros à participação em movimentos de libertação e à fundação de uma sociedade em novas bases, em que as relações de autoridade não tivessem mais aquele componente psicológico "regressivo", isto é, não se apoiassem mais no sado-masoquismo. Cf. Erich Fromm, "Sozialpsychologischer Teil", op. cit., pp. 130-132. Mais de trinta anos depois, na introdução escrita por volta de 1970 com vistas à republicação estendida dessas pesquisas, Fromm empregou o termo "anti-autoritário". Ainda que na opção por esse último adjetivo possa ter pesado o afastamento do autor em relação aos temas da revolução e da luta de classes, é possível também atribuí-la meramente aos resultados a que chegou a pesquisa após a contabilização estatística das respostas, feita ainda nos anos trinta, no período do exílio norte-americano, e que confirmou aquilo de que a história viria a dar provas e que desautorizava possíveis esperanças revolucionárias ainda cultivadas pelos autores no início dos anos trinta: a ampla difusão de tendências autoritárias entre os trabalhadores alemães. Sobre o tipo ambivalente, que ao final das contas haveria de se revelar o predominante, a única informação disponível, reproduzida acima no corpo do texto, se encontra no relatório da pesquisa sobre trabalhadores e funcionários, contido nos "Estudos sobre autoridade e família" e de autoria incerta, mas provavelmente redigido por Fromm ou por Hilde Weiß, assistente de pesquisa do Instituto à época. Cf. "Arbeiter- und Angestelltenerhebung". In: Max Horkheimer et al., Studien über Autorität und Familie, op. cit., p. 249. Essa definição se confunde, entretanto, com aquela do "caráter rebelde", descrito por Fromm como um subtipo do caráter autoritário, no qual a tendência à revolta se apoiaria em larga medida nos mesmos impulsos sado-masoquistas e portanto, nos termos de Fromm, resultaria no comportamento político de indivíduos que se insurgem contra a autoridade vigente apenas para substituí-la por outra. Cf. Erich Fromm, "Sozialpsychologischer Teil", op. cit., pp. 130-131. Os problemas da teoria do caráter autoritário elaborada por Fromm são discutidos mais adiante.
} 
Cinco foram as pesquisas relativas aos temas da autoridade e da família feitas nos primeiros anos em que o Instituto esteve sob a direção de Horkheimer. Seus resultados preliminares estão contidos na segunda seção dos "Estudos sobre Autoridade e Família". A primeira pesquisa, realizada entre 1929 e 1931, tinha por objeto a "estrutura de caráter" predominante entre os trabalhadores alemães no início da década de 1930: realizada, segundo Fromm, com vistas a prever qual seria a postura desses trabalhadores diante da provável ascensão do nazismo, o objetivo da pesquisa era averiguar em que medida as opiniões políticas dos trabalhadores - a maioria votantes de partidos de esquerda - convergiam ou não com sua estrutura psíquica. Essa era a pergunta de primeiro plano da pesquisa, e a consideração do papel da família na formação do "caráter autoritário" conduziu aos demais levantamentos: uma segunda pesquisa foi realizada em 1932 com cerca de 360 médicos alemães, e tinha por finalidade obter informações a respeito das mudanças pelas quais, no período do entre-guerras, teria passado o comportamento sexual da população alemã. Essa teria se tornado mais conservadora, e essas mudanças eram vistas como um indício do aumento de posturas autoritárias. Após essas duas primeiras pesquisas os membros do Instituto voltaram sua atenção para as relações de autoridade no âmbito da família europeia da época: a terceira pesquisa, realizada em 1933, consistiu na aplicação de questionários sobre o tema, e os respondentes eram professores universitários de psicologia e pedagogia, professores de escolas, líderes de organizações políticas e religiosas juvenis, assistentes sociais, membros do judiciário que estivessem em contato com questões ligadas aos jovens, padres e pastores. Devido à impossibilidade do prosseguimento das pesquisas na própria Alemanha após o fechamento do Instituto pelo governo nazista, os questionários dessa terceira pesquisa foram aplicados em outros países europeus (Bélgica, França, Holanda, Áustria e Suíça), e dos 589 questionários enviados foram devolvidos $251^{104}$. A quarta pesquisa foi feita com jovens suíços, que responderam a perguntas sobre as relações de autoridade entre eles e seus pais - dos 1000 questionários aplicados, 508 foram respondidos; sobre a quinta pesquisa, que tinha por objetivo aferir a influência da situação de desemprego sobre a autoridade exercida pelo pai no âmbito da família, os autores informam que foi iniciada na França, mas não é indicado o número dos questionários aplicados e respondidos, e nem fornecido qualquer resultado. De qualquer maneira, devido à falta de recursos no período em que o Instituto estava no exilio, esse último levantamento teve um alcance muito limitado e foi retomado apenas nos Estados Unidos,

\footnotetext{
${ }^{104}$ Um levantamento com base no mesmo questionário foi iniciado um pouco mais tarde na Inglaterra, e dele o volume dá algumas notícias preliminares. Cf. Max Horkheimer et al.., Studien über Autorität und Familie, op. cit., pp. 292 e 351.
} 
quando seu enfoque também foi modificado, pois então a pesquisa teve por objeto a relação dos desempregados com as instituições de assistência social que proviam o seu sustento - disso a publicação de 1936 dá uma amostra meramente preliminar, a partir dos poucos questionários (20) até então aplicados ${ }^{105}$.

Essa última pesquisa, devido à pouca importância em relação às demais, à quase inexistência de resultados significativos e à distância temática do segundo levantamento em relação às preocupações gerais dos "Estudos", não será objeto de nossa atenção. A quarta pesquisa, conduzida por Käthe Leichter na Suíça (ela não recorreu à psicologia social de Fromm), também não trouxe resultados significativos, apesar de extensa: ela consistiu basicamente em uma tentativa de medir quantitativamente o grau de influência dos pais na educação dos filhos, por meio de uma classificação simplista do comportamento dos filhos em dois tipos básicos - "autoridade abrangente" e "revolta" - pouco elaborados conceitualmente ${ }^{106}$. Apesar de alguns dados interessantes sobre as especificidades nacionais que tornavam a família uma instituição coesa tanto na França quanto na Suíça ${ }^{107}$, o estudo chegou a algumas conclusões tautológicas ${ }^{108}$, e boa parte da intenção dos textos é fornecer informações metodológicas sobre a realização da pesquisa ${ }^{109}$.

A seguir faz-se uma rápida síntese das questões que orientaram a segunda e a terceira pesquisas e dos resultados a que elas chegaram. Depois disso, analisamos com mais vagar a

105 Cf. Erich Fromm, "Geschichte und Methoden der Erhebungen”. In: Max Horkheimer et al. Studien über Autorität und Familie, op. cit., pp. 232-236. Cf. também as informações relatadas junto a cada conjunto de relatórios, na segunda seção do volume. Sobre o direcionamento dado às pesquisas parecem ter contribuído também o longo trato dos membros e colaboradores do Instituto com a bibliografia sobre o tema da família produzida pela sociologia europeia e norte-americana. Além das já mencionadas contribuições individuais publicadas na terceira parte da obra, a seção de resenhas da Revista do Instituto mantinha os autores a par das transformações pelas quais passava a família nas primeiras décadas do século XX.

${ }^{106}$ Cf. Max Horkheimer et al.., Studien über Autorität und Familie, op. cit., pp. 391-392. Uma das preocupações era saber qual a influência da aplicação de castigos físicos no grau de confiança que os filhos tinham nos pais, o que erra medido por meio de técnicas quantitativas (cf. p. 400). Isso foi feito quando do tratamento estatístico dos questionários por Paul Lazarsfeld, no período do exílio norte-americano. As perguntas se concentravam sobre as relações de poder no interior da família, e as relações de autoridade em outros âmbitos não foram consideradas (como o tinham sido, de maneira proveitosa, na primeira das pesquisas), ainda que as respostas fossem corelacionadas com outras variáveis (a de "classe", por exemplo, compreendida como nível de renda das famílias). 107 Tratava-se da ausência, nesses países, de diferenças socio-psicológicas significativas entre o proletariado e a classe média, devido às peculiaridades do mercado de trabalho. As inferências feitas a esse respeito são, contudo, fundamentadas de maneira bastante precária. Cf. Max Horkheimer et al.., Studien über Autorität und Familie, op. cit., pp. 364-414 e pp. 448-454.

${ }^{108}$ Por exemplo: “(...) quando os pais cuidam dos assuntos dos filhos mais intensamente, cresce a confiança dos filhos neles”. Cf. Max Horkheimer et al.., Studien über Autorität und Familie, op. cit., p. 399 infra. Cf. também a conclusão à p. 412: “(...) as chances de revolta [dos filhos] são maiores onde a autoridade é menor, e vice-versa”. ${ }^{109}$ Cf. a página 418, onde os próprios autores afirmam que sua intenção na apresentação dos relatórios é fornecer informações metodológicas sobre a formulação, aplicação e interpretação dos questionários. Além disso, as respostas dos especialistas ao tema da pesquisa não foram interpretadas, e aparecem em estado bruto no livro (o que é pouco compreensível, dada a alegada falta de espaço e à necessidade de apresentar os estudos da terceira seção em forma reduzida). 
principal, mais importante e primeira das pesquisas, aquela com trabalhadores e funcionários alemães.

A segunda e a terceira pesquisas chegaram à conclusão de que teria havido, no período posterior à primeira guerra, um processo de emancipação da mulher, expresso tanto em maior liberdade sexual quanto no aumento de sua participação nas decisões familiares sobre o consumo e a educação os filhos ${ }^{110}$. As pesquisas também constataram a existência de estruturas de autoridade fundamentalmente diferentes quando se comparavam as famílias camponesas com as das cidades: em virtude das diferenças da divisão social do trabalho (no campo, a família ainda era em larga medida uma unidade de produção econômica), nas famílias camponesas o pai exercia um papel de autoridade que tenderia ao declínio nas famílias urbanas:

"[Das informações constantes dos questionários respondidos pelos especialistas] resulta a imagem geral de que a família camponesa representa um tipo mais extremado da família patriarcal do que a família dos trabalhadores urbanos. Em todas as perguntas, nas quais o poder do pai desempenha algum papel, esse poder é significativamente maior dentre os camponeses do que em meio aos trabalhadores urbanos. As despesas e a mesada são determinadas, nas famílias desses últimos, pela mãe, e junto aos camponeses pelo pai - nas famílias camponesas, é apenas o pai quem pune os filhos, e nas famílias dos trabalhadores urbanos a mãe também é mencionada em um número grande de casos. A influência do pai é maior entre os camponeses também no que diz respeito à educação"111.

A terceira pesquisa também constatou que a participação das crianças e jovens em organizações recreativas e desportivas conduziria, na opinião dos especialistas, a um declínio do papel da família em sua socialização ${ }^{112}$ (concomitantemente, o papel da mulher na família aumentava à medida em que a instituição diminuía sua importância na socialização dos jovens) ${ }^{113}$.

O interesse dessas pesquisas era, portanto, verificar em que medida era verdadeira a hipótese do declínio da autoridade paterna, e aferir também o papel da mulher na família e as possíveis tendências à sua emancipação. Embora a psicanálise ocupasse um lugar central no

\footnotetext{
${ }^{110}$ Cf. Max Horkheimer et al.., Studien über Autorität und Familie, op. cit., p. 273, pp. 303-305 e pp. 315-316. Essas pesquisas também elaboraram, em um nível ainda elementar, tipificações dos especialistas (médicos, assistentes sociais, professores etc.) que responderam aos questionários, esboçando ainda que em nível bastante incipiente uma sociologia dessas profissões.

${ }^{111}$ Cf. Max Horkheimer et al.., Studien über Autorität und Familie, op. cit., p. 317.

112 Cf. Max Horkheimer et al.., Studien über Autorität und Familie, op. cit., pp. 318-320.

113 Outras questões foram abordadas nessa pesquisa, como os fatores que conduziriam a mulher a assumir uma posição mais ou menos influente nas relações familiares, a influência que a educação sexual teria sobre essas relações, e também questões ligadas à criminalidade juvenil. Contudo, o extremo grau de subjetivismo que incidia nas respostas dadas pelos especialistas a perguntas desse tipo as tornava pouco apropriadas para fornecerem um quadro das rerlações familiares no entre-guerras.
} 
programa de pesquisas de Horkheimer e na psicologia social de Fromm, esse temário ocupava um lugar importante no marxismo desde Engels, e a atenção de Fromm a esse conjunto de questões foi dirigida pelas teorias do matriarcado. A sociedade matriarcal, tal qual concebida por Bachofen, apresentaria muitos traços em comum com o modo comunista de produção, e essa concepção se associou, no interior do movimento socialista, à luta pela emancipação da mulher: as duas lutas - pela emancipação da mulher e pela superação do capitalismo - eram unidas pela ideia de que a dominação patriarcal estaria intimamente vinculada ao caráter de classe da sociedade capitalista ${ }^{114}$. Fromm se interessava principalmente pelos aspectos sociopsicológicos dessa vinculação:

\begin{abstract}
“A estrutura social patriarcal é vinculada em suas bases sociopsicológicas ao caráter de classe da sociedade vigente. Essa repousa em não pequena medida em determinadas tendências psíquicas, em parte inconscientes, que complementam de maneira eficientíssima a coerção externa exercida pelo aparato de dominação"115.
\end{abstract}

A interpretação das sociedades matriarcais como formas de sociabilidade em que as relações de dominação estariam ausentes provavelmente influiu sobre o conceito de "caráter revolucionário" de Fromm, que é o simétrico exato do "caráter patricêntrico" formulado no texto de 1934 em antecipação ao conceito de "caráter autoritário" de mesmo conteúdo, desenvolvido no tex to de 1936. Esse tipo de caráter repousaria em "supereu severo, sentimentos de culpa, amor submisso à autoridade paterna, vontade de dominação dos mais fracos" e teria sido uma força produtiva que permitiu a internalização da coerção social e da dominação, transformadas nos indivíduos pertencentes à burguesia em uma "ética do trabalho"116

Essa é também a questão que orienta a primeira das pesquisas: realizada entre os anos de 1929 e 1931, ela tinha por objeto a "estrutura de caráter" de trabalhadores alemães, e foi a mais importante das cinco pesquisas, pois correspondia diretamente aos interesses de investigação formulados por Horkheimer em seu discurso de posse ${ }^{117}$ - além disso, ela originou os demais levantamentos, que podem ser vistos como desdobramentos do primeiro. O extenso

\footnotetext{
${ }^{114}$ A dominação da mulher seria a garantia da transmissão hereditária da propriedade privada, que tornada patrilinear em oposição à coletividade "fraterna" e "democrática" que teria vigido nas sociedades matriarcais, expressão de uma organização social voltada ao bem-estar e à felicidade dos indivíduos. Cf. Fromm, "Die sozialpsychologische Bedeutung der Mutterrechtstheorie", Gesamtausgabe, op. cit., vol. 1, p. 92 e pp. 94-101. No âmbito do movimento socialista, teve grande destaque o livro de Bebel, A Mulher e o Socialismo, que segundo Fromm foi durante anos a obra mais lida pelos marxistas.

${ }^{115}$ Cf. Erich Fromm, "Die sozialpsychologische Bedeutung der Mutterrechtstheorie”, op. cit., p. 97.

${ }^{116}$ Cf. Erich Fromm, "Die sozialpsychologische Bedeutung der Mutterrechtstheorie", op. cit., p. 104 e p. 107.

${ }^{117}$ Cf. Cf. Max Horkheimer, "A presente situação da filosofia social e as tarefas de um instituto de pesquisa sociais", op. cit., pp. 130-131.
} 
questionário (271 perguntas) ${ }^{118}$ foi distribuído a 3000 trabalhadores fabris, funcionários de escritório e funcionários públicos de baixo escalão, que devolveram 1150 questionários respondidos ${ }^{119}$. Desses 1150 questionários respondidos, apenas 584 foram avaliados, dos quais a absoluta maioria (537) era de questionários respondidos por homens (apenas 47 questionários foram respondidos por mulheres). A maior parte dos questionários (71\%) havia sido distribuída em áreas urbanas situadas entre Frankfurt e Berlim. Dentre os trabalhadores fabris, estavam principalmente tipógrafos, telhadeiros e mestres de oficina, e a composição profissional do conjunto de trabalhadores que responderam ao questionário era a seguinte: mais da metade era composta por trabalhadores manuais com formação técnica $(55 \%)$, pouco menos de um terço eram funcionários de empresas privadas ou do serviço público (29\%), poucos eram os trabalhadores manuais sem formação técnica (9\%) e menos ainda os profissionais autônomos, estudantes e donas de casa (7\%). Desse universo, cerca de um sétimo se encontrava em situação de desemprego à época da pesquisa $(16 \%)^{120}$. A imensa maioria dos trabalhadores que responderam aos questionários votava em partidos de esquerda (79\%), e um traço comum a eles era a sua forte vinculação a sindicatos, principalmente a sindicatos controlados pelo partido social-democrata (SPD). Além disso, em todas as empresas nas quais trabalhavam os respondentes - à exceção das microempresas de menos de dez funcionários - havia comissões de fábrica atuantes ${ }^{121}$.

${ }^{118}$ Cf. Max Horkheimer et al.., Studien über Autorität und Familie, op. cit., pp. 240-248.

${ }^{119} \mathrm{Na}$ versão da pesquisa publicada em 1980, Fromm falaria em 3300 questionários distribuídos quando dessa primeira pesquisa. Cf. Erich Fromm, "Arbeiter und Angestellte am Vorabend des Dritten Reichs”, op. cit., p. 7. Responsável pela condução da pesquisa foi uma assistente de pesquisa do Instituto, Hilde Weiß, que ao que tudo indica também redigiu o texto dos "Estudos" que apresenta a pesquisa. Sua familiaridade com os temas que à época faziam parte da sociologia do trabalho alemã e europeia, e também com as pesquisas empíricas que tinham por objeto processos e relações de trabalho foi indispensável para a realização dos "Estudos", a ponto de Wolfgang Bonß afirmar que "sem a colaboração de Hilde Weiß o estudo provavelmente não teria sido feito". Cf. Wolfgang Bonß, "Psychoanalyse als Wissenschaft und Kritik. Zur Freudrezeption der Frankfurter Schule". In: Wolfgang Bonß; Axel Honneth (Orgs.). Sozialforschung als Kritik, op. cit., p. 418 (nota 19).

${ }^{120}$ Não há detalhes sobre quais espécies de funcionários de escritório e funcionários públicos responderam ao questionário, mas nas respostas que constam do volume como exemplos podem-se encontrar um policial, um assistente administrativo, um corretor e uma vendedora. Cf. Erich Fromm, "Arbeiter und Angestellte am Vorabend des Dritten Reichs”, op. cit., p. 7 e também, sobre o número de questionários respondidos e o perfil dos respondentes, especialmente p. 23, p. 32 e p.35.

${ }^{121}$ Dos 584 respondentes, 451 (77\%) eram sindicalizados, e um terço desses exercia funções oficiais no âmbito do respectivo sindicato. Dos 451 trabalhadores sindicalizados, a absoluta maioria (92\%) era filiada a sindicatos controlados pelo partido social-democrata (SPD), e o mesmo partido tinha sob seu controle a quase totalidade das comissões de fábrica. $53 \%$ dos trabalhadores que participaram da pesquisa votavam nos social-democratas, $26 \%$ nos comunistas, apenas $7 \%$ nos partidos da direita liberal e apenas 3\% no partido nacional-socialista. Essa distribuição correspondia, segundo Fromm, à distribuição das preferências partidárias da população alemã da época. Cf. Erich Fromm, “Arbeiter und Angestellte am Vorabend des Dritten Reichs”, op. cit., pp. 36-41. Um dado interessante, que revelava a proximidade desses trabalhadores com orientações políticas de inspiração socialista e marxista, era a quantidade de ateus: $57 \%$, em comparação com $25 \%$ de protestantes, $11 \%$ de católicos e $7 \%$ de judeus e outras minorias religiosas. 
O questionário foi aplicado por voluntários que tivessem fácil acesso aos trabalhadores, tais quais funcionários de sindicatos, médicos e professores da educação de $\operatorname{adultos}^{122}$, e se dividia entre duas principais ordens de perguntas. De um lado havia as perguntas relativas à "situação real de vida", isto é, perguntas que tinham por fim obter dados pessoais (como o estado civil, o ano de nascimento e a origem dos respondentes) assim como informações relativas à profissão dos respondentes e à sua renda, sua formação, suas condições de moradia e seu acesso a bens de consumo. De outro lado, as questões se referiam, segundo a própria divisão estabelecida pelos autores, aos seguintes grupos temáticos ${ }^{123}$ : convicções políticas (perguntando, por exemplo, se o respondente participava ou não do conselho de fábrica da empresa e do sindicato, em qual partido votava e de qual jornal ou revista mais gostava); visão de mundo (perguntas sobre crença religiosa, sobre o papel do destino na vida e sobre a possibilidade de os indivíduos mudarem a história, assim como perguntas sobre temas como a participação da mulher na vida social, o aborto, o vegetarianismo, a educação dos filhos e o papel que nela deveriam ter os castigos físicos e o esclarecimento sobre questões sexuais); questões de gosto (por exemplo, os tipos de filme, teatro e programas de rádio preferidos, e também a opinião sobre os cortes curtos de cabelo à la garçonne, então na moda entre as mulheres, sobre o jazz e a arquitetura moderna que à época se começava a praticar na Europa); uso do tempo livre (prática de esportes, atividades de fim-de-semana, hobbies); e todas essas questões se orientavam ao tema central da pesquisa, às relações de autoridade na família e fora dela (perguntando sobre os papéis do marido e da esposa na vida familiar, a relação com os colegas e os superiores hierárquicos no trabalho, a opinião sobre o sistema de justiça da época e sobre qual seria a forma ideal de governo). Além disso, em consonância com o referencial teórico da pesquisa, o questionário também continha perguntas que pretendiam aferir diretamente alguns traços de caráter dos respondentes, como avareza e hipocondria, de acordo com o conceito de "caráter autoritário" elaborado por Fromm a partir das indicações de Freud referentes ao sadomasoquismo e ao erotismo da fase anal ${ }^{124}$.

As perguntas sobre visão de mundo e gosto eram especialmente importantes, pois abordavam fatores apenas indiretamente influenciados pela concepção política, e todas essas perguntas foram misturadas para que não ocasionassem desconfiança nos respondentes ou os levassem a tentar produzir, para um conjunto de questões semelhantes, uma coerência artificial

\footnotetext{
${ }^{122}$ Cf. Erich Fromm, “Arbeiter und Angestellte am Vorabend des Dritten Reichs”, op. cit., pp. 14-15. Essa obra contém muito mais informações sobre a condução da pesquisa e as concepções que a norteraram do que os textos contidos no volume de 1936.

${ }^{123}$ Max Horkheimer et al., Studien über Autorität und Familie, op. cit., pp. 248-249.

${ }^{124} \mathrm{Cf}$., para mais detalhes, o item sobre a teoria do caráter autoritário de Fromm.
} 
nas respostas. A ideia subjacente ${ }^{125}$ era verificar se havia correspondência entre as ideologias políticas professadas pelos trabalhadores, por um lado (a maioria deles votava em partidos vinculados ao marxismo), e aspectos subjetivos mais profundos de seu comportamento, enraizados em larga medida em impulsos inconscientes e expressos, seja nas relações de trabalho, seja em outros aspectos da vida social, que à época passavam por mudanças profundas e que por isso foram alçados à condição de objetos de interesse da pesquisa: assim, por exemplo, da postura dos trabalhadores em relação à arte moderna, aos direitos da mulher e às inovações pedagógicas que pregavam a supressão do recurso a castigos físicos na educação infantil seria possível inferir tendências globais da personalidade dos respondentes ${ }^{126}$.

As respostas à essa segunda ordem de perguntas, de caráter "subjetivo", permitiria, assim rezava a intenção da pesquisa, classificar os respondentes em cada um dos tipos caracterológicos constituídos por Fromm. A interpretação de cada questionário seria feita de maneira global, considerando o conjunto de respostas em sua integralidade e sem recorrer a critérios quantitativos para sua avaliação, mas sim tentando interpretar as respostas fornecidas a cada questionário de maneira "orgânica", de maneira a inferir a "estrutura de caráter" de cada respondente. Após a interpretação daquelas perguntas que visavam à obtenção dos dados “subjetivos" capazes de permitir a classificação de cada questionário em um tipo de caráter, seria então feita a correlação estatística com os dados referentes à camada social (definida pela renda), à profissão, à idade e à orientação política ${ }^{127}$.

Alguns problemas saltam facilmente aos olhos: Fromm sabia que uma avaliação mais precisa de qual seria a "estrutura de caráter" em que poderia ser classificado cada um dos respondentes demandaria técnicas mais precisas, semelhantes àquelas utilizadas na clínica psicanalítica. Isso decorria da própria hipótese fundamental que norteou o estudo, a saber, a

\footnotetext{
${ }^{125} \mathrm{Cf}$, dentre outras passagens do texto, as formulações à página 185 de Erich Fromm, “Arbeiter und Angestellte am Vorabend des Dritten Reichs", op. cit..

${ }^{126}$ A ideia era, portanto, de que as questões mais claramente vinculadas às ideologias político-partidárias fossem respondidas em relativa consonância com os programas e teses defendidos, de uma maneira geral, pelos respectivos partidos em que os trabalhadores votavam. Assim, por exemplo, à pergunta sobre "quem possui o poder real no Estado", 56\% responderam serem o capital ou os capitalistas e, apenas 5\%, se referiram à bolsa de valores ou aos judeus, o que indica a forte presença dos partidos de esquerda e o reduzido impacto que a propaganda nazista tinha à época sobre o movimento operário. A correspondência seria menos esperada em questões não vinculadas explicitamente ao tema da luta de classes. Cf. Erich Fromm, “Arbeiter und Angestellte am Vorabend des Dritten Reichs", op. cit., pp. 45-47.

127 “Quando as respostas individuais tiverem sido classificadas, por meio de uma interpretação cuidadosa, aos tipos de estrutura [de caráter] fundamentados teoricamente, será possível constatar as relações numéricas entre os tipos e comparar os caracteres, então, com outros dados tais quais a camada social ou o pertencimento religioso". Cf. Fromm, "Geschichte und Methoden der Erhebungen". In: Max Horkheimer et al., Studien über Autorität und Familie, op. cit., p. 237. O maior interesse estava na correlação entre a estrutura de caráter dos respondentes e sua filiação ou simpatia partidária (isso é afirmado por Fromm na publicação de 1980). Cf. Fromm, "Arbeiter und Angestelte am Vorabend des Dritten Reichs", op. cit., p. 26.
} 
convivência, dentre os indivíduos pertencentes à classe trabalhadora, de ideologias políticas progressistas com estruturas autoritárias de caráter. E foi por isso que o questionário empregado na pesquisa dos anos trinta era um questionário aberto, em que os respondentes podiam escrever e eram estimulados a fornecer razões para suas respostas. A previsão inicial era de que as respostas a cada uma das perguntas não fossem codificadas ou avaliadas estatisticamente segundo critérios gerais válidos para todos os respondentes, e sim interpretadas tendo em vista o conjunto geral delas no contexto de cada questionário respondido. $\mathrm{O}$ procedimento concebido como ideal seria que as motivações inconscientes dos respondentes fossem consideradas na avaliação do questionário: “(...) a fim de avaliar o pertencimento de uma resposta a determinado tipo [de caráter], é necessário interpretar o seu sentido e, com frequência, o sentido que não é consciente ao respondente do questionário" 128 . Essa condição, entretanto, apenas poderia ser preenchida satisfatoriamente por meio de um contato longo e intensivo com o respondente, que se assemelhasse à situação da clínica psicanalítica, e a inexequibilidade do procedimento logo conduziu ao seu abandono, tendo sido reduzido a um mero ideal do qual a análise das respostas deveria se aproximar na medida do possível $^{129}$.

O objetivo da pesquisa seria, como Fromm haveria de formular alguns anos mais tarde, averiguar em que medida as opiniões "revolucionárias" corresponderiam ou não a "estruturas revolucionárias de caráter", a fim de que se pudesse nutrir expectativas de uma eventual resistência dos trabalhadores contra a ascensão do nazismo: "presumimos que apenas representam motivações fortes para o agir aquelas opiniões que estão enraizadas na estrutura de caráter dos homens"130. Aqui se revela com nitidez como Fromm empreendeu uma "psicologização" do conceito de "consciência revolucionária" de Lukács, uma tentativa da qual seu conceito de "caráter revolucionário" é expressão ${ }^{131}$. Essa psicologização do problema da consciência de classe, se por um lado estava em sintonia com a psicologia social de Fromm e portanto revelava uma coerência entre as pesquisas dos anos trinta e sua obra pessoal, por outro

\footnotetext{
${ }^{128}$ Cf. Erich Fromm, "Geschichte und Methoden der Erhebungen”, op. cit. p. 236.

${ }^{129}$ Escrevendo alguns anos mais tarde, mas ainda provavelmente na década de 1930 (o texto consultado é o do manuscrito publicado por Wolfgang Bonß após a morte de Fromm), o autor fazia ressalvas aos resultados alcançados pela pesquisa: "nossas afirmações têm validade restrita também no que tange o método, pois os procedimentos que empregamos mal podem reivindicar ser capazes de contribuir para uma avaliação precisa de cada um dos respondentes". A interpretação psicanalítica permanece, portanto, como um ideal que orientava a avaliação dos questionários, mas que não podia ser cumprido. Cf. Erich Fromm, “Arbeiter und Angestellte am Vorabend des Dritten Reichs", op. cit., p. 188. Cf. também, sobre esse ponto, pp. 3-6 e p. 84 infra. Um outro problema que ocorreu algumas vezes foi a formulação imprecisa das perguntas contidas no questionário. Cf., por exemplo, a página 61 da mesma obra.

${ }^{130}$ Erich Fromm, “Arbeiter und Angestellte am Vorabend des Dritten Reichs”, op. cit., p. 3.

${ }^{131}$ Cf. Helmut Dubiel, Wissenschaftsorganisation und politische Erfahrung, op. cit., pp. 38-47.
} 
lado redundou em uma abordagem bastante restrita do problema da integração social do proletariado. Vejamos alguns dos procedimentos e resultados da pesquisa.

O texto que a apresenta no volume de 1936 previa que da avaliação dos questionários resultasse um estudo, a ser publicado na edição seguinte da Revista do Instituto ${ }^{132}$. O planejado estudo, porém, não foi publicado pelo Instituto à época, o que é habitualmente atribuído às divergências surgidas entre Fromm e os outros membros do Instituto, que não concordavam com as suas críticas à psicanálise ${ }^{133}$. Dessa maneira, não foi feita, para o volume de 1936 , a correlação entre, de um lado, os questionários - avaliados quanto à "estrutura de caráter" dos respondentes - e, de outro, os “dados objetivos" (profissão, idade, renda, estado civil, origem), uma correlação que revelaria com mais precisão a distribuição dos indivíduos de "caráter autoritário" ${ }^{134}$. Se em 1936 os pesquisadores haviam chegado à conclusão, a partir de uma visão preliminar dos questionários devolvidos ${ }^{135}$, de que havia padrões de coerência entre as respostas dadas a esses grupos de perguntas - padrões classificados com recurso aos conceitos de "caráter autoritário", "caráter revolucionário" e "caráter ambivalente" - apenas em 1980 haveria de ser publicada a avaliação completa dos questionários e o cotejo dos dados "objetivos" de cada questionário com a "estrutura de caráter" inferida para cada caso: essa publicação nasceu de um texto manuscrito que Fromm tinha redigido a partir da pesquisa de 1929-1931 e que foi preparado e publicado, pouco após sua morte, por Wolfgang Bon $\beta^{136}$. Recorremos a essa

${ }^{132}$ Cf. Fromm, "Geschichte und Methode der Erhebungen”, op. cit., p. 231. Além da previsão de um estudo mais elaborado, que não chegou a se comcretizar, o texto de apresentação da pesquisa, provavelmente escrito por Erich Fromm ou então por um de seus assistentes, também menciona um estudo feito a partir das respostas que ao questionário haviam sido fornecidas pelos tipógrafos. A autora teria sido Hilde Weiß - Fromm, contudo, não fornece referências bibliográficas, e não foi possível localizar o referido estudo. É de se cogitar se ele foi mesmo feito ou não: em vez desse estudo, o volume 5 da Revista, 1936, contém um artigo em que a pesquisadora apresenta a "enquete operária" (enquête ouvrière) de Marx, que até então não havia sido traduzida ao alemão. Cf. Hilde Weiß, “Die 'Enquête Ouvrière' von Karl Marx”. Zeitschrift für Sozialforschung, vol. 5, 1936. pp. 76-98.

${ }^{133}$ Quanto às divergências entre Fromm e os demais membros, cf. Martin Jay, A Imaginação Dialética, op. cit., pp. 149-153, e também Rainer Funk, "Zu Leben und Werk Erich Fromms”. In: Erich Fromm. Gesamtausgabe, op. cit., vol. 1, pp. XIX-XXIV.

${ }^{134} \mathrm{O}$ texto de 1936 também afirma que os dados objetivos que correspondiam à "situação real de vida" dos trabalhadores teriam sido apresentados em uma monografia separada, elaborada a partir de entrevistas, textos jornalísticos e da literatura disponível sobre esses grupos de trabalhadores -a previsão do emprego dessa metodologia foi inspirada pelo estudo feito pelo casal de sociólogos norte-americanos Robert e Helen Lynd, Middletown, citado como referência por Horkheimer (à p. X do prefácio aos Studien). O texto não fornece, entretanto, nenhuma referência bibliográfica quanto à publicação desse estudo, e nem é possível encontrá-lo em meio a outras fontes dos anos trinta (como seria o caso da Revista).

${ }^{135}$ Cf. Max Horkheimer et al., Studien über Autorität und Familie, op. cit., p. 270-271.

${ }^{136} \mathrm{O}$ texto escrito por Fromm a partir das pesquisas foi publicado por Wolfgang Bonß sob o título de Arbeiter und Angestellte am Vorabend des Dritten Reichs. Eine sozialpsychologische Untersuchung. Stuttgart: DVA, 1980. A edição que consultamos é a do volume 3 das obras completas de Erich Fromm. Quanto à legitimidade do recurso à publicação de 1980, julgamos que ela representa um desenvolvimento lógico do texto de 1936, e que a posição de Fromm como coordenador das pesquisas teria levado a que um texto não muito diferente fosse incorporado aos Studien editados por Horkheimer, Fromm e Marcuse, caso houvesse tempo e espaço na publicação para isso. Além disso, é claro, o material das pesquisas continuava sendo o mesmo, isto é, os questionários aplicados entre 1929 e 1931. Trabalhou como assistente de Fromm na interpretação dos questionários, no período do exílio, Ernst 
publicação para, cotejando-a com o volume publicado em 1936, conseguir obter uma visão mais completa da pesquisa de 1936 e identificar alguns dos pressupostos teóricos que nortearam a pesquisa, principalmente a concepção que nesses materiais se faz presente das relações entre classe social, estrutura psíquica e ideologia ${ }^{137}$.

O texto publicado em 1980 mostra que o procedimento empregado para a interpretação de cada questionário respondido consistia em avaliar grupos temáticos de respostas de acordo com sua tendência a revelaram posturas "autoritárias" ou "radicais". Os três grupos temáticos escolhidos correspondiam às perguntas que, no questionário aplicado entre 1929 e 1931, incidiam sobre as concepções políticas (por exemplo: “como o Sr. crê que o mundo possa ser melhorado?", “quem em sua opinião é o culpado pela inflação?”); sobre a questão da autoridade (perguntas relativas à educação dos filhos e aos direitos das mulheres); e sobre a solidariedade de classe (perguntas acerca da relação com os colegas e com os superiores hierárquicos) ${ }^{138}$. $\mathrm{O}$ interesse da divisão entre esses complexos temáticos de perguntas estava em que o segundo e o terceiro deles seriam capazes de revelar traços de posturas autoritárias para além das convicções políticas. Assim ocorreu, por exemplo, no que dizia respeito à postura dos respondentes com relação à emancipação feminina: quando perguntados se eram favoráveis a que mulheres casadas exercessem uma profissão além de seu trabalho como donas de casa, pouco mais da metade dos comunistas e socialistas declarou-se contrária (51\%), parcela que subia entre os social-democratas ( $71 \%$ contrários), mais ainda entre os nacional-socialistas $(89 \%)$ e os liberais $(100 \%)^{139}$.

Ao interpretar as respostas, Fromm as "media" segundo uma métrica correspondente aos interesses de classe do proletariado, com a esperança de encontrar os fundamentos psicológicos de uma ideologia revolucionária. Ao explicitar os procedimentos de interpretação dos questionários, no manuscrito que serviu à publicação de 1980, o autor afirmava: “a

Schachtel e, embora Wolfgang Bonß apenas faça referência aos “assistentes” de Fromm, sem especificá-los, é de se supor que também Hilde Weiß tenha continuado a trabalhar como assistente na pesquisa. Cf. Erich Fromm, “Arbeiter und Angestellte am Vorabend des Dritten Reichs", op. cit., pp.542-547.

${ }^{137}$ Isso significa também que não nos deteremos demasiadamente em questões metodológicas stricto sensu, isto é, como a propriedade das técnicas de pesquisa empregadas e da interpretação das respostas dadas aos questionários. Quanto a isso, pode-se afirmar de uma maneira geral que o procedimento intrepretativo usado ainda na publicação de 1936, e que ilustramos acima com alguns exemplos, foi mantido posteriormente no texto que viria a ser publicado em 1980: apesar da introdução de alguns critérios mais claros para a classificação de cada questionário como correspondente ao tipo "autoritário" ou "radical", esses critérios eram basicamente quantitivos. A grande novidade operada no exílio foi a correlação estatística entre os "tipos" de respondentes e os dados referentes à orientação política e a o grupo profissional. Nessa corelação estatística Fromm contou com o apoio de Paul Lazarsfeld.

${ }^{138}$ Cf. Erich Fromm, “Arbeiter und Angestellte am Vorabend des Dritten Reichs”, op. cit., pp. 165-183.

${ }^{139}$ Cf. Erich Fromm, “Arbeiter und Angestellte am Vorabend des Dritten Reichs”, op. cit., p. 128. Um padrão parecido foi constatado na correlação entre as filiações político-partidárias dos respondentes e a aprovação do corte de cabelo à la garçonne usado pelas mulheres nos anos 20 e 30. Cf. a páginas 118 da mesma obra. 
classificação dos traços de personalidade (...) foi feita com atenção à sua relação com os pontos de vista dos diferentes partidos políticos"140. Isso era feito por meio da construção, para cada uma das três principais orientações políticas - o socialismo revolucionário, o reformismo socialdemocrata e as ideologias dos partidos de direita - de tipos-ideais: "em um procedimento desse tipo, a imagem típico-ideal de uma determinada postura anímica é construída diretamente a partir da visão política global - nessa imagem é descrita a postura anímica à qual a doutrina política apela" ${ }^{" 141}$. Assim, por exemplo, no que diz respeito à pergunta sobre como o mundo poderia ser melhorado, as respostas eram classificadas em "radicais" (por exemplo: "por meio do socialismo"), "orientadas para o compromisso" (uma classificação que correspondia grosso modo a posturas social-democratas, por exemplo: "por meio da ética", "por um processo de esclarecimento") ou "autoritárias" (por exemplo: "por meio de melhores exemplos dos governantes"); as respostas às perguntas sobre a aplicação de castigos físicos na educação dos filhos e sobre o direito das mulheres casadas de exercerem uma profissão eram classificadas segundo padrões parecidos, em que o "sim" e o "não" representavam, conforme o caso, os polos "autoritário" ou "radical", e as respostas condicionadas (isto é, "sim, em alguns casos") resultavam na atribuição de um coeficiente intermediário (“orientado para o compromisso") que seria usado na contabilização das respostas ${ }^{142}$.

Os questionários respondidos que no volume de 1936 servem de exemplo aos procedimentos interpretativos adotados são uma fonte melhor do que os exemplos constantes da obra de 1980, pois nos "Estudos sobre autoridade e família" de 1936 o procedimento transparece melhor do que na obra de 1980: ali, os diferentes "tipos" de caráter se encontram lado a lado e é possível acompanhar as diferentes respostas dadas a um mesmo questionário,

\footnotetext{
${ }^{140}$ Erich Fromm, “Arbeiter und Angestellte am Vorabend des Dritten Reichs”, op. cit., p. 167.

${ }^{141} \mathrm{Na}$ expressão do próprio Fromm, cada um deles seria um "tipo-ideal" que "corresponderia à realidade". É provável que o autor, formado em Heidelberg sob a orientação de Alfred Weber, tenha sido influenciado pela sociologia weberiana não apenas sob o aspecto temático (como em suas análises do espírito do capitalismo e da alienação, entendida fundamentalmente como racionalização), mas também sob o aspecto metodológico. Cf. Erich Fromm, "Arbeiter und Angestellte am Vorabend des Dritten Reichs", op. cit., p. 168.

142 Cf. Erich Fromm, "Arbeiter und Angestellte am Vorabend des Dritten Reichs", op. cit., p. 171. Esse procedimento de interpretação já se encontra exemplificado no volume de 1936, não tendo sido significativamente modificado no texto organizdo por Bonß e publicado em 1980. Cf. Max Horkheimer et al., Studien über Autorität und Familie, op. cit., pp. 250-270. Sobre os critérios usados para contabilizar os tipos de respostas ("autoritário", "radical" e "orientado para o compromisso") de maneira a produzir uma classificação geral para cada respondente, cf. Erich Fromm, “Arbeiter und Angestellte am Vorabend des Dritten Reichs”, op. cit., pp. 183-186. De uma maneira geral, pode-se dizer que a classificação resultava de um critério combinado, tanto quantitativo, isto é, dependente da frequências dos tipos espercíficos de respostas, quanto qualitativo, pois algumas perguntas eram consideradas mais "significativas" do que outras no que respeito à sua capacidade de indicar traços de caráter: por exemplo, foi considerado índice de uma postura "radical", no que tange o complexo de perguntas relativas à questão da autoridade, o fato de o respondente ser contra os castigos físicos em crianças ou favorável a que mulheres casadas pudessem ter uma profissão, independentemente do tipo de resposta que ele fornecesse às outras perguntas desse mesmo conjunto de questões.
} 
enquanto na publicação de 1980 avultam estatísticas e observações metodológicas que “ocultam" o método empregado. É verdade que em ambas as obras é possível perceber que a "ideologia" é reduzida a um conjunto de representações, que podem ser "de esquerda" ou "de direita", "conservadoras" ou "libertárias": no caso das ideologias de esquerda, elas incluiriam a filiação partidária, a leitura de obras teóricas e romances socialistas, assim como opiniões políticas sobre o caráter de classe da justiça e sobre o melhor sistema de governo. O cotejo dessas opiniões mais estritamente "políticas" com outras posturas que revelassem traços mais profundos da personalidade dos respondentes se mostra mais claro, contudo, no volume de 1936: assim, por exemplo, o "caráter revolucionário", definido por Fromm como aquele em que os impulsos sadomasoquistas "se enfraquecem ou então desaparecem inteiramente", de maneira a proporcionar uma postura contrária às relações de autoridade ${ }^{143}$, foi associado grosso modo aos indivíduos que não apenas cultivavam ideias políticas tais quais aquelas professadas pelos partidos ligados ao movimento operário (o que poderia se expressar seja na sua filiação a partidos e sindicatos, seja na leitura de obras teóricas marxistas ou romances socialistas), mas que também, em suas posturas com relação a outros temas da vida cotidiana e da vida social em geral (como as relações familiares e os direitos das mulheres) se aproximavam de um ideário "revolucionário", que remetia à fundação de uma sociedade em novas bases. Assim, por exemplo, era classificado como de "caráter revolucionário" o motorista que lia as obras de Marx e Engels, pendurava na parede de casa quadros de Lênin e Rosa Luxemburgo, admirava a arquitetura de Gropius, passava suas noites e fins-de-semana em reuniões políticas, considerava a justiça alemã uma justiça de classe, defendia que a mulher tinha o direito de trabalhar profissionalmente e era a favor do aborto e contra o uso de castigos físicos na educação das crianças. Um outro trabalhador, tipógrafo que cultivava convicções políticas, gostos e inclinações parecidas ao do motorista mencionado (participação política em organizações proletárias e leitura de livros marxistas e socialistas), mas que era a favor do castigo físico dos filhos e considerava o uso de perfume e maquiagem pelas mulheres um sinal de "decadentismo burguês e falsidade", também era considerado como pertencente ao tipo "revolucionário", provavelmente devido ao fato de que a sua posição a respeito dos dois últimos assuntos não fosse considerada suficiente para alterar a classificação. Já um outro tipógrafo, socialista que votava no partido social-democrata (SPD), mas cujo gosto e atividades de tempo livre eram menos marcados por critérios ligados à orientação política do que por padrões que poderiam ser considerados "clássicos" ou "burgueses" (como ópera e literatura clássica), foi classificado

${ }^{143}$ Cf. Erich Fromm, “Sozialpsychologischer Teil”, op. cit., pp. 130-131. 
como pertencente ao tipo "ambivalente", para o que deve ter contribuído decisivamente o fato de ser contra o aborto, a favor do castigo físico em crianças e contra o direito da mulher de trabalhar fora de casa. Por sua vez, o funcionário público que pendurava na sala de sua casa quadros com temas de guerra e retratos dos pais, era contra o aborto e o trabalho fora de casa das mulheres casadas e acreditava que o mundo só iria melhorar quando "se convertesse novamente a deus e ao Kaiser" era obviamente um representante do "caráter autoritário"144.

Depois disso, partia-se para a correlação dos questionários interpretados com os dados “objetivos” (sexo, renda, estado civil, idade, grupo profissional ${ }^{145}$ e orientação política) ${ }^{146}$, e a conclusão a que se chegou foi que, dessas seis variáveis mencionadas, apenas a orientação política e o grupo profissional eram relevantes para a existência de diferenças na "estrutura de personalidade" 147 dos respondentes: se a relação da renda com as inclinações subjetivas era “causalmente determinada (...) apenas em uma reduzida medida", a "influência" da posição profissional sobre a personalidade "apareceu com mais nitidez ainda à medida em que era comparada com tipos frequentes de caráter" ${ }^{148}$. Essas formulações de Fromm, ainda que a técnica de correlação de variáveis não pressuponha necessariamente uma concepção de causalidade entre os fenômenos observados, estão em sintonia com sua concepção "naturalista" de psicologia social: na sua fusão entre marxismo e psicanálise, essa seria "uma psicologia materialista, com as características próprias das ciências naturais"149 e explicaria os fatores psíquicos do comportamento humano, enquanto ao marxismo caberia a explicação dos fatores sociais e econômicos que, “em última instância”, determinariam aqueles fatores psíquicos: “(...) instâncias anímicas como o supereu e o eu, um mecanismo como o recalque, impulsos como os sadomasoquistas, (...) são, eles próprios, sempre condicionados pelo modo de vida dos homens e, ao fim das contas, pelo modo de produção e pela estrutura social dele resultante" ${ }^{150}$.

\footnotetext{
${ }^{144}$ Cf. Max Horkheimer et al.. Studien über Autorität und Familie, op. cit., pp. 250-270. A arbitrariedade das classificações é transparente aqui, mas por enquanto aceitames, neste primeiro momento, as categorias "autoritário" e "radical"/"revolucionário" sem nenhuma objeção.

145 No texto, chamado de "status econômico".

${ }^{146}$ Como afirmamos acima, dos 1150 questionários respondidos apenas 584 foram avaliados. Além disso, Fromm registrou o auxílio de Paul Lazarsfeld na elaboração estatística do material disponível (Cf. Erich Fromm, “Arbeiter und Angestellte am Vorabend des Dritten Reichs", op. cit., p. 3).

${ }^{147}$ O termo é empregado na publicação de 1980, principalmente no capítulo 4: nos textos dos anos 30, os termos mais constantes eram "estrutura de caráter", "estrutura libidinal” e "estrutura pulsional”. Segundo informações do editor da obra (Wolfgang Bonß), apenas o capítulo 1 foi datado por Fromm (sendo uma primeira versão de 1937, a segunda, de 1938), mas da pouca fluência das formulações em língua inglesa, em comparação com a obra posterior do autor, seria possível inferir que os capítulos restantes tenham sido redigidos ainda nos anos 30 (Wolfgang Bonß, "Editorische Bemerkungen”, in Fromm, Gesamtausgabe, op. cit., vol. 3, pp. 542-547).

${ }^{148}$ Cf. Erich Fromm, "Arbeiter und Angestellte am Vorabend des Dritten Reichs”, op. cit., p. 24.

${ }^{149}$ Erich Fromm, "Über Methode und Aufgabe einer analytischen Sozialpsychologie”, op. cit., p. 37.

${ }^{150}$ Erich Fromm, "Sozialpsychologischer Teil”, op. cit., p. 92.
} 
A correlação entre as classificações dos questionários segundo os tipos psicológicos, por um lado, e os "dados objetivos", por outro, permitiu que se inferissem as nuances dentre os diferentes setores da classe trabalhadora: como era de se esperar, à medida que a orientação política (o vínculo eleitoral) tendia para a esquerda, mais "radicais" ("revolucionárias" ou "antiautoritárias") eram as respostas, de maneira que Fromm podia afirmar que "os agrupamentos políticos consistiam em unidades em sentido sociopsicológicos" ${ }^{" 151}$. Isso se revelava nitidamente no que diz respeito às diferenças entre eleitores do partido socialdemocrata (SPD) e aqueles do partido comunista (KPD): apenas 28\% dos social-democratas tinham inclinações antiautoritárias, percentual que subia a $60 \%$ entre os comunistas, e inclinações autoritárias foram constatadas entre $28 \%$ dos social-democratas contra apenas $8 \%$ dentre os comunistas. De uma maneira geral, contudo, a avaliação das inclinações dos membros ou simpatizantes de partidos vinculados ao movimento operário foi decepcionante: dentre os social-democratas e os comunistas, apenas $40 \%$ tinham tendências antiautoritárias, $39 \%$ deles tinham tendências autoritárias, e $21 \%$ do mesmo grupo apresentavam tendências que não podiam ser discernidas com clareza. No conjunto geral de trabalhadores que responderam ao questionário, esses números eram de apenas $15 \%$ de antiautoritários, $10 \%$ de autoritários e 75\% de "ambivalentes", ou seja, dada a proximidade do "caráter ambivalente" ao "autoritário" stricto sensu, pôde-se afirmar que $85 \%$ dos respondentes apresentavam tendências autoritárias $^{152}$.

Quanto ao grupo profissional, Fromm concluiu que os trabalhadores manuais tinham opiniões políticas em geral "mais críticas" do que os funcionários, isto é, suas declarações tendiam a se aproximar do socialismo revolucionário e a se afastar do reformismo socialdemocrata $^{153}$ - além disso, no que se referia à sua estrutura de caráter, em geral os trabalhadores manuais eram mais inclinados a posturas antiautoritárias do que os funcionários: constatou-se que a maior parte $(46 \%)$ dos funcionários tinha inclinações autoritárias, e que apenas de menos

\footnotetext{
${ }^{151}$ Cf. Erich Fromm, "Arbeiter und Angestellte am Vorabend des Dritten Reichs", op. cit., p. 24. "Radical" é o termo usado por Fromm na apresentação dos resultados da pesquisa; "anti-autoritário" é o termo empregado na introdução a essa publicação, escrita em 1970; "revolucionário" foi o termo usado nos textos constantes da publicação de 1936. Os três termos, contudo, são empregados aparentemente no mesmo sentido.

${ }^{152}$ Cf. Erich Fromm, "Arbeiter und Angestellte am Vorabend des Dritten Reichs", op. cit., p. 6 e pp. 188-190. Esses dados são apresentados, com algumas diferenciações internas mais sutis entre os três grupos. Fromm destaca (pp. 186-187) o significado histórico que teve, na Alemanha da época, o grupo dos indivíduos "rebeldesautoritários", correspondente grosso modo aos trabalhadores para os quais a filiação aos partidos de esquerda teria representado meramente uma oportunidade de exprimir seu desejo de que a autoridade vigente fosse derrubada e substituída por outra, do que teria decorrido a facilidade com que aderiram ao nazismo logo que esse movimento se revelou o mais capaz de pôr abaixo a República de Weimar. Cf. também, para a descrição desse subtipo do "caráter autoritário", a contribuição de Fromm ao volume de 1936: "Sozialpsychologischer Teil", op. cit., pp. 131132.

${ }^{153}$ Cf. Erich Fromm, “Arbeiter und Angestellte am Vorabend des Dritten Reichs”, op. cit., p. 54.
} 
de um terço deles (29\%) se poderia afirmar o contrário. Da ocorrência de uma tendência inversa entre os trabalhadores manuais, tanto dentre os especializados quanto dentre aqueles que não tinham formação técnica, concluiu-se que ao aumento do prestígio social do grupo profissional correspondia uma maior tendência a estruturas autoritárias de caráter ${ }^{154}$.

Algumas questões, entretanto, ficam de fora da pesquisa. O próprio Fromm, como chamamos à atenção acima, reiteradamente afirmou o caráter limitado das tendências que a pesquisa tinha por objetivo descobrir - se, contudo, dentre as intenções dos "Estudos sobre Autoridade e Família" estava iluminar o processo de integração social do proletariado e descobrir possíveis contra-tendências à ascensão do nazismo, é necessário se indagar como os mesmos trabalhadores que, em um momento estavam organizados em sindicatos e nos partidos social-democrata e comunista, em um outro momento passavam a aderir maciçamente ao partido nazista. Isso se devia apenas a uma estrutura autoritária de caráter, que estava ali, "escondida" desde sempre entre os trabalhadores que votavam nos partidos ligados ao movimento operário? De onde provinha historicamente essa tendência ao autoritarismo? ${ }^{155}$

Talvez, como se depreende de formulações como aquela reproduzida acima ${ }^{156}$, não fosse objetivo de Fromm produzir uma teoria crítica da integração do proletariado (no sentido de uma teoria que ressaltasse elementos críticos e emancipatórios que, inscritos no modo de produção capitalista, apontassem para além dele). De qualquer maneira, o problema da consciência de classe não pode ser reduzido a dados psicológicos e precisa, para que se elucide o grau de integração do proletariado, da consideração de processos históricos mais amplos, que se desenvolvem ao longo de várias décadas e incluem fenômenos de caráter especificamente político (como o papel dos sindicatos na vida política nacional, sujeito a oscilações dadas pela luta de classes e pelo contexto internacional em que o que vale é o imperialismo) e também cultural (como o estilo de vida e a ação integradora exercida pelo consumo) ${ }^{157}$.

\footnotetext{
154 Dentre os especializados, 33\% de "autoritários" contra 39\% de "radicais", dentre os não especializados, 34\% contra 43\% (na porcentagem, os restantes correspondiam a casos que não se conseguiu diferenciar suficientemente). Cf. Erich Fromm, “Arbeiter und Angestellte am Vorabend des Dritten Reichs”, op. cit., p. 191. ${ }^{155}$ Sobre essa ausência, cf. também John Abromeit, Max Horkheimer and the foundations of the Frankfurt School, op. cit., pp. 224-225.

${ }^{156}$ No prefácio à segunda versão da pesquisa, Fromm afirmava: "presumimos que apenas representam motivações fortes para o agir aquelas opiniões que estão enraizadas na estrutura de caráter dos homens". Cf. Erich Fromm, "Arbeiter und Angestellte am Vorabend des Dritten Reichs", op. cit., p. 3.

${ }^{157}$ Uma pesquisa empírica com trabalhadores realizada pelo Instituto de Pesquisa Social em 1954, quando Adorno era diretor, teve como objeto o "clima na empresa" e deteve-se sobre o grau de satisfação dos entrevistados com suas condições de trabalho e com as relações com seus superiores, sem considerar que daí pudesse inferir conclusões generlizantes sobre o nível de integração do proletariado: "o conceito de consciência de classe nunca designou um dado sócio-psicológico, com o qual se poderia contar como se fosse uma grandeza fixa". Theodor W. Adorno e Walter Dirks (Orgs.). Betriebsklima - eine industriesoziologische Untersuchung aus dem Ruhrgebiet. Frankfurt am Main: Europäische Verlagsanstalt, 1955, p. 15.
} 
A própria pesquisa sugeria uma pista para esse tipo de interrogação: o fato de que, no universo estudado, o grupo dos funcionários concentrasse os eleitores do partido socialdemocrata em escala consideravelmente maior do que os trabalhadores manuais sugeria que aquele primeiro grupo tivesse mais afinidades com o reformismo social-democrata do que era o caso dos segundos ${ }^{158}$. Isso se revelava nitidamente no fato de que esses trabalhadores tendiam a responder as questões explicitamente políticas em conformidade com o fato de o partido estar na situação àquela época: eles tendiam, por exemplo, a avaliar positivamente o sistema de justiça, a atribuir a inflação de 1923 não às tendências do capitalismo ou às decisões políticas tomadas sob influência da burguesia alemã, mas sim às decorrências da primeira guerra e à interferência de outras nações (por meio do Tratado de Versalhes), e tendiam também, esses respondentes, a considerar que as guerras poderiam ser evitadas por meio de tratados internacionais ou por um "aperfeiçoamento moral dos homens"159.

Mais que isso, a já citada tendência geral ao autoritarismo dos funcionários, que os distinguia dos trabalhadores manuais, também se manifestava na sua maior tendência à solidariedade com os superiores hierárquicos, em detrimento da solidariedade com os colegas que exerciam as mesmas funções ${ }^{160}$. Isso se mostra nitidamente em uma das mais relevantes perguntas do questionário, a pergunta sobre as medidas de "racionalização" dos processos de trabalho, tomadas com o objetivo de aumentar a produtividade do trabalho. Essas medidas também haveriam de ficar historicamente conhecidas sob o nome de "taylorização", e consistiam na fragmentação e mecanização do processo de trabalho, com o aprofundamento da separação entre tarefas de concepção e tarefas de execução, e na intensificação dos ritmos de trabalho. Parece proveitoso demorarmos nossa atenção nessa pergunta, dentre as demais constantes do questionário, pois ela incide diretamente sobre o fenômeno da integração do proletariado, que era o tema mais amplo da pesquisa: cremos que uma atenção maior ao movimento de "racionalização" dos processos de trabalho seria uma possibilidade de responder àqueles limites da pesquisa aos quais aludimos acima, e compreender a integração do proletariado em seu caráter processual.

\footnotetext{
${ }^{158}$ Cf. Erich Fromm, "Arbeiter und Angestellte am Vorabend des Dritten Reichs", op. cit., pp. 38-42. Na amostra realizada, 36\% dos eleitores do partido nazista eram funcionários, e 30\% pertenciam ao grupo heterogêneo formado por profissionais autônomos, estudantes e donas de casa.

${ }^{159} \mathrm{Cf}$. Erich Fromm, “Arbeiter und Angestellte am Vorabend des Dritten Reichs", op. cit., pp. 52-59. É interessante notar, contudo, que ainda assim os eleitores do SPD tendiam a posições mais radicais do que aquelas adotadas oficialmente pelo partido. Cf. Erich Fromm, "Arbeiter und Angestellte am Vorabend des Dritten Reichs", op. cit., p. 138 infra.

${ }^{160}$ Cf. Erich Fromm, “Arbeiter und Angestellte am Vorabend des Dritten Reichs”, op. cit., pp. 142-147.
} 
Assim como no caso de diversas outras perguntas, as diferenças mais significativas nas respostas correspondiam às diferenças de orientação política e de status (profissão) ${ }^{161}$ : ainda que a maior parte dos respondentes desaprovasse a taylorização (34\% dos questionários devolvidos, dos quais $48 \%$ não continham resposta a essa pergunta, isto é, apenas 18\% a avaliavam positivamente), quando se compara essa proporção no interior dos grupos profissionais constata-se que os funcionários eram o grupo com maior frequência de respostas “do ponto de vista do empresário" (20\%, contra 28\% de respostas "do ponto de vista do trabalhador"), e os social-democratas eram o grupo político que mais respondeu desse ponto de vista (apenas 19\% deles vinculavam a taylorização aos interesses dos empresários, um percentual que subia a $34 \%$ entre os socialistas e os comunistas, e a $35 \%$ entre os nacionalsocialistas ${ }^{162}$ ). Fromm atribui o número elevado de ausência de respostas à falta de clareza na formulação da pergunta - parece-nos entretanto mais provável atribuí-lo, segundo indicações do próprio autor, ao caráter complexo da questão e à inconsistência, a esse respeito, das posições assumidas pelos partidos: à exceção do Partido Comunista Alemão, nenhum dos demais partidos tinha posicionamentos claros com relação à “racionalização' dos processos de trabalho. Se, no caso do partido nazista, a base que esse partido tinha na grande indústria convivia com o apoio conquistado junto aos trabalhadores por meio de um discurso anticapitalista e impedia por isso uma tomada de posição nitidamente contrária ou favorável à taylorização, no caso do partido social-democrata a ausência de uma posição clara decorria do seu reformismo e da concepção de socialismo como caminho evolutivo no qual o desenvolvimento das forças produtivas (inclusive por meio da taylorização) desempenharia o papel decisivo, o que levava muitos sindicatos social-democratas a apoiarem a taylorização ${ }^{163}$.

\footnotetext{
${ }^{161}$ Altero um pouco, na reprodução desses dados, a classificação estabelecida por Fromm, que parece se perder em algumas distinções pouco proveitosas e a classificar diferentemente respostas que podem ser agrupadas sob a mesma categoria. Cf. Erich Fromm, “Arbeiter und Angestellte am Vorabend des Dritten Reichs”, op. cit., p. 63.

162 Note-se que a pesquisa constatou que os eleitores do partido nazista liam mais literatura anti-capitalista de esquerda (30\% de suas preferências) do que literatura propriamente nacional-socialista (apenas $6 \%$ de suas preferências). $\mathrm{O}$ sentimento anti-capitalista dos trabalhadores que apoiaram o nacional-socialismo haveria de ser direcionado, como as sabe, contra os judeus e o "capital improdutivo". Cf. Erich Fromm, "Arbeiter und Angestellte am Vorabend des Dritten Reichs", op. cit., pp. 62-65 e p. 101.

${ }^{163}$ Cf. Erich Fromm, "Arbeiter und Angestellte am Vorabend des Dritten Reichs", op. cit., p. 61. Apesar do reformismo do SPD e de seus sindicatos, os seus eleitores tendiam a se mostrar, em sua maioria, contrários à taylorização. Cf. p. 65. Os sindicatos social-democratas mantiveram posições ambíguas diante da "racionalização" dos processos de trabalho, pois se por um lado ela haveria de resultar na intensificação dos ritmos de trabalho e na redução do controle dos trabalhadores sobre os processos de trabalho (e consequentemente na redução de seu poder de barganha nas greves), por outro lado havia a expectativa de que trouxesse redução do tempo de trabalho, elevação dos salários e consumo de massa. Cf. Rüdiger Hachtmann, Adelheid von Saldern, “ 'Gesellschaft am Fliessband' - Fordistische Produktion und Herrschaftspraxis in Deutschland" [A sociedade na linha de montagem - produção fordista e práticas de dominação na Alemanha]. Zeithistorische Forschungen/Studies in Contemporary History, edição online, vol. 6 (2009), caderno 2. Disponível em:
}

URL: http://www.zeithistorische-forschungen.de/2-2009/id=4509. 
Considerando que os funcionários foram o grupo em que estavam mais presentes as inclinações autoritárias, o que explicaria o fato de eles, em sua maioria, se identificarem com os interesses dos patrões e, por isso, serem contrários à taylorização em menor medida do que os outros grupos de trabalhadores? Apenas o fato de não executarem as tarefas do processo de trabalho mais diretamente atingidas pela "racionalização", do que decorreria uma "situação intermediária" que os permitia aspirar à ascensão social? Essa foi a explicação dada por Fromm ${ }^{164}$, e ainda que ela possa ser em alguma medida correta seria preciso, a nosso ver, compreender a ideologia desse grupo social específico em conexão com o seu processo histórico de formação. Uma perspectiva que vinculasse os processos ocorridos no âmbito restrito das empresas àqueles mais amplos que perpassam a luta de classes em um nível nacional e internacional poderia resolver pelo menos parte dos problemas, mas Fromm reduzia "classe social" a grupos profissionais e de status, e concebia a sociedade como uma soma de indivíduos ${ }^{165}$.

Voltando à pergunta sobre a "racionalização" dos processos de trabalho, uma das possibilidades seria sair do âmbito da pesquisa e compreender o taylorismo e o fordismo como um tipo específico de resposta dada pela burguesia industrial à crise econômica e às tentativas de revolução proletária que ocorreram entre o fim da primeira guerra mundial e o início dos anos vinte: esse processo consistiu na construção de uma hegemonia burguesa em direção à integração da classe trabalhadora, por meio da implantação, primeiramente, de uma reestruturação dos processos de trabalho, de modo a aumentar a sua produtividade (no que se destacou o emprego das técnicas de Taylor, que podem ser reduzidas ao denominador comum do controle minucioso do tempo de trabalho dos operários), e, posteriormente, da organização da sociedade sobre a produção e o consumo de massas (seguindo o modelo preconizado por Ford de introdução da linha de montagem e elevação relativa dos salários).

\footnotetext{
${ }^{164}$ Cf. Erich Fromm, “Arbeiter und Angestellte am Vorabend des Dritten Reichs”, op. cit., p. 62..

${ }^{165}$ No texto programático de 1932, "sobre o método e a função de uma psicologia social analítica", Fromm afirmara que a sociedade se constitui "sempre de indivíduos vivos específicos, que não podem estar submetidos a outras leis psicológicas além daquelas que a psicanálise descobriu no indivíduo". Cf. Fromm "Über Methode und Aufgabe einer analytischen Sozialpsychologie", op. cit., p. 40. A sociologização da psicanálise feita por Fromm, e que examinaremos em maior detalhe no item seguinte, se apoia em sua concepção de sociedade como soma de indivíduos. Quando se refere às classes sociais, Fromm costuma falar em "camadas" (Schichten) e em "situação econômica". Cf. "Sozialpsychologischer Teil", op. cit., pp. 89-90 e 232-233. Fromm, também usa às vezes o termo "situação de classe" [Klassenlage], aproximando-se do conceito de classes sociais de Weber. Cf. Erich Fromm, "Arbeiter und Angestellte am Vorabend des Dritten Reichs", op. cit., p. 27. Note-se também que, ao comentar no texto publicado em 1980 os objetivos gerais da pesquisa e a impossibilidade de analisar a fundo cada um dos questionários respondidos segundo o método originalmente preconizado na publicação de 1936, Fromm afirmava: "A finalidade da nossa investigação não repousava na análise psicológica de alguns indivíduos, mas na descoberta de traços e posturas típicas em meio a diferentes grupos de status". Cf. Erich Fromm, "Arbeiter und Angestellte am Vorabend des Dritten Reichs", op. cit... p? (cap. 4).
} 
Na década de 1920, a "racionalização" ("taylorização") dos processos de trabalho reduziu o trabalho concreto ao exercício mecânico de tarefas repetitivas, por meio da vigilância sobre os trabalhadores e do emprego de máquinas e recursos técnicos que asseguravam maior controle sobre o processo, evitando-se desperdícios de tempo e energia e tornando-se mais eficaz a exploração do trabalho. A submissão dos processos de trabalho ao controle gerencial garantia a um tempo a destituição dos trabalhadores do poder sobre o processo de trabalho e a transferência, às gerências, dos conhecimentos técnicos acumulados ao longo de gerações por operários qualificados. Embora a proposta de redução dos desperdícios de tempo e energia por meio de uma especialização exaustiva das tarefas do processos de trabalho, com ênfase na separação estrita entre tarefas de concepção e execução, já fizesse parte do discurso da administração empresarial desde as últimas décadas do século XIX, incluindo mesmo a proposta de elevação dos salários ${ }^{166}$, foi em 1911, com a obra de Taylor, que o estudo "científico" dos processos de trabalho, com vistas ao aumento de sua produtividade, se tornou conhecido do grande público e encontrou aplicações na indústria ${ }^{167}$. A "organização científica do trabalho" tornava os processos menos dependentes dos trabalhadores, e um modo de produção caracterizado por Pollock como "intensivo em capital" e "escasso em pessoas" provocava desemprego e uma diferenciação crescente no âmbito da classe trabalhadora: de um lado, os operários pouco ou não-qualificados, facilmente substituíveis e condenados a baixos salários, de outro, aqueles qualificados, ocupados com a construção e o reparo de máquinas e que passavam a formar a "aristocracia operária"168. A situação toda provocava dificuldades à formação de uma classe trabalhadora que pudesse se opor à burguesia, como já notara Horkheimer em seu conjunto de aforismos escritos na década de vinte:

"Como mostrou Marx, no processo econômico capitalista o número dos trabalhadores empregados decresce tendencialmente em relação ao emprego da maquinaria. Um percentual cada vez menor do proletariado é realmente ocupado. A diminuição muda também as relações das camadas específicas entre si. Quanto mais raras se tornam a ocupação temporária em geral, ou mesmo a ocupação duradoura e remunerada de um indivíduo, tanto mais claramente se distinguem, em relação às camadas não ocupadas, a vida e a consciência dos

\footnotetext{
${ }^{166}$ Cf. Eric J. Hobsbawm, "Costumes, Salários e Carga do Trabalho na Indústria do Século Dezenove”. In: Eric J. Hobsbawm, Os Trabalhadores - Estudos sobre a História do Operariado. Tradução de Maria Leão Teixeira Viriato de Medeiros. Rio de Janeiro, São Paulo: Paz e Terra, 1981, pp. 363-364.

${ }^{167}$ Nos Princípios da Administração Científica, Frederick Winslow Taylor afirmava: "demonstraremos adiante, neste estudo, que afastando este hábito de fazer cera ["enrolar", "vadiar" durante o trabalho] em todas as suas formas e encaminhando as relações entre empregados e patrões, a fim de que o operário trabalhe do melhor modo e mais rapidamente possível em íntima cooperação com a gerência e por ela ajudado, advirá, em média, aumento de cerca do dobro da produção de cada homem e de cada máquina" Frederick W. Taylor, Princípios da Administração Científica. Tradução de Arlindo Vieira Ramos. São Paulo: Atlas, 1982. p. 33.

${ }^{168}$ Cf. Friedrich Pollock, "Bemerkungen zur Wirtschaftskrise”, op. cit., p. 352.
} 
operários regularmente ocupados. Dessa maneira, a solidariedade de interesses do proletariado é cada vez mais inibida" ${ }^{169}$.

O emprego de métodos de produção mais sistemáticos e de técnicas amparadas na aplicação de conhecimentos científicos foi um processo que se tornou mais intenso depois da primeira guerra, como notara Pollock em $1933^{170}$. Mas não se tratava, obviamente, de uma mera reorganização de forças produtivas supostamente neutras: na República de Weimar, a "racionalização" era uma ideologia que se estendia para além da fábrica e prometia a solução dos conflitos sociais e políticos por meio do progresso técnico-científico. Ao desemprego e à inflação de início dos anos vinte se seguiu um "movimento pela racionalização" que congregou os grandes industriais, os sindicatos e a burocracia estatal ansiosa por estabilidade política. A produção e o consumo em massa, forma que o capitalismo começava a esboçar a partir de então, era transfigurada em promessa de bem-estar geral e paz social ${ }^{171}$. Em 1928, o importante sindicalista social-democrata Fritz Tarnow vislumbrava o surgimento de uma nova relação entre as classes sociais, na medida em que "à dependência do trabalho assalariado em relação ao capital soma-se a dependência do capital em relação ao trabalhador consumidor", e considerava “o livro de Ford, 'Minha Vida e Obra', o escrito mais revolucionário de toda a literatura econômica produzida até agora"172.

$\mathrm{O}$ fordismo, que ao longo do século XX dotaria a classe trabalhadora dos países capitalistas centrais de um poder de consumo maior do que nunca, ensejou a promessa de "paz

\footnotetext{
${ }^{169}$ Max Horkheimer, "Die Ohnmacht der deutschen Arbeiterklasse" (aforismo de "Dämmerung"). In: Max Horkheimer, Gesammelte Schriften, op. cit., vol. 2, pp. 373-374.

${ }^{170}$ Cf. Friedrich Pollock, "Bemerkungen zur Wirtschaftskrise”, op. cit., pp. 330-331.

${ }^{171} \mathrm{Cf}$. Thomas von Freyberg, Industrielle Rationalisierung in der Weimarer Republik - untersucht an Beispielen aus dem Maschinenbau und der Elektroindustrie. Frankfurt am Main: Campus Verlag, 1989. especialmente pp. 312-316.

172 Fritz Tarnow, "Warum arm sein?", citado em Thomas von Freyberg, Industrielle Rationalisierung in der Weimarer Republik. pp. 312-314. A "revolução" a que se referia Fritz Tarnow consistiu em linhas gerais no seguinte: em 1914, Henry Ford transformou a produção lenta e artesanal de automóveis, que dependia do conhecimento acumulado de mecânicos altamente qualificados e resultava na fabricação de carros vendidos a preços elevados, em uma produção em massa de automóveis idênticos. Para fazê-lo, adotou métodos tayloristas a fim de promover o maior parcelamento possível das tarefas, introduziu a linha de montagem e a integração "vertical" da produção, reunindo numa mesma empresa a fabricação dos diversos itens necessários à elaboração do produto final. Ao mesmo tempo, Ford fixou o pagamento de seus operários em cinco dólares por dia (um nível salarial bastante elevado à época), além de ter condicionado o recebimento do salário a uma observância estrita, por parte de seus trabalhadores, das normas de comportamento que, estabelecidas pelo departamento pessoal da empresa, deviam regular a vida privada dos operários e de suas famílias e garantir que o tempo passado fora do trabalho se mantivesse livre de práticas como o jogo, o consumo de álcool e a prostituição, consideradas prejudiciais ao equilíbrio psicofísico da força de trabalho. Os ganhos de produtividade resultaram num tamanho crescimento das vendas que o modelo de organização das empresas Ford se impôs às demais concorrentes, além de ter se espalhado para empresas dos demais setores industriais, dado o lugar central que a indústria automobilística assumiu nas economias ao longo do século vinte. Sobre isso, cf. Thomas Gounet, Fordismo e toyotismo da civilização do automóvel. Tradução de Bernardo Joffily. São Paulo: Boitempo Editorial, 1999. pp. $22-23$.
} 
social" que alimentou nos anos vinte as esperanças de parte considerável dos social-democratas alemães. Embora até 1933 tenha sido reduzido o recurso das empresas à linha de montagem, e o fordismo, entendido enquanto produção e consumo de massa, só fosse se desenvolver na Alemanha a partir do regime nazista, já estava em curso na República de Weimar a "racionalização" (taylorização) dos processos de trabalho. E, se apenas sob a ditadura nazista o sindicalismo de tendência social-democrática ou socialista seria substituído por uma organização sindical totalmente atrelada ao Estado e ao partido nazista ${ }^{173}$, é importante ressaltar que a "racionalização", defendida tanto por empresários quanto por líderes sindicais na Alemanha dos anos vinte, também instituiu parâmetros de negociação que, amparados em uma suposta cientificidade, tinham a função de restringir o campo de ação das comissões de fábrica que haviam sido reconhecidas legalmente em 1920, quando passaram a constar da legislação trabalhista da recém-fundada república: durante os anos vinte, as empresas fundamentaram na “organização científica do trabalho" tanto a reorganização dos processos de trabalho quanto o cálculo dos salários ${ }^{174}$.

A fragmentação do processo de trabalho, ao separar tarefas de concepção e execução, resultou também em uma polarização da força de trabalho: desse processo é expressão o aumento da relevância dos funcionários qualificados, e a formação dessa fração da classe trabalhadora pode ser vinculada, portanto, ao mesmo processo de taylorização que, de uma maneira geral, consistiu no controle capitalista dos processos de trabalho. Além disso - e aqui remetemos ao tema das relações de autoridade na família e do papel da mulher - ainda que o fordismo só fosse se instituir efetivamente na Alemanha durante o período nazista, é oportuno mencionar que ele representou também uma maior segregação entre os papéis de gênero, e contribuiu para o fortalecimento de modelos tradicionais de família, com o reforço da subordinação da mulher por meio da sua exclusão parcial do mercado de trabalho e sua redução ao papel de dona de casa, o que foi permitido pela relativa elevação dos salários ${ }^{175}$.

\footnotetext{
173 Tratava-se da DFA, "Frente dos Trabalhadores Alemães"[Deutsche Arbeiterfront].

${ }^{174}$ Cf. Rüdiger Hachtmann e Adelheid von Saldern, “"Gesellschaft am Fliessband' - Fordistische Produktion und Herrschaftspraxis in Deutschland”, op. cit.. Um pouco à margem das considerações que fazemos aqui, seria necessário ainda considerar a questão da existência ou não de um regime fordista na Alemanha dos anos de 1930, uma questão controversa para a qual ainda não foi possível encontrar solução satisfatória no âmbito desta tese: caso o fordismo seja compreendido como um processo de construção de hegemonia, apoiado tanto no uso da força quanto em um consenso construído junto à classe trabalhadora, então não haveria razão para se falar de fordismo para o período da ditadura nazista. Agradeço ao Prof. Ruy Braga, do Departamento de Sociologia da Universidade de São Paulo, as observações a esse respeito, quando da defesa desta tese.

${ }^{175}$ Cf. Rüdiger Hachtmann, Adelheid von Saldern, “ 'Gesellschaft am Fliessband' - Fordistische Produktion und Herrschaftspraxis in Deutschland" [A sociedade na linha de montagem - produção fordista e práticas de dominação na Alemanha], op. cit.
} 
Nesse longo processo, a taylorização dos processos de trabalho caminhou par a par à integração de trabalhadores e sindicatos, atraídos por um discurso "modernizante" e pela promessa de elevação de salários e redução do tempo de trabalho. Já na República de Weimar se difundiam as ideologias sobre as quais o Estado nazista haveria de fundar as relações de trabalho, e que pregavam a "comunidade de fábrica" e a "paz nas empresas" [Betriebsgemeinschaft, Betriebsfrieden $]^{176}$. Posteriormente, no período nazista, viriam a proibição do direito de greve e a subordinação dos sindicatos ao Estado. Como afirmou Gramsci, em referência à difusão do taylorismo-fordismo nos Estados Unidos:

“(...) foi relativamente fácil racionalizar a produção e o trabalho, combinando habilmente a força (destruição do sindicalismo operário de base territorial) com a persuasão (altos salários, diversos benefícios sociais, habilíssima propaganda ideológica e política) e conseguindo centrar toda vida do país na produção. A hegemonia nasce da fábrica e necessita apenas, para ser exercida, de uma quantidade mínima de intermediários profissionais da política e da ideologia" 177 .

Essa interpretação, contudo, já estaria além dos limites do que é oferecido pela pesquisa com trabalhadores e funcionários: tomadas em si mesmas, as pesquisas apresentadas na segunda seção da obra e mesmo na sua republicação mais de quarenta anos depois, apesar da riqueza temática e de sua capacidade de fornecer um quadro de características relevantes da classe trabalhadora alemã da época, estão vinculadas a uma concepção empirista de ciência, e deixadas a si mesmas pouco revelam daquela "interpenetração e desenvolvimento dialéticos e contínuos da teoria filosófica e da prática científica especializada" a que Horkheimer se referira em seu discurso de posse ${ }^{178}$. Teria o diretor do Instituto se entusiasmado pelas técnicas norte-

\footnotetext{
${ }^{176}$ Cf. esse respeito, Fromm, Arbeiter und Angestellte am Vorabend des Dritten Reichs, op. cit.,, p. 62.

177 Antonio Gramsci, Americanismo e Fordismo, op. cit., pp. 247-248. Em relação ao processo de taylorização, Gramsci afirmou: "Taylor exprime com cinismo brutal o objetivo da sociedade americana: desenvolver ao máximo, no trabalhador, as atitudes maquinais e automáticas, romper o velho nexo psicofísico do trabalho profissional qualificado, que exigia uma determinada participação ativa da inteligência, da fantasia, da iniciativa do trabalhador, e reduzir as operações produtivas apenas ao aspecto físico maquinal. Mas, na realidade, não se trata de novidades originais, trata-se somente da fase mais recente de um longo processo que começou com o próprio nascimento do industrialismo, fase que é apenas mais intensa do que as precedentes e manifesta-se sob formas mais brutais, mas que também será superada com a criação de um novo nexo psicofísico de um tipo diferente dos precedentes e, indubitavelmente, superior" (Antonio Gramsci, Americanismo e Fordismo. Tradução de Gabriel Bogossian. São Paulo: Hedra, 2008 [1928-1935], p. 397).

178 Max Horkheimer, "Die gegenwärtige Lage der Sozialphilosophie und die Aufgaben eines Instituts für Sozialforschung”. In: Id., Gesammelte Schriften. Alfred Schmidt e Gunzelin Schmid Noerr (Orgs.). Vol. 3. Frankfurt am Main: Fischer, 1985. p. 29. O traço de fundo eminentemente positivista que presidiu à pesquisa positivista no sentido genérico de uma concepção de ciência que se ocupa com a constatração de "fatos" sem historicizar os próprios conceitos em que se baseia - fica muito claro quando Fromm discorria, na publicação de 1980, sobre a necessidade de identificar os casos em que as respostas seriam meras "racionalizações" e não "fatos irrefutáveis", e também quando, apoiado em considerções metodológicas de Lazarsfeld - que havia participado do tratamento estatístico dos questionários nos anos 30 - defende a necessidade de distinguir entre os conteúdos
} 
americanas de pesquisa social e deixado espaço para uma mera "teoria tradicional"? Além disso, mesmo se restringirmos as pretensões das pesquisas sobre autoridade e família, pode-se considerar ainda o seguinte: se por um lado Middletown parece ter inspirado Horkheimer (cf. nota acima), por outro lado a pesquisa conduzida pelo Instituto fez um uso bastante reduzido das técnicas de pesquisa empregadas na obra do casal Lynd, restringindo-se ao questionário e não realizando, apesar da previsão ${ }^{179}$, um estudo mais detalhado sobre as características e a formação histórica dos grupos de trabalhadores que foram objeto da pesquisa, de maneira a obter uma visão sobre as mudanças pelas quais esses grupos passaram ao longo do tempo. Além disso, e mais importante, o próprio Horkheimer inúmeras vezes reiterou o caráter hipotético, inacabado e experimental da pesquisa. No prefácio à primeira edição da Revista, ele afirmava que boa parte das contribuições de disciplinas especializadas publicadas na Revista, assim como as pesquisas em curso no Instituto, tinham um caráter hipotético e provisório, e que a vinculação de seus resultados com o todo histórico, feita naqueles estudos de maneira apenas provisório, deveria ser posteriormente corrigido:

\begin{abstract}
"Aos ensaios teóricos de caráter mais geral, que abordam problemas filosóficos, psicológicos e sociológicos, somam-se investigações individuais sobre questões concretas da sociedade e economia contemporâneas. Esses estudos, que ao tentar compreender os fenômenos abordados em suas conexões históricas se distinguem de meras descrições, terão com frequência um caráter hipotético. Isso vale especialmente para os resultados provisórios das investigações conduzidas no Instituto de Pesquisa Social, a serem comunicados nesta Revista. Alguns elementos poderão se revelar falsos, mas a perspectiva de correção futura não pode impedir a tentativa de empregar os recursos das diferentes ciências no problema da sociedade contemporânea e suas contradições, e assim compreender os processos relevantes ao funcionamento e à modificação da vida social de uma maneira correspondente ao conhecimento atingido até o presente" 180 .
\end{abstract}

Por outro lado, sua afirmação de que a aplicação dos questionários e a formulação dos "tipos" (de acordo com a caracterologia de Fromm) tinha principalmente as funções de preparar os autores para pesquisas mais amplas e mantê-los "em contato com os fatos da vida diária",

\footnotetext{
"latentes" e "manifestos" presentes nas respostas fornecidas aos questionários, considerando possível submeter as respostas a classificações que ora seriam meramente "descritivas", ora seriam "interpretativas". Cf. Erich Fromm, “Arbeiter und Angestellete am Vorabend des Dritten Reichs", op. cit., pp. 16-22 e Gunzelin Schmid Noerr (Orgs.). Vol. 3. Frankfurt am Main: Fischer, 1985. p. 29.

${ }^{179}$ Cf. Max Horkheimer et al., Studien über Autorität und Familie, op. cit., p. 239.

${ }^{180}$ Max Horkheimer, "Vorwort [zu Heft 1/2 des I. Jahrgangs der Zeitschrift für Sozialforschung]". In: Max Horkheimer, Gesammelte Schriften, op. cit., vol. 3, pp. 37-38.
} 
precavendo-os de "hipóteses estranhas ao que se passava no mundo" 181 , não nos deve iludir sobre a expectativa que os organizadores nutriam quanto à pesquisa: a vinculação das questões da pesquisa e os resultados dos levantamentos a uma teoria social mais ampla poderia ocorrer ainda que inexistisse o propósito de, a partir das respostas dadas aos questionários, partir para generalizações estatísticas (como haveria de fazer Fromm nos primeiros anos do exílio norteamericano) ou para a elaboração de um estudo mais acabado que sintetizasse as múltiplas questões da pesquisa. Esse problema nos remete à questão do papel das técnicas clássicas de pesquisa empírica (questionários, entrevistas e outras) na pesquisa social praticada pelos membros do Instituto. Já no discurso de posse, Horkheimer afirmava que o emprego de questionários e de técnicas de pesquisa próprias à sociologia norte-americana eram apenas uma parte do seu programa:

\begin{abstract}
"Entre outros meios, as nossas pesquisas podem utilizar de muitas maneiras os questionários, que podem prestar preciosos serviços, contanto que se tenha sempre presente que não é lícito tirar conclusões indutivas apenas dos questionários, porque seriam prematuras e apressadas. No nosso caso o sentido essencial dos questionários vai em duas direções: em primeiro lugar, eles devem estimular a pesquisa e mantê-la constantemente em contato com a vida real; em segundo lugar, permitir que se controlem os conhecimentos adquiridos de outras maneiras e prevenir possíveis erros" ${ }^{\prime 182}$.
\end{abstract}

Na recepção dominante da teoria crítica dos anos trinta, por sua vez, há a tendência a uma sobrevalorização das pesquisas sobre autoridade e família e do caráter interdisciplinar do programa de Horkheimer. Ao localizar nas pesquisas empíricas e na interdisciplinaridade o elemento mais relevante daquele programa, essa interpretação tendeu, em suas versões mais extremas, a associar o caráter inacabado dos "Estudos" a um suposto fracasso do projeto

\footnotetext{
${ }^{181}$ Max Horkheimer, "Vorwort". Studien über Autorität und Familie, p. X.

${ }^{182}$ Cf. Max Horkheimer, "A presente situação da filosofia social e as tarefas de um instituto de pesquisa sociais", op. cit., p. 131. Na já referida pesquisa empírica feita em 1954, Betriebsklima, os autores chamam a atenção para o fato de que aquilo que os "dados" observados no nível meramente empírico precisam de uma teoria que confira a eles o seu sentido, o qual apenas podeia ser corretamente conhecido no âmbito da totalidade. Sem que isso ocorra, a sociologia se degradaria a uma mera "ciência da sociedade sem sociedade". Isso não excluiria, contudo, o proveito a ser retirado do emprego de técnicas como o questionário, a entrevista e os grupos focais, os quais, embora frequentemente associados à sociologia positivista, ofereceriam a possibilidade de um conhecimento mais preciso da estrutura interna de certos fenômenos de relevância para o conhecimento da sociedade, como os processos e as relações de trabalho. O recurso a essas técnicas de pesquisa seria, além disso, necessário para "alçar a sociologia da empresa [Betriebssoziologie] praticada na Alemanha ao estado mais adiantado em que se encontra essa disciplina nos Estados Unidos”. Cf. Theodor Adorno e Walter Dirks (Orgs.). Betriebsklima, op. cit., pp. 1314.
} 
intelectual desenvolvido por Horkheimer à época ${ }^{183}$. Essa interpretação caminha par a par com a atribuição, ao programa desenvolvido no Instituto nos anos trinta sob a direção de Horkheimer, de um duplo significado: por um lado essas pesquisas, em seu caráter inacabado, representariam o máximo a que teria chegado um programa científico supostamente abandonado ao fim dos anos trinta (o programa de pesquisas anunciado por Horkheimer em seu discurso de posse de 1931), por outro lado, elas representariam um potencial pouco desenvolvido, ao qual seria preciso retornar. Alfons Söllner, por exemplo, atribuiu ao programa interdisciplinar de pesquisas da primeira metade dos anos trinta um "potencial bastante atual, pois ainda não realizado ao longo da história das ciências" ${ }^{184}$. De maneira semelhante, Helmut Dubiel associou a publicação dos "Estudos" e do artigo "Teoria tradicional e teoria crítica", no ano seguinte, ao fim do programa de pesquisas de Horkheimer e ao ingresso do Instituto em uma fase intermediária de reflexões que duraria até 1940/41, quando o marxismo seria definitivamente abandonado, sob a influência da tese de Pollock do "capitalismo de Estado" e de sua interpretação do fascismo como o "primado da política" 185 . No mesmo espírito, Martin Jay sustentou que o programa de pesquisas de Horkheimer apenas haveria de ser retomado quando da realização dos "Estudos sobre o Preconceito", publicados a partir de 1949 e de cujos cinco volumes o mais conhecido é "A Personalidade Autoritária”: “os "Estudos sobre o Preconceito' retomaram o assunto no ponto em que os 'Studien über Autorität und Familie' o haviam deixado, mas o foco passou a incidir nas formas norte-americanas de autoritarismo"186.

Horkheimer, de fato, anunciando o caráter inacabado da publicação, logo à primeira página do prefácio aos "Estudos" afirmava que o conjunto de questões que orientaram a pesquisa só poderia ser compreendido no âmbito de uma "abrangente teoria da vida social, à qual ele está vinculado", remetendo-a para além dos limites do livro ${ }^{187}$. Fromm, por sua vez,

\footnotetext{
${ }^{183}$ Essa interpretação, que influenciou nossa decisão de estudar as pesquisas dos anos trinta e em parte explica o espaço ocupado por elas nesta tese, foi defendida por exemplo por Rolf Wiggershaus em A Escola de Frankfurt história, desenvolvimento teórico, significação política, op. cit., p. 181. O autor afirma à página 185 que os "Estudos sobre autoridade e família" de 1936 representaram o "apogeu" do trabalho interdisciplinar do Instituto depois deles, o "materialismo interdisciplinar" teria chegado ao fim. Wolfgang Bonß também defendeu tese semelhante, ao argumentar que a desistência de Horkheimer de publicar a versão dada por Fromm às pesquisas, elaborada nos primeiros anos do exílio norte-americano, representaria o fim do projeto intelectual enunciado no discurso de posse e o ingresso da produção do Instituto em uma nova fase. Cf. Wolfgang Bonß, "Psychoanalyse als Wissenschaft und Kritik. Zur Freudrezeption der Frankfurter Schule”. In: Wolfgang Bonß; Axel Honneth (Orgs.). Sozialforschung als Kritik: zum sozialwissenschaftlichen Potential der kritischen Theorie. Frankfurt: Suhrkamp, 1982. p. 390-392.

${ }^{184}$ Alfons Söllner. Geschichte und Herrschaft - Studien zur materialistischen Sozialwissenschaft: 1929-1942. Frankfurt am Main: Suhrkamp, 1979, p. 220.

${ }^{185}$ Cf. Helmut Dubiel, Wissenschaftsorganisation und politische Erfahrung, op. cit., pp. 74-100.

${ }^{186}$ Martin Jay, A Imaginação Dialética, op. cit., p. 228.

${ }^{187}$ Cf. Horkheimer, "Vorwort", p. VII. No texto que serviu à publicação "estendida" da pesquisa, em 1980, Fromm também afirma que a correlação de variáveis aí feita seria apenas um primeiro passo para uma interpretação posterior. Cf. Fromm, “Arbeiter und Angestellte...”, op. cit., p . 22. Não parece haver razão, portanto, para
} 
que parece ter sido a influência maior sobre as pesquisas empíricas e em cuja obra, portanto, aquela teoria talvez pudesse ser encontrada, afirmava ser a sua contribuição individual para o volume uma investigação "puramente psicológica", relativa "à dinâmica psicológica da atitude em relação à autoridade"188, e que só poderia ser compreendida em conjunto com os demais estudos presentes no volume. Como, entretanto, nem as contribuições individuais da terceira seção, feitas de pontos de vista teóricos, temáticos e disciplinares bastante específicos, e nem as contribuições de Horkheimer e de Marcuse ao volume contêm por si só uma teoria social capaz de conferir sentido aos estudos publicados, somos levados a buscá-la na obra maior produzida por Fromm e Horkheimer nos anos trinta ${ }^{189}$.

Qual seria essa teoria? Do que havia formulado Horkheimer em seu discurso de posse, depreende-se que seria uma teoria capaz explicar aquelas "conexões" entre, por exemplo, o papel de um grupo "no processo econômico, a transformação ocorrida na estrutura psíquica dos seus membros singulares e os pensamentos e as instituições que agem sobre esse mesmo grupo" ${ }^{190}$, relações que Horkheimer e Fromm concebem como de "ação recíproca" entre “diferentes esferas culturais"191, e que nos "Estudos sobre Autoridade e Família" são vinculadas às transformações pelas quais havia passado a família europeia nos anos precedentes (ainda que essas transformações só tenham sido consideradas na pesquisa com trabalhadores e funcionários como um referencial para a formulação de algumas das perguntas, e não como um fator para a construção de alguma teorização mais ampla, que como vimos não há de todo). A própria pergunta feita por Horkheimer, contudo, pressupõe uma teoria dessas relações, isto é, do problema entre "base e superestrutura", "economia e cultura", "relações sociais de produção e ideologia", "condições materiais e condições espirituais da vida social" etc. Os "Estudos sobre Autoridade e Família", contudo, se tomados isoladamente não oferecem essa teoria - como Fromm e Horkheimer entendiam essas relações?

\footnotetext{
considerar, como o faz Wiggershaus, as pesquisas publicadas em 1936 como o "apogeu" do trabalho interdisicplinar do Instituto (cf. nota acima).

${ }^{188}$ Erich Fromm, "Sozialpsychologischer Teil", op. cit., p. 80.

${ }^{189}$ Ainda que Marcuse tenha sido um dos organizadores do volume, a escolha dos textos de Fromm e Horkheimer como objeto de atenção privilegiada se deve ao fato de ser reduzida a obra marxista prévia de Marcuse, que na Revista do Instituto apenas havia publicado um artigo, na edição de 1934. O autor teve, é verdade, um papel importante como colaborador crítico da obra escrita por Horkheimer nos anos trinta, no âmbito dos seminários do Instituto em que eram discutidos os textos de Horkheimer anteriormente à sua publicação. Sobre isso, cf. a introdução escrita por Alfred Schmidt para a reedição da Revista de Pesquisa Social, "Die 'Zeitschrift für Sozialforschung' - Geschichte und Gegenwärtige Bedeutung”. In: Max Horkheimer (ed.) Zeitschrift für Sozialforschung. Munique: DTV, 1980, vol. 1, pp. 5-63 - sobre o papel de Marcuse nas discussões do Instituto, p. 28.

190 Max Horkheimer, “A presente situação...”, op. cit., p. 131.

${ }^{191}$ Max Horkheimer, "Vorwort". In: Studien über Autorität und Familie, p. VIII. Cf. também Erich Fromm, "Sozialpsychologischer Teil”, op. cit., p. 231.
} 
O primeiro passo a seguir será mostrar que a pesquisa sobre trabalhadores e funcionários, publicada em 1936, encontra suas raízes na teoria social de Fromm, a quem Horkheimer delegara a coordenação das pesquisas: embora afirme que sua contribuição para o volume de 1936 é uma investigação "puramente psicológica", o autor desenvolveu uma integração entre marxismo e psicanálise que pretende dar conta não só dos fenômenos psíquicos, mas também de sua relação com os fenômenos econômicos e com as ideologias. Do exame de sua contribuição para o volume coletivo, feito à luz dos outros textos que o autor publicou na primeira metade dos anos trinta, esperamos que resulte claro o vínculo entre sua teoria e a realização da pesquisa publicada em $1936^{192}$.

\section{Capítulo 2 - A contribuição de Erich Fromm}

\footnotetext{
192 Segundo Wolfgang Bonß, os "Estudos sobre autoridade e família" não teriam sido possíveis sem os textos prévios de Fromm, isto é, sem a psicologia social por ele desenvolvida no início dos anos de 1930 e que foi a condição do trabalho empírico e teórico contido no volume coletivo. Essa afirmação, contudo, necessita de maior precisão, pois desconsidera as especificidades da teoria social de Horkheimer, que seguia um caminho próprio em seus ensaios dos anos trinta (dentre eles, a "Parte Geral" dos "Estudos sobre autoridade e família") e desenvolvia de modo específico os problemas abordados por Fromm. Ainda que a psicologia social de Fromm ocupasse um lugar importante no âmbito do Instituto e também nas próprias reflexões de Horkheimer, ela seria, nas palavras desse, uma "ciência auxiliar da história" (Cf., do autor, "História e psicologia", op. cit., pp. 21-23). Permanece, contudo, resguardada em seus direitos a vinculação das pesquisas empíricas dos primeiros anos do Instituto à obra de Fromm. Cf. Wolfgang Bonß, "Psychoanalyse als Wissenschaft und Kritik. Zur Freudrezeption der Frankfurter Schule”. In: Wolfgang Bonß; Axel Honneth (Orgs.). Sozialforschung als Kritik: zum sozialwissenschaftlichen Potential der kritischen Theorie. Frankfurt: Suhrkamp, 1982, p. 380.
} 


\section{$\underline{2.1 \text { - A teoria do caráter autoritário e a fusão entre marxismo e psicanálise }}$}

Principalmente o texto "Psicologia de massas e análise do eu", de Freud, forneceu a Fromm um ponto de apoio importante para a formulação de sua teoria do "caráter autoritário": o grande apoio popular que à época recebiam os movimentos fascistas inspirava facilmente o recurso à teoria de Freud sobre as origens que, na dinâmica psíquica dos indivíduos, tem a sociabilidade do tipo de "massa", uma associação caracterizada pela dissolução das características individuais, pela vinda à tona do inconsciente e seus impulsos reprimidos e pela tendência dos indivíduos a pensarem por imagens em vez de conceitos. Partindo das lacunas que identificava na psicologia das massas desenvolvida por autores como Le Bon, McDougall e Tarde, Freud desenvolveu uma explicação própria para o fenômeno, com base em sua teoria da formação do eu: enquanto a psicologia das massas pretendia derivar o comportamento individual de impulsos que surgiriam quando de sua participação na massa, mas que não se manifestariam em outras situações, Freud, por sua vez, remontava o comportamento dos indivíduos na massa a uma dinâmica psíquica individual, iniciada no âmbito da socialização familiar. A ideia básica é que indivíduos que nesse processo não introjetaram satisfatoriamente a autoridade paterna passariam a buscar, no líder, um substituto para seu "ideal do eu"193: "Uma tal massa primária é uma quantidade de indivíduos que puseram um e o mesmo objeto no lugar de seu ideal do eu, e em consequência disso se identificaram uns com os outros em seu eu"194.

Por serem essencialmente dialéticos, argumentava Fromm, os conceitos freudianos seriam aptos à teorização da relação entre o aparelho psíquico e os processos sociais: em primeiro lugar, "supereu", "eu” e id consistiriam não em partes estáticas do aparelho psíquico, mas em funções dinâmicas dele, pois não apenas interagiriam reciprocamente, mas também estariam em permanente processo de formação, não havendo entre eles demarcações rígidas; além disso, o supereu estaria indissoluvelmente ligado à sociedade, pois não apenas se formaria, na infância, por meio da introjeção pela criança da função paterna da interdição (função que reproduz, real e simbolicamente no âmbito da família, as relações de poder que vigem na

\footnotetext{
193 Sigmund Freud, "Massenpsychologie und Ich-Analyse”. In: Sigmund Freud, Gesammelte Werke. Vol. XIII. Fischer: Frankfurt am Main, 1987, p. 74. Horkheimer, em um de seus textos programáticos do início dos anos 30, também faz menção à importância das concepções que Freud desenvolvera especialmente nesse texto. Cf. Horkheimer, "História e Psicologia“, op. cit., pp. 22-23. A crítica que Freud faz às limitações da psicologia de Le Bon em explicar o poder do líder sobre a massa - entendido como decorrência de seu "prestígio", um poder misterioso e irresistível - também parece ser aplicável à teoria weberiana do "carisma". Cf. Freud, "Massenpsychologie und Ich-Analyse", op. cit., pp. 85-87.

${ }^{194}$ Sigmund Freud, "Massenpsychologie und Ich-Analyse", op. cit., p. 128 [o destaque do texto é dado pelo autor].
} 
sociedade), mas se renovaria continuamente por meio da projeção - pela criança e, depois dela, pelo adulto - das qualidades do supereu sobre as figuras de autoridade que se apresentam a ela ao longo da vida (familiares, educadores, padres, professores, modelos de conduta etc.). Essa projeção das qualidades do supereu sobre as autoridades reais contribuiria para "transfigurálas" [verklären], isto é, dotá-las de qualidades de força, superioridade moral e sabedoria que não necessariamente lhes são próprias, e os indivíduos, ao se defrontarem com o poder real que nessas autoridades se encarna, o interiorizariam novamente, renovando o processo de formação do supereu de uma maneira parecida à da criança em relação ao pai. A relação entre supereu e a autoridade real seria, portanto, segundo o entendimento de Fromm, dialética, um não existindo sem o outro, e é por isso que os conceitos de Freud seriam, segundo o autor, apropriados para que a formação psíquica do indivíduo fosse concebida como um processo também social ${ }^{195}$.

O papel exercido pela autoridade na sociedade seria compreensível, do ponto de vista filogenético, à luz de um duplo processo de dominação: a dominação tanto da natureza externa (isto é, do meio ambiente e da sociedade) quanto da natureza interna (correspondente aos impulsos do id). Esses dois momentos estando intimamente conjugados, a transformação da natureza pelo homem envolveria a transformação de si mesmo, e nesse pressuposto a incorporação feita por Fromm das contribuições de Freud se conjugava com o conceito marxiano de trabalho como "metabolismo entre homem e natureza"196. Nos termos psicanalíticos a que o autor recorre, esse processo era concebido da seguinte maneira: ao transformar o seu meio ambiente natural e social ao longo da história, o homem transforma também o seu aparelho psíquico ${ }^{197}$. Vejamos como, na esteira de Freud, Fromm concebia esse duplo processo, com atenção ao desenvolvimento do supereu ${ }^{198}$.

\footnotetext{
${ }^{195}$ Erich Fromm, “Sozialpsychologischer Teil”, op. cit., p. 81 e pp. 85-87.

196 “Antes de tudo, o trabalho é um processo entre o homem e a Natureza, um processo em que o homem, por sua própria ação, media, regula e controla seu metabolismo com a Natureza”. Cf. Karl Marx, O Capital - Crítica da Economia Política. Vol. 1 - O Processo de Produção do Capital. Tradução de Regis Barbosa e Flávio Kothe. São Paulo: Abril Cultural, 1983, p. 149

${ }^{197}$ Cf. Erich Fromm, "Sozialpsychologischer Teil", op. cit., p. 94.

${ }^{198}$ Aqui se reproduz alguns aspectos da leitura que Fromm faz da obra de Freud, correspondente a uma apropriação particular da psicanálise pelo autor - uma apropriação que, desde os anos trinta, ou seja, antes do exílio norteamericano de Fromm e de sua aproximação de Karen Horney e da escola "neofreudiana", já continha elementos "revisionistas", que elencamos a seguir. Em primeiro lugar, Fromm criticava a universalização do complexo de Édipo (ao mesmo tempo em que resgatava a teoria do matriarcado, como vimos anteriormente, no item dedicado às pesquisas sobre autoridade e família) e descartava por completo a pulsão de morte, por considerar as formulações de Freud acerca de um conflito insuperável entre Eros e Tânatos como uma naturalização das relações típicas da sociedade burguesa, cuja moral repressora a psicanálise acataria. Cf. Erich Fromm, "Über Methode und Aufgabe einer analytischen Sozialpsychologie”, op. cit.. A crítica a Freud já se inicia na primeira página do texto. De Freud, cf. O Mal-Estar na Cultura. Tradução de Renato Zwick. Porto Alegre: L\&PM Pocket, 2010, pp. 170185. Em segundo lugar, essa naturalização das normas morais burguesas também teria consequências para a prática psicanalítica: ao demandar do analista uma postura "livre de valores" e seu distanciamento objetivo em relação ao
} 
Nesse duplo processo de dominação da natureza ao longo do qual se constitui o "eu", o medo desempenharia um papel necessário, ao proteger o eu contra os perigos apresentados pelo meio externo (natural e social) e pelas pulsões internas, provindas do id. Esse medo seria, ainda segundo a incorporação que Fromm faz da teoria da libido de Freud, de dois tipos fundamentais. Um deles seria o "medo real" do indivíduo frente aos perigos oferecidos pela realidade. Esse tipo de medo, relativo às consequências indesejáveis, claramente delineadas, que uma determinada ação pode provocar, seria de natureza consciente, "racional". Além dele, haveria o medo do supereu e da autoridade em geral, de natureza inconsciente e de fundo emocional, pois consistente no medo da perda do amor da autoridade (um sentimento que, no processo de socialização no âmbito familiar, aparece como medo da perda do amor paterno). Nesse último caso, a pulsão seria recalcada e nem mesmo chegaria a vir à consciência, daí decorrendo, em grau muito maior do que ocorre no caso do "medo real", a sua relevância como fator de dominação social, ao favorecer a manutenção da autoridade por meio de sua internalização como supereu. O medo "real", por outro lado, decorreria de uma clareza racional acerca dos perigos que determinada ação representa e, por isso, seria menos útil como fator de dominação social.

A internalização da autoridade seria acompanhada, portanto, de uma expansão da função do recalque, ou seja, de um desenvolvimento progressivo do "supereu". O recalque, útil nesse duplo processo de dominação, se faria acompanhar, entretanto, de um enfraquecimento do eu, e ao mesmo tempo em que o "eu" se constitui e se fortalece, mais se torna refém de um supereu repressor: "quanto mais abrangentes e intensos os recalques, mais protegido, é verdade, está o indivíduo contra transbordamentos perigosos dos impulsos, tanto mais, porém, está a força de seu eu restringida, tanto mais rígidas e inelásticas são as suas reações" ${ }^{199}$. Assim, o

analisando, a psicanálise freudiana acataria com resignação a impossibilidade de satisfação sexual no âmbito da sociedade burguesa, e seria por isso incapaz de promover a superação dos conflitos dos pacientes. Cf. Erich Fromm, "Die gesellschaftliche Bedingtheit der psychoanalitischen Therapie" [1935]. In: Erich Fromm, Gesamtausgabe, op. cit., vol. 1, pp. 127-129. Segundo Wolfgang Bonß, esses elementos revisionistas que já se encontravam nos textos da primeira metade dos anos trinta só iriam se desenvolver plenamente por volta de 193839, quando do rompimento de Fromm com o Instituto. Se sua saída foi à época justificada com razões financeiras (em um momento em que as ações da bolsa que sustentavam o Instituto perdiam valor em virtude da guerra que se aproximava), é mais provável que para tanto tenham contribuído mais ainda as pressões de Adorno, que discordava fontalmente da apropriação feita por Fromm da psicanálise e aparentemente desde os primeiros anos do Instituto, em Frankfurt, tinha uma relação tensa com Fromm e com ele disputava a influência sobre Horkheimer. Cf. Wolfgang Bonß, "Psychoanalyse als Wissenschaft und Kritik. Zur Freudrezeption der Frankfurter Schule". In: Wolfgang Bonß; Axel Honneth, Sozialforschung als Kritik - zum sozialwissenschaftlichen Potential der kritischen Theorie. pp. 392-396. Sobre o afastamento de Fromm do Instituto, cf. especialmente a nota 28. Sobre assunto, cf. também Martin Jay, A Imaginação Dialética, op. cit., pp. 149-153.

199 Erich Fromm, "Sozialpsychologischer Teil", op. cit., p. 98. Sigo aqui a tradução de Trieb por "impulso", empregue por Renato Zwick em suas traduções de Freud. Cf., do autor, "Sobre a tradução de um termo empregado por Freud”. In: Sigmund Freud, O Mal-Estar na Cultura. Porto Alegre: L\&PM Pocket. 2010. A tradução de Trieb 
recalque, que no processo de dominação da natureza serve como mecanismo de defesa do eu frente às pulsões do $i d$, contribui para a formação do "eu" e, ao mesmo tempo, termina contraditoriamente por enfraquecê-lo: trata-se, segundo Fromm, de um processo dialético, em que ambos os polos se conjugam.

O processo de dominação da natureza e de formação do “eu”, argumentava Fromm, seria eminentemente social, consistindo em uma "repressão socialmente necessária dos impulsos" ${ }^{200}$, quantitativa e qualitativamente determinada pela direção social dada às necessidades do inconsciente, assim como pela incapacidade de a sociedade atender a todas, sem distinção. É verdade, concedia Fromm, que a explicação fornecida por Freud para o desenvolvimento do supereu, ao vinculá-lo à relação que a criança tem, primeiro com os pais, e depois com as demais autoridades, conteria em germe a referência ao caráter social do processo: a formação do supereu é explicada por Freud como resultado da introjeção da função paterna da interdição, o medo [Angst] externo da castração e da perda do amor paterno sendo transformado em um medo interno que exerce a função do recalque das pulsões do $i d$, e a identificação com a figura paterna servindo de base às identificações posteriores com outras autoridades, ao longo da vida. Freud não teria, contudo, segundo o autor, extraído as consequências plenas dessa explicação.

E é por isso que uma concepção plenamente dialética da relação entre o processo de socialização na família e a sociedade mais ampla da qual ele adquire seu sentido e seus conteúdos específicos teria de considerar o seguinte estado de coisas: não apenas o complexo de Édipo representa as condições para as relações de autoridade em geral, mas também essas mesmas relações fornecem o modelo seguido por aquele complexo, ou seja, não apenas a figura do pai seria a instância à qual se vinculam as outras autoridades que se apresentam ao indivíduo ao longo da vida, mas é dessas próprias autoridades que emanaria o modelo seguido pela figura paterna no âmbito restrito da família. "Supereu” e "autoridade" estão, portanto, em uma relação de ação recíproca, de maneira que um não pode ser concebido sem o outro, isto é, a constituição

por "impulso" já havia sido empregada por Hilde Cohn em sua tradução dos textos de Horkheimer dos anos trinta. Cf., por exemplo, o já mencionado "História e Psicologia".

${ }^{200}$ Cf. Fromm, "Sozialpsychologischer Teil", op. cit., p. 101. O termo que Fromm emprega é "gesellschaftlich notwendige Triebunterdrückung". Não parece ser relevante aqui a distinção feita por Freud entre "Unterdrückung" e "Verdrängung", que têm sido traduzidos, respectivamente, por "repressão" e "recalque". Cf. a nota do tradutor ao texto de Freud, "O Recalque". In: Sigmund Freud, Escritos sobre a Psicologia do Inconsciente. Vol. 1. Rio de Janeiro: Imago, 2004. Coordenação da tradução: Luiz Alberto Hanns: "Freud diferencia Unterdrückung ("repressão") de Verdrängung ("recalque"), o primeiro referindo-se ao esforço consciente de reprimir um sentimento consciente e inadmissível, e o segundo, ao processo pré-consciente de evitar o acessos desses sentimentos à consciência (...)" (p. 191). 
do supereu, ao longo do processo de socialização, seria uma continuação da função exercida pela autoridade na sociedade - por outro lado, a possibilidade dessa decorreria da formação do supereu. A família seria, por isso, na descrição de Fromm, a "agência psicológica da sociedade", e cumpriria a função de produzir uma estrutura libidinal ${ }^{201}$ adequada às necessidades sociais ${ }^{202}$.

Já se note preliminarmente, a respeito dos argumentos reproduzidos acima, que Fromm concebia o caráter dialético dos conceitos freudianos como se ele residisse na ação recíproca entre as instâncias do aparelho psíquico, e na coexistência de tendências contrárias na formação do eu. "Dialética" era aqui, portanto, compreendida como o conjunto de determinadas propriedades daqueles fenômenos naturais (no caso, como o conjunto de propriedades da natureza psíquica), por exemplo, a interação recíproca entre as instâncias do aparelho psíquico e a essência intrinsecamente "contraditória" dos fenômenos psíquicos, isto é, a coexistência de tendências opostas em seu âmbito.

Esse juízo estava vinculado à concepção de psicanálise que tem o autor: essa seria, na formulação que lhe deu Freud, "uma psicologia materialista, com as características próprias das ciências naturais", e sua contribuição residiria na explicação do comportamento humano por meio de necessidades e estímulos de fundo biológico, pois "alimentados pelos 'impulsos' [Triebe] ancorados fisiologicamente, eles próprios não observáveis imediatamente"203. Contudo, se um dos méritos de Freud foi a sua capacidade de reconhecer o caráter dialético dos processos em que atuam tais impulsos, por outro lado a psicanálise apresentaria lacunas que só poderiam ser supridas por meio de sua conjugação com uma teoria social, pois entre a formação das três instâncias psíquicas e os processos sociais haveria um vínculo íntimo que a psicanálise, por si só, não conseguiria desvelar. Ao discorrer sobre as relações entre a psicanálise a e a sociologia, Fromm afirmava que "aquilo que a psicanálise pode trazer à sociologia é o conhecimento, ainda que imperfeito, do aparelho anímico do homem", que na explicação dos

\footnotetext{
${ }^{201}$ Fromm empregava, alternadamente, e aparentemente como sinônimos, os termos "estrutura libidinal" (libidinöse Struktur), "estrutura anímica" (seelische Struktur) e "estrutura pulsional" (Triebstruktur).

${ }^{202} \mathrm{O}$ aparente simplismo da conjugação feita por Fromm entre o marxismo e a psicanálise parece respaldar a acusação de "funcionalismo", feita por Axel Honneth às explicações sobre o caráter autoritário desenvolvidas nos anos trinta por ele e também por Horkheimer, que recorria ao conceito e, do ponto de vista institucional, havia confiado a Fromm a coordenação das pesquisas sobre "autoridade e família". Honneth não considera, entretanto, as diferenças entre as teses de Fromm e aquelas de Horkheimer: a compreensão que cada um dos autores tem do fenômeno da autoridade, se por si só já são distintas, se tornam mais nítidas ainda quando vinculamos as contribuições de cada um dos autores aos Studien ao conjunto geral da obra de cada um deles. Cf. Axel Honneth, Kritik der Macht - Reflexionsstufen einer kritischen Gesellschaftstheorie. Frankfurt am Main: Suhrkamp, 1985. pp. 33-41.

${ }^{203}$ Erich Fromm, "Über Methode und Aufgabe einer analytischen Sozialpsychologie”, op. cit., p. 37.
} 
fenômenos sociais e históricos deveria ser considerado ao lado dos fatores técnicos, sociais e econômicos, de maneira que seria possível “(...) investigar em que medida e de que maneira o aparelho anímico do homem atuou causalmente sobre o desenvolvimento ou determinantemente sobre a formação da sociedade"204.

Essa leitura, que haveria de ser conhecida como "revisionista", julga que a psicanálise conteria um "biologismo" que seria necessário complementar com uma teoria social. O revisionismo haveria, por sua vez, de ser combatido por Adorno e Marcuse, para quem, nos conceitos da psicanálise, já estaria contida uma teoria social dialética. Para Adorno, por exemplo, poderia ser encontrado na psicanálise de Freud

"um tema surpreendentemente dialético, embora certamente, caso lhe afirmássemos isso, ele teria ficado estarrecido tanto quanto qualquer sociólogo positivista dos dias de hoje. O tema dialético é que Freud, de maneira genuína, meramente ao trabalhar em seu próprio material, descobriu que, quanto mais profundamente descemos aos fenômenos da individuação dos homens, quanto mais sem reserva alguma compreendemos o indivíduo em sua própria dinâmica, tanto mais nos aproximamos àquilo que, no próprio indivíduo, não é indivíduo" ${ }^{205}$

O juízo segundo o qual a psicanálise de Freud não conteria em si uma teoria social levou Fromm a considerar necessário complementá-la com o marxismo - daí decorreu que, na perspectiva desenvolvida por Fromm em sua apropriação das contribuições de Freud, os fenômenos do aparelho psíquico deveriam ser situados no âmbito do modo de produção:

"Neste trabalho deve ser justamente mostrado que instâncias anímicas como o supereu
e o eu, um mecanismo como o recalque, impulsos como os sadomasoquistas, os quais
condicionam o sentir, o pensar e o agir dos homens de maneira tão decisiva, não são,
digamos, dados 'naturais', mas são, eles próprios, sempre condicionados pelo modo de

${ }^{204}$ Cf. Erich Fromm, "Psychoanalyse und Soziologie". In: Erich Fromm, Gesamtausgabe, op. cit., vol. 1, p. 3.

${ }^{205}$ Cf. Theodor Adorno, Einleitung in die Soziologie. Frankfurt am Main: Suhrkamp, 1993 [1968], p. 192. E, segundo Adorno, é por isso que "a teoria analítica [isto é, a psicanálise] denuncia a não-liberdade e o rebaixamento dos homens na sociedade não-livre, de maneira semelhante à que a crítica materialista denuncia um estado dominado cegamente pela economia". Cf. Theodor W. Adorno, "Zum Verhältnis von Soziologie und Psychologie". In: Soziologische Schriften I. Frankfurt am Main: Suhrkamp, 1997 [1955]. p. 62, Marcuse, por sua vez, criticou os revisionistas por não se darem conta de que "a teoria de Freud é, em sua própria substância, 'sociológica', e e que nenhuma nova orientação cultural ou sociológica e necessária para revelar essa substância. O 'biologismo' de Freud é teoria social numa dimensão profunda, que tem sido obstinadamente nivelada pelas escolas neofreudianas". Herbert Marcuse, Eros e Civilização - Uma Interpretação Filosófica do Pensamento de Freud. Tradução de Álvaro Cabral. 8ª edição. Rio de Janeiro: LTC, 2009 [1955], p. 29. 
vida dos homens e, ao fim das contas, pelo modo de produção e pela estrutura social dele resultante" 206 .

O quadro tinha seus contornos delineados pela estrutura de classes: as formas e os graus em que seria exercida a autoridade, internalizada no supereu, se diferenciariam segundo Fromm de acordo com o lugar ocupado por cada família na estrutura de classes: de uma maneira geral os indivíduos das classes dominadas teriam de recalcar seus impulsos em um grau maior do que aqueles pertencentes à classe dominante, do mesmo modo que esses impulsos seriam de outros tipos. A ideia básica era que a estrutura libidinal dos indivíduos se adaptaria às relações sociais de produção: ela seria a "argamassa"207 que conferiria a essas relações uma estabilidade sólida, pois assentada no aparelho psíquico dos indivíduos.

Assim, em uma família de pequenos camponeses, e também nas famílias proletárias do início do século XIX, a necessidade econômica que compelia os pais a empregar, para o sustento da família, os filhos como mão-de-obra na agricultura ou na fábrica daria ensejo a relações de autoridade baseadas em um grau elevado de recalque. Em seu tipo-ideal da família camponesa, Fromm considerava que o pai "se encontra diante do filho em uma relação que é caracterizada essencialmente por hostilidade e pela tendência à exploração, e quase nada por amor”, uma situação que teria sido comum também às famílias proletárias: “(...) também para elas, os filhos eram essencialmente objetos de uso econômico, e ninguém reagiu mais à legislação restritiva do trabalho infantil do que esses próprios pais (...)". Em situação radicalmente oposta se encontrariam as famílias abastadas, em que os filhos não seriam considerados como meios para aumentar a renda familiar, mas sim seriam "postos no mundo, porque os pais se alegram em ter filhos", do que resultaria uma atmosfera de "incentivo e amabilidade", na qual a introjeção da autoridade, não mais conjugada, como no caso das famílias camponesas e proletárias, à exploração econômica dos filhos, assumiria outros contornos: "muitos dos desejos e ideias não satisfeitos dos pais são transpostos para os filhos,

\footnotetext{
${ }^{206}$ Fromm, "Sozialpsychologischer Teil”, op. cit., p. 92. Segundo Fromm, Freud já havia, em suas ressalvas contra o marxismo (que ele tomava como um materialismo mecanicista) prestado atenção à diferença de tempos históricos entre as mudanças ocorridas ao nível da economia e aquelas que atingem os fenômenos culturais: das mudanças na ordem econômica não decorreriam automaticamente mudanças ao nível da ideologia, e o supereu seria a mediação responsável pela estabilização das ideologias. As mudanças psíquicas e culturais se dariam, portanto, em uma velocidade mais lenta. O problema é que o marxismo que Freud conheceu havia sido o materialismo mecanicista e evolucionista da passagem do século XIX ao XX. Cf. Fromm, "Sozialpsychologischer Teil", op. cit., p. 91. Semelhante crítica às tendências economicistas do marxismo havia sido feita por Weber. Cf., do autor, A Ética Protestante e o "Espírito" do Capitalismo. Edição de Antônio Flávio Pierucci. Tradução de José Marcos Mariani de Macedo. São Paulo: Companhia das Letras, 2004, p. 167.

${ }^{207}$ Erich Fromm, "Über Methode und Aufgabe einer analytischen Sozialpsychologie”, op. cit., p. 57.
} 
e a sua realização junto aos filhos é vivenciada como satisfação própria, seja pelo caminho da identificação, seja pelo caminho do amor objetal"208.

Salta aos olhos o mecanicismo do raciocínio, que busca derivar comportamentos e ideias do lugar ocupado pelos indivíduos e famílias na estrutura produtiva, e não é de espantar que, em sequência aos exemplos das famílias camponesa, proletária e burguesa, Fromm se detenha sobre o caso da família pequeno-burguesa, associando a ela uma situação de repressão dos impulsos intermediária entre aquelas duas descritas anteriormente: imaginando o caso de um funcionário dos correios de baixo escalão, que teria uma renda suficiente para que os filhos não precisassem trabalhar, Fromm concluía que em uma situação dessas “desaparece uma parte da oposição de interesses e da hostilidade que resultam das tendências do pai à exploração [econômica dos filhos]", oposição e hostilidade vigentes em famílias de baixa renda. Contudo, os filhos dessas famílias pequeno-burguesas não poderiam gozar do mesmo grau de "incentivo e amabilidade" que aqueles das famílias abastadas, pois "a vida do pai é tão pobre em satisfações e (...) tão destituída da possibilidade de dominar e comandar por si mesmo, que o filho e a mulher adquirem a função de restituir a ele o que a vida lhe nega"209.

No recurso feito por Fromm ao tema do complexo de Édipo, portanto, se imiscuía uma psicologia utilitarista que derivava o exercício da autoridade paterna da "situação de classe" da família $^{210}$, compreendida basicamente como sua renda e como a necessidade de ajustamento às relações sociais de produção dadas. Dessa maneira, ainda que Fromm tenha se esforçado por refutar a leitura de adversários do marxismo que identificavam-no a uma psicologia economicista, que explicaria toda a ação humana com base em uma suposta tendência dos indivíduos à maximização do ganho, o autor terminava por recorrer a uma psicologia desse tipo, que reduz as relações de autoridade na família ao lugar ocupado por ela na estrutura produtiva. Não fazendo jus, por meio dessa teorização, nem à psicanálise e nem ao marxismo, Fromm, a fim de explicar as diferenças "quantitativas e qualitativas" entre seus tipos ideais de conflito edipiano, tinha de recorrer a uma distinção idealista entre, por um lado, uma relação instrumental e "hostil" em que os pais assimilariam os filhos a bens sujeitos à exploração econômica (predominante nos casos da família camponesa e proletária) e, por outro lado, uma

\footnotetext{
${ }^{208}$ Erich Fromm, "Sozialpsychologischer Teil”, op. cit., pp. 89-90.

${ }^{209}$ Erich Fromm, "Sozialpsychologischer Teil”, op. cit., pp. 90-91.

${ }^{210}$ Erich Fromm, "Sozialpsychologischer Teil”, op. cit., p. 89.
} 
relação em que os filhos seriam tratados com "amor" e como "fins em si mesmos", relação predominante nas famílias abastadas ${ }^{211}$.

As formulações de Fromm sobre o assunto, citadas acima, se tornam ainda mais incompreensíveis se considerarmos os resultados da pesquisa com trabalhadores e funcionários realizada entre 1929 e 1931, e que revelou - em consonância com a tese de que a baixa classe média teria sido o apoio social do fascismo - que os funcionários, correspondentes ao grupo de status de maior prestígio, eram os trabalhadores que tinham inclinações autoritárias em maior grau ${ }^{212}$. Pode-se, contudo, abstrair da ênfase dada por Fromm, nas passagens citadas acima, ao aspecto da renda - ainda assim, elas contêm o essencial da relação de continuidade que Fromm estabelecia entre classe social, estrutura psíquica e ideologia: os "impulsos” eram considerados como expressão dos interesses de classe, e as ideologias, meras racionalizações daqueles impulsos. As consequências desse funcionalismo para as insuficiências de sua teoria do "caráter autoritário" se tornarão claras mais adiante - antes disso, é necessário apresentar ainda um outro elemento da teoria de Fromm: sua elaboração do conceito de "caráter", tal qual havia sido primeiramente esboçado, embora pouco desenvolvido, por Freud.

O “caráter" consistiria em um conjunto de traços dominantes da personalidade, e era entendido por Freud como expressão fenomênica da estrutura libidinal constituída em meio ao desenvolvimento do indivíduo ao longo das diferentes fases da sexualidade (fases oral, anal e genital): "os traços permanentes do caráter são ou continuações não modificadas das pulsões originais [Freud se referia aqui às 'fixações'], ou sublimações delas, ou formações reativas que se constituem contra as mesmas" ${ }^{213}$. Na teoria da libido formulada por Freud na primeira

\footnotetext{
${ }^{211}$ Erich Fromm, "Sozialpsychologischer Teil”, op. cit., p. 89. O recurso a conceitos idealistas como esses, que na passagem referida (à p. 89 do texto citado) é explícito, é feito subrepticiamente - e adquire proporções mais significativas - na formulação de algumas das teses centrais de Fromm, como veremos adiante no que diz respeito à sua discussão sobre a estrutura libidinal da burguesia ao longo do século XIX.

${ }^{212}$ Sobre isso, cf. o item da tese dedicado às pesquisas sobre autoridade e família .

${ }^{213}$ Sigmund Freud, "Charakter und Analerotik". In: Sigmund Freud, Gesammelte Werke. Frankfurt am Main: Fischer, vol. VII, p. 209. Cf. também seus "Três Ensaios sobre a Teoria da Sexualidade", em que o autor desenvolveu considerações semelhantes. Wilhelm Reich elaborou, a partir de Freud, uma teoria própria acerca do “caráter", mas em sua conjugação de marxismo e psicanálise se apoia no "materialismo histórico" tal qual fora concebido pelo marxismo soviético, isto é, como uma ciência da cultura e da natureza. Além disso, enquanto Fromm mantinha o caráter individual da psicanálise (a interpretação psicanalítica incidia sobre indivíduos, e não sobre as classes), Reich considerava que a psicanálise poderia ser aplicada às classes enquanto sujeito, e por isso não incorporou as críticas que Freud já fizera às tentativas de se construir uma psicologia de massas. A esse respeito, cf. Wolfgang Bonß, "Psychoanalyse als Wissenschaft und Kritik. Zur Freudrezeption der Frankfurter Schule”. In: Wolfgang Bonß; Axel Honneth (Orgs.). Sozialforschung als Kritik, op. cit., p. 372 e p. 382 . No que diz respeito às diferenças mais específicas da interpretação da psicanálise feita por cada um deles, Fromm também considera que Reich teria superestimado o elemento fisiológico do sexo, equiparando o desenvolvimento da sexualidade à prática sexual concreta. Sobre essas diferenças, assim como sobre o apoio da teoria de Fromm nas formulações de Freud sobre o "caráter" e nos trabalhos de Karen Horney sobre o fenômeno do masoquismo, cf. Fromm, "Sozialpsychologischer Teil”, op. cit., p. 113 e ss.
} 
década do século $\mathrm{XX}$, as manifestações pré-genitais da sexualidade tanto mais persistiriam, ainda que sob forma modificada, quanto menos desenvolvida fosse a sexualidade genital - para o objeto deste estudo importa ressaltar que são as pulsões típicas da "fase anal" aquelas que se sedimentariam na estrutura libidinal mais adequada ao capitalismo, em suas diferentes fases: dentre essas pulsões, encontram-se tanto o "erotismo anal", quanto as pulsões "sádicas" e "masoquistas" próprias a essa fase da sexualidade infantil.

Em seu texto de 1935 sobre "a caracterologia psicanalítica e seu significado para a psicologia social”, Fromm empreendeu à luz das contribuições de Freud uma reconstrução das análises de Weber e Sombart sobre o "espírito do capitalismo", esse passando a ser, na perspectiva de Fromm, o conjunto de traços de personalidade predominantemente constituídos a partir da permanência ou transformação das pulsões típicas da fase anal ${ }^{214}$. Como havia sido ressaltado por Weber, os atos de adquirir e poupar teriam passado, a partir do protestantismo, a ter um valor em si, independentemente das vantagens e do prazer que os bens obtidos pudessem trazer: a racionalização pela qual passou a ação econômica capitalista teria, assim, tido por pressuposto subjetivo um conjunto de valores e normas de ação que favorecessem justamente a adequação entre meios e fins, o que no âmbito da ação econômica se traduzia como o isolamento da sua finalidade própria - a obtenção de lucro - em relação aos fins próprios às demais esferas sociais.

Ocorria, argumentava Fromm, que a satisfação proporcionada diretamente pela posse (e, indiretamente, pela economia de dinheiro ou de tempo) poderia ser interpretada como uma continuação das pulsões pertencentes ao erotismo anal. Na criança originalmente manifestas, segundo a teoria freudiana, no prazer associado à produção e posse das próprias fezes, essas pulsões teriam permanecido atuantes na estrutura libidinal típica da burguesia ascendente entre os séculos XVI e XIX, não apenas sob a forma de satisfação pela posse, mas também sob a forma de "sublimações" e de "formações reativas". Assim, a racionalização progressiva da ação econômica teria caminhado ao lado da ascensão do cumprimento do dever moral à condição de virtude suprema, via sublimação do prazer sexual (com o consequente predomínio das tendências anais sobre as genitais). "Formações reativas" das pulsões próprias à fase anal, a sistematicidade, a pontualidade, a organização e a obstinação na consecução dos próprios objetivos - notadamente daqueles relativos à propriedade e ao acúmulo de bens - seriam outros

\footnotetext{
${ }^{214}$ Cf. Fromm, "Die psychoanalytische Charakterologie und ihre Bedeutung für die Sozialpsychologie". In: Erich Fromm, Gesamtausgabe, op. cit., vol. 1, pp. 59-77, especialmente, para esse ponto, pp. 70-77.
} 
componentes importantes daquilo que, de uma maneira idealista, chamou-se de "espírito do capitalismo" 215 .

Assim, a estrutura libidinal que seria típica da burguesia ascendente era derivada por Fromm do lugar ocupado por ela na estrutura de produção: as necessidades de acumulação de capital na época de formação do novo modo de produção teriam determinado que os indivíduos pertencentes a essa classe desenvolvessem traços de caráter que podiam ser compreendidos, genericamente, como aquelas "sublimações" e "formações reativas" dos impulsos próprios à fase anal. O autor se deparava, entretanto, com o fato de que no século XX, à época do capitalismo monopolista, tanto a pequena burguesia quanto o proletariado apresentavam uma estrutura libidinal parecida ${ }^{216}$. A insuficiência de uma explicação determinista daquele tipo se torna flagrante pelo menos no caso do proletariado: por que indivíduos que só tem a vender sua própria força de trabalho desenvolveriam as características típicas do "espírito do capitalismo", já que não são detentores de capital?

O modelo de Fromm, em que o lugar ocupado pela classe na esfera produtiva explica a estrutura libidinal de seus membros e a ideologia à qual eles estão vinculados, à primeira vista não parece contemplar esse caso, e Fromm é obrigado a atribuir tal fato a uma "retroação" da superestrutura e à transmissão das ideologias pela família e pela educação, não obstante terem se alterado as condições socioeconômicas específicas que assistiram a seu desenvolvimento original $^{217}$ :

\begin{abstract}
"A razão decisiva nos parece estar no fato de que a estrutura libidinal sobre a qual repousam esses traços de caráter é influenciada pela família, mas também por outras influências culturais em sentido antigo, e que ela [a estrutura libidinal] tem um certo peso próprio e se modifica mais devagar do que os fatos econômicos aos quais estava conformada anteriormente" 218 .
\end{abstract}

\footnotetext{
${ }^{215}$ Fromm acusava o conceito de idealista porque ele restringia a explicação da ação econômica capitalista a valores e normas de ação, tomados como absolutos, ou seja, não redutíveis a suas raízes materiais. Parece-nos mais correto, entretanto, e também mais afim ao materialismo de Marx e Engels, considerar que "valores" e "normas" são expressões da realidade material. Até mesmo em virtude disso, a sociologia de Max Weber resiste à crítica de idealismo, sendo essencialmente materialista. Talvez mais apropriado fosse enfatizar que a compreensão do "espírito do capitalismo" como um conjunto de normas e valores é lacunosa porque supõe um processo de racionalização que poderia ser compreendido em sua "legalidade específica", isto é, independentemente de suas mediações econômicas, políticas e - considerando o a argumento de Fromm - também psíquicas.

${ }^{216}$ No texto de 1935 Fromm não fundamentava muito precisamente essa constatação, mas é de se supor que tivesse em mente os resultados da pesquisa da qual era o coordenador no âmbito do Instituto.

${ }^{217}$ Cf. Erich Fromm, "Die psychoanalytische Charakterologie und ihre Bedeutung für die Sozialpsychologie", op. cit., p. 76-77.

${ }^{218}$ Cf. Erich Fromm, "Die psychoanalytische Charakterologie und ihre Bedeutung für die Sozialpsychologie", op. cit., p. 77.
} 
De qualquer maneira, esse não parece ser um problema muito grande, já que Fromm sustentava a tese de que as formas sob as quais se apresenta a estrutura libidinal mais adequada a cada modo de produção, não obstante variarem e apresentarem graus diferenciados quanto à composição das pulsões típicas das três fases do desenvolvimento da sexualidade, teriam sempre tido um elemento comum a todas elas: ao longo da história, dada a alienação entre o indivíduo e a sua vida social, a relação com a autoridade teria sido o traço fundamental da estrutura psíquica dos indivíduos. Isso significa que a estrutura libidinal predominante ao longo da história teria correspondido ao "caráter autoritário", isto é, um conjunto de traços de personalidade calcados basicamente no fato de a submissão à autoridade ser fonte de gratificação pulsional, isto é, nos impulsos sadomasoquistas próprios à fase anal da sexualidade $^{219}$.

A associação entre prazer e obediência à autoridade decorreria do medo da perda do amor da autoridade: um eu enfraquecido se submeteria aos ditames do supereu, como meio de se libertar do medo. Como visto acima, há uma relação de continuidade dialética entre o supereu e a autoridade (familiar e social), de maneira que a formação do supereu, no âmbito da socialização familiar, seria a base para a relação do indivíduo adulto com as demais autoridades que lhe vierem ao encontro ao longo da vida. A introjeção da figura paterna pela criança seria uma etapa necessária à constituição do eu; o excesso de recalque, contudo, conduziria a um eu enfraquecido que se submeteria aos ditames do supereu e, por consequência, da autoridade familiar e social em geral $^{220}$.

Essa estrutura libidinal, na leitura que Fromm fez da psicanálise e da obra de Freud, seria a estrutura demandada por uma sociedade que impede os indivíduos de desenvolverem satisfatoriamente o eu, e o traço essencial da estrutura libidinal autoritária seria o sadomasoquismo (por isso Fromm também chamava o "caráter autoritário" de "caráter sadomasoquista"):

\footnotetext{
${ }^{219}$ Cf. Erich Fromm, "Sozialpsychologischer Teil”, op. cit., p. 121.

${ }^{220}$ A explicação que Fromm fornece para a submissão à autoridade é semelhante à que Freud desenvolve para a religião: os homens cultivariam concepções religiosas em virtude do medo e do sentimento de impotência, que os faria ansiar pela figura paterna (representada na ideia de deus). Em O Futuro de uma Ilusão, Freud afirmava: "Procurei mostrar que as ideias religiosas resultaram da mesma necessidade que todas as demais conquistas da cultura, da necessidade de se defender da prepotência opressora da natureza. Somou-se a isso um segundo motivo, o ímpeto de corrigir as imperfeições da cultura, sentidas como algo penoso". Sigmund Freud, O Futuro de uma Ilusão. Tradução de Renato Zwick. Porto Alegre: L\&PM, 2010.
} 


\begin{abstract}
"As tendências [Strebungen] masoquistas visam à entrega do indivíduo ao poder, por meio do abandono da individualidade inerente à sua personalidade, assim como da renúncia à própria felicidade, de maneira que ele como que se dissolva no poder, encontrando prazer e satisfação nessa entrega, que pode chegar, em caso patológicos, a incluir o padecimento de dores físicas. As tendências sádicas têm a meta contrária: fazer de um outro um instrumento de sua própria vontade, indefeso e sem vontade própria, dominando-o absolutamente e sem restrições, e nos casos extremos forçando-o ao sofrimento e às manifestações de sentimento ligadas a ele"221.
\end{abstract}

A estrutura libidinal autoritária seria útil à manutenção das estruturas hierárquicas garantidoras do trabalho: essa estrutura se tornaria, então, uma força produtiva, pois se os indivíduos obedecessem apenas por medo consciente, não só os governos constituídos teriam de ter à disposição um aparato repressor que seria insustentável no longo prazo, mas também a produtividade dos próprios indivíduos seria paralisada. Isso não exclui, é claro, que a força física e o exercício do poder por meios meramente coercitivos desempenhem um papel importante na conformação das relações de autoridade - o que importa aqui é o elemento voluntário presente nessas relações, apoiadas sobre os traços de caráter dos indivíduos e por isso mais passíveis de estabilização: “onde esse caráter sente que há poder, ele quase como de maneira automática tem de venerá-lo e amá-lo. É indiferente se trata-se do poder de um homem, uma instituição ou uma ideia reconhecida (...)"222.

As raízes inconscientes do "caráter autoritário" seriam a base também das ideologias conservadoras, explicadas como racionalizações dos impulsos sadomasoquistas. Fromm acreditava mesmo ser possível falar em um "pensamento masoquista”, cujos temas básicos seriam o "desamparo" do homem diante de poderes que transcenderiam sua existência, assim como a perspectiva de que a única felicidade possível residiria, não na construção de uma sociedade emancipada, mas na sujeição a forças alheias à vontade humana - forças que, nas ideologias irracionalistas que conheceram sua maior difusão à época do capitalismo monopolista, atendiam pelos nomes de "destino", "poder do passado" ou "curso da natureza" 223.

${ }^{221}$ Erich Fromm, "Sozialpsychologischer Teil", op. cit., p. 115.

${ }^{222}$ Erich Fromm, "Sozialpsychologischer Teil", op. cit., p. 115.

${ }^{223}$ Cf. Fromm, "Sozialpsychologischer Teil", op. cit., pp. 118-120. 
Em sua análise da obra de Moeller van den Bruck, cujo pensamento, com seus traços racistas e nacionalistas, teve grande influência sobre os membros e seguidores do partido nazista, Fromm argumentava que "o caráter masoquista endeusa o passado. Como sempre foi, há sempre de permanecer; querer algo que ainda não houve é crime ou loucura"224: de fato, na filosofia do autor de $O$ Terceiro Reich, a "continuidade" seria uma "lei do movimento" histórico, e "tudo o que se move hoje, no ano e no dia em que por acaso escrevemos, na verdade não se 'move' por si mesmo, mas é ‘movido' pelos milênios que por detrás impelem”. Contra qualquer tentativa de superação daquela lei da continuidade, exerceriam uma força implacável a "soma dos milênios", a "natureza cósmica dessa estrela [em que habitamos]" e a "natureza biológica de seus seres", e esse raciocínio leva o autor a concluir que, se o cristianismo, em sua opinião a maior e mais profunda revolução já ocorrida, teve de se submeter àquelas forças manifestas à época nas características raciais e culturais do "homem antigo" e em sua correspondente expressão geopolítica - então essa lição nos permitiria antever que o anseio por uma revolução comunista, baseado em algumas poucas décadas de participação do proletariado da luta de classes, também teria por fim de ceder à "total mudança de feição do Ocidente, em decorrência da ação do homem nórdico”. Em sua defesa da ideia de um destino inelutável ao qual os povos e os indivíduos estariam submetidos, Moeller van den Bruck sustentava que a decepção decorrente da crença ingênua no progresso só poderia ser evitada pela aceitação "da catástrofe" e "da impotência dos homens em impedi-la" 225.

No "caráter autoritário", base de sustentação dessa ideologia, os impulsos de ambas as espécies, sádicos e masoquistas, se apresentariam sempre juntos, de maneira que apenas se poderia propriamente falar de um caráter "predominantemente masoquista", ou então "predominantemente sádico", no primeiro sendo mais recalcadas as tendências sádicas e, no segundo, em maior medida as tendências masoquistas. Além disso, dada a coexistência dos dois impulsos, a sociedade que produz como estrutura pulsional típica o sadomasoquismo teria de fornecer satisfações para ambas as tendências, de maneira que essas formas sociais conheceriam uma série de relações autoritárias, encadeadas de cima abaixo: assim, os membros da classe dominante oprimiriam sadicamente os membros das classes dominadas, mas suas tendências masoquistas seriam satisfeitas, por sua vez, por meio da submissão aos que se encontrem no topo da "pirâmide", fossem eles governantes eleitos, monarcas, líderes fascistas, ou então as meras ideias de um deus ou um destino aos quais se submeter. De maneira

\footnotetext{
${ }^{224}$ Cf. Fromm, "Sozialpsychologischer Teil", op. cit., p. 119.

${ }^{225}$ Arthur Moeller van den Bruck, Das dritte Reich. Hamburgo, 1930 apud Erich Fromm, "Sozialpsychologischer Teil", op. cit., p. 119-120.
} 
semelhante, os membros das classes oprimidas, se por um lado exprimiriam seu masoquismo por meio do amor e da admiração dos opressores, satisfariam suas tendências sádicas por meio da opressão das mulheres e de minorias étnicas, crianças e animais: "tudo o que existir de hostilidade e agressão e não puder vir à tona contra o mais forte, encontra o seu objeto no mais fraco (...) e o que significa mais domínio do que obrigá-lo ao sofrimento!’226.

Note-se aqui, mais uma vez, em consonância ao que foi exposto anteriormente no que diz respeito às análises de Fromm sobre as diferenças constatáveis nas relações de autoridade exemplares das famílias camponesas e burguesas, que a luta de classes é substituída por uma relação que, examinada pelo autor com respeito a seus elementos psíquicos, é funcional à dominação. Nessa funcionalidade nada muda a observação do autor de que a relação de continuidade existente entre as tendências sádicas e as masoquistas tornaria ambivalentes os sentimentos presentes nas relações de autoridade: o amor aos mais fortes estaria misturado com certa dose de inveja ou ódio, mas esse seria recalcado ou dirigido a outros objetos, o ódio aos governantes, por exemplo, sendo recalcado e dirigido, em situações de guerra, contra os chefes dos Estados estrangeiros, o ódio ao capital produtivo, redirecionado contra o capital financeiro, e assim por diante. $\mathrm{O}$ fundamental é que a persistência do trabalho alienado e da dominação de classe na "história até agora", ao se apoiar na estrutura libidinal autoritária, teria convertido todas sociedades em um "sistema de dependências estruturado para cima e para baixo", que organizaria hierarquicamente a distribuição de um sado-masoquismo que atuaria como força produtiva $^{227}$.

A ausência de predomínio da estrutura libidinal autoritária seria constatável apenas em escassos exemplos históricos, como "naquelas primitivas organizações sociais, nas quais a luta comum contra a natureza cria uma solidariedade originária de interesses”, ou então, no presente, "nos casos em que é produzido um interesse comum que se diferencia da mera igualdade recíproca de interesses, baseada em existências individuais e isoladas" ${ }^{\text {"22 }}$. Fromm tinha em mente, aqui, os comunismos primitivo e contemporâneo, que o autor identificava a sociedades em que a ausência da divisão por classes sociais permitiria um outro modo de organização das relações de autoridade, a obediência dos trabalhadores aos dirigentes do processo produtivo por eles escolhidos ocorrendo em virtude da persecução de interesses comuns entre os dois polos da relação, tal qual se daria entre médico e doente, entre professor e aluno ${ }^{229}$.

\footnotetext{
${ }^{226}$ Erich Fromm, "Sozialpsychologischer Teil”, op. cit., p. 115-117. A citação foi retirada da página 117.

${ }^{227}$ Erich Fromm, "Sozialpsychologischer Teil”, op. cit., pp. 117-118 e p. 121.

${ }^{228}$ Erich Fromm, "Sozialpsychologischer Teil", op. cit., pp, p. 112.

${ }^{229}$ Cf. Erich Fromm, "Sozialpsychologischer Teil”, op. cit., p. 122.
} 
Se o "caráter autoritário" teria, por um lado, sido uma constante na história humana, pois ensejado pela alienação, por outro lado, em certas passagens Fromm empregava o termo “formas sociais autoritárias" para se referir a casos específicos em que as condições sociais “impedem o fortalecimento do eu além de certa medida", de maneira que o eu enfraquecido não conseguiria intermediar satisfatoriamente as funções do id e do supereu, tornando-se refém das "fixações" e "formações reativas" e tendo de se subordinar ao supereu, isto é, à autoridade $^{230}$. Dentre as formas sociais que produziriam essa configuração se encontraria o "Estado autoritário", visto como um caso específico da "sociedade burguesa em geral" ${ }^{\text {231 }}$, um caso no qual seria possível verificar uma acentuação do apoio da dominação social sobre o "caráter autoritário".

Fromm tinha em vista aqui a transformação do capitalismo concorrencial em um novo tipo de capitalismo, em que o Estado e os trustes, sucessores do empresário individual da época liberal, se conjugariam na tarefa de organizar a produção e a circulação de mercadorias. $\mathrm{Na}$ fase monopolista do capitalismo, o próprio Estado seria responsável pela exploração, e não mais exerceria a função de fornecer fundamentos jurídico- ideológicos à troca de equivalentes, ocultando a exploração do trabalho pela burguesia. Nessa fase, o sucesso ou fracasso econômico teriam passado a ser creditados cada vez mais à inevitabilidade dos acontecimentos, a submissão ao mundo cego das leis econômicas e do "destino" passando a dominar as representações ideológicas em uma sociedade caracterizada pela concentração cada vez maior de capital, e a estrutura libidinal sadomasoquista seria favorecida pela acentuação das "contradições dentro da sociedade", isto é, pela luta de classes e pelos fenômenos surgidos em decorrência das crises de superprodução, como o desemprego e as guerras vinculadas à expansão imperialista ${ }^{232}$.

De um lado, concentração de capital, crises econômicas e diminuição do raio da ação individual. De outro, acentuação dos elementos sadomasoquistas na estrutura libidinal dos indivíduos. Como o autor estabelecia o elo entre esses dois polos?

Fromm ressaltava que, ao longo da história, a presença dos traços sadomasoquistas na estrutura pulsional dos indivíduos teria variado de acordo com as condições socioeconômicas inerentes aos diversos modos de produção e suas fases internas: assim, os membros da classe burguesa da época do capitalismo liberal teriam conseguido diminuir a importância dos

\footnotetext{
${ }^{230}$ Cf. Erich Fromm, "Sozialpsychologischer Teil", op. cit, p. 110.

${ }^{231}$ Erich Fromm, "Sozialpsychologischer Teil", op. cit., p. 118.

${ }^{232}$ Cf. Fromm, "Sozialpsychologischer Teil", op . cit., pp. 121, 124.
} 
elementos sadomasoquistas para a estrutura pulsional típica de sua classe, e a burguesia teria, a partir do século XVIII, sido capaz de dominar a natureza e a sociedade de maneira mais eficaz do que a classe dominante no modo de produção anterior, o feudal. Em virtude disso, ela teria conseguido desenvolver um senso de autonomia correspondente ao aumento da importância dos elementos da sexualidade genital, um processo expresso, à época do liberalismo clássico e do capitalismo concorrencial, nas ideias de autonomia do indivíduo criador e de distribuição social das recompensas de acordo com os méritos individuais. Conquanto não correspondessem ao funcionamento real da sociedade às condições reais de vida da maioria dos indivíduos, tais ideias tinham uma base real: o processo de ascensão social da burguesia e o rompimento com os "grilhões" feudais, que permitiam, pelo menos em tese, uma maior mobilidade social. É isso que permitia a Fromm se referir a uma estrutura libidinal em que a relação com a autoridade conteria elementos "democráticos": em sociedades em que a mobilidade social por meio do trabalho era uma possibilidade, a legitimidade das autoridades no âmbito da economia e da política apareceria à maioria dos indivíduos como derivada menos de qualidades inatas suas do que de seu desempenho econômico e político.

Esse exemplo deixa claro como Fromm estabelecia um paralelismo entre a dominação da natureza por uma classe social, o desenvolvimento sexual genital dos seus membros (isto é, nos termos de Fromm, o desenvolvimento de um "eu forte" em cuja estrutura libidinal os elementos sadomasoquistas sofreriam uma perda relativa de importância), e o surgimento de ideologias "mais democráticas" ou "menos autoritárias". Nesse paralelismo há diversos pressupostos que é necessário examinar com atenção.

O primeiro é uma distinção entre "autonomia" e "heteronomia" que considera que um eu "autônomo" ou "fortalecido" seria capaz de prescindir cada vez mais dos mecanismos de recalque e de submissão à autoridade, esses sendo vistos como fontes de "heteronomia". Nesse sentido, Fromm se afastava da dialética entre formação do eu e recalque, que o próprio autor, como chamamos à atenção mais acima, havia apresentado como um elemento de seu referencial psicanalítico: nessa dialética, o recalque, ao servir no processo de dominação da natureza como mecanismo de defesa do "eu" frente às pulsões do id, contribuiria contraditoriamente por enfraquecer o eu, pois "quanto mais abrangentes e intensos os recalques, mais protegido, é verdade, está o indivíduo contra transbordamentos perigosos dos impulsos, tanto mais, porém, está a força de seu eu restringida, tanto mais rígidas e inelásticas são as suas reações”233. Apesar de enunciar esse postulado teórico, ao passar para suas análises históricas, como no exemplo

${ }^{233}$ Cf. Erich Fromm, "Sozialpsychologischer Teil”, op. cit., p. 98. 
da burguesia liberal que reproduzimos acima, Fromm introduzia a ideia segundo a qual o eu fortalecido seria capaz de prescindir em grau crescente do recalque e da autoridade, e procedia a uma distinção estanque entre "autonomia" e "heteronomia", associando os impulsos da fase genital à primeira, e os impulsos sadomasoquistas, à segunda ${ }^{234}$.

O segundo pressuposto é a relação de implicação entre o domínio socioeconômico de uma classe social, isto é, o seu controle sobre os meios de produção, de um lado, e o grau de autonomia que seus indivíduos alcançam, de outro, o que nos termos de Fromm também equivale a dizer: o paralelismo entre o domínio da natureza externa e o domínio da natureza interna, esse último compreendido como um fortalecimento do eu, que se tornaria capaz de melhor exercer sua função de intermediação entre os impulsos do id e a função repressora do supereu. Nesse processo seriam reduzidos, e tendencialmente extintos, os elementos sadomasoquistas na estrutura libidinal dos indivíduos, e favorecidos seus impulsos genitais. Esse teria sido o caso dos membros da classe burguesa que ascendeu no século XVIII: indivíduos com o eu "fortalecido", capazes de dominar melhor a natureza interna e externa e, ao mesmo tempo, mais autônomos. Por outro lado, no capitalismo monopolista do século XX os indivíduos pertencentes à pequena burguesia e ao proletariado seriam indivíduos com o eu enfraquecido e tendentes à sujeição à autoridade, isto é, à heteronomia calcada em uma estrutura libidinal em que predominariam os elementos pré-genitais da sexualidade.

Na teoria de Fromm, a formação do eu, a partir da socialização familiar, seria um processo a ocorrer paralelamente à formação da classe social ao longo do desenvolvimento do modo de produção. Como já mencionado anteriormente, na referência aos tipos-ideais das famílias camponesa e burguesa, a estrutura básica da sociedade, dividida entre opressores e oprimidos, seria reproduzida no interior das famílias, e a autoridade seria exercida em graus diferentes de acordo com a maior ou menor necessidade de recalque, uma necessidade dada pelo lugar ocupado pelas famílias na estrutura produtiva: assim, nas famílias das classes oprimidas, isto é, dominadas socialmente, os filhos seriam submetidos a uma educação mais

\footnotetext{
${ }^{234} \mathrm{Na}$ fase "culturalista" de sua obra, isto é, após a emigração para os Estados Unidos, quando as influências de Marx e Freud são diluídas em uma antropologia filosófica e em uma "psicanálise humanista", essa perspectiva ganharia corpo no conceito de "produtividade": Fromm considerava como "improdutivas" as orientações de caráter que não são capazes de proporcionar o progressivo afastamento do homem de sua existência passiva em direção a uma existência autodeterminada. Tais orientações seriam favorecidas por condições sociais alienantes, e contribuiriam para reforçar as situações de alienação em que se encontram os indivíduos, "produtivas", pelo contrário, seriam as orientações de caráter que contribuiriam para que os indivíduos mantenham entre si relações que sejam favoráveis à superação do estado de alienação.

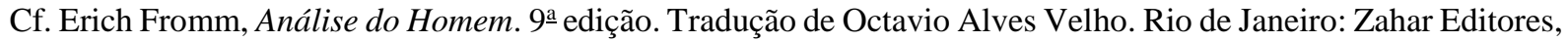
1974.
} 
repressora do que no caso das famílias mais abastadas, nessas, o fato de elas exercerem seu domínio sobre as demais classes permitiria uma educação menos repressora. Nesse raciocínio, a família era considerada uma estrutura que manteria uma relação de continuidade com uma ordem social que ela meramente reproduz, sem que a especificidade das relações familiares (e das demais relações sociais nos âmbitos da política, da cultura etc.) fosse levada em conta. O mecanicismo da teoria é facilmente desmontado por qualquer observação de um número mínimo de casos concretos. Além disso, se realmente fosse assim, bastaria analisar as estruturas familiares para se saber o que se passa na estrutura social ${ }^{235}$.

O que mais importa observar, contudo, é o vínculo entre o domínio da natureza e o favorecimento da autonomia, entendida naquela acepção problemática de fortalecimento do eu por meio do desenvolvimento da sexualidade genital. Nutridos pelo solo da sociedade de classes, os impulsos sadomasoquistas tenderiam ao desaparecimento em uma sociedade emancipada, quando o domínio da natureza deixasse de estar atrelado à divisão de classes: quando os homens tivessem um papel "ativo e racional" na organização da sociedade, tendo se libertado da alienação, seria possível promover relações racionais de autoridade, em que as hierarquias estariam subordinadas à consecução de interesses comuns e o sadomasoquismo não mais seria a estrutura libidinal típica, sendo reduzido a uma manifestação patológica de indivíduos isolados ${ }^{236}$. Aqui, Fromm conjugava sua interpretação peculiar dos impulsos sadomasoquistas, que os reduz à alienação ${ }^{237}$, com uma concepção de emancipação que a equipara ao desenvolvimento de uma classe por meio da progressiva dominação da natureza o que é o mesmo que dizer que sua leitura do conceito de alienação o reduz aos dois primeiros dos quatro aspectos do fenômeno que foram apresentados por Marx nos Manuscritos Econômico-Filosóficos, a saber, a alienação do trabalhador em relação ao produto e também em relação ao processo do trabalho ${ }^{238}$. Nada impede que se compare essas formulações de Fromm, ainda que provavelmente a contragosto do autor, a uma concepção de passagem ao

\footnotetext{
${ }^{235} \mathrm{Na}$ visão de Görlich, as análises de Fromm padecem de fato de um "familismo". Cf. Bernard Görlich, Individuum und Gesellschaft, op. cit., p. 98.

${ }^{236}$ Erich Fromm, "Sozialpsychologischer Teil", op. cit., p. 122.

${ }^{237}$ Segundo Görlich, essa leitura confirma a funcionalização dos conceitos psicanalíticos empreendida por Fromm, que os destitui de sua especificiade ao derivar fenômenos psíquicos de relações sociais: “(...) os conceitos centrais do sadismo e do masoquismo, na versão sócio-psicológica frommiana, perderam o significado especificamente sexual que tinham em Freud. Disposições sádicas e masoquistas crescem imediatamente a partir do solo de estruturas sociais autoritárias". Cf. Bernard Görlich, Individuum und Gesellschaft, op. cit., p. 97.

${ }^{238}$ Cf. Karl Marx, Manuscritos Econômico-Filosóficos. Tradução, apresentação e notas de Jesus Ranieri. São Paulo: Boitempo, 2004 [1844]. pp. 79-90. As duas outras formas da alienação são a alienação de si e a alienação do gênero. A desconsideração dessas duas outras formas caminha par a par com a naturalização, por Fromm, do conceito de "caráter", sobre a qual discorremos mais abaixo.
} 
socialismo como um processo evolutivo, tal qual na tese reformista de Bernstein de que o socialismo seria um processo em curso, caracterizado pelo aumento da participação política do proletariado, por sua transformação em uma classe média de pequenos proprietários e pelas reformas graduais que melhoravam a vida dos trabalhadores.

O terceiro pressuposto é que as ideologias, sejam as "autoritárias", sejam as "liberais" ou "democráticas", seriam racionalizações dos impulsos que, originários do $i d$, se sedimentariam no "caráter" dos indivíduos. Para compreender melhor essa ideia, examinemos mais de perto a fusão feita por Fromm entre marxismo e psicanálise, a partir das relações que o autor estabelecia entre aparelho psíquico, relações sociais de produção e ideologias. Como explicitado na definição de sua "psicologia social analítica" no texto programático de 1932, a tarefa dessa seria "explicar as disposições anímicas e as ideologias comuns (socialmente relevantes) e, sobretudo, suas raízes inconscientes, a partir da atuação das condições econômicas sobre as tendências libidinais" ${ }^{239}$. As ideologias se apoiariam, portanto, em fenômenos relativos ao inconsciente, ao mesmo tempo, o aparelho psíquico dos indivíduos seria formado de acordo com exigências da estrutura produtiva. É por isso quer o "caráter" exerceria, na teoria de Fromm, o papel de "força produtiva", e as ideologias seriam "expressão de determinados desejos e necessidades ancorados nos impulsos", "manifestações racionalizadas de impulsos" 240 .

\begin{abstract}
"Na alternância da atuação, uns sobre os outros, dos estímulos psíquicos e das condições econômicas, as últimas detêm a primazia (...) no sentido de que a satisfação de uma grande parte das necessidades - especialmente das mais urgentes, as necessidades de autoconservação - está vinculada à produção material, e no sentido de que a mutabilidade da realidade econômica extrahumana é muito menor do que a dos impulsos do aparelho psíquico humano, especialmente no que diz respeito aos impulsos sexuais" ${ }^{241}$.
\end{abstract}

Ao atribuir-lhe a qualidade de "extra-humana", Fromm concebia uma esfera econômica que subsistiria independentemente dos homens que a criaram, isto é, não seria socialmente mediada, e permanecia, assim, preso a um dualismo entre matéria e espírito, sucumbindo ele próprio à inversão entre sujeito e objeto que caracteriza o fetichismo das relações sociais no modo de produção capitalista. Disso decorrem as insuficiências de seu conceito de ideologia, que não parece muito distante daquela que se desenvolveu na esteira da obra de Engels, cuja

\footnotetext{
${ }^{239}$ Erich Fromm, "Über Methode und Aufgabe einer Analytischen Sozialpsychologie”, op. cit., p. 46.

${ }^{240}$ Erich Fromm, "Über Methode und Aufgabe einer analytischen Sozialpsychologie", op. cit., p. 37.

${ }^{241}$ Erich Fromm, "Über Methode und Aufgabe einer analytischen Sozialpsychologie", op. cit., p. 46.
} 
apresentação da teoria elaborada por ele e por Marx atribui à estrutura econômica da sociedade a propriedade de ser, em todos os tempos, a "base real" sobre a qual se erige "em última instância, todo o edifício das instituições jurídicas e políticas, da ideologia filosófica, religiosa etc., de cada período histórico" ${ }^{242}$. Fromm, apesar de ter entrado em contato com A Ideologia Alemã, interpretou as formulações de Marx e Engels sobre o caráter material e histórico das ideias fundamentalmente como uma teoria positiva das relações entre a produção das condições sociais da vida e as formas da consciência e desconsiderou o aspecto crítico e negativo do conceito de ideologia, apresentada por Marx e Engels naquela obra como uma "consciência invertida", que apresentaria as ideias como se subsistissem por si mesmas, quando na verdade elas possuem um fundamento material do qual são a expressão distorcida. Em vez disso, Fromm apoiou suas análises em um conceito de "ideologia" que a reduz a um mero epifenômeno da infraestrutura e se aproximou, ainda que involuntariamente e a contragosto, das versões economicistas do marxismo, nutridas pela leitura do Anti-Dühring e por uma interpretação determinista do "Prefácio à Contribuição à Crítica da Economia Política" de 1859. A ideologia se tornava, então, uma mera expressão dos interesses contraditórios das classes sociais - interesses que, da estrutura econômica à ideologia, passariam pelos impulsos psíquicos, pelo “caráter” dos indivíduos: "na seguinte análise dos desejos pulsionais satisfeitos na relação de autoridade, não é pressuposta a igualdade ou comunidade dos interesses individuais, e sim uma relação baseada no interesse contraditório"243.

$\mathrm{Na}$ pesquisa com trabalhadores e funcionários, realizada entre 1929 e 1931 e cujos primeiros resultados foram publicados nos "Estudos sobre Autoridade e Família" de 1936, o princípio que orientou a interpretação das respostas aos questionários foi o de uma continuidade entre ideologias políticas e caráter: ao apresentar os resultados da pesquisa e comentar o seu método, no texto que apenas viria a ser publicado em 1980 por Wolfgang Bonß, Fromm afirmava que

"doutrinas políticas abrangem não apenas uma série de concepções, mas apelam também a determinadas emoções e paixões ou a uma estrutura de caráter e a algumas posturas na qual essas paixões e esses sentimentos dominam. Pode-se descrever tanto o complexo de concepções políticas quanto

\footnotetext{
${ }^{242}$ Friedrich Engels, Anti-Dühring ("Introdução" e Parte III-Socialismo - Cap.I - Traços Históricos), op. cit..

${ }^{243}$ Erich Fromm, "Sozialpsychologischer Teil”, op. cit., p. 112. A única diferença entre os desejos pulsionais dos membros da classe burguesa e aqueles dos indivíduos pertencentes à classe trabalhadora seria que, nos primeiros, o elemento sádico estaria mais pronunciado do que nos segundos, sendo diferentes também os seus alvos.
} 
o complexo de posturas e traços de personalidade que correspondem à visão de mundo de uma determinada doutrina política"244.

Isso seria possível porque tanto as ideologias políticas quanto os impulsos inconscientes e a estrutura de caráter que é expressão deles - e que subjazeria àquelas ideologias políticas seriam resultado dos interesses e "desejos" resultantes da "situação material" de cada classe social: as diferenças entre uns e outros indivíduos no que diz respeito a suas estruturas de caráter decorreriam do fato de que os elementos psíquicos se desenvolveriam de um modo mais lento do que as força produtivas, e apenas nos indivíduos mais "avançados" os seus impulsos corresponderiam aos interesses da respectiva classe social ${ }^{245}$. O fato de ter situado a ideologia na superestrutura e o psiquismo na infraestrutura, em meio à qual ele exerceria o papel de força produtiva, ficava claro quando o autor avaliava a contribuição de Freud ao marxismo:

\begin{abstract}
"Ao comprovar que os homens são impelidos em larga medida não por suas intenções racionais, conscientes, mas sim por suas paixões inconscientes, e ao demonstrar justamente a elasticidade e a capacidade de acomodação dessas paixões, Freud forneceu a chave para a compreensão da questão de como a estrutura social e econômica modifica, justamente por meio da mediação da estrutura pulsional formada por ela, o homem inteiro e, com isso, suas concepções e desejos, em sua, a superestrutura cultural inteira. Ele, entretanto, por conta de certas reservas somente empregou essa chave na compreensão das diferenças individuais dos homens, mas não para os traços que os homens têm em comum, de acordo com as diferentes sociedades e classes"246.
\end{abstract}

Ao suprir essa suposta lacuna do pensamento de Freud, o "caráter" seria, na conjugação de marxismo e psicanálise feita por Fromm, uma força produtiva que permitiria a intermediação entre, de um lado, determinadas estruturas socioeconômicas e, de outro, as ideologias correspondentes. Ele assumiria, por isso, formas diferentes segundo o estado das relações sociais de produção e a condição de classe do indivíduo, o objetivo do processo de socialização sendo reduzir ao máximo a distância entre o caráter individual e a estrutura pulsional mais adequada às condições socioeconômicas do respectivo modo de produção, sendo premiados os indivíduos aos quais o comportamento socialmente desejável aparece como o comportamento

\footnotetext{
${ }^{244}$ Erich Fromm, “Arbeiter und Angestellte am Vorabend des Dritten Reichs”, op. cit., p. 168. Fromm afirmava ainda: "Como resultado sem dúvida mais importante há que se reter, em primeiro lugar, o baixo percentual de pessoas de esquerda que concordem tanto em pensamento quanto em sentimento com a linha socialista" (Fromm, "Arbeiter und Angestrellte am Vorabend des Dritten Reichs", op. cit., p. 188).

${ }^{245}$ Cf. Erich Fromm, “Arbeiter und Angestellte am Vorabend des Dritten Reichs - eine sozialpsychologische Untersuchung”, op. cit., pp. 168-169.

${ }^{246}$ Erich Fromm, "Sozialpsychologischer Teil”, op. cit., p. 92.
} 
natural (uma ideia que grosso modo foi formulada, sob outra perspectiva, em sociologias como as de Durkheim e Parsons).

Fromm julgava fugir à acusação de mecanicismo ao respeitar a cláusula da "última instância”: assim, como vimos acima, quando na fase monopolista do capitalismo os indivíduos pertencentes à pequena burguesia e ao proletariado apresentavam uma estrutura libidinal que não corresponde às condições econômicas específicas àquela fase, o autor explicava a discrepância como resultado do descompasso entre as relações sociais de produção e as ideologias que, formadas no período anterior (a fase concorrencial do capitalismo) e transmitidas pela família e pela educação, atuariam sobre a formação do aparelho psíquico dos indivíduos. Esse descompasso deslegitimaria qualquer inferência direta entre processos econômicos, por um lado, e ideologias, por outro, e obrigaria o analista a considerar que:

“(...) do esbater-se dos fatores economicamente condicionantes sobre esse meio, isto é, sobre o mundo dos impulsos, surgem certas refrações, isto é, que em virtude da peculiaridade da estrutura pulsional o processo social se desenrola de maneira diferente, principalmente quanto ao ritmo - mais rápido ou mais devagar - do que seria esperado ocorrer quando se desconsidera o fator psíquico. Da aplicação da psicanálise ao âmbito do materialismo histórico resulta portanto uma sofisticação do método, uma ampliação do conhecimento das forças atuantes no processo social, uma segurança ainda maior na compreensão dos processos históricos e no prognóstico dos acontecimentos sociais futuros, e especialmente a compreensão perfeita da produção das ideologias"247.

Lembremo-nos aqui brevemente do conceito de ideologia elaborado por Marx e Engels em A Ideologia Alemã: nessa obra, os autores argumentam que as representações ideológicas de uma determinada classe não são uma função de sua posição nas relações sociais de produção, condição em que supostamente se apresentariam como "visão de mundo" ou elaboração conceitual dos interesses da respectiva classe. Pelo contrário, o distintivo da ideologia seria que as ideias se apresentariam como se fossem universais, quando no fundo exprimem o particularismo da dominação de classe, distorcido e oculto: "os pensamentos dominantes nada mais são do que a expressão ideal das relações dominantes; eles são essas relações materiais dominantes consideradas sob a forma de ideias (....) em outras palavras, são as ideias de sua dominação" 248 .

\footnotetext{
${ }^{247}$ Erich Fromm, "Über Methode und Aufgabe einer analytischen Sozialpsychologie”, op. cit., pp. 53-54. Itálico nosso.

${ }^{248}$ Karl Marx e Friedrich Engels. A Ideologia Alemã. Tradução: Luiz Claudio de Castro e Costa. São Paulo: Martins Fontes, 2001. p. 48.
} 
A passagem do texto programático de Fromm citada acima revelava, por sua vez, que o esperado pelo autor é que as ideologias resultassem daquela "realidade econômica extrahumana" mencionada pouco antes, a consideração do fenômeno psíquico sendo entendida como a construção de uma teoria "plurifatorial" que evitasse o determinismo econômico direto. Seu conceito de ideologia a reduzia a um conjunto de representações, e ao fazê-lo Fromm deixou de lado o problema do fetichismo. É verdade que o autor se referiu em algumas passagens de seus textos ao fenômeno da "reificação". Ele o compreendia, contudo, muito mais como "racionalização", seguindo as pegadas dos elementos weberianos da formulação do conceito por Lukács, em História e Consciência de Classe: assim, aquelas características associadas ao "espírito do capitalismo", presentes não apenas entre os membros da classe burguesa dos séculos XVIII e XIX, mas também em meio à pequena burguesia e ao proletariado do século XX, seriam expressões particulares do fenômeno mais geral da "reificação de todas as relações humanas na sociedade burguesa"249. O autor reduzia esse fenômeno, contudo, a suas expressões psicológicas: a sistematicidade e a indiferença, dentre outros elementos, se conjugariam bem com a tendência à racionalização e mercantilização de potencialmente todas as relações sociais, assim como a limitação do prazer sexual seria compreensível como uma função das necessidades da produção, e o traço de caráter da obstinação caminharia par a par com o sentimento formalista do dever, próprio à cultura burguesa em geral, e especialmente às religiões protestantes ${ }^{250}$.

Mais importante do que isso, contudo, seria considerar que o próprio fato de se poder falar em um “caráter", isto é, em um conjunto de traços de comportamento sedimentados, indica que as relações sociais assumem no capitalismo a forma de um fetiche, isto é, de uma aparência socialmente necessária, ao mesmo tempo verdadeira e falsa. O "caráter", assim se pode imaginar uma crítica a Fromm, exprimiria uma forma social que seria resultado da "inversão" entre sujeito e objeto proporcionada pela reificação das relações sociais. Ao desconsiderar essa inversão, Fromm naturalizava o conceito de "caráter"251; ao postular uma funcionalidade entre

\footnotetext{
${ }^{249}$ Erich Fromm, "Die psychoanalytische Charakterologie und ihre Bedeutung für die Sozialpsychologie", op. cit., p. 73.

${ }^{250}$ Erich Fromm, "Die psychoanalytische Charakterologie und ihre Bedeutung für die Sozialpsychologie", op. cit., p. 70-74.

${ }^{251}$ É verdade que algumas afirmações de Fromm aparentemente vão em sentido contrário. Por exemplo, em determinada passagem da análise dos resultados da pesquisa, Fromm afirmava que "a própria estrutura autoritária de caráter é um produto da história" (Erich Fromm, "Arbeiter und Angestellte am Vorabend des Dritten Reichs", op. cit., p. 126). Isso não deve, contudo, ser tomado isoladamente, e sim compreendido à luz de sua concepção de psicologia social, que como visto acima identificou na psicanálise uma ciência natural que teria por objeto os fenômenos psíquicos da mesma maneira que outras ciências se ocupariam dos fenômenos "econômicos" e "sociais".
} 
condições socioeconômicas, caráter e ideologias, aceitava os fenômenos sociais em sua positividade e reduzia o potencial crítico de sua teoria. Como argumentou Wolfgang Bonß, a psicologia social de Fromm, ao naturalizar a dicotomia entre sujeito e objeto e adotar um método inspirado nas ciências naturais, consegue em medida muito reduzida ultrapassar as tentativas de conjugação entre marxismo e psicanálise feitas pela esquerda freudiana (Reich, Bernfeld e Fenichel) $)^{252}$.

Lembrando que os revisionistas haviam criticado Freud por supostamente defender a tese de uma dinâmica pulsional que seria uma constante antropológica (do que decorreria a necessidade de complementar sua teoria da libido com uma teoria social), Adorno argumentou que "aquilo que Freud teria feito com os impulsos, a escola neofreudiana faz com os traços de caráter", isto é, ao mesmo tempo em que acusavam Freud de biologismo e de ter permanecido atado a um naturalismo que o teria impedido de considerar o condicionamento social dos impulsos e das instâncias psíquicas, os neofreudianos hipostasiariam, segundo Adorno, as manifestações da dinâmica pulsional, por exemplo, ao considerar os traços de caráter meros resultados daquela dinâmica, como se fossem entidades fixas, dados "absolutos", elevados pela escola revisionista à condição de categorias da psicanálise. Ao fazê-lo, naturalizariam o processo de autonomização do "eu" em relação à energia pulsional difusa do $i d$ e, sem considerar (como já estava presenta na obra de Freud) que tanto a formação do indivíduo quanto a história são dotadas de uma dialética que inclui momentos tanto de progresso quanto de regressão, estabeleciam uma separação entre as duas instâncias psíquicas por meio da qual promoviam a hipóstase de categorias como "caráter" e "personalidade". Esses seriam, argumentava Adorno, ideais que não poderiam se concretizar na sociedade tal qual a conhecemos, mas que, na teoria revisionista eram substancializadas e compreendidas, não como reificações da dinâmica dos impulsos, mas como coisas, elas próprias sempre existentes e em relação com um meio social que lhes daria uma forma diferente em cada caso, de acordo com as "influências" específicas que agem sobre o indivíduo, de maneira a promover uma personalidade adaptada e uma "normalidade psíquica", no âmbito da integração entre indivíduo

\footnotetext{
${ }^{252}$ Cf. Wolfgang Bonß, "Psychoanalyse als Wissenschaft und Kritik. Zur Freudrezeption der Frankfurter Schule". In: Wolfgang Bonß; Axel Honneth (Orgs.). Sozialforschung als Kritik, op. cit., pp. 381-382. Em seu breve comentário a respeito das contribuições de Fromm à revista do Instituto, na introdução escrita para a edição de republicação da Revista, Alfred Schmidt chamou a atenção para os elementos gerais da psicologia social de Fromm e a maneira como o autor concebia o marximo, aproximando-o de uma teoria sociológica tradicional: "Mesmo com toda a dinâmica própria que o social possa apresentar, as suas estruturas, conquanto alienadas possam confrontar os indivíduos, surgem sempre da interação, da alternância [Wechselspiel] de atos individuais. Da mesma maneira que o indivíduo e a sociedade se refletem um no outro, assim também a psicologia e a sociologia. A sociologia passível em maior grau de ser enriquecida pelos métodos psicanalíticos é parra Fromm o materialismo histórico". Cf. Alfred Schmidt, "Die 'Zeitschrift für Sozialforschung'”, op. cit., p. 33.
} 
e sociedade. Nessa ideia residiria a crítica dos revisionistas à formulação que Freud deu ao complexo de Édipo e ao papel tanto das experiências infantis quanto da compulsão à repetição, cuja relevância Adorno defendia por serem expressão da desarmonia entre o indivíduo e a cultura, e indícios portanto do caráter necessariamente traumático da experiência na sociedade civilizada ${ }^{253}$.

A concepção de marxismo de Fromm, que o reduz a uma teoria das relações de determinação e retroação entre base (relações sociais de produção e forças produtivas, dentre elas o "caráter"), de um lado, e superestrutura (ideologias), do outro, o tornava refém de um determinismo cuja pouca capacidade explicativa se revelava nitidamente quando o autor trata do papel que a subjetividade (aqui vista pelo prisma do psiquismo) poderia ter na superação das relações sociais capitalistas. Dessa maneira, Fromm sugeria, por um lado, que as crises econômicas e a acentuação da luta de classes poderia favorecer uma estrutura libidinal que atue no sentido da desestabilização das relações de dominação:

\begin{abstract}
"Naturalmente, a estrutura libidinal de uma sociedade permanece tão pouco constante quanto a sua estrutura econômica e social. Ela tem, contudo, uma relativa constância, enquanto a estrutura social estiver em um certo equilíbrio, isto é, nas fases relativamente consolidadas do desenvolvimento social. Com o crescimento das contradições objetivas na sociedade, com o início da decomposição mais acentuada de uma determinada forma social, surgem também certas mudanças na estrutura libidinal da sociedade; desaparecem os vínculos tradicionais, mantenedores da estabilidade social, disposições de sentimento tradicionais se alteram. As forças libidinais são liberadas para novos empregos, e modificam assim a sua função social. Elas não contribuem mais para conservar a sociedade, mas conduzem à construção de novas formações sociais, é como se elas deixassem de ser argamassa e passassem a ser dinamite" 254 .
\end{abstract}

\footnotetext{
${ }^{253}$ Como formulou José Leon Crochik, "a psicologia do eu indicaria uma possibilidade de adaptação à cultura com ênfase voltada à normalidade psíquica, enquanto Adorno (...) tenta mostrar que a própria inadaptabilidade das pulsões já é sinal de desarmonia entre a cultura e o indivíduo". Cf., do autor, Preconceito, Indivíduo e Cultura. São Paulo: Casa do Psicólogo, 2006, p. 102. Tendiam os revisionistas, por isso, a uma postura conformista, aproximando-se das concepções sociológicas tradicionais que perpetuam a relação entre indivíduo e sociedade e desenvolvendo uma teoria de traços tão ou mais racionalistas quanto aqueles que, segundo eles, estariam na obra de Freud - ironizando-os, Adorno afirmava que "projetam" em Freud o seu próprio procedimento científico racionalista. Theodor Adorno, "Die revidierte Psychonalyse”. In: Max Horkheimer; Theodor Adorno. Sociologica II. Reden und Vorträge. 1962. pp. 120-125. O texto de Adorno, embora tenha tomado por referência representativa da escola revionista neofrerudiana uma obra de Karen Horney publicada em 1947 e apenas de passagem mencione um dos livros de Fromm ( $O$ Medo à Liberdade), contém críticas que são extensivas também à obra de Fromm, não apenas em virtude de sua estreita colaboração, a partir do período de seu exílio norte-americano, com Karen Horney no âmbito do movimento revisionista ocorrido nos EUA, mas principalmente porque os aspectos revisionistas criticados por Adorno também se encontram na obra de Fromm, tanto naquela escrrita durante o exílio norte-americano quanto em seus textos da primeira metade dos anos trinta.

${ }^{254}$ Fromm, “Über Methode und Aufgabe einer analytischen Sozialpsychologie”, op. cit., pp. 56-57.
} 
Por outro lado, a acentuação das contradições sociais poderia ter o efeito oposto:

\begin{abstract}
"Quanto mais crescem as contradições na sociedade e quanto mais insolúveis elas se tornam, mais cegas e incontroláveis são as forças econômicas, mais as catástrofes como a guerra e o desemprego assombram a vida do indivíduo como poderes irresistíveis do destino, mais forte e generalizada se torna a estrutura sadomasoquista dos impulsos, e com isso a estrutura autoritária de caráter, tanto mais a entrega ao destino se torna virtude suprema e prazer. É apenas graças a esse prazer que os homens suportam voluntariamente uma tal vida, e o masoquismo se revela como uma das condições psíquicas mais importantes para o funcionamento da sociedade, como um dos elementos principais da argamassa que a mantém coesa" 255 .
\end{abstract}

É isso que, segundo Fromm, teria ocorrido no período que transcorreu na Alemanha entre o fim da era guilhermina, em 1918, e a ascensão do regime nazista, em 1933: a pequena burguesia, que servira de suporte ao regime monárquico e à sua ideologia autoritária, após o advento da República de Weimar teria se encontrado em uma situação na qual os seus membros teriam sido impelidos a buscar novas relações de autoridade e ideologias que pudessem substituir o prestígio da nobreza em declínio. Diante da relativa instabilidade política (pluripartidarismo) e econômica (inflação de início dos anos vinte) após décadas de uma monarquia que havia servido de suporte ao processo de modernização capitalista no país, os indivíduos pertencentes a essa classe teriam vinculado o seu "caráter autoritário" a novos objetos de investimento dos impulsos sado-masoquistas: esse papel teria sido exercido tanto pelos partidos de extrema esquerda quanto pelos partidos de extrema direita. Classe, aqui, é uma soma de indivíduos (e seus respectivos "caracteres"), ideologia, um conjunto de representações que servem à racionalização dos impulsos - a mediação política, que poderia explicar aquelas mudanças, era ausente. Ainda que Fromm em princípio não excluísse esse elemento, a sua concepção de psicologia social o dispensava, como vimos acima, e não é por acaso que as pesquisas contidas nos "Estudos sobre autoridade e família" de 1936 concentraram-se sobre os trabalhadores e funcionários sem prestar atenção à formação histórica da classe trabalhadora alemã e à luta de classes nas primeiras décadas do século $\mathrm{XX}^{256}$.

\footnotetext{
${ }^{255}$ Fromm, "Sozialpsychologischer Teil”, op. cit., pp. 121-122.

${ }^{256}$ Cf. Erich Fromm, “Arbeiter und Angestellte am Vorabend des Dritten Reichs”, op. cit., pp. 186-187. Às mediações políticas do fascismo os membros do Instituto, principalmente Horkheimer, Pollock e Neumann, dedicariam sua atenção a parrtir de fins dos anos trinta. Note-se de passagem que Reich, em sua análise da adesão da classe média baixa ao nacional-socialismo, já havia chamado a atenção para o conhecido fato de que a propaganda nazista conseguiu catalisar boa parcela dos sentimentos anti-capitalistas das massas, aproveitando-se do ódio dos trabalhadores e pequenos comerciantes contra o capital financeiro (associado aos judeus) e ao grande capital em geral (representado nas grandes casas comerciais). Cf. Wilhelm Reich, Psicologia de Massas do Fascismo, op. cit. pp. 52-57. Lembre-se, a respeito do sucesso obtido pelos nazistas, que a primeira das pesquisas, feita entre 1929 e 1931, havia revelado que os trabalhadores e funcionários que votavam no partido nazista eram, em sua maioria (78\%) contrários à taylorização dos processos de trabalho, considerando-as "boas apenas para os
} 
O determinismo de fundo (apesar de todas as asseverações acerca da necesssidade de considerar o "fator psíquico") se revela também na inconsistência presente em seu conceito de “caráter revolucionário", mobilizado nas pesquisas empíricas dos anos trinta: esse corresponderia meramente ao desaparecimento dos impulsos sado-masoquistas ${ }^{257}$. Mas, se os impulsos sado-masoquistas são decorrência necessária das contradições de classe, como imaginar que haveria indivíduos de "caráter revolucionário" dentre os trabalhadores imersos no processo de produção capitalista? ${ }^{258}$.

Em decorrência do modelo que construiu para pensar as relações entre economia, psiquismo e formas de consciência, em que o "caráter" é considerado como um dado natural, Fromm não conseguia empreender uma crítica da ideologia que ressaltasse os potenciais emancipatórios inscritos no próprio modo de produção capitalista, e sua teoria social recorria à previsão não dialética de uma dominação baseada na "solidariedade de interesses" atuantes na organização do trabalho e na dominação da natureza. Essa solidariedade, que seria aquela da sociedade sem classes, permitiria uma "comunidade autêntica entre superiores e inferiores hierárquicos", à qual Fromm associava o comunismo primitivo e a transição socialista na Rússia, contemporânea ao momento em que escreve o texto e na qual a constituição desse tipo de dominação estaria em curso ${ }^{259}$.

empresário, e ruins para os trabalhadores". Além disso, eles liam mais literatura anti-capitalista de esquerda (30\% de suas preferências) do que literatura propriamente nacional-socialista (apenas $6 \%$ de suas preferências). Cf. Erich Fromm, “Arbeiter und Angestellte am Vorabend des Dritten Reichs”, op. cit., pp. 64-65 e p. 101.

${ }^{257}$ Erich Fromm, "Sozialpsychologischer Teil", op. cit., p. 131.

${ }^{258}$ Note-se que, escrevendo cerca de dez anos depois de Lukács ter introduzido, em História e Consciência de Classe, a distinção entre "consciência empírica" e "consciência atribuída", Fromm meramente dá uma formulação psicanalítica à constatação banal de que ao agravamento das contradições sociais pode conduzir tanto a uma revolução proletária quanto à formação de um regime fascista. A fỉm de fundamentar sua distinção entre consciência empírica, isto é psicológica, e consciência adjudicada, Lukács resgatara a seguinte formulação de Marx e Engels em A Sagrada Famíla, que relaciona a consciência de classe à totalidade do processo histórico: "Não se trata do que este ou aquele proletariado, ou mesmo todo o proletariado, imagina em dado momento como fim. Trata-se do que ele é e do que, de acordo com esse ser, será historicamente coagido a fazer”. Georg Lukács, História e Consciência de Classe, op. cit., pp. 133.

${ }^{259}$ Erich Fromm, "Sozialpsychologischer Teil”, op. cit., p. 112. Como sustentado por Wolfgang Bonß, a ideia de que o psiquismo poderia ter um papel revolucionário foi apenas esboçada por Fromm, e não encontrou propriamente muito espaço em sua teoria: "a tese da libido como um momento natural de resistência, que mais tarde foi retomada sobretudo por Marcuse, permaneceu vaga e desempenhou apenas um papel secundário". Wolfgang Bonß, "Psychoanalyse als Wissenschaft und Kritik. Zur Freudrezeption der Frankfurter Schule". In: Wolfgang Bonß; Axel Honneth (Orgs.). Sozialforschung als Kritik, op. cit., p. 384. 


\section{2 - O programa de pesquisas dos anos trinta: entre Fromm e Horkheimer}

Em "História e Psicologia“, um dos textos "programáticos” do início dos anos de 1930, Horkheimer retomou a crítica feita por Freud à psicologia de massas e a ênfase dada pelo pai da psicanálise à necessidade de considerar a dinâmica psíquica individual em deterimento de uma suposta dinâmica psicológica própria das massas - ao mesmo tempo, Horkheimer ressaltava que Fromm desenvolvia à época uma psicologia social que tornaria possível conjugar o estudo da dinâmica psíquica dos indivíduos com a análise do processo histórico, sem adotar o ponto de vista da psicologia de massas: ao fazer tais considerações, Horkheimer criticava implicitamente a psicologia de massas de Reich. A psicologia social de Fromm permitiria, por sua vez, descobrir quais relações existiriam entre uma classe social específica (no caso, o proletariado) e o "caráter" dos seus membros, considerado esse como uma força importante para a conservação das relações sociais especialmente quando das contradições de ordem econômica não resultasse, por si só, a superação do modo de produção. Era a psicologia social de Fromm que Horkheimer tinha em mente quando escreveu estas linhas:

"Em lugar da psicologia de massas surge uma diferenciada psicologia de grupos, isto é, a pesquisa daqueles mecanismos de impulsos, que são comuns aos membros dos principais grupos do processo de produção. Ela terá de investigar, sobretudo, até que ponto a função do indivíduo no processo de produção é determinante - pelo seu destino dentro de uma família de certa constituição, pela influência dos poderes sociais de formação, mas também pelo tipo e maneira de seu próprio trabalho dentro da economia - para a estruturação de suas formas de caráter e de consciência. Seria o caso de indagar como se produzem os mecanismos psíquicos que possibilitam manter latentes entre as classes sociais as tensões que suscitam a eclosão de conflitos com base na situação econômica“260.

Se a psicologia social de Fromm foi decisiva para a realização da pesquisa com trabalhadores e funcionários, disso não decorre, contudo, que Horkheimer e Fromm

\footnotetext{
${ }^{260}$ Max Horkheimer, "História e Psicologia", op. cit. p. 22. Partindo da crítica feita por Freud à psicologia de massas, Horkheimer declarava que: “(...) todo este complexo de questões, que estuda a relação entre líder e massa como um problema especial, ainda precisa de um aprofundamento psicológico. O conceito de habitude, ao qual a pesquisa francesa [Horkheimer tinha aqui em mente Tarde e Le Bon] destina uma importante função no tratamento das questões sócio-psicológicas, marca muito bem o resultado do processo de formação: a força das disposições psíquicas que motivam a ação socialmente exigida. É preciso, porém, penetrar mais fundo e compreender a origem deste resultado, sua reprodução e contínua assimilação ao processo social em princípio mutável. Isso só se torna possível com base em experiências que podem ser dquiridas através da análise individual" (Max Horkheimer, "História e Psicologia", op. cit., pp. 22-23). Na nota de rodapé acrescentada a essa passagem, o autor continua: "a fundamentação de uma psicologia social sobre bases psicanalíticas está sendo tentada nos trabalhos de Erich Fromm".
} 
cultivassem teorias sociais idênticas. Se Fromm, como vimos no capítulo anterior, foi refém de um funcionalismo que termina por absolutizar o "caráter autoritário", deixando pouco espaço para que seja tematizada a mudança social, uma concepção diferente dos vínculos entre relações sociais de produção, ideologia e psiquismo pode ser encontrada na obra de Max Horkheimer. É possível que Horkheimer concordasse, na primeira metade da década de trinta, com a leitura da psicanálise feita por Fromm: como lembra Martin Jay, até 1936 Horkheimer, tal qual seu colega, não aceitava a tese da pulsão de morte, e considerava a primeira fase de Freud superior, mais dialética do que a última fase, de teor supostamente biologicista - uma leitura afinada com os "revisionistas"261. É verdade também que Adorno, ingresso formalmente no Instituto apenas em 1938, pode ter exercido uma influência considerável no afastamento de Horkheimer em relação à psicologia social de Fromm, assim como em sua desistência de publicar parte dos resultados da pesquisas com trabalhadores e funcionários, dirigida por Fromm entre 1929 e $1931^{262}$. Cremos ser possível, entretanto, sustentar que apesar das referências feitas pelo diretor do Instituto em seus textos do início dos anos trinta à psicologia social de Fromm e à pesquisa com trabalhadores, já no período da mais intensa colaboração com Fromm Horkheimer orientava suas reflexões por uma teoria social que, em construção naqueles anos, assentava em outras bases ${ }^{263}$.

\footnotetext{
${ }^{261}$ Isso foi ressaltado por Martin Jay em A Imaginação Dialética, op. cit., p. 149-153, e pode ser verificado em "Egoismus und Freiheitsbewegung". In: Max Horkheimer, Gesammelte Schriften, op. cit., vol. 4 , p. 81.

${ }^{262}$ Tais textos, na sergunda versão redigida por Fromm entre 1937 e 1938, quando ainda membro do Instituto, mas já em processo de ruptura, apenas seriam organizados e publicados em 1980 por Wolfgang Bonß, sob o título de Arbeiter und Angestellte am Vorabend des Dritten Reiches. Eine sozialpsychologische Untersuchung ("Trabalhadores e Funcionários às Vésperas do Terceiro Reich: uma investigação sócio-psicológica"). Quanto a Adorno, ele considerava o conceito de "caráter autoritário" de Fromm estático, tomado como uma constante ao longo do tempo quando na verdade ele próprio seria expressão da dinâmica histórica da sociedade capitalista. Cf. a carta de Adorno a Horkheimer de 23 de março de 1937. In: Max Horkheimer, Gesammelte Schriften, op. cit., vol. 16 (Briefwechsel 1937-1940), pp. 98-99.

${ }^{263}$ As próprias diferenças terminológicas são um indício disso: apenas no texto de 1936 que constitui a "Parte sócio-psicológica" dos Estudos sobre autoridade e Família" Fromm recorreu ao termo "caráter autoritário". Seus textos anteriores falavam esporadicamente em "sociedade autoritária", "autoridade política" e "autoritade paterna", e ao tratar das estruturas de caráter na maioria das vezes empregavam diretamente a terminologia freudiana, referindo-se aos impulsos "sádicos" e ao caráter "anal", "oral", ou "genital", (excepcionalmente, mencionavam também os traços "capitalista-burgueses" de caráter). Helmut Dubiel considerou que a psicologia social de Fromm desempenhou no Instituto, no período entre 1930 e 1937, o papel de uma orientação geral "supradisciplinar", e dessa maneira teria ingressado no interior dos trabalhos dos demais membros, até o final da década de 1930. Mas os exemplos fornecidos pelo autor para comprovar esse argumento são poucos (um trabalho de Löwenthal, um de Sternheim e um de Adorno, sendo que no caso desse último não transparece a incorporação assinalada por Dubiel). Cf. Helmut Dubiel, Wissenschaftsorganisation und politische Erfahrung, op. cit., pp. 175184 (especialmente pp. 177-178 e p. 183). É verdade, contudo, que a ideia geral dos traços autoritários de caráter como uma mediação importante para se compreender a dominação social acompanhou a obra dos membros do Instituto ao longo de várias décadas. É só pensar, por exemplo, na Personalidade Autoritária. Assim, por exemplo, a partir de uma relação com a psicanálise fundamentalmente diferente daquela mantida por Fromm, Adorno recorreu à sua tipificação do "caráter sado-masoquista" para compreender o comportamento dos músicos e ouvintes de jazz. Cf. Theodor W. Adorno, "Moda intemporal - sobre o jazz". In: Idem, Prismas - crítica cultural e sociedade. Tradução de Augustin Wernet e Jorge Mattos Brito de Almeida. São Paulo: Editora Ática, 1998, p. 118 e p. 121. Como sublinhado por Katia Genel, a noção de "caráter autoritário", presente no início da teoria crítica
} 
É importante realçar as diferenças entre Horkheimer e Fromm, pois boa parte da recepção contemporânea da obra do primeiro recorre a uma suposta afinidade entre o pensamento de ambos os autores, na primeira metade da década de trinta. Essa interpretação, que até onde foi possível averiguar remonta às leituras de Martin Jay e Helmut Dubiel ${ }^{264}$, foi mobilizada tanto por Axel Honneth, quando esse acusou de "déficit sociológico" a teoria crítica dos anos de 1930, atribuindo a suas análises um caráter funcionalista, quanto por John Abromeit, quando esse, em uma direção diferente, argumentou que de supostas "afinidades eletivas teóricas" entre Fromm e Horkheimer teria resultado que a pesquisa com trabalhadores alemães, iniciada por Fromm em 1929, se constituísse sob o influxo da teoria crítica de Horkheimer, da qual um dos maiores, senão o maior mérito, na opinião de Abromeit, seria o seu caráter "não-dogmático", expresso na incorporação dos modernos métodos norteamericanos de pesquisa empírica ao marxismo ${ }^{265}$. Como ressaltou recentemente Katia Genel, contudo, as convergências entre Fromm e Horkheimer foram essencialmente "efêmeras" e "ambivalentes"266. Dessa maneira, se por um lado a psicologia social de Fromm ocupou um lugar institucional relevante no programa de Horkheimer e foi determinante para a pesquisa com trabalhadores e funcionários, por outro lado a concepção que Horkheimer tinha da relação entre a psicanálise e o marxismo era fundamentalmente diferente, e sua distância da funcionalização dos conceitos psicanalíticos (tal qual essa ocorre na obra de Fromm) se mostra nítida quando prestamos atenção ao fato de que Horkheimer não naturalizava o conceito de "caráter", antes o compreendendo como um conceito crítico, que exprime a reificação dos impulsos psíquicos:

“(...) em cada época, as forças psíquicas totais que possam evoluir no indivíduo, as aspirações, que formam a base de suas realizações manuais e espirituais, além dos fatores psíquicos enriquecedores do processo de vida social e individual, é que devem ser diferenciados daquelas constituições psíquicas relativamente

por meio da obra de Fromm, haveria de ser incorporada de diferentes maneiras pelos membros do Instiuto ao longo dos anos, e por isso não se poderia sustentar que, à existência de um "primado" da psicologia social de Fromm, nos primeiros anos da execução do programa de Horkheimer, teria se seguido um "primado da política", a partir da incorporação da tese de Pollock do capitalismo de Estado, n início da década de 1940. Cf. Katia Genel, Autorité et emancipation: Horkheimer et la théorie critique, op. cit., p. 26 e p. 148.

${ }^{264}$ Cf. Helmut Dubiel, Wissenschaftsorganisation und politische Erfahrung, op. cit., p. 177; e também Martin Jay, A Imaginação Dialética, op. cit. pp. 149-153.

265 Cf. Cf. Axel Honneth, "Teoria Crítica", in Anthony Giddens; Jonathan Turner (Orgs.). Teoria Social Hoje. Tradução de Gilson César Cardoso de Sousa. São Paulo: Unesp 1996. pp. 524-536; e John Abromeit, Max Horkheimer and The Foundations of the Frankfurt School, op. cit., pp. 207-219.

${ }^{266}$ Katia Genel, Autorité et emancipation: Horkheimer et la théorie critique. Paris: Payot, 2013, pp. 134-148. Infelizmente foi apenas ao final desta pesquisa que tomamos conhecimento do rico e instigante comentário escrito pela autora. Ainda assim, nele foi possível encontrar apoio e inspiração para a sustentação de algumas das ideias centrais desenvolvidas nesta tese. Em uma próxima oportunidade, é nossa intenção realizar uma leitura mais minuciosa do livro, a fim de aprofundar o diálogo estabelecido com ele. 
estáticas dos indivíduos, grupos, classes, raças, nações, em suma, dos seus caracteres determinados pela respectiva estrutura social" 267 .

O fato de que a perspectiva de Horkheimer era menos refém da visão funcionalista que acometia a teorização de Fromm é nítido em sua concepção do papel da família, que se transformava à medida em que o Estado e outras instituições (como as associações de jovens, o rádio e aquilo que mais tarde Horkheimer e Adorno chamarão de "indústria cultural") assumiam boa parte de suas funções socializadoras. A família não era, para Horkheimer, uma mera instância na qual o "caráter autoritário" haveria de se formar (tal qual na concepção de Fromm da família como "agência psicológica da sociedade"), e sua legalidade própria diante das outras esferas sociais a tornava capaz tanto de reforçar quanto de oferecer resistência ao processo de reprodução das condições da dominação ${ }^{268}$.

Isso nos leva também a considerar melhor o papel das pesquisas sobre autoridade e família na produção do Instituto. Como vimos anteriormente, a pesquisa com trabalhadores e funcionários fazia parte do programa intelectual de Horkheimer para o Instituto, tendo sido inclusive citada já em seu discurso de posse de 1931 - julgamos, entretanto, haver a tendência geral, entre os comentadores, a uma superestimação do valor das pesquisas empíricas no projeto intelectual dos anos trinta ${ }^{269}$. Se as pesquisas sobre autoridade e família foram parte importante do projeto intelectual delineado por Horkheimer para o Instituto, não é no recurso às técnicas clássicas de pesquisa empírica (no caso, ao questionário) que consistiu o caráter "nãodogmático" e, por fim, a contribuição maior da teoria crítica dessa época. Em primeiro lugar, porque a publicação de 1936 tinha um caráter meramente provisório, cumprindo a mera função de apresentar ao público o andamento dos trabalhos do Instituto (como assinalou o próprio Horkheimer no prefácio). A avaliação dos questionários foi feita por Fromm, como já mencionado, depois da publicação dos "Estudos sobre autoridade e família", o estudo resultante apenas vindo a ser publicado em $1980^{270}$. Em segundo lugar, porque as pesquisas sobre

\footnotetext{
${ }^{267}$ Max Horkheimer, "História e Psicologia”, op. cit., p. 20.

${ }^{268}$ Cf. o prefácio aos "Estudos sobre autoridade e família": Max Horkheimer, "Vorwort". In: Max Horkheimer et al., Studien über Autorität und Familie, op. cit., p. VIII e também "Autoridade e família" ("Parte Geral”). In: Teoria Crítica I - uma documentação. Tradução de Hilde Cohn. São Paulo: Perspectiva, 1990. pp. 179-180, pp. 216-217 e p. 225.

269 Apesar de a estrutura das pesquisas empíricas não costumar ser objeto de análise detalhada, boa parte da recepção, ao mesmo tempo em que considerou os "Estudos sobre autoridade e família" como o ápice do trabalho interdisciplinar no âmbito do Instituto - trabalho frequentemente tomado como sinônimo do programa intelectual de Horkheimer - também identificou no caráter fragmentário da obra e no abandono posterior das pesquisas empíricas o suposto fracasso daquele programa intelectual. Cf. Rolf Wiggershaus, A Escola de Frankfurt..., p. 181; John Abromeit, Max Horkheimer and The Foundations of the Frankfurt School, op. cit., pp. 207-219.

${ }^{270}$ Cf. o prefácio de Horkheimer aos "Estudos": "Vorwort". In: Max Horkheimer et al., Studien über Autorität und Familie, op. cit., pp. VII-X.
} 
autoridade e família, tais quais apresentadas nos "Estudos" de 1936, empregaram recursos técnicos muito inferiores àqueles disponíveis à época de sua realização e já então amplamente utilizados pelas ciências sociais ${ }^{271}$. Em parte isso se deve à pouca difusão das técnicas empíricas de pesquisa na Alemanha, onde dominava uma sociologia da cultura de caráter fundamentalmente histórico, e também à pouca familiaridade dos membros do Instituto com o emprego dessas técnicas ${ }^{272}$. A própria desistência de Horkheimer de publicar a versão da pesquisa tal qual fora elaborada por Fromm em 1937-1938 (isto é, depois de terem sido publicados em 1936, nos "Estudos", apenas o modelo do questionário e algumas respostas consideradas exemplares da diversidade encontrada em meios aos respondentes) parece ter sido mais expressão da concepção de teoria social de Horkheimer, já no início dos anos trinta fundamentalmente diferente da fusão entre marxismo e psicanálise feita por Fromm, do que indicativa de uma mudança, sob influência de Adorno, da leitura de Freud feita por Horkheimer, uma mudança expressa na divergência de Horkheimer quanto ao revisionismo psicanalítico que se aprofundou na obra de Fromm por volta de 1935 (principalmente em seu texto sobre o "caráter socialmente condicionado da psicanálise") ${ }^{273}$.

Um primeiro indício parece confirmar nosso argumento sobre as diferenças teóricas entre Fromm e Horkheimer já na primeira metade dos anos trinta: trata-se das próprias intenções que o diretor do Instituto pretendia alcançar com as pesquisas sobre autoridade e família. Não se tratava apenas de averiguar, por meio dessas pesquisas, a disseminação do "caráter autoritário" entre os trabalhadores alemães, como formulado por Fromm na introdução escrita em 1970 para a segunda edição da pesquisa: a expectativa teria sido de que a pesquisa revelasse a disposição do proletariado alemão a aderir ao nazismo ou rejeitá-1o ${ }^{274}$. Acreditamos que essa declaração deva ser relativizada, em proveito mesmo das formulações que podem ser encontradas nos próprios textos da época. Tratava-se, antes - pelo menos para Horkheimer - de

\footnotetext{
${ }^{271}$ Essa é a opinião também de Helmut Dubiel, Wissenschaftsorganisation und politische Erfahrung, op. cit., p. 186. As técnicas de pesquisa empírica empregadas no Instituto passariam nos anos seguintes, contudo, por uma progressiva sofisticação. Sobre isso, cf. Deborah Christina Antunes, Por um conhecimento sincero no mundo falso - teoria crítica, pesquisa social empírica e The Authoritarian Personality. Jundiaí: Paco Editorial, 2014. Como mostrou a autora no capítulo 2 de seu livro, os estudos sobre antissemitismo realizados nos Estudos Unidos em meados da década de quarenta, ao recorrerem a entrevistas e outras técnicas qualitativas para além dos questionários, superaram as limitações das pesquisas sobre autoridade e família dos anos trinta e pavimentaram o caminho rumo aos "Estudos sobre Preconceito" (dos quais "A Personalidade Autoritária" foi parte).

272 À exceção de Hilde Weiß, que foi a responsável pela execução das pesquisas e talvez até mesmo pela elaboração do questionário, o que só poderia ser decidido á base de pesquisa histórica mais profunda.

${ }^{273}$ Cf. Erich Fromm, "Die gesellschaftliche Bedingtheit der psychoanalytischen Therapie". In: Erich Fromm, Gesamtausgebe, op. cit., vol. 1. Essa é a interpretação de Martin Jay, A Imaginação Dialética, op. cit., pp. 149153; e também de John Abromeit, Max Horkheimer and the foundations of the Frankfurt School, op. cit., pp. 336337.

${ }^{274}$ Cf. Erich Fromm, “Arbeiter und Angestellte am Vorabend des Dritten Reichs - eine sozialpsychologische Untersuchung”. In: Erich Fromm, Gesamtausgabe, vol. 3, p. 3.
} 
entender as mudanças pelas quais passava a subjetividade dos membros da classe trabalhadora (sua estrutura psíquica e sua ideologia), e em que medida (se é que de fato) essas mudanças ocorriam em conexão com transformações no processo produtivo (se é que se seguiriam, já que no âmbito da história não poderia haver nenhuma necessidade estabelecida a priori $)^{275}$. Lembremos a formulação presente no discurso de posse de Horkheimer:

"quais conexões é possível apurar - num determinado grupo social, num período determinado, em determinados países - entre o papel desse grupo no processo econômico, a transformação ocorrida na estrutura psíquica dos seus membros singulares e os pensamentos e as instituições que agem sobre esse mesmo grupo, como totalidade menor no todo da sociedade, e que são por sua vez o seu produto? (...) Num primeiro momento pretendemos direcioná-los [os trabalhos de pesquisa] a um grupo social particularmente importante e característico, aos operários qualificados e aos empregados na Alemanha: depois a pesquisa deverá ser estendida também às classes sociais correspondentes dos outros países europeus altamente desenvolvidos" 276 .

Em consonância a isso, a afirmação de Horkheimer, no prefácio ao volume coletivo de 1936, de que um clássico estudo sobre mudança cultural - Middletown - havia lhe servido de referência em seu estímulo dado às pesquisas feitas no Instituto, e também, principalmente, a atenção dada pelas pesquisas de início dos anos trinta às mudanças ocorridas no âmbito da família (principalmente o declínio da autoridade paterna - um fenômeno largamente favorecido pelo desemprego - e a emancipação feminina), nos levam a crer que o interesse da pesquisa com trabalhadores e funcionários era, para Horkheimer, menos saber qual a estrutura de caráter predominante entre os trabalhadores alemães (pelo menos da maneira como Fromm havia formulado a pergunta em suas pesquisas) do que entender, em seus aspectos econômicos, psicológicos e ideológicos, o processo de integração do proletariado na fase monopolista do capitalismo. Por isso eram relevantes, por iluminar aspectos da mudança social em curso, os resultados das demais pesquisas feitas após a principal (com trabalhadores e funcionários): ao se debruçarem mais especificamente sobre o papel da família (a quarta e a quinta atingiram, como tentamos mostrar, resultados pouco significativos), elas se encontravam de certa maneira mais próximas às intenções de Horkheimer do que a primeira pesquisa (o levantamento com trabalhadores e funcionários coordenado por Fromm e executado por Hilde Weiß), pois

\footnotetext{
${ }^{275}$ Cf. Max Horkheimer, "História e Psicologia”, op. cit., passim.

${ }^{276}$ Max Horkheimer, "A presente situação da filosofia social e as tarefas de um instituto de pesquisas sociais", op. cit., p. 131. A psicologia social de Fromm prestaria, na condição de "ciência auxiliar" da história, uma contribuição fundamental para se poder construir os vínculos entre a base econômica e as ideologias. Cf. Max Horkheimer, "História e Psicologia", op. cit., pp. 21-23. Sobre esse ponto, cf. Helmut Dubiel, Wissenschaftsorganisation und politische Erfahrung, op. cit., pp. 175-177. Na obra de Fromm, como vimos, esses vínculos eramo feitos com recurso a uma teoria de base naturalista.
} 
ressaltaram com maior nitidez as mudanças que estão no núcleo da questão norteadora do programa de investigação ${ }^{277}$.

Por sua vez, seu ponto fraco consistia em que as conclusões obtidas baseavam-se predominantemente nas respostas fornecidas por médicos, professores, pedagogos e outros especialistas e, se as mudanças na estrutura de autoridade na família foram diagnosticadas em suas linhas gerais, o processo não apenas não foi objeto de nenhum estudo mais consistente (devido às fontes utilizadas, que não ultrapassavam em muito o senso comum), como também estavam distantes da abrangência explicativa pretendida por Horkheimer em seu discurso de posse. A primeira pesquisa, por sua vez, se por um lado consistiu na aplicação direta de questionários aos trabalhadores, não conseguiu, por outro lado, capturar as mudanças que teriam ocorrido em sua "estrutura de caráter". Para tanto seria preciso o recurso a uma metodologia que analisasse as mudanças pelas quais passaram os grupos profissionais estudados - apesar de esse tipo de análise ser previsto, não chegou a ser concretizado ${ }^{278}$.

Em uma conclusão preliminar, talvez seja possível afirmar que as pesquisas sobre autoridade e família, tais quais foram expostas no volume de 1936, só adquirem seu pleno sentido se conjugadas com outras contribuições do programa de pesquisas concebido por Horkheimer. A teorização do problema da autoridade seguia em sua obra um curso próprio, e

\footnotetext{
${ }^{277}$ Relembrando o que foi dito acima, quando da análise das pesquisas sobre autoridade e família: a segunda e a terceira pesquisas chegaram à conclusão de que teria havido, no período posterior à primeira guerra, um processo de emancipação da mulher, expresso tanto em uma maior liberdade sexual quanto no aumento da participação da mulher nas decisões familiares sobre o consumo e a educação os filhos. As pesquisas também constataram a existência de estruturas de autoridade fundamentalmente diferentes quando se comparavam as famílias camponesas com as das cidades: em virtude das diferenças da divisão social do trabalho (no campo, a família ainda era em larga medida uma unidade de produção econômica), nas famílias camponesas o pai exercia um papel de autoridade que tenderia ao declínio em meio às famílias urbanas. Cf. Max Horkheimer et al., Studien über Autorität und Familie, op. cit., p. 273, pp. 303-305 e pp. 315-316. Helmut Dubiel argumentou que a relação entre os ensaios teóricos da primeira seção da obra e os levantamentos contidos na segunda seção poderia ser constatada no fato de que a avaliação dos questionários seguia a psicologia social de Fromm, e que a formulação da problemática seguia a teorização de Horkheimer sobre o problema da "autoridade". Essa afirmação teria, contudo, de ser mais precisada: em primeiro lugar, porque Dubiel não diferenciou suficientemente as pesquisas específicas que deram origem aos "Estudos sobre Autoridade e Família": assim, se a pesquisa com trabalhadores e funcionários seguiu a psicologia social de Fromm e sua caracterologia tanto na formulação das perguntas quanto na avaliação dos questionários (ela, aliás, tinha sido iniciada anteriormente à tomada de posse de Horkheimer como diretor do Instituto), são a segunda e terceira pesquisas, em seu curso relativamente independente de Fromm, que apesar de suas limitações parecem ter espelhado melhor os interesses teóricos de Horkheimer. Cf. Helmut Dubiel, Wissenschaftsorganisation und politische Erfahrung, op. cit., pp.186-187. A interpretação de Abromeit a esse respeito parece convergir com o que tentamos mostrar. Cf. John Abromeit, Max Horkheimer and the foundations of the Frankfurt School, op. cit. pp. 294-300.

${ }^{278}$ Como indicado anteriormente, a metodologia utilizada em Middletown, estudo dos sociólogos norte-americanos Robert e Helen Lynd que serviu de inspiração a Horkheimer, cumpria esse propósito ao acrescentar, às entrevistas com os habitantes da pequena cidade estudada, análises de estatísticas, jornais e documentos oficiais para descrever os padrões da mudança cultural que ali transcorrera nas três décadas anteriores à realização da pesquisa. Essas técnicas de pesquisa, se o seu uso chegou a ser previsto nos "Estudos", não foram empregadas na pesquisa com trabalhadores e funcionários e apenas o foram de maneira parcial e reduzida nos demais levantamentos. Cf. a introdução de Robert S. Lynd e Helen Merrel Lynd a sua obra Middletown - a Study in Modern American Culture. Nova York: Harvest, HBJ, 1959 [1929].
} 
o desafio posto pela questão formulada no discurso de posse (sobre as conexões que podem ser feitas entre os processos econômicos, as estruturas psíquicas e as ideologias e instituições sociais) haveria de ser melhor satisfeito, como talvez fique claro mais adiante, se considerarmos as pesquisas em conjunto com os ensaios escritos por Horkheimer nos anos trinta ${ }^{279}$.

\footnotetext{
${ }^{279}$ Axel Honneth, ao não diferenciar suficientemente a obra de Fromm daquela escrita por Horkheimer nos anos trinta, acusou de "déficit sociológico" a teoria crítica da época, à qual teria faltado uma concepção da produção intersubjetiva das normas culturais que regulam a ação social. As análises sobre o autoritarismo empreendidas nos anos trinta seriam devedoras de um raciocínio economicista, que derivaria o comportamento das classes sociais do lugar ocupado por elas na estrutura produtiva, e dessa equação teria partido a teoria crítica inicial, ainda confiante nas possibilidades de superação do capitalismo. Não se tendo, a partir de 1936/1937, verificado mais potencial revolucionário algum no proletariado, o marxismo teria sido paulatinamente abandonado em favor de uma crítica à razão instrumental, concretizada na Dialética do Esclarecimento. Cf. Axel Honneth, Kritik der Macht Reflexionsstufen einer kritischen Gesellschaftstheorie. Frankfurt: Suhrkamp, 1985, pp. 33-41. Um conjunto de objeções à tese do "déficit sociológico" da primeira geração da teoria crítica pode ser encontrado na tese de Stefan Fornos Klein, A universidade e a sociologia sergundo Max Horkheimer: teoria, pesquisa e crítica. Tese de doutorado. FFLCH-USP. São Paulo, 2012, pp. 133-148.
} 
PARTE II 


\section{Capítulo 3 - A crítica de Horkheimer à ideologia contemporânea}

\section{$\underline{3.1 \text { - Ciência e metafísica }}$}

Em seu discurso de posse como diretor do Instituto de Pesquisa Social, Horkheimer lembrava a oposição dominante na filosofia de seu tempo, dada entre o positivismo que reduz a realidade a fatos individuais, de um lado, e as correntes da filosofia social que postulavam a existência de essências ou totalidades de caráter absoluto, de outro. Segundo o autor, nas últimas décadas do século XIX teria surgido, como uma reação ao cientificismo predominante, o anseio por uma "filosofia social" que desempenhasse o papel de conciliação entre a existência singular e a história universal, um papel exercido pela filosofia hegeliana antes de seu "desmoronamento". Esse anseio, concretizado nos sistemas éticos neokantianos que consideravam o sentido da existência humana apenas capaz de se realizar em totalidades históricas supra-individuais como a nação e o Estado, estaria expresso também na antropologia filosófica de Max Scheler, em sua concepção da história como desenrolar de uma essência humana ${ }^{280}$. Essas vertentes da "filosofia social" consistiriam em tentativas de empreender algum tipo de conciliação entre o indivíduo e a universalidade, por meio da pressuposição de uma verdade supratemporal. Dessa maneira, conferiam sentido à existência singular, e repetiam a operação de "transfiguração" presente na filosofia de Hegel:

\footnotetext{
"Como vimos, a filosofia social hoje tem uma relação polêmica sobretudo com o positivismo. Este veria apenas o singular e, portanto, na esfera da sociedade, somente o indivíduo e as relações entre os indivíduos: tudo se reduziria a facticidades. A filosofia não coloca em dúvida essas facticidades, verificadas com os meios da análise científica; mas contrapõe-lhes, de modo mais ou menos construtivo, de modo mais ou menos 'filosofante', ideias, essencialidades, totalidades, esferas autônomas do espírito objetivo, unidades de sentido e espíritos dos povos, que ela considera serem formas não apenas mais originais como 'mais autênticas' do ser"'281.
}

\footnotetext{
${ }^{280}$ Cf. Max Horkheimer, "A presente situação da filosofia social e as tarefas de um instituto de pesquisas sociais", op. cit., pp. 124-126; e também, do mesmo autor, "História e Psicologia", op. cit., pp. 13-15.

${ }^{281}$ Max Horkheimer, "A presente situação da filosofia social e as tarefas de um instituto de pesquisas sociais", op. cit., p. 126. Cf. também a passagem entre as páginas 124 e 125 do mesmo texto. Não muda muito aqui a possibilidade de o emprego por Horkheimer do termo "filosofia social" se dever menos à classificação sob esse título de um conjunto preciso de correntes de pensamento do que à circunstância de o autor ter sido recém-nomeado para a cátedra de "filosofia social", criada na Universidade de Frankfurt especialmente como forma de Horkheimer se tornar diretor do Instituto de Pesquisa Social, função que apenas poderia ser ocupada por um catedrático.
} 
Horkheimer considerava a ambas como idealismos complementares, a ciência (na acepção positivista descrita acima) e a metafísica (na acepção ampla de um conhecimento que rejeita a experiência sensível em suas tentativas de conhecer o ser e buscar uma fundamentação última para o conhecimento e a ação). Essa crítica deve ser entendida no contexto do "materialismo" de Horkheimer. Em seus ensaios do início da década de trinta, o autor o concebeu como "um aspecto dos esforços para melhorar as condições humanas" 282. Teoria indelevelmente vinculada à prática, o materialismo, diferentemente da metafísica, não seria uma concepção de mundo que procure um fundamento último do qual possam ser derivados todos os conhecimentos possíveis e todas as normas necessárias à ação: a realidade, historicamente mutável, não pode fornecer um conhecimento conclusivo, fechado e que abranja todos os casos disponíveis, tal qual ocorre nos sistemas metafísicos. Um conhecimento absoluto pressupõe um sujeito infinito, dado o caráter infinito da realidade: se não quiser recorrer à pressuposição idealista do espírito absoluto, o conhecimento deve admitir uma tensão permanente entre sujeito e objeto. A ciência seria o esforço para continuamente superar essa tensão - caso a considerasse superada, se converteria em metafísica ${ }^{283}$.

Continuando em certa medida as críticas que havia feito a Lênin em fins da década de vinte, Horkheimer apresentava o materialismo como distinto da afirmação de um primado da matéria. A ação só poderia ser decidida com base na situação histórica concreta, a ser convertida em proveito das finalidades humanas de aumento da felicidade e diminuição do sofrimento. Enquanto a metafísica busca os fundamentos últimos da realidade para deles derivar normas para a ação, os materialistas, por considerarem que a realidade se reduz à matéria, e em sendo essa desprovida de um sentido transcendente, orientariam sua ação pelas tarefas concretas que, historicamente, surgem do anseio de felicidade dos homens. A perspectiva da construção de uma sociedade racional, que deixe de se submeter ao poder cego das leis econômicas, é animada pela constatação de que as forças produtivas se desenvolveram a tal ponto que já seria possível garantir a felicidade para todos e libertar os homens da coerção irracional exercida por processos sociais reificados que se converteram em segunda natureza:

"a teoria econômica da sociedade e da história não se originou de motivos puramente teóricos, mas da necessidade de entender a sociedade contemporânea; pois esta sociedade chegou ao ponto de barrar para um número cada vez maior de pessoas a felicidade que seria possível com base na abundância geral de recursos econômicos. (...) Decerto, não faltam ideais ao materialismo. Eles se definem a partir das necessidades da comunidade e são

\footnotetext{
${ }^{282}$ Max Horkheimer, "Materialismus und Metaphysik”, op. cit., pp. 85-86.

${ }^{283}$ Max Horkheimer, "Materialismus und Metaphysik", op. cit., pp. 87-88.
} 
medidos por aquilo que, num futuro discernível, é possível com as forças humanas existentes" 284 .

Isso não significa, contudo, que a objetividade do conhecimento deva se medir por sua eficácia na resolução de problemas: Horkheimer mão deixou de criticar o pragmatismo que, ao identificar o conhecimento à resolução eficaz de problemas, reduziria a verdade à harmonia do conhecimento com a reprodução das condições sociais dadas. A teoria, para os pragmatistas, seria uma mera recapitulação do que tem êxito na prática: para os materialistas, por sua vez, a unidade entre teoria e prática depende de um processo histórico para se concretizar, e não existe ainda no âmbito de uma sociedade cindida. Ela só poderia se afirmar em uma sociedade futura - mas a consideração da vida social em sua totalidade não pertenceria ao âmbito do pragmatismo, ele próprio incompatível com a "ideia de uma verdade perigosa, capaz de pôr tudo pelos ares" 285 .

Se o materialismo é uma teoria e um comportamento prático que visam à melhoria das condições humanas, então ele, devido ao estado atual do conhecimento, estaria na época contemporânea indissoluvelmente ligado a uma teoria social. Na Antiguidade, face o sofrimento humano e à dificuldade de superá-lo com recurso às parcas forças produtivas disponíveis, os materialistas propuseram práticas que conduzissem à "tranquilidade da alma"; no século XVII, o materialismo dos pensadores ligados à burguesia em ascensão legitimava a ideia da dominação da natureza e sua conversão em forças produtivas apropriadas a serem pelos indivíduos, que naquela época apreciam como a categoria básica da teoria do conhecimento e da filosofia moral; a sociedade contemporânea, por sua vez, se configurou de modo a permitir que o sofrimento seja compreendido como intimamente vinculado à estrutura social: o reconhecimento do caráter histórico do processo de trabalho por meio do qual o homem transforma a natureza e a si mesmo leva a teoria materialista do presente a dirigir seus esforços para a mudança da sociedade como um todo ${ }^{286}$.

$\mathrm{Na}$ época moderna, o proletariado conseguiu formular seus interesses como uma crítica à contradição entre a realidade e a ideologia dominante. A contradição entre o princípio da troca

\footnotetext{
${ }^{284}$ Max Horkheimer, "Materialismo e metafísica", op. cit., p. 58. Cf. também "Materialismus und Metaphysik", op. cit., p. 73 e pp.76- 79. Sobre essa questão, cf. Maurício Garcia Chiarello, Das lágrimas das coisas - estudo sobre o conceito de natureza em Max Horkheimer. Campinas: Editora da Unicamp, 2001, pp. 33-34.

${ }^{285}$ Max Horkheimer, "Zum Problem der Wahrheit”, op. cit., pp. 300-301.

${ }^{286}$ Cf. Max Horkheimer, "Materialismus und Metaphysik", op. cit., p. 84. Infelizmente não podem ser tratados aqui adequadamente aspectos importantes da concepção de "materialismo" de Horkheimer, como a compaixão e o "interesse" na superação do sofrimento e no estabelecimento de um "estado racional". Uma investigação desse tema foi feita por Herbert Schnädelbach, Max Horkheimer und die Moralphilosophie des deutschen Idealismus". In: Alfred Schmidt; Norbert Altwickler (Orgs.). Max Horkheimer heute: Werk und Wirkung, op. cit., p. 52-78.
} 
justa e a existência da sociedade burguesa, baseada na mais-valia, seria a base para o projeto de uma sociedade racional. A consciência da divisão da sociedade em classes, elemento imprescindível ao materialismo atual, não significava, porém, a identificação de uma "ideologia proletária" ou de uma "consciência de classe" como o ponto de vista privilegiado a partir do que se poderia ter acesso à realidade social: o materialismo é "uma ideia proferida por certos homens e condicionada pelas relações da sociedade de classes" ${ }^{287}$. Isso significava que o materialismo, consciente da divisão da sociedade em classes, se orientaria pelos interesses do proletariado, mas sem identificação imediata com suas organizações: a teoria materialista, "ideia proferida por certos homens", não seria nem "consciência de classe”, como em Lukács, nem "ideologia proletária”, como em Lênin ${ }^{288}$.

Quanto à distinção feita por Horkheimer entre o materialismo e a metafísica, ela não significa que ele seja indiferente a ela: a metafísica, ao recobrir fins humanos e particulares com a aparência da eternidade e dessa maneira remetê-los a um fundamento não condicionado, exerceu ao longo da história, funções tanto progressivas quanto regressivas. Caberia à teoria materialista da sociedade reconhecer as funções exercidas pelo pensamento metafísico e elaborar suas críticas a ele de acordo com essa função ${ }^{289}$. A própria justificação metafísica e religiosa sempre esteve ligada às lutas sociais: as classes em luta apresentaram historicamente seus interesses como universais, como postulados transcendentes. As diferentes versões do idealismo contemporâneo se constituiriam como expressões intelectuais da luta histórica que tem sido travada contra a teoria e a prática materialista, e a essa restaria denunciar a transfiguração promovida por aquelas ${ }^{290}$. Apesar de alguns elementos em comum com o materialismo, o próprio positivismo seria idealista, na medida em que absolutiza os fatos e considera haver um sujeito de conhecimento independente do processo histórico:

"O materialismo tem em comum com a teoria positivista o fato de que ele só reconhece como real aquilo se apresenta na experiência sensível. Desde seu surgimento ele contém em si o sensualismo. 'Tudo o que vemos no espírito parte das percepções sensíveis', diz Epicuro. (...) Toda afirmação tem de se comprovar pela experiência sensível. Mas o

\footnotetext{
${ }^{287}$ Max Horkheimer, "Materialismo e metafísica", op. cit., p. 40.

${ }^{288}$ Segundo Helmut Dubiel, isso historicamente se exprimiu, no âmbito do Instituto, em uma proximidade, mas sem adesão, ao Partido Comunista Alemão, assim como em uma "solidariedade crítica" à União Soviética. Cf. Helmut Dubiel, Wissenschaftsorganisation und politische Erfahrung, op. cit., p. 50. Cf. também pp. 38-47. Essa questão é pouco clara na historiografia da teoria crítica. Sabe-se que alguns dos membros do Instituto foram membros ativos (como Marcuse) ou simpatizantes (como Horkheimer) de conselhos operários durante o período da revolução alemã. Cf., por exemplo, John Abromeit, Max Horkheimer and the foundations of the Frankfurt School, op. cit., pp. 41-45.

${ }^{289}$ Cf. Max Horkheimer, "Materialismus und Metaphysik", op. cit., p. 81.

${ }^{290}$ Max Horkheimer, "Materialismus und Metaphysik", op. cit., p. 76, p. 81 e p. 86.
} 
materialismo não absolutiza o sensualismo. A exigência de uma comprovação da existência por meio da sensibilidade não significa que essa não se modifique no processo histórico, ou que os seus elementos tivessem de ser considerados os componentes fixos do mundo" 291 .

Por outro lado, Horkheimer considerava a ideia de uma apreensão imediata por meio da introspecção, própria às correntes fenomenológicas em geral, tão falsa quanto a afirmação de que dados sensíveis não mediados teoricamente seriam o elemento básico da realidade. Ambas as perspectivas desconsiderariam o caráter histórico do conhecimento: “o empiriocriticismo coincide com a metafísica idealista ao pressupor um sujeito independente do tempo" ${ }^{292}$. A única diferença entre ambas as correntes - a defesa, pela fenomenologia, de um fluxo contínuo da consciência, ao passo que o positivismo postularia a sua segmentação em meio a dados isolados - não seria suficiente para lhes retirar o caráter de filosofias que hipostasiariam determinados aspectos do conhecimento sem considerar a necessidade de realizar mediações entre eles e o processo social. Referindo-se à filosofia de Bergson, Horkheimer afirmava: “o positivismo é, na realidade, muito mais próximo da metafísica da intuição do que o materialismo, ao qual essa costuma, de maneira errônea, reuni-lo" ${ }^{\text {293 }}$.

A crítica de Horkheimer às correntes filosóficas dominantes passaria, contudo, por mudanças. Vimos acima que, no discurso de posse de 1931, Horkheimer havia notado que a situação cultural da época era dominada pela oposição entre o positivismo e a metafísica. Se em 1933 ambos foram considerados como expressões diferentes de um idealismo cujo efeito transfigurador caberia à teoria materialista denunciar, pouco tempo depois Horkheimer passou a ver que essa oposição exprimia algo da sociedade capitalista em geral, e vieram ao primeiro plano dos ensaios de Horkheimer elementos que até então, como talvez fique claro a seguir, se encontravam esparsos e pouco desenvolvidos. Tentemos acompanhar essas mudanças.

\footnotetext{
${ }^{291}$ Max Horkheimer, "Materialismus und Metaphysik”. In: Max Horkheimer, Gesammelte Schriften, vol. 3, op. cit., pp. 101-102.

${ }^{292}$ Cf. Max Horkheimer, "Materialismus und Metaphysik". In: Max Horkheimer, Gesammelte Schriften, op. cit., vol. 3, p. 96.

${ }^{293}$ Cf. Max Horkheimer, "Materialismus und Metaphysik", op. cit., p. 99 do mesmo texto. Em suas "Observações sobre a antropologia filosófica", Horkheimer afirmaria que "o desejo de fundamentar o agir em rígidas visões da essência [Wesenseinsichten] motivou a fenomenologia desde a sua origem" (Max Horkheimer, "Bemerkungen zur philosophischen Anthropologie". In: Max Horkheimer, Gesammelte Schriften, op. cit., vol. 3, p. 255).
} 
A explicação da sociedade como um conjunto de fatos, se ao enfatizar o papel da ação individual na história e no processo de conhecimento havia exercido nos séculos XVII e XVIII um papel progressista em meio à luta contra as instituições e a ideologia do Antigo Regime, nas últimas décadas do século XIX se mostrava insuficiente frente à constatação de que os avanços técnico-científicos e a busca do interesse individual não acarretavam a superação dos problemas da sociedade como um todo, antes contribuindo para o seu agravamento. Segundo Horkheimer, o método científico consistente na coleta e classificação de fatos e no estabelecimento das regularidades entre eles vigentes fora revolucionário ao desprezar considerações religiosas e políticas, em sua oposição às regras escolásticas que balizavam o pensamento científico até a revolução técnico-científica do século XVII. Ele cumprira uma função social progressista quando, em sua vinculação histórica com a ascensão social e política da burguesia na passagem do século XVIII e XIX, esteve associado ao interesse na transformação da natureza e da sociedade em prol de mudanças históricas emancipatórias. À medida, entretanto, em que a partir da segunda metade do século XIX a ciência cada vez mais se reduzia a mera força produtiva aplicada na indústria, desligando-se de finalidades relativas à transformação social e assumindo a forma do entendimento calculador orientado para a adequação de meios a fins previamente dados e voltados à conservação das relações sociais, ela teria se transformado, segundo o autor, em uma ideologia de eternização do presente (ao situar essa passagem em meados do século XIX, Horkheimer provavelmente pensava aqui na postura contrarrevolucionária da burguesia no período que se seguiu às revoluções de 1848). A ciência dominante, bem-sucedida em sua utilização como força produtiva na indústria, era incapaz de explicar o processo social em seu todo. Daí decorreria um estreitamento da racionalidade científica: ao se ater ao empirismo que estava em suas origens, a ciência dominante entraria em contradição com os próprios elementos de racionalidade imanentes à ciência ${ }^{294}$.

Essa transformação da ciência em ideologia envolvia, portanto, também uma crise interna, pois seus próprios elementos de racionalidade passaram a se encontrar em risco: a redução da atividade científica ao método típico das ciências naturais tornava a ciência incapaz de apreender o processo histórico e as mudanças que abrangiam o conjunto das esferas sociais: ainda que o método das ciências naturais, aplicado a algumas dessas esferas isoladamente, conseguisse descrever e explicar os fenômenos correspondentes, o processo social como um todo e portanto os fenômenos potencialmente vinculáveis à transformação histórica - como as

\footnotetext{
${ }^{294}$ Max Horkheimer, "Bemerkungen über Wissenschaft und Krise”, op. cit., pp. 42-43. Sobre esse ponto, cf. também o ensaio do autor "Sobre o problema da verdade": "Zum Problem der Wahrheit". In: Max Horkheimer, Gesammelte Schriften, vol. 3, p. 282.
} 
crises - eram excluídos do âmbito da explicação científica. Mesmo no âmbito interno das ciências da natureza e do homem, a fetichização dos conceitos - tomados como entidades fixas e isoladas, desvinculadas do movimento histórico que os originou - resultava em limitações de sua capacidade explicativa, o que se expressava nas dicotomias entre corpo e alma, natureza e espírito (cultura), e também na fragmentação das disciplinas científicas, com frequência incapazes de explicar os próprios fenômenos que se propunham compreender. Talvez mais fundamental até do que isso, o método científico dominante, incapaz de abranger o movimento histórico, deixava fora de seu campo de visão o todo social do qual depende a própria definição das tarefas da ciência, e dessa maneira acatava sem crítica uma divisão estática entre sujeito e objeto, identificando em uma a-histórica "consciência de si” a fonte da ciência e se abstendo de explicar a própria constituição histórica do sujeito. Ao fazê-lo, a ciência entrava em contradição com os elementos de racionalidade do próprio pensamento científico:

\begin{abstract}
"Também na ciência aparece uma dupla contradição. Em primeiro lugar, vale como princípio que cada um de seus passos tenha um fundamento no conhecimento, mas o passo mais importante, isto é, a própria definição de suas tarefas, prescinde da fundamentação teórica e parece estar entregue ao arbítrio. Em segundo lugar, a ciência se ocupa do conhecimento de conexões abrangentes; ela é incapaz, contudo, de compreender em sua vida efetiva a abrangente conexão da qual depende sua própria existência e a direção de seu trabalho, isto é, a sociedade" $" 295$.
\end{abstract}

A situação de crise da ciência não passava, contudo, despercebida ao pensamento filosófico, e no período compreendido entre as últimas décadas do século XIX e as primeiras décadas do século XX não tardaram em aparecer as reações ao predomínio do positivismo: as limitações do método das ciências naturais foram objeto de um amplo conjunto de reações ao cientificismo e à sua incapacidade de fornecer respostas à diminuição crescente do raio de ação do indivíduo na sociedade burguesa e à ausência de realização das promessas emancipatórias que haviam acompanhado a ascensão da burguesia e o desenvolvimento do capitalismo. A filosofia de Bergson significara, assim como o pensamento de Nietzsche e também a literatura e a pintura impressionistas surgidas na virada do século, "um protesto contra o aprisionamento da vida individual pela crescente acumulação de capital" 296 . Invocando a "vida" e a

\footnotetext{
295 Max Horkheimer, "Bemerkungen über Wissenschaft und Krise", op. cit., p. 45. Cf. também, a esse respeito: "A presente situação da filosofia social e as tarefas de um instituto de pesquisa sociais", op. cit., pp. 124-126; "História e Psicologia", op. cit., p. 17; "Bemerkungen über Wissenschaft und Krise", pp. 42-43.

296 Max Horkheimer, "Zum Rationalismusstreit in der gegenwärtigen Philosophie". In: Max Horkheimer, Gesammelte Schriften, vol. 3, op. cit., p. 168.
} 
"concretude" contra a circunscrição do pensamento à ciência orientada pelo método analítico, essa crítica teria acertado ao considerar a racionalidade típica das ciências naturais como insuficiente para o conhecimento preciso da experiência social, psíquica e estética. Mais até do que isso, ela teria feito um aparo necessário a um "progressismo [aquele da ciência], que já havia se convertido em seu oposto"297.

A realidade concreta não poderia, e nisso Horkheimer concordava com a crítica ao cientificismo, ser conhecida apenas por meio de um método que decompõe seus objetos em traços específicos que, após serem observados em abstração do todo, são submetidos à comparação com traços de outros objetos, para assim conduzir ao estabelecimento de relações explicativas e à formulação de leis gerais, notadamente aquelas baseadas na noção de causalidade. Ao confundir esse procedimento com o conhecimento em geral, as diversas escolas racionalistas teriam conduzido a um estreitamento do pensamento racional ${ }^{298}$. E por isso teriam sido bem-sucedidas em desautorizar a pretensão de exclusividade do pensamento analítico correntes racionalistas de pensamento como a psicologia da Gestalt e a fenomenologia. Elas rejeitaram o pressuposto comum às teorias racionalista e empirista do conhecimento ao mostrar que o conhecimento não se reduz à organização, pela consciência individual, de um conjunto caótico de dados sensíveis:

\begin{abstract}
"Na luta contra esse mito racionalista saíram vitoriosas, na filosofia e na psicologia, a metafísica da vida e escolas aparentadas a ela. Um dos principais meios para a obtenção dessa vitória foi a comprovação de que as estruturas que são pré-encontradas nas coisas não provêm do sujeito pensante, mas estão fundadas objetivamente. A crença segunda a qual um caos de elementos sensíveis estaria dado originariamente, um caos a partir do qual o conceito haveria de, em primeiro lugar, criar um mundo organizado, pode ser refutada tanto por meio da descrição daquilo que é dado na intuição [des anschaulich Gegebenen] quanto por meio do estudo dos atos intelectuais. Principalmente a teoria da Gestalt atestou o caráter estruturado do dado e pôs a descoberto, por meio de investigações pormenorizadas, o caráter mitológico dos fatores intelectuais, espirituais, independentes [tal qual sustentado pelo racionalismo em geral]" 299 .
\end{abstract}

O "caráter mitológico" ao qual Horkheimer se referia na passagem acima diz respeito à hipóstase da consciência individual promovida tanto pelo racionalismo cartesiano quanto pelo empirismo inglês. Ambas as correntes se fundariam em um pressuposto comum: a verdade seria

\footnotetext{
297 Cf. Max Horkheimer, "Bemerkungen über Wissenschaft und Krise”, op. cit., p. 44; e também, do mesmo autor, "Zum Rationalismusstreit in der gegenwärtigen Philosophie", op. cit., pp. 188-189.

${ }^{298}$ Max Horkheimer, "Zum Rationalismusstreit in der gegenwärtigen Philosophie”. op. cit., p. 181.

${ }^{299}$ Cf. Max Horkheimer, "Zum Rationalismusstreit in der gegenwärtigen Philosophie”, op. cit., pp. 174-175. Ainda a esse respeito, cf. a breve passagem à página 102 de "Materialismus und Metaphysik", op. cit..
} 
concebida como a capacidade do indivíduo de formular conceitos que manteriam uma relação de estrita correspondência com a realidade ${ }^{300}$. A diferença entre as escolas residiria apenas no seguinte: enquanto o cartesianismo defenderia a tese de que os conceitos a expressar a realidade seriam inatos e portanto já se encontrariam na razão, os empiristas, por sua vez, associariam a formulação dos conceitos a um processo de abstração progressiva do material fornecido pelos sentidos. Essa diferença não impediria que ambas se apresentassem como "filosofias da consciência": "assim como os cartesianos, os empiristas ingleses também veem o ser humano como se fosse composto de processos avulsos da consciência, 'cogitationes' "301. Tanto o cartesianismo quanto o empirismo enfatizariam com razão aspectos necessários do processo de conhecimento (a atividade do sujeito e o papel das impressões sensíveis), mas incidiram as duas em um erro básico: a suposição de uma correspondência entre o juízo e a realidade que fosse independente da práxis histórica. Ao fazê-lo, hipostasiariam a consciência individual, considerada como a única fonte e portanto como o limite do conhecimento: esse seria independente de processos ocorridos para além da "mônada". A prática e os atos de vontade, em vez de serem considerados como participantes do processo de conhecimento, seriam considerados como passíveis de serem derivados de uma razão que se encontraria para além deles:

\begin{abstract}
"Segundo a escola racionalista, os problemas parecem resolvidos quando o indivíduo adquiriu um conceito claro e nítido de si mesmo; segundo a escola empirista trata-se mais de trazer ordem à amplidão das vivências dadas: em ambos os casos, a verdade deve resultar da introspecção do indivíduo racional. O agir é então considerado essencialmente sob o ponto de vista de ser ou não a consequência correta dessa verdade" 302 .
\end{abstract}

Ambas as escolas poderiam ser compreendidas como o "racionalismo" em sentido amplo, e seriam expressão do modo de produção capitalista e do lugar central ocupado nele pelo indivíduo. Considerado como independente de instâncias que ultrapassem a "mônada" ou, então, as sensações e impressões individuais, o ato de conhecimento, purgado de seus elementos volitivos e emotivos, seria apartado tanto da ação - que na perspectiva racionalista dele deve decorrer como conclusão lógica - quanto dos processos sociais que o originaram, sendo sediado no indivíduo. O irracionalismo contemporâneo, por sua vez, era remontado por Horkheimer às

\footnotetext{
${ }^{300}$ Cf. Max Horkheimer, "Zum Rationalismusstreit in der gegenwärtigen Philosophie”, op. cit., pp. 163-167.

${ }^{301}$ Cf. Max Horkheimer, "Zum Rationalismusstreit in der gegenwärtigen Philosophie”, op. cit., p. 164.

${ }^{302}$ Cf. Max Horkheimer, "Zum Rationalismusstreit in der gegenwärtigen Philosophie”, op. cit., p. 166.
} 
ideias historicistas e organicistas surgidas a partir da Revolução Francesa e contrárias à supressão das antigas instituições e tradições feudais e absolutistas ameaçadas por formas de sociabilidade afinadas com o modo de produção capitalista. Essas ideias ressoaram nos conceitos sociológicos de "comunidade" e "sociedade", expressão de formas sociais existentes previamente aos indivíduos e que determinariam inapelavelmente a sua ação. Neles, a anterioridade da sociedade sobre os indivíduos é apresentada como um caso específico da anterioridade do todo sobre as partes, isto é, como um dado eterno, metafísico. A contraparte dessas teorias, isto é, a tese da primazia do indivíduo no conhecimento, seria da mesma maneira que ela uma "abstração vazia", incapaz de por em relação dialética os dois polos, indivíduo e sociedade. A crítica a ambas as correntes permitira a "destruição interna" de suas teses: "o racionalismo e o irracionalismo cancelam reciprocamente sua reivindicação metafísica; o pensamento exerce sobre ambos seu poder destruidor, e sem dúvida pode resultar algo da crítica feita por cada umas das correntes uma à outra" ${ }^{303}$.

$\mathrm{Na}$ passagem entre os séculos XIX e XX, a filosofia da vida teria enfatizado corretamente, contra o racionalismo, o caráter pré-estruturado do dado: "os elementos abstratos obtidos por meio da análise conceitual não concordam com o objeto vivo ainda quando adicionados uns aos outros. A soma dos traços de um desenho não resulta ainda na imagem"304. Horkheimer chega a conceder que a "intuição" poderia desempenhar, enquanto função psíquica do indivíduo no processo de conhecimento, algum papel na obtenção do "todo" - muito antes das correntes antipositivistas da virada do século, contudo, o pensamento dialético já havia sido capaz desse tipo e consideração ${ }^{305}$. Mais fundamental do que isso, a ideia de uma apreensão imediata do objeto, uma ideia central às correntes irracionalistas, seria insustentável: a metafísica da vida estaria sempre correndo o risco de considerar a existência de uma verdade imediata, sem considerar a relação entre o conhecimento e os indivíduos historicamente determinados que o produzem. Ela confundiria a recusa da teoria racionalista segundo a qual o conhecimento seria produto da organização, pelo indivíduo, de um conjunto caótico de dados recebidos passivamente, com a crença em uma intuição capaz de fornecer uma objetividade dos dados da consciência que fosse independente da práxis social. Da afirmação da existência de uma estrutura própria aos dados não poderia ser derivada a crença em verdades imediatas: ao supor uma intuição não mediada por processos sociais, a filosofia da vida se tornaria uma

\footnotetext{
${ }^{303}$ Cf. Max Horkheimer, "Zum Rationalismusstreit in der gegenwärtigen Philosophie”, op. cit., p. 175. Cf. também as passagens às páginas 166-167 e 205-206.

${ }^{304}$ Cf. Max Horkheimer, "Zum Rationalismusstreit in der gegenwärtigen Philosophie”, op. cit., p. 183.

${ }^{305}$ Cf. Max Horkheimer, "Zum Rationalismusstreit in der gegenwärtigen Philosophie”, op. cit., p. 187.
} 
“filosofia da identidade" tão a-histórica quanto o racionalismo tradicional. Tendo corretamente identificado a insuficiência do pensamento analítico, a filosofia irracionalista não operaria como a dialética materialista, que considera a ciência como um elemento necessário da verdade, o qual é preciso suprassumir em um pensamento mais amplo, apoiado na categoria de "totalidade". Ao recusar o pensamento racional em favor de categorias supostamente mais concretas, como "vida" ou "existência", mas sem extrapolar o âmbito do indivíduo em direção à história e a sociedade, essa filosofia recairia em um pensamento tão abstrato quanto aquele por ela criticado ${ }^{306}$.

A dialética entre ciência e metafísica, racionalismo e irracionalismo, se encontraria já no seio do próprio pensamento racionalista, tal qual ele se desenvolveu ao longo da formação do modo de produção capitalista e da ascensão social da burguesia. O espírito burguês seria caracterizado por toda a parte por uma contradição entre "de um lado, análise conduzida até o fim e desconfiança cética em relação à teoria em geral, de outro, disposição para a crença ingênua em princípios rígidos e isolados" ${ }^{307}$. A oposição entre racionalismo e o irracionalismo seria, portanto, a forma filosófica assumida pelas contradições do modo de produção capitalista.

Na obra de Descartes, a afirmação de que o conhecimento é infinito e incerto, e deve sempre se subordinar à dúvida metódica, era apaziguada pela ideia de uma res cogitans fixa: o catolicismo de Descartes o levava dessa maneira a supor a existência de uma alma, fechada em si mesma e separada do mero espaço ao qual devem se reduzir todos os fenômenos, para assim garantir o seu caráter de verdade, superando a dúvida. Em Kant, a crítica capaz de estabelecer os limites e condições do conhecimento convivia com a afirmação dogmática dos postulados da razão prática. No âmbito do comportamento dos cientistas com relação aos problemas mais candentes de sua época, coexistiriam lado a lado métodos refinados do conhecimento das ciências naturais e uma "infantil credulidade na Bíblia", caracterizando uma relação cindida com a verdade: a redução da ciência a uma mera coleta e sistematização de fatos isolados deixava espaço para que as perguntas sobre a totalidade social e o destino dos indivíduos na coletividade fossem respondidas pelo dogmatismo metafísico ${ }^{308}$. A contradição entre ciência e metafísica se arrastaria ao longo do pensamento moderno inteiro:

"O conhecimento científico de uma época é formalmente considerado correto; ao mesmo tempo, dá-se continuidade a perspectivas metafísicas. A ciência, como espelho da realidade sem sentido encontrada na natureza e na sociedade, teria abandonado as massas

\footnotetext{
${ }^{306}$ Cf. Max Horkheimer, “Zum Rationalismusstreit in der gegenwärtigen Philosophie”, op. cit., p. 175 e p. 195.

${ }^{307}$ Cf. Max Horkheimer, “Zum Problem der Wahrheit”, op. cit., p. 280.

${ }^{308}$ Cf. Horkheimer, "Zum Problem der Wahrheit", op. cit., vol. 3, pp. 278-281.
} 
insatisfeitas e o indivíduo pensante a um estado perigoso e de desespero - nem no âmbito público nem naquele do próprio psiquismo foi possível sair-se razoavelmente sem uma ideologia capaz de a tudo recobrir. Dessa maneira, ambas foram mantidas de pé, ciência e ideologia metafísica, uma ao lado da outra" ${ }^{309}$.

Essa contradição se exprimiu, segundo Horkheimer, em sua forma mais consumada na filosofia transcendental kantiana. Ao realizar sua "revolução copernicana" e defender, ao contrário da compreensão filosófica tradicional, que o conhecimento não seria regulado pelos objetos, e sim pelo sujeito, Kant teria conseguido explicar a objetividade dos juízos sobre o mundo: tanto a harmonia entre a percepção e o juízo quanto a validez intersubjetiva desse, em meio aos indivíduos cognoscentes, remontariam ao papel ativo do sujeito no conhecimento. As faculdades da sensibilidade e do entendimento seriam responsáveis pela constituição dos objetos, e a existência em ambas de elementos a priori, independentes de qualquer experiência (respectivamente, as formas do espaço e do tempo, assim como as "categorias"), dotaria de necessidade e universalidade o conhecimento obtido por meio de uma síntese dos dados sensíveis, que perderiam o seu caráter múltiplo e desordenado para se transformarem em fenômenos suscetíveis de conceitualização ${ }^{310}$. Ao explicar a adequação dos dados sensíveis às categorias do entendimento, porém, o idealismo transcendental esbarrou em limites intransponíveis no âmbito de uma teoria do conhecimento circunscrita à consciência individual: a suposição de que a sensibilidade seria meramente passiva e que apenas o entendimento teria um caráter ativo levou Kant a se perguntar por aquilo que garantiria a adequação entre ambos. A defesa de uma "afinidade transcendental" entre as categorias do entendimento e o material dado na intuição, de maneira que esse já seria de certa maneira pré-formado pelo entendimento, seria dotada de um grau de obscuridade reconhecido pelo próprio Kant em sua identificação do esquematismo a uma "arte oculta nas profundidades da alma humana, cujo manejo verdadeiro nós dificilmente arrancaremos da natureza, colocando-a a descoberto diante dos olhos" ${ }^{\text {"311. Essa }}$ dificuldade, entretanto, apenas poderia ser superado no âmbito de uma teoria social e histórica capaz de desvendar os processos supra-individuais de formação do pensamento ${ }^{312}$. A Kant isso

\footnotetext{
${ }^{309}$ Max Horkheimer, "Der neueste Angriff auf die Metaphysik". In: Max Horkheimer, Gesammelte Schriften, op. cit., vol. 4, p. 110.

${ }^{310}$ Essa validade intersubjetiva se daria pelo menos em áreas como a das ciências naturais, não vinculadas imediatamente, como Horkheimer ressaltava, a lutas sociais. Cf. Max Horkheimer, "Traditionelle und kritische Theorie". In: Max Horkheimer, Gesammelte Schriften, vol. 4, p. 176.

311 Citado por Horkheimer em "Teoria tradicional e teoria crítica". In: Walter Benjamin; Max Horkheimer; Theodor W. Adorno; Jürgen Habermas, Textos escolhidos. Traduções de José Lino Grünewald et al. São Paulo: Abril Cultural, 1980 (Coleção Os Pensadores), p. 127.

${ }^{312}$ Cf. Max Horkheimer, "Traditionelle und kritische Theorie". In: Max Horkheimer, Gesammelte Schriften, vol. 4, pp. $175-178$.
} 
ainda não era possível, e essa dificuldade se exprimia internamente em sua filosofia transcendental. Seus conceitos principais teriam um caráter duplo que exprimiria de maneira idealista as contradições da sociedade capitalista: "por um lado, a máxima unidade e orientação, e, por outro lado, algo de obscuro, de inconsciente, de intransparente" ${ }^{313}$. Em vez de decorrência de uma limitação individual do filósofo, essa contradição exprimiria, de maneira idealista, as contradições da sociedade capitalista: nessa, a atividade da sociedade seria "cega e concreta", pois ela atuaria sobre o todo mas não de maneira consciente, não estando vinculada a um plano; a atividade do indivíduo, por sua vez, seria "abstrata e consciente", pois sua clareza sobre os fins e os meios de sua ação seria restrita a um momento abstraído do todo social. Nas palavras de Horkheimer:

"A atividade social aparece como poder transcendental, isto é, como
suprassumo de fatores espirituais. A afirmação de Kant de que a eficácia desta
atividade está envolvida por uma obscuridade, ou seja, apesar de toda a
racionalidade é irracional, não deixa de ter um fundo de verdade. O modo
burguês de economia não é orientado por nenhum planejamento nem é
orientado conscientemente para um objetivo geral, apesar da perspicácia dos
indivíduos concorrentes; a vida do todo resulta numa figura deformada, como
que por acaso, mesmo assim sob enormes atritos. As dificuldades internas que
acompanham os conceitos mais elevados da filosofia kantiana, principalmente
o Eu da subjetividade transcendental, a apercepção pura ou original e a
consciência em si testemunham a profundidade e sinceridade de seu
pensamento"314

A estreita relação entre a ciência e a metafísica, estruturante do pensamento moderno em geral, foi objeto da atenção de Horkheimer também em seu exame da obra de Bergson, feito em ensaio publicado em 1934 na Revista de Pesquisa Social ${ }^{315}$. Segundo Horkheimer, Bergson acertara ao criticar o conceito espacializado de tempo, denunciando seu caráter quantitativo como adequado meramente ao desenvolvimento da indústria e das ciências naturais ligadas a ela: a filosofia, ao se apoiar predominantemente sobre esse conceito de tempo, hipostasiaria um

\footnotetext{
${ }^{313}$ Max Horkheimer, "Teoria tradicional e teoria crítica”. In: Walter Benjamin et al., Textos escolhidos, op. cit., pp 127-128.

${ }^{314}$ Max Horkheimer, “Teoria tradicional e teoria crítica”. In: Walter Benjamin; Max Horkheimer; Theodor W. Adorno; Jürgen Habermas, Textos escolhidos, op. cit., p. 127. Ao contrário das teses desenvolvidas por Lukács em História e Consciência de Classe, as antinomias da filosofia kantiana não serão objeto, na obra de Horkheimer, do mesmo processo de superação a partir de um ponto de vista da totalidade, associado por Lukács à consciência de classe do proletariado. Sobre esse assunto, cf. Ricardo Musse, $O$ duplo giro copernicano - Adorno e Kant. Dissertação de mestrado. UFGRS, 1991, pp. 32-36.

315 Cf. Max Horkheimer, "Zu Bergsons Metaphysik der Zeit”. In: Gesammelte Schriften, op. cit., vol. 3, pp. 225248. Uma tradução brasileira do ensaio, da qual só tomamos conhecimento após a redação deste texto, foi feita por Maurício G. Chiarello e publicada nos Cadernos de Filosofia Alemã. São Paulo, vol. 6, 2000, pp. 61-83.
} 
conceito limitado e historicamente determinado, e para dar conta da experiência qualitativa do tempo, o "tempo vivido" que se distinguiria do tempo abstrato capaz de ser medido, Bergson formulara o conceito de "duração". O erro de Bergson, contudo, argumentou Horkheimer, foi ter elevado esse conceito a um princípio universal, para além do indivíduo e da história: sua tese de que o mundo humano e natural seria movido por um "evolução criadora" subordinou seu conceito de tempo a uma finalidade metafísica. O tempo se tornaria, dessa maneira, um princípio atemporal, não submetido ele próprio à mudança, e por isso a filosofia de Bergson, segundo Horkheimer, entraria por fim em contradição consigo mesma: "Bergson, ao afirmar, em analogia ao tempo interno vivido pelo indivíduo, a existência de um interior espiritual do mundo - ou seja, ao fantasiar como ser absoluto um fluxo divino de vivências - tem igualmente de negar o tempo", e por isso o pensamento de Bergson "nega o tempo quando o alça a um princípio metafísico"316.

Dessa maneira, argumentava Horkheimer, se por um lado seria verdade que o conceito de "duração" de Bergson foi uma contribuição frutífera para a psicologia e supriu uma lacuna que o conceito espacializado de tempo não poderia suprir, por outro lado, a crítica do positivismo e da absolutização dos conceitos reificados das ciências naturais feita por Bergson, em si válida, terminou por servir à instauração de um novo "mito": sua tese da evolução criadora cumpriria a mesma função transfiguradora da metafísica em geral, sendo uma ideologia que "reduz o mundo inteiro a uma única e eterna essência, afirma um sentido espiritual do acontecer e remete, à união com aquela essência, os homens que sofrem sob as condições reais"317. Assim, de maneira semelhante a Kant - prossegue o argumento de Horkheimer - Bergson criticou a ciência, examinando suas condições e enunciando seus limites, apenas para, em seguida, salvar a metafísica: no caso de Bergson, a hipóstase do fluxo de consciência, elevado a princípio supratemporal, conviveria com a concessão de legitimidade aos métodos e conceitos das ciências naturais: reduzido a seu direito restrito, o método analítico poderia subsistir ao lado do método da intuição, próprio da metafísica. Ironicamente, Bergson recairia dessa maneira em um dualismo que seria muito mais afim ao pensamento cartesiano do que ao método intuitivo que ele pretendeu promover ${ }^{318}$.

No pensamento de Bergson, a complementação do pensamento analítico por meio do conceito de "tempo vivido" exprimia a contradição entre a sociedade burguesa e os ideais

\footnotetext{
${ }^{316}$ Max Horkheimer, “Zu Bergsons Metaphysik der Zeit”, op. cit, p. 235 e p. 228, respectivamernte.

${ }^{317}$ Max Horkheimer, "Zu Bergsons Metaphysik der Zeit”, op. cit, p. 235.

${ }^{318}$ Max Horkheimer, “Zu Bergsons Metaphysik der Zeit”, op. cit, p. 232 e pp. 240-241.
} 
burgueses $^{319}$ : a incapacidade de esses se realizarem sob o capitalismo e com os meios intelectuais típicos da burguesia, contudo, levara Bergson a deslocar metafisicamente as promessas de emancipação e desenvolvimento do indivíduo para o âmbito de uma vida espiritual supra-individual, transfigurando a realidade existente por meio de seu conceito de “evolução criadora" ${ }^{320}$. No âmbito de sua filosofia, segundo Horkheimer, o elemento crítico ao positivismo teria se transformado em um novo mito, e por isso nessa análise feita por Horkheimer da obra de Bergson já se insinua a "dialética entre mito e esclarecimento" que seria formulada pelo autor em conjunto com Adorno alguns anos mais tarde: Bergson teria sucumbido à contradição entre elementos críticos do pensamento, por um lado, e seus traços míticos, por outro ${ }^{321}$.

A coexistência de elementos racionalistas e irracionalistas assinalaria a filosofia moderna em geral. Nas décadas de vinte e trinta, contudo, as contradições do pensamento moderno assumiam segundo Horkheimer uma forma mais aguda. A ela passamos a seguir ${ }^{322}$.

\footnotetext{
${ }^{319}$ Max Horkheimer, "Zum Rationalismusstreit in der gegenwärtigen Philosophie”, op. cit., p. 171-172.

${ }^{320}$ Max Horkheimer, "Zu Bergsons Metaphysik der Zeit”, op. cit., p. 230-232. Em uma discussão travada com Adorno e alguns assistentes e estudantes em 17 de novembro de 1931, no âmbito de seu curso sobre "ciência e crise", Horkheimer identificara na filosofia de Bergson uma negação abstrata do positivismo: "Bergson é o melhor exemplo do 'ficar parado' [Stehenbleiben] hegeliano depois da primeira negação. Ele crê ser possível, por meio da mera rejeição das diferenciações produzidas pelo entendimento, remontando-se ao estágio anterior, encontrar a realidade verdadeira, que nada mais é do que um mingau indiferenciado". Max Horkheimer, Theodor Adorno et al. "Wissenschaft und Krise. Differenz zwischen Idealismus und Materialismus. Diskussionen über Themen zu einer Vorlesung Max Horkheimers". In: Max Horkheimer. Gesammelte Schriften, vol. 12, p. 368.

321 Segundo Alfred Schmidt, Horkheimer pouco distinguiria entre "mito" e "ideologia", termos que se confundiriam em sua obra. Cf., do autor, "Aufklärung und Mythos im Werk Max Horkheimers". In: Alfred Schmidt; Norbert Altwickler (Orgs.). Max Horkheimer heute: Werk und Wirkung. Frankfurt am Main: Fischer, 1986, p. 185.

${ }^{322}$ A recepção da obra de Horkheimer tendeu a julgar que a razão de ser da crítica do autor a essas correntes teria residido na oposição, por Horkheimer, de seu próprio programa de pesquisa social contra os extremos tanto do positivismo quanto do anti-cientificismo, típico das correntes irracionalistas. Helmut Dubiel, por exemplo, viu na crítica à filosofia contemporânea feita por Horkheimer nos anos trinta principalmente o "contexto históricocientífico do programa de pesquisa" (conforme o título do capítulo 2 da Parte II de seu livro). Essa crítica cumpriria a função de evitar que a produção científica no âmbito do Instituto recorresse a pressupostos filosóficos e teóricos problemáticos. Cf. Helmut Dubiel, Wissenschaftsorganisation und politische Erfahrung, op. cit., pp. 152-155. De modo semelhante, Abromeit julgou que nas críticas de Horkheimer a Bergson e a Heidegger teria se exprimido uma recusa da metafísica e a defesa da necessidade da realização de pesquisas históricas e empíricas. Cf. John Abromeit, Max Horkheimer and the foundations of the Frankfurt school, op. cit., p. 259.
} 


\section{$\underline{3.2-\text { A reificação dos conceitos filosóficos }}$}

"A participação da atividade própria dos homens na conservação e renovação da vida social fica bem atrás do esforço em manter coesa, de maneira mecânica, uma ordem em estado de dissolução. O espírito público passa a ser dominado de maneira crescente por alguns juízos fixos e algumas poucas representações hipostasiadas" (Max Horkheimer, "Zum Problem der Wahrheit", op. cit., p. 278).

O pensamento de Bergson teria cultivado, ainda que de uma maneira problemática e contraditória, as questões concernentes à totalidade social e ao destino da humanidade, que a ciência dominante havia banido de seu horizonte e confiado à metafísica e à religião ${ }^{323}$. Entretanto, se essa filosofia e também, como mencionado acima, a teoria da Gestalt e os movimentos artísticos impressionistas se caracterizavam pelo protesto contra o mundo legitimado pela ciência moderna e exprimiam "a insegurança da burguesia quanto à sua tradição humanista" 324 , em meio a vertentes de pensamento de certa maneira herdeiras desse movimento de crítica ao positivismo, iniciado em fins do século XIX, aquela insegurança e aquele protesto teriam desaparecido completamente. Assim, por exemplo, na obra de Oswald Spengler a história era considerada como se consistisse em um destino que os homens não conseguiriam pôr a seu serviço, devendo antes aceitá-lo como a expressão de "poderes mais robustos", sem ter a pretensão de "dominar a história viva por meio de ideias e sistemas de papel” ${ }^{325}$. A rejeição do pensamento teórico em suas versões idealista e materialista em favor de um fatalismo com ressonâncias mitológicas e racistas e com um componente de darwinismo social era acompanhada da condenação da técnica e da vida moderna e urbana em geral: Spengler considerava que "a cidade mundana se põe como o extremo do inorgânico em meio à paisagem

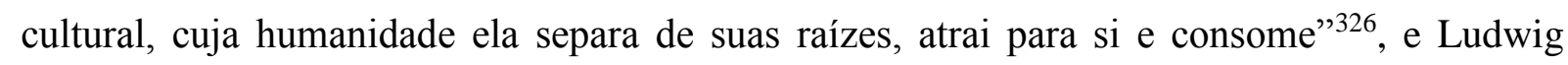
Klages, por sua vez, rejeitando as possibilidades de emprego da ciência e da técnica para fins emancipatórios escrevia que "a máquina - ela própria também natureza, embora uma natureza

\footnotetext{
${ }^{323}$ Max Horkheimer, "Zu Bergsons Metaphysik der Zeit”, op. cit., p. 227.

${ }^{324}$ Max Horkheimer, "Zum Rationalismusstreit in der gegenwärtigen Philosophie”, op. cit., p. 168. Não é possível abordar aqui a correção ou não da designação de "irracionalista", atribuída por Horkheimer à filosofia de Nietzsche.

${ }^{325}$ Oswald Spengler, Jahre der Entscheidung, citado por Horkheimer em sua resenha "Zu Oswald Sepnglers Jahre der Entscheidung". Gesammelte Schriften, vol. 3, p. 422.

${ }^{326}$ Oswald Spengler, Der Untergang des Abendlandes, citado por Horkheimer em "Zum Rationalismusstreit in der gegenwärtigen Philosophie", op. cit., p. 177.
} 
ludibriada e coagida a ser serva de si mesma - pode muito bem destruir a vida - nunca, entretanto, criá-la!" 327 . Dessa maneira, se à época em que aquele amplo movimento anticientificista se iniciara, por volta de 1900, a filosofia de Bergson havia feito a crítica do positivismo em nome da "vida", a reação conservadora desencadeada após a Revolução Russa e o fim da primeira guerra mundial também se exprimiu na função ideológica que passou a exercer o conceito de "vida", apropriado cada vez mais por correntes filosóficas irracionalistas caracterizadas pela ideia da subordinação dos indivíduos à vida autêntica que se realizaria no âmbito do Estado, da história dos povos ou então da natureza. Nas palavras de Horkheimer,

"O irracionalismo, na forma por ele assumida hoje em dia, rompeu com aquelas tradições: nele também se reflete, é verdade, o sofrimento dos indivíduos sob a ordem dominante que se tornou irracional, mas é como se esse reflexo agora estivesse invertido, pois a irrazão e o sofrimento que dela emana para os indivíduos são aceitos como necessidade e virados conceitualmente ao avesso, para se transformarem em um bem cultural" ${ }^{\prime 22}$.

Como vimos, também Fromm dedicara algumas páginas a essas correntes de pensamento, representativas, segundo o autor, do "caráter autoritário". Horkheimer concedeu alguma atenção a essa vertente do irracionalismo contemporâneo, mas a considerava de valor principalmente "histórico" e "psicológico"329, pois não via no anticapitalismo romântico o irracionalismo ideologicamente mais relevante nos anos trinta ${ }^{330}$. Se em Spengler e Klages a condenação do racionalismo em todos os seus matizes caminhava lado a lado com a pregação romântica de um retorno a uma época pretérita em que o pensamento científico ainda não teria exercido, na expressão de Spengler, seu efeito "mortal" sobre a vida, foi na obra de autores como Max Scheler, Martin Heidegger e Othmar Spann que Horkheimer encontrou expoentes de uma ideologia capaz de conciliar a rejeição da ciência empirista (ou pelo menos a sua depreciação como fonte rebaixada de conhecimento) com a legitimação do modo de produção capitalista em sua fase contemporânea. Referindo-se a Max Scheler e a Heidegger, Horkheimer afirmava que seria “(...) difícil se posicionar em relação às concepções específicas da antropologia filosófica e fazer-lhes uma crítica produtiva" ${ }^{331}$. Isso se devia, segundo o autor, à

\footnotetext{
${ }^{327}$ Ludwig Klages, Der Geist als Widersacher der Seele, citado por Horkheimer em "Zum Rationalismusstreit in der gegenwärtigen Philosophie”, op. cit., p. 177.

${ }^{328}$ Max Horkheimer, "Zum Rationalismusstreit in der gegenwärtigen Philosophie”, op. cit. p. 168.

${ }^{329}$ Cf. a já citada resenha do livro de Spengler Jahre der Entscheidung.

${ }^{330}$ Max Horkheimer, “Zum Rationalismusstreit in der gegenwärtigen Philosophie”, op. cit., p. 179, e também a resenha de Horkheimer sobre o livro de Oswald Spengler, na edição de 1933 da Revista de Pesquisa Social,: resenha "Zu Oswald Sepnglers Jahre der Entscheidung", op cit., p. 424.

${ }^{331}$ Max Horkheimer, ,"Bemerkungen zur philosophischen Anthropologie”, op. cit., p. 261.
} 
amplitude de suas questões e a seu afastamento da história concreta. O exame dessas vertentes do pensamento contemporâneo não deixava, contudo, de ter para Horkheimer o seu interesse, pois ela seria capaz de revelar algo do processo histórico.

Se a crítica de Bergson ao positivismo trouxera contribuições importantes ao conhecimento (ainda que, por fim, seu conceito de "tempo vivido" tenha sido submetido a uma transfiguração metafísica), a denúncia da ciência, quando feita pelos fenomenólogos das décadas de vinte e trinta, seria paradoxalmente acompanhada de conceitos metafísicos que exprimiam justamente o contrário daquilo que fora reclamado pela filosofia da vida e pelas correntes antipositivistas em geral: enquanto Bergson, ao rejeitar a redução do pensamento à análise e aos métodos das ciências naturais, havia conseguido formular um conceito de tempo que ressaltava seus aspectos qualitativos e a possibilidade de mudança e de criação, os conceitos centrais das obras dos mais recentes representantes do movimento anticientificista se caracterizavam pela abstração desses elementos e pela ênfase na repetição, no destino e na finitude. Em consequência, Horkheimer considerou a filosofia de sua época como objeto de uma progressiva reificação. O autor se aproximava, dessa maneira, da tese lukácsiana da extensão da forma mercantil a todas as expressões subjetivas e objetivas da vida social. Em História e Consciência de Classe, Lukács afirmara que a forma mercantil "tem de penetrar (...) no conjunto das manifestações vitais da sociedade e remodelar tais manifestações à sua própria imagem"332. As relações sociais entre os homens apareceriam à consciência reificada de maneira a perder seu caráter qualitativo, material e concreto, e a assumir a forma abstrata do cálculo de equivalentes. No âmbito da filosofia contemporânea, essa tendência se exprimiria no enrijecimento de seus conceitos, cada vez mais vazios e com cada vez maior pretensão de atemporalidade $^{333}$.

Assim, por exemplo, a antropologia filosófica de Max Scheler tinha por objetivo mostrar como de uma "estrutura fundamental do ser do homem" poderiam ser derivados "a linguagem, a consciência moral, os instrumentos, as armas, as ideias de justiça e injustiça, o Estado, a liderança, a função representacional das artes, o mito, a religião, a ciência, a historicidade e a sociabilidade" 334 . A revelação dessa estrutura permitiria trazer ao homem clareza quanto ao sentido de sua vida e ajudá-lo a adquirir uma segurança que antes era fornecida pela religião. Contudo, argumentava Horkheimer, esse sentido universal, obtido por meio de uma intuição

\footnotetext{
${ }^{332}$ Lukács, História e Consciência de Classe, op. cit., p. 196.

333 Sobre as características fundamentais do processo de reificação, cf. ainda Lukács, História e Consciência de Classe, op. cit., pp. 194-195 e pp. 209-213.

334 A passagem provém da obra de Max Scheler, e se encontra citada em Max Horkheimer, "Bemerkungen zur philosophischen Anthropologie", op. cit., p. 251.
} 
independente da experiência, seria essencialmente indeterminado e, quando a antropologia filosófica o identificava às manifestações cambiantes que, ao longo do devir humano, exprimiriam uma essência que seria em sua raiz a mesma, ela revelava seu conformismo em relação à realidade existente e sua indiferença em face da história: "não importa especialmente que uma determinada imagem seja realmente desenhada como finalidade (...) pois o próprio devir 'do' homem na história aparece como a sua destinação [Bestimmung]"335. O agir humano que poderia ser fundamentado com base em um sentido supra-histórico seria igualmente vago e desvinculado do processo histórico real, pois a antropologia filosófica forneceria apenas, nas palavras de um de seus formuladores, "uma segurança, ainda que apenas uma tal que torne possível a ousadia [Wagnis] e a ela impulsione" ${ }^{\text {"36. A }}$. Ao remeter a totalidade dos fenômenos a uma estrutura independente da experiência, a antropologia filosófica exercia uma função transfiguradora e legitimava ideologicamente a subordinação dos indivíduos ao curso real dos acontecimentos.

No irracionalismo contemporâneo, a impotência dos indivíduos diante da história receberia uma sanção metafísica. Como referido acima, a fenomenologia e a psicologia da Gestalt haviam, por meio da análise dos atos intelectivos, mostrado que no objeto da percepção a objetividade do todo precede a das partes, e que o conhecimento não equivaleria à reunião, pelo sujeito cognoscente, de um amontoado caótico de dados sensíveis ${ }^{337}$. Não apenas desse ponto de vista, mas também de acordo com o pensamento materialista, a filosofia empirista seria, ao afirmar a precedência das partes sobre o todo, limitada e incapaz de transcender a alienação dos indivíduos em relação a uma sociedade cujo processo de produção se autonomizou em relação a eles. Mas o irracionalismo contemporâneo, ao transformar a afirmação correta de que o todo é algo diferente da soma das partes na tese da indiferença das partes para o todo, terminou por se revelar tão unilateral quanto o pensamento analítico por ele recusado. Ambos considerariam de maneira não dialética a relação entre o todo e as partes, e falhariam em reconstruir em pensamento o "todo concreto" capaz de valer como uma "imagem de processos vivos" ${ }^{\prime 38}$. O pensamento deveria, segundo a perspectiva irracionalista, se apoiar na intuição imediata em vez de recorrer, como à luz do empirismo, à análise dos fenômenos da experiência e daí proceder por meio de abstração rumo à obtenção de conceitos supostamente

\footnotetext{
${ }^{335}$ Max Horkheimer, "Bemerkungen zur philosophischen Anthropologie", op. cit., p. 254.

${ }^{336}$ A passagem provém da obra de Landsberg, um representante da antropologia filosófica que à época era membro do Instituto de Pesquisa Social. A passagem está citada no mesmo texto de Horkheimer, "Bemerkungen zur philosophischen Anthropologie", op. cit., pp. 254-255.

${ }_{337}$ Cf. Max Horkheimer, "Materialismus und Metaphysik", op. cit., p. 102; e também "Zum Rationalismusstreit in der gegenwärtigen Philosophie", op. cit., pp. 174-175.

${ }^{338}$ Max Horkheimer, "Zum Rationalismusstreit in der gegenwärtigen Philosophie”, op. cit., p. 201.
} 
universais. Mas nada garantiria que da afirmação metafísica da prioridade do todo sobre as partes poderia se extrair um conhecimento mais próximo da verdade do que por meio da abstração feita a partir dos dados sensíveis:

\begin{abstract}
“A maioria das exposições filosóficas e sociológicas contemporâneas sobre indivíduo e comunidade não costuma repousar sobre um modo rigoroso de consideração. Elas não são de modo algum superiores a seus oponentes individualistas, que afirmam a tese inversa, ou seja, a prioridade lógica e ontológica das partes sobre o todo; sim, esses estão ainda mais próximos da verdade, na medida em que, visto de modo superficial, sua teoria é correta no caso das ciências mecânicas da natureza e, no caso da sociologia, os indivíduos detêm a primazia [sobre o todo caracterizado pela alienação], pelo menos no sentido do controle ambicionado [pela ciência]. Ambos os partidos falham em perceber que a ênfase exclusiva de um lado da relação é uma 'abstração vazia', ambos recaem em pura metafísica" 339 .
\end{abstract}

Ao rejeitar a redução do pensamento à análise e às categorias do entendimento sediadas no indivíduo, o irracionalismo contemporâneo rejeitaria também os aspectos morais do individualismo, correspondentes às ideias do interesse próprio e da ação em conformidade a fins, e tenderia a considerar como o sentido e finalidade da atividade humana o interesse do todo, não mediado pelos interesses dos indivíduos que dele são partes (como ainda era o caso na ideologia liberal clássica dos séculos XVIII e XIX): o sentido da vida social e política não dependeria, portanto, das necessidades dos indivíduos, mas consistiria na entrega irrefletida do indivíduo ao todo ${ }^{340}$. Segundo Othmar Spann, por exemplo, poderiam ser distinguidas duas características básicas na relação entre o indivíduo e sociedade: “(...) a) O todo, a sociedade, é a própria realidade, e b) o todo é o primário (o conceitualmente primeiro), e o indivíduo está presente como se fosse apenas um componente, (...) ele é o derivado" ${ }^{\text {341 }}$. Ao entender o todo como a única realidade verdadeira, o irracionalismo contemporâneo negaria aos indivíduos a possibilidade de satisfação de seus interesses e transferiria à sociedade, ao Estado, à nação, à história ou à natureza a autonomia e a realização das próprias qualidades, que no pensamento liberal dos séculos XVIII e XIX haviam aparecido como ideais a serem perseguidos por indivíduos que se encontrariam em harmonia sob o todo social ${ }^{342}$. $\mathrm{O}$ papel transfigurador que no presente exerceriam as ideias liberais seria complementado, na fase mais recente do capitalismo monopolista, pelas correntes filosóficas anticientificistas: elas naturalizariam a

\footnotetext{
${ }^{339}$ Max Horkheimer, “Zum Rationalismusstreit in der gegenwärtigen Philosophie”, op. cit., p. 206.

${ }^{340}$ Max Horkheimer, "Zum Rationalismusstreit in der gegenwärtigen Philosophie”, op. cit., pp. 199-201 e pp. 203-205.

${ }^{341}$ Othmar Spann, Gesellschaftslehre, citado à p. 206 de "Zum Rationalismusstreit in der gegenwärtigen Philosophie".

${ }^{342}$ Max Horkheimer, “Zum Rationalismusstreit in der gegenwärtigen Philosophie”, op. cit., p 209 e p. 216.
} 
supressão da autonomia e dos interesses do indivíduo não mais remetendo, por meio da ideia de uma harmonia preestabelecida, à sua possível realização, mas sim legitimando essa impossibilidade com recurso a categorias como "destino", "trágico" e "heroísmo" 343 . As questões filosóficas relativas à relação entre o indivíduo e a sociedade, embora vinculadas à prática social, seriam tratadas como se exprimissem normas eternas, capazes de conferir sentido e finalidade ao agir. Os conceitos das correntes filosóficas dominantes assumiam formas cada vez mais reificadas ${ }^{344}$ : a imbricação do pensamento com as necessidades e lutas reais dos homens seria desconsiderada e, em princípio desvinculados da prática, esses conceitos, ao proclamarem a necessidade de submissão dos indivíduos à universalidade abstrata do "todo" (fosse ele encarnado no Estado, na nação, na história ou natureza), exerceriam uma função ideológica de reforço da particularidade dominante ${ }^{345}$. Ainda que não tivesse clareza sobre isso, a teoria irracionalista se tornaria mero método de dominação e de legitimação do presente:

"O irracionalismo que, por meio da exigência da obediência impensada e do sacrifício cego, nega os interesses individuais que se encontram nas massas, em vez de modificá-los em sua estrutura por meio da reflexão sobre os fundamentos do processo social e alçá-los para além da mera aspiração a tirar vantagem, serve hoje inconscientemente a interesses particulares, que de modo algum se encontram negados" ${ }^{\prime 46}$.

Tendo corretamente identificado a insuficiência do pensamento analítico, a filosofia irracionalista não operaria como a dialética materialista, que considera a ciência como um elemento necessário da verdade, o qual seria necessário suprassumir em um pensamento que reconstrua a totalidade. Ao recusar o pensamento racionalista em favor de um método intuitivo e de categorias supostamente mais concretas, como "vida" ou "existência", mas sem incluir no processo de conhecimento a história e a sociedade, essas correntes recairiam em um pensamento

\footnotetext{
${ }^{343}$ Segundo Horkheimer, "a fase monopolista conserva a negação das oposições de classe, mas a luta no mercado mundial entre poucos grupos de poder se torna de tal maneira o tema principal da época, que em vez da concordância entre as existências individuais aparecem aqui como categorias histórico-filosóficas conceitos como o trágico, o heroísmo e o destino. Os interesses materiais dos indivíduos são tidos por algo de insignificante, que precisam menos ser atendidos do que superados". Cf. Max Horkheimer, "Materialismus und Metaphysik", pp. 7273, vol. 3 das Gesammelte Schriften. Ainda sobre isso, cf. também Max Horkheimer, "Zu Bergsons Metaphysik der Zeit", op. cit., p. 233.

${ }^{344}$ Cf. Max Horkheimer, "Zum Rationalismusstreit in der gegenwärtigen Philosophie”, op. cit., , p. 195 e p. 207.

${ }^{345}$ Max Horkheimer, "Zum Rationalismusstreit in der gegenwärtigen Philosophie”, op. cit., p. 207.

346 Max Horkheimer, "Zum Rationalismusstreit...”, op. cit., pp. 202-203. Como observou, em nota de rodapé, o editor desse volume das obras de Horkheimer, na primeira versão do texto - que fora publicada na Revista de Pesquisa Social em 1934 - a última passagem fora formulada de uma maneira que evidenciava ainda mais a função de dominação exercida pela ideologia irracionalista: "[o irracionalismo] serve hoje inconscientemente aos interesses particulares dos dominantes que continuam a tirar vantagem do existente em sua velha forma, interesses que de modo algum se encontram negados".
} 
tão abstrato quanto aquele por elas criticado ${ }^{347}$. Os seus conceitos poderiam, tanto quanto aqueles da ciência, exprimir momentos de verdade e, apesar de aparentarem possuir concretude e "movimento interno", seriam tão reificados quanto o conceito racionalista de "eu" ou o conceito empirista de "soma das sensações". Ao confundirem seu caráter de abstrações com uma suposta propriedade absoluta, desvinculada do processo histórico de sua constituição, esses conceitos se tornariam meramente ideológicos: "todas essas unidades isoladas, em meio às quais o processo por meio do qual elas foram obtidas é esquecido ou considerado inalcançável, cumprem hoje a função ideológica de categorias metafísicas" ${ }^{348}$. Ao responder ao sofrimento dos indivíduos com o aceno de um sentido metafísico da vida, as correntes irracionalistas empreenderiam uma conciliação com a realidade, pois tomariam a própria existência dos homens no presente como se fosse dotada de um sentido a ser buscado sem que se revelasse o caráter historicamente condicionado do agir humano e das contradições sociais produtoras do sofrimento: a antropologia filosófica “(...) transfigura o presente ao escolher por tema a possibilidade da vida 'autêntica' - ou mesmo da morte 'autêntica' - e ao tentar conferir à existência um significado mais profundo" ${ }^{\text {349. }}$.

Se parte do irracionalismo contemporâneo ressaltava a prioridade do todo sobre as partes, outras vertentes da "metafísica do pós-guerra" tomavam o rumo oposto. Em Ser $e$ Tempo, Heidegger partia de uma análise da experiência cotidiana do ser-no-mundo e reduzia a totalidade à existência singular, empreendendo uma analítica existencial do "ser-aí"350. Ao fazêlo, considerou o não-ser como a essência da existência: desde o princípio o ser-aí seria um "serpara-a-morte". Sendo determinado pelo seu fim, a partir desse fim ele poderia, segundo Heidegger, desenvolver as suas possibilidades. Nas palavras do autor: "na medida em que 'é', a morte é essencialmente e cada vez, minha. E de fato, significa uma possibilidade ontológica singular, na medida em que coloca totalmente em jogo o ser próprio da pre-sença" ${ }^{351}$. O próprio

\footnotetext{
${ }^{347}$ Em suas "Observações sobre a antropologia filosófica", Horkheimer afirmara que "o desejo de fundamentar o agir em rígidas intuições da essência [Wesenseinsichten] motivou a fenomenologia desde a sua origem" (Max Horkheimer, "Bemerkungen zur philosophischen Anthropologie", op. cit., p. 255).

${ }^{348}$ Max Horkheimer, "Zum Rationalismusstreit in der gegenwärtigen Philosophie", op. cit., 195. Na Dialética do Esclarecimento, Horkheimer e Adorno afirmariam que "toda reificação é um esquecimento". Cf., dos autores, Dialética do Esclarecimento. Tradução de Guido A. de Almeida. Rio de Janeiro: Jorge Zahar Editor, 1985, p. 215. ${ }^{349}$ Max Horkheimer, "Bemerkungen zur philosophischen Anthropologie”, op. cit.,p. 253.

${ }^{350}$ Martin Heidegger, Ser e Tempo. Tradução de Marcia Schuback. $13^{\mathrm{a}}$ edição. Petrópolis: Vozes, 2005, vol. 2, p. 27.

${ }^{351}$ Martin Heidegger, Ser e Tempo, op. cit., vol. 2, p. 20. A esse respeito, cf. Benedito Nunes, Heidegger \& Ser e Teтро. Rio de Janeiro: Jorge Zahar Editor, 2004, p. 22-24. Ainda nas palavras de Heidegger: "o que cabe é buscar na própria pre-sença o sentido existencial de seu chegar-ao-fim e mostrar que esse 'findar' pode constituir todo $o$ ser desse ente que existe"; "há na pre-sença uma 'não-totalidade' contínua e ineliminável, que encontra seu fim com a morte" (passagens extraídas respectivamente das páginas 22 e 23 da edição mencionada do segundo volume de Ser e Tempo).
} 
Heidegger contrastou a sua analítica existencial com a filosofia de Dilthey e Simmel, e chamou a atenção para o fato de que o problema da morte já estava necessariamente presente na obra daqueles autores ${ }^{352}$. A centralidade por ele conferida a esse problema em sua "analítica existencial" lhe pareceu, assim, o desenvolvimento lógico de uma questão à qual seus predecessores não deram a devida atenção. Horkheimer, por sua vez, contrastando essas premissas com aquelas da filosofia da vida, considerou o pensamento de Heidegger como representativo da reificação à qual estão submetidas as manifestações da sociedade capitalista.

Em Heidegger, essa reificação assumia uma configuração específica. Vimos acima como Horkheimer criticara a transfiguração presente na tese de Bergson de uma "evolução criadora" que conciliaria a vida interior do indivíduo com um sentido inerente ao curso do mundo. Heidegger, por sua vez, reduziria a história à "historicidade" do ser-aí: "essa filosofia da existência humana individual é, segundo o seu simples conteúdo, não transfiguradora no sentido hegeliano do termo. O ser humano é somente o ser-para-a-morte, a pura finitude: é uma filosofia melancólica"353. Sua filosofia empreenderia, portanto, um aplainamento das contradições entre a existência singular e existência universal, entre a realidade material e a vida do espírito: como vimos anteriormente, essas contradições haviam sido, na filosofia moderna em geral, submetidas à transfiguração (como em Hegel) ou deixadas sem resolução (como em Kant). Segundo Horkheimer, esses problemas receberiam no presente soluções cada vez mais dogmáticas ${ }^{354}$. Heidegger participaria desse movimento ao desconsiderar a imbricação entre o indivíduo e a história:

\begin{abstract}
"Segundo a concepção de que a história deve ser compreendida, primeiramente, a partir da historicidade interior do existir, o entrelaçamento do existir com o processo histórico real deveria ser apenas ilusório. Mas o ocupar-se com a história externa leva tão bem à compreensão do respectivo existir, quanto a análise das respectivas existências condiciona o entendimento da história. $\mathrm{O}$ existir está ligado indissoluvelmente à história exterior e, portanto, sua análise não poderá descobrir qualquer razão que, como tal motivada em si mesma, não deixe de ser independente de toda determinação exterior. Neste caso, a história real, com suas múltiplas estruturas a transcender o indivíduo, não é apenas algo derivado, secundário e objetivado, como o quer a filosofia da existência"355.
\end{abstract}

\footnotetext{
${ }^{352}$ Cf. Ser e Tempo, op. cit., vol. 2, pp. 30-31 (nota de rodapé).

353 Max Horkheimer, "A presente situação da filosofia social e as tarefas de um instituto de pesquisas sociais", p. 126. Cf. também "História e psicologia", op. cit., p. 14, e "Zum Rationalismusstreit in der gegenwärtigen Philosophie", op. cit., pp. 179-180.

${ }^{354}$ Cf. Max Horkheimer, "A presente situação da filosofia social e as tarefas de um instituto de pesquisas sociais", op. cit., p. 130.

${ }^{355}$ Max Horkheimer, "História e psicologia", op. cit., pp. 14-15.
} 
Nesse texto, de 1932, assim como no discurso de posse citado pouco antes (de 1931), a crítica feita por Horkheimer às filosofias de Max Scheler e Martin Heidegger lhes opunha a necessidade de considerar as questões ligadas à existência humana em conexão com a história concreta, empírica. O trecho acima era, por isso, seguido da seguinte recomendação, que ressoava um elemento central do programa de pesquisas do Instituto: “(...) todo tipo de antropologia filosófica oriunda de uma ontologia apesar de tudo estática se converte na psicologia dos homens que vivem dentro de uma determinada época histórica" ${ }^{\text {356 }}$. Aos poucos, entretanto, o caráter da crítica se transformava. Em suas "Observações sobre a antropologia filosófica”, de 1935, Horkheimer defendia que autores como Heidegger e Scheler teriam elevado à condição de constantes filosóficas os elementos característicos da dominação dos indivíduos sob o capitalismo monopolista: "cada uma das escolas antropológicas costuma estar correta e errada ao mesmo tempo, pois elas retiram certos conteúdos da história (...) e os transformam em 'disposições genuinamente pertencentes ao ser-aí' (...)"357. Dessa maneira, “(...) perturbações do ânimo, o humor [Stimmung], a alegria, o tédio, a angústia, a credulidade, o adestramento [Zucht]", seriam alçados ao posto de condições de uma intuição verdadeira, em vez de serem tomados pelo que eram, traços de comportamento dos indivíduos socializados sob o modo de produção capitalista e, portanto, submetidos a uma crescente diferenciação da vida social, que caminhava paralelamente a um controle cada vez maior sobre os indivíduos atomizados $^{358}$. A própria indiferença em face da história seria também expressão de uma situação real, e a ênfase na repetição e no destino exprimiu, na obra daqueles autores, o processo de integração social ocorrido sob o capitalismo monopolista:

\begin{abstract}
“A existência das massas pertencentes à pequena burguesia da cidade e do campo se reduz a mero meio, a estar à disposição para os fins externos e internos dos grupos dominantes. A adequação a essa situação resulta, como sempre, de uma transfiguração ideológica. (...) A glorificação da pessoa consciente de seu dever, mas ao mesmo tempo autônoma, tal qual essa glorificação apareceu na filosofia de Leibniz até Fichte, transformou-se - por exemplo, digamos, na obra de Max Scheler - em um hino ao sentido do sofrimento. A renúncia e a disposição a sacrificar-se de bom grado, que por fim são inequivocamente assumidas como a virtude da obediência e da negação dos próprios interesses, tornam-se parte da inclinação geral e revelam a adequação de uma grande parte dos indivíduos à sua situação atual. O homem não é tido por si mesmo mais como um fim, mas essencialmente como um meio"359.
\end{abstract}

\footnotetext{
${ }^{356}$ Max Horkheimer, "História e psicologia", op. cit., p.15.

${ }^{357}$ Max Horkheimer, "Bemerkungen zur philosophischen Anthropologie”, op. cit., p. 261. A expressão citada por Horkheimer entre aspas provém de Heidegger.

${ }^{358}$ Max Horkheimer, "Zum Rationalismusstreit in der gegenwärtigen Philosophie”, op. cit., pp. 194-195.

${ }^{359}$ Max Horkheimer, "Zum Rationalismusstreit in der gegenwärtigen Philosophie”, op. cit., pp. 168-169. "Eles [os conteúdos específicos das correntes irracionalistas] podem ser agrupados sobretudo ao redor do conceito de
} 
Apesar de sua recusa da ciência empirista, a metafísica do pós-guerra deixaria intacta a ética do trabalho, a submissão à autoridade política e os demais aspectos centrais do modo de produção capitalista. O "sacrifício" [Opfer] seria, segundo Horkheimer, a ideia à qual as concepções daquelas correntes de pensamento poderiam ser reduzidas. A glorificação da entrega do indivíduo ao existente seria o traço principal de uma ideologia correspondente à fase de intensa integração social, no âmbito de um modo de produção irracional: "o pensamento concreto é em certa medida mais incentivado do que até agora, e a técnica é afirmada. Bem, a ética do trabalho, uma ética que inclui essa relação positiva aos poderes racionais é, ela própria, irracional" ${ }^{360}$. Isso parece ter ocorrido de maneira bastante nítida na obra de Heidegger. Consideremos brevemente sua defesa de uma refundação radical do pensamento, que haveria de ser possível por meio do resgate de uma forma originária do filosofar, contraposta à lógica e ao entendimento:

\begin{abstract}
"Se assim se rompe o poder do entendimento no campo da interrogação acerca do nada e do ser, então também se decide com isto, o destino do domínio da 'lógica' no interior da filosofia. A própria ideia da 'lógica' se dissolve no redemoinho de uma interrogação mais originária" ${ }^{\text {361 }}$.
\end{abstract}

A ciência, o pensamento racionalista moderno e a metafísica inteira deveriam ser superados em proveito desse tipo de interrogação, uma ontologia fundamental que os rejeitaria como expressões de um "esquecimento do ser". Como notava Horkheimer, a "filosofia existencial (...) está decidida a recomeçar desde o começo e ambiciona redefinir o sentido de existir sem considerar a posição da pesquisa atual"362. Ao mesmo tempo, porém, a recusa do pensamento racionalista caminhava lado a lado com a ambiguidade do tratamento dado por Heidegger à técnica. A mera recusa da ciência e da vida urbana (como aparecia nas obras de Spengler e Klages) não seria a expressão ideológica máxima do irracionalismo contemporâneo. Heidegger, ao contrário das ideologias neorromânticas, não considerava a técnica como sinônimo da alienação: se ela por um lado representaria um "perigo", pois poderia reduzir o homem à condição de mero ente e assim retirar-lhe a sua "diferença ontológica”, seria também

sacrifício" (p. 180 do mesmo texto). Mais uma vez, aqui infelizmente não é possível um tratamento detalhado da obra desses autores. Interessa-nos principalmente a crítica feita por Horkheimer a suas principais concepções.

${ }^{360}$ Max Horkheimer, "Zum Rationalismusstreit in der gegenwärtigen Philosophie”, op. cit., p. 180.

${ }^{361}$ Martin Heidegger, “O que é metafísica?”. In: Martin Heidegger, Marcas do caminho. Tradução de Enio Paulo Giachini e Ernildo Stein. Petrópolis: Vozes, 2008, p. 127.

${ }^{362}$ Max Horkheimer, "História e psicologia", op. cit., p. 14. 
por outro lado um "destino" a ser cumprido pelo homem, que não poderia se furtar a um domínio técnico do mundo. No cumprimento desse destino, entretanto, o homem apenas manteria sua liberdade, segundo Heidegger, caso conseguisse estabelecer com a técnica uma outra relação que não a do recurso a ela com vistas ao domínio sobre os demais entes ${ }^{363}$. Horkheimer percebeu essa ambivalência entre refundação do pensamento e aceitação da técnica como um "destino": "a razão e a técnica não são mais meramente condenadas ao opróbrio, e sim apenas alguns determinados conteúdos são protegidos do pensamento conceitualizador, ao serem deslocados 'para o refúgio do irracional' "364.

Dessa maneira, o irracionalismo contemporâneo, justamente na medida em que recusava o pensamento racionalista em favor de um tipo de conhecimento superior ou originário, terminava por redundar em uma relação de resignação acrítica diante do predomínio de uma ciência e de uma técnica cada vez mais voltadas à reprodução das condições vigentes. Mais do que mera resignação diante do presente, contudo, na própria reificação característica dos elementos centrais das obras de Heidegger, Max Scheler e Othmar Spann se exprimia o processo de integração social característico daquele período histórico. Esse era um dos elementos que aproximavam a "metafísica do pós guerra" de uma tradição de pensamento justamente contra a qual ela se constituíra, o positivismo. Já chamamos pontualmente a atenção para a crítica geral que lhe foi feita por Horkheimer em seus ensaios - nos anos trinta, essa crítica teve o seu ponto alto no exame do "empirismo lógico".

De uma maneira parecida a Heidegger, também os membros do Círculo de Viena tentaram empreender uma refundação do pensamento e uma superação da metafísica. Em ensaio publicado na Revista de Pesquisa Social em $1937^{365}$, Horkheimer fez uma crítica da escola, caracterizada pela unificação entre, de um lado, as premissas básicas do empirismo (tal qual se apresentava nas obras de Bacon, Locke e Hume) e, de outro, a lógica matemática desenvolvida por Boole e Frege, dentre outros. Preservando a concepção legitimadora da ciência moderna de que todo o conhecimento adviria da realidade sensível, o empirismo lógico considerava que além das observações diretas só teriam validade as proposições lógicas. Entretanto, por considerarem a lógica tradicional desenvolvida desde os gregos carregada de pretensões de conhecimento conteudístico da realidade, viram na lógica matemática um meio

\footnotetext{
${ }^{363} \mathrm{Na}$ atitude de "senhor da técnica", o homem se tornaria uma simples peça do "esquema de disponibilidade" . A esse respeito, cf. Franklin Leopolodo e Silva, "Martin Heidegger e a técnica". Scientiae Studia. São Paulo, vol. 5, número 3, 2007, especialmente pp. 372-373.

${ }^{364}$ A expressão entre aspas é de Heidegger. Cf. Max Horkheimer, "Zum Rationalismusstreit in der gegenwärtigen Philosophie", op. cit., pp. 179-180.

${ }^{365}$ Max Horkheimer, "Der neueste Angriff auf die Metaphysik". In: Max Horkheimer, Gesammelte Schriften, vol. 4, pp. 108-161.
} 
de realizar duas tarefas: em primeiro lugar, "clarificar" conceitualmente a linguagem das ciências, livrando-as de formulações imprecisas originadas da filosofia e da linguagem cotidiana; em segundo lugar, transformar a filosofia em uma teoria do conhecimento científico: “apenas na moderna lógica simbólica é possível obter a precisão das definições conceituais e enunciados e formalizar o processo intuitivo de inferência do pensamento" ${ }^{366}$.

Apesar de algumas diferenças entre as obras de seus membros específicos (que passaram, elas próprias, por fases diferentes e se constituíram ao longo das discussões travadas nos anos trinta na revista Erkenntnis), a escola caracterizou-se em primeiro plano por uma forte rejeição da metafísica e, mais do que isso, de qualquer filosofia que defendesse a ideia de que o conhecimento não se reduz aos fatos apreendidos pela ciência: "asseio e clareza é o que se almeja, recusam-se obscuras longitudes e profundezas imperscrutáveis. Na ciência não há 'profundezas', o que há por toda a parte é a superfície"367. A filosofia, consequentemente, perderia o seu papel de uma reflexão que estaria acima das ciências e lhe forneceria sua fundamentação: segundo a "concepção científica de mundo" defendida pelos autores pertencentes ao Círculo de Viena, a filosofia deveria ser transformada em mera teoria de uma ciência a transcorrer independentemente dela e de quaisquer conhecimentos obtidos sem o recurso à experiência. Ao defender essa tese, rejeitavam a maior parte da filosofia e inclusive a existência de juízos sintéticos a priori (nos quais haveria uma "metafísica escondida"), e da tradição filosófica apenas retinham as contribuições que exprimissem, segundo a sua interpretação, reflexões proveitosas ao problema do conhecimento empírico. A aplicação da lógica matemática aos enunciados contidos nas obras dos filósofos canônicos permitiria seja revelar como "problemas ilusórios" as questões filosóficas tradicionais, seja transformá-las em problemas empíricos capazes de serem abordados pela ciência, única maneira de obter para eles alguma resposta válida ${ }^{368}$. Ao fazê-lo, a análise lógica dos enunciados filosóficos revelaria serem eles em sua maior parte "enunciados ilusórios", que não atenderiam às pré-condições lógicas de constituição de sentido. A maior parte da metafísica seria, dessa maneira, "sem sentido" e portanto passível de ser "superada"369.

\footnotetext{
${ }^{366}$ Cf. o manifesto de fundação da escola: Otto Neurath; Hans Hahn; Rudolf Carnap. Wissenschaftliche Weltauffassung - der Wiener Kreis. Moritz Schlick gewidmet. Viena: Artur Wolf Verlag, 1929, p. 308.

367 Otto Neurath; Hans Hahn; Rudolf Carnap. Wissenschaftliche Weltauffassung, op. cit., p. 305. Nesse manifesto se lê ainda: "em meio a diferenças de opinião é possível, ao fím das contas, um consenso, que é ao mesmo tempo exigido e virtude daquelas diferenças. Mostrou-se com cada vez maior clareza ser o objetivo comum a todos não apenas uma postura livre de metafísica, e sim uma postura antimetafísica” (p. 304).

368 Otto Neurath; Hans Hahn; Rudolf Carnap. Wissenschaftliche Weltauffassung, op. cit., pp. 305-307.

369 Cf. Rudolf Carnap, "Überwindung der Metaphysik durch logische Analyse der Sprache". In: Erkenntnis. Holanda: Springer, vol. 2, 1931-32, pp. 219-220. Os pré-requisitos da constituição de sentido em cada enunciado seriam basicamente dois: a reunião, de acordo com a "sintaxe lógica da linguagem", das palavras que o compõem, e a possibilidade de vincular cada palavra a uma referência obtida por meio de observação, o que poderia ser feito
} 
No que diz respeito à tarefa de ordenar o trabalho empreendido pelas ciências especializadas, a lógica matemática eliminaria as imprecisões da linguagem científica com o auxílio de procedimentos de formalização, que atuariam na simplificação e uniformização dos conceitos, reduzindo a distância entre as disciplinas em proveito do ideal de uma ciência unitária que, baseada no menor número possível de princípios, também permitisse a previsibilidade da ocorrência de eventos futuros. A ciência inteira deveria ser um sistema de relações lógicas baseadas em enunciados significativos, considerando-se esses últimos seja os enunciados baseados em observações diretas, seja aqueles que pudessem ser postos em relação lógica com enunciados baseados em observações diretas, isto é, que fossem passíveis de "redução aos mais simples enunciados sobre o empiricamente dado"370. Com essa tese já se impunha desde o início a questão de saber como conferir validade ao conhecimento obtido a partir dos sentidos, e qual o estatuto das observações diretas: apesar das diferentes soluções dadas pelos empiristas lógicos a esse problema, um ponto comum era que a física, por consistir em uma combinação de observações diretas com formalização lógica, deveria servir como ideal para a ciência unitária almejada, o que em medida mais extrema significou (ainda que quanto a isso não tenha reinado unanimidade) a defesa da redução de todo o conhecimento científico à física, transformada em uma ciência universal e estendida aos fenômenos tradicionalmente estudados pela biologia, pela psicologia e pela sociologia ${ }^{371}$. Com vistas à constituição da "ciência unitária" deveria ocorrer o trabalho coletivo dos especialistas, fundamentado epistemologicamente nas ideias tanto da intersubjetividade da validade das observações empíricas quanto da validade universal da linguagem da lógica matemática, que superaria as imperfeições das linguagens historicamente surgidas ${ }^{372}$.

de maneira direta ou indireta (por meio de conceitos intermediários aos quais a palavra poderia ser reduzida até se alcançar a observação direta da qual, em última instância, ela derivaria). Cf., sobre a referência das palavras, pp. 220-222, e sobre a sintaxe lógica da linguagem (não coincidente com a sintaxe gramatical), pp. 227-228 do mesmo texto de Carnap.

${ }^{370}$ Otto Neurath; Hans Hahn; Rudolf Carnap. Wissenschaftliche Weltauffassung, op. cit., pp. 305-306. Cf. também Rudolf Carnap, "Überwindung der Metaphysik durch logische Analyse der Sprache”, op. cit., p. 236. A defesa de uma "ciência unitária", feita naquele manifesto de lançamento da escola, não seria seguida unanimemente por seus membros nos anos seguintes.

${ }^{371}$ A posição de Schlick a esse respeito era mais moderada: ainda que o autor também visse na física um ideal de conhecimento científico, não defendia a redução das demais ciências a ela. Cf. a esse respeito Christian Damböck, "Nachwort". In: Christian Damböck (Org.). Der Wiener Kreis - Ausgewählte Texte. Stuttgart: Reclam, 2013, pp. 6-7.

372 No caso das ciências sociais e históricas, por exemplo, a eliminação dos conceitos metafísicos e a reunião das contribuições científicas de diversas origens foi imaginada seguinte maneira: "não é difícil deixar de fora conceitos como 'espírito do mundo' e, em vez disso, tomar como objetos grupos de indivíduos de determinada espécie. Quesnay, Adam Smith, Ricardo, Comte, Marx, Menger, Walras, Müller-Lyer (...) atuaram com base em uma postura empirista, antimetafísica. O objeto da história e da economia política são os homens, as coisas e sua combinação". Cf. Otto Neurath; Hans Hahn; Rudolf Carnap. Wissenschaftliche Weltauffassung, op. cit., p. 313. Um pouco antes se lê: "Apresenta-se a nós como objetivo a ciência unitária. Os esforços se dirigem no sentido de vincular e tornar harmônicas entre si as contribuições dos pesquisadores individuais nas mais diversas áreas da 
A defesa de uma "concepção científica do mundo" estava estreitamente ligada à visão de que a ciência poderia contribuir decisivamente para a superação dos problemas econômicos e sociais que assolavam a Europa do entreguerras: parte significativa dos membros do Círculo de Viena era socialista e conjugou a sua atividade filosófica a uma intensa atuação política em partidos e associações de esquerda, notadamente no campo da educação popular. Um espírito iluminista e reformista caracterizava os esforços da escola: "trata-se de instituir ferramentas de pensamento para o cotidiano, para o cotidiano dos estudiosos, mas também para o cotidiano de todos que de alguma maneira colaboram na constituição consciente da vida" ${ }^{373}$. Remetemos a esse aspecto do programa do Círculo de Viena porque ele torna nítida a sua relação com a situação de crise social, da ciência e do pensamento filosófico que caracterizou o período do entreguerras e à qual também o programa intelectual de Horkheimer foi, em certa medida, uma resposta. Com efeito, a defesa pelos empiristas lógicos de um trabalho interdisciplinar e de uma transformação da filosofia que a reduzisse a um instrumentário para a melhor abordagem dos problemas científicos levou alguns comentadores recentes a verem nesse programa semelhanças com aquele desenvolvido por Horkheimer nos anos trinta e delineado em seu discurso de posse, no qual o autor sustentara a necessidade de uma "interpenetração e desenvolvimento dialéticos e contínuos entre a teoria filosófica e a prática científica especializada" ${ }^{374}$.

ciência. Desse objetivo resulta a ênfase dada ao trabalho coletivo; daí resulta também que ressaltemos aquilo que é apreensível intersubjetivamente; daí a procura de um sistema neutro de fórmulas, de uma linguagem simbólica livre das impurezas das línguas históricas; daí a procura também de um sistema total dos conceitos” (p. 308).

373 Otto Neurath; Hans Hahn; Rudolf Carnap. Wissenschaftliche Weltauffassung, op. cit., p. 304.

374 Max Horkheimer, "Die gegenwärtige Lage der Sozialphilosophie und die Aufgaben eines Instituts für Sozialforschung”, op. cit., p. 29. O ensaio de crítica ao empirismo lógico, publicado no sexto volume da Revista de Pesquisa Social, teria representado segundo alguns intérpretes a ruptura de uma colaboração pontual que vinha se processando entre Horkheimer e Neurath, em reuniões na sede do Instituto em Nova York e por meio de cartas, e que teria sido possível em virtude da postura supostamente favorável de Horkheimer, em seus primeiros anos como diretor do Instituto de Pesquisa Social, ao pressuposto básico do empirismo lógico - a ideia de que os fatos apreendidos pelos sentidos seriam o ponto de partida do conhecimento - e também à concepção de que a filosofia deveria ser "transformada" em um apêndice da prática científica. Cf., por exemplo, o artigo de John O' Neill e Thomas Ueble, "Horkheimer and Neurath: Restarting a Disrupted debate". European Journal of Philosophy, vol. 12, n. 1. Oxford: Blackwell, 2004, pp. 75-105. Os autores recorreram aos trabalhos de Helmut Dubiel, Martin Jay e Rolf Wiggershaus para enfatizar a especificidade do programa delineado por Horkheimer em seu discuso de posse, caracterizado principalmente a partir da interdisciplinaridade e da incorporação dos resultados obtidos por meio da prática científica especializada. Nesse "materialismo interdisciplinar" quiseram identificar, contudo. na contracorrente da maioria das interpretações, elementos que aproximariam a obra de Horkheimer do positivismo. A obra de Horkheimer de início dos anos trinta estaria, portanto, distante do marxismo, e também mais especificamente, em um grau muito maior do que se costuma admitir, da obra de Lukács. Cf. as páginas 79-80 do artigo mencionado. Os primeiros trabalhos nessa linha interpretativa parecem ter sido os de Michiel Korthals, "Die kritische Gesellschaftstheorie des frühen Horkheimer - Missverständnisse über das Verhältnis von Horkheimer, Lukács und dem Positivismus". Zeischrift für Soziologie, ano 14, número 4, agosto de 1985, pp. 315-329, e também de Hauke Brunkhorst, "Dialektischer Positivismus des Glücks - Max Horkheimers materialistische Dekonstruktion der Philosophie”. Zeitschrift für philosophische Forschung. Frankfurt am Main, Vittorio Klostermann Verlag. Vol. 39, caderno 3, julho-setembro de 1985. Korthals viu nas críticas de Horkheimer a Lukács uma suposta rejeição da categoria de totalidade, e também defendeu a ausência do conceito de reificação na obra 
A crítica ao empirismo lógico, entretanto, nos parece antes ter sido um elemento fundamental do programa desenvolvido a partir de 1931, e não um afastamento dele, pois em seu exame do empirismo lógico Horkheimer deu prosseguimento à crítica da ciência e da metafísica feita nos anos anteriores, e que já podia ser notada no discurso de posse quando Horkheimer ressaltava que a oposição dominante na filosofia de seu tempo se dava entre, de um lado, o positivismo que tomava a realidade como um conjunto de "facticidades" e, de outro, as correntes metafísicas que postulavam a existência de "essências" ou "totalidades" de caráter absoluto $^{375}$. Mais especificamente, a crítica às ideias centrais do empirismo lógico não foi feita apenas no ensaio de 1937 que se ocupou mais detidamente da escola, mas já se encontrava formulada nos ensaios escritos nos anos anteriores, nos quais o autor criticava a absolutização dos dados sensíveis pelo positivismo, assim como a redução da ciência a mera força produtiva aplicada na indústria ${ }^{376}$.

Quanto ao ensaio sobre o empirismo lógico publicado por Horkheimer em 1937, seu objetivo declarado era "mostrar a insuficiência dessa maneira de pensar e a sua conexão com a história da burguesia" 377 . A mais recente versão do positivismo seria, assim como algumas das vertentes da "metafísica do pós-guerra", a expressão ideológica de uma pequena burguesia que, insatisfeita com o estado de coisas, mas impotente diante dos processos econômicos e políticos característicos do capitalismo monopolista, decidira voltar as costas para a história e propor uma refundação radical do pensamento ${ }^{378}$. Mais importante, contudo, do que essa filiação social, cremos ser o fato de Horkheimer considerar que as teses neopositivistas revelavam algo bastante significativo do próprio capitalismo contemporâneo.

escrita por Horkheimer até 1937 - em vez da reificação, muito mais importante teria sido a noção de "sofrimento", em sua versão schopenhauriana. De maneira semelhante, Brunkhorst argumentou que Horkheimer concebeu o programa de pesquisas interdisciplinares sob influência mista de Schopenhauer e do empiriocriticismo, do qual ele seria um adepto ao mesmo tempo que conservava, em seus ensaios, as referências à dialética e ao marxismo. $\mathrm{O}$ autor teria então tentado promover uma "transformação científico-social" da filosofia, e os ganhos obtidos pelas pesquisas empíricas do Instituto seriam a expressão de uma teoria tradicional que corresponderia a um "trigo" a ser separado do "joio metafísico" dos ensaios de Horkheimer (cf. especialmente as páginas 354-355 do mencionado artigo de Brunkhorst).

${ }^{375}$ Max Horkheimer, "A presente situação da filosofia social e as tarefas de um instituto de pesquisas sociais", op. cit., p. 126.

${ }^{376}$ Cf. Max Horkheimer, "Bemerkungen über Wissenschaft und Krise”, op. cit., pp. 42-43; e também ,

"Materialismus und Metaphysik", pp. 101-102.

${ }^{377}$ Max Horkheimer, "Der neueste Angriff auf die Metaphysik", op. cit., pp. 116-117. Horkheimer não explicitou com clareza as diferenças entre as posições dos três mais conhecidos membros do Círculo (Carnap, Neurath e Schlick), tendo se detido em maior medida sobre Carnap, e também sobre Russel. Uma análise mais detalhada da crítica de Horkheimer ao empirismo lógico poderia, é verdade, examinar as obras desses autores em separado, e também considerar a recepção que elas tiveram ao longo da história da filosofia analítica. Isso não alteraria, contudo, o cerne da crítica de Horkheimer à escola, pois permaneceria de qualquer maneira intocável o fato de que os membros do Círculo de Viena concordavam quanto a certas teses fundamentais, explicitadas acima quando reproduzimos algumas passagens de seu manifesto de 1929.

${ }^{378}$ Cf. Max Horkheimer, "Der neueste Angriff auf die Metaphysik”, op. cit., pp. 115-116 e p. 154. 
O empirismo lógico foi criticado por Horkheimer por ser uma filosofia da ciência que, ao se inspirar no modelo oferecido pelas ciências exatas, absolutizava o "dado sensível”, isto é, o "fato" que se apresenta à observação, tomando-o como fonte exclusiva do conhecimento sem que fosse, esse dado singular, posto em conexão com outros dados e teorias para a construção de uma totalidade de caráter histórico. Os empiristas lógicos reduziam o conhecimento à verificação empírica de juízos individuais (ou então ao estabelecimento de relações lógicas entre juízos que pudessem ser reduzidos, em última análise, a observações diretas), e consideravam lícito decidir sobre a verdade dos juízos caso a caso, isto é, tomando-os individualmente, "quando na realidade", argumentava Horkheimer, "pelo menos em muitos casos bem importantes, o que importa primeiro é conhecer o todo, para que depois se possa decidir" ${ }^{\prime 37}$. A tese fundamental que balizou o trabalho da escola foi a ideia, presente no Tractatus de Wittgenstein, de que o mundo seria um conjunto de fatos: "ele [o empirismo lógico] se atém àquilo que há, ou seja, à constatação. 'O mundo é tudo o que é o caso (...) O mundo se desmorona em fatos', se diz na principal obra filosófica de seus modernos adeptos" 380 . Ao pressupor que o mundo seria composto de fatos, os empiristas lógicos teriam enunciado, eles próprios, uma tese tão metafísica como aquelas que julgavam combater:

\begin{abstract}
“Apesar da luta contra a ideia básica do racionalismo, isto é, contra os juízos sintéticos a priori, enunciados de teor factual que nenhuma experiência poderia contradizer, o filósofo empirista toma por constantes as formas do ser. $\mathrm{O}$ mundo inteiro tem lugar fundamentalmente em um sistema fixo que, a bem da verdade, nunca é definitivo. Para um empirista 'é absurdo falar de um sistema único e total da ciência'. E, no entanto, a afirmação de que a feição correta de todo o conhecimento seria idêntica à física, e de que a física seria a grande 'ciência unitária' que teria de tudo abarcar, essa afirmação toma como constantes determinadas formas. Ela representa um juízo $a$ priori ${ }^{381}$.
\end{abstract}

Horkheimer não negava validade às observações diretas e à incorporação dos dados imediatos ao pensamento científico - o problema é que a ciência empirista estancaria em meio eles: "a ideia de que a ciência se limitaria a constatar e a classificar fatos dados a fim de predizer

\footnotetext{
${ }^{379}$ Max Horkheimer, "Der neueste Angriff auf die Metaphysik", op. cit., p. 152.

${ }^{380}$ Max Horkheimer, "Der neueste Angriff auf die Metaphysik”, op. cit., p. 119.

${ }^{381}$ Max Horkheimer, "Der neueste Angriff auf die Metaphysik", op. cit., p. 122. A primeira afirmação citada por Horkheimer provinha de um artigo escrito por Neurath em 1936, e a defesa da "ciência unitária", que contradiz a primeira tese, havia sido feita no já mencionado manifesto de fundação da escola, assinado em 1929 por Neurath, Hahn e Carnap. Entretanto, antes de exprimirem pontos de vista de autores diferentes, ou então a mudança de suas concepções ao longo do tempo, essas contradições exprimiriam, para Horkheimer, limites inerentes à própria perspectiva adotada.
} 
fatos futuros isola o conhecimento, sem que volte a suprassumir esse isolamento" 382 . É verdade que Neurath defendera, em comparação com seus colegas, uma posição mais matizada no que diz respeito à primazia da verificabilidade como critério último do conhecimento, e por isso considerava, segundo um comentador, que "vista em sua dinâmica histórica, a maneira pela qual surgem os dados empíricos e a pergunta pelas condições sob as quais uma pessoa percebe isso ou aquilo é de suma relevância" 383 . Contudo, embora Horkheimer não tenha considerado a especificidade da posição de Neurath no debate sobre as "sentenças protocolares" travado com Carnap e Schlick, o fundamental a esse respeito é que para nosso autor não apenas esse ou aquele dado empírico, mas a própria redução do pensamento aos "dados" seria um fenômeno histórico. O empirismo lógico hipostasiaria o caráter crescentemente abstrato assumido pela experiência de indivíduos isolados uns dos outros ${ }^{384}$.

No caso do empirismo lógico, o “isolamento” do conhecimento sensível representou um aprofundamento de tendências que já se encontravam no empirismo tradicional. A contradição aludida anteriormente (o caráter metafísico da rejeição, feita pelos empiristas lógicos, da metafísica em favor dos "fatos") se desdobrava em outras. Ao separar fato de valor, como de resto o pensamento científico moderno em geral se esforçou por fazer, o empirismo lógico seria incapaz de vincular a atividade de conhecimento a finalidades racionais que ultrapassassem o pensamento analítico: "só há razão no âmbito das empresas e das especialidades individuais, isto é, ela existe apenas como entendimento" ${ }^{385}$. O movimento radicalizou, dessa maneira, uma tendência já presente nos primórdios da filosofia moderna: se, por exemplo em Bacon, a ciência baseada na observação e na experimentação era pensada como um recurso para uma prática social voltada ao domínio da natureza em proveito de finalidades humanas (não obstante a constituição da ciência segundo critérios internos), no empirismo lógico ela - apesar das intenções reformistas e democráticas de muitos de seus defensores - foi reduzida a meros atos de observação e matematização. A reivindicação do empirismo tradicional de que a ciência fosse útil aos indivíduos se esfumava em meio à transformação do pensamento em mera coleta e sistematização de fatos: "o pensar renuncia à sua reivindicação de, ao mesmo tempo, ser crítico e estipular finalidades. Suas funções puramente registradoras e calculadoras são

\footnotetext{
382 Max Horkheimer, "Der neueste Angriff auf die Metaphysik", op. cit., p. 130.

${ }^{383}$ Cf. Christian Damböck, "Nachwort", op. cit., p. 5.

${ }^{384}$ A crítica de Horkheimer à escola revelava, portanto, algo da sociedade da época. Segundo Olgária Matos, "para a Teoria Crítica, o neopositivismo filosófico ou científico, a despeito de sua pretensa universalidade, reflete simplesmente a condição antropológica contemporânea, o isolamento do indivíduo". Olgária C.F. Matos, Os arcanos do inteiramente outro: a Escola de Frankfurt, a melancolia e a revolução. $2^{\mathrm{a}}$ edição. São Paulo: Brasiliense, 1995, p. 238.

${ }^{385}$ Max Horkheimer, "Der neueste Angriff auf die Metaphysik”, op. cit., p. 131.
} 
separadas de sua espontaneidade" 386 . A epistemologia defendida pelo empirismo lógico entraria em contradição com as próprias finalidades iluministas do programa ${ }^{387}$ :

\begin{abstract}
“ 'A ideia de que teríamos, no pensamento, um recurso à mão para saber mais sobre o mundo do que aquilo que foi observado (...) nos parece totalmente misteriosa', se lê em uma publicação do Círculo de Viena. $\mathrm{O}$ acolhimento desse princípio está particularmente malsinado em um mundo cuja fachada ornada reflete unidade e ordem em todas suas partes, enquanto em seu interior reside o terror. Autocratas, alcaides impiedosos de províncias coloniais e comandantes sádicos de prisões sempre se alegraram ao receber visitantes com essa disposição de espírito. Mas, se a ciência toda assume esse caráter, o pensar perde inteiramente a sua contumácia, assim como a resolutividade de trespassar uma floresta de observações e 'saber mais sobre o mundo' do que a bem-intencionada imprensa diária - dessa maneira, o pensamento e a ciência participam passivamente da injustiça geral" 388 .
\end{abstract}

Consequentemente, o empirismo lógico aprofundou, dando a ela uma nova direção, o pressuposto empirista básico. "O empirismo antigo tem, em comum com o empirismo lógico, a perspectiva de que todo o saber que diga respeito ao conteúdo de objetos emanaria, em última instância, de fatos da experiência sensível”, afirmava Horkheimer ${ }^{389}$. Entretanto, a separação entre ciência e filosofia no empirismo do início da idade moderna convivia com a ideia de que o indivíduo seria uma instância incontornável no processo de conhecimento (uma ideia expressa no conceito de "sensação", considerada como o ponto de partida do conhecimento). No empirismo lógico, por sua vez, se havia diferenças de opinião que consistiam em defender ora a possibilidade de observação exclusiva do dado imediato (como sustentava Schlick) ora a necessidade de que se considerasse também o contexto da observação (como argumentavam Neurath e Carnap) $)^{390}$, o essencial residia na eliminação dos fatores individuais do conhecimento, de maneira a permitir o registro livre de pressuposições de conteúdos que pudessem ser verificados intersubjetivamente e submetidos à formalização.

Os empiristas lógicos eliminavam, assim, o papel do sujeito no conhecimento, a caminho de uma ideia de ciência baseada na linguagem supostamente a-histórica e objetiva da lógica matemática, responsável pela formalização dos conhecimentos disponíveis. O empirismo de Locke e Hume, argumentava Horkheimer, não os havia impedido de elaborar uma teoria do

\footnotetext{
${ }^{386}$ Max Horkheimer, "Der neueste Angriff auf die Metaphysik", op. cit., pp. 153-154.

${ }^{387}$ Cf. o que foi dito acima, a partir do manifesto publicado em 1929, sobre a "concepção científica de mundo".

${ }^{388}$ Max Horkheimer, "Der neueste Angriff auf die Metaphysik”, op. cit., p. 127.

${ }^{389}$ Max Horkheimer, "Der neueste Angriff auf die Metaphysik", op. cit., p. 117.

${ }^{390}$ Cf. Christian Damböck, "Nachwort", op. cit., pp. 4-5.
} 
conhecimento e uma reflexão sobre o homem em geral: sua filosofia continha a referência a um sujeito $^{391}$. No empirismo lógico, por sua vez, a única referência era a ciência realmente existente, tal qual ela se dá no âmbito das divisões disciplinares tradicionais. A tensão entre sujeito e objeto, que incluía a ideia de uma realidade para além da experiência sensível, seria apagada em proveito de uma concepção de conhecimento que reduz a realidade aos fatos imediatos, a serem fixados em sentenças protocolares e incluídos em um sistema de cálculo e previsão ${ }^{392}$.

A redução da realidade a "dados" supostamente obtidos sem a mediação do sujeito representaria, por isso, um "aplainamento" das contradições que atravessaram o pensamento moderno em geral, como aquelas entre sujeito e objeto, teoria e prática, pensamento e vontade. Ao contrário da teoria materialista, o empirismo lógico não seria consciente da necessária mediação do sujeito no processo de conhecimento e radicalizaria um aplainamento já em processo no empirismo do início da época moderna. Nesse, entretanto, a redução da realidade à experiência sensível era ainda vista como algo negativo: isso se mostrara, segundo Horkheimer, na desconfiança de Hume de que, dadas as premissas de sua própria filosofia, pudesse haver algum conhecimento objetivo. No empirismo contemporâneo, por sua vez, o ceticismo de Hume não encontraria mais lugar: "seus herdeiros não falam mais disso - a impotência da razão não suscita mais nenhuma expressão de luto" ${ }^{\text {393. }}$.

A par disso, as observações diretas não tinham no empirismo lógico o mesmo estatuto que elas possuíam na obra dos empiristas do período inicial da idade moderna. Enquanto Bacon defendia ser possível partir de observações meticulosas e chegar às generalizações teóricas de maneira indutiva e respeitando as regras do método (o que incluía a extirpação dos "ídolos"), no ideal de conhecimento do empirismo lógico, por sua vez, os fatos deveriam ser transformados em sinais matemáticos a serem incluídos em um sistema de inferências lógicas: “o positivismo atual costuma, por um lado, invocar Hume, por outro lado, Leibniz. (...) Seu ideal é o conhecimento como ciência universal formulada matematicamente e deduzível do menor número possível de axiomas" 394 . O dado empírico deveria ser submetido a um processo de formalização, a fim de excluir dele as "impurezas" da linguagem corrente, e por isso o papel da observação sensível na ciência decresceria, na interpretação de Horkheimer, em proveito do estabelecimento de um sistema fixo de fórmulas que, se é verdade que os empiristas lógicos

\footnotetext{
${ }^{391}$ Cf. Max Horkheimer, "Der neueste Angriff auf die Metaphysik", op. cit., p. 118.

${ }^{392}$ Cf. Max Horkheimer, "Der neueste Angriff auf die Metaphysik”, op. cit., p. 129 e pp. 131-132.

${ }^{393}$ Cf. Max Horkheimer, "Der neueste Angriff auf die Metaphysik", op. cit., pp. 131-132.

${ }^{394}$ Max Horkheimer, "Der neueste Angriff auf die Metaphysik", op. cit., p. 114.
} 
reconheciam como provisório - pois em princípio poderia ser alterado por novas observações ao mesmo tempo assumia para eles a dianteira do processo de conhecimento:

\begin{abstract}
"Como a física, enquanto técnica intelectual rigidamente delimitada, sempre lida com juízos já formados por observadores, e não imediatamente com as percepções, o critério da experiência não significa aqui a própria sensação, como em Locke ou Hume, mas o juízo acabado que, em cada caso, se tem acerca da sensação. A tarefa exclusiva da ciência seria erigir um sistema do qual pudessem ser derivadas proposições que fossem confirmadas inequivocamente por juízos de observadores, por "sentenças protocolares" ["Protokollsätze"]. Um sinal descritivo é tido por comprovado quando ele pode ser reduzido, por meio de definições ou de novos princípios, a sinais que apareçam em sentenças protocolares. Daí decorre que a ciência e, por isso, também a filosofia científica, só teriam que considerar o dado sob a forma de proposições sobre o dado. $\mathrm{O}$ cientista trata do mundo apenas na medida em que ele está fixado linguisticamente" 395 .
\end{abstract}

Extirpava-se dessa maneira do âmbito do conhecimento tudo aquilo que não posa ser reduzido a princípios já reconhecidos. A necessidade de se ater a um sistema fixo de fórmulas entraria em contradição com a noção mais básica do empirismo, a origem do conhecimento na experiência. A "lógica” e o "empirismo" estariam por isso, segundo Horkheimer, unidos um ao outro apenas superficialmente ${ }^{396}$. A ciência seria reduzida ao procedimento de reunir dados em sentenças protocolares suscetíveis de formalização lógica, e sob essa fetichização do método ela se converteria em uma racionalidade que, cada vez mais restrita à formalização do existente, se convertia no contrário do conhecimento. Como afirmaria o autor alguns anos mais tarde, a concepção de conhecimento defendida pelo empirismo lógico reduziria a ciência a um conjunto de operações vazias e de enunciados cada vez mais abstratos: "[a semântica contemporânea] hoje afirma que apenas pode ter sentido a frase puramente simbólica e operacional, isto é, a frase absolutamente sem sentido" ${ }^{397}$. Assim, a crítica de Horkheimer ao empirismo lógico antecipava em certa medida sua análise da razão subjetiva em $O$ Eclipse da Razão e também a crítica à conversão da razão em mito, feita por ele e Adorno na Dialética do Esclarecimento ${ }^{398}$.

\footnotetext{
${ }^{395}$ Max Horkheimer, "Der neueste Angriff auf die Metaphysik", op. cit., p. 118.

${ }^{396}$ Max Horkheimer, "Der neueste Angriff auf die Metaphysik", op. cit., p. 147.

${ }^{397}$ Max Horkheimer, “Zur Soziologie der Klassenverhältnisse”. In: Max Horkheimer, Gesammelte Schriften, op . cit., vol. 12. Tradução ao alemão do manuscrito original inglês feita por Hans Günther Zoll, p. 92.

${ }^{398}$ Cf., por exemplo, o capítulo inicial, sobre "O Conceito de Esclarecimento", da obra escrita em conjunto com Adorno (Adorno e Horkheimer, Dialética do Esclarecimento, op. cit., especialmente pp. 19-30). A figura assumida pela razão no positivismo contemporâneo seria, então, capaz de iluminar o seu desenvolvimento anterior: "Para o esclarecimento, aquilo que não se reduz a números e, por fim, ao uno, passa a ser ilusão: o positivismo moderno remete-o para a literatura. 'Unidade' continua a ser a divisa, de Parmênides a Russel. O que se continua a exigir
} 
Apesar de sua oposição frontal a Heidegger ${ }^{399}$, o empirismo lógico seria mais próximo dele do que poderia imaginar, pois seu aplainamento da tensão entre sujeito e objeto por meio da redução da realidade aos dados imediatos não estaria muito distante da defesa, feita por Heidegger, do abandono daquela contradição por meio da instauração de uma "interrogação mais originária" capaz de resgatar o sentido do ser (cf. acima). Ambos tinham por meta a "superação" da metafísica: os empiristas lógicos, por meio da análise lógica dos enunciados e da redução do conhecimento aos dados imediatos, Heidegger, por meio do abandono da lógica e do retorno do pensamento a uma estrutura pré-predicativa que poderia ser encontrada em meio aos filósofos pré-socráticos. Ambos se conciliariam, dessa maneira, com a realidade existente e voltariam as costas à história ${ }^{400}$. Essa, entretanto, penetraria no âmago de seus respectivos métodos: a dissolução da lógica em meio a uma "interrogação mais originária", capaz de resgatar um sentido esquecido do ser, e a eliminação por meio da formalização matemática das “impurezas" historicamente constituídas no âmbito da linguagem corrente estariam vinculadas, uma como a outra, a um processo social em curso. Referindo-se aos regimes totalitários à época em profusão na Europa, Horkheimer afirmava:

"A profunda conexão entre, por um lado, a transfiguração da qualidade isolada do asseio e, por outro, a demanda por assepsia à qual são feitas naqueles Estados as mais terríveis concessões, deve passar despercebida àqueles filósofos já em virtude do fato de que eles, em sua relação bárbara com a linguagem, consideram a alusão contida na palavra como uma mera fonte de confusão. Eles cometem, de forma invertida, o erro de uma determinada espécie moderna da metafísica, que transforma a filosofia em hermenêutica e alega ir ao encalço das coisas meramente ao perseguir o significado historicamente originário das palavras" ${ }^{\prime 401}$.

Nesse percurso, da "sensação", ao "dado", do "tempo vivido", ao "ser-para-a-morte", a metafísica, que em sua ocupação com a totalidade e os problemas mais gerais do ser e da

insistenmente é a destruição dos deuses e das qualidades" (Adorno e Horkheimer, Dialética do Esclarecimento, op. cit., p. 23).

399 O artigo de Carnap mencionado acima, sobre a "superação da metafísica por meio da análise lógica da linguagem", do qual são retiradas aqui algumas indicações sobre as teses da escola, fora escrito em polêmica com o texto-conferência de Heidegger, "O que é metafísica", também citado mais acima.

${ }^{400}$ Max Horkheimer, "Der neueste Angriff auf die Metaphysik", op. cit., p. 158. Décadas mais tarde, e partindo de outra problemática e outro ponto de vista teórico, Gottfried Gabriel argumentou pela existência de semelhanças profundas entre Carnap e Heidegger. Cf. Gottfried Gabriel, "Carnap und Heidegger". In: Deutsche Zeitschrift für Philosophie, vol. 48. Berlim, De Gruyter, 2000, pp. 487-497. Um aprofundamento desse tema estaria, entretanto, para além das capacidades desta tese e de seu autor.

${ }^{401}$ Max Horkheimer, "Der neueste Angriff auf die Metaphysik", op. cit., p. 147. 
existência humana tradicionalmente havia guardado as promessas de superação da alienação contra uma ciência empirista ao longo do século XIX cada vez mais reduzida a mera força produtiva vinculada à reprodução da ordem burguesa, teria se transformado, nas versões surgidas a partir da década de vinte, em mera apologia do existente, e o fazia quanto mais recusava o conhecimento científico em prol de uma intuição indiferente à experiência sensível; e o empirismo, que se definia pela recusa da metafísica e pela necessidade de a ciência se ater à realidade tal qual ela aparece, passava a se apoiar cada vez mais em pressupostos dogmáticos, transformando-se em uma nova metafísica ao mesmo tempo em que deitava por terra os elementos críticos que haviam caracterizado a escola nos séculos XVII e XVIII. A crítica de Horkheimer mostrou, dessa maneira, como os polos da contradição entre ciência e metafísica, quanto mais se separavam, mais se aproximavam um do outro: a metafísica do pós-guerra, em mera legitimação da sociedade caracterizada pela organização industrial e pela técnica, contra as quais o movimento anticientificistas se insurgira; o empirismo lógico, em um novo irracionalismo ${ }^{402}$.

\footnotetext{
${ }^{402}$ Em seus estudos sobre a dialética, Jürgen Ritsert analisou os aspectos formais desse tipo de crítica. Partindo de Adorno e de Hegel, o autor ressaltou a "mediação interna" dos opostos como o cerne da contradição: na consideração de momentos definidos pela exclusão terminante um do outro, a análise precisa de cada um deles mostraria que a sua composição interna contém, ao mesmo tempo, a referência a seu oposto. Uma simultaneidade de exclusão e inclusão seria constitutiva da contradição e, não obstante a impropriedade de se falar em "definições" quando se trata de conceitos históricos, essa simultaneidade poderia aspirar à condição de "princípio da dialética", como se depreende de indicações de Adorno: a dialética consistiria "não no fato de que ambos os momentos contrapostos, digamos, se refiram um ao outro, mas sim no fato de que a análise de cada um deles em si mesmo remeta a um momento a ele contraposto, como uma implicação de seu sentido. Isso poderia ser denominado de princípio da dialética, em oposição a um pensamento que meramente operaria diferenciaçoes externas, dualistas ou disjuntivas". Theodor Adorno, Philosophische Terminologie. Frankfurt am Main: Suhrkamp, vol. 2, 1974, p. 142. A passagem é citada aqui a partir de: Jürgen Ritsert, Materialien zur kritischen Theorie der Gesellschaft Dialektik, caderno 8. Frankfurt am Main: Goethe Universität/Karl-Marx-Buchhandlung, 2011, p. 11-17. Sobre esse tema, cf. também, de Jürgen Ritsert, Dialektische Argumentationsfiguren in Philosophie und Soziologie Hegels Logik und die Sozialwissenschaften. Münster: MV-Verlag, 2008, especialmente pp. 26-32.
} 


\section{Capítulo 4 - Da ideologia contemporânea à história, da ciência contemporânea à teoria crítica}

\section{$\underline{4.1 \text { - A forma contemporânea da ideologia }}$}

Como vimos anteriormente, Horkheimer analisou a maneira pela qual as contradições do pensamento moderno se atualizavam de uma maneira específica nas ideologias dominantes nas décadas de vinte e trinta. A contradição básica entre sujeito e objeto, encontrada a descoberto na filosofia moderna em geral (e expressa em diversas contradições específicas no âmbito das obras de Descartes e Kant), era aplainada pelas correntes filosóficas que reduziam o pensamento aos "dados" ou a "intuições" de caráter imediato. Cada vez mais aprofundada, a oposição dominante entre ciência e metafísica daria continuidade "de forma distorcida" às contradições da filosofia moderna, cujos conceitos eram submetidos a um processo de progressiva reificação ${ }^{403}$. Se na filosofia burguesa clássica a pretensão de conhecimento da realidade convivera de maneira contraditória com a noção de que a verdade não poderia ser reduzida aos fenômenos, na contemporaneidade o positivismo reduzia a experiência aos meros fatos, e as correntes que surgiram em oposição a ele, reivindicassem ou não o racionalismo, associavam um sentido mais elevado a uma realidade independente das mudanças históricas e dos interesses dos homens. Em ambos os casos, a dependência em relação ao existente se exprimia em conceitos cada vez mais fetichizados, que redundavam, como Horkheimer defendia, em formas complementares de irracionalismo que exerciam uma função ideológica ligada à reprodução da vida social.

A subordinação dos indivíduos à realidade em suas formas dadas foi considerada inicialmente por Horkheimer sob um prisma sociopsicológicos: o aparelho psíquico seria a principal mediação entre a história e a ação individual, entre os processos de produção e as ideologias. Os homens tenderiam a adaptar seus valores e suas ações a interesses condicionados por sua situação econômica, e nessa relação o aparelho psíquico exerceria o papel de mediador responsável pela harmonia entre as duas esferas: “(...) por causa de seu aparato psíquico, os homens costumam aceitar o mundo desde já de uma forma tal que suas ações podem corresponder ao seu saber". Foi dessa maneira que Horkheimer considerou, em "História e

${ }^{403}$ Cf. Max Horkheimer, "Zum Problem der Wahrheit”, op. cit., p. 278. 
psicologia" (texto de 1932), a concordância entre a vida material e os conceitos organizadores do conhecimento e da ação, empreendendo uma espécie de "tradução", para o âmbito do materialismo histórico e da psicanálise, de um problema que, segundo o autor, tradicionalmente fora solucionado de maneira idealista, como se fosse, tal qual se lê em seu discurso de posse de 1931, uma questão de relações eternas entre a vida material e o espírito, a realidade e a ideia ${ }^{404}$. Essa concordância fora explicada por Kant com recurso à noção de "esquematismo": garantidora de uma certa espontaneidade do pensamento, a harmonia entre as impressões sensíveis e os conceitos seria possível por meio de uma "arte oculta nas profundezas da alma humana", capaz de formar previamente as impressões. Essa pré-formação poderia ser melhor compreendida, segundo Horkheimer, como um efeito psíquico, produzido de acordo com as condições de vida empiricamente dadas. O aparelho psíquico do membro de cada classe social seria decisivo em sua adaptação às condições materiais, e conhecer essa interação, apostava Horkheimer, poderia trazer luz ao problema da relação entre a história e as representações ideológicas: “(...) não é impossível que, nesta ocasião, se descubra algo sobre o esquematismo, como Kant o entende" 405.

Àquela época o autor considerava o "caráter" como a mediação decisiva para a compreensão da relação entre vida material e vida espiritual, entre os processos econômicos e aqueles relativos às esferas da política e da cultura, e daí decorriam também suas expectativas quanto às pesquisas sobre autoridade e família e em relação à psicologia social de Fromm. A incorporação da psicologia social era admitida sem que a própria historicidade de suas categorias fosse posta em questão, pelo menos àquela época:

"Entre as diretrizes metodológicas de uma psicologia frutífera para a história será especialmente importante a capacidade de adaptação dos membros de um grupo social à sua situação econômica. Os respectivos mecanismos psíquicos que permitem continuamente essa adaptação surgiram, sem dúvida, no curso da história, mas temos de pressupô-los como dados quando se tratar de explicar determinadas ocorrências históricas do presente; eles constituem, então, uma parte da psicologia

\footnotetext{
${ }^{404}$ Cf. Max Horkheimer, “A presente situação da filosofia social e as tarefas de um instituto de pesquisas sociais”, op. cit., p. 130.

${ }^{405}$ Max Horkheimer, "História e psicologia", op. cit., p. 23. Foi nesse sentido que Horkheimer formulou em seu discurso de posse a pergunta que orientou de uma maneira geral os "Estudos sobre autoridade e família": "quais conexões é possível apurar - num determinado grupo social, num período determinado, em determinados países entre o papel desse grupo no processo econômico, a transformação ocorrida na estrutura psíquica dos seus membros singulares e os pensamentos e as instituições que agem sobre esse mesmo grupo, como totalidade menor no todo da sociedade, e que são por sua vez o seu produto? (...) Num primeiro momento pretendemos direcionálos [os trabalhos de pesquisa] a um grupo social particularmente importante e característico, aos operários qualificados e aos empregados na Alemanha: depois a pesquisa deverá ser estendida também às classes sociais corespondentes dos outros países europeus altamente desenvolvidos”. Cf. Max Horkheimer, "A presente situação da filosofia social e as tarefas de um instituto de pesquisas sociais", op. cit., p. 131.
} 
da época presente. A isso está ligado, por exemplo, a capacidade das pessoas de verem o mundo de tal maneira que a satisfação de seus interesses, resultante da situação de seu próprio grupo, concorde com a essência das coisas, estando fundada em uma moral objetiva" ${ }^{406}$.

Mas, se na obra de Fromm a subordinação à autoridade era entendida essencialmente como expressão do caráter sadomasoquista que levaria os indivíduos a conceberem a realidade como um sistema hierárquico baseado em relações de opressão e subordinação, na obra de Horkheimer esse problema assumia uma feição diferente. Nos anos seguintes àqueles primeiros textos, a ênfase na mediação psíquica assumiu paulatinamente um lugar secundário em relação à ênfase no fenômeno da reificação. Do ponto de vista da história da obra de Horkheimer e do Instituto, dois processos mutuamente relacionados parecem ter concorrido para tanto.

Em primeiro lugar, nos ensaios do próprio Horkheimer os temas da reificação e do fetichismo (presentes pelo menos desde as "Observações sobre ciência e crise" de 1932) passavam a ocupar o centro de suas reflexões, principalmente a partir do ensaio de 1934 "Sobre a controvérsia do racionalismo contemporâneo", que assinalou o aprofundamento da critica do autor às correntes filosóficas contemporâneas, a partir de então consideradas à luz da reificação de seus conceitos ${ }^{407}$. Essa passagem pode ser localizada no âmbito do desenvolvimento interno da obra do autor: segundo Alfred Schmidt, a passagem de Horkheimer ao marxismo foi gradual, e se deu no período entre 1926 (ano da publicação dos aforismos de Dämmerung) e 1932 (ano da publicação de "História e psicologia" e das “Observações sobre ciência e crise") ${ }^{408}$. Essa informação reforça nossa hipótese de que, à época de realização das primeiras pesquisas de Fromm (1929-31), iniciadas pouco antes do ingresso de Horkheimer como diretor do Instituto, a compreensão do marxismo pelo autor ainda estava em seus momentos iniciais, e seria enriquecida a partir de 1932: a partir de então, o autor passou cada vez mais das formulações da Ideologia Alemã e da ênfase na reprodução da vida dos indivíduos a uma crítica do fetichismo, como vimos anteriormente com respeito à sua crítica das correntes filosóficas contemporâneas $^{409}$. Um indicativo desse deslocamento de ênfase é a própria mudança de

\footnotetext{
${ }^{406}$ Max Horkheimer, "Geschichte und Psychologie”, op. cit., pp. 61-62.

${ }^{407}$ Cf. "Bemerkungen über Wissenschaft und Krise", op. cit., pp. 43-45. Sobre o ensaio de 1934, cf. o capítulo anterior desta tese.

${ }^{408}$ Cf. o posfácio de Alfred Schmidt ao volume 10 das Gesammelte Schriften de Max Horkheimer: "Nachwort des Herausgebers - Horkheimer als Historiker des deutschen Idealismus und der philosophischen Renaissance der zwanziger Jahre", p. 423.

409 Como vimos no item 1.1, a leitura de A Ideologia Alemã influenciou decisivamente a primeira fase da apropriação do marxismo por Horkheimer, iniciada por volta de 1925/26. Essa influência se estendeu até os ensaios escritos nos primeiros anos da década de 1930, e é por isso que discordamos de John Abromeit, quando o autor afirma que a obra desenvolvida por Horkheimer no peródo de 1925 a 1930 explicaria a sua teoria crítica
} 
terminologia - de "concepção econômica da história" em "História e psicologia" (1932), o autor logo passava (em "Materialismo e metafísica", de 1933) a "materialismo" (às vezes também “materialismo histórico" ou, menos frequentemente, "materialismo dialético") e, já a partir de "Materialismo e moral" (do mesmo ano), empregava "materialismo" e "crítica da Economia Política" de maneira aparentemente indistinta, até a segunda expressão se tornar, a partir de 1936, dominante em relação à primeira, à medida que se firmava a concepção da "teoria crítica" ${ }^{410}$. Em consequência, ao final desse processo, a tese kantiana do esquematismo seria considerada sob nova luz: no ensaio de 1937, como vimos, as contradições da filosofia transcendental foram interpretadas como uma aparência socialmente necessária, como a expressão idealista da contradição entre a atividade dos indivíduos, abstrata e consciente, e aquela da sociedade, cega e concreta ${ }^{411}$.

Em segundo lugar, esse deslocamento parece ter se dado também sob influência das pesquisas sobre autoridade e família (incluindo-se aí não apenas os levantamentos conduzidos pelo próprio Instituto, mas também o estudo da literatura disponível sobre o assunto). Elas haviam revelado o declínio da função socializadora da família, um processo ocorrido ao longo do capitalismo monopolista e caracterizado pela diminuição da autoridade paterna em meio ao avanço do desemprego estrutural e à transformação da família de unidade de produção econômica em unidade de consumo ${ }^{412}$. Em consonância a esse deslocamento, Horkheimer se afastava também das concepções presentes na psicologia social de Fromm e da ênfase no “caráter" dos indivíduos, tomado como uma mediação não problematizada. A mediação

desenvolvida ao longo de toda a década de trinta (essa interpretação é desenvolvida ao longo dos capítulo 3, 4 e 5 de seu já mencionado Max Horkheimer and the Foundations of the Frankfurt School).

${ }^{410}$ Cf. Max Horkheimer, "Geschichte und Psychologie" (1932), op. cit., p. 51, pp. 54-55; "Materialismus und Moral" (1933), op. cit., p. 128; "Zum Problem der Wahrheit" (1935), p. 311; "Autoridade e família" (1936), op. cit., p. 177.

${ }^{411}$ Cf. Max Horkheimer, "Teoria tradicional e teoria crítica", op. cit., p. 127. Katia Genel chamou a atenção para esse deslocamento de Horkheimer, do compartilhamento das teses de Fromm à crítica da reificação. Ele corresponderia a uma "assimetria" no programa de pesquisas de Horkheimer: nele, o "primado" da psicologia social haveria tido uma vigência bem mais curta do que se costuma admitir, cedendo lugar por volta de 1935 a uma crítica da reificação. Cf., da autora, Autorité et emancipation: Horkheimer et la théorie critique, op. cit., pp. 25-27 e pp. 43-48. A isso acrescentemos que, se é verdade que a crítica de reificação só começou a assumir um papel central a partir do ensaio "sobre a controvérsia do racionalismo", de 1934, ela já se encontra antes, embora de maneira relativamente isolada, na crítica de Horkheimer às contradições da ciência feita nas "Observações sobre ciência e crise", de 1932, assim como, em germe, no discurso de posse, sob a forma da oposição entre a metafísica e o positivismo, embora essa oposição aparecesse ali principalmente, para usar os termos de Helmut Dubiel, como o "contexto histórico-científico" do programa de pesquisas de Horkheimer, na condição de extremos dos quais o autor pretendia se afastar. Cf. Helmut Dubiel, Wissenschaftsorganisation und politische Erfahrung, op. cit., pp. 152-155. Nos anos seguintes, porém, aquela contradição servou ao autor de ponto de partida para sua crítica às correntes filosóficas contemporâneas, como tentamos argumentar.

${ }^{412}$ Cf. Max Horkheimer, "Autoridade e família", op. cit., p. 221; e também, sobre esse ponto, Martin Jay, Dialectical Imagination - a History of the Frankfurt School and the Institue of Social research. Londres: Heinemann, 1973, pp. 126-127. 
psíquica continuava fundamental para a compreensão dos processos de dominação no capitalismo contemporâneo, mas ela se revelava cada vez mais como expressão do fetichismo das relações sociais.

Quanto à família, Fromm a considerava, como vimos, a "agência psicológica da sociedade", uma instituição de caráter repressor e responsável pela transmissão da autoridade, por meio da formação de uma estrutura libidinal adequada às necessidades sociais. Horkheimer, por sua vez, via na família uma esfera social dotada de legalidade própria, relativamente independente da sociedade e que poderia por isso exercer funções tanto de reprodução das relações sociais vigentes quanto de oposição a elas. Instituição responsável pela formação dos indivíduos e sua preparação para a vida pública, ela necessariamente reprimiria seus impulsos, atuando como representante da sociedade diante deles. Ao mesmo tempo, a família seria um ambiente relativamente distante das pressões do mercado e no Estado, uma esfera na qual os indivíduos cultivariam relações imediatas e poderiam expressar o sofrimento e dar vazão à sua individualidade. Ela seria, por isso, um "reservatório de forças de resistência contra a conversão do mundo em um mundo totalmente desalmado", e conteria "um momento antiautoritário em si” ${ }^{\prime 13}$. Sob determinadas condições, tanto o amor sexual quanto o afeto incondicional da mãe pelos filhos poderiam ser defesas contra o poder da economia e da política, assim como exercer, tal qual no início da idade moderna havia sido o caso do amor romântico, o papel de antagonistas da sociedade: “(...) dentro da família, onde as relações não se processam por intermédio do mercado e os indivíduos não se enfrentam como concorrentes, o homem sempre teve a possibilidade de atuar não só como função, mas também como pessoa"414.

Mas não havia lugar, na perspectiva de Horkheimer, para a idealização do matriarcado que servira a Fromm como inspiração para a sua noção de caráter "revolucionário", identificado ao "caráter matricêntrico" (generoso e solidário, em oposição ao caráter patricêntrico, agressivo, egoísta e voltado à dominação da natureza e dos outros homens). Se é verdade que a família poderia ser uma instância de resistência à ordem dominante, a dependência da mulher em relação aos homens impediria continuamente as possibilidades de exercício do amor capaz de se contrapor aos poderes da sociedade: condenada à insuficiência econômica e por isso dependente da posição e do salário do marido para garantir a sobrevivência própria e dos filhos, a mulher estimularia o "chefe da família" a se integrar ao mundo do trabalho e a manter a instituição familiar coesa e em consonância com os valores dominantes; ao mesmo tempo, a mãe e esposa, "espírito dedicado à ordem vigente", acataria a representação de ser etéreo e não

\footnotetext{
${ }^{413}$ Cf. Max Horkheimer, "Allgemeiner Teil”, op. cit., p. 67.

${ }^{414}$ Cf. Max Horkheimer, “Autoridade e família”, op. cit., p. 225. Cf. também p. 184.
} 
sexual a ela associada, reforçando a desvalorização do prazer e atuando como base da cisão entre o desejo sexual e o amor idealista. Ao fazê-lo, a mulher exerceria um papel de fortalecimento da "autoridade do existente", e as possibilidades de resistência da família contra as demais esferas seriam constantemente bloqueadas por uma estrutura econômica patriarcal ${ }^{415}$.

O desempenho de um papel conservador pela mulher se tornaria mais agudo ainda com o enfraquecimento da função socializadora da família, pois essa mudança estaria vinculada à perda, por essa instituição, daqueles potenciais de resistência. A sua transformação progressiva de unidade de produção em mera unidade de consumo, assim como a concorrência de outras instituições na educação dos jovens (a escola e o que mais tarde Horkheimer e Adorno chamariam de "indústria cultural”) e, não menos importantes, a crise econômica e o desemprego estrutural conduziam ao declínio da autoridade paterna. Enfraquecida como se encontrava, a família poderia em princípio, é verdade, exercer funções tanto de reforço da ordem vigente quanto de preparação de uma nova ordem, e Horkheimer sugeria de passagem que a dissolução das bases materiais de exercício da autoridade paterna poderia tornar a família uma instituição propícia para o surgimento de uma nova sociabilidade, não mais baseada no respeito ao existente e na educação com vistas à adaptação, mas sim em um "sentimento de comunidade" capaz de se estender, do círculo estrito da família, à construção de uma sociedade livre de pobreza e injustiça: “(...) nesse caso, a família leva não à autoridade burguesa, mas à ideia de uma condição humana melhor" ${ }^{416}$.

A perda do poder econômico pelo pai também poderia, contudo - e era o que se notava ocorrer em larga escala na família europeia contemporânea - ser compensada por outros meios que contribuíssem para o reforço do "caráter autoritário". A gradual passagem da família de unidade de produção econômica a unidade de consumo (um processo ocorrido ao longo do capitalismo inteiro) a teria levado a ser cada vez mais atravessada pela mediação da mercadoria, reduzindo o papel do pai ao de provedor e desvinculando progressivamente a obediência dos filhos de sua condição superior de indivíduo dotado de força física e capacidade de desempenho singulares, vinculando a dominação paterna à mediação mercantil. A dominação no interior da família se dava cada vez mais por meio da mera coerção financeira, aprofundando-se uma relação de dependência baseada na mera troca e que, se não cumprisse sua função (como era recorrente em uma era de desemprego estrutural), precisava apelar aos aspectos meramente

\footnotetext{
${ }^{415}$ Cf. Max Horkheimer,““AAutoridade e família”, op. cit., pp. 229-232; “Allgemeiner Teil”, op. cit., pp. 68-71.

${ }^{416}$ Max Horkheimer, “Autoridade e família”, op. cit., p. 226.
} 
irracionais da relação: a violência física e a idealização psíquica do pátrio poder. As relações de autoridade no âmbito da família assumiam, assim, um aspecto cada vez mais irracional ${ }^{417}$.

Essa configuração interna da família se vinculava à nova função por ela estabelecida com as outras esferas: de âmbito de resistência à sociedade, passava a ser uma instituição cada vez mais reduzida ao papel de mera correia de transmissão das reivindicações provindas do exterior. Isso permitia o Estado incentivar artificialmente o modelo tradicional (patriarcal) da família, por meio, por exemplo, de uma legislação que restringisse o trabalho das mulheres fora do lar e as confinasse aos papéis de mães e donas-de-casa, como segundo Horkheimer se notava à época em diversos países europeus: o Estado atuava, então, no sentido de reforçar o papel da família de transmissora da autoridade, garantindo a formação do caráter autoritário de indivíduos obedientes aos regimes políticos que se difundiam à época ${ }^{418}$. Dessa maneira, por um lado o enfraquecimento da família trazia consigo alguns elementos emancipatórios: tratavase, no período do entreguerras, das maiores possibilidades abertas a grupos tradicionalmente oprimidos no âmbito da família burguesa tradicional, principalmente as mulheres, as minorias étnicas (os judeus), e também os homossexuais ${ }^{419}$. Esse processo era acompanhado, por outro lado, da conversão da família em uma instância em certa medida "transparente" às relações sociais de dominação:

\footnotetext{
"As medidas educativas conscientes que promovem o espírito do respeito ao existente e a capacidade de adaptar-se são, assim, complementadas pela eficácia sugestiva da situação na família restrita. Se, onde a família ainda é uma comunidade de produção, o chefe se apresenta imediatamente associado a seu desempenho social produtivo, a sua posição na família reduzida é essencialmente mediada pelo dinheiro por ele trazido à casa, e aparece aos seus como algo fatal. Em virtude dessa separação espaço-temporal entre existência profissional e familiar, todo pai burguês, mesmo que na vida social exerça uma função miserável e tenha que se curvar a todo o tempo, pode aparecer em casa como senhor e desempenhar a função sumamente importante de acostumar os filhos à humildade e à obediência. Será então possível que, não apenas das camadas da alta burguesia, mas também de muitos grupos de trabalhadores e funcionários, sempre surjam gerações que não coloquem em xeque a estrutura do sistema socioeconômico, mas a reconheçam como natural e eterna e até mesmo deixem a sua insatisfação e rebelião se converterem em forças executantes da ordem dominante" 420 .
}

\footnotetext{
${ }^{417}$ Max Horkheimer,““"Autoridade e família”, op. cit., p. 232.

${ }^{418}$ Cf. Max Horkheimer, “Autoridade e família”, op. cit., pp. 232-235. A esse respeito, cf. também o já mencionado curso ministrado pelo autor na Universidade de Columbia: “Aus Vorlesungen über Autorität und Gesellschaft", op. cit., pp. 61-62.

${ }^{419}$ Cf. John Abromeit, Max Horkheimer and the foundations of the Frankfurt School, op. cit., p. 296.

${ }^{420}$ Max Horkheimer, “Allgemeiner Teil”, op. cit., p. 58 (“Autoridade e família”, p. 221).
} 
Vimos que Fromm explicava de maneira relativamente mecânica a intensificação dos traços sadomasoquistas de caráter na passagem do capitalismo liberal ao capitalismo monopolista. Sua análise ficava refém de um funcionalismo que, na obra de Horkheimer, era evitado por meio da consideração do processo de enfraquecimento da mediação familiar, expressão de uma cada vez maior integração social e reveladora do aplainamento das oposições entre indivíduo e sociedade. A interiorização psíquica da dominação continuaria a ser, na perspectiva do autor, um processo indispensável para a permanência da dominação, mas seria, ela própria, a expressão de um processo mais fundamental, o fetichismo capaz de fazer as relações sociais assumirem uma "forma fantasmagórica de uma relação entre coisas" mediação da mercadoria atravessaria as relações familiares, e restringiria as funções de resistência que a família poderia exercer. E por isso Horkheimer não considerava a desintegração da família tradicional de uma maneira romântica, suas reflexões sobre o assunto não se assemelhando à crítica conservadora que, à época, pregava a restauração do poder da família por meio de uma educação voltada para valores tradicionais ligados ao exercício do pátrio poder ${ }^{422}$.

A dominação mediada pela mercadoria, ao tornar a sujeição de uma classe à outra dependente de um mecanismo anônimo, tornou os homens sujeitos à irracionalidade do processo econômico, e fez as diferenças de classe, a riqueza e a pobreza aparecerem como fatos naturais, como uma necessidade decretada pelo destino. A realidade apareceria aos indivíduos como um conjunto de fatos independentes, como coisas dotadas de existência própria e sem relação umas com as outras, fenômeno que já havia sido bastante analisado por Lukács ${ }^{423}$. Se por um lado os trabalhadores estão condenados à miséria e não dispõem, como os proprietários, de meios de produção, crédito bancário e influência política, por outro lado tanto a eles quanto aos empresários o concurso cego das forças econômicas apareceu sempre como algo "natural", que poderia assumir as figuras ideológicas da liberdade e genialidade do empresário, da exigência ética do trabalho, ou então do fracasso pessoal legitimador de diferenças produzidas socialmente $^{424}$. Se na Idade Média a autoridade era exercida diretamente, sob o capitalismo passou a ser cada vez mais mediada por "coisas", pelos meros fatos apresentados à percepção: “a constatação de fatos é a forma sob a qual o homem moderno percebe as condições às quais

\footnotetext{
${ }^{421}$ Karl Marx, O Capital - crítica da Economia Política. Tradução de Regis Barbosa e Flávio Kothe. São Paulo: Abril Cultural, 1983, volume 1, tomo 1, p. 71.

${ }^{422}$ Cf. Max Horkheimer, "Autoridade e família”, op. cit., pp. 216-217.

${ }^{423}$ Cf. Lukács, História e consciência de classe, op. cit., p. 175.

${ }^{424}$ Cf. Max Horkheimer, "Autoridade e família", op. cit., pp. 201-205, p. 215.
} 
ele tem de se sujeitar" ${ }^{\prime 25}$. Contrastando as formas imediatas de dominação prevalecentes nos modos de produção pré-capitalistas com a dominação impessoal, mediada, típica do capitalismo, Horkheimer afirmava em suas aulas sobre "Autoridade e sociedade":

\begin{abstract}
"Nós não nos orientamos imediatamente pelas outras pessoas, mas pela realidade tal qual ela é, pelos fatos. A distribuição dos recursos, a situação do mercado de trabalho, as crises econômicas aparecem como poderes assujeitadores, que talvez se possa prever, e até mesmo regular um pouco, da mesma maneira que nos curvamos, por exemplo, a uma má colheita. Ao fim e ao cabo, contudo, temos que aceitá-los. A dependência dos homens em relação às condições sociais se impõe, então, também no âmbito do indivíduo, e revelase na cultura inteira, nas representações da filosofia e da religião, e também no caráter das personalidades ${ }^{\prime 426}$.
\end{abstract}

No capitalismo contemporâneo, a suscetibilidade dos indivíduos aos jornais, ao rádio e à propaganda seria apenas a expressão intensificada daquele traço central da sociabilidade moderna. De maneira semelhante, o empirismo, o positivismo e o pragmatismo dominantes nas primeiras décadas do século XX seriam as formas de consciência mais desenvolvidas do modo de produção capitalista, assim como o "senso para os fatos", a "abertura à realidade" e a “admiração pelo sucesso" seriam as características típicas do indivíduo contemporâneo ${ }^{427}$. No âmbito dos regimes fascistas, a identificação emocional com os líderes seria, não obstante a importância desse mecanismo, secundária em relação à subordinação dos homens à necessidade anônima dos fatos, e os governos autoritários dos anos trinta dependeriam fundamentalmente de um tipo de relação com a autoridade que atravessaria a sociedade burguesa inteira:

\begin{abstract}
"a própria relação nova de autoridade, que hoje se situa no primeiro plano do pensamento e do sentimento, só é possível porque aquela outra, mais comum e ao mesmo tempo mais profunda, ainda não perdeu seu poder, um poder que, por outro lado, é certamente apoiado por ela. A liderança política é eficaz, pois grandes massas reconhecem consciente e inconscientemente ser necessária sua dependência econômica ou, pelo menos, não a compreendem totalmente, e esta situação é consolidada retroativamente pela relação política. (...) com o colapso da autoridade no sentido burguês, esta nova autoridade também perderia sua base ideológica mais forte. Portanto, o julgamento indiscriminado dos governos autoritários, sem levar em conta a estrutura econômica em que se baseiam, deixa de lado o essencial" ${ }^{428}$.
\end{abstract}

\footnotetext{
${ }^{425}$ Max Horkheimer, “Aus Vorlesungen über Autorität und gesellschaft”, op. cit., p. 60.

${ }^{426}$ Trata-se de um curso ministrado na Universidade de Columbia entre 1936 e 1937. Cf. Max Horkheimer, “Aus Vorlesungen über Autorität und Gesellschaft”. In: Max Horkheimer, Gesammelte Schriften, op. cit., vol. 12, p. 64. ${ }^{427}$ Cf. Max Horkheimer, “Aus Vorlesungen über Autorität und Gesellschaft”, op. cit., pp. 57-58. Cf. também "Autorridade e família", op. cit., p. 222.

${ }^{428}$ Cf. Max Horkheimer, "Autoridade e família”, op. cit., p. 207-208. Cf. também “Aus Vorlesungen über Autorität und Gesellschaft”, op. cit., pp. 61-62.
} 
Essa "relação nova de autoridade" exprimia, portanto, uma intensificação da relação de autoridade própria da era burguesa: tratava-se de uma intensificação, cumpre ressaltar, mediada pelas ideologias e pela violência política e psíquica (na Parte III examinamos em maior detalhe as formas política e psíquica de dominação). No período do entreguerras, segundo Horkheimer, as diversas esferas sociais seriam cada vez mais atravessadas pela característica comum da crença na necessidade da "obediência"429. Não apenas na família, na política e no âmbito das concepções filosóficas, mas também no pensamento econômico desapareciam os vestígios de liberalismo e apareceria com cada vez mais força a tendência de subordinação à realidade dos fatos: a divisão da sociedade em classes e a separação estanque do processo de trabalho - entre indivíduos condenados às tarefas mecânicas da linha de montagem e outros destinados às posições de comando na indústria e no comércio - era glorificada pela literatura dedicada às relações de trabalho, e a crescente irracionalidade do sistema econômico, marcado pela sujeição dos indivíduos aos poderes cegos do capitalismo monopolista, não impedia que o sucesso se tornasse um "Deus do mundo moderno"430.

Tratava-se aqui da nova configuração assumida, sob o capitalismo monopolista, pela ideologia: sua estrutura e sua função se alteravam em relação ao período do capitalismo liberal, do que decorria também uma mudança importante para o sentido da crítica a lhe ser feita. No século XIX, a ideologia da sociedade burguesa, centrada na igualdade formal dos indivíduos e no seu direito à liberdade, tinha por base objetiva a existência de um mercado formado por pequenos e médios proprietários, concorrentes entre si - o fetichismo da mercadoria era, por isso, uma "ilusão socialmente necessária". Ao mesmo tempo em que estava em contradição com a realidade (visto que a igualdade e a "troca justa" entre os proprietários se revelavam ilusórias ao se considerar a origem do lucro na exploração da força de trabalho de uma classe que não detinha os meios de produção), aquela ideologia remetia a uma sociedade mais justa, formada por indivíduos livre e iguais. Sua crítica podia consistir, portanto, em mostrar a contradição entre as noções correntes de liberdade e igualdade e uma realidade social baseada na dominação e na exploração.

\footnotetext{
429 "Vorwort". In: Max Horkheimer et al.. Studien über Autorität und Familie, op. cit., p. VIII.

${ }^{430}$ Max Horkheimer, “Autoridade e família”, op. cit., pp. 205-206 e p. 210.
} 
Fomentadas durante o período de ascensão social da burguesia e em meio à sua luta contra as ideologias vinculadas ao Antigo Regime (como a religião e o dogmatismo metafísico), essas noções se tornaram secundárias durante o capitalismo monopolista: a concentração de capital e a redução do poder a um pequeno número de cliques formadas por magnatas industriais e líderes políticos acarretou o declínio do universalismo jurídico e moral ${ }^{431}$. Nesse processo, a dominação se tornaria cada vez mais "transparente" e dispensaria suas mediações tradicionais $^{432}$. Segundo Horkheimer, mudava então o sentido da dependência das esferas sociais em relação à economia: a determinação da cultura, da política e do psiquismo pela economia se tornava mais imediata, pois desapareciam o "relativo poder de resistência e substancialidade das esferas culturais" ${ }^{\prime 33}$.

Concomitantemente, a ideologia dominante passou a consistir cada vez mais em mera “duplicação" da realidade: desaparecia a antiga oposição entre a esfera ideológica e a realidade, da qual a primeira passava a ser um mero prolongamento. Em vez de remeter à possibilidade de uma outra sociedade, a ideologia dominante passava a consistir na afirmação reiterada do existente. O positivismo contemporâneo exemplificava bem essa nova função da ideologia: a sua redução do conhecimento à mera catalogação de fatos e a perseguição intransigente da contradição exprimiam o aplainamento de qualquer tensão entre a ideologia e a realidade. A ideologia continuava, não obstante, a ser uma "aparência socialmente necessária", pois a redução da realidade a fatos isolados capazes de serem subsumidos a um sistema nãocontraditório exprimia o processo real de dissolução do indivíduo enquanto instância capaz de fazer oposição à sociedade: em uma época de integração social, os indivíduos se convertiam cada vez mais em meras funções do mecanismo econômico. A reiteração do existente, nova função exercida pela ideologia, impedia que a crítica se apoiasse nos elementos racionais contidos na própria ideologia, para assim denunciar a sua oposição à realidade (que cessava de existir $)^{434}$.

\footnotetext{
${ }^{431}$ Cf. Max Horkheimer, "Traditionelle und kritische Theorie", op. cit., pp. 208-213. Os temas da nova função do Estado e das transformações pelas quais passaram as classes sociais ao longo do capitalismo monopolista são desenvolvidos no capitulo 5 .

${ }^{432}$ Max Horkheimer, "'Bemerkungen zur philosophischen Anthropologie", op. cit., p. 267.

${ }^{433}$ Cf. Max Horkheimer, "Traditionelle und kritische Theorie", op. cit., p. 211.

${ }^{434} \mathrm{Cf}$. sobre esse assunto, o artigo de Kurt Lenk, "Ideologie und Ideologiekritik im Werk Max Horkheimers". In: Alfred Schmidt; Norbert Altwickler (Orgs.). Max Horkheimer heute: Werk und Wirkung. Frankfurt am Main: Fischer, 1986, especialmente pp. 251-255. Como efeito secundário da nova estrutura da ideologia, Horkheimer constatava que o fenômeno podia assumir também uma outra figura. O desaparecimento da oposição entre a esfera ideológica e a realidade permitia que, ao lado de seu sentido de "ilusão socialmente necessária" - uma ilusão dotada, portanto, de objetividade - a ideologia passasse a se apresentar também como mera mentira, sendo reduzida a uma função meramente instrumental, e assumindo por isso um caráter meramente subjetivo. Segundo Horkheimer, na fase mais recente do capitalismo "cresce a possibilidade de uma dupla verdade, na qual o saber é
} 


\section{2 - "Autoridade"}

A nova configuração da ideologia, caracterizada essencialmente pela subordinação à realidade em suas formas dadas, levou Horkheimer a examinar a constituição do sujeito moderno à luz do problema da dominação. Sua forma contemporânea, que incluía uma configuração específica da ideologia, da classe burguesa e do Estado, acentuava seus traços irracionais (a mera subordinação, desvinculada dos elementos emancipatórios presentes ainda no capitalismo liberal) e permitia que a exposição do curso histórico pusesse em relevo determinações que até então não tinham sido relevantes para o próprio marxismo. $\mathrm{O}$ desenvolvimento do capitalismo levou a resultados capazes de esclarecer as próprias origens do modo de produção: cada vez mais patente, a irracionalidade presente jogava luz sobre o processo histórico de sua formação ${ }^{435}$.

Na passagem da Idade Média à Idade Moderna, a supressão de formas imediatas de dominação significou não apenas a supressão dos poderes feudais, mas também a interiorização da dominação e o preparo dos indivíduos para a subordinação à realidade em suas formas dadas: “as autoridades aparentemente são derrubadas e reaparecem filosoficamente na forma de conceitos metafísicos" ${ }^{\text {436 }}$. A filosofia burguesa, iniciada como uma luta contra a autoridade da tradição, havia lhe contraposto como fonte da verdade a razão abstrata do indivíduo, considerada de maneira independente da práxis histórica. Ao fazê-lo, pôs no lugar das antigas autoridades a autoridade abstrata do indivíduo, e terminou por "divinizar a mera autoridade como tal", justificando a subordinação dos indivíduos à autoridade do existente ${ }^{437}$. A autonomia do indivíduo conteve sempre, portanto, um elemento irremediável de heteronomia, e uma dialética entre esses dois momentos marcaria a história do sujeito moderno. É por isso que a autoridade seria uma "categoria histórica central", e seu caráter contraditório conteria tendências repressivas e emancipatórias ${ }^{438}$.

reservado aos insiders, e a versão ao povo, e se dissemina o cinismo contra a verdade o pensamento em geral". Cf. Max Horkheimer, "Traditionelle und kritische Theorie”, op. cit., p. 210.

435 Tratava-se aqui, para o autor, da relação específica que a teoria crítica tem com o tempo: recorrendo a Marx e a Hegel, Horkheimer argumentava que essa relação não é concebida como se a cada segmento da teoria correspondesse um recorte temporal, à maneira de um reflexo, e que portanto a situação atual seria capaz de iluminar o passado. Cf. Max Horkheimer, "Traditionelle und kritische Theorie”, op. cit., pp. 208-213.

${ }^{436}$ Max Horkheimer, "Autoridade e família”, op. cit., p. 199.

${ }^{437}$ Max Horkheimer, “Autoridade e família”, op. cit., pp. 194-195.

${ }^{438}$ O recurso ao termo "autoridade" não deixa de causar certa estranheza a quem se confronta hoje com os "Estudos sobre autoridade e família", e somos levados facilmente a ler os trabalhos dessa época do Instituto à procura de uma "teoria do autoritarismo". É necessário, contudo, precaução a esse respeito. Como ressaltou Olgária Matos, 
A persistência de um conceito de razão vazio a reduziu à mera adaptação a uma realidade social dominada pela economia mercantil: "a mais completa adaptação possível do sujeito à autoridade efetiva da economia é, ao mesmo tempo, a forma da razão na realidade burguesa"439. O princípio de autoridade vigente na Idade Média, baseado na mera tradição e no nascimento, havia sido substituído pelo princípio de autoridade centrado nas qualidades do indivíduo, mas esse princípio era, já em seu início, viciado pela particularidade, pois a dominação de classe tornava desiguais as condições de sua realização. A irracionalidade das correntes filosóficas contemporâneas seria, por isso, apenas a intensificação de um momento de irracionalidade presente no pensamento moderno desde seu começo: "se a filosofia, após a Primeira Guerra Mundial, ajudou a preparar a vitória das formas autoritárias de governo, ela podia reportar-se a uma longa tradição" 440 .

$\mathrm{Na}$ preparação dos indivíduos para a sujeição à realidade em suas formas dadas, a família desempenharia um papel sumamente relevante, pois atuaria no sentido de garantir a formação de indivíduos acostumados à submissão: em seu âmbito o indivíduo seria preparado para a aceitação incondicional da realidade, para a sujeição a uma estrutura exterior de autoridade, baseada nos fatos ${ }^{441}$. A família moderna em geral, e especialmente a família protestante, seria caracterizada por uma "educação para a justiça da realidade", capaz de tornar os indivíduos aptos à disciplina e ao uso sóbrio da razão. Malgrado as suas possibilidades de resistência contra as pressões sociais e seu "momento antiautoritário", a família burguesa seria desde seus primórdios uma instituição atravessada pela tendência a incutir nos indivíduos o respeito à realidade como um valor em si, no que diferia da obediência defendida pelos pensadores católicos da Idade Média em associação com noções do papel do indivíduo como cristão e membro da comunidade. A qualidade abstrata do "dever", tão reluzente na filosofia moral burguesa, já estaria prefigurada na concepção protestante de família: “o homem não deve curvar-se perante a Igreja, como acontecia no catolicismo; deve apenas aprender a curvar-se, a obedecer e a trabalhar" ${ }^{\prime 42}$.

\footnotetext{
"o conceito de autoridade é tomado em sua tensão interna, não se confundindo com autoritarismo", pois a auctoritas também significa "ser autor de algo". Cf. sua "Introdução" a: Max Horkheimer, Teoria Crítica I - uma documentação, op. cit., p. XIX. Horkheimer, aliás, raras vezes empregou, pelo menos nos textos dessa época, o termo "autoritarismo", se é que alguma vez o fez. Isso pode estar relacionado a uma questão linguística: até onde foi possível averiguar, o termo alemão "Autoritarismus" não era corrente à época, e parece ter surgido antes em suas versões francesa e inglesa. É de se supor também que tenha ingressado na língua alemã por intermédio da ciência e da filosofia política anglo-saxônica. Mais do que mera questão terminológica, contudo, trata-se da perspectiva crítica do autor, como talvez fique claro mais adiante.

${ }^{439}$ Max Horkheimer, "Autoridade e família”, op. cit., p. 202.

${ }^{440}$ Max Horkheimer, "Autoridade e família”, op. cit., p. 208. Cf. também p. 202.

${ }^{441}$ Max Horkheimer, "Autoridade e família", op. cit., p. 215.

${ }^{442}$ Cf. Max Horkheimer, “Autoridade e família”, op. cit., pp. 214.
} 
Cada vez mais abstrata, a educação familiar preparava os indivíduos para a mera obediência à realidade, para o domínio de si e a disciplina em um mundo no qual as antigas autoridades tinham desaparecido e era preciso interiorizá-las. Da mesma maneira, o conceito protestante de Deus, ao condenar como pecaminosa a justificação da obediência com recurso às qualidades do ser supremo (tal qual em parte da teologia católica), expressava a subordinação irrefletida da criatura, sua mera heteronomia ${ }^{443}$. Em vez de especificidade cultural da religião protestante, contudo, esse elemento seria a expressão da subordinação das representações familiares, religiosas, políticas - ao caráter assumido pela experiência na sociedade capitalista, sob influxo da forma mercadoria que reduz a realidade a fatos aparentemente eternos e isolados: a autoridade cada vez mais reificada se convertia em uma qualidade fixa das coisas, longe de qualquer relação de subordinação racional. A mediação da família exerceria cada vez mais o papel de uma estrutura reificada, independentemente das intenções dos indivíduos específicos envolvidos: “(...) o caráter infantil é formado muito mais pela própria estrutura da família do que pelas intenções e métodos conscientes do pai” ${ }^{444}$. A família, atravessada pela racionalidade mercantil, assistiu desde o início da Idade Moderna ao desaparecimento de seus elementos de oposição à ordem vigente.

A sujeição consciente dos homens, a aceitação ativa da dominação, conviveria portanto necessariamente com um elemento irracional de coerção [Zwang], que poderia se manifestar de maneira direta (por meio da violência física ou da ameaça da fome) ou atuar a partir das formas reificadas da sociabilidade. Não se tratava aqui, contudo, do mero elemento psicológico masoquista ${ }^{445}$. A subordinação dos indivíduos a estruturas como a família e o Estado se valia de um elemento de irracionalidade presente no próprio processo pelo qual aquelas esferas se autonomizaram em relação ao processo histórico que as engendrou. As esferas sociais não seriam meras racionalizações do poder econômico e político, e sim a expressão de um processo contraditório: a formação do aparelho psíquico, constituído, tal qual mostrara Freud, a partir da interiorização da coerção, servia a Horkheimer de referência à compreensão da formação das demais esferas sociais - política, moral, família, arte, religião. A elas corresponderia um misto de autonomia e de internalização reiterada da violência:

"Entretanto, se por um lado a coerção passada e presente penetram nas mais sublimes manifestações da alma humana, por outro lado têm a sua legalidade própria também essa mesma alma, assim como todos aqueles

\footnotetext{
${ }^{443}$ Cf. Max Horkheimer, "Autoridade e família”, op. cit., pp. 217-218.

${ }^{444}$ Max Horkheimer, "Autoridade e família”, op. cit., p. 223.

${ }^{445}$ Cf. Max Horkheimer, “Aus Vorlesungen über Autorität und Gesellschaft”, op. cit., pp. 53-54.
} 
fatores mediadores pelos quais ela é formada, como a família, a escola e a igreja. Na história transcorrida até os dias de hoje é impossível superestimar, quando da explicação da vida social, o papel exercido pela coerção, que caracteriza não apenas o começo, mas também o desenvolvimento que se segue à formação de todos os Estados" ${ }^{\text {"46 }}$

Horkheimer argumentava, então, que a legalidade própria das esferas sociais, sua autoridade frente aos indivíduos, derivaria do fato de que elas são expressão de uma coerção internalizada, e recorria às teses de Nietzsche sobre a origem que a moral e o ascetismo teriam no sacrifício e na autonegação: a formação do indivíduo e das demais esferas sociais corresponderia à racionalização da violência constitutiva das relações entre os homens. Nessa racionalização, os sacrifícios rituais coletivos e as punições físicas foram substituídos pela coerção auto-imposta e pelo sacrifício dos próprios impulsos. O autor sublinhava, dessa maneira, o caráter irracional da racionalização, a contradição entre o todo irracional e a racionalidade intrínseca a cada uma das esferas sociais, orientadas pela irracionalidade formal da troca. O "sacrifício", que havia se tornado uma categoria dominante nas correntes irracionalistas da filosofia contemporânea, era parte inseparável da constituição da cultura, e a racionalidade da troca de equivalentes era projetada por Horkheimer nos períodos da civilização anteriores ao desenvolvimento do capitalismo ${ }^{447}$.

Haveria entre a subordinação à realidade dos fatos, a violência direta e a violência interiorizada nas esferas sociais específicas uma intrincada relação, que para o autor resultaria em uma "complicada estrutura da autoridade" 448 . Nessa estrutura, a imbricação entre a violência extra-econômica e o fetichismo da mercadoria daria a tônica da dominação. Na formação da sociedade burguesa isso já era evidente, na medida em que as concepções religiosas, filosóficas e políticas da época moderna inteira seriam perpassadas pela exaltação da obediência, da abnegação, do cumprimento do dever. Não é, portanto, que o capitalismo liberal tenha sido um período de expansão de potenciais emancipatórios e racionais, interrompido a partir do capitalismo monopolista e da ação conservadora da burguesia a partir de 1848. Segundo Horkheimer, o fato de "que a configuração e a existência de relações irracionais de autoridade

\footnotetext{
${ }^{446}$ Max Horkheimer, "Allgemeiner Teil", op. cit., p. 12. O autor afirmava ainda: "o aparelho psíquico inteiro dos membros de uma sociedade de classes, na medida em que eles não pertençam àquele núcleo de privilegiados, consiste em larga medida na mera interiorização ou ao menos na racionalização e complementação da coação física" (Cf. Max Horkheimer, "Allgemeiner Teil", op. cit., p. 11).

${ }^{447}$ Cf. Max Horkheimer, "Autoridade e família", op. cit., pp. 179-184. Horkheimer desenvolvia aqui o tema da"introversão do sacrifício", tão presente na Dialética do Esclarecimento, especialmente no excurso sobre Ulisses. Como sintetizou Olgária C. F. Matos: "Os sacrifícios rituais externos foram substituídos por sacrifícios instintuais internos enquanto constrangimento e autocoerção". Cf., da autora, Os arcanos do inteiramente outro, op. cit., p. 158.

${ }^{448}$ Max Horkheimer, “Autoridade e família”, op. cit., p. 207.
} 
de forma aberta estão entre os fatores que reforçam a relação econômica mais profunda e se encontram em ação recíproca com ela já se evidencia a partir da propagação do protestantismo"449. A acumulação primitiva de capital, violência direta, "extra-econômica", "parteira" do capitalismo, seria continuada na violência política, psíquica e ideológica sem as quais a estrutura econômica não conseguiria se reproduzir.

Nos movimentos políticos orientados para o socialismo, a "mais elevada forma social que é possível hoje" ${ }^{" 450}$, o autor considerava possível identificar a possibilidade de se elaborar um tipo racional de relação com a autoridade, em que a subordinação se desse com base nos interesses de classe comuns dos membros da organização. Ao recusar como não-dialética a oposição entre "liberdade" e "autoridade", ou entre absoluta autonomia e mera heteronomia, Horkheimer reconhecia a presença inexorável de um elemento de "coerção" [Zwang] nas relações de autoridade. Nesse sentido, diferenciava-se da configuração sob a qual o problema, como vimos, se apresentava na obra de Fromm. Nas palavras do autor:

"A ordem vinda de fora é apenas a expressão do interesse próprio, pois ele é simultaneamente comum a todos em geral. Na disciplina e na obediência daqueles que lutam por esta condição já se esboça a ideia de uma outra autoridade. Portanto, o simples fato da subordinação absoluta não produz critério para a estrutura de uma relação de autoridade. O formalismo de opor razão e autoridade, de se confessar adepto de uma e desdenhar a outra, o anarquismo e a convicção autoritária do Estado pertencem ambos à mesma época cultural” ${ }^{\prime 51}$.

As esferas sociais, contudo, uma vez constituídas, seriam dotadas de "legalidade própria" e capazes de retroagir sobre o processo social que as engendrou: "trabalhando e lutando, os indivíduos e grupos da sociedade reagem às respectivas condições econômicas, e o fazem com recurso a habilidades que, é verdade, haviam sido formadas pelo desenvolvimento histórico prévio" ${ }^{452}$. Nessa retroação, as esferas sociais extra-econômicas poderiam até mesmo oferecer resistência às transformações econômicas em processo. Assim, por exemplo, se na Índia uma antiga divisão do trabalho havia instituído a casta sacerdotal dos brâmanes como detentora de privilégios políticos e hierarquicamente superior às demais, e se na China a agricultura intensiva praticada ao longo dos séculos havia sido acompanhada do

\footnotetext{
${ }^{449}$ Max Horkheimer, “Autoridade e família”, p. 208. Muito da reflexão feita por Horkheimer nesses anos tem sido interpretada como um lamento pela passagem do capitalismo liberal e pelo declínio do indivíduo. Cf. Martin Jay, Dialectical Imagination, op. cit., p. 125.

${ }^{450}$ Max Horkheimer, "Autoridade e família”, op. cit., p. 212.

${ }^{451}$ Max Horkheimer, "Autoridade e família”, op. cit., p. 213.

${ }^{452}$ Max Horkheimer, “Allgemeiner Teil”, op. cit., p. 7.
} 
desenvolvimento do culto dos antepassados e de estruturas de autoridade baseadas tanto na burocracia estatal quanto no poder dos membros mais idosos de cada família, vistos como guardiões do saber prático acumulado ao longo de gerações, esses mesmos elementos culturais, surgidos ao longo do processo de produção material da vida (mas não, lembra Horkheimer, como uma racionalização de interesses particulares), tornavam-se resistências quando da passagem, provocada no século XIX pelo imperialismo britânico, do modo de produção anterior ("feudal" ou "asiático", conforme a interpretação) ao capitalismo: a crença indiana nas castas, conservadas ao longo dos séculos como princípio da divisão social do trabalho, era um obstáculo à economia capitalista e à transformação da força de trabalho em mera mercadoria; na China, o culto dos antepassados, base do papel de extrema autoridade que detinham os membros mais idosos da família, era um entrave às reformas políticas e educacionais que acompanhavam a introdução de relações sociais capitalistas naquele país ${ }^{453}$.

Os conflitos entre as diferentes esferas sociais, assim como as dificuldades pelas quais havia passado a expansão do capitalismo à China e à Índia - um tema que se ramificava, no âmbito do Instituto, nas pesquisas de Karl Wittfogel sobre a história econômica e social chinesa $^{454}$ - serviam a Horkheimer como recurso para iluminar a história europeia contemporânea: no período que se seguiu aos ensaios de revolução na Alemanha e na Europa central, as esferas da cultura e da constituição psíquica (autoritária) dos indivíduos teriam assumido a primazia histórica e contribuiriam para "manter latentes entre as classes sociais as tensões que suscitam a eclosão de conflitos com base na situação econômica" ${ }^{\text {"455 }}$, exercendo o papel de obstáculos à luta de classes. Em uma época de crise, as esferas sociais assumiam tendências divergentes: a crise econômica e o desemprego apontavam para a dissolução do modo de produção, ao mesmo tempo em que as esferas ideológica, política e psíquica reforçavam a dominação e atuavam como contra-tendências que reforçavam uma ordem que se esvaía $^{456}$.

\footnotetext{
${ }^{453}$ Max Horkheimer "Allgemeiner Teil”, op. cit., pp. 8-9; pp. 15-20.

${ }^{454}$ Cf. os artigos de Wittfogel nas edições de 1935 e 1938 da Revista, além de sua contribuição para os "Estudos sobre Autoridade e Família".

${ }^{455}$ Max Horkheimer, "História e Psicologia", op. cit. p. 22. Sobre a avaliação acerca das oscialações da moral sexual no período do entre-guerras, cf. a segunda seção dos Studien, op. cit., p. 272. Na avaliação feita pelos organizadores dos "Estudos" concorreram também as pesquisas acerca da instituição familiar feitas, no período, pela sociologia alemã e européia em geral. Cf. Herbert Marcuse, "Autorität und Familie in der deutschen Soziologie bis 1933". In: Max Horkheimer et alii. Studien über Autorität und Familie, op. cit., pp. 739-752, especialmente, para esse ponto. pp. 751-752.

${ }^{456}$ Cf. Max Horkheimer, "Autoridade e família”, op. cit., pp. 235-236; e também “Aus Vorlesungen über Autorität und Gesellschaft", op. cit., pp. 53-54. Sobre esse assunto, cf. Alex Demirović, Der nonkonformistische Intellektuelle - die Entwicklung der kritischen Theorie zur Frankfurter Schule. Frankfurt am Main: Suhrkamp, 1999 , p. 83.
} 
Disso decorria a elevação daqueles fatores ao primeiro plano das análises empreendidas pela crítica marxista: na luta de classes que opunha os interesses da burguesia àqueles do proletariado, a ideologia e o psiquismo haveriam assumido, com sua legalidade própria, uma função relativamente autônoma no âmbito de uma história determinada, ainda assim, fundamentalmente pelo processo econômico: “a conservação de formas sociais antiquadas não remonta imediatamente ao mero poder ou ao engano das massas quanto a seus interesses materiais (...), e sim a permanência tem suas raízes também na chamada natureza humana"457. Era da seguinte maneira que o autor exprimia a relação entre suas preocupações de pesquisa e aquele momento histórico:

"Na luta pela melhoria das condições humanas há épocas em que não é de especial importância, na prática, o fato de a teoria considerar essas relações [entre a cultura e o processo social total] apenas de modo extremamente sumário. Esses são aqueles momentos nos quais, em virtude da decadência econômica de um determinado modo de produção, as formas culturais de vida que a ele correspondem já estão tão afrouxadas que a miséria da maioria da população facilmente se converte em indignação, e só se faz necessária a vontade decidida dos grupos progressistas para vencer a mera força das armas, sobre as quais o sistema essencialmente ainda repousa. Mas esses momentos são raros e duram pouco, a ordem que se tornara má é corrigida sofrivelmente e aparentemente renovada, os períodos de restauração duram bastante, e neles o aparato cultural antiquado ganha novo poder, tanto sob a forma da constituição psíquica dos homens quanto sob a forma de instituições que se entrelaçam reciprocamente. Então é preciso que ele seja perscrutado com exatidão" 458 .

\footnotetext{
${ }^{457}$ Max Horkheimer, "Allgemeiner Teill". In: Max Horkheimer; Erich Fromm; Herbert Marcuse (Orgs.). Studien über Autorität und Familie. Forschungsberichte aus dem Institut für Sozialforschung. Lüneburg: Dietrich zu Klampen, 1987, p. 20. À página IX do mesmo texto, o autor ainda afirmava: "o processo de produção influencia os homens não apenas na forma imediata e atual que eles o vivenciam em seu trabalho, mas também da maneira pela qual ele está conservado em instituições como a família, a escola, a igreja, as instituições de arte etc., que são relativamente fixas, isto é, que se transformam apenas lentamente".

${ }^{458}$ Max Horkheimer, "Allgemeiner Teil”, op. cit., pp. 14-15.
} 


\section{3 - A fetichização da ciência}

Tal qual as demais esferas, a ciência conteria em si um elemento de submissão irracional ao existente. A própria entrega do cientista à sua atividade seria motivada pela necessidade de submissão a uma instância superior, capaz de fornecer à sua ação "uma "instrução firme como meta e caminho". A esse propósito, Horkheimer citava Nietzsche: "Pensais que procurais a

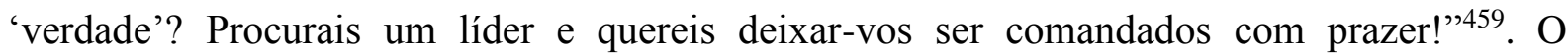
pensamento, tanto o cotidiano quanto o científico, seria o resultado de uma "educação realista", baseada na submissão ao existente: "uma falha aqui traz sofrimentos, fracassos e castigos" 460 . Mas tratava-se aqui, para o autor, menos de uma questão psicológica do que da forma fetichizada assumida no modo de produção capitalista pela ciência, ela própria um caso específico da reificação das relações sociais.

O ensaio "Teoria tradicional e teoria crítica", publicado por Max Horkheimer em 1937, mais do que um elenco das diretrizes metodológicas a opor duas espécies distintas de conhecimento, contém uma crítica ao caráter fetichista da ciência contemporânea, ela própria um caso específico do processo mais geral de reificação das relações sociais. A concepção tradicional de teoria, argumentava o autor, a compreenderia como um conjunto fechado de proposições vinculadas entre si e deduzíveis umas das outras - pretensamente independente do ambiente natural e histórico em meio ao qual se constituiu, para se considerar válido a esse conjunto seria necessária, em primeiro lugar, a consonância entre as proposições científicas e os fatos observados: "tem-se sempre, de um lado, o saber formulado intelectualmente, e de outro um estado de coisas que deve ser apreendido sob ele, e esse subsumir, esse produzir da relação entre a mera percepção ou constatação do estado de coisas e a estrutura conceitual de nosso saber se chama a sua explicação teórica" ${ }^{461}$. Além disso, a fim de se garantir a sua coerência - outro requisito da validade das teorias científicas - os fatos constatados são simplificados e, após suas contradições internas serem eliminadas, são integrados em um sistema conceitual pré-existente, desprezando-se as singularidades que possam conflitar com ele. Ao fazê-lo, a ciência tenderia ao ideal, conquanto distante, da constituição de um sistema universal que abrangesse todos os objetos possíveis, pertencentes à natureza viva ou morta. É

\footnotetext{
${ }^{459}$ Max Horkheimer, “Autoridade e família”, op. cit., p. 223.

${ }^{460}$ Max Horkheimer, "Teoria tradicional e teoria crítica", op. cit., p. 139.

${ }^{461}$ Max Horkheimer, "Traditionelle und kritische Theorie". In: Max Horkheimer, Gesammelte Schriften. Alfred Schmidt; Gunzelin Schmid Noerr (Orgs.). Frankfurt am Main: Fischer, 1985.

p. 167.
} 
irrelevante aqui a distinção entre as concepções epistemológicas que defendem a primazia da pesquisa teórica e aquelas que defendem a exclusividade do recurso à pesquisa empírica: a teoria tradicional pode tanto seguir as concepções empiristas clássicas e proceder por meio da indução feita a partir de casos singulares, conhecidos por meio da observação dos "fatos" e universalizados para a constituição de teorias, quanto consistir, em primeiro lugar, no recurso a teorias gerais e princípios estabelecidos de antemão, para então se verificar a adequação dos fatos observados às hipóteses que presidiram à sua seleção ${ }^{462}$.

Como mencionado acima, a concepção tradicional de teoria a reduz a um conjunto fechado de enunciados, vinculados logicamente entre si e ligados a proposições mais gerais das quais eles podem ser deduzidos. Seu traço distintivo é a inadmissibilidade das contradições entre teoria e a experiência, entre sujeito e objeto: a teoria tradicional, ao postular essa identidade em meio a uma sociedade cindida, é levada a simplificar os fatos, eliminando suas contradições internas a fim de permitir sua classificação em sistemas conceituais préexistentes $^{463}$. Ao fazê-lo, desloca as contradições sociais que penetram em seus objetos para outros níveis. Um deles corresponde às contradições entre as disciplinas e suas subdivisões: como lembra Horkheimer, o que é tido por um pressuposto não problemático na Física é objeto de discussão na Biologia, e vice-versa (o mesmo poderia ser dito das relações entre a Sociologia e a Psicologia), e no âmbito de cada disciplina esse tipo de contradição se reproduziria em meio a suas segmentações internas ${ }^{464}$. Aquela contradição básica, que não depende da iniciativa individual e não poderia ser superada no âmbito do modo de produção capitalista, se faria sentir em diversos outros níveis da prática científica contemporânea, cuja configuração passa a se dar de acordo com aquela combinação de minuciosa racionalidade, por um lado, e mera e arbitrária irracionalidade, por outro. É por isso que seria possível falar de uma crise interna da ciência: ela não apenas participaria do destino geral das forças produtivas sob o capitalismo e estaria condenada, apesar de seu alto grau de desenvolvimento, ao desperdício e à utilização para fins particulares, mas sua própria forma seria afetada em razão disso: a ciência contemporânea passaria por um "aplainamento metódico e conteudístico" 465 que a condenaria a uma crescente irracionalidade. Partícipes da crise, os conceitos científicos tendem a ser fetichizados, considerados como se não tivessem história e fossem naturais, tornando-se rígidos e conduzindo

\footnotetext{
${ }^{462}$ Essa última posição tem se revelado a predominante, a ela podendo ser vinculadas as concepções metodológicas presentes em boa parte da teoria sociológica clássica (Durkheim e Weber) e da epistemologia contemporânea (Popper).

${ }^{463}$ Cf. Max Horkheimer, "Teoria tradicional e teoria crítica", op. cit., p. 128.

${ }^{464}$ Cf. Max Horkheimer, "Teoria tradicional e teoria crítica", op. cit., p. 124.

${ }^{465}$ Cf. Max Horkheimer, "Bemerkungen über Wissenschaft und Krise", op. cit., p. 43.
} 
a insuficiências das mais diversas ordens, expressas na já mencionada arbitrariedade na definição dos problemas de investigação, na falta de clareza (pensemos, por exemplo, na adequação muitas vezes forçosa dos fatos às teorias previamente estabelecidas), na incapacidade da ciência dominante de compreender o processo social em sua totalidade e em uma divisão em certa medida arbitrária entre as disciplinas, ao longo da qual o privilégio de determinados objetos e questões em detrimento de outros conduz a obscuridades e juízos errôneos. Além de se dar ao nível das disciplinas científicas, a fetichização dos conceitos, esse "enrijecimento" conceitual, poderia se dar ainda no âmbito da reflexão epistemológica e filosófica em geral, por exemplo, na extrapolação do conceito de "leis naturais" eternas para a descrição de tendencialmente toda a realidade natural e humana, assim como na manutenção de dicotomias que apenas poderiam ser plenamente compreendidas por meio de sua historicização, como aquelas entre sujeito e objeto, espírito e natureza, corpo e alma (psiquismo) ${ }^{466}$. Essas dicotomias resultariam, por sua vez, das contradições próprias à sociedade burguesa, expressas de maneira idealista no pensamento de Kant (cf. o capítulo anterior).

Aquele conceito tradicional de teoria, contudo, revela a um rápido exame o seu caráter ideológico: a suposta independência das teorias científicas em relação à sociedade (na qual se encontrariam suas fontes meramente "externas"), a ilusão de que as teorias científicas subsistiriam por si mesmas (da qual decorre a ideologia da liberdade dos cientistas, cuja atividade seria "livre de valores"), é apenas um caso específico da ilusão que na sociedade burguesa acomete os processos de trabalho em geral: seus produtos são considerados como se não tivessem história e não fossem expressão de relações sociais, antes subsistindo por si mesmos, na forma imediata sob a qual se apresentam à percepção. Nesse mesmo sentido, de acordo com a concepção tradicional de teoria o sujeito do conhecimento seria passivo, o mundo aparecendo a ele como um conjunto de fatos aos quais ele tem de se adaptar, fatos que existiriam independentemente dele. Esses fatos, contudo, são um produto da prática social, e tanto os objetos para os quais se dirige o conhecimento são produto do trabalho humano, quanto os próprios órgãos dos sentidos que percebem aqueles objetos são resultado do trabalho humano:

"O que percebemos no nosso meio ambiente, as cidades, povoados, campos e bosques trazem em si a marca do trabalho. (...) Os fatos que os sentidos nos fornecem são pré-formados de modo duplo: pelo caráter histórico do objeto percebido e pelo caráter histórico do órgão perceptivo" $"$ "67.

\footnotetext{
${ }^{466}$ Cf. Max Horkheimer, "Bemerkungen über Wissenschaft und Krise”, op. cit., pp.43- 45, "Traditionelle und kritische Theorie", op. cit., p. 173 ("Teoria tradicional e teoria crítica", op. cit., p. 124).

${ }^{467}$ Max Horkheimer, "Teoria tradicional e teoria crítica", op. cit., p. 125.
} 
As teorias científicas são, portanto, na própria forma independente e supostamente ahistórica sob a qual se apresentam, a expressão reificada do processo social capitalista, e sua conexão com as demais atividades humanas, não sendo transparente, apenas pode ser compreendida por meio da construção das mediações que vinculam ao processo social esse conceito abstrato de "teoria" 468 . Nesse sentido, argumentava Horkheimer, aquela identidade postulada pela teoria tradicional entre sujeito e objeto, isto é, entre a teoria e os fatos, seria produzida socialmente: não podendo essa identidade se realizar em uma sociedade fundada na alienação, a relação entre sujeito e objeto é, na verdade, trespassada de mediações, das quais decorrem o caráter pré-formado dos "fatos" (eles próprios codeterminados de antemão por representações, antes mesmo de sua teorização propriamente científica) e o caráter histórico, e por isso no fundo transitório e contingente, das "teorias" (elas próprias determinadas de antemão pelo material empírico, factual $)^{469}$.

A ciência seria um ramo da produção social como os outros, uma particularização da maneira pela qual a sociedade se defronta com a natureza. A aparente autonomia dos processos do trabalho científico corresponderia à ilusão de liberdade que têm os sujeitos econômicos na sociedade burguesa. Ela é uma aparência socialmente necessária nessa sociedade, e por isso o conhecimento científico é dotado de certa objetividade, embora parcial, e encontra aplicação fecunda em meio às relações sociais dadas. Ele pode muito bem transcorrer sem questionar os dualismos entre ser e pensar, entendimento e percepção, atividade do cientista e passividade do material, dualismos em meio aos quais se formou. Ao não considerar o caráter histórico dessas relações, contudo, a teoria tradicional sancionaria a reificação da experiência:

"o mundo perceptível inteiro, tal qual ele existe para o membro da sociedade burguesa e é interpretado na concepção tradicional de mundo que se encontra em ação recíproca com ela, é tido por seu sujeito como um conjunto de facticidades, ele está aí e tem de ser aceito" $" 470$.

E por quais mediações passa a ciência no modo de produção capitalista? A resposta de Horkheimer é bem conhecida: “(...) da mesma maneira que a influência do material sobre a teoria, também a aplicação da teoria ao material não é apenas um processo intracientífico, mas

\footnotetext{
${ }^{468}$ Cf. Max Horkheimer, "Traditionelle und kritische Theorie", op. cit., p. 171, p. 173.

${ }^{469}$ Cf. Max Horkheimer, "Traditionelle und kritische Theorie", op. cit., p. 174.

${ }^{470}$ Max Horkheimer, "Traditionelle und kritische Theorie", op. cit., p. 173.
} 
também, ao mesmo tempo, um processo social. Afinal de contas, a relação entre as hipóteses e os fatos não se realiza na cabeça dos estudiosos, e sim na indústria"471. Essa adequação deve resultar na constituição de um sistema não contraditório de proposições apoiadas em um número o menor possível de princípios gerais, capazes de serem empregados na investigação dos domínios mais variados e aplicados aos mais diversos fatos singulares. A adequação dos fatos constatados ao sistema conceitual pré-existente é feita, sem dúvida, por meio de sua simplificação e da eliminação de suas contradições internas, de acordo com os preceitos cartesianos de apenas aceitar como verdadeiro aquilo que se apresente como evidência indubitável, e de decompor em suas partes mais simples os objetos complexos, para poder então partir dos elementos mais simples e proceder à formulação de leis gerais. Esse tipo de ciência, sendo o mais apto ao domínio da natureza através do controle dos objetos de investigação enquadrados em esquemas teóricos coerentes e de aplicação geral - é o mais adequado ao funcionamento e reprodução da sociedade burguesa.

Segundo a concepção tradicional de teoria, a direção imprimida às investigações, o estabelecimento de hipóteses, a descoberta de novos fatos e relações, a aplicação da teoria ao material de pesquisa e a reconfiguração que esse pode promover naquela, a fim de se promover aquela unidade entre teoria e experiência, e ainda também o rumo dado às pesquisas, seriam todos eles processos intracientífico, próprios à lógica imanente da ciência. Na verdade, contudo, todos esses aspectos da ciência estariam vinculados ao processo social, e os cientistas participam da reprodução do existente na medida mesmo em que se julgam independentes e conduzem a sua prática de modo supostamente isolado das demais esferas. A aplicação do método cartesiano a potencialmente todos os objetos da natureza e da sociedade se deve, como visto, à necessidade do controle o maior possível sobre os fatos e da sua simplificação com vistas à adequação à teoria: esse procedimento - cuja generalização levaria a ciência tendencialmente a se converter em um mero conjunto de sinais lógico-matemáticos - é inseparável do processo de reprodução do capital e da transformação do saber científico em fonte de valor, em uma época - o capitalismo monopolista - na qual a ciência passou a ser aplicada sistematicamente ao processo produtivo. O saber produzido pela teoria tradicional possui portanto, já em sua origem, uma constituição tal que o torna capaz de gerar valor (sendo um saber "valorizável", verwertbar). O modelo da lógica dedutiva torna-se, então, o paradigma dessa teoria: da mesma maneira que o capital reduz o mundo (inclusive o próprio conhecimento) a valores de troca que se justapõem abstratamente na realidade sem quaisquer qualidades

\footnotetext{
${ }^{471}$ Cf. Max Horkheimer, "Traditionelle und kritische Theorie", p. 170.
} 
próprias e sem história ou desenvolvimento ulterior propriamente dito, a ciência que a ele corresponde também pretende reduzir seu objeto a um "sistema de sinais puramente matemáticos" cada vez mais abstrato e livre de "excessos" qualitativos ${ }^{472}$.

Postulada pela teoria tradicional, a identidade entre sujeito e objeto também anima o pensamento crítico, ao apontar para a superação das contradição entre a atividade da sociedade e a passividade do indivíduo. Ele a considera, contudo, como uma finalidade que ainda não foi atingida ${ }^{473}$. O "comportamento crítico" compreende o isolamento da atividade científica, tal qual esse isolamento é aceito pela concepção tradicional de teoria, como uma função da atividade humana e que por isso poderia, tanto quanto a divisão da sociedade em classes, ser superada em proveito de uma organização racional da sociedade, de uma "sociedade futura como coletividade de homens livres, tal como seria possível em virtude dos meios técnicos existentes" ${ }^{474}$. A teoria crítica seria uma espécie de consciência das contradições da sociedade cindida, orientada para a emancipação por meio da transformação do todo, e consistiria na crítica às categorias dominantes na vida social. Nessa crítica, ela poderia se servir também das categorias da teoria tradicional e dos fatos reconhecidos por ela, caso seja capaz de historicizálos: "os fatos concretos que estão dados na percepção devem despojar-se do caráter de mera facticidade na medida em que forem compreendidos como produtos que, como tais, deveriam estar sob o controle humano e que, em todo o caso, passarão futuramente a este controle" ${ }^{\natural 75}$.

Criadas pelos homens em suas relações sociais, as teorias e conceitos científicos passam a se apresentar como coisas, como se fossem independentes do processo histórico que os originou, e nisso mesmo o caráter supostamente independente da ciência revela a sua própria historicidade, isto é, o seu pertencimento ao processo de reificação típico do capitalismo. A própria ciência se torna um fato entre outros, e um de seus elementos passa a ser a submissão irracional ao existente, característica da atitude passiva na qual os indivíduos se defrontam com a realidade no modo de produção capitalista: os indivíduos se submetem, então, à autoridade da ciência da mesma maneira que se submetem à autoridade dos fatos, sendo a primeira apenas um caso particular do modo geral sob o qual se dá a experiência nessa sociedade ${ }^{476}$.

\footnotetext{
${ }^{472}$ Max Horkheimer, "Traditionelle und kritische Theorie", op. cit, p. 164, pp. 168-171, "Teoria tradicional e teoria crítica", op. cit., p. 118 infra, p. 122-123, e também "Bemerkungen über Wissenschaft und Krise", op. cit., pp. 41-42.

${ }^{473}$ Cf. Max Horkheimer, "Teoria tradicional e teoria crítica”, op. cit., pp. 132-135.

${ }^{474}$ Max Horkheimer, "Teoria tradicional e teoria crítica", op. cit, p. 137.

${ }^{475}$ Cf. Max Horkheimer, "Teoria tradicional e teoria crítica”, op. cit., pp. 131-132. Cf. também p. 124 e pp. 130132.

${ }^{476}$ Cf. Max Horkheimer, "Traditionelle und kritische Theorie", op. cit., p. 173, "Teoria tradicional e teoria crítica", op. cit., p. 125. Citar também: Max Horkheimer, "Teoria tradicional e teoria crítica", op. cit., p. 139 (conferir qual é a paginação no original - trata-se da educação para a realidade dos fatos - retirei essa referência da minha tese), e também Max Horkheimer, "Autoridade e família", op. cit., p. 223. Ao contrário do que ocorreu com as críticas
} 
Horkheimer se alinhava, nessa concepção, à tese de Lukács segundo a qual a experiência, na sociedade capitalista, seria reduzida à apercepção de fatos que apareceriam necessariamente como unidades isoladas, independentizadas de seu contexto de produção. A aparente adequação do método científico tradicional seria, portanto, uma expressão da reificação das relações sociais, e a ciência, tal qual as demais esferas sociais, não passaria incólume a esse processo ${ }^{477}$. Esse quadro recebeu de Horkheimer, contudo, uma resposta bastante diferente daquelas oferecidas em História e Consciência de Classe. Lukács havia contraposto à ciência burguesa o marxismo, compreendido como uma ciência revolucionária baseada em uma identidade entre sujeito e objeto possível em virtude da especificidade do ponto de vista do proletariado. Enquanto a ciência burguesa apreenderia os fatos como se eles fossem a expressão de uma mera necessidade fatalista, apenas a consciência de classe seria capaz de conhecer a totalidade social e de revolucioná-la, efetivando a unidade entre teoria e prática.

Embora concordasse em linhas gerais com a análise do fetichismo feita por Lukács, Horkheimer recusava a identificação do marxismo a algo como uma "consciência de classe". O proletariado consiste, é verdade, na classe que revela de maneira mais nítida as contradições da sociedade burguesa, sendo em princípio capaz de conhecer, em virtude de sua própria situação, a contradição entre o desenvolvimento das forças produtivas e a manutenção de

de Adorno ao positivismo, a crítica feita por Horkheimer em seus ensaios da década de trinta ao caráter fetichista da ciência, apesar de bastante nítida, e também indissociável da noção do autor de que a ciência estaria em crise, nem sempre tem sido ressaltada nos comentários à sua obra, nem mesmo naqueles mais minuciosos. Cf., por exemplo, John Abromeit, Max Horkheimer and the foundations of the Frankfurt School, especialmente o capítulo 8 , onde caberia uma discussão a esse respeito. Helmut Dubiel, por sua vez, em seu clássico estudo ressaltou o caráter "abstrato" do conhecimento produzido segundo o método analítico da ciência empirista, mas o associou à especialização crescente das disciplinas, sem considerar a vinculação desse processo com o fenômeno da reificação. Cf., do autor, Wissenschaftsorganisation und politische Erfahrung - Studien zur frühen kritischen Theorie. Frankfurt am Main: Suhrkamp, 1978, pp. 167-169. Papel determinante nessa ausência parece ter exercido a interpretação dominante da obra de Horkheimer, provinda de Habermas e seus colaboradores, que contrapõe o "materialismo interdisciplinar" dos anos trinta, com sua ênfase na pesquisa empírica e no recurso às disciplinas científicas, à suposta "fillosofia pessimista da história", desenvolvida a partir dos anos quarenta e do trabalho realizado em conjunto com Adorno, que haveria de resultar na Dialética do Esclarecimento. Nessa direção também tende a se desenvolver o comentário de Maurício Chiarello, Das lágrimas das coisas - estudo sobre o conceito de natureza em Max Horkheimer. Campinas: Editora da Unicamp, 2001. Uma exceção a essa tendência, que destaca com nitidez a crítica de Horkheimer ao fetichismo presente na ciência contemporânea, é o livro de Katia Genel, Autorité et emancipation: Horkheimer et la théorie critique. Paris: Payot, 2013. Ainda na primeira fase da recepção da obra do autor, Wolfgang Bonß e Norbert Schindler também haviam chamado a atenção para as críticas feitas por Horkheimer, nos anos trinta, ao fetichismo inerente à ciência dominante. Cf. Wolfgang Bonß; Norbert Schindler. "Kritische Theorie als interdisziplinärer Materialismus". In: Wolfgang Bonß; Axel Honneth. Sozialforschung als Kritik - zum sozialwissenschaftlichen Potential der kritischen Theorie. Frankfurt: Suhrkamp, 1982.

${ }^{477}$ Cf. Georg Lukács. História e consciência de classe: estudos sobre a dialética marxista. Tradução de Rodnei Nascimento. São Paulo: Martins Fontes, 2003, pp. 71-73. Helmut Dubiel também ressaltou o caráter "abstrato" do conhecimento produzido segundo o método analítico da ciência empirista, mas o associou à especialização crescente das disciplinas, sem considerar a vinculação desse processo com o fenômeno da reificação. Cf. Helmut Dubiel, Wissenschaftsorganisation und politische Erfahrung - Studien zur frühen kritischen Theorie. Frankfurt am Main: Suhrkamp, 1978, pp. 167-169. 
relações sociais que o emperram, assim como o seu resultado: o acúmulo de riqueza material e intelectual, de um lado, e a condenação de largas parcelas da população à miséria e à impotência política, de outro. Apesar de seus interesses apontarem para a superação desse modo de produção, não haveria, contudo, necessidade alguma da formação de uma consciência de classe que escapasse à ideologia em suas formas dominantes. Horkheimer era levado, dessa maneira, a propor uma "unidade dinâmica" entre os portadores da teoria crítica e a classe trabalhadora, uma unidade que fosse capaz de comportar discordâncias e tensões. $\mathrm{O}$ autor negava, assim, ao proletariado a condição de sujeito da teoria crítica, e definia esse como "um indivíduo determinado, em suas relações efetivas com outros indivíduos e grupos, em seu confronto com uma classe determinada e, enfim, no entrelaçamento assim mediado com o todo social e a natureza" ${ }^{478}$.

Não apenas quanto ao sujeito da teoria crítica, mas também quanto à relação entre o marxismo e a ciência tradicional Horkheimer se distanciava de Lukács. Se esse rejeitava a ciência burguesa como expressão da alienação à qual os homens estão submetidos no capitalismo, Horkheimer, por sua vez, defendia que a teoria tradicional poderia servir à teoria crítica: a adequação entre as hipóteses e os fatos, promovida pela primeira, teria uma validade objetiva e a ela a teoria crítica poderia recorrer, os fatos seriam produtos da práxis social, e "por isso tem de haver neles, mesmo que em um sentido limitado, razão" ${ }^{479}$. Assim como as ciências naturais hão de guardar a sua validade em uma sociedade que tenha superado a divisão em classes, a teoria crítica pode recorrer, em sua formulação, aos conhecimentos fornecidos pela teoria tradicional: constituídos segundo um modelo de conhecimento que cumpre a função de conservar e reproduzir as relações sociais dadas, esses conhecimentos mudam de função quando integrados a uma exposição do todo histórico orientada pelo futuro, isto é, pela ideia da superação do modo de produção capitalista ${ }^{480}$.

\footnotetext{
${ }^{478}$ Cf. "Traditionelle und kritische Theorie", p. 184. Cf. ainda o trecho às pp. 186-188. Sobre esse assunto, cf. ainda Ricardo Musse, Do socialismo científico à teoria crítica - modificações na autocompreensão do marxismo entre 1878 e 1937. Tese de doutorado. FFLCH-USP. São Paulo, 1997, p. 76.

${ }^{479}$ Cf. Max Horkheimer, "Traditionelle und kritische Theorie", p. 125.

${ }^{480}$ Cf. Max Horkheimer, "Traditionelle und kritische Theorie”, p. 190, p. 202 infra e p. 214. Sobre a concepção de Lukács do marxismo como ciência revolucionária e sua indiferença em relação à ciência burguesa, cf. Ricardo Musse, “A dialética como discurso do método". Tempo Social. São Paulo, vol. 17, número 1, junho de 2005, pp. 384-386. Sobre a posição de Horkheimer a esse respeito, cf. ainda, do mesmo autor, Do Socialismo Científico à Teoria Crítica, op. cit., p. 70.
} 


\section{4 - "Exposição" e "pesquisa"}

Nos ensaios que publicou na Revista de Pesquisa Social nos anos trinta, Horkheimer fez reflexões sobre o método dialético e sobre as especificidades que o separam do método analítico próprio à ciência dominante. Tendo essas reflexões incidido principalmente sobre as diferenças entre o conhecimento dialético e aquele conhecimento orientado pela lógica formal, típico das disciplinas especializadas, elas são capazes de iluminar o tipo de incorporação feito por Horkheimer, em seus ensaios, das contribuições oriundas das obras de seus colegas do Instituto, e que pretendemos examinar mais detalhadamente na Parte III da tese. Passemos aos principais elementos daquelas reflexões. Aqui nosso objetivo é apenas chamar a atenção, resumidamente, para alguns elementos da concepção de dialética do autor ${ }^{481}$.

O pensamento materialista, como vimos, considera que as teorias e os conceitos científicos têm um caráter histórico e estão inextricavelmente vinculados ao processo social: eles são formados em meio às relações dos homens entre si e com a natureza. Tanto a definição das tarefas de pesquisa quanto os recursos empregados em sua resolução são, portanto, condicionados socialmente, uma característica que se faz presente também na relação entre o juízo e o estado de coisas correspondente que é descrito ou explicado ${ }^{482}$. A relação entre um e outro não é imediata, e sim mediada pelas relações que os homens estabelecem entre si:

"Já em meio à pesquisa e à constatação de estados de coisas, e mormente quando da verificação das teorias, desempenham o seu papel tanto a direção imprimida à atenção, quanto o refinamento dos métodos e a estrutura do material de

\footnotetext{
${ }^{481}$ No que diz respeito ao caráter institucional (relativo à interação entre as obras dos membros do Instituto de Pesquisa Social) assumido pelas reflexões sobre a dialética feitas por Horkheimer seguimos, embora com algumas diferenças (que detalhamos mais adiante), o argumento já desenvolvido por Helmut Dubiel em seu estudo clássico: Wissenschaftsorganisation und politische Erfahrung, op. cit., pp. 161-183. John Abromeit, por sua vez, considerou aquelas reflexões um elemento menor da obra escrita pelo autor nos anos trinta: elas seriam, em sua visão, ponderações metodológicas apartadas das pesquisas empíricas do Instituto e das investigações históricas que o próprio Horkheimer empreendia em seus ensaios, e representariam "o crescente desespero e isolamento em que Horkheimer, como intelectual socialista, se encontrava em meados da década de trinta", assim como "uma tentativa de restabelecer a validade - ou a ausência dela - do projeto teórico de Marx, em uma época na qual ele parecia ter sido desacreditado de diversos modos". Cf. John Abromeit, Max Horkheimer and the Foundations of the Frankfurt School, op. cit., p. 334 e também, sobre esse assunto, pp. 301-302.

${ }^{482}$ Cf. Max Horkheimer, "Zum Rationalismusstreit in der gegenwärtigen Philosophie”, op. cit., pp. 192-194.
} 
categorias, em suma, a atividade humana, tal qual ela corresponde ao determinado período social" 483 .

Trata-se, portanto, de uma identidade produzida socialmente, construída entre fatos percebidos de acordo com a forma da experiência na sociedade capitalista (isto é, isolados e independentizados em relação ao contexto de sua produção) e sistemas teóricos pré-existentes, destituídos de contradições internas (cf. o item anterior, sobre a reificação da ciência). Ao aparecerem dessa maneira, como se fossem independentes de sua origem, os conceitos e juízos produzidos de acordo com o método analítico são abstrações, que reivindicam seu caráter de verdade de modo isolado de seu contexto de produção e também da função social que desempenham. Ao contrário da lógica formal, porém, que considera suficiente a adequação entre a coisa e o pensamento, para a teoria materialista é necessário, no processo de obtenção da verdade, que esse critério, sem ser desprezado, seja ultrapassado rumo à vinculação entre as unidades isoladas do conhecimento e o todo histórico ${ }^{484}$.

Isso fora reconhecido primeiramente por Hegel, com sua ênfase nas contradições imanentes ao pensamento, que determinariam o automovimento do conceito: a identidade só se constituiria por meio da sua própria negação, ultrapassando portanto os seus limites iniciais. O conhecimento teria um caráter processual, e nele os juízos isolados teriam uma validade apenas provisória: seu caráter abstrato deveria ser superado rumo à construção de uma totalidade concreta. A pretensão da filosofia hegeliana ao sistema absoluto, entretanto, sua exigência de um estado em que sujeito e objeto coincidissem e se "reconciliassem", repousava na tese da identidade entre sujeito e objeto, cujo idealismo Horkheimer não cessava de denunciar (cf. o item 1.1). A dialética materialista, pelo contrário, não se crê concluída: ela compreende as circunstâncias dominantes como condicionadas e transitórias, mas não identifica o conhecimento da realidade com a sua superação ${ }^{485}$.

Horkheimer mantinha de Hegel, entretanto, a ideia da relação necessária entre alógica do entendimento e o pensamento dialético. Esse não rejeita o saber obtido analiticamente, pois considera que os conhecimentos específicos provindos das disciplinas científicas especializadas constituem pressupostos para o conhecimento abrangente da realidade: nas palavras de Hegel, lembrava Horkheimer, "a empiria prepara a matéria empírica para o conceito dialético, para que esse então a possa receber" ${ }^{\natural 46}$. Central aqui é a noção de dialética como um tipo de

\footnotetext{
${ }^{483}$ Cf. Cf. Max Horkheimer, "Zum Problem der Wahrheit”, op. cit., p. 293.

${ }^{484}$ Cf. Max Horkheimer, "Zum Problem der Wahrheit”, op. cit., pp. 285-287.

${ }^{485}$ Cf. Max Horkheimer, "Zum Problem der Wahrheit”, op. cit., pp. 291-292.

486 Hegel, Vorlesungen über die Geschichte der Philosophie, citado em Max Horkheimer, "Zum Rationalismusstreit in der gegenwärtigen Philosophie", op. cit., p. 187.
} 
pensamento que refaz o caminho das abstrações: "o método dialético é o conjunto de todos os recursos intelectuais para tornar os momentos abstraídos obtidos pelo entendimento separador frutíferos para a imagem do objeto vivo" ${ }^{\text {487 }}$. Como se sabe, essa ideia também foi importante para Marx. No Capital, ele distinguia da seguinte maneira o pensamento dialético da ciência analítica à qual ele faz a crítica:

"É, sem dúvida, necessário distinguir o método de exposição, formalmente, do método de pesquisa. A pesquisa tem de captar detalhadamente a matéria, analisar as suas várias formas de evolução e rastrear sua conexão íntima. Só depois de concluído esse trabalho é que se pode expor adequadamente o movimento real. Caso se consiga isso, e espelhada idealmente agora a vida da matéria, talvez possa parecer que se esteja tratando de uma construção $a$ priori" ${ }^{\prime 488}$.

A “exposição" não é entendida aqui como a reunião dos saberes especializados em uma totalidade, à maneira meramente aditiva da ciência orientada pelo método analítico. Trata-se, antes, de uma crítica das representações que se apresentam como expressão da totalidade, aquilo que Marx chamou nos Grundrisse de "concreto concebido" (ou "concreto da representação"). Nessa crítica, as representações são analisadas em suas contradições e remontadas à totalidade concreta da qual se originaram. Segundo Horkheimer, o pensamento dialético teria por função realizar o "rompimento e reestruturação [das Zerbrechen und Umstrukturieren] de sistemas e categorias rígidos" ${ }^{489}$. Ao assimilar a distinção de Marx tendo em vista as disciplinas científicas presentes no seu próprio programa de pesquisas, o autor afirmava:

"As ciências específicas transmitem apenas os elementos para a construção do curso histórico, e esses não permanecem na exposição aquilo que ele eram nas ciências específicas, mas adquirem novas funções em seu significado, das quais não havia menção anterior"490.

\footnotetext{
${ }^{487}$ Cf. Max Horkheimer, “Zum Rationalismusstreit in der gegenwärtigen Philosophie”, op. cit., p. 184.

${ }^{488}$ Cf. Karl Marx, O Capital - Crítica da Economia Política. Vol. 1 - O Processo de Produção do Capital, op. cit., p. 20. A noção do "caminho de volta" das abstrações à realidade foi mais extensamente desenvolvida na Introdução dos Grundrisse. Aqui não é o lugar, entretanto, para um tratamento mais profundo desse tema.

${ }^{489}$ Cf. Max Horkheimer, "Zum Problem der Wahrheit”, op. cit., p. 297.

${ }^{490}$ Cf. Max Horkheimer, "Zum Rationalismusstreit in der gegenwärtigen Philosophie”, op. cit., p. 186. Segundo Alfred Schmidt, Horkheimer foi um dos primeiros a considerar seriamente a distinção marxiana entre pesquisa ("Forschung") e exposição ("Darstellung"). Cf., do autor, "Zum Erkenntnisbegriff der Kritik der politischen Ökonomie". In: Walter Euchner; Alfred Schmidt (Orgs.). Kritik der politischen Ökonomie heute - 100 Jahre Kapital. Europäische Verlagsanstalt, 1968, p. 37.
} 
Esses elementos apenas poderiam perder o seu caráter limitado, contudo, se integrados a uma "exposição do todo histórico", compreendida também à luz dos elementos subjetivos que influem no processo de conhecimento. Se na ciência tradicional e na metafísica os conceitos e juízos estão ligadas à reprodução da vida em suas formas dadas, no pensamento dialético a reunião dos elementos empíricos obedece aos interesses históricos aos quais a teoria crítica serve, e que dizem respeito às condições de superação ou conservação da totalidade representativa de uma época histórica ${ }^{491}$.

De maneira análoga à que Marx analisou as contradições dos conceitos da Economia Política e os remeteu às condições históricas de sua formação (por exemplo, por meio de sua vinculação ao processo de acumulação primitiva), Horkheimer também analisou as contradições básicas que perpassavam as contribuições de Fromm, Pollock e Neumann, relativizando as oposições internas a seus conceitos e teorias (ou pondo em relação as teorias opostas, tal qual ocorreu em sua apreensão de elementos das teses de Pollock e Neumann, como veremos a seguir). Ao fazê-lo, Horkheimer estendia às investigações realizadas no âmbito de seu próprio programa de pesquisas no Instituto o tipo de relação entre "teoria tradicional e teoria crítica" que preconizara no ensaio de mesmo nome. Como defendera ali, a exposição do curso histórico tem um caráter crítico porque ela é orientada pelo futuro e analisa as contradições da época histórica presente (considerada como totalidade) que podem conduzir à sua superação. Disso decorrem mudanças para os conhecimentos específicos provindos da teoria tradicional, quando incorporados à teoria crítica: seu sentido é alterado, pois passam a ser considerados em relação à superação ou conservação do todo social ${ }^{492}$. Ao se desprenderem da forma de identidade entre sujeito e objeto e serem remetidos ao processo histórico de sua formação, os juízos e conceitos da teoria tradicional adquiriam um caráter crítico, pois se tornam como que conscientes de sua própria "abstratividade".

Ainda que devamos ao estudo pioneiro de Dubiel a indicação detalhada e teoricamente sólida do modo como Horkheimer se inspirou na distinção marxiana entre "pesquisa" e "exposição" para conceber o trabalho coletivo realizado no Instituto - trabalho no qual as contribuições disciplinares de Fromm, Pollock, Adorno, Löwenthal e outros seriam integradas

\footnotetext{
${ }^{491}$ Cf. Max Horkheimer, "Der neueste Angriff auf die Metaphysik", op. cit., passim.

${ }^{492}$ Sobre isso, cf. Max Horkheimer, "Traditionelle und kritische Theorie", op. cit., pp. 199-200.
} 
em uma "exposição fillosófica" a cargo do próprio Horkheimer -, o comentador erroneamente parece julgar que a "teoria do curso histórico" proposta por Horkheimer não teria sido desenvolvida, tendo sido apenas esboçada ${ }^{493}$. Nossa hipótese, entretanto, é que essa teoria, entendida por Horkheimer como uma atualização da crítica marxista para as condições do capitalismo monopolista, se realizou nos ensaios do próprio autor. Examinamos no capítulo 3 as críticas feita por Horkheimer à ideologia contemporânea, e neste capítulo suas críticas à ciência em particular. Como vimos, a partir de sua crítica à forma assumida pelo fetichismo na contemporaneidade o autor chegou a uma compreensão própria do fenômeno da dominação, baseada na categoria de "autoridade". Na Parte III veremos como essa compreensão influiu sobre as reflexões de Horkheimer acerca das formas especificamente política e psíquica de dominação: ao criticá-las, o autor realizava uma espécie de dialetização das teorias desenvolvidas por Fromm sobre o "caráter autoritário", e por Pollock e Neumann sobre as relações entre economia e política naquela quadra do capitalismo ${ }^{494}$. Fazê-lo permitiu Horkheimer buscar as tendências que, embora exíguas, apontavam para a superação do existente ${ }^{495}$.

\footnotetext{
${ }^{493}$ Cf. Helmut Dubiel, Wissenschaftsorganisation und politische Erfahrung, op. cit., pp. 161-186. O autor, assim como faria Rolf Wiggershaus alguns anos mais tarde, tende a vincular o modelo de um programa interdisciplinar de pesquisas à forma coletiva de publicação consubstanciada nos "Estudos sobre autoridade e família", que passam a ser vistos por esses intérpretes como o apogeu do programa intelectual desenvolvido por Horkheimer nos anos trinta. Cf. Rolf Wiggershaus, A Escola de Frankfurt, op. cit., p. 185. Negligencia-se, dessa maneira, a especificidade que as contribuições disciplinares assumiam nos ensaios do próprio Horkheimer.

${ }^{494}$ Helmut Dubiel apresentou detalhadamente a distinção hegeliana e marxiana entre "exposição" e "pesquisa", mas terminou por mobilizá-la, entretanto, em seu intuito de analisar o programa de pesquisas de Horkheimer a partir da problemática da interdisciplinaridade - uma problemática dada por tradições teóricas outras que não o marxismo. Consoante essa perspectiva, Dubiel afirmava que a "crítica"- no sentido da crítica da Economia Política feita por Marx em $O$ Capital - apenas teria orientado o programa intelectual de Horkheimer a partir de "Teoria Tradicional e Teoria Crítica", ensaio que assinalaria também o afastamento de Horkheimer de seu programa de pesquisas da primeira metade dos anos trinta. Cf. Helmut Dubiel, Wissenschaftsorganisation und politische Erfahrung, op. cit., pp. 74-86.

${ }^{495}$ Não por acaso a forma escolhida por Horkheimer para essa dialetização dos conhecimentos disciplinares foi a forma do ensaio. Neles, o autor organizava de uma nova maneira conhecimentos já obtidos em outro lugar, dando nova vida às "coisas que em algum momento já foram vivas", para usar uma expressão de Lukács citada por Adorno. Cf., de Adorno, "O ensaio como forma". In: Theodor W. Adorno, Prismas - crítica cultural e sociedade, op. cit., p. 17.
} 
PARTE III 


\section{Capítulo 5 - O Estado como "estrutura de comandantes e comandados"}

\section{$\underline{5.1 \text { - Economia e política na fase mais recente do capitalismo monopolista }}$}

Sob diversos aspectos diferente do capitalismo liberal estudado por Marx e Engels foi a fase do modo de produção capitalista em que surgiu a teoria crítica e em que Horkheimer escreveu a sua obra. O desenvolvimento do capitalismo a partir da dissolução do modo de produção feudal havia culminado, no século XIX, em uma sociedade baseada na concorrência entre capitalistas individuais e caracterizada pela "anarquia da produção" e pela progressiva anulação dos impedimentos à circulação das mercadorias. Se é verdade que em meados do século XIX essa descrição valia principalmente para a Inglaterra, ela ainda assim fornecia um quadro do desenvolvimento tendencial das demais sociedades, em uma época de expansão do modo de produção capitalista para o restante do mundo. As ideologias calcadas nos conceitos de "liberdade" e de "igualdade" tinham, então, uma base objetiva, pois formava-se uma sociedade em que os indivíduos considerados detentores de direitos (isto é, aqueles que fossem homens, adultos e brancos) eram formalmente livres para produzir mercadorias e trocá-las no mercado. Em sua teoria da mais-valia, Marx havia mostrado que a origem do lucro dos capitalistas residia na exploração do trabalho realizado por uma outra classe, formalmente livre para produzir e vender quaisquer mercadorias, mas que não era, ela própria, possuidora dos meios de produção: Marx tornara dessa maneira nítido o caráter ilusório da ideia de que a venda da força de trabalho em troca de salário exprimiria uma "troca justa", e mostrara que a igualdade no âmbito da circulação dependida de uma desigualdade básica que consistia na exploração do trabalho alheio e que apenas se revelava no âmbito da produção. A partir das últimas décadas do século XIX, contudo (mais especificamente, após a crise de 1873 e, com mais ênfase, a partir da passagem ao século XX), alterou-se significativamente a situação: primeiro, a concorrência, apesar de ainda formalmente válida, deixou de ser o elemento característico do modo de produção capitalista, e da tendência à concentração de capital, já prevista por Marx, resultou que os proprietários individuais - que produziam para um mercado no qual não sabiam qual seria o rumo dado às suas mercadorias - fossem substituídos por grandes monopólios e oligopólios, associados a bancos e atuantes em setores cada vez mais extensos da economia; em segundo lugar, à extração da mais-valia nos moldes do capitalismo liberal do século XIX somaram-se a formação de um mercado mundial e o colonialismo na África e na Ásia, que incluía a exploração do trabalho em moldes não-capitalistas (servil e até mesmo escravo); por fim, nos países capitalistas centrais a classe trabalhadora passou por um processo de 
complexificação que resultou no aburguesamento de significativos setores seus e na constituição de uma "aristocracia operária". Daí seguiram-se também desafios para a crítica das ideologias: "a propriedade privada baseada no trabalho do pequeno patrão, a livre concorrência, a democracia, todas essas palavras de ordem por meio das quais os capitalistas e a sua imprensa enganam os operários e os camponeses, pertencem a um passado distante" ${ }^{\text {״96 }}$. É necessário observar ainda que, após as crises dos anos vinte, o desenvolvimento do capitalismo monopolista tomou um novo rumo ${ }^{497}$. Lênin vira na concentração crescente de capital a superação dos limites da propriedade privada e portanto uma oportunidade para a transição a um regime de propriedade coletiva dos meios de produção ${ }^{498}$ - finda a primeira guerra, contudo, e principalmente após as crises econômicas dos anos vinte, iniciaram-se, com vistas à superação das crises e, sobretudo, a impedir que tivessem sucesso os processos revolucionários em curso na Europa, processos de redefinição do papel do Estado na organização da economia e de reorganização das forças produtivas.

A mudança do papel do Estado na economia foi uma transformação basilar pela qual passou o capitalismo monopolista no período posterior à primeira guerra. No período do capitalismo liberal, a concorrência entre os capitalistas acarretava regularmente a falência de empresas individuais, e os períodos de crise se resolviam com a destruição regular das forças produtivas, por meio da mera atuação dos mecanismos especificamente econômicos, como a lei da oferta e da procura: após um período de falências e de desemprego, a economia podia voltar a seu funcionamento normal. No âmbito do capitalismo monopolista, por sua vez, a falência dos grandes conglomerados que constituíam os monopólios e oligopólios tinha um tamanho efeito desestabilizador sobre o conjunto da economia que o Estado não tinha outra opção a não ser intervir para salvar empresas que empregavam grandes contingentes de mãode-obra e das quais dependiam, unidos em cadeia, diversos setores econômicos. Principalmente após a crise de 1929, o Estado passou a intervir na economia também por meio da fixação de preços (inclusive do preço da força de trabalho), da manutenção do protecionismo alfandegário, do estabelecimento das regras dos contratos de trabalho e da formulação de políticas sociais. A atuação do Estado como garantidor do lucro das empresas, que não obstante continuava a ser apropriado privadamente, levou Pollock a denominar essa fase mais recente do capitalismo

\footnotetext{
${ }^{496}$ Cf. V.I. Lenine, O Imperialismo, Fase Superior do Capitalismo. $3^{\mathrm{a}}$ edição. Tomo 1. São Paulo: Editora AlfaÔmega, 1980, p. 582.

${ }^{497}$ Se a crise de 1929 foi mais significativa em termos mundiais, é preciso lembrar que em 1922 e 1923 ocorreram, na Alemanha por exemplo, surtos inflacionários de consequências devastadoras.

${ }^{498}$ Cf. V.I. Lenine, O Imperialismo, Fase Superior do Capitalismo, op. cit., pp. 593-594 e pp. 604-605.
} 
monopolista - caracterizada também por uma intensa financeirização da economia - de “capitalismo garantido" ou, por vezes também, de "economia controlada"499.

Apenas em 1941 seria publicado o artigo em que Pollock desenvolveu sua tese do "capitalismo de Estado", com a qual o autor sustentava haver uma estreita semelhança entre a economia soviética, o planejamento keynesiano feito nos Estados Unidos e aquele próprio da Alemanha nazista ${ }^{500}$. No início dos anos trinta, por sua vez, antes da ascensão dos nazistas ao poder, Pollock ainda perguntava de maneira otimista pela possibilidade de uma planificação econômica socialista: embora considerasse que em virtude da ultrapassagem dos limites da propriedade privada pelo alto grau de concentração das forças produtivas já estivessem dadas as bases para tanto, Pollock rejeitava a tese que previa a ocorrência da revolução a partir de um colapso inevitável do capitalismo (tese defendida no Instituto por Grossmann ${ }^{501}$ ), e argumentava que a passagem ao socialismo não seria feita a partir de bases meramente econômicas. O autor chamava a atenção para o fato de que a experiência soviética inspirava os economistas ocidentais a refletirem sobre as vantagens que poderiam advir, para o capitalismo, de uma planificação da economia, e ao fazê-lo se alinhava ao mesmo tempo à perspectiva social-democrata que considerava a estatização da economia um passo necessário à transição ao socialismo ${ }^{502}$. Mas o autor sustentava também, em oposição a essa concepção, ser improvável que uma economia pudesse ser submetida à planificação sem antes ser abolida a propriedade privada dos meios de produção, ainda que inicialmente a planificação pudesse garantir ao capitalismo alguma estabilidade e a saída, pelo menos por alguns anos, da crise. À época, portanto, Pollock ainda identificava a abolição da propriedade privada dos meios de produção com o fim do capitalismo (a formulação de seu conceito de "capitalismo de Estado", sob o qual a propriedade privada mudaria de função e o Estado passaria a desempenhar um papel fundamental na exploração do trabalho, representou para Pollock por isso uma rejeição

\footnotetext{
${ }^{499}$ Cf. Friedrich Pollock, "Die gegenwärtige Lage des Kapitalismus und die Aussichten einer planwirtschaftlichen Neuordnung". Zeitschrift für Sozialforschung, vol. 1, 1932. pp. 10-16. O termo "economia controlada" [gebundene Wirtschaft], que aparece nos artigos escritos por Pollock para o volume 2 da Revista de Pesquisa Social, de 1933, aparentemente foi cunhado por Josef Dobretsberger, economista cujo livro de 1932, Freie oder gebundene Wirtschaft? Zusammenhänge zwischen Konjunkturverlauf und Wirtschaftsform, recebeu uma resenha no primeiro volume da Revista de Pesquisa Social, publicado no mesmo ano. No artigo citado, de 1932, Pollock se referia a uma "economia controlada" e a um "capitalismo garantido".

${ }^{500}$ Cf. "State Capitalism”, Studies in Phiosophy and Social Sciences, vol. 9, 1941, p. 221 (trata-se ainda da Revista de Pesquisa Social, mas publicada em inglês nos Estados Unidos)..

501 Cf. Henryk Grossmann, Das Akkumulations- und Zusammenbruchsgesetz des kapitalistischen Systems. Frankfurt am Main: Neue Kritik, 1967 (1929). Escrito à época em que o Instituto ainda se encontrava sob a direção de Grünberg, o livro foi publicado às vésperas da crise de 1929, que pareceu em um primeiro momento confirmar suas teses.

${ }^{502}$ Cf. Ulrich Ruschig, "Weiterdenken in marxistischer Tradition: die Lehre vom autoritären Staat". Ulrich Ruschig; Hans-Ernst Schiller (Orgs.) Staat und Politik bei Adorno und Horkheimer, op. cit., p. 78.
} 
dos conceitos marxistas de exploração e de valor, assim como a suposição de que o mundo teria ingressado em uma era "política", na qual a economia não seria mais a esfera predominante) $)^{503}$.

Os textos de Pollock publicados em 1932 e 1933 foram escritos tendo no horizonte a eventual possibilidade de uma transição socialista, ainda que o autor não considerasse haver indícios de que ela fosse ocorrer em um curto prazo e por isso essa transição fosse considerada uma perspectiva distante. Pollock se alinhava, por isso, ao reformismo social-democrata que considerava a estatização dos meios de produção uma etapa rumo à superação do capitalismo ${ }^{504}$. Além disso, também o método de análise empregado nesses artigos era diferente daquele presente no posterior, que haveria de se tornar mais famoso e debatido na recepção da obra dos autores ligados ao Instituto de Pesquisa Social: a análise da crise e das tendências ao planejamento estatal partiam, nos textos de início da década, do desenvolvimento das forças produtivas (cada vez mais concentradas) e de sua contradição com a propriedade privada dos meios de produção - no texto de 1941, por sua vez, a análise se deteria sobre uma pluralidade de fatores econômicos e políticos entrelaçados. Não obstante a existência dessas diferenças, de maneira semelhante ao que faria em sua tese do "capitalismo de Estado" de 1941, Pollock já nos textos do início da década de 1930 ressaltava um fenômeno de importância central na determinação do objeto da crítica marxista: tratava-se do aparente primado assumido pela política em relação à economia, que passava a ser planejada segundo diretrizes estatais.

$\mathrm{Na}$ fase do capitalismo monopolista que lhe era contemporânea e que grosso modo podemos assinalar como o período posterior à primeira guerra, os fatores políticos seriam "forças aparentemente autônomas", e o intervencionismo estatal teria decorrido de um desenvolvimento endógeno da economia capitalista ${ }^{505}$. Em suas "Observações sobre a crise econômica”, Pollock afirmara ser possível mostrar que

“(...) os chamados fatores políticos brotam das condições econômicas e sociais do capitalismo e surgem como forças aparentemente autônomas com tanto mais frequência quanto mais o sistema capitalista se torna rígido e quanto mais crescem as suas tensões internas" ${ }^{\prime 506}$.

\footnotetext{
${ }^{503}$ Friedrich Pollock, "Die gegenwärtige Lage des Kapitalismus und die Aussichten einer planwirtschaftlichen Neuordnung”, pp. 16-17; p. 21. Sobre a relação, à essa época considerada por Pollock como necessária, entre a planificação econômica e a abolição da propriedade privada dos meios de produção, cf. o artigo, também de Pollock, "Autarkie und Planwirtschaft”, publicado sob o pseudônimo de Kurt Baumann no vol. 2 da Zeitschrift für Sozialforschung, 1933, pp. 99-101. Essa perspectiva, como se sabe, seria abandonada no artigo de 1941 sobre o "capitalismo de Estado", em que a planificação convivia com a propriedade privada dos meios de produção.

${ }^{504}$ Cf. Friedrich Pollock, "Bemerkungen zur Wirtschaftskrise”, Zeitschrift für Sozialforschung, vol. 2, 1933, pp. 337-338. Cf. Ulrich Ruschig, "Weiterdenken in marxistischer Tradition: die Lehre vom autoritären Staat". Ulrich Ruschig; Hans-Ernst Schiller (Orgs.) Staat und Politik bei Adorno und Horkheimer. Baden-Baden: Nomos, 2014, pp. 77-80 e pp. 84-86.

${ }^{505}$ Cf. Friedrich Pollock, "Bemerkungen zur Wirtschaftskrise”, op. cit., p. 328.

${ }^{506}$ Cf. Friedrich Pollock, "Bemerkungen zur Wirtschaftskrise”, op. cit., p. 328.
} 
No início dos anos trinta, a aparente autonomização da política era um elemento central da explicação desenvolvida por Pollock para a reorganização da economia que permitira a sobrevivência do capitalismo no período posterior à crise de 1929: as crises de superprodução, ocorridas a partir de 1873, surgiam da contradição entre a concentração crescente de capital e o aumento exponencial da produção, por um lado, e a tendência à queda da taxa de lucro, por outro, que tornava cada vez mais difícil a realização do valor ${ }^{507}$. Para contornar as crises apelava-se, então, à intervenção estatal, que se dava por meio da concessão de crédito às empresas, da regulação dos preços e do protecionismo alfandegário (além das já citadas regulação do trabalho e implementação de políticas sociais). A intervenção estatal significava, dessa maneira, uma redução do poder dos proprietários individuais de dispor sobre a produção e distribuição das mercadorias, o que antes mesmo do aumento da intervenção estatal já estava em curso no âmbito dos cartéis e em geral nas grandes corporações, organizadas como sociedades por ações em que a propriedade jurídica (detida pelos acionistas) era separada do comando da empresa, nas mãos do corpo diretor. O Estado ampliava sua atuação econômica e nesse início dos anos trinta se desenhavam tendências de uma possível planificação total da economia, que preservasse os interesses dos grandes grupos empresariais e recorresse, como meio indispensável para a reorganização do capitalismo, a formas políticas radicalmente distintas do parlamentarismo até então vigente ${ }^{508}$.

A política assumiria, portanto, a aparência de uma esfera autônoma em relação ao desenvolvimento das forças produtivas - essa aparência seria, contudo, apenas a expressão manifesta de processos econômicos subjacentes e de maior amplitude tanto espacial quanto temporal: para a esfera política seriam deslocadas as contradições impossíveis de serem resolvidas no âmbito da "legalidade própria" da esfera econômica, por meio de mecanismos típicos da economia de mercado. No início do século XX, a manifestação política mais notável desse fenômeno foi sem dúvida a primeira guerra mundial: considerada à época por muitos analistas como o fator desencadeador da crise econômica que se arrastou pela década de vinte, ela teria correspondido na verdade, segundo Pollock, ao deslocamento para o âmbito da política

\footnotetext{
${ }^{507}$ Cf. Friedrich Pollock, "Bemerkungen zur Wirtschaftskrise”, op. cit., p. 321.

${ }^{508}$ Cf. Friedrich Pollock, "Bemerkungen zur Wirtschaftskrise", op. cit., pp. 345-350 e também p. 353. Nesses textos do início da década de trinta, portanto, Pollock já esboçava a possibilidade de que o Estado viesse a se tornar "o maior capitalista", o que para o autor só se tornaria um fenômeno em curso anos mais tarde, como viria a sustentar em seu artigo de 1941. A esse respeito, cf. o comentário de Fernando Rugitsky, "Friedrich Pollock limites e possibilidades". In: Marcos Nobre (Org.) Curso Livre de Teoria Crítica, pp. 63-64. Mais do que isso, porém, é importante ressaltar que nesses primeiros artigos Pollock já compreendia a reorganização econômica em curso como expressão de uma aparente autonomia da política.
} 
(no caso, o conflito bélico entre as potências imperialistas) da concorrência econômica entre os países europeus, que não havia sido resolvida nem mesmo com a expansão colonial e a transformação de várias das sociedades africanas e asiáticas em mercados fornecedores de matérias-primas e consumidores de produtos industrializados europeus ${ }^{509}$.

A ideia de uma progressiva autonomização das esferas sociais e de seu desenvolvimento segundo suas respectivas "legalidades próprias", se já estava de certa maneira presente no pensamento de $\operatorname{Marx}^{510}$, foi desenvolvida talvez da maneira mais conhecida por Weber e, posteriormente, por Lukács em História e Consciência de Classe. No caso de Pollock, a relação entre as esferas da economia e da política era compreendida com recurso ao par conceitual "essência e aparência", fundado na necessidade de se distinguir entre as formas aparentes dos fenômenos e a totalidade social (totalidade que corresponderia ela própria ao "ser", à "essência" [Wesen] da sociedade), assim como de tomar como ponto de partida da análise a esfera social determinante das demais, que se apresentariam aos indivíduos como formas autonomizadas, de maneira a ocultar a sua origem e a sua função social no todo, apresentando-se portanto, em sua suposta autonomia, de maneira falsa, "invertida"

A tese de uma "autonomia da política" não era, naturalmente, de exclusividade de Pollock, pois tanto Lênin quanto Gramsci defenderam, em suas críticas ao economicismo, a existência de um "primado da política": da contradição entre as forças produtivas e as relações sociais de produção não se seguiu a revolução, e o papel determinante assumido pelas esferas subjetivas da ideologia e da política parecia ter decepcionado as expectativas históricas nutridas pelas correntes dominantes do marxismo até pelo menos o fim da primeira guerra mundial. $\mathrm{O}$ próprio surgimento da teoria crítica, como vimos anteriormente, pode ser explicado a partir desse contexto histórico que desautorizava perspectivas economicistas e impunha a consideração dos fatores políticos, psicológicos e culturais. A diferença residia em que Lênin vira, em fins dos anos de 1910, no primado da política a possibilidade da revolução - Pollock, por sua vez, escrevia em inícios dos anos trinta após um período de intensa reação da burguesia,

\footnotetext{
${ }^{509}$ Friedrich Pollock, "Bemerkungen zur Wirtschaftskrise", op. cit., pp. 327 infra-328.

${ }^{510}$ Cf. a introdução aos Grundrisse, em que Marx se detém sobre as relações entre a esfera da produção e aquelas da distribuição, da troca e do consumo, que seriam relativamente independentes apesar de a esfera da produção sobrepujar a todas.

511 Sobre esse ponto, cf. o texto de Marcuse na edição de 1936 da Revista: "Zum Begriff des Wesens", especialmente pp. 23-25. Sobre esse texto de Marcuse, Alfred Schmidt notou na sua introdução aos volumes da Revista de Pesquisa Social que os economistas do Instituto lançavam mão do par conceitual "aparência e essência" para se referir ao predomínio da esfera econômica na totalidade social, e sugeriu que o estudo de Marcuse tenha sido escrito com a finalidade de expor detalhadamente os aspectos da relação entre "essência" e "aparência" na filosofia de Hegel e no marxismo. O texto também cumpria a finalidade de criticar a reificação desses conceitos nas correntes filosóficas contemporâneas. Cf. Alfred Schmidt, "Einleitung”. Zeitschrift für Sozialforschung, vol. 1. Munique: DTV, 1980. p. 28.
} 
que à violência proletária que se seguiu à primeira guerra respondeu primeiramente e sobretudo com violência direta, isto é, com a repressão dos movimentos revolucionários, mas também, ao longo das décadas de vinte e trinta, com uma variedade de estratégias (no níveis da organização do processo produtivo, do Estado e da ideologia) a fim de restabelecer com nova segurança as bases de sua hegemonia.

A relação entre o processo econômico e a constituição das novas formas de dominação recebeu de Horkheimer uma atenção específica no tratamento dado pelo autor ao "Estado autoritário", título de ensaio escrito em 1940 e publicado em $1942^{512}$. A recepção de que esse texto tem sido objeto costuma considerar que Horkheimer o escreveu sob influência da tese do “capitalismo de Estado", sustentada por Pollock em artigo publicado em 1941 na revista do Instituto $^{513}$ : autores como Habermas e Postone sustentaram que a adoção da tese de Pollock do "capitalismo de Estado" por Horkheimer, no início dos anos quarenta, teria significado ao mesmo tempo o abandono da crítica do capitalismo em favor de uma crítica da civilização e da técnica, ao que teria se seguido a "filosofia pessimista da história" presente na Dialética do Esclarecimento. Mas esse argumento esteve imbuído da imputação, a Pollock e também a Horkheimer, de uma suposta concepção determinista e a-histórica da relação entre base e superestrutura: como tanto Habermas quanto Postone identificaram seja a obra de Marx e o marxismo em geral (no caso de Habermas) seja a maior parte dessa tradição teórica (no caso de Postone) respectivamente a uma "dialética trans-histórica entre homem e natureza" 514 e a uma "teleologia entre forças produtivas e relações sociais de produção" "515 que apostaria na dominação da natureza pelo trabalho com vistas à revolução, foi-lhes fácil identificar, na tese de que a partir de determinada fase do capitalismo a política teria assumido a primazia, um abandono do marxismo ou, pelo menos, do "marxismo tradicional" 516.

\footnotetext{
512 Max Horkheimer, "Autoritärer Staat". Gesammelte Schriften, vol. 5, pp. 293-319. O texto, escrito por Horkheimer no primeiro semestre de 1940, constava originalmente de um fascículo mimeografado que continha as teses "sobre o conceito de história" de Walter Benjamin. Tratava-se de uma edição de circulação restrita ao Instituto de Pesquisa Social, à época sediado nos Estados Unidos, e que foi dedicada a Benjamin, que se suicidara poucos anos antes (Walter Benjamin zum Gedächtnis, "Em memória de Walter Benjamin"). Cf. as informações do editor no quinto volume das obras de Horkheimer publicadas pela editora Fischer, p. 460.

${ }^{513}$ Friedrich Pollock, "State Capitalism", Studies in Phiosophy and Social Sciences, vol. 9, 1941.

${ }^{514}$ Cf. introdução de Moishe Postone a seu Time, work and social domination, op. cit..

${ }^{515}$ Cf. Jürgen Habermas, Teoria do Agir Comunicativo, vol. 2: sobre a crítica da razão funcionalista. Tradução de Paulo Astor Soethe. São Paulo: WMF Martins Fontes, 2012, pp. 687-8.

516 O termo "marxismo tradicional" é de Postone. A interpretação que acentua o papel da tese de Pollock nos rumos tomados pela teoria crítica pode ser encontrada no posfácio escrito por Habermas para uma das edições da Dialética do Esclarecimento: Jürgen Habermas, "Nachwort". In: Max Horkheimer; Theodor W. Adorno, Dialektik der Aufklärung - Philosophische Fragmente. Frankfurt am Main: Fischer, 1986, p. 281. Dessa perspectiva partilharam, dentre outros, Helmut Dubiel, Wissenschaftsorganisation und politische Erfahrung, op. cit., pp. 97100; Moishe Postone no capítulo 3 de seu já citado Time, work and social domination; e John Abromeit, Max Horkheimer and the Foundations of the Frankfurt School, op. cit., pp. 410 ss. Entre nós, Marcos Nobre argumentou, de maneira semelhante (mas sem recorrer às extrapolações feitas por Habermas e Postone), que o
} 
As leituras feitas nesse sentido tendem a supor que Horkheimer até fins da década de trinta não teria extraído para sua teoria crítica todas as consequências necessárias da especificidade do capitalismo monopolista de sua época: não obstante consciente da nova fase do modo de produção, o autor teria desenvolvido sua crítica das ideologias com recurso a uma categoria básica, a de mercadoria, que havia sido adequada ao capitalismo concorrencial predominante no século XIX, mas que supostamente perdia força explicativa, dada a tendencial supressão do mercado e a preeminência da política na configuração da economia (um fenômeno do qual Horkheimer só teria extraído suas plenas consequências a partir do início da década de quarenta, sob a influência de Pollock). Essa interpretação, contudo, nos parece errônea, pois Horkheimer não apenas percebeu o profundo processo de reorganização da economia no período posterior à crise de 1929 (processo apoiado em uma mudança drástica do papel que nela tinha o Estado), mas também já sabia, na década de 1930, que o papel central da mercadoria na estruturação da totalidade social passava por uma alteração face à importância adquirida pelos mecanismos de dominação psicológica e política, dotados de legalidade própria em relação à infraestrutura econômica ainda que essa determinasse o rumo geral do processo histórico ${ }^{517}$. Antes de tratarmos do ensaio de Horkheimer sobre o "Estado autoritário" e mostrarmos as linhas de continuidade entre os argumentos ali desenvolvidos e algumas das ideias presentes nos textos publicados por Horkheimer nos anos trinta, examinemos brevemente o modo como a relação entre as tendências do capitalismo monopolista e as transformações pelas quais passou o Estado foram tematizadas por dois autores com os quais Horkheimer travou um diálogo a esse respeito: o economista Friedrich Pollock e o jurista e cientista político Franz Neumann.

A ideia defendida por Pollock na década de trinta de uma aparente autonomia da política (cf. acima) era diferente daquela do "primado da política" associado pelo autor, no texto de

programa do "materialismo interdisicplinar" havia se orientado, nos anos trinta, pela categoria da mercadoria: a crítica teria então incidido sobre a ilusão de que o capitalismo seria uma sociedade de indivíduos livres e iguais, uma ilusão que também exprimiria, dado o elemento de racionalidade da troca (a busca do interesse próprio), a possibilidade de superação dessa sociedade. A adoção da tese de Pollock do "primado da política", por sua vez, teria implicado o abandono dessa categoria, assim como das possibilidades de emancipação nela inscritas. Cf. Marcos Nobre, "Max Horkheimer: a teoria crítica entre o nazismo e o capitalismo tardio". In: Marcos Nobre (Org.). Curso Livre de Teoria Crítica. Campinas: Papirus, 2008, pp. 45-47. Não obstante terem os ensaios sobre o "Estado autoritário" e sobre "Razão e autoconservação" representado um momento de passagem na obra de Horkheimer (rumo à radicalização da crítica na Dialética do Esclarecimento) é preciso entretanto, a nosso ver, considerar em maior detalhe as linhas de continuidade entre a obra escrita nos anos trinta e esses textos (o próprio comentário de Marcos Nobre chama a atenção para a existência de linhas de continuidade entre os dois períodos). Como vimos no capítulo anterior, a compreensão de Horkheimer do fetichismo da mercadoria era dotada de uma especificidade, concernente à fase monopolista do modo de produção, que tornava para ele o fenômeno distinto de sua forma sob o capitalismo liberal.

517 Cf. o prefácio aos "Estudos sobre Autoridade e Família”, p. VIII, e também "Geschichte und Psychologie”, op. cit., p. 58. 
1941, ao "capitalismo de Estado". As análises do autor tomaram, com efeito, um outro rumo no início da década de quarenta: em vez de julgar ser o primado da política uma manifestação aparente da essência de uma sociedade dominada pela esfera econômica (um modo de produção), a tese do "capitalismo de Estado" consistia, nas palavras do autor, em um "modelo" ou "tipo-ideal" da tendência dominante do capitalismo da época, investigado por Pollock como um conjunto de fatores econômicos e políticos cujo entrelaçamento consistia em uma pluralidade causal na qual não haveria nenhuma esfera que de antemão sobrepujasse as demais. Sua conclusão era a ocorrência, àquela época, da passagem de uma "era econômica" para uma "era política"518. À época de Marx, o capitalismo liberal se caracterizara por basear a dominação na "coerção muda das relações econômicas", e o Estado exercera em primeiro lugar o papel de garantidor da circulação de mercadorias e da propriedade privada, e "apenas excepcionalmente" recorreria à violência direta, extra-econômica para garantir a subordinação dos trabalhadores aos capitalistas (a violência extra-econômica caracterizaria primordialmente os processos de acumulação primitiva de capital $)^{519}$.

Segundo Pollock, porém, a partir dos anos trinta a produção, a distribuição, a poupança e o investimento seriam cada vez mais dirigidos pelo Estado, os preços e salários seriam controlados e o lucro, ainda que apropriado privadamente pelos donos dos meios de produção, seria subordinado aos fins do planejamento estatal, que teria transformado o empresário individual em "mero rentista". Essa situação, de uma certa maneira, já havia sido prefigurada pela constituição das sociedades de ações e pela separação, no âmbito das empresas, entre o proprietário e o corpo administrativo ${ }^{520}$, e ainda que o mercado não fosse extinto a sua autonomia seria suprimida e ele se tornaria um "pseudo-mercado", que face o dirigismo estatal perderia o seu antigo papel de esfera reguladora da economia. Em consequência, também no que diz respeito às demais esferas sociais a mediação exercida pela mercadoria teria perdido sua centralidade: a "anarquia da produção", típica do século XIX, teria sido substituída por um "primado da política" e, se a divisão da sociedade em compradores e vendedores da força de trabalho trazia consigo um conjunto de normas legais abstratas e impessoais (o direito moderno) que valiam tanto para o proletariado quanto para a burguesia, e junto com ele uma ideologia da

\footnotetext{
${ }^{518}$ Cf. Friedrich Pollock, "State Capitalism", Studies in Philosophy and Social Sciences, 1941, p. 207. Sobre o caráter de "modelo" ou "tipo-ideal" do "capitalismo de Estado", cf. a página inicial e a primeira nota de rodapé do texto, que foi publicado em 1941 no vol. IX da Revista e suscitou discussões entre o autor e Neumann, Kirchheimer, Gurland e Marcuse (uma discussão que em parte está documentada no mesmo vol. IX da Revista e que havia ocorrido também no debate promovido pelo Instituto, na Universidade de Columbia, sobre a natureza do nacional-socialismo).

${ }^{519}$ Cf. o capítulo de Marx sobre a "acumulação primitiva”: Karl Marx, O Capital - crítica da Economia Política. Tradução de Regis Barbosa e Flávio Kothe. São Paulo: Abril Cultural, 1983, volume 1 - tomo 2, p. 277.

${ }^{520}$ Cf. Friedrich Pollock, "State capitalism", op. cit., pp. 209-210.
} 
liberdade e da igualdade cuja crítica poderia ser um elemento da luta dos trabalhadores para pôr fim à exploração oculta pela forma fetichizada do salário, na nova fase do modo de produção o excedente seria apropriado diretamente (sem a mediação da mercadoria) e os trabalhadores e empresários se tornariam algo próximo a funcionários do Estado: como o mercado não seria mais autônomo em relação ao Estado, os indivíduos que, sob o capitalismo liberal, eram em primeiro lugar "compradores" e "vendedores" de mercadorias ("máscaras econômicas", na expressão de Marx), se dividiriam a partir de então primordialmente entre "comandantes e comandados" ${ }^{\prime 21}$. O protagonismo exercido pelo Estado excluía a centralidade da circulação de mercadorias para o processo social de produção e a pertinência de se recorrer à tese da exploração do trabalho para criticar os conceitos da economia política, do que Pollock concluía estar em causa o conceito de "valor" 522.

Ressaltado o caráter hipotético desse "capitalismo de Estado", sublinhado por Pollock logo no início de deu artigo, de seu surgimento resultaria uma fase completamente diferente do modo de produção, que estaria em processo de transição de uma era predominantemente econômica a uma era em que a política deteria o primado sobre as demais esferas sociais: o Estado seria o maior capitalista, e por isso estavam de certa maneira desmentidas as previsões de que o crescimento das forças produtivas e sua concentração cada vez maior permitiriam um "crescer socialismo adentro" [Hineinwachsen in den Sozialismus], tal qual havia sido acalentado pela social-democracia alemã ${ }^{523}$. As reflexões de Pollock sobre o "capitalismo de Estado" e de Horkheimer sobre o "Estado autoritário" são por isso, ainda que não apenas, objeções à tese formulada por Engels de que o desenvolvimento das forças produtivas conduziria, por meio da concentração de capital, a uma situação em que o Estado se tornaria o “capitalista total" que exploraria os trabalhadores assalariados: na visão de Engels, essa seria a última forma da exploração, à qual a classe trabalhadora poderia pôr fim por meio da tomada do Estado e de sua subordinação a seu comando. Como o tipo de capitalismo descrito por Pollock seria dotado de coesão e portanto relativamente imune a crises, um certo grau de pessimismo era inerente à tese, pois ela supunha que o desenvolvimento técnico teria conduzido, não ao socialismo, mas a um tipo de capitalismo relativamente estável e duradouro,

\footnotetext{
${ }^{521}$ Cf. Friedrich Pollock, "State Capitalism", op. cit., p. 207.

522 Isso foi, contudo, apenas sugerido pela análise de Pollock, e o autor expressamente afirmava ser temerário declarar que teria perdido sua objetividade o conceito de "valor". Cf. a nota de rodapé à p. 217. Neumann, por sua vez, criticou a tese de Pollock em primeiro lugar por seu caráter assumidamente hipotético, que a tornaria indigna de crédito. Cf. a carta de Neumann a Horkheimer de 23 de julho de 1941, no volume 17 das Gesammelte Schriften de Horkheimer, pp. 103-104.

${ }^{523}$ Cf. Friedrich Pollock, "State capitalism”, op. cit., pp. 204-207 e passim. Cf. também o comentário de Fernando Rugitsky, "Friedrich Pollock - Limites e Possibilidades", op. cit., pp. 65-68.
} 
capaz de manter sob seu controle as massas de trabalhadores. O ensaio de Horkheimer, aliás, não por acaso havia sido incluído no livro em homenagem a Walter Benjamin, ao lado de suas teses "sobre o conceito de história", em que o autor rejeitava o recurso, para pensar sobre a história, ao conceito espacializado de tempo (homogêneo e vazio), próprio da ciência natural moderna, a esse contrapondo o tempo qualitativo do "agora", capaz de propiciar a recordação e, com ela, uma interpretação do passado que permitisse o salto para fora do continuum da história, para o futuro. A revolução não seria, portanto, a consequência de um curso lógico ${ }^{524}$. Era como se a crítica de Benjamin à ideologia do progresso cultivada pela social-democracia alemã (e à sua crença, influenciada por correntes filosóficas positivistas e evolucionistas, em um percurso linear rumo ao socialismo) fosse secundada pela tese de Horkheimer de que a concentração de capital nos países europeus havia conduzido não ao socialismo, mas apenas a um "capitalismo de Estado", e que a sociedade soviética da época havia se tornado apenas uma das formas desse (o "estatismo integral") ${ }^{525}$.

Na versão de Pollock, o "capitalismo de Estado" poderia assumir configurações diferentes em meio a dois extremos: a forma "democrática", em que o Estado seria sujeito ao controle popular, e a forma "totalitária", na qual ele seria um mero instrumento do domínio exercido sobre a população pelo grupo dominante. A primeira forma ainda estaria presente apenas em germe, no âmbito do "New Deal" norte-americano, ao passo que a segunda corresponderia à Alemanha nazista. A União Soviética também se aproximava do "capitalismo de Estado", e ainda que o autor cautelosamente afirmasse que a abolição da propriedade privada dos meios de produção impedia que o país fosse considerada um caso do modelo, a tese havia sido escrita principalmente tendo em vista a suposta semelhança da jovem nação com as outras duas $^{526}$. No caso da Alemanha, o grupo dominante seria constituído não apenas a partir das relações de produção, e sim, em maior medida, por meio do acesso a poder e prestígio social: os quatro grupos sociais sobre os quais se apoiaria o Estado nazista eram "as grandes corporações, o exército, o partido e a burocracia" e, se durante o capitalismo concorrencial a

\footnotetext{
${ }^{524}$ Cf. Walter Benjamin, "Sobre o conceito de história”. In: Walter Benjamin, Obras escolhidas - vol. 1: Magia e técnica; arte política - ensaios sobre literatura e história da cultura. Tradução de Sérgio Paulo Rouanet. São Paulo: Brasiliense, 1987, pp. 22-232.

${ }^{525}$ Max Horkheimer, “Autoritärer Staat”, op. cit., pp. 300-301; sobre a perspectiva de Engels, cf. as páginas 293 294 do mesmo texto. O tratamento do caso da União soviética como um exemplo de capitalismo de Estado transparece claro em um texto publicado por Horkheimer em 1939 sobre "Os judeus e a Europa": segundo o autor, o bolchevismo "hipostasiaria teoricamente a forma da socialização da propriedade e, na prática, não conseguiria deter sob seu controle a monopolização do aparelho produtivo. Não consiste nenhuma antítese essencial o fato de o Estado receber o seu quinhão sob o título de dividendos privados sujeito às regulação ou, de maneira direta, sob a forma dos honorários dos funcionários públicos", Cf. Max Horkheimer, "Die Juden und Europa", Zeitschrift für Sozialforschung, vol. 9, 1939-1940, p. 120.

${ }^{526}$ Cf. Friedrich Pollock, "State capitalism”, op. cit., pp. 223-225, e também p. 218 e a nota de rodapé à p. 221.
} 
propriedade e a renda tinham efeitos sobre a mobilidade social, no capitalismo de Estado o poder e o prestígio dependeriam em primeiro lugar das relações dos indivíduos com o governo e a burocracia partidária, pois mesmo que a posse de riqueza facilitasse o acesso a posições poder, o decisivo aí seria o vínculo com o partido e os órgãos do Estado ${ }^{527}$. De certa maneira, o capitalismo de Estado representaria um retorno ao tipo de dominação direta, não mediada pela mercadoria, característico do modo de produção feudal ${ }^{528}$.

De acordo com a situação histórica e a forma específica do capitalismo de Estado, a economia seria tendencialmente de pleno emprego e capaz de proporcionar um elevado padrão de vida aos principais grupos sociais ou, quando isso não constasse do plano geral, manteria os trabalhadores em um estado permanente de economia de guerra, em que a obediência fosse conseguida pela propaganda política e pelo terror ${ }^{529}$. No caso da espécie "totalitária" do capitalismo de Estado, a integração desses grupos seria feita por meio do acesso a bens de consumo de diversas ordens, dentre os quais se encontravam não apenas os produtos da indústria fordista de recente formação, mas também a satisfação psicológica pela possibilidade oferecida as trabalhadores de exercer seu sadismo contra as minorias (judeus e homossexuais, dentre outros perseguidos pelo regime) e o prazer proporcionado pelas mudanças na moralidade sexual incentivadas pelo regime nazista ${ }^{530}$.

Mas Pollock não explicava que processos trouxeram à tona essa nova forma de dominação, e não se perguntava pelas possibilidades que, nela inscritas, poderiam deixar entrever a possibilidade de sua superação rumo a uma sociedade emancipada: ele meramente se limitava a perguntar pelas possibilidades de instaurar a forma democrática, que seria o modelo preferível, pois nela haveria a possibilidade de subordinar o poder ao controle popular. Ela já estaria em curso nos Estados Unidos (país em relação ao qual, note-se, apenas de modo bastante restrito seria possível falar de um “controle popular") e a ela poderia levar a luta política durante a guerra e depois dela. No que diz respeito às possibilidades de a forma totalitária de dominação sucumbir, contudo, suas perguntas eram igualmente abstratas: além de sugerir que as disputas internas ao grupo dominante poderiam ocasionar conflitos insolúveis que ameaçassem o sistema, ele imaginava o que aconteceria em uma situação de paz mundial na qual a guerra não mais pudesse servir de estímulo à expansão da produção e à subordinação

\footnotetext{
${ }^{527}$ Talvez por isso Pollock alterne os termos "classe dominante" e "grupo dominante".

${ }^{528}$ Cf. Friedrich Pollock, "State capitalism”, op. cit., p. 207 e p. 223.

${ }^{529}$ Cf. Friedrich Pollock, "State capitalism", op. cit., p. 210.

${ }^{530}$ Cf. Friedrich Pollock, "Is National Socialism a New Order?”, Studies in Phiosophy and Social Sciences, vol. 9 , 1941, pp. 448-449. As mudanças na moralidade sexual a que Pollock se refere diziam respeito ao incentivo que os nazistas davam à frequência a maior possível nas relações sexuais, conjugais e extra-conjugais, como meio de aumentar a população e dessa maneira atender às finalidades imperialistas do regime.
} 
dos trabalhadores, que em uma situação de estabilidade poderiam se beneficiar do bem-estar material promovido pelo Estado e se sublevar em busca de maior liberdade, empreendendo um movimento inverso àquele imaginado pela teoria do colapso e pela previsão da ocorrência da revolução em seguida à crise. Essa possibilidade, contudo, não era vinculada a nenhuma tendência histórica concreta, e a tese de Pollock previa a estabilidade de um tipo de capitalismo do qual a crise estaria potencialmente excluída ${ }^{531}$.

No âmbito do Instituto, destacou-se como contraponto às ideias de Pollock o trabalho de Franz Neumann. Assim como Pollock, Neumann constatava a existência de um Estado totalitário na Alemanha, que apoiado em um grupo dominante composto pelo exército, pela burocracia civil, pelo partido e pelos empresários monopolistas havia não apenas abolido os partidos políticos e destituído de poder os sindicatos, mas também suprimido o mais básico direito econômico, a liberdade de contrato, em favor da intervenção estatal direta por meio de atos administrativos ${ }^{532}$. Mas Neumann rejeitava a tese do "capitalismo de Estado" e via nela a desconsideração do caráter capitalista dessa sociedade: em oposição a Pollock considerava que o nazismo deveria ser entendido como uma variante "autoritária" do capitalismo monopolista, uma variante na qual a abolição das liberdades civis, políticas e econômicas havia sido feita justamente para garantir a sobrevivência dos cartéis e a expansão imperialista da grande indústria, de maneira a ampliar o mercado de seus produtos. A necessidade do regime totalitário adviria, portanto, da impossibilidade de se empreender uma política de expansão militar sob o

\footnotetext{
${ }^{531}$ Friedrich Pollock, "State Capitalism", op. cit., pp. 215-220. A falha em ter previsto a possibilidade de crises econômicas e políticas (ou crises sistêmicas) é recorrentemente citada nas críticas ao modelo de "capitalismo de Estado" concebido por Pollock, e foi acusada, por exemplo, por Moishe Postone em seu Time, work and social domination. p. 96, e por Joachim Hirsch em "Staatskapitalismus? Zur Kontroverse zwischen Friedrich Pollock, Max Horkheimer und Franz Neumann in Bezug auf den Charakter des nationalsozialistischen Systems". In: Ulrich Ruschig; Hans-Ernst Schiller (Orgs.) Staat und Politik bei Adorno und Horkheimer, op. cit., pp. 62-63. Elas estão prefiguradas na crítica feita por Adorno à "hipótese totalmente antidialética de que em uma sociedade antagônica seja possível uma economia não antagônica". Cf. a carta de Adorno a Horkheimer de 8 de junho de 1941, às páginas 53 e ss. do vol. 17 das Gesammelte Schriften de Horkheimer. O já citado comentário de Fernando Rugitsky também confirma essa lacuna. Cf., do autor, "Friedrich Pollock - limites e possibilidades", op. cit., pp. 68-69. Moishe Postone criticou a tese de "capitalismo de Estado" de Pollock por ser "estática" e, seguindo uma indicação feita pelo próprio Pollock na primeira página de seu artigo, por se basear em "tipos-ideais" pouco capazes de abrigar a mudança histórica. Cf. Moishe Postone, Time, work and social domination, p. 96. Especificamente sobre a questão dos "tipo-ideias" é preciso fazer algumas considerações: a crítica de Postone parece correta, mas somos levados a crer, adicionalmente, que Pollock talvez devesse ter empregado apenas a expressão "modelos", dada a especificidade do sentido do "tipo-ideal" na reflexão metodológica de Weber. Como Neumann de maneira correta ressaltou em carta enviada a Horkheimer em 23 de julho de 1941, o "tipo-ideal" é uma abstração feita a partir da realidade, e não um modelo que a transcende e a ela pode ser oposto pela teoria. Em sua resposta de 2 de agosto do mesmo ano, Horkheimer defendeu Pollock das críticas de Neumann, dentre elas dessa crítica específica quanto à incompreensão do conceito de "tipo-ideal". Mas nesse ponto Horkheimer parece ter errado, pois afirmava que os tipos-ideais “(...) formam utopias, belas ou feias, sob as quais a realidade é medida”. Cf. Max Horkheimer, Briefwechsel 1941-1948, vol. 17 das Gesammelte Schriften, p. 104 e p. 116 respectivamente. A partir meramente de cartas não é possível, contudo, reconstruir nenhuma discussão sólida a esse respeito.

${ }^{532}$ Franz Neumann, Behemoth: The Structure and Practice of National Socialism, 1933-1944. Oxford, University Press, 1944. pp. 213-214.
} 
Estado democrático de Weimar, e consistiria na "resolução pela guerra imperialista da discrepância entre as potencialidades do aparato industrial da Alemanha e a realidade" 533 .

Chamando a atenção para a relativa independência das empresas privadas face o poder estatal, o autor explicava que a intervenção direta do Estado nas empresas não ameaçava os interesses dos proprietários individuais, deixados intocados em virtude da limitação das empresas estatais a áreas estratégicas (eletricidade e petróleo) e de um planejamento econômico plurianual que incidia principalmente sobre a indústria armamentista, e nem tanto sobre aquela de bens de consumo ${ }^{534}$. Dessa maneira, o caráter totalitário do Estado não se sobreporia aos interesses da burguesia monopolista, e o autor discordava de Pollock quanto ao suposto desaparecimento do mercado autônomo, argumentando ser ainda presente a sua função reguladora: o valor de troca das mercadorias não teria, portanto, cedido lugar a meros valores de uso administrados pelo Estado. A exploração, segundo Neumann, continuaria a ter um caráter econômico, pois baseada na extração de mais-valia, e não haveria se tornado meramente "política". O autor negava, por isso, que se estaria vivendo uma nova fase histórica, baseada no primado da dominação política: embora a propaganda e a identificação entre as massas e os líderes fascistas fossem importantes técnicas de dominação, a dinâmica econômica mundial, dada pelo imperialismo, continuava a exercer o papel decisivo na estrutura social e política, e seria um erro tomar a intervenção direta dos grupos dominantes na produção pelo fim da exploração de classe ${ }^{535}$. Mas Neumann não conseguia explicar a forma autoritária que o Estado havia assumido sob o nazismo: preso à ideia, válida para o capitalismo liberal, de que o Estado repousaria sobre um conjunto de normas universais e impessoais, o autor explicava a forma assumida pela dominação sob o "capitalismo monopolista autoritário" como o controle direto daqueles quatro grupos de poder mencionados sobre a população, e defendia que sob o nazismo teria constituído uma espécie de "não-Estado" [Unstaat], caracterizado pela dissolução das normas jurídicas e pelo exercício direto da violência ${ }^{536}$. A concentração de capital na fase monopolista teria exigido a instituição de uma "economia de comando" em que o Estado teria sido na prática substituído por meras estruturas de poder: dada a ineficácia do Estado liberal para o atendimento dos interesses da burguesia monopolista, esses interesses teriam levado à

\footnotetext{
${ }^{533}$ Franz Neumann, Behemoth, op. cit., p. 40. Sobre as divergências entre Pollock e Neumann, cf. Rolf Wiggershaus, A Escola de Frankfurt, op. cit., p. 312 e ss.

${ }^{534}$ Franz Neumann, Behemoth, op. cit., pp. 289-293. Conferir onde estão as informações sobre esses setores da indústria.

535 Franz Neumann, Behemoth, op. cit., p. 182, pp. 184-185. Ao tomar as manifestações mais aparentes do capitalismo pelo fim da exploração e pelo início de uma era histórica baseada na dominação técnica, em erro semelhante incorreriam, algumas décadas mais tarde, as teses sobre o "fim do trabalho" e sobre a "sociedade pósindustrial", defendidas a partir de fins dos anos sessenta.

${ }^{536}$ Franz Neumann, Behemoth, op. cit., pp. 383-384.
} 
aniquilação da instituição estatal, e por isso Neumann, refém de uma concepção rígida de Estado, que não contemplava a dialética entre as mudanças econômicas e a nova forma de dominação política, considerava o nacional-socialismo como uma espécie de caos anárquico ${ }^{537}$.

Surgia aqui, até onde pudemos seguir o argumento do autor, ao que tudo indica uma contradição: se Neumann sustentava que o poder era exercido diretamente pelo grupo dominante sobre a população, como poderia ao mesmo tempo defender a tese de permanência de uma esfera econômica autônoma? Cremos que, ao se deter exclusivamente sobre a permanência da propriedade privada dos meios de produção, aos lucros e ao atendimento, pelo nacional-socialismo, dos interesses da burguesia monopolista, o autor deixou de considerar que os lucros auferidos pela burguesia monopolista podiam muito bem conviver com a supressão da autonomia do mercado (por meio da mudança de função dos preços, salários e lucros, controlados por aquilo que o próprio Neumann chamava de "economia de comando"). O que unia a ambos e garantia os interesses burgueses - ainda que a dominação política se desse sob uma forma que não era instrumentalizável pela burguesia e desse margem a conflitos internos no âmbito do grupo dominante - era a transformação da exploração de classe, por meio do deslocamento da realização da mais-valia para a circulação de mercadorias no plano internacional (e portanto com a tendencial redução da exploração do trabalho no âmbito nacional a uma exploração direta, em que a mercadoria tendencialmente se convertia em mero valor de uso, mera dominação imediata que deixava a descoberto seu caráter irracional) ${ }^{538}$. Esse deslocamento era garantido por uma forma de dominação que, ao contrário do "não-Estado" anárquico e conflitivo de Neumann, se revelava uma forma de dominação coesa e capaz de manter sob controle os conflitos que surgiam na base econômica (entre os líderes das indústria e seus comandados) e também entre as distintas frações do grupo dominante (os industriais, a burocracia civil, o exército e o partido).

\footnotetext{
${ }^{537}$ Daí a denominação "Behemoth", em referência ao monstro bíblico ao qual Hobbes havia associado à guerra civil inglesa e à desordem, em oposição ao Leviatã, o Estado que manteria os indivíduos sob controle por meio da lei. Cf. Franz Neumann, Behemoth, op. cit., p. 5. É preciso notar, contudo, que o pensamento de Neumann vem sendo objeto de uma recepção que, divergente de nossa leitura, tem sido inspirada pela noção de Axel Honneth segundo a qual Neumann pertenceria a um "círculo externo" dos membros do Instituto de Pesquisa Social, formado por Neumann, Kirchheimer. Benjamin e também por Fromm em sua fase de exílio norte-americano: as obras desses autores não padeceriam das supostas deficiências a acometer as reflexões dos membros do "círculo interno", composto por Horkheimer, Adorno e Pollock. Cf. Axel Honneth, "Teoria Crítica". In: Anthony Giddens; Jonathan Turner (Orgs.). Teoria Social Hoje. Tradução de Gilson César Cardoso de Sousa. São Paulo: Unesp 1996, pp. 524536. Um estudo que, seguindo essa trilha, ressalta os potenciais da obra de Neumann para se pensar a democracia é o artigo de José Rodrigo Rodriguez, "Franz Neumann, o direito e a teoria crítica". Lua Nova. São Paulo, n. 61, 2004, pp. 53-73.

${ }^{538}$ Cf. Max Horkheimer, “Autoritärer Staat”, pp. 301-302.
} 
Quanto a esses conflitos, as diferenças de Neumann em relação a Pollock também se faziam notar no que dizia respeito às possibilidades de superação dessa fase do capitalismo. Em oposição à ausência de perspectivas de superação do "capitalismo de Estado", Neumann sustentava que o antagonismo básico entre capitalistas e trabalhadores continuava a operar sob o nazismo, e que a ideia do "primado da política" sobre a economia correspondia, no fundo, à ideologia pseudo-anticapitalista defendida pelos nazistas ${ }^{539}$. O autor tinha, entretanto, uma concepção instrumentalista de ideologia: segundo ele, a ideologia da "comunidade popular" cultivada pelo partido nazista em sua relação com as massas era um "papo furado" [em inglês, bunk $]^{540}$, que não conseguiria por muito tempo impedir o advento da insatisfação das massas oprimidas. Neumann apostava que o próprio caráter do desenvolvimento técnico - no qual os defensores da tese do capitalismo de Estado viam a base do planejamento estatal e a fonte da coesão social - conteria em si contradições que permitiriam a formação de uma ideologia contrária àquela dominante: isso ocorreria, segundo o autor, porque o processo de produção seria em si racional, em oposição à ideologia racista e nacionalista central ao regime, uma ideologia de caráter "mágico" e, por isso, tendente a sucumbir diante da progressiva racionalização da vida social fomentada pela própria forma autoritária de dominação. Ecoando as teses de Lukács, Neumann apostava na crescente racionalização do processo de trabalho e na reificação do trabalhador como condição para o surgimento da consciência de uma classe capaz de apreender as possibilidades de transformação da totalidade: os trabalhadores qualificados e os engenheiros, imprescindíveis ao regime e, segundo Neumann, vocacionados para a eficiência e o controle racional da produção, representariam o maior potencial de contradição com as relações de produção vigentes, pois a eles se apresentaria em cada vez maior profundidade o "antagonismo entre a ideologia pseudo-socialista [do nacional-socialismo] e a nudez dos fatos do capitalismo monopolista autoritário"541. Seria possível, portanto, segundo Neumann, que esses setores desenvolvessem uma consciência de classe e a partir de algum momento contrapusessem à ideologia dominante uma outra ideologia, afinada com a racionalidade da produção ("uma ideologia correspondente aos processos racionais de trabalho" ${ }^{, 52}$ ) e capaz de conduzir a um uso racional o potencial técnico à época empregado pelos grupos dominantes como forma de dominação, tanto na guerra quanto no controle interno das massas por meio do terrorismo. Essa possibilidade, como se sabe, não se concretizou, assim

\footnotetext{
${ }^{539}$ Franz Neumann, Behemoth, op. cit., pp. 188-190.

${ }^{540}$ Franz Neumann, Behemoth, op. cit., pp. 385.

${ }^{541}$ Franz Neumann, Behemoth, op. cit., pp. 386-387.

${ }^{542}$ Franz Neumann, Behemoth, op. cit., p. 385.
} 
como não foram os conflitos no interior do grupo dominante que levaram à derrota do nazismo. Neumann não percebeu, portanto, que a dominação era garantida por formas de ideologia e de Estado que garantiam uma razoável coesão interna, e que a contradição entre valor de uso e valor de troca não poderia ser uma fonte de disrupção do regime, pois havia sido transferida, como Horkheimer e também Pollock já haviam percebido desde o início da década de trinta, para o âmbito internacional ${ }^{543}$.

A impressão que resulta das leituras dos textos de Pollock e Neumann é que o primeiro, economista, hipostasiou o Estado, desconsiderando sua imbricação com os processos econômicos e os interesses da burguesia monopolista ao supor um "primado da política" independente da dinâmica econômica mais profunda, ao passo que o segundo, jurista, hipostasiou a economia, deduzindo o fim do Estado liberal da concentração crescente de capital e sendo incapaz de perceber que o Estado assumia uma nova forma e não havia se dissolvido sob o exercício direto do poder pelos grupos dominantes ${ }^{544}$. Horkheimer concebia esses processos de uma maneira diferente, e como veremos o autor incorporou criticamente elementos das teses de ambos, superando as suas deficiências, que em boa parte se deviam à abstração do conjunto de fenômenos analisados em relação ao processo histórico mais amplo. Nesse sentido, pode-se afirmar que Horkheimer empreendeu por meio desse diálogo uma crítica da "teoria tradicional", tal qual previra no programático ensaio de 1937, “Teoria tradicional e teoria crítica" $" 545$.

\footnotetext{
${ }^{543}$ Horkheimer nunca depositou confiança na tese de Lukács segundo a qual a racionalização dos processos de trabalho e a transformação do trabalhador em mera mercadoria conteria em si a possibilidade de superação da reificação. Em texto de 1935, ele afirmava: "essa igualdade [entre os explorados] não significa que, em virtude do processo de racionalização do processo de trabalho, cada um tenha uma visão geral do todo e encontre conservados [aufgehoben] nele seus objetivos, e sim significa a igualdade negativa diante do poder que não conhece diferenças" ("Bemerkungen zur philosophischen Anthropologie", vol. 4 da Zeitschrift für Sozialforschung, 1935, p. 23).

544 Aparentemente, em seu texto publicado em 1937 na Revista de Pesquisa Social, "Der Funktionswandel des Gesetzes im Recht der bürgerlichen Gesellschaft", Neumann desenvolvera uma perspectiva mais dialética da relação entre o Estado e os processos econômicos. De maneira semelhante, como vimos, Pollock tinha no início dos anos trinta uma concepção dialética da relação entre a economia e a política, abandonada em seu texto de 1941 sobre o "capitalismo de Estado". É como se, com o passar dos anos, tanto um autor quanto o outro tivessem recaído, respectivamente, em economicismo e politicismo. É preciso reconhecer, contudo, que é possível que a obra de Neumann mereça um exame mais profundo do que aquele que foi possível de fazer aqui, e que considere a sua obra escrita nos anos trinta, anteriormente à publicação de Behemoth. Agradecemos ao Prof. Rúrion Soares Melo, do Departamento de Ciência Política da FFLCH-USP, pelas observações feitas nesse sentido no III Seminário Discente da Pós-Graduação em Sociologia da USP (setembro de 2017), em que este capítulo tese foi apresentado.

545 Nessa relação, os conhecimentos das ciências especializadas, que representariam abstrações do todo social produzidas pelo processo de divisão social do trabalho, seriam postos em relação uns com os outros de maneira a se obter uma teoria capaz de expor as transformações históricas pelas quais passa seu objeto, a sociedade. Cf. Max Horkheimer, "Traditionelle und kritische Theorie", vol. de 1937 da Zeitschrift für Sozialforschung, p. 263 e p. 279.
} 
5.2 - O "Estado autoritário" de Horkheimer: diferenças e semelhanças em relação às teses de $\underline{\text { Pollock e Neumann }}$

Em suas "Observações sobre a antropologia filosófica", Horkheimer discorria, dentre outros assuntos, sobre o desaparecimento de alguns dos elementos característicos da moralidade burguesa vigente de maneira geral até fins do século XIX:

"Enquanto nos últimos séculos fez parte da manutenção do comércio o
fato de as promessas serem mantidas sem a intromissão do poder, ou ao
menos sem sua intromissão contínua, entrementes essa necessidade
diminuiu. A camada dominante não consiste mais de inúmeros sujeitos
que celebram contratos, mas de grandes grupos de poder, controlados
por poucas pessoas e que concorrem uns com os outros no mercado
mundial. Com férrea disciplina, eles transformaram vastas áreas da
Europa em imensos campos de trabalho. Quanto mais a concorrência
no mercado mundial se converte em mera luta pelo poder, maior a
rigidez com a qual eles se estruturam e se organizam dentro e fora. O
fundamento econômico da relevância das promessas se torna, por isso,
a cada dia mais estreito. Pois agora não é mais o contrato que caracteriza
o comércio interno, e sim, em medida crescente, o poder de mando e a
obediência". ${ }^{546}$

No ensaio, publicado na edição de 1935 da Revista de Pesquisa Social, o autor assinalava a redução da importância da esfera da circulação, o que significava a substituição da relação de troca de mercadorias em favor de relações mediadas por estruturas de comando, e deixava entrever, de maneira bastante condensada na passagem citada, aqueles que seriam os elementos centrais da fase mais recente do capitalismo monopolista: as mudanças na forma do Estado (que passou a se sobrepor ao mercado), o imperialismo, e, no que diz respeito à estrutura de classes, de um lado a liquidação das empresas individuais e a transformação dos burgueses em acionistas de grandes corporações, de outro, a redução do proletariado a uma "massa" de trabalhadores, submetidos à rigidez dos processos de trabalho e destituídos de solidariedade de classe. Rastreamos a seguir esses temas nos ensaios do autor, tomando por eixo o já mencionado "Estado autoritário". Ao fazê-lo, perceberemos que nos ensaios de Horkheimer assumiu dimensões históricas mais profundas aquilo que Pollock, em seus textos publicados em 1941, conceberia como "capitalismo de Estado", apresentado de maneira estática tanto como uma descrição da fase específica pela qual passava o modo de produção capitalista na Alemanha da época ${ }^{547}$, quanto como um modelo de uma tendência mundial aparentemente inescapável, e da

\footnotetext{
${ }^{546}$ Cf. Max Horkheimer, "Bemerkungen zur philosophischen Anthropologie", Gesammelte Schriften, vol. 3, p. 264.

${ }^{547}$ Cf. Friedrich Pollock, "Is National Socialism a New Order?", op. cit..
} 
qual a versão "democrática" seria a preferível ${ }^{548}$, e em ambos os casos de maneira a supor que a primazia e independência assumidas pelo Estado produziriam um sistema auto-regulatório e imune à crise. Se por um lado a interpretação de Horkheimer concordava em sua maior parte com a tese do "capitalismo de Estado", por outro lado a adoção pura e simples dessa tese significaria perder de vista diversos dos problemas que o modelo de Pollock acarretava, e para os quais acreditamos que a interpretação de Horkheimer forneceu respostas mais consistentes $^{549}$.

Em seu ensaio sobre o "Estado autoritário", é possível constatar, é verdade, a incorporação das descrições principais de Pollock sobre o capitalismo de Estado, principalmente no que dizia respeito à mudança de função do mercado, subordinado ao planejamento estatal. Essa situação correspondia a uma radicalização dos traços gerais da fase do capitalismo monopolista que se seguiu à crise de 1929, e que já haviam sido objeto da atenção de Pollock em seus textos da década de trinta, como vimos anteriormente. A partir de 1940, tanto ele quanto Horkheimer passavam a considerar como elemento central dessa nova fase a tendencial supressão da esfera da circulação, reduzida a meros "resíduos", ou a um "pseudo-mercado": a produção e a distribuição de mercadorias (uma denominação, acrescentamos, que se tornava sujeita à dúvida) teria passado a ser feita ou pelo próprio Estado, ou então por trustes financeirizados que seguiam o plano econômico estatal ${ }^{550}$. Mas não parece haver razão para assimilar as ideias de um autor às do outro, e traços bastante significativos distinguem o "Estado autoritário" de Horkheimer do "capitalismo de Estado" de Pollock.

Em primeiro lugar, Horkheimer recorria a processos históricos não considerados por Pollock em seu modelo, e que eram pressupostos necessários à tese do "capitalismo de Estado"

\footnotetext{
${ }^{548}$ Cf. Friedrich Pollock, "State Capitalism", op. cit., pp. 223-225.

${ }^{549}$ As diferenças entre Horkheimer e Pollock podem ser notadas, como têm ressaltado os comentadores, antes de tudo já na hesitação do diretor do Instituto em aceitar a tese de seu colega, o que se depreende da leitura das cartas trocadas entre Horkheimer e Adorno, e também entre Horkheimer e Neumann: Adorno advertira Horkheimer contra a "suposição totalmente não-dialética de que em uma sociedade antagônica seja possível uma economia não antagônica", e Neumann sustentava que a Alemanha ainda estaria muito distante do que Pollock descreveu como "capitalismo de Estado", essa hipótese não passando de um modelo de um possível desenvolvimento futuro, mas que à época ainda tinha pouca base histórica. Cf. a carta de Adorno a Horkheimer de 8 de junho de 1941, e a carta de Neumann a Horkheimer de 23 de julho do mesmo ano no volume 17 das Gesammelte Schriften de Horkheimer, especialmente as páginas 54 e 104. Aparentemente, o ensaio de Horkheimer foi escrito antes, e dele Pollock teria retido alguns dos elementos (o papel do Estado e o desaparecimento da esfera da circulação), desprezando contudo as relações históricas estabelecidas por Horkheimer entre o Estado autoritário, o imperialismo e as transformações na estrutura de classes. As indicações de Adorno a esse respeito são bastante claras: “(...) os temas do ensaio de Fritz [Pollock] provêm com certeza do seu, e estão meramente simplificados e desdialetizados de uma tal maneira que os inverte em seu contrário". Adorno sugeria, por isso, que ambos os textos fossem publicados conjuntamente, e que essa seria a melhor maneira de exprimir a visão do grupo, à qual o texto de Pollock por si só não faria justiça. Cf. a carta de Adorno a Horkheimer de 8 de junho de 1941 no referido volume 17, p. 55, e também o estudo de Rolf Wiggershaus, A Escola de Frankfurt, p.?

${ }^{550}$ Max Horkheimer, “Autoritärer Staat”, op. cit., p. 293.
} 
- tal era o caso do imperialismo e das transformações sofridas ao longo do capitalismo monopolista pela estrutura de classes ${ }^{551}$. Horkheimer conseguia dessa maneira explicar, ao contrário de Pollock, o capitalismo de Estado como uma continuação modificada do capitalismo liberal. Ao fazê-lo, se por um lado compartilhava com Pollock a tese da supressão da autonomia do mercado interno sob o poder do Estado, Horkheimer por outro lado concordava com Neumann quanto à continuidade da exploração econômica nessa fase mais recente do capitalismo monopolista e também em relação à centralidade assumida pelo imperialismo. Contudo, ao contrário de Neumann, Horkheimer não reduzia a permanência da esfera econômica ao lucro obtido pelos empresários, e sim associava a mais-valia ao Estado, responsável pela forma praticamente direta assumida pela exploração e também pela garantia da circulação de mercadorias no plano internacional, âmbito no qual a mais-valia se realizaria $^{552}$. O autor se aproximava, assim, da compreensão de Neumann quanto ao papel da burguesia monopolista na instauração de uma forma de dominação que servia a seus interesses, mas conseguia ao contrário de Neumann perceber que o Estado o fazia ao se autonomizar em relação a essa classe e ao incorporar em seu âmbito outros grupos de poder (o que Neumann interpretava de maneira diversa, com sua teoria do "não-Estado") ${ }^{553}$. Em segundo lugar, veremos como Horkheimer conseguiu, por isso, iluminar a relação entre os interesses da burguesia monopolista, o desenvolvimento das forças produtivas na fase taylorista-fordista e a nova forma assumida pelo Estado, uma relação cuja interpretação pelo autor pode ser vista como mais uma contribuição especificamente sua ao debate. Para Pollock, a relação entre o desenvolvimento técnico e a forma do Estado seria aleatória: "totalitária" ou "democrática" de acordo com as possibilidades da ação política. Neumann, por sua vez, tinha dificuldade em explicar a relação, pois tinha, como vimos, além de uma concepção das forças produtivas como "racionais em si", uma concepção de Estado presa ao modelo liberal da universalidade e impessoalidade das normas jurídicas, e por isso supunha que o Estado tivesse se dissolvido frente aos interesses dos grupos dominantes e se tornado um "não-Estado". Horkheimer, por sua vez, teorizou sobre a relação entre o desenvolvimento técnico, os interesses da burguesia monopolista e a forma de dominação política de uma maneira que escapou a ambos os autores, e percebeu, ao enfatizar os papéis de dominação exercidos pela "burocracia” e pela "técnica",

\footnotetext{
${ }^{551}$ Horkheimer, “Autoritärer Staat”, op. cit., pp. 295-296.

552 Horkheimer, "Autoritärer Staat”, op. cit., pp. 301-302.

${ }^{553}$ Cf. Max Horkheimer, "Die Juden und Europa", p. 125 do volume de 1939-40 da Zeitschrift für Sozialforschung, e também, em menor medida, as indicações no prefácio ao volume 9 de 1941 da mesma Revista, publicada naquele ano em inglês: Max Horkheimer, "Preface", Studies in Philosophy and Social Sciences, op.cit., pp. 195-196 (tratase do prefácio ao volume de 1941 da Revista).
} 
a relação entre a nova forma do Estado e o desenvolvimento assumido pelas forças produtivas sob o regime taylorista-fordista ${ }^{554}$.

A incorporação por Horkheimer da tese de Pollock não significou, portanto, um abandono do marxismo: apesar da falta de perspectivas quanto a uma revolução proletária e da consideração de que a União Soviética também seria um caso de "capitalismo de Estado", Horkheimer continuava a fazer crítica do capitalismo, embora deparasse com a necessidade de alterar alguns de seus elementos centrais, em consonância com o fim do período liberal ${ }^{555}$.

Sobre as mudanças ocorridas no âmbito do Estado havia relativo consenso: se durante o capitalismo liberal havia sido um mero garantidor da propriedade privada dos meios de produção e das condições necessárias à circulação de mercadorias, sob o capitalismo monopolista o Estado ampliara suas funções e passara a atuar nos principais setores da indústria e a fornecer as bases para a financeirização da economia ${ }^{556}$. Essa mudança também acarretou a instituição de formas de controle estatal que passavam a se sobrepor ao mercado e ao direito contratual dos indivíduos: a partir das primeiras décadas do século $\mathrm{XX}$, esse direito era factualmente transferido aos sindicatos e aos monopólios industriais, que institucionalizavam o capital e o trabalho em unidades econômicas que ultrapassavam o âmbito do contrato que, na era liberal, vinculava a empresa e o trabalhador individuais ${ }^{557}$. O Estado passava a se sobrepor ao contrato individual e a garantir as necessidades do capitalismo monopolista de maneira direta, e ainda que não estivesse claro e nem fosse consensual em que medida se poderia falar

\footnotetext{
554 Joachim Hirsch chamou a atenção para a necessidade de se teorizar a conexão entre a forma do Estado e o desenvolvimento das forças produtivas - aqui importando o seu grau de concentração - sem recair em uma interpretação economicista do Estado, que o reduza a mera força produtiva empregada como instrumento da classe dominante. $\mathrm{O}$ autor, contudo, ao partilhar da interpretação dominante que julga ter Horkheimer aderido à tese de Pollock, terminou preso à dicotomia que opõe, de um lado, Neumannn e Kirchheimer, de outro, Pollock, Adorno e Horkheimer, e não conseguiu identificar no próprio ensaio de Horkheimer indícios daquela conexão. Cf. Joachim Hirsch, "Staatskapitalismus? Zur Kontroverse zwischen Friedrich Pollock, Max Horkheimer und Franz Neumann in Bezug auf den Charakter des nationalsozialistischen Systems", op. cit., p. 60.

${ }^{555}$ A insuficiência da interpretação dominante que costuma considerar a adesão sem mais de Horkheimer à tese de Pollock do "capitalismo de Estado" (o que teria supostamente significado um abandono do marxismo, entendido de maneira reducionista pelos intérpretes que partilham dessa leitura) foi captada com muita propriedade por Gustavo Pedroso: “(...) não se trata da simples substituição de uma abstrata determinação econômica por uma igualmente abstrata determinação pela política". Cf. Gustavo Pedroso, "Entre o capitalismo de Estado e o Behemoth: o Instituto de Pesquisa Social e o fenômeno do fascismo". São Paulo, Cadernos de ética e filosofia política, vol. 15, n. 2, 2009. p. 170. Discordamos do autor, contudo, quanto à sua tendência a desconsiderar a incorporação por Horkheimer das teses de Pollock e a supor uma proximidade entre o "Estado autoritário" de Horkheimer e o "não-Estado" de Neumann (cf. pp. 174-175).

${ }^{556}$ Gramsci chamou o Estado liberal de "vigia noturno" do capital, função que viria a ser apenas uma dentre as diversas exercidas pelo Estado "ampliado".

${ }^{557}$ Cf. Max Horkheimer, "Autoritärer Staat", op. cit., p. 296.
} 
de uma extinção do mercado (e, portanto de uma perda de validade de categorias com o "valor" e a "mercadoria", tal qual levava a crer a argumentação de Pollock) ${ }^{558}$, era pelo menos relativamente consensual que o Estado progressivamente perdia a sua antiga função de mediação da dominação de classe, pelo menos da maneira como ela havia sido exercida até então: o próprio direito não era mais um sistema de normas universais a serem aplicadas pelo poder judiciário, mas sim era reduzido em parte significativa aos atos administrativos do poder executivo, o poder judiciário se convertendo em mero "assistente" desse, de maneira a atender aos interesses dos monopólios ${ }^{559}$.

Da concentração dos meios de produção não decorria mecanicamente, contudo, a conversão do Estado em um órgão que reuniria sob si a absolutamente maior parte desses meios e suprimiria, na prática, a esfera da circulação: Horkheimer criticava, por isso, a tese de Engels segundo a qual um desenvolvimento imanente das forças produtivas conduziria da empresa individual às sociedades por ações, trustes, à assunção do Estado à condição de "capitalista total" e, finalmente, à socialização dos meios de produção e à transformação do Estado burguês em um Estado proletário. A revolução não decorreria, contudo, de um automatismo (“deduzível era o colapso econômico, não a revolução"560) e ao censurar o economicismo Horkheimer pensava na impossibilidade de deduzir a revolução de um processo histórico que fosse mecânico: “o fim da exploração não é mais uma aceleração do progresso, e sim o salto para fora do progresso" 561 , afirmava o autor fazendo coro com Walter Benjamin e recusando uma teoria da revolução que assentasse no desenvolvimento das forças produtivas. Essa concepção poderia ser válida para o passado, como Marx notara: a extensão desse princípio para o futuro, tal qual Engels o fizera, não teria razão de ser: "é possível dizer, acerca de empreendimentos históricos passados, que o tempo não teria estado maduro para eles. No presente, o discurso da maturidade insuficiente transfigura a harmonização com o ruim" ${ }^{462}$. Por extensão, Horkheimer criticava a concepção de que seriam condições suficientes para a instauração do socialismo a tomada do Estado e a sua instrumentalização para os fins próprios à classe trabalhadora, sem

\footnotetext{
${ }^{558}$ Como vimos acima, Pollock era cauteloso com afirmações desse tipo.

${ }^{559}$ Cf. Horkheimer, “Autoritärer Staat”, op. cit., p. 301 infra; Franz Neumann, "Der Funktionswandel des Gesetzes im Recht der bürgerlichen Gesellschaft”, vol. 6 da Zeitschrift für Sozialforschung, 1937, pp. 565-566; e, especialmente sobre os novos papéis do direito e do poder judiciário (que haveria sido degradado da posição de árbitro dos conflitos a mero "assistente" da administração), Otto Kirchheimer, "Changes in the structure of political compromise”, Studies in Philosophy and Social Sciences, vol. 9, 1941, pp. 273-274 e pp. 280-283. Todos esses autores, e Pollock pode ser a esse respeito também incluído aqui, concordavam quanto à ocorrência, nessa fase do capitalismo monopolista, de profundas mudanças na estrutura jurídico-política.

${ }^{560}$ Cf. Max Horkheimer, "Die Juden und Europa”, Zeitschrift für Sozialforschung, vol. 8 de 1939-40, p. 121.

${ }^{561}$ Cf. Max Horkheimer, "Autoritärer Staat", op. cit., p. 307.

${ }^{562}$ Cf. Max Horkheimer, "Autoritärer Staat”, op. cit., , p. 302.
} 
que se alterasse a forma que a instituição estatal assumira durante o longo período de dominação burguesa $^{563}$.

Mas a crítica que Horkheimer fazia a Engels não consistia em uma mera rejeição daquela tese. Horkheimer verificara que, de fato, havia ocorrido um processo de transformação do Estado em algo próximo ao "capitalista total", que na formulação engelsiana concentrava sob si a propriedade dos meios de produção, reduzia a quase nada a importância da esfera do mercado e se sobrepunha às relações de produção que haviam vigorado sob o capitalismo liberal, convertendo os proprietários burgueses em algo próximo a funcionários pagos pelo Estado e destituindo-os, portanto, de sua antiga condição de sujeitos autônomos ${ }^{564}$. A concentração de capital, considerada como lei imanente da produção capitalista, era a base objetiva da progressiva passagem do capitalismo liberal ao capitalismo de Estado (fase mais recente do capitalismo monopolista e, na tese de Engels, fase derradeira do capitalismo), no que Horkheimer concordava com Engels. Mas o seu prognóstico de que a constituição do "capitalista total" permitiria a passagem ao socialismo era equivocada. Engels, e em sequência a ele o marxismo da II Internacional, concebera a passagem ao socialismo como um processo natural $^{565}$. A revolução, entretanto, segundo Horkheimer seria algo "não-natural”: "a teoria [de Engels] determina ao curso natural da ordem mundial capitalista um fim não natural: os proletários unidos destroem a última forma da exploração, a escravatura capitalista estatal"566.

Mais precisamente, para Horkheimer a concepção de socialismo de Engels, que previa a abolição da exploração de classe por meio da universalização do trabalho, havia em parte se concretizado, dado o desaparecimento da burguesia típica do século XIX: a existência de um Estado que, proprietário (nominal ou de fato) dos meios de produção, se aproximava por isso do "capitalista total” previsto por Engels, permitiu ser a exploração feita abertamente e também a universalizou, ao incorporar a pequena e média burguesia. Horkheimer ironizava a tese de Engels, cuja previsão, ao se realizar, converteu o socialismo em seu contrário: a universalização do trabalho resultou em uma exploração aberta e abrangente de camadas cada vez mais extensas da população, em vez de ter permitido a abolição da dominação de classe. Dando continuidade ao capitalismo liberal, a dominação continuava a ser exercida em favor de interesses

\footnotetext{
${ }^{563}$ Em carta a seus pais de 7 de fevereiro de 1940, Adorno afirmava ser o ensaio sobre o "Estado autoritário", em cuja redação ele colaborava, uma crítica ao marxismo da época, que ele e Horkheimer tentavam "pôr em ordem". Citado em Dirk Braunstein, Adornos Kritik der politischen Ökonomie. Bielefeld: Transcript, 2011. p. 146.

${ }^{564}$ Não importa aqui o fato de que essa autonomia fosse uma "aparência objetivamente necessária", inclusive porque Engels tinha uma concepção de ideologia que não havia incorporado a tese do fetichismo.

${ }_{565}$ Cf. Ricardo Musse, Do Socialismo Científico à Teoria Crítica - modificações na autocompreensão do marxismo entre 1878 e 1937. Tese de doutorado. FFLCH-USP, 1997. Sobre esse ponto, especialmente pp. 35-64 e também o capítulo 3.

${ }^{566}$ Max Horkheimer, “Autoritärer Staat”, op. cit, p. 294.
} 
particulares, e a diferença residia na transferência do comando máximo da exploração para o Estado, cujos burocratas se confundiam com os proprietários particulares: "confundem-se a exploração estatal e privada sobre o trabalho alheio" ${ }^{\text {"67 }}$. A concepção evolucionista de história, ao se confirmar, atestaria a permanência da dominação, como afirmava Horkheimer na última frase do ensaio sobre o "Estado autoritário": "enquanto a história mundial seguir o seu curso lógico, ela não cumprirá sua destinação humana [menschliche Bestimmung]"568. E é por isso que, segundo Horkheimer, Engels teria sido, ele próprio, utópico ao supor que o Estado desaparecia depois de os meios de produção serem socializados: “(...) ele vê a socialização e o fim da dominação como a mesma coisa (...). A prática não refutou a teoria [de Engels], e sim, a interpretou" ${ }^{, 59}$. O marxismo teria, até então, previsto a passagem ao socialismo por meio fosse da crise econômica capaz de conduzir ao colapso, fosse por meio da transformação do Estado no "capitalista total" a ser apropriado pelos trabalhadores. Esse dualismo, segundo Horkheimer, teria sido superado pelo próprio Estado autoritário, que passou a administrar a crise e a integrar os trabalhadores de uma maneira inédita em relação ao período no qual o mercado ainda era relevante ${ }^{570}$.

Ao formular sua concepção do "Estado autoritário" sob a forma de uma crítica à tese de Engels de uma transição socialista como decorrência do desenvolvimento das forças produtivas rumo à abolição da propriedade privada e ao desaparecimento do Estado depois que esse tivesse se tornado o "capitalista total", Horkheimer por extensão criticava os pressupostos que haviam orientado as análises de Pollock e de outros economistas do Instituto que, orientados no início dos anos trinta pela política reformista do SPD, apostavam na planificação econômica no âmbito do capitalismo como um meio de promover uma lenta desintegração do modo de produção. Essa orientação se fundamentava em pressupostos problemáticos que geravam limitações nas análises. Pollock, por exemplo, identificava como contradição fundamental do capitalismo aquela entre o caráter social da produção e o caráter privado da apropriação do resultado do trabalho: abolida a propriedade privada, a socialização dos meios de produção

\footnotetext{
567 Cf. Max Horkheimer, "Autoritärer Staat", op. cit., p. 298. Cf. também, sobre esse ponto, as afirmações de Horkheimer em "Die Juden und Europa", op. cit., p. 125.

568 Max Horkheimer, "Autoritärer Staat", op. cit, p. 319.

${ }^{569}$ Cf. Max Horkheimer, "Autoritärer Staat”, op. cit., p. 312-313 e também, sobre esse ponto, p. 294. Ulrich Ruschig, superando a maior parte da recepção dos ensaios de Horkheimer sobre o tema, ressaltou com muita propriedade as críticas de Horkheimer a Engels e também a reelaboração das teses de Pollock por Horkheimer. Aparentemente lhe passou, contudo, despercebida a teorização feita por Horkheimer sobre a nova forma assumida, sob o imperialismo, pelo processo de extração de mais-valia. Cf., do autor, "Weiterdenken in marxistischer Tradition: die Lehre vom autoritären Staat". In: Ulrich Ruschig; Hans-Ernst Schiller (Orgs.) Staat und Politik bei Adorno und Horkheimer, op. cit., especialmente pp. 87-92 e pp. 98-102.

${ }^{570}$ Max Horkheimer, "Autoritärer Staat”, op. cit, p. 294-295.
} 
poderia conduzir à superação do capitalismo ${ }^{571}$. Alguns anos mais tarde, ao perceber que a mudança de função da propriedade (com a redução do mercado a um "pseudo-mercado") e a tendencial transformação do Estado no "capitalista total" não garantiriam a superação do capitalismo, as análises de Pollock, presas àquele pressuposto, desembocaram no abandono do marxismo e na tese pessimista do "capitalismo de Estado", por ele considerada uma nova formação social, estável e imune às crises, e sob a qual a classe trabalhadora apenas poderia aspirar a uma participação (maior ou menor, de acordo com sua força política) no controle da burocracia. Apesar da situação de guerra e da ausência de perspectivas políticas favoráveis, o caráter reformista da tese estava ainda em continuidade com as teses de Pollock no início dos anos trinta ${ }^{572}$.

Negando as previsões da II Internacional e do reformismo, nem o proletariado conseguiu fazer a revolução após o colapso econômico, nem a estatização dos meios de produção conduziu à superação progressiva do capitalismo, e em lugar desses processos (as duas possibilidades de superação do capitalismo previstas pelo marxismo da social-democracia, como lembrava Horkheimer ${ }^{573}$ ) o Estado foi tomado de assalto pelas grandes corporações industriais em conluio com os fascistas - exatamente da mesma maneira, porém, que era necessário evitar o raciocínio mecanicista e considerar as mediações subjetivas que impediriam ou estimulariam a passagem ao socialismo, o processo que por meio da concentração de capital conduziu do capitalismo liberal ao "capitalismo de Estado" também precisou de algumas mediações para se efetivar. Engels acertara quanto à passagem do capitalismo liberal ao capitalismo de Estado por meio da concentração crescente de capital, mas o seu acerto confirmava a submissão da história à lógica econômica e consistia, ao mesmo tempo, no erro da prática política reformista que apenas atualizava essa submissão:

"O automovimento do conceito de mercadoria conduz ao conceito de capitalismo de Estado como em Hegel a certeza sensível conduz ao saber absoluto. Se, entretanto, em Hegel os estágios do conceito têm de corresponder sem grandes complicações à natureza física e social, porque conceito e efetividade, tal qual ao final, também já em sua base não são apenas diferentes, mas também a mesma coisa, o pensamento materialista, por sua vez, não pode contar com essa identidade. $\mathrm{O}$ aparecimento de relações que podem ser

\footnotetext{
${ }^{571}$ Cf. Friedrich Pollock, "Bemerkungen zur Wirtschaftskrise", Zeitschrift für Sozialforschung, vol. 2, 1933, pp. 337-338; e também Ulrich Ruschig, "Weiterdenken in marxistischer Tradition: die Lehre vom autoritären Staat", op. cit., pp. 77-80 e pp. 84-86.

${ }^{572}$ Sobre as críticas de Horkheimer a Engels e à social-democracia alemã, aspecto do ensaio sobre o "Estado autoritário" nem sempre ressaltado, cf. a tese de Vladimir Ferrari Puzone, Capitalismo perene: reflexões sobre a estabilização do capitalismo a partir de Lukács e da teoria crítica. Tese de doutorado. FFLCH-USP, 2014, pp. $140-141$

${ }^{573}$ Max Horkheimer, “Autoritärer Staat”, op. cit., p. 294.
} 
extraídas do conceito traz ao idealista o sentimento de satisfação, ao materialista histórico, a indignação. (...) A diferença entre o conceito e a realidade fundamenta a possibilidade da prática transformadora" ${ }^{974}$.

Ao mesmo tempo, portanto, em que o desenrolar da história confirmava a previsão de Engels e parecia legitimar uma visão mecanicista do processo histórico, a passagem ao capitalismo de Estado não foi expressão de um telos que de antemão já estivesse dado na forma da mercadoria, base do capitalismo liberal: Horkheimer estava ciente das determinações que antecederam a passagem ao capitalismo de Estado, e considerava como uma delas o próprio economicismo e a prática política conduzida de acordo com ele. É por isso que, logo à entrada do ensaio, Horkheimer afirmava, se referindo a Engels, que "as previsões históricas sobre o destino da sociedade burguesa se comprovaram"575. Como já chamamos à atenção anteriormente, em seu discurso de posse o autor punha lado a lado o determinismo econômico em sua versão a-histórica, por ele chamado de "um Marx abstrato e por isso mal interpretado", e a tese oposta segundo a qual conteúdos espirituais independentes dos fenômenos históricos singulares determinariam o agir humano ("um Hegel abstrato e mal interpretado"). Ambas as teses seriam idealistas, pois repousariam na subordinação da realidade a um conceito prévio, a um sentido do mundo ao qual a história estaria submetida - elas deveriam entretanto, segundo o autor, ser "tomadas seriamente nessa sua abstração" 576 . O raciocínio economicista seria para Horkheimer, produzido pelo próprio capitalismo: a história tem sido determinada pela subordinação das relações humanas ao movimento da mercadoria, que em sua forma fetichizada se move aparentemente sem depender dos indivíduos. Mas, como lembrou Marx, "as mercadorias não podem por si mesmas ir ao mercado e se trocar. Devemos, portanto, voltar a vista para seus guardiões, os possuidores de mercadorias" ${ }^{\circ 77}$.

\footnotetext{
574 Cf. Max Horkheimer, "Autoritärer Staat”, op. cit., p. 308-309. Implicitamente, Horkheimer criticava aqui a interpretação da relação do marxismo com o pensamento de Hegel feita por Engels. No Anti-Dührung, Engels defendera a concepção da dialética materialista como uma inversão necessária da dialética hegeliana, a fim de se pôr em seu devido lugar a realidade que o idealismo de Hegel havia virado ao avesso: “As ideias de seu cérebro não eram, para ele, imagens mais ou menos abstratas das coisas e dos fenômenos da realidade, mas coisas que, em seu desenvolvimento, se lhe apresentavam como projeções realizadas de uma 'ideia', existente não se sabe onde, antes da existência do mundo. Esse modo de ver tudo subvertia, revirando pelo avesso toda a concatenação real do universo". Cf. a introdução de Friedrich Engels, Anti-Dühring, op. cit.. Sobre esse assunto, cf. Ricardo Musse, Do Socialismo Científico à Teoria Crítica - modificações na autocompreensão do marxismo entre 1878 e 1937 , op. cit., pp. 35-45.

575 Cf. Max Horkheimer, “Autoritärer Staat”, op. cit., p. 293.

${ }^{576}$ Cf. Max Horkheimer, “A presente situação da filosofia social e as tarefas de um instituto de pesquisas sociais”, op. cit., pp. 130-131 (trata-se da já citada edição brasileira publicada na Revista praga).

${ }^{577}$ Karl Marx, O Capital (Livro Primeiro, Capítulo II: “O processo de troca”), p. 79. São Paulo: Abril Cultural, 1983.
} 
A perspectiva de Horkheimer de interpretação do capitalismo de Estado havia sido prenunciada em uma discussão travada em 1937 no âmbito do Instituto, e na qual Horkheimer discorria, juntamente com Grossmann, Gumperz e Wittfogel, sobre a maneira de explicar a passagem do capitalismo liberal ao capitalismo monopolista. Os dois primeiros tentavam explicar como (e se) era possível deduzir o capitalismo monopolista da evolução da taxa média de lucro. Horkheimer e Wittfogel, por sua vez, argumentavam ser por um lado necessário que a explicação se ativesse à tendência econômica básica do capitalismo (a acumulação de capital, da qual a taxa de lucro seria uma mera expressão fenomênica), mas advertiam por outro lado que entender a maneira pela qual essa lei teria levado ao capitalismo monopolista requeria mediações que contemplassem as particularidades históricas desse desenvolvimento ${ }^{578}$. A elas

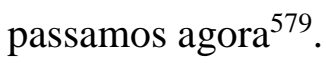

\section{$\underline{5.2 .1 \text { - Imperialismo e classes sociais }}$}

Uma primeira diferença em relação a Pollock residia no lugar que, na exposição de Horkheimer, era conferido ao fenômeno do imperialismo: nas análises de Pollock, das quais estava ausente a explicação da passagem do capitalismo liberal para o capitalismo de Estado, o tema do imperialismo apenas aparecia lateralmente, e além disso reduzido à sua expressão contemporânea mais imediata (a política bélica alemã então em curso), sem que fosse explicitado o vínculo entre o surgimento do nazismo e as necessidades da expansão imperialista. Mas havia um vínculo estreito entre a concentração crescente de capital, o deslocamento da concorrência para o âmbito internacional (que alterava suas condições, pois era realizada a partir de então por grandes grupos empresariais em associação com os Estados) e a formação de um Estado autoritário que suprimia a autonomia do mercado em uma situação na qual tornara-se "problemática a direção da produção por interesses e grupos de interesses particulares, concorrentes entre si”, tal qual havia ocorrido, pelo menos majoritária e tendencialmente, no período do capitalismo liberal ${ }^{580}$. O capitalismo monopolista e o Estado autoritário que sob ele se desenvolveu só poderiam, na perspectiva de Horkheimer, ser

\footnotetext{
${ }^{578}$ Cf. Henryk Grossmann, Julian Gumperz, Max Horkheimer, Karl August Wittfogel, "Diskussion aus einem Seminar über Monopolkapitalismus”. Max Horkheimer, Gesammelte Schriften, vol. 12, pp. 427-430.

${ }^{579}$ Como argumenta, por exemplo, Werner Bonefeld, o valor não se reproduz automaticamente por meio de uma "dominação impessoal", e são as relações sociais de produção específicas, baseadas na dominação de classe, que assumem a forma abstrata das categorias econômicas. Cf. Werner Bonefeld, Critical Theory and the Critique of Policital Economy - On Subversion and Negative Reason. Londres: Bloomsbury Academic, 2014. pp. 5-9.

${ }^{580}$ Cf. Max Horkheimer, "Autoridade e família". In: Teoria Crítica I - uma documentação. Tradução de Hilde Cohn. São Paulo: Perspectiva, 1990, p. 207.
} 
compreendidos em conexão com o imperialismo, pois a concentração de capital levara à unificação das empresas em grandes conglomerados que dominavam o mercado interno e deslocavam a concorrência para o mercado internacional:

"a competição entre os empresários independentes culminou, ao final, nos gigantes conglomerados da indústria monopolista. Sob a sua hegemonia, a competição assumiu uma forma diferente. Seu estímulo a competir com iguais nos limites da nação diminuiu, e com isso a motivação para o investimento cada vez maior e o pleno emprego [que passaram a ser feitos pelo Estado]. Os grandes líderes dos negócios e de outras avenidas da vida social apenas encontravam os seus pares ao trespassar as várias fronteiras nacionais" ${ }^{\prime 51}$.

Assim como Neumann, Horkheimer percebeu o deslocamento da circulação para o âmbito internacional e, superando a análise de Neumann, a continuidade da extração da maisvalia, cujo circuito de realização de alterara. Se Horkheimer, juntamente com Pollock, supunha ser a exploração feita pelo Estado de maneira direta, ao contrário de Pollock, porém, Horkheimer não acreditava que a "exploração" houvesse se tornado uma categoria meramente política, e não mais econômica: uma vez modificada a exploração do trabalho, a realização da mais-valia era deslocada para o âmbito do mercado mundial, e o Estado atuava como mediador entre a exploração e o ganho dos capitalistas, que não mais poderia ser classificado sob a forma de "lucro" e passava a se assemelhar à "renda". Transformado em renda, o lucro teria deixado de ser uma categoria econômica válida e permaneceria apenas nominalmente: segundo Horkheimer, a mais-valia “(...) é adquirida e distribuída sob o controle estatal - sob o antigo nome de 'lucro' ela continua todavia a correr em grandes quantidades para as mãos dos magnatas da indústria e dos proprietários de terras" ${ }^{" 582}$. Além disso, ao mesmo tempo em que a concorrência era deslocada para o mercado internacional, a destruição interna da autonomia do mercado (e também, portanto, dos compradores e vendedores da força de trabalho) significava um controle rígido sobre a produção, a distribuição e o consumo, ensejando formas totalitárias de dominação:

"Embora ela não seja mais embolsada como lucro, é da mais-valia que se trata. A circulação é abolida, a exploração, modificada. O princípio que havia sido cunhado em relação à economia de mercado, segundo o qual à anarquia na sociedade corresponde a ordem rígida na fábrica, significa hoje que o estado de

\footnotetext{
${ }^{581}$ Cf. Max Horkheimer, "Preface". In: Studies in Philosophy and social sciences, op. cit., p. 195.

582 Cf. Max Horkheimer, "Autoritärer Staat", op. cit., p. 300. Uma situação semelhante caracterizaria o capitalismo de nossos dias. A esse respeito, cf. Leda Maria Paulani, “Acumulação e rentismo: resgatando a teoria da renda de Marx para pensar o capitalismo contemporâneo". Revista de Economia Política. São Paulo, vol. 36, número 3, (144), pp. 514-535, jul-set de 2016.
} 
natureza internacional - a luta pelo mercado mundial - e a disciplina fascista dos povos condicionam-se mutuamente" ${ }^{583}$.

A Alemanha e a Itália, que ingressaram tardiamente na corrida imperialista e colonialista, não haviam expandido o seu capital de maneira tão eficiente quanto a Inglaterra e a França, países nos quais a luta de classes podia ser amenizada pelo influxo de capitais obtidos nas colônias e semicolônias. Essa diferença era decisiva para a formação do Estado autoritário nos regimes fascistas, assim como para o expansionismo militar, uma tentativa de atualização frente ao domínio imperial que as nações que compunham a dianteira do capitalismo mundial (Inglaterra e França) haviam consolidado ao longo do século XIX. Na Alemanha, desde a primeira guerra os social-democratas haviam apoiado a política imperialista e, "embora a extinção dos Estados estivesse em sua divisa", o partido social-democrata "transformou a sua pátria economicamente atrasada no modelo secreto das potências industriais que não passavam muito bem de seu parlamentarismo e não podiam mais viver sem o fascismo" ${ }^{584}$.

Além do imperialismo, mas ainda em conexão com ele, outra mediação histórica fundamental para a formação do "capitalismo de Estado" foram as transformações pelas quais passaram as classes sociais. No texto de Pollock, aquela fase do capitalismo aparecia, de maneira pronta e acabada, como uma sociedade composta por "comandantes e comandados". Horkheimer incorporava essa ideia, porém se detinha sobre os processos que haviam conduzido a esse resultado, principalmente sobre as mudanças ocorridas na estrutura de classes: na passagem ao capitalismo monopolista, a burguesia deixou de ser um conjunto de indivíduos autônomos que celebravam e cumpriam seus contratos na esfera da circulação $^{585}$ e se transformou, como Horkheimer estava ciente desde 1937, em uma “clique de dirigentes"586, um conjunto de diretores de grandes corporações (o mais das vezes, vale lembrar ainda que nos textos não esteja clara essa distinção, seus acionistas majoritários) agindo em conjunto com os membros da burocracia estatal, tanto em nível nacional quanto em nível internacional, e que competiam entre si não mais nos moldes da concorrência típica do capitalismo liberal, mas de

\footnotetext{
${ }^{583}$ Cf. Max Horkheimer, "Autoritärer Staat", op. cit., pp. 301-302. Dessa maneira, Horkheimer supera uma limitação da tese de Pollock criticada, por exemplo, por Postone: ter considerado que a regulação do mercado significaria o fim do valor. Cf. Time, work and social domination, op. cit., p. 86 e ss.

${ }^{584}$ Cf. Max Horkheimer, "Autoritärer Staat", op. cit., p. 297 e p. 300. O papel que na formação do Estado autoritário teve o caráter retardatário da industrialização alemã havia sido defendido por Wittfogel na já mencionada discussão travada em 1937 no Instituto, da qual participaram, além de Wittfogel e Horkheimer, Henryk Grossmann e Julian Gumperz, que assim como Wittfogel eram economistas do Instituto. Cf., dos quatro autores, "Diskussion aus einem Seminar über Monopolkapitalismus", op. cit., p. 425. A mesma tese seria defendida por Neumann em Behemoth. ${ }^{585}$ Cf. Max Horkheimer, "Bemerkungen zur philosophischen Anthropologie", Gesammelte Schriften, vol. 3, p. 264.

${ }^{586}$ Max Horkheimer, "Traditionelle und kritische Theorie". In: Max Horkheimer (ed.), Zeitschrift für Sozialforschung, vol. 6 de 1937, p. 260.
} 
maneira a reduzir progressivamente o espaço de liberdade mercantil que essa fase do modo de produção tinha promovido (ainda que esse espaço tenha vigido no âmbito restrito dos países capitalistas centrais, e ainda assim para uma esfera reduzida de competidores, pertencentes à burguesia de pequenos e médios proprietários). A concorrência se mesclava a disputas por poder, que na fase anterior do modo de produção eram o privilégio negativo dos povos coloniais e das minorias étnicas dos territórios submetidos à conquista militar: tanto no âmbito interno quanto naquele da concorrência imperialista, os monopólios se juntavam ao poder estatal e, assim como as burocracias dos sindicatos e partidos de massas, eram perpassados por uma estrutura de poder que opunha os líderes (ali, os sindicalistas, aqui a “clique de dirigentes”), à massa (ali, os trabalhadores, aqui, os acionistas destituídos de poder). A constituição do "Estado autoritário", coroaria esse processo e daria continuidade a um processo de estabilização da dominação e de contrarrevolução que já havia se iniciado anos antes: "a estabilidade do fascismo repousa na aliança contra a revolução e no cancelamento do corretivo econômico [exercido na fase do capitalismo liberal pelo mercado]" ${ }^{\prime 57}$.

$\mathrm{Na}$ passagem do mercantilismo ao capitalismo liberal, argumentava o autor, a propriedade privada dos meios de produção havia sido um meio de emancipação do indivíduo e de ascensão da burguesia, que no instituto jurídico da propriedade teve um meio de defesa de seu trabalho contra o Estado estamental do Antigo Regime. A instituição da propriedade privada, que existira pelo menos desde o modo de produção antigo, assumira no surgimento do capitalismo liberal uma função específica, pois deveria resguardar os direitos da burguesia contra a nobreza e o clero. Em fins do século XIX, contudo, a intensa concentração de capital e a formação de monopólios e oligopólios alteraria significativamente a situação: os pequenos e médios estabelecimentos sucumbiriam progressivamente às grandes empresas de dimensões transnacionais, o que deslocou parte considerável dos burgueses para a classe trabalhadora, para a classe média das profissões liberais ou então para o rentismo. O último caso decorria do fato de a magnitude dos trustes ter conduzido à difusão das sociedades por ações e a uma dissociação entre a propriedade legal e o exercício do comando sobre a empresa, que reduziu os burgueses a acionistas que não decidiam sobre o investimento de capital e direcionavam seus rendimentos para o consumo próprio, ao passo que a decisão sobre os investimentos era transferida às diretorias das grandes corporações, que formavam uma "burocracia industrial" crescentemente atrelada ao Estado ${ }^{588}$.

\footnotetext{
${ }^{587}$ Max Horkheimer, "Die Juden und Europa", op. cit., p. 126.

${ }^{588}$ Sobre esse ponto, cf. também Max Horkheimer, "Die Juden und Europa”, op. cit., pp. 116-120.
} 
Em uma época de capitalismo monopolista, em que as crises de superprodução indicavam a crescente irracionalidade do modo de produção, a burguesia se aferrou ao princípio da propriedade privada, cuja antiga função progressista havia desaparecido, e foi "dizimada" e reduzida a uma massa de "parasitas" 589 . Horkheimer resumiu esse processo da seguinte maneira, em ensaio publicado no ano de 1933: "a intangibilidade da propriedade foi uma proteção do trabalho burguês contra os funcionários do Estado - hoje ela tem como consequência a monopolização, a expropriação de largas camadas da burguesia e a inutilização da riqueza social" ${ }^{, 50}$. A burguesia, ao persistir na defesa da propriedade privada dos meios de produção quando esses se encontravam concentrados de tal maneira que apenas a sua socialização impediria as crises de superprodução em que se enredava o capitalismo monopolista, pagou com a subordinação do mercado ao Estado a perpetuação da dominação social, que na nova fase do modo de produção passava a ser feita por via "diretamente política", e não mais por meio da mediação econômica exercida pela mercadoria ${ }^{591}$. Isso levava Horkheimer a afirmar, em consonância com Pollock, que o fetichismo das mercadorias teria deixado de ser a forma básica da sociabilidade: “a igualdade dos proprietários de mercadorias é uma ilusão ideológica que se desfaz no sistema industrial e cede lugar, no Estado autoritário, à dominação aberta" ${ }^{" 592}$. O mercado propriamente dito só seria reivindicado pelos membros da pequena burguesia (pequenos comerciantes e profissionais liberais), crescentemente arruinados pelo movimento de concentração de capital, e os apelos dos grandes industriais por liberalismo econômico consistiam, na verdade, em apelos por privilégios sobre os demais grupos, numa tentativa de subordinar o Estado a seu controle e assim extinguir as poucas esferas de mercado que ainda existiam. Na verdade, é necessário precisar aquela afirmação um tanto drástica de Horkheimer sobre o fim do fetichismo da mercadoria: o mercado havia se transformado, para dizer com Pollock, em um "pseudo-mercado", e à relação mercantil havia se sobreposto a relação de mera dominação. A concorrência entre as empresas, praticamente ausente no interior

\footnotetext{
${ }^{589}$ Cf. Max Horkheimer, “Autoritärer Staat”, op. cit, p. 293 e p. 296.

${ }^{590}$ Cf. Max Horkheimer, "Materialismus und Moral”, op. cit., p. 189. Sobre a mudança de função da propriedade e do direito, cf. o artigo de Franz Neumann, "Der Funktionswandel des Gesetzes im Recht der bürgerlichen Gesellschaft", op. cit., pp. 565-566, e também Otto Kirchheimer, "Changes in the structure of political compromise", op. cit., p. 273.

${ }^{591}$ Cf. Max Horkheimer, "Die Juden und Europa", op. cit., p. 121. Em 1942, Adorno teceria em suas "Reflexões sobre a teoria das classes" as mesmas considerações sobre a expropriação sofrida por largas parcelas da burguesia: "a igualdade de interesses se reduz à participação no butim dos grandes [proprietários]. (...) a classe como um todo deve estar pronta para entregar-se com afinco ao princípio da propriedade, que se refere, em primeiro lugar, efetivamente à propriedade dos grandes". Cf. "Reflexionen zur Klassentheorie", Gesammelte Schriften, vol. 8. Berlim: Suhrkamp, 1997. p. 378.

${ }^{592}$ Cf. Max Horkheimer, “Autoritärer Staat", op. cit., p. 309, e também Friedrich Pollock, "State Capitalism”, op. cit., pp. 207-210.
} 
das nações europeias, havia sido transferida para o plano internacional, em que as burguesias monopolistas competiam entre si e tomavam parte na disputa imperialista e colonialista ${ }^{593}$.

No âmbito da classe trabalhadora, a institucionalização dos sindicatos, integrados no âmbito do Estado lado a lado com as grandes corporações monopolistas, os tornava intermediários da compra e venda da força de trabalho, cujo estatuto de mercadoria se alterava na medida em que ela não circulava mais livremente. Os líderes sindicais controlariam a oferta de trabalho e se esforçariam pela elevação de seu preço tanto quanto os diretores das grandes companhias controlariam a oferta de matérias-primas, máquinas e demais fatores de produção ${ }^{594}$. A exploração seria feita diretamente, e a repressão, a propaganda ideológica e a integração social em organizações estatais garantiam, sob o regime fascista, a inocuidade dos sindicatos e a sua reduzida capacidade de negociação. A classe trabalhadora havia sido convertida em uma massa de trabalhadores, e suas organizações se desvincularam progressivamente de qualquer estratégia revolucionária:

\begin{abstract}
"A palavra de ordem da união em sindicatos e partidos foi seguida à risca, mas esses menos executaram as tarefas não naturais dos proletários unidos, isto é, a resistência contra a sociedade de classes em geral, do que obedeceram às condições naturais de seu próprio desenvolvimento rumo a organizações de massa" ${ }^{, 595}$.
\end{abstract}

Essa situação não significava o fim da sociedade de classes: a exploração do trabalho, ainda que feita de maneira a dispensar o mercado, permanecia estruturante da vida social, calcada portanto no antagonismo básico entre a burguesia e o proletariado - a diferença era que, em sociedades nas quais o proletariado havia sido convertido em uma massa de indivíduos, a classe progressivamente deixava de ser fonte de resistência política e ideológica. No caso específico do nazismo, esse período foi o mesmo da construção do fordismo na Alemanha, um período ao longo do qual, paralelamente à instituição da produção e do consumo de massas, partidos e sindicatos socialistas foram proibidos, e as organizações proletárias foram atreladas ao Estado. A propaganda e a superação das crises econômicas dos anos vinte lograram obter uma base estável de apoio ao regime, e não obstante ter havido dissenso e resistência, expressa

\footnotetext{
${ }^{593}$ Como vimos, o caráter da exploração do trabalho e a existência ou não do mercado e da concorrência eram, além da estabilidade do sistema, os principais objetos da controvérsia entre Pollock e Neumann.

594 Cf. o texto de Horkheimer escrito em 1943 e publicado postumamente, "Zur Soziologie der Klassenverhältnisse", vol. 12 das Gesammelte Schriften. Tradução ao alemão do original inglês feita por Hans Günther Zoll. p. 87.

${ }^{595}$ Max Horkheimer, “Autoritärer Staat”, op. cit , p. 295. Cf. também p. 296, p. 300, p. 312 e passim.
} 
até mesmo em greves e em pressões por melhores salários ${ }^{596}$, a repressão policial foi principalmente um mero complemento da integração dos trabalhadores no âmbito das organizações político-partidárias.

Horkheimer estava ciente, ademais, de que a transformação da classe trabalhadora em uma massa integrada havia sido preparada durante o período do auge da social-democracia. As vitórias eleitorais do Partido Social-Democrata e o crescimento dos sindicatos ligados a ele foi acompanhado de seu crescente reformismo, e a burocratização dos sindicatos, com a separação crescente entre seus líderes politicamente atuantes e as bases condenadas à inércia, era no âmbito da organização da classe operária o correlato da divisão, no âmbito das grandes empresas, entre os acionistas e o corpo diretor:

"O dirigente e a sua clique se tornam na organização trabalhista tão independentes quanto no outro monopólio, o industrial, a diretoria se torna independente da assembleia geral. Os meios de poder - aqui as reservas da empresa, lá o caixa do partido ou do sindicato - ficam à disposição da direção no combate aos estraga-prazeres" ${ }^{\prime 597}$.

A tecnicização dos aparelhos sindicais e partidários conservava o enrijecimento da divisão, e a adequação ao capitalismo substituía o programa revolucionário, transformado no melhor dos casos na perspectiva evolucionista que previa o "crescer socialismo adentro" (e que foi ela própria, como chamamos à atenção acima, um componente da prática reformista que contribuiu para a formação do capitalismo de Estado). A votação pelos créditos de guerra e a República de Weimar que seguiu à queda da monarquia dotaram o processo de renovado ímpeto, e se dispersou em grupos minoritários o protesto contra as direções dos partidos e sindicatos alinhados com a ideia de uma melhoria das condições de vida dentro do capitalismo: "na República de Weimar, a oposição proletária, caso não tenha perecido em meio a um conjunto de seitas, sucumbiu, ela própria, ao espírito da administração" ${ }^{258}$.

A relevância adquirida pela administração e pela tecnicização na indústria, no Estado, e mesmo no interior dos sindicatos e partidos representou uma mediação importante para se entender a nova configuração das classes sociais e a mudança das relações entre o Estado e a

\footnotetext{
${ }^{596}$ Cf. Tim Mason, “The Workers' Opposition in Nazi Germany”. History Workshop Journal, vol. 11, 1981, pp. 120-137. Disponível em libcom.org.

${ }^{597}$ Max Horkheimer, “Autoritärer Staat”, op. cit., p. 296.

${ }^{598}$ Max Horkheimer, “Autoritärer Staat”, p. 296. Sobre a integração do proletariado no âmbito dos sindicatos e partidos de massa, cf. a passagem inteira entre as páginas 295 e 298, e também o já mencionado ensaio, também de Horkheimer, "Die Juden und Europa", op. cit., pp. 126 infra-127. Sobre essas questões, cf. Vladimir Ferrari Puzone, Da revolução à integração: a trajetória do proletariado vista por Horkheimer. Dissertação de mestrado. FFLCH-USP, 2009. pp. 94-102.
} 
economia, e pode jogar luz sobre a própria tese do capitalismo de Estado. É preciso ressaltar, por isso, que ao se compreender a crescente intervenção estatal na economia como um mecanismo adotado ao longo dos anos trinta para superar a crise, deve-se ter em mente que outro fenômeno, de natureza igualmente política, foi determinante para a configuração do capitalismo na década de 1920: trata-se da reestruturação produtiva taylorista, que preparou o caminho para a implantação do fordismo na década seguinte. Era a ela que se referia Pollock em seu texto de 1941, ao afirmar que em "todas esferas do Estado a suposição e a improvisação dão lugar aos princípios da administração científica [scientific management]": a racionalização taylorista que os industriais alemães aprenderam de seus colegas norte-americanos preparou, segundo Pollock, o caminho para o controle totalitário sobre todas as esferas da vida social ${ }^{599}$. É verdade que Horkheimer, Adorno e outros membros do Instituto de Pesquisa Social de Frankfurt analisaram o fordismo principalmente a partir da concentração de capital (em monopólios e oligopólios) e da ampliação de sua circulação (por exemplo, na ciência e na indústria cultural), e dessa maneira prestaram pouca atenção ao processo de trabalho concreto: pode-se afirmar que eles de uma maneira geral tomaram como dadas a taylorização dos processos de trabalho e, a partir da segunda metade dos anos trinta, a integração do proletariado $^{600}$. Não obstante, cremos ser impossível compreender adequadamente o Estado autoritário sem considerar esses processos (o taylorismo-fordismo e as consequências que ele teve para a integração do proletariado e para a nova forma de dominação estatal), capazes de iluminar como se pôde passar, de uma situação histórica que em fins da década de 1910 poderia ser caracterizada como pré-revolucionária, à situação de uma integração social que no decorrer da década de trinta se tornava cada vez mais rígida e "totalitária". A relevância desse processo não poderia ser subestimada, como afirmava Horkheimer em 1939:

\footnotetext{
"A transformação do premido trabalhador, que no século XIX andava à busca de trabalho, no membro aplicado das organizações fascistas lembra, em seu significado histórico, a transformação, empreendida pela Reforma, do mestre artesão medieval no burguês protestante, ou do pobre aldeão inglês no moderno trabalhador industrial"601.
}

\footnotetext{
${ }^{599}$ Friedrich Pollock, "State capitalism”, op. cit., p. 206.

${ }^{600}$ Cf. Alex Demirović, "Rekrutierung von Intellektuellen im Fordismus. Vergleichende Anmerkungen zu Horkheimers und Adornos Analyse der Kulturindustrie und Gramscis Analyse der Zivilgesellschaft". In: Oliver Brüchert; Christine Resch (Orgs.). Zwischen Herrschaft und Befreiung - kulturelle, politische und wissenschaftliche Strategien. Münster: Westfälisches Dampfboot, 2002. p. 63.

${ }^{601}$ Max Horkheimer, "Die Juden und Europa", op. cit., p. 118.
} 
Se é verdade que "toda reificação é um esquecimento" 602 , quando analisamos a integração do proletariado (tema central para a teoria crítica) não devemos esquecer que ela foi um processo que teve um de seus principais elementos na reestruturação produtiva dos anos vinte, que haveria de ficar conhecida sob os títulos de "taylorização", "organização científica do trabalho" ou, tal qual era conhecida à época, "racionalização". É por isso que gostaríamos de argumentar aqui que a transformação da classe trabalhadora em "massa", passo fundamental da constituição do "Estado autoritário", não foi algo que tenha ocorrido da noite para o dia, ou então, automaticamente, por meio da sobreposição do movimento do capital para a subjetividade do proletariado, amoldando a sua política, sua cultura e o psiquismo de seus membros à racionalidade instrumental reduzida à conformação de meios a fins e alheia à transformação do todo. Esse processo ocorreu ao longo do século XX (e ocorre até hoje) sob o influxo de mecanismos históricos específicos, em um longo e contínuo processo de reiteração e aprofundamento da dominação burguesa ${ }^{603}$.

Quando Horkheimer afirmava em 1935, como chamamos à atenção acima, que a burguesia monopolista transformara "vastas áreas da Europa em imensos campos de trabalho" ${ }^{604}$, estava se referindo a um processo ocorrido ao longo das décadas de 1920 e 1930 e que teve um impacto decisivo sobre a fragmentação da classe trabalhadora, tendo sido o fator fundamental de sua impotência política: o taylorismo-fordismo ${ }^{605}$. Ao final do processo, os trabalhadores se reduziram cada vez mais a meros "suportes de força de trabalho" "606, e a progressiva abstração de sua espontaneidade conseguiu adequá-los a um processo social de produção cada vez mais racionalizado e que constituía a base histórica do desaparecimento do indivíduo. Expresso no aplainamento da tensão entre o pensamento e a realidade, no

\footnotetext{
${ }^{602}$ Adorno e Horkheimer, Dialética do Esclarecimento. Tradução de Guido A. de Almeida. Rio de janeiro: Jorge Zahar Editor, 1985, p. 215.

${ }^{603}$ Em meados da década de 1940, quando da redação da Dialética do Esclarecimento a indústria cultural apareceu a Horkheimer e a Adorno como um dos principais mecanismos de dominação nos países ocidentais, capaz de conformar a subjetividade individual a um sistema no qual o aparente poder de decisão dos consumidores repousaria sobre o fato de que "a cultura contemporânea confere a tudo um ar de semelhança". Cf. Adorno e Horkheimer, Dialética do Esclarecimento, op. cit., p. 113. É preciso reconhecer, por outro lado, que a sua constituição foi resultado de um momento de inflexão histórica consistente na contrarrevolução burguesa que, por meio do fordismo, promoveu a integração da classe operária após os ensaios de revolução na Europa, no período imediatamente posterior à primeira guerra mundial.

${ }^{604} \mathrm{Cf}$. a passagem, citada no início deste item, de "Bemerkungen zur philosophischen Anthropologie", op. cit., p. 264.

${ }^{605}$ Em 1941, referindo-se ao período nazista, Neumann de maneira semelhante a Horkheimer alguns anos antes se referiria ao nacional-socialismo como "(...) uma ditadura totalitária que foi capaz de transformar algumas de sua vítimas em seus apoiadores e de organizar, sob férrea disciplina, o país inteiro em uma campo armado" (Franz Neumann, Behemoth, op. cit., p. 38). Sobre o taylorismo-fordismo, cf. o capítulo desta tese em que são examinadas as pesquisas sobre autoridade e família.

${ }^{606}$ Herbert Marcuse e Max Horkheimer, "Philosophie und kritische Theorie", Zeitschrift für Sozialforschung, volume 6 de 1937, p. 642 .
} 
amalgamento entre o id e o supereu e na redução do indivíduo a uma mera função econômica, esse processo (que em seus diversos aspectos seria objeto de diversas análises feitas pelos autores ligados ao Instituto de Pesquisa Social) foi considerado por Horkheimer também no que dizia respeito à nova configuração entre o Estado e as classes sociais. A classe trabalhadora, segundo o autor, havia sido reduzida a "massas apartadas dos meios de produção"607, e ao mesmo tempo em que se tornava impotente em virtude da racionalização dos processos de trabalho, era integrada na burocracia sindical-partidária, que assim preparava sua submissão ao Estado autoritário: os partidos de massa preparavam as massas para a nova forma de dominação, de maneira que elas eram "vítimas" dos partidos de massas antes de o serem do Estado autoritário $^{608}$. A redução de seus membros a meros objetos de dominação os dotava de uma "igualdade negativa diante do poder que não conhece diferenças" ${ }^{609}$, do poder da dominação que se estendia da fábrica ao conjunto de uma sociedade que, ao submeter cada vez mais esferas à mercantilização e ao processo de trabalho capitalista, tendia na direção da "exploração universal”, paródia da abolição da dominação de classe à qual conduziu o desenvolvimento das forças produtivas sob o capitalismo monopolista: “o capitalismo de Estado aparece sob certa medida quase como uma paródia da sociedade sem classes" ${ }^{\text {610 }}$. O caráter universal dessa exploração significava que a irracionalidade da dominação sobre o trabalho alheio, que à época do capitalismo liberal convivia com a racionalidade de uma esfera da circulação composta por sujeitos aparentemente autônomos, após a mudança de função do mercado passava a ser executada diretamente pelo Estado, que não mais se apresentava por isso como uma esfera de suposta universalidade.

A integração do proletariado não significou de modo algum o desaparecimento das desigualdades entre as classes sociais e muito menos a amenização das relações de dominação. A diferença básica entre burgueses e proletários se mantinha, mas era complexificada pela multiplicação de outras distinções, por exemplo, entre trabalhadores qualificados e nãoqualificados, membros do sindicato e trabalhadores não-sindicalizados, trabalhadores de nações mais desenvolvidas e menos desenvolvidas: "não é que a desigualdade tenha diminuído. Às

\footnotetext{
${ }^{607}$ Max Horkheimer, "Die Philosophie der absoluten Konzentration”. In: Gesammelte Schriften, vol. 4, p. 303.

${ }^{608}$ Cf., de Horkheimer, "Die Juden und Europa”, op. cit., p. 127 e também "Autoritärer Staat", op. cit., pp. 295296.

609 Cf. Max Horkheimer, "Bemerkungen zur philosophischen Anthropologie", vol. 4 da Zeitschrift für Sozialforschung, 1935, p. 23. Neumann, por sua vez, como chamamos à atenção anteriormente, ainda em 1944 pensava que da racionalização do processo produtivo poderia advir alguma consciência de classe.

${ }^{610}$ Max Horkheimer, “Autoritärer Staat”, p. 316.
} 
velhas discrepâncias entre o poder social de membros específicos dos diversos grupos sociais se acrescentaram outras diferenças. (...) O princípio não mudou"611.

\section{$\underline{5.2 .2 \text { - Estado, burguesia monopolista e a forma autoritária da dominação }}$}

No capitalismo de Estado o princípio de organização social mais proeminente não seriam mais as trocas econômicas na esfera da circulação, e os indivíduos deparariam uns com os outros não mais como sujeitos autônomos que celebram contratos, mas na condição de comandantes e comandados ${ }^{612}$. Um número cada vez maior de funções seria reservada aos burocratas da indústria, dos partidos e dos sindicatos, reunidos no Estado, e a maior parte dos indivíduos seria composta de empregados assalariados. O amalgamento das esferas da política e da economia se exprimiria no próprio vocabulário: durante o período nazista, os empresários eram "líderes de empresa" [Betriebsführer], e os trabalhadores, seus "séquitos" [Gefolgschaften $]^{613}$. A aceitação das hierarquias era a base mais eficaz da dominação, ainda quando a violência direta (física) e a identificação emocional com os líderes também pudessem atuar, de maneira coadjuvante ${ }^{614}$.

Nas análises de Pollock e Horkheimer, o Estado era tido como independente dos interesses imediatos dos trabalhadores e empresários. Seria um erro, contudo, interpretar as formulações de ambos os autores sobre a integração do proletariado à burocracia estatal como se houvesse uma equiparação entre os interesses dos trabalhadores e aqueles da burguesia também institucionalizada, pois se os trabalhadores e suas organizações (os sindicatos reformistas e o partido social-democrata) haviam preparado a nova forma de dominação, eles foram excluídos do poder tão logo aquele complexo grupo dominante assumiu o governo: como lembrou Horkheimer, a burguesia monopolista sempre suspeitara das organizações dos trabalhadores, e por isso "o capital alemão, ao retomar em suas mãos a política imperialista,

\footnotetext{
${ }^{611}$ Cf. Max Horkheimer, "Zur Soziologie der Klassenverhältnisse”, op. cit., p. 89.

${ }^{612}$ Yves Cohen, em trabalho recente, chamou a atenção para o fato de que o comando e a hierarquia teriam se estabelecido ao longo do capitalismo monopolista como princípios centrais da organização social. Cf., do autor, “Por que chamar o século XX de o ' século dos chefes'?”. Sociologia e antropologia, vol. 5, número 3. Rio de Janeiro, set-dez. de 2015.

${ }^{613}$ Cf. Friedrich Pollock, "State capitalism”, op. cit, p. 222-223.

${ }^{614}$ Horkheimer parece ter sempre considerado relativamente secundárias a coação física e a identificação psicológica com o líder (tal qual ressaltado pela psicologia das massas). Muito mais básica para a dominação seria a aceitação da ordem social tal qual ela se apresenta. Cf. as reflexões feitas pelo autor alguns anos antes: "História e psicologia", op. cit., p. 22 e o curso sobre "autoridade e sociedade" ministrado na Universidade de Columbia: "Aus Vorlesungen über Autorität und Gesellschaft". In: Max Horkheimer, Gesammelte Schriften, vol. 12, op. cit., p. 62.
} 
deixou para trás a burocracia política e sindical que o tinha auxiliado a tanto" "615. Na edição da Revista de Pesquisa Social em que publicou o texto de Pollock, Horkheimer não deixou por isso de ressaltar que "o nacional-socialismo tenta manter e fortalecer a hegemonia de grupos privilegiados por meio da abolição de liberdades econômicas para o resto da sociedade" ${ }^{\text {"16 }}$.

Isso nos leva a ressaltar um aspecto importante das teses tanto de Pollock quanto de Horkheimer. É verdade que ambos os autores equiparavam o estatismo dos países capitalistas ao "estatismo integral", ou "socialismo de Estado", da União Soviética, e por isso não depositavam esperanças em um estatismo "vindo de baixo" 617 . A reestruturação tayloristafordista, ao longo da qual aprofundou-se o processo de integração da classe trabalhadora nos Estados Unidos e na Europa, se deu paralelamente à ascensão do stalinismo, imediatamente após a morte de Lênin, em 1924 (iniciada em 1915 nos EUA, na Alemanha a "racionalização" taylorista data de uma década depois, e o desenvolvimento do fordismo se deu concomitantemente ao regime nazista, a partir de 1933). Entretanto, formulações como aquelas mencionadas acima, feitas por Horkheimer acerca dos proprietários das grandes corporações (fossem eles "de direito" ou "de fato", dada a separação entre o título jurídico de propriedade e o exercício de comando sobre as empresas), sugerem uma proximidade de Horkheimer com a tese de Neumann, como se no prefácio da edição de 1941 da Revista o diretor do Instituto houvesse tentado fazer aparos aos elementos da tese do "capitalismo de Estado" capazes de sugerir o fim da base econômica da dominação ${ }^{618}$.

De fato, na perspectiva de Horkheimer o Estado autoritário, garantidor da realização da mais-valia no âmbito internacional, havia sido instituído em decorrência das necessidades da expansão imperialista e atendia principalmente aos interesses da burguesia monopolista. Isso não significa que Horkheimer tivesse uma concepção instrumental do Estado: ele sabia ser o

\footnotetext{
${ }^{615}$ Max Horkheimer, "Die Juden und Europa", op. cit, p. 118.

${ }^{616}$ Cf. Max Horkheimer, "Preface", Studies in Philosophy and Social Science, op. cit., p. 198.

${ }^{617}$ Cf. Max Horkheimer, “Autoritärer Staat”, op. cit, pp. 300-304.

${ }^{618}$ Neumann, em carta de 30 de julho de 1941, elogiava Horkheimer pelo prefácio, considerado por ele uma "reinterpretação" do "capitalismo de Estado", na qual Horkheimer por motivos pessoais não enunciaria com clareza sua discordância das teses de Pollock, mas exprimiria sua concordância com Neumann. Cf. a página 110. O tom geral da última carta de Horkheimer a Neumann a abordar diretamente a divergência entre esse e Pollock, por sua vez, era de uma defesa de Pollock, fundamentada pela necessidade de manter um ambiente saudável de discussão no Instituto. Mas das cartas não é possível inferir nada de muito conclusivo: Horkheimer oscila entre observações críticas à tese do "capitalismo de Estado", de um lado, e a defesa do texto de Pollock perante Neumann, de outro. Assim como não parece ser possível inferir - das resistências pessoais de Horkheimer a Neumann, e nem de sua oposição, depois do retorno do exílio, à publicação de Behemoth na Alemanha - que Horkheimer não tenha incorporado algumas das teses de Neumann, ainda que tenha adotado o essencial do conceito de "capitalismo de Estado" de Pollock. Cf. a carta de Horkheimer a Neumann de 2 de agosto de 1941. Vol. 17, p. 119. A informação sobre a oposição de Horkheimer à publicação do Behemoth, por ele considerado um livro que não pertencia à orientação do Instituto, provém do estudo de Francisco Colom González, Las caras del Leviatán: uma lectura política de la teoría crítica. Barcelona: Anthropos, 1992. p. 152, citado apud Ricardo P. Regatieri, Do capitalismo monopolista ao processo civilizatório, op. cit., p. 91.
} 
grupo dominante composto não apenas pelos grandes industriais, mas também - e quanto a isso concordavam Horkheimer, Pollock e Neumann - pelo exército, pelo partido nazista e pela alta burocracia $^{619}$. Horkheimer estava ciente, portanto, de que essa composição tornava o Estado um órgão incapaz de ser submetido diretamente aos interesses da burguesia monopolista, pois embora houvesse um íntimo vínculo entre o Estado e os interesses dos grandes industriais, cada um daqueles grupos tinha seus interesses próprios e o Estado seguia por isso uma dinâmica própria, que não podia ser reduzida aos imperativos de nenhum deles: “o plano, concebido e executado no interesse de grupos econômicos privados, é constantemente obstruído pelas necessidades cambiantes das disputas por poder" ${ }^{\prime 620}$.

Dessa maneira, embora a nova forma de dominação política atendesse aos interesses da burguesia monopolista, ela não detinha a representação exclusiva no âmbito estatal. Ao mesmo tempo, porém, o Estado autoritário era, sob o capitalismo monopolista, a forma mais adequada para o cumprimento de seus interesses, e tanto nessa fase do capitalismo quanto no período concorrencial a totalidade social funcionava de maneira a atender aos interesses burgueses: a diferença era que havia desaparecido a oposição entre os interesses particulares e um Estado que se apresentava como uma universalidade. Essa oposição, mediada pelo mercado regido pelas normas abstratas e impessoais do direito moderno, era funcional à burguesia no período liberal - sob a nova fase do capitalismo, por sua vez, as mudanças de função do mercado e do direito dispensavam a apresentação do Estado (e também da ideologia, como vimos no capitulo anterior) como uma universalidade, tal qual ocorria no período da livre concorrência, quando a burguesia apresentava seus interesses de classe como os interesses da sociedade em geral. Horkheimer compreendeu que o Estado, embora se autonomizasse em relação às classes e não pudesse ser vinculado a uma delas em particular, não apenas continuava servindo a interesses privados, mas o fazia ao mesmo tempo em que deixava de basear sua legitimidade na representação de um vínculo com os interesses gerais e não precisava mais da referência a esses

\footnotetext{
${ }^{619}$ Cf. as passagens já citadas dos textos de Pollock e Neumann, no item anterior. Quanto a Horkheimer, em seu ensaio sobre o "Estado autoritário" não há menção nominal aos quatro grupos, da maneira que frequentemente ocorre nos textos de Pollock e Neumann, mas é a eles que o autor se referia ao mencionar a "disciplina fascista dos povos" (p. 302) e a institucionalização, no Estado, da burocracia sindical e dos dirigentes dos monopólios (passim). Em outros textos do autor e referência aos quatro grupos é explícita: cf. "Die Juden und Europa", op. cit., p. 121, e o prefácio do autor à edição de 1941 da Revista, em que foi publicado o texto de Pollock: "os setores de proa da indústria, a administração, a propaganda e as forças armadas tornaram-se idênticas ao Estado na medida em que estabelecem o plano da economia nacional da mesma maneira que, antes deles, o empresário havia determinado a política a ser seguina em sua fábrica. Ao mesmo tempo, o Estado manifesta o seu caráter privado na medida em que o enorme poder arrebatado pelas elites inevitavelmente as segrega do todo, na condição de detentoras de interesses muito especiais" Cf. Max Horkheimer, "Preface", Studies in Philosophy and Social Sciences, op. cit., pp. 195-196.

${ }^{620}$ Max Horkheimer, "Preface”, In: Studies in Philosophy and social sciences, op. cit., p. 197.
} 
interesses para se impor. Como percebera Horkheimer em seu ensaio sobre "Os judeus e a Europa", o conceito de Estado "perde completamente a sua contradição com o conceito de uma particularidade dominante, ele é o aparelho dos líderes coligados, uma ferramenta particular de poder, e isso tanto mais quanto mais se autonomiza, quanto mais é endeusado"621.

É por isso que o Estado poderia se apresentar como uma abstração dos interesses específicos, como um ente absoluto cuja legitimidade repousaria na sua própria irredutibilidade a interesses, algo que os nazistas souberam explorar bem na sua ideologia pretensamente anticapitalista e desvinculada dos interesses econômicos, baseada em ideias de pertencimento racial e destino nacional. Tal qual na fase do capitalismo liberal, a exploração continuava a ser transfigurada ideologicamente com vistas à dominação burguesa, mas os conflitos imperialistas se sobrepunham àquele entre a burguesia e o proletariado, a oposição entre os interesses das classes não sendo mais negada com recurso às ideias liberais da igualdade e de uma suposta harmonia dos interesses concorrentes, e sim - pelo menos em tempos de guerra - com recurso a ideologias que ressaltavam a inevitabilidade do destino e a necessidade do heroico sacrifício pessoal a propósitos maiores (como aqueles encarnados na nação). A superposição entre o imperialismo e o antagonismo das classes aparecia a Horkheimer desde cedo como um problema central:

\begin{abstract}
“A fase monopolista conserva a negação das oposições de classe, mas a luta no mercado mundial entre poucos grupos de poder se torna de tal maneira o tema principal da época, que em vez da concordância entre as existências individuais aparecem aqui como categorias histórico-filosóficas conceitos como o trágico, o heroísmo e o destino. Os interesses materiais dos indivíduos são tidos por algo de insignificante, que precisam menos ser atendidos do que superados" ${ }^{\prime 22}$.
\end{abstract}

O Estado autoritário não era estritamente funcional a nenhum dos grupos que o controlavam, mas justamente por isso ele não era uma novidade na história da sociedade burguesa, e podia ser considerado como uma atualização, para as condições do capitalismo monopolista, do fenômeno do bonapartismo, que desde a reação termidoriana havia expressado a resistência da burguesia à possibilidade, nas palavras de Horkheimer, de um estatismo que proviesse "de baixo" (no caso da Revolução Francesa, um estatismo construído pelos jacobinos): em uma situação de crise, o Estado se elevava acima das classes sociais e, ainda que sua atuação eventualmente entrasse em conflito com a burguesia e não pudesse ser identificada como funcional a nenhuma classe social específica, ela servia no fim das contas para aprofundar

\footnotetext{
${ }^{621}$ Cf. Max Horkheimer, "Die Juden und Europa", op. cit., p. 125.

${ }^{622}$ Cf. Max Horkheimer, "Materialismus und Metaphysik", op. cit., pp. $72-73$ (o ensaio é de 1933).
} 
a dominação burguesa. Em O Dezoito de Brumário de Luís Bonaparte Marx mostraria, dessa maneira, como o atendimento direto dos interesses materiais da burguesia não era a única maneira de o Estado favorecer a sua dominação: se por um lado Luís Bonaparte tinha nos camponeses reacionários e desfavorecidos pela república sua base de apoio político, por outro lado o Estado, ao se fortalecer e assumir a forma de um complexo aparato, atuava em apoio à contrarrevolução e, portanto, em favor da burguesia industrial. De maneira análoga, pode-se pensar que seria apenas parcialmente verdadeiro entender o fascismo como um movimento de "classe média", em virtude de seu apoio na pequena burguesia arruinada pela crise e pela

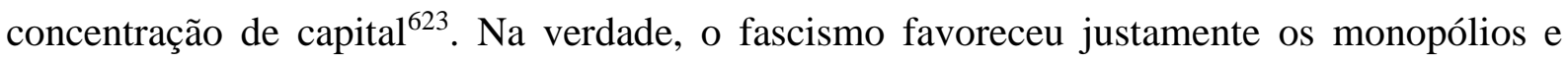
oligopólios contra os quais vociferavam os líderes nazifascistas e sua propaganda anticapitalista, e o fez não apenas por meio da garantia direta de seus interesses (uma verdade parcial em que Neumann insistia), mas também por meio de um tipo de dominação destituída de vínculo direto com a burguesia, e que submetia a si a maior parte dos membros das duas classes fundamentais (uma verdade parcial em que Pollock insistia) ${ }^{624}$.

O que caracterizava essencialmente a forma autoritária assumida pelo Estado no período posterior à crise de 1929? Pollock, se ao que tudo indica errara ao supor o fim da extração de mais-valia e a inexistência de uma esfera econômica com legalidade própria frente ao Estado, acertara entretanto ao examinar a forma assumida pelas relações sociais no âmbito do capitalismo de Estado como uma estrutura de comandantes e comandados, uma burocracia econômica e política que na perspectiva também de Horkheimer teria substituído o contrato que unia os indivíduos no mercado e sob um Estado representante dos interesses gerais. A concorrência que condicionava certa margem de autonomia era deslocada para o mercado internacional, enquanto no âmbito interno da nação o elo entre o Estado e os indivíduos assumia a forma do controle típico do processo de trabalho da época do capitalismo liberal: o “despotismo fabril” se estendia à política e fazia da nação uma comunidade na qual os direitos individuais fundados na universalidade dos direitos (contratos que vinculavam o Estado a seus cidadãos e aos interesses desses) cediam lugar ao pertencimento nacional baseado em uma particularidade étnica inata e em princípio indissolúvel. O cidadão se tornava um "camarada de etnia" [Volksgenosse ${ }^{625}$, e a dominação política perdia o elemento de racionalidade, tornando-

\footnotetext{
${ }^{623}$ Como já ressaltamos anteriormente, essa era a interpretação, por exemplo, de Reich: “Do ponto de vista da base social, o nacional-scoialismo foi sempre um movimento da classe média baixa". Cf. Wilhelm Reich, Psicologia de massas do fascismo, op. cit., p. 52.

${ }^{624}$ Horkheimer lembrava que na Alemanha, Estado-nação surgido já em meio ao imperialismo e aos monopólios, o capitalismo de Estado teria começado a se formar já com Bismarck, em um processo político de traço bonapartista. Cf. Max Horkheimer, "Autoritärer Staat", op. cit., p. 300.

${ }^{625}$ A tradução é a mesma que se encontra na edição brasileira da Dialética do Esclarecimento, op. cit..
} 
se tão irracional quanto sob o capitalismo liberal era, em contraste com a racionalidade do mercado, a dominação no âmbito da produção.

O Estado autoritário seria por isso, nas palavras de Horkheimer, uma "redução ao absurdo" da irracionalidade presente no capitalismo liberal. A irracionalidade da dominação (antes restrita à propriedade privada dos meios de produção e ao despotismo fabril dela decorrente) se desvinculava da aparente racionalidade da troca e se estendia ao Estado: não haveria mais mediação do contrato (que continha um elemento de racionalidade), e a mediação entre o valor de uso (a exploração do trabalho) e o valor de troca (deslocado para o mercado internacional) seria feita pelo Estado, apresentado como a comunidade popular baseada no vínculo étnico (e, portanto, meramente irracional). O Estado autoritário promoveria algo como um aprofundamento da contradição ente o valor de uso e o valor de troca, enrijecendo-a ao separar os polos da relação:

“(...) a ordem totalitária é nada além do que a sua precursora, que perdeu as suas amarras. (...) O fascismo é a verdade da sociedade moderna, que desde o início havia sido alcançada pela teoria. Ele fixa as diferenças extremas que a lei do valor produzia ao final" ${ }^{\prime 626}$.

O Estado autoritário garantiria os interesses da burguesia monopolista, mas na concepção de Horkheimer a relação entre base e superestrutura não seria mecânica, de mero reflexo. A estrutura de poder dos sindicatos e das corporações, as mudanças jurídicas do Estado, a repressão política direta e a concentração de poder (em sua forma extrema, nas mãos dos governantes fascistas) correspondiam à extensão, ao conjunto da sociedade, da relação entre comandantes e comandados típica da fábrica: "o regulamento da fábrica se estendeu para a sociedade inteira"627, "em vez do comando fragmentado nas fábricas individuais surge a dominação totalitária do interesse particular sobre o povo inteiro"628. Dessa maneira, a concentração da propriedade privada foi acompanhada pela extensão do despotismo fabril para o conjunto do Estado-nação. Era como se a mudança de função do mercado e do direito e o deslocamento da relação mercantil para o âmbito internacional tivessem sido acompanhados da supressão dos elementos de universalidade do Estado e da extensão do despotismo fabril até os

\footnotetext{
${ }^{626}$ Max Horkheimer, "Die Juden und Europa", p. 116 do vol. 8 de 1939-40 da Zeitschrift für Sozialforschung. Na carta a Grossmann de 20 de janeiro de 1943, Horkheimer afirmaria que “(...) o fascismo é o capitalismo total, existente em sua negação”. Max Horkheimer, Gesammelte Schriften, vol. 17, p. 407.

${ }^{627}$ Max Horkheimer, "Autoritärer Staat", op. cit., p. 301.

${ }^{628}$ Max Horkheimer, "Die Juden und Europa", op. cit., p. 118. Cf. também a passagem já citada anteriormente: “o princípio que havia sido cunhado em relação à economia de mercado, segundo o qual à anarquia na sociedade corresponde a ordem rígida na fábrica, significa hoje que o estado de natureza internacional - a luta pelo mercado mundial - e a disciplina fascista dos povos condicionam-se mutuamente". "Autoritärer Staat", op. cit., p. 302.
} 
confins da nação, abrangendo as esferas econômica e política em uma só relação de comando, que tinha na burocracia sua forma mais depurada.

A respeito dessa forma de dominação, Kirchheimer podia ter razão quando afirmava, em sintonia com as teses de Neumann e em oposição à compreensão de Horkheimer e Pollock sobre o capitalismo de Estado, que a administração de diversos setores econômicos por uma burocracia estatal plasmada com os líderes dos negócios seria apenas uma fachada aparente que mal encobriria o caráter particular dos interesses aos quais servia, tese defendida pelo autor à base, dentre outros, do argumento segundo o qual os cargos centrais das seções dessa burocracia relevantes à indústria seriam ocupados por representantes diretos dos grandes industriais:

"Na esfera dos negócios em grande escala, a transformação das posições de poder privado em órgãos públicos da 'autoadministração' econômica, apesar de acompanhada pela transferência de plenos poderes legais para ministros e órgãos especiais encarregados da supervisão, aumentou o poder daqueles que dominam as organizações, em vez de diminuí-lo. Por trás da moldura legal do princípio de liderança, que requer que os líderes de cada grupo sejam designados pelas autoridades públicas, continuam inalterados os princípios absolutistas que governam os negócios monopolizados (...)"629.

Não importava tanto para a dominação, contudo, que a burocracia estatal fosse ocupada ou não por representantes diretos dos interesses burgueses, pois representantes provindos da burocracia sindical poderiam ocupar esses lugares em igual ou maior medida e ainda assim atender aos mesmos interesses, dado que os mecanismos de dominação se autonomizavam em relação às classes sociais responsáveis por sua instituição. A dominação do particular sobre o universal se servia de outros mecanismos que garantiam a subordinação dos indivíduos às estruturas burocráticas econômico-políticas, e se o nacionalismo e as ideologias de superioridade racial tiveram (e sempre têm) um papel bastante proeminente em tempos de conflito bélico, além deles outros mecanismos de sustentação do Estado autoritário tiveram vida longa e subsistiram por muitas décadas após o fim da segunda guerra mundial ${ }^{630}$.

\footnotetext{
${ }^{629}$ Cf. Otto Kirchheimer, "Changes in the structure of political compromise", op. cit., , p. 278. Cf. também a página 274 do mesmo texto.

${ }_{630}$ Ao ressaltar a autonomização dos mecanismos de dominação em relação à classe dominante por eles servida, Horkheimer não reduziu portanto o Estado a um epifenômeno, como defendido por Postone no capítulo 3 de seu já mencionado Time, work and social domination. Quando se lê o ensaio de Horkheimer sobre o "Estado autoritário", pode-se notar ali, como tentamos mostrar, uma reflexão sobre a relação entre a forma do Estado, as relações sociais de produção e o desenvolvimento técnico. Não é preciso, portanto, proceder como Hirsch e recorrer ao Behemoth de Neumann à procura de indícios "não desenvolvidos" dessa relação. Cf. Joachim Hirsch, "Staatskapitalismus? Zur Kontroverse zwischen Friedrich Pollock, Max Horkheimer und Franz Neumann in Bezug auf den Charakter des nationalsozialistischen Systems", op. cit..
} 
De partida, as crises econômicas passavam a ser controladas: enquanto à época da economia de mercado a crise aparecera como um momento propício à desintegração do sistema e à revolução, no capitalismo de Estado ela seria administrada de maneira a garantir a perpetuação da dominação ${ }^{631}$. Ao contrário de Neumann, que pensava que o capitalismo monopolista autoritário poderia ser ameaçado pela crise e pelo movimento dos trabalhadores, Horkheimer concordava com Pollock no que dizia respeito à resistência dessa fase do capitalismo a ameaças originadas da produção: “A sociedade totalitária tem chances econômicas de longo prazo. (...) As crises eram sinais racionais, a crítica alienada [entfremdete] da economia de mercado, que embora cega era orientada pelo carecimento [dos indivíduos]"632. $\mathrm{Na}$ nova fase, a crise seria institucionalizada pelo Estado autoritário, tornada permanente e politicamente inofensiva, pois objeto da administração estatal. Ainda que a produção e o consumo de massas não atingisse a todos e tivesse suas brechas, o desemprego seria organizado pelo planejamento econômico, e o grupo dominante passaria a "alimentar os trabalhadores", em vez do contrário tradicionalmente observado ao longo da história ${ }^{633}$. Também a guerra e a fome seriam utilizadas como técnicas de dominação: a desobediência ao comando políticoeconômico poderia implicar em sucumbir a uma das duas. Mas o que em Pollock aparecia como duas situações opostas, associadas respectivamente às formas "democrática" e "totalitária" do capitalismo de Estado, em Horkheimer aparecia como uma única e mesma dominação, sendo indiferente, para a permanência do Estado autoritário, a situação de paz e bem-estar material, por um lado, ou aquela de guerra e escassez, por outro ${ }^{634}$. Se Neumann considerava que os interesses das massas de trabalhadores ainda podiam ser uma fonte de insurgência revolucionária, Horkheimer considerava que a subordinação de seus interesses de sobrevivência imediata àqueles da nação garantiria ao Estado autoritário longa vida:

"Por maior e mais poderoso que seja o país, como é o caso dos Estados Unidos, a máquina de opressão contra o inimigo interno tem de encontrar um pretexto na ameaça do inimigo externo. A fome e o perigo de guerra, na economia de mercado consequências necessárias e não controladas, produzidas contra a vontade, são aplicadas de maneira construtiva pelo Estado autoritário" ${ }^{635}$.

\footnotetext{
${ }^{631}$ Cf. Max Horkheimer, “Autoritärer Staat”, op. cit., p. 294.

${ }^{632}$ Cf. Max Horkheimer, "Die Juden und Europa", op. cit., p. 122.

${ }^{633}$ A possibilidade de uma situação como essa, que corresponderia alguns anos mais tarde ao "Estado de bemestar" e de certa maneira já aparecia em germe nos países de "capitalismo de Estado" da época, que superavam as devastações provocadas pela crise e pela primeira guerra, foi entrevista por Pollock e Horkheimer. Cf. Max Horkheimer, “Autoritärer Staat”, op. cit., pp. 294-296 e Friedrich Pollock, "State capitalism”, op. cit., pp. 213 215 e p. 223.

${ }^{634}$ Cf. Max Horkheimer, "Die Juden und Europa”, op. cit., p. 122.

${ }^{635}$ Cf. Max Horkheimer, “Autoritärer Staat", p. 302. Cf. também, a esse respeito, p. 313. No ensaio sobre "Os judeus e a Europa", Horkheimer afirmara que "na economia totalitária a fome aparece, em tempos de guerra e de
} 
paz, menos como perturbação do que como dever pátrio. Não haveria por que prever, economicamente, um fim para o fascismo enquanto sistema mundial". Cf. Max Horkheimer, "Die Juden und Europa", op. cit., p. 122. 


\section{Capítulo 6 - Para além do Estado autoritário: o indivíduo e a emancipação}

Sobre os trabalhos em geral do Instituto de Pesquisa Social nos anos trinta e quarenta, Wolfgang Bonß e Norbert Schindler afirmaram:

"Nem foi discutida a questão das condições de possibilidade de uma consciência de classe do proletariado (uma questão que poderia ser abordada do ponto de vista de uma teoria da constituição da consciência), nem se perguntou de maneira sistemática por posturas antiestruturais escondidas. O que permaneceu foi a análise da funcionalidade da consciência para a má base econômica e sua canalização unidimensional em direção a modelos autoritários de pensamento e comportamento - um tema que determinou de maneira central os trabalhos empíricos tanto dos anos trinta quanto dos anos quarenta" ${ }^{\prime 636}$.

Essa interpretação nos parece pouco compatível com os ensaios escritos por Horkheimer (e também com as próprias pesquisas sobre autoridade e família, malgrado suas limitações). Tentaremos neste capítulo examinar como Horkheimer esboçou, ainda que não o tenha feito “de maneira sistemática”, algumas saídas possíveis para o estado de subordinação aparentemente total e irreversível dos indivíduos na quadra do capitalismo correspondente ao "Estado autoritário" Mas para o autor as fissuras da dominação não deveriam ser buscadas, como supunha Neumann, em uma consciência de classe formada a partir da racionalidade técnica dos processos de trabalho (pois essa racionalidade havia sido alçada para além dos muros da fábrica e convertida cada vez mais em mero mecanismo de dominação), e nem na mera perspectiva de que a crise econômica, por si só, fosse conduzir a uma transformação significativa. Como vimos anteriormente, as críticas dirigidas a Pollock tendem a se concentrar nesse último ponto, uma hipótese que parece insustentável diante da institucionalização das crises econômicas, naturalizadas e sujeitas à administração estatal (como notado por Horkheimer em seu ensaio sobre o "Estado autoritário").

É verdade que a teoria crítica nunca elaborou sistematicamente uma teoria da ação revolucionária, e nem se vinculou explícita e disciplinadamente a uma estratégia política. Isso não excluiu, contudo, que Horkheimer se esforçasse por analisar algumas tendências históricas que indicavam "brechas" no regime de dominação política. Trata-se mais de esboços, nem

\footnotetext{
${ }^{636}$ Cf. Wolfgang Bonß; Norbert Schindler. "Kritische Theorie als interdisziplinärer Materialismus”. In: Wolfgang Bonß ; Axel Honneth. Sozialforschung als Kritik-zum sozialwissenschaftlichen Potential der kritischen Theorie. Frankfurt: Suhrkamp, 1982. p. 60.
} 
sempre feitos com clareza, do que de teses desenvolvidas até o fim, e por isso a crítica exemplificada acima com o comentário de Bonß e Schindler não deixa de ter em parte razão.

Na década de 1930, Horkheimer vinculou suas reflexões sobre a ação política a questões relacionadas à estrutura psíquica dos indivíduos, entendida como "caráter". Recorrendo às contribuições de Fromm sobre o tema, mas sem trilhar os mesmos caminhos da psicologia social de seu colega, Horkheimer elaborou uma "antropologia da era burguesa" (objeto do item 6.1 a seguir), um conjunto de reflexões em meio às quais se destaca o tema da "autoconservação", entendida como o elemento central da constituição do indivíduo no modo de produção capitalista. Essa concepção haveria de ganhar maior espaço (e uma nova direção) nos ensaios escritos pelo autor no início da década de quarenta, e mais notadamente na Dialética do Esclarecimento. Nos anos trinta, porém, o autor já extraía dela algumas consequências, ainda no âmbito de sua compreensão dos potencial emancipatório do proletariado (esse é o objeto do item 6.2). Embora tenham sido relativamente breves as suas formulações a esse respeito, julgamos conveniente ressaltá-las aqui, pois trata-se de reflexões que revelam o quanto a teoria crítica se esforçou por vincular o tema da classe àquele do indivíduo - ao ressaltar a compreensão que Horkheimer tinha dessa relação, pretendemos chamar a atenção ao mesmo tempo para o fato de que o tratamento dado a ela pelo Instituto de Pesquisa Social na década de 1930 não se resumia à psicologia social de Fromm e à pesquisa sobre a estrutura de caráter predominante entre os trabalhadores e funcionários alemães. A recepção da teoria crítica tende (como vimos no item 2.2) a superestimar o papel das pesquisas sobre autoridade e família, dentre elas, a pesquisa com trabalhadores coordenada por Fromm: ao fazê-lo, negligencia o modo próprio como Horkheimer, em seus ensaios, refletia sobre alguns dos temas mais caros ao Instituto (no capítulo 5, tratamos do "Estado autoritário" e da distância que separava Horkheimer de Pollock e Neumann - no caso em questão, trata-se da relação entre indivíduo e classe social, tendo em vista a ação política transformadora, e portanto trata-se também, de uma certa maneira, da distância a separar Horkheimer e Fromm a esse respeito).

$\mathrm{Na}$ passagem da década de trinta à de quarenta, as reflexões sobre a emancipação tomavam um novo rumo. Aos ensaios de Horkheimer que antecederam a Dialética do Esclarecimento frequentemente se associou o fim da crítica do capitalismo no âmbito do Instituto de Pesquisa Social e se atribuiu um irremediável pessimismo, contradizendo a perspectiva do autor de uma teoria crítica orientada para a transformação social ${ }^{637}$. Cremos ser

\footnotetext{
${ }^{637}$ Sobre essa orientação, cf. Max Horkheimer, "Teoria tradicional e teoria crítica”, op. cit., p. 139. Sobre o caráter pessimista da obra de Horkheimer na passagem entre as décadas de trinta e quarenta, cf. a obra de Moishe Postone,
} 
possível, entretanto, delinear ao menos dois movimentos da obra do autor que, dando continuidade à crítica do capitalismo, encaminharam a análise das contradições da sociedade burguesa para outros níveis de análise, sem abrir mão da exigência, formulada em "Teoria tradicional e teoria crítica", de considerar as tendências à emancipação inscritas no próprio desenvolvimento histórico. O ponto de partida para tanto foi a consideração de que a universalização da racionalidade da troca estendeu a forma da mercadoria às demais esferas e, ao tornar a vida social totalmente mediada, a converteu em algo próximo à imediaticidade, para a qual tenderiam as relações sociais na fase mais recente do capitalismo ${ }^{638}$. Era como se o desaparecimento das mediações tradicionais (do Estado liberal e da família burguesa) tivesse conduzido ao surgimento de espécies menos mediadas de dominação, nas quais Horkheimer, contudo, não deixava de ver possibilidades de crítica ao existente. Dois foram os caminhos tomados pela obra do autor a fim de descobrir, sob o Estado autoritário, possibilidades de ruptura da dominação.

Um dos caminhos foi a elaboração de uma teoria dos "rackets". Horkheimer assinalara, como indicamos acima, a transformação das duas classes fundamentais em "massas": a massa de trabalhadores, na qual havia sido transformada a classe trabalhadora a partir de sua integração nas organizações burocráticas de partidos e sindicatos, e a massa de acionistas, na qual haviam sido convertidos os burgueses "expropriados" pelo processo de concentração de capital. O poder econômico e político passava a se concentrar nas “cliques de dirigentes", compostas pelos comandantes das grandes corporações econômicas e por membros da burocracia estatal. A partir dessa figura contemporânea assumida pela dominação de classe, Horkheimer foi levado a seu conceito de "rackets", que representou um esforço para compreender o grau de particularismo presente nas relações de dominação sob o Estado autoritário. Essa ideia punha a descoberto a dominação ao denunciar a imbricação permanente entre capitalismo e violência "extra-econômica", reduzindo a um mero intervalo passageiro na história da humanidade a racionalidade do mercado, justificadora da dominação no período do capitalismo liberal. Ao conceber a dominação como um misto de mediação mercantil e dominação direta, exercida por grupos em permanente disputa pela mais-valia, Horkheimer enfatizava também o caráter instável e pouco coeso da dominação ${ }^{639}$.

\footnotetext{
Time, work and social domination, principalmente seu capítulo 3, sobre "os limites do marxismo tradicional e a virada pessimista da teoria crítica".

${ }^{638}$ Max Horkheimer, "Vernunft und Selbsterhaltung", op. cit., p. 339.

${ }^{639}$ Aparentemente foi Iring Fetscher o primeiro a chamar a atenção para a teoria dos rackets, encontrada de maneira dispersa em "Razão e autoconservação" e na Dialética do Esclarecimento, e de maneira mais concentrada apenas em textos publicados postumamente (o ensaio "Sobre a sociologia das relações de classe" e o pequeno texto sobre "Os rackets e o espírito", ambos contidos no volume 12 das Gesammelte Schriften de Horkheimer). Cf. Iring
} 
O segundo caminho foi um conjunto de reflexões sobre o indivíduo em declínio, no qual Horkheimer viu uma dialética entre dominação e emancipação, que considerava a condição de “isolamento" à qual o capitalismo tende a reduzir os indivíduos (cf. a passagem citada acima). Horkheimer tentava encontrar, em meio à atomização dos indivíduos e à redução de sua ação à autoconservação, elementos de uma ainda que paradoxal possibilidade de resistência à dominação, e por isso afirmava: "Isolados estão todos. O anseio contrariado das massas atomizadas e a vontade consciente daqueles [opositores políticos] que estão na ilegalidade apontam na mesma direção" 640 . Dessa maneira, sua "antropologia da era burguesa" passava a ser mobilizada em outra direção, ocupando lugar cada vez maior em suas reflexões o tema do "indivíduo" e de suas contradições .

Neste capítulo veremos, portanto, em primeiro lugar, como Horkheimer refletia sobre o tema da emancipação : no item 6.1., como Horkheimer empreendeu, a partir das contribuições de Fromm, uma "antropologia da era burguesa" (formulada entre 1935 e 1936); no item 6.2, como foi a partir de reflexões sobre o "caráter burguês" que Horkheimer pensou, naqueles anos, as possibilidades de emancipação, conjugando essas reflexões com a consideração das relações entre o indivíduo e a massa organizada politicamente; no item 6.3, passaremos à sua teoria dos rackets, forma de dominação político-econômica relativamente instável; no item 6.4, passamos ao tema do indivíduo não-idêntico, cujas contradições também exprimiriam a incompletude do processo de dominação.

Fetscher, "Die Ambivalenz des liberalistischen 'Erbes' in der Sicht von Max Horkheimer. Eine Skizze zu seinen politischen Reflexionen im Exil". In: Alfred Schmidt; Norbert Altwickler; Mas Horkheimer heute: Werk und Wirkung, op. cit., pp. 298-327. Sobre os rackets, cf. especialmente o trecho entre as páginas 311 e 322. No âmbito da bibliografa brasileira, o assunto foi tratado por Rafael Cordeiro Silva em seu Max Horkheimer: teoria crítica e barbárie. Uberlândia: EDUFU, 2011, pp. 100-108.

${ }^{640}$ Max Horkheimer, "Autoritärer Staat", op. cit., p. 312. 
$\underline{6.1 \text { - Historicizando o conceito frommiano de "caráter": alguns elementos da "antropologia da }}$ era burguesa" de Horkheimer

Ao distinguir a teoria tradicional da teoria crítica, Horkheimer afastava dessa a formulação das representações, sentimentos e conteúdos psíquicos dos indivíduos pertencentes à classe dominada: "a simples descrição da autoconsciência burguesa não é suficiente para mostrar a verdade sobre sua classe. Tampouco a sistematização dos conteúdos da consciência do proletariado fornece uma verdadeira imagem do seu modo de ser e dos seus interesses" $\mathrm{O}$ autor afirmava que a teoria crítica não poderia se reduzir à sistematização de "dados sociopsicológicos" dos trabalhadores, pois isso a transformaria em mera "teoria tradicional com uma problemática peculiar" ${ }^{\prime 2}$. Como, entretanto, relacionar essas afirmações sobre a inconfundibilidade da teoria crítica com algo como uma sociologia das classes dominadas e uma psicologia dos seus membros, por um lado, com o programa de pesquisas do Instituto, por outro, no qual teve presença destacada, dentre outras disciplinas, a psicologia social de Fromm? Como tentamos mostrar no capítulo 2 , somos levados a crer que essa, na positividade com que concebia as relações entre relações de produção, caráter e ideologias, seria um tipo de pensamento com todas os traços atribuídos por Horkheimer à "teoria tradicional" - isso não impediu, contudo, que ela fornecesse elementos à teoria crítica de Horkheimer.

Para compreendê-lo, é preciso em primeiro lugar considerar a concepção de "caráter autoritário" de Horkheimer. Se na obra de Fromm o conceito era naturalizado, sendo equiparado a uma constante psicológica que mudaria de acordo com as condições históricas, nos ensaios de Horkheimer - consoante suas análises sobre o surgimento do sujeito moderno - a própria noção de "caráter" passava a ser concebida como resultado do processo de reificação, e portanto como uma forma da subjetividade, indissociável do capitalismo. Fromm definira o "caráter autoritário" a partir do sadomasoquismo: ele seria uma propriedade da sociedade alienada em geral, intensificada sob o capitalismo monopolista, a partir do qual teriam sumido os elementos emancipatórios ainda possíveis de se encontrar sob o capitalismo liberal. De maneira semelhante a Fromm, o sadomasoquismo também era um elemento importante para a compreensão de Horkheimer da situação do indivíduo na sociedade capitalista, fazendo-se presente, por exemplo, nas relações de dominação política, por meio da identificação emocional com o líder. Como vimos anteriormente (no capítulo 4), entretanto, a subordinação à autoridade assentava para Horkheimer não tanto sobre elementos sociopsicológicos das relações sociais,

\footnotetext{
${ }^{641}$ Cf. Max Horkheimer, "Teoria tradicional e teoria crítica”, op. cit., p. 135.
}

${ }^{642}$ Max Horkheimer, "Teoria tradicional e teoria crítica", op. cit., p. 135. 
conquanto esses pudessem desempenhar o seu papel, mas primordialmente sobre o caráter reificado da experiência na sociedade capitalista, expresso na subordinação à "necessidade dos fatos". Além disso, tampouco para a compreensão profunda do "caráter" dos indivíduos pertencentes à sociedade capitalista o sadomasoquismo seria o elemento decisivo: o traço fundamental do indivíduo burguês, para Horkheimer, seria a sua "abstratividade" 643 . Até mesmo por se tratar de uma época em que a família estava em declínio, não bastava para explicar o caráter dos indivíduos a pressuposição de uma estrutura que reproduzisse continuamente o sadomasoquismo. Uma descrição feita por Horkheimer alguns anos mais tarde pode ajudar a esclarecer esse traço específico de sua compreensão do "caráter burguês":

\begin{abstract}
"Enquanto o caráter vinculado à autoridade, sadomasoquista, não é de maneira alguma um fenômeno novo - ele pode ser observado na história inteira da sociedade burguesa - a sua abstratividade peculiar e seu enrijecimento parecem sintomáticos de um mundo que se aferra à autoridade familiar, depois que a substância interna da família se dissolveu. À glorificação abstrata da família corresponde uma ausência quase completa de relações concretas com os pais, sejam elas positivas ou negativas. Em consequência, a vida sentimental inteira do caráter vinculado à autoridade apresenta traços de superficialidade e frieza que às vezes se aproximam das características observáveis em alguns psicóticos" ${ }^{\prime 4}$.
\end{abstract}

No texto, escrito em 1947, a referência ao traço psicótico do indivíduo contemporâneo remete às análises da Dialética do Esclarecimento e ao tema da paranoia, sobre o qual se apoiaram as análises do antissemitismo. Na obra escrita por Horkheimer nos anos trinta já se encontravam, contudo, análises do caráter burguês que iam nessa direção. Desde a constituição da ordem burguesa, argumentava Horkheimer, a frieza e a indiferença seriam os traços característicos dos indivíduos isolados, que aparecem no mercado como sujeitos dos próprios interesses. O processo histórico de constituição do indivíduo moderno, essa "abstratividade" remontaria ao período de ascensão da burguesia. A "educação para a justiça da realidade" e para o uso da disciplina, característica da família protestante desde seus primórdios, seria o nascedouro de uma indiferença quanto ao sofrimento e a opressão dos demais indivíduos (na medida em que os próprios interesses ou aqueles dos membros do círculo mais próximo não fossem postos em risco). Essa indiferença caracterizaria o comportamento dos indivíduos em

\footnotetext{
${ }^{643}$ Cf. Max Horkheimer, "Autoridade e família”, op. cit., p. 198.

${ }^{644}$ Max Horkheimer, “Autorität und Familie in der Gegenwart”. In: Max Horkheimer, Gesammelte Schriften, op. cit., vol. 5, p. 389.

${ }^{645}$ Cf. Max Horkheimer, “Autoridade e família”, op. cit., p. 198.
} 
um mundo cada vez mais atravessado pela mediação da forma mercadoria, e o "alheamento" [Fremdheit] seria por isso, segundo o autor, a "categoria antropológica" da época burguesa:

“Toda comunicação é um negócio, uma transação entre áreas construídas solipsisticamente. $\mathrm{O}$ ser consciente dessas pessoas pode ser reduzido a um pequeno número de relações entre grandezas fixas. A linguagem da lógica matemática é a sua expressão adequada" ${ }^{646}$.

Na tentativa de compreender a configuração do "caráter burguês", o autor recusava, é certo, as soluções idealistas oferecidas a esse pergunta pelas diversas antropologias filosóficas surgidas ao longo dos séculos: descobrir uma constante atemporal da qual pudessem ser derivadas todas as possíveis formas assumidas pela "natureza humana" - tal qual Horkheimer compreendia o empreendimento filosófico de Max Scheler - seria uma tarefa "impossível", dado que o indivíduo está inextricavelmente relacionado com a história, sobre a qual não é possível afirmar nada de atemporal ${ }^{647}$. As teses filosóficas acerca da "natureza humana" exprimiriam, por isso, igualmente condições sociais e históricas: a afirmação aristotélica de que os homens trariam já desde o nascimento a disposição para a liberdade ou a escravidão quadraria a períodos históricos caracterizados pela estabilidade (a Idade Média), assim como a afirmação de Hobbes sobre o caráter naturalmente egoísta do homem estaria afinado com o estabelecimento de um modo de produção que atribui ao indivíduo a responsabilidade exclusiva por sua preservação e felicidade ${ }^{648}$.

Ao mesmo tempo em que recusava a possibilidade de qualquer antropologia idealista, que postulasse algo como uma natureza humana imutável, válida para todos os tempos, Horkheimer considerava válido perguntar se o capitalismo não tenderia a produzir determinados traços de personalidade em vez de outros: especialmente relevante para uma teoria comprometida com a mudança histórica (em vez de voltada para a obtenção de uma imagem eterna do homem) seria a distinção, no que tange as características típicas de comportamento e constituição psíquica, entre as pessoas e grupos "melhor preparados para mudar e configurar as circunstâncias", por um lado, e aqueles que tenderiam a se reduzir a funções da realidade dada, por outro ${ }^{649}$. Isso permitiria, por sua vez, incorporar à teoria

\footnotetext{
${ }^{646}$ Max Horkheimer, "Egoismus und Freiheitsbewegung - zur Anthropologie des bürgerlichen Zeitalters". In: Max Horkheimer, Gesammelte Schriften, op. cit., vol. 4, p. 71.

${ }^{647}$ Cf. Max Horkheimer, "Bemerkungen zur philosophischen Anthropologie", op. cit., p. 250-251, p. 275.

${ }^{648}$ Cf. Max Horkheimer, "Bemerkungen zur philosophischen Anthropologie", op. cit., pp. 267-269.

${ }^{649}$ Cf. Max Horkheimer, "Bemerkungen zur philosophischen Anthropologie”, op. cit., pp. 251-253.
} 
marxista, e portanto sob uma chave materialista, algumas das questões elaboradas pela antropologia filosófica:

\begin{abstract}
"Os estudos antropológicos não precisam ser desprovidos de valor; eles podem dar prosseguimento ao conhecimento das tendências históricas, assim como sofisticá-lo. Eles sem dúvida se referem, então, não ao homem em geral, mas sim a homens e grupos humanos historicamente determinados, e tentam compreender o seu ser e devir não de maneira isolada, mas em conjunto com a vida da sociedade" ${ }^{650}$.
\end{abstract}

As reflexões antropológicas feitas por Horkheimer tomaram por objeto a contradição entre o elemento básico da filosofia moral burguesa - a condenação do egoísmo - e o comportamento prático exigido pela economia capitalista, caracterizado pela busca do interesse próprio, a ser perseguido sem considerações pelos demais indivíduos. A economia baseada na troca acarretara consigo o desenvolvimento de traços de caráter que remetiam à constituição de uma sociedade melhor, tais quais o respeito aos demais indivíduos enquanto igualmente dotados de direitos, assim como a capacidade de se ater, independentemente do interesse próprio, a ideias morais, à verdade e à palavra dada: em resumo, ao lado do egoísmo a sociedade burguesa fora também capaz de fomentar elementos altruístas de caráter, conquanto esses exprimissem um tipo limitado de solidariedade, pois condicionada pela participação na circulação de mercadorias. Se, entretanto, no período do capitalismo liberal a moral burguesa se afirmara como uma instância dotada de relativa autonomia frente às necessidades da produção, no capitalismo contemporâneo a moral burguesa perdia seus elementos críticos e em lugar do imperativo categórico se firmava o interesse imediato, a identificação entre moralidade e persecução dos próprios fins que tornava a "autoconservação" a característica antropológica básica $^{651}$.

Essa contradição e seus desenvolvimentos deveriam, contudo, ser examinados historicamente, em sua imbricação com processos concretos de dominação. O autor argumentava nesse sentido que, à época das ascensão social da burguesia, imprimiu-se ao psiquismo dos membros da sociedade capitalista (o que inclui seus elementos sadomasoquistas) uma nova direção. Como exemplo histórico para demonstrá-lo, Horkheimer apoiou a análise daquela contradição entre moral burguesa e interesse próprio no exame dos movimentos de libertação de fins da Idade Média e do início do período moderno: esses movimentos traziam à luz do dia o tipo específico de mecanismos sociopsicológicos de dominação que, de maneira o

\footnotetext{
${ }^{650}$ Cf. Max Horkheimer, "Bemerkungen zur philosophischen Anthropologie", op. cit., p. 260.

${ }^{651}$ Cf. Max Horkheimer, "Bemerkungen zur philosophischen Anthropologie”, op. cit., pp. 262-263, p. 267 e pp. 273- 275.
} 
mais das vezes latente, perpassam o cotidiano da sociedade burguesa, apenas se manifestando em momentos de crise e disrupção da ordem ${ }^{652}$.

Conduzidos no sentido da revolta contra a dominação política absolutista, os movimentos burgueses de início da época moderna ao mesmo tempo reforçavam a disposição das massas à obediência, sua subordinação às autoridades vigentes ${ }^{653}$. Os movimentos liderados por Cola di Rienzo, Savonarola, Calvino, além do período do Terror de Robespierre, haviam se apoiado no ódio das massas, mobilizado contra o egoísmo associado às classes dominantes. Eram movimentos representativos da ascensão da burguesia, mas que precisavam ganhar o apoio das massas para seu êxito. A representação corrente de uma aristocracia entregue ao luxo e ao prazer insuflava o sadismo popular, e o "populacho" - a "choldra" [Mob] - castigava nos inimigos da respectiva revolução os "egoísticos" anseios por prazer que tinham de reprimir em si mesmos. Surgiam, assim, os precursores do antissemitismo baseado nas representações do judeu como explorador e dedicado a uma vida de ócio intelectual: "ressentimento pequenoburguês contra a nobreza e ódio aos judeus têm funções parecidas para a alma" ${ }^{654}$. A exteriorização do ressentimento em terror e crueldade cumprira, portanto (e continuou sempre a cumprir), uma função psicossocial importante, na medida em que permitia que os indivíduos, depois de participarem ativamente ou enquanto público de decapitações e linchamentos, voltassem a uma vida de trabalho duro e privações. A maldade e crueldade exercitadas contra os inimigos dos processos revolucionários mantinham um vínculo estreito com a violência mobilizada contra si e expressa em ascetismo, como havia sido revelado pelas análises de Nietzsche e Sade ${ }^{655}$.

Os líderes dos movimentos seriam, eles próprios, figuras caracterizadas pelo ascetismo e pela renúncia, e com as quais as massas podiam estabelecer uma identificação emocional. No processo de formação do indivíduo burguês, portanto, o sadomasoquismo bem teve o seu papel. A constituição sadomasoquista seria socialmente condicionada, e se formou historicamente no período da ascensão da burguesia: "na história inteira até agora (...) demandou-se da absoluta maioria um excesso se renúncias" ${ }^{\prime 656}$. Mas, note-se bem, não se tratava aqui de graus diferentes

\footnotetext{
${ }^{652}$ Max Horkheimer, "Egoismus und Freiheitsbewegung - zur Anthropologie des bürgerlichen Zeitalters", op. cit., p. 23, p. 70 .

${ }^{653}$ Max Horkheimer, "Egoismus und Freiheitsbewegung - zur Anthropologie des bürgerlichen Zeitalters”, op. cit., p. 33.

${ }^{654}$ Max Horkheimer, "Egoismus und Freiheitsbewegung - zur Anthropologie des bürgerlichen Zeitalters", op. cit., p. 77.

${ }^{655}$ Max Horkheimer, "Egoismus und Freiheitsbewegung - zur Anthropologie des bürgerlichen Zeitalters”, op. cit., pp. 86-88.

${ }^{656}$ Max Horkheimer, "Egoismus und Freiheitsbewegung - zur Anthropologie des bürgerlichen Zeitalters", op. cit., p. 19.
} 
de renúncia pulsional, de acordo com o pertencimento dos indivíduos a essa ou àquela classe: a condenação do egoísmo se dirigia tanto às massas quanto à burguesia, ainda que ela se ligasse, em cada caso, a funções específicas no processo de trabalho. Os anseios por uma vida melhor eram sublimados e se voltavam contra os próprios indivíduos, sob a forma de exigências morais: nos movimentos de libertação a dialética entre liberdade e sua interiorização por meio do ascetismo, da repressão interna, enfim, do "sacrifício", se apresentava de maneira exemplar.

Ao empreender essas análises, é como se Horkheimer historicizasse elementos da teoria de Fromm, a quem se referia nominalmente no ensaio mencionado: o resultado foi a elaboração de uma "antropologia da era burguesa", na qual o autor tentou perscrutar aquilo que constituiria a "essência humana" sob o capitalismo ${ }^{657}$. O autor superava, dessa maneira, o dualismo, existente na obra de Fromm e concebido de maneira parecida ao modelo das ciências naturais, entre a história e uma estrutura de caráter concebida como uma "coisa em si”, sem o estabelecimento das mediações necessárias à compreensão de sua relação com o todo histórico. Ao fazê-lo, Horkheimer mostrava haver um processo histórico de "enrijecimento" dos impulsos psíquicos, a partir do qual se formava o "caráter": a constância de determinadas qualidades psíquicas e comportamentais, necessárias ao cálculo necessário à vida social contemporânea, seria expressão de um processo de reificação. E mais: de uma reificação constituída historicamente por meio de processos concretos de dominação - nas palavras do autor, "com a fome e a casa de correção como pano de fundo" $" 658$.

Aqueles processos históricos referidos se exprimiram no âmbito da filosofia burguesa desde suas origens: a diferença entre escolas antropológicas que concebiam o homem de maneira otimista e ressaltavam suas virtudes (Locke, Rousseau) e outras essencialmente pessimistas, que enfatizavam a sua "bestialidade" (Lutero, Hobbes e Maquiavel, ou pelo menos o que se associou a esse último na posteridade $)^{659}$, era uma diferença muito mais "política" e circunstancial do que propriamente "antropológica": o humanismo que pregava a superioridade

\footnotetext{
${ }^{657}$ A interpretação que tentamos esboçar aqui tem traços em comum com a de John Abromeit, que também interpretou a antropologia da era burguesa de Horkheimer como uma historicizaçãoda psicologia social de Fromm. O comentador, entretanto, realçou como a contribuição específica de Horkheimer o recurso à pesquisa histórica tendo como objeto os movimentos de ascensão da burguesia (um recurso que, ao mesmo tempo em que permitia, no espírito do "materialismo interdisciplinar", a incorporação de elementos da psicologia social de Fromm a uma teoria sobre o desenvolvimento do capitalismo, também afastaria Horkheimer do dogmatismo ao qual a teoria marxista da história poderia conduzir, ainda que a contragosto do próprio Marx). Cf. o capítulo 7 de seu Max Horkheimer and the foundations of the Frankfurt School, op. cit., especialmente pp. 249-261. Nosso impressão, contudo, é que esse recurso àpesquisa histórica está, antes de tudo, subordinado a um objetivo maior: a crítica do fetichismo presente no "caráter burguês".

${ }^{658}$ Cf. Max Horkheimer, "Bemerkungen zur philosophischen Anthropologie", op. cit., p. 263.

${ }^{659}$ Max Horkheimer, "Egoismus und Freiheitsbewegung - zur Anthropologie des bürgerlichen Zeitalters", op . cit., pp. 9-12.
} 
do homem, seu gênio criador, sua independência frente à natureza era apenas o outro lado da Reforma e de sua misantropia, com sua condenação da "vaidade" terrena: a diferença é que, conscientemente ou não, o primeiro estava destinado à burguesia em ascensão, e a segunda, às $\operatorname{massas}^{660}$. Lutero e Calvino viam no homem a mera maldade a ser reprimida; Rousseau, de quem Robespierre foi "aluno ortodoxo", concebia o homem como um ser aperfeiçoável, e por isso a condenação do vício logo se convertia em perseguição política. A diferença entre ambas as correntes se anulava, contudo, naquilo que elas tinham em comum como ideal: a noção de uma natureza humana orientada para a autoconservação, refratária ao prazer e portanto baseada na condenação do egoísmo.

Essa se tornou uma constante no universalismo abstrato da filosofia moral dominante, que superou aquela oposição presente ainda na antropologia de princípios do capitalismo. A contradição entre o ascetismo moral e uma prática social baseada no interesse individual, insuperável no âmbito da sociedade classes, se resolvia naquilo que elas tinham de comum, a indiferença e o alheamento em relação aos demais indivíduos:

"A condenação do egoísmo, ao qual a antropologia contrapõe a tese de uma natureza humana mais nobre ou a mera estigmatização como bestialidade, no fundo não atinge a busca dos poderosos por poder, o bem-estar face o sofrimento, a conservação de formas de sociedade envelhecidas e injustas" $"$.661.

Segundo Horkheimer, tanto a condenação do egoísmo, em si e nos outros, quanto a indiferença em relação ao destino dos demais membros da sociedade seriam redutíveis à "frieza burguesa"662. O indivíduo se reduziria à "autoconservação", marcada pela exclusão de todos os instintos que não se movessem em um sentido pré-definido e pela indiferença para consigo e para com os outros, condição do progresso individual nessa sociedade ${ }^{663}$. Toda demanda incondicionada por felicidade desapareceria, sendo os anseios por prazer e felicidade preteridos em favor de valores morais mais elevados, como são as ideias relativas à moralidade e ao "bem comum", ou então meramente condenados como expressão de vileza e amoralidade. O prazer

\footnotetext{
${ }^{660}$ Max Horkheimer, "Egoismus und Freiheitsbewegung - zur Anthropologie des bürgerlichen Zeitalters", op. cit., pp. 9-16 e pp. 73-74.

${ }^{661}$ Max Horkheimer, "Egoismus und Freiheitsbewegung - zur Anthropologie des bürgerlichen Zeitalters", op. cit., p. 17. Cf. também pp. 9-16.

662 O tema da "frieza burguesa" haveria de ser desenvolvido por Horkheimer e Adorno na Dialética do Esclarecimento, em suas considerações sobre a formação do sujeito (cf., por exemplo, os excursos sobre Ulisses e Juliette). O tema apareceria também de maneira bastante expressiva nas análises de Adorno sobre o fascismo. Cf., por exemplo, o seu "Educação após Auschwitz". In: Theodor W. Adorno, Educação e Emancipação. $3^{\mathrm{a}}$ edição. Tradução de Wolfgang Leo Maar. São Paulo: Paz e Terra, 2003, pp. 119-138.

${ }^{663}$ Cf. Max Horkheimer, "Bemerkungen zur philosophischen Anthropologie", op. cit., p. 275.
} 
teria sido cada vez mais condenado a seguir um dos seguintes caminhos: ou se nobilitar em uma associação com os valores culturais, tais quais a atividade científica e artística ou a política moralizante, ou ser banido para o "triste refúgio da piada obscena pequeno-burguesa e da prostituição" 664 . O mundo ocidental teria se desenvolvido de maneira a fazer prevalecer a ideia segundo a qual a cultura corresponderia a um mundo de valores espirituais apartado da vida prática. O mundo da "cultura", distinto da existência cotidiana, supostamente poderia ser vivenciado pelos indivíduos a partir de sua interioridade, sem que a facticidade do mundo precisasse ser alterada. A superioridade e eternidade atribuída aos valores culturais lhes atribuiria uma "dignidade" que tornaria sua recepção um ato de mera celebração e enlevo, sem que se estendesse à sua realização ${ }^{665}$. Predominante no âmbito da ideologia, esse conceito teria sido a contrapartida da "religião da prática" que dominou de fato a vida na sociedade burguesa:

\begin{abstract}
"Na época moderna, a relação de dominação é encobrida economicamente pela aparente independência dos sujeitos econômicos, filosoficamente pelo conceito idealista de uma liberdade absoluta do homem, e internalizada por meio da subjugação e mortificação das pretensões de prazer" $"$ "66 .
\end{abstract}

Em uma sociedade racional, contudo, desapareceria o ascetismo idealista, assim como o "caráter afirmativo da cultura" 667 . O caráter deletério do egoísmo residiria em sua mobilização por classes, nações e indivíduos em concorrência uns com os outros - em uma sociedade racional, o egoísmo mudaria de função, pois a repressão pulsional não estaria mais vinculada às relações de classe. Tanto ele quanto os impulsos sadomasoquistas continuariam a existir nessa sociedade, mas sua repressão não seria mais mobilizada com vistas à dominação de classe.

Afirmações conclusivas sobre o papel a ser desempenhado em uma sociedade emancipada pelas pretensões de prazer dos indivíduos seriam impossíveis, mas Horkheimer considerava que essas contradições do "caráter" burguês, dilacerado entre moralidade e egoísmo, influiriam necessariamente nos movimentos de mudança social ${ }^{668}$. Examinemos a perspectiva do autor a esse respeito.

\footnotetext{
${ }^{664}$ Max Horkheimer, "Egoismus und Freiheitsbewegung - zur Anthropologie des bürgerlichen Zeitalters", op . cit., p. 19.

${ }^{665}$ Cf. Herbert Marcuse, “Über den affirmativen Charakter der Kultur”. In: Zeitschrift für Sozialforschung, op. cit., vol. 6, 1937, p. 60.

${ }^{666}$ Max Horkheimer, "Egoismus und Freiheitsbewegung - zur Anthropologie des bürgerlichen Zeitalters", op. cit., p. 21.

${ }^{667}$ Max Horkheimer, "Egoismus und Freiheitsbewegung - zur Anthropologie des bürgerlichen Zeitalters", op. cit., pp. 74-75.

${ }^{668}$ Max Horkheimer, "Egoismus und Freiheitsbewegung - zur Anthropologie des bürgerlichen Zeitalters”, op. cit., p. 86.
} 


\section{$\underline{6.2 \text { - A massa, o indivíduo e os "pequenos grupos" }}$}

Como já ressaltado na abertura deste capítulo, a teoria crítica nunca elaborou sistematicamente uma estratégia política - nos ensaios escritos por Horkheimer não foi diferente, suas afirmações a esse respeito assumindo muito mais o caráter de prognósticos incertos, ou mesmo de apelos. Em vez de procurar algum vínculo político concreto que a teoria crítica pudesse ter à época, o que é oferecido pelos ensaios do autor é a vinculação entre suas reflexões sobre potenciais destinatários da teoria crítica e o tema da "antropologia burguesa": Horkheimer apostava que a transformação revolucionária viria apenas de grupos de indivíduos que não tivessem uma "natureza psíquica enrijecida" ${ }^{669}$. Conquanto nem o autor e nem o Instituto de Pesquisa Social tivessem um vínculo "orgânico" com os partidos ligados à classe trabalhadora (na Alemanha da época, o KPD e o SPD), Horkheimer desenvolveu em seus ensaios considerações sobre os traços de caráter que poderiam ser úteis aos movimentos revolucionários. Em um ensaio de 1935, “Observações sobre a antropologia filosófica”, o autor afirmava:

\footnotetext{
"A dependência [do indivíduo em relação à sociedade e à natureza] não é nem unilateral, nem sempre estruturada da mesma maneira. O desenvolvimento social conduz, antes, a que grupos específicos e específicas personalidades estejam melhor preparadas para mudar e configurar as circunstâncias do que outras, que em seu pensar e agir são sobretudo funções das condições dadas. O agir histórico consciente está ligado, é verdade, a determinados pressupostos, de acordo com o seu momento e seu conteúdo, mas o está de maneira diferente da existência totalmente dependente da realidade, assim como dos modos de reação aprisionados na situação social tal qual ela se dá" ${ }^{670}$.
}

Como havia se manifestado ao longo da história, a condenação do egoísmo e a pregação de uma moral do sacrifício individual em prol da coletividade esteve recorrentemente vinculada à mobilização do sadomasoquismo para a dominação. Horkheimer associava, por isso, a questão da estrutura psíquica individual dos membros dos movimentos políticos à possibilidade contemporânea da revolução: as ideologias contrarrevolucionárias se nutriam de um discurso moralizante cuja disseminação os movimentos comprometidos com a revolução deveriam combater $^{671}$. Tratava-se aqui do irracionalismo do entreguerras, que glorificava a abstenção

\footnotetext{
${ }^{669}$ Max Horkheimer, “Autoridade e família”, op. cit., p. 191.

${ }^{670}$ Max Horkheimer, "Bemerkungen zur philosophischen Anthropologie”, op. cit., p. 251.

${ }^{671}$ Max Horkheimer, "Egoismus und Freiheitsbewegung - zur Anthropologie des bürgerlichen Zeitalters", op. cit., p. 88.
} 
pulsional e negava a satisfação do indivíduo real, transferindo-a para o todo, para a sociedade que seria o "verdadeiro Selbst", e proclamando a superioridade da nação e do Estado. No plano psíquico, isso correspondia ao direcionamento da agressividade para o próprio indivíduo (por meio do recalque da próprias pulsões), ou então para inimigos da coletividade (externos ou internos):

\begin{abstract}
"Nessa postura ascética os homens estão presos a valores individualistas tanto quanto no caso do egoísmo mais sem consideração - a única diferença é que essas ideias são transferidas como positivas para o todo e surgem no âmbito do próprio indivíduo com o sinal trocado: em vez do poder pessoal tem-se então a obediência, em vez da riqueza, a pobreza, em vez da libertinagem, a castidade. (...) Como os indivíduos nesse processo apenas trocam o sinal de seus impulsos e mesmo nessa transformação pelo menos uma parcela da massa pulsional egoística é conservada na forma original, é comum que se apresentem, nessas pessoas dispostas ao sacrifício, ao lado da ascese uma certa porção de egoísmo, ambição e esforço por alcançar o poder na sociedade, que se manifestam onde quer que a realidade lhes deixe algum campo de ação" ${ }^{\text {"72 }}$.
\end{abstract}

E também por isso não fazia muito sentido, na perspectiva do autor, a oposição nãodialética feita por Fromm entre um "caráter revolucionário/matricêntrico" (generoso e solidário) e um "caráter autoritário/patricêntrico" (egoísta e agressivo, calcado na predominância dos elementos sadomasoquistas) ${ }^{673}$. Supor esse tipo de dualismo seria mesmo cremos que Horkheimer assim pudesse pensar -assimilar parte da ideologia daquele irracionalismo: os " militantes e mártires" da grande transformação social em curso que poderia conduzir à superação do capitalismo seriam indivíduos infensos ao ascetismo moral burguês ${ }^{674}$. Nesse sentido, a massa do movimento revolucionário seria fundamentalmente diferente daquela do movimento contrarrevolucionário. No primeiro, a massa seria "diferenciada e alerta", e poderia ser convencida e levada a sério pela "ala mais consciente" do movimento, sem ser reduzida a uma mera multidão de indivíduos reduzidos à insignificância diante do líder. A massa do movimento contrarrevolucionário, por sua vez, seria o “populacho” [Mob], diferente da massa revolucionária em tudo, até mesmo quanto à estrutura psíquica de seus membros,

\footnotetext{
${ }^{672}$ Max Horkheimer, "Zum Rationalismusstreit in der gegenwärtigen Philosophie”, op. cit., p. 210. Cf. também Max Horkheimer, "Bemerkungen zur philosophischen Anthropologie”, op. cit., p. 274. No capitulo 4 tratamos desse iracionalismo do entreguerras.

${ }^{673}$ Sobre esse par conceitual desenvolvido por Fromm, cf. o capítulo 2.

${ }^{674} \mathrm{Cf}$. as passagens finais de Max Horkheimer, "Egoismus und Freiheitsbewegung - zur Anthropologie des bürgerlichen Zeitalters", op. cit.. No ensaio escrito no ano anterior - as "Observações sobre a antropologia filosófica" - o autor ainda vinculava sua imagem dos indivíduos predispostos à transformação social aos traços positivos do caráter burguês, como a fidelidade às ideias do movimento e a capacidade de se ater à palavra dada. Cf. Max Horkheimer, "Bemerkungen zur philosophischen Anthropologie”, op. cit., p. 263 e p. 267.
} 
mobilizados para a agressão e para a satisfação, por meio da destrutividade, dos próprios impulsos reprimidos. Os ensaios de revolução ao fim da primeira guerra não poderiam, por isso, ser igualados à adesão de parcelas da classe trabalhadora à "pseudo-revolução" de apelo popular empreendida pelos fascistas ${ }^{675}$.

Pouco tempo depois, porém, essa perspectiva começa a se esvair, e Horkheimer transitava em seus ensaios, de formulações voltadas para as organizações de massa do proletariado, para a consideração de que as perspectivas de superação do capitalismo haviam se concentrado, à época, em setores minoritários do movimento operário ${ }^{676}$. Além de empreender uma crítica à ciência contemporânea e desenvolver reflexões sobre o comportamento orientado para a emancipação, o ensaio de 1937 sobre "Teoria tradicional e teoria crítica" também se deteve sobre a questão do vínculo entre a teoria crítica e a classe trabalhadora. Embora a teoria crítica continuasse, tal qual nos ensaios de 1933 sobre o "materialismo", afinada com os seus interesses, a adesão ativa de largas parcelas do proletariado aos regimes fascistas, sua integração à sociedade capitalista, e ainda os caminhos tomados pela revolução na União Soviética tornavam a relação entre a teoria crítica e o proletariado mais problemática do que fora anteriormente: se em 1933 a teoria materialista aparecia em certa medida como um "porta-voz" do proletariado (Horkheimer a apresentava ali como "uma ideia proferida por certos homens e condicionada pelas relações da sociedade de classes" ${ }^{\text {677 }}$ ), em 1937 a relação da teoria crítica com o proletariado seria a de uma "unidade dinâmica", na qual a exposição das contradições sociais, por um lado, estimularia a prática e estaria orientada para a transformação, devendo-se ao mesmo tempo admitir, por outro, a possibilidade de a relação entre a classe trabalhadora e os intelectuais adeptos da teoria crítica ser atravessada por tensões ${ }^{678}$. Dessa maneira, o marxismo seria a "face intelectual do processo histórico de emancipação do proletariado" ${ }^{979}$, mas estaria longe (mais longe ainda do que o autor já considerava em 1933) de constituir algo como uma consciência de classe. Horkheimer concebia, então, o sujeito da teoria crítica como “(...) um indivíduo determinado em seus relacionamentos efetivos com outros indivíduos e grupos, em seu confronto com uma classe

\footnotetext{
${ }^{675}$ Max Horkheimer, "Egoismus und Freiheitsbewegung - zur Anthropologie des bürgerlichen Zeitalters”, op. cit., pp. 71-72.

${ }^{676}$ Sobre esse assunto, cf. Helmut Dubiel, Wissenschaftsorganisation und politische Erfahrung, op. cit., pp. 2537 e pp. 66-74.

${ }^{677}$ Max Horkheimer, "Materialismo e metafísica”, op. cit., p. 40.

${ }^{678}$ Max Horkheimer, "Teoria tradicional e teoria crítica", op. cit., p. 136. Segundo Helmut Dubiel, isso se exprimiu, no âmbito do Instituto de Pesquisa Social, em uma crítica cada vez mais intensa à União Soviética. Cf. Helmut Dubiel, Wissenschaftsorganisation und politische Erfahrung, op. cit., pp. 56-66.

${ }^{679}$ Max Horkheimer, "Teoria tradicional e teoria crítica", op. cit., p. 135.
} 
determinada e, por último, mediado por este entrelaçamento, em vinculação com o todo social e a natureza" 680 .

No mesmo ensaio, Horkheimer conferia alguma atenção a potenciais destinatários da teoria crítica, capazes de perfazer aquela "unidade dinâmica" referida. O autor se referia então a "determinados grupos" que poderiam oferecer resistência à dominação, a "grupos mais avançados das camadas dominadas", a "minorias" nas quais a verdade poderia se "refugiar", assim como a "grupos inquebrantáveis" que não coincidiriam necessariamente com a parcela dominante do proletariado ${ }^{681}$. É pouco claro, contudo, a quais grupos o autor se referia, se é que havia alguma referência implícita concreta, fosse ela unívoca ou não. Tratava-se, contudo, de setores não dominantes das bases proletárias, assim como de intelectuais desvinculados das burocracias partidárias. Poucos anos mais tarde, em seu ensaio sobre o "Estado autoritário", Horkheimer se referiria a "pequenos grupos", herdeiros de uma tradição "que remonta a 1871, a 1905 e a outros acontecimentos" ${ }^{682}$ : à época descrente dos partidos de massas, por ele identificados com o "estatismo integral" da União Soviética, Horkheimer se referia favoravelmente ao comunismo conselhista. $\mathrm{O}$ autor julgava encontrar em grupos políticos não integrados às burocracias partidárias e em indivíduos dispersos a ação capaz de preparar a derrocada do Estado autoritário: “a atividade de grupos políticos e indivíduos isolados pode contribuir decisivamente para a preparação da liberdade; quanto aos partidos de massas opositores, o Estado autoritário só precisa temê-los na condição de concorrentes"683.

Formuladas no ensaio de 1937 ainda em tom otimista, essas expectativas, que ainda exprimiam alguma esperança no processo de resistência ao fascismo, se tornavam cada vez mais raras nos textos escritos anteriormente à Dialética do Esclarecimento. Nessa fase de sua obra, o tema da "autoconservação", entendida como traço central do caráter burguês, passou a ocupar um espaço cada vez maior - as reflexões de Horkheimer não deixaram, contudo, de ser feitas tendo em vista os elementos disruptivos dos mecanismos de dominação. À diferença do

\footnotetext{
${ }^{680}$ Max Horkheimer, "Teoria tradicional e teoria crítica", op. cit, p. 132. Como forrmulou Ricardo Musse, "Horkheimer acaba transformando-a [a teoria marxista] em 'mera tradição intelectual' ". Cf., do autor, De socialismo científico a teoria crítica, op. cit., p. 202.

${ }^{681}$ Cf. Max Horkheimer, "Teoria tradicional e teoria crítica", op. cit., pp. 138-139 e pp. 152-153.

${ }^{682}$ Cf. Max Horkheimer, “Autoritärer Staat”. In: Max Horkheimer, Gesammelte Schriften, op. cit., vol. 5, p. 304.

${ }^{683}$ Max Horkheimer, "Autoritärer Staat", op. cit., p. 302. Imediatamente antes, o autor afirmava: "por mais que o fim dessa última fase possa vir de forma inesperada no que diz respeito a tempo e lugar, ele não será provocado por um partido de massas ressuscitado mais uma vez - esse meramente substituiria o partido dominante". Cf. também as passagens às pp. 303-304 e p. 312. Sob um ponto de vista biográfico, a relação de Horkheimer com os conselhistas foi examinada por John Abromeit em seu já mencionado Max Horkheimer and the foundations of the Frankfurt School, pp. 41-45. Quando estudante em Munique, o autor participou, ainda que de maneira pouco engajada, de um círculo de militantes envolvidos na instalação da república de conselhos existente entre novembro de 1918 e maio de 1919.
} 
que ocorrera em 1935/36, contudo, as considerações feitas a partir daquele tema não se dirigiam aos membros dos movimentos revolucionários, mas tinham como alvo a própria instabilidade das estruturas de dominação. A seguir tentaremos mostrar como Horkheimer examinou essa instabilidade por meio de sua teoria dos rackets e de suas considerações sobre o indivíduo em estado de dissolução.

\section{$\underline{6.3 \text { - Mudanças no conceito de classes sociais: das cliques aos rackets }}$}

A tendência à concentração de capital e à diminuição da importância da concorrência trouxe à luz do dia o problema do poder e da dominação não mediados pelas leis do mercado e pelas normas universais do Estado. A necessidade de uma atualização do conceito de classes sociais à luz da nova forma de dominação foi tematizada por Horkheimer principalmente em dois textos publicados apenas postumamente, um deles "Sobre a sociologia das relações de classe", o outro, sobre "Os rackets e o espírito" ${ }^{684}$. O autor continuava a argumentação desenvolvida em textos anteriores sobre as mudanças introduzidas pelo capitalismo monopolista: enquanto ao longo do capitalismo liberal a existência de uma esfera da circulação na qual os indivíduos se apresentavam como iguais tornava a irracionalidade da dominação reconhecível apenas no controle dos capitalistas sobre os meios de produção (um controle garantidor da mais-valia e irracional, pois fundado sobre a mera violência dos processos de acumulação primitiva do capital), a fase do capitalismo monopolista permitia que a essência da dominação de classe se apresentasse sem a aparência de racionalidade assumida durante aquele breve período histórico no qual predominara a concorrência (um período que mostrava ter sido, portanto, uma ilusão passageira). Nas palavras de Horkheimer, “o fascismo apenas revelou aquilo que já se encontrava no liberalismo: o caráter ilusório do contrato de trabalho como um acordo entre duas partes iguais" 685 .

A concorrência entre os capitalistas sempre foi diferente daquela entre os próprios trabalhadores, mas o caráter de mercadoria da força de trabalho ocultava a diferença entre elas. A fase monopolista do capitalismo, por sua vez, conduziu a uma situação na qual o exercício do mero poder - em nível nacional e internacional - se sobrepunha à circulação das mercadorias, e tornava possível apresentava-se com clareza cada vez maior o elemento característico dos

\footnotetext{
${ }^{684}$ Cf. Max Horkheimer, "Zur Soziologie der Klassenverhältnisse”. Tradução ao alemão do original inglês feita por Hans Günther Zoll; e "Die Rackets und der Geist". Ambos se encontram no volume 12 das obras de Max Horkheimer publicadas pela editora Fischer, respectivamente às páginas 75-104 e 287-191.

${ }^{685}$ Cf. Max Horkheimer, "Zur Soziologie der Klassenverhältnisse”, op. cit., p. 79. A esse respeito, cf. também, do mesmo autor, 'Vernunft und Selbsterhaltung”, op. cit., p. 332.
} 
mais diversos períodos históricos: as disputas por poder no interior dos grupos dominantes, assim como a união de suas frações internas contra as massas exploradas, nas ocasiões em que essas resistiam à dominação. Referindo-se à Idade Média, Horkheimer afirmava:

\begin{abstract}
"Os diferentes grupos dominantes tornavam-se sempre bastante unidos quando se tratava de quebrar a resistência das massas exploradas ou quaisquer forças que ameaçavam construir uma nova ordem social. Quando em virtude disso eram adotadas medidas punitivas contra os burgueses progressistas do sul da França ou então contra elementos proletários em Flandres, os poderes seculares e eclesiásticos se esqueciam por algum tempo de suas desavenças tradicionais e se aliavam para a defesa da hierarquia social dominante. A história da Idade Média, contudo, não fornece um quadro de solidariedade entre os dominantes do mundo cristão. Pelo contrário: entre os diferentes grupos hierárquicos surgiam constantemente lutas pelo butim. Cada um deles queria conquistar o poder sobre grandes regiões, para serem alimentados, alojados e servidos por uma população tão grande quanto possível. $\mathrm{O}$ mesmo vale para os grupos dominantes na Antiguidade grega, representados pelas cidades-Estados e pelas cliques. A classe dominante, mantida coesa pelo interesse comum no modo específico de exploração, foi sempre caracterizada por lutas internas, pelos esforços de uma de suas partes em garantir o butim, esforços que poderiam também ter sido feitos pelas outras. A luta da elite por segurança era uma disputa pelo maior poder de comando possível, em outras palavras, pelo controle da produção" ${ }^{986}$.
\end{abstract}

O capitalismo monopolista, caracterizado pela disputa imperialista e pelo vínculo íntimo entre as grandes corporações e o poder político-militar, reviveria a imediaticidade da dominação, relativamente constante ao longo da história humana e que, no período do capitalismo liberal, embora não houvesse desaparecido cedeu espaço à mediação exercida pela mercadoria. Isso fez do capitalismo liberal do século XIX algo como um intervalo no qual a mediação exercida pela concorrência dotara a dominação de uma aparência de racionalidade. Sob o capitalismo monopolista, por sua vez, a perda de importância da concorrência e do contrato alterariam fundamentalmente o quadro.

Uma nova concepção das classes sociais se tornava tanto mais urgente quanto mais se constatava que a classe trabalhadora havia se integrado à estrutura da economia monopolista: os sindicatos, como vimos acima, intermediavam a compra e a venda da força de trabalho, e por isso os líderes sindicais teriam se tornado, segundo Horkheimer, “(...) uma espécie de agrupamento no interior da classe dominante" ${ }^{687}$. A burocratização dos sindicatos e partidos tornara seus dirigentes cada vez mais distantes das bases, e o quadro era agravado ainda pela complexificação da classe trabalhadora e pela divergência de interesses entre trabalhadores

\footnotetext{
${ }^{686}$ Cf. Max Horkheimer, "Zur Soziologie der Klassenverhältnisse”, op. cit., p. 78.

${ }^{687}$ Cf. Max Horkheimer, “Zur Soziologie der Klassenverhältnisse”, op. cit., p. 94.
} 
especializados e não especializados. A representação dos interesses dos trabalhadores pelos sindicatos e partidos teria por isso se desvinculado da crítica da exploração do trabalho, e no contexto do imperialismo a luta de classes teria sido substituída pela concorrência entre as nações. A classe trabalhadora, ao abandonar a sua vocação de portadora dos interesses universais que poderiam conduzir a uma nova forma de sociedade, teria adotado uma racionalidade tão particularista quanto a dos demais grupos dominantes, pois assim como eles as suas organizações subsistiriam à base da mais-valia: "vivem todos daquilo que conseguem abocanhar da mais-valia circulante" ${ }^{688}$. As organizações dos trabalhadores, ao concorrer com os demais grupos dominantes, colaboravam na exploração e conciliavam os seus interesses com os daqueles grupos: “(...) agora predomina uma nova solidariedade entre as antigas e as novas elites; a história social das últimas décadas trouxe consigo uma colaboração mais estreita entre elas" ${ }^{689}$. Horkheimer argumentava, por isso, ser necessária uma reformulação do conceito marxista de classes sociais: se é verdade que as formulações de Marx a esse respeito não permitem a definição da classe social a partir meramente do lugar ocupado por determinado grupo de indivíduos na estrutura de produção, um elemento da teoria das classes relativamente consensual na tradição marxista é a separação histórica entre os produtores diretos e os meios de produção (concebida por Marx como o processo de acumulação primitiva de capital). Esse critério se tornava, contudo, insuficiente para definir as classes sociais face o tipo de dominação política desenvolvido sob o capitalismo monopolista, que sob o Estado integrava o proletariado e suas associações ${ }^{690}$.

Desde "Teoria tradicional e teoria crítica" (1937) Horkheimer empregava a noção de clique para descrever a nova forma assumida pela dominação de classe, tendo em vista principalmente as grandes corporações que, no âmbito do mercado internacional, constituíam monopólios e oligopólios, o mais das vezes com o amparo estatal das potências imperialistas (cf. o item acima sobre "imperialismo e classes sociais):

\footnotetext{
"Hoje o desenvolvimento é determinado muito menos pelas existências médias que, na
} sua concorrência entre si, são obrigadas a melhorar o aparelho material de produção e

\footnotetext{
${ }^{688}$ Cf. Max Horkheimer, "Zur Soziologie der Klassenverhältnisse”, op. cit., pp. 94-95. Cf. também, no mesmo texto, p. 88, p. 94 e p. 98 infra.

${ }^{689}$ Cf. Max Horkheimer, "Zur Soziologie der Klassenverhältnisse”, op. cit., p. 97. Cf. também, no mesmo texto, p. 81 e p. 85. Para a compreensão de Horkheimer do papel dos sindicatos de intermediários da força de trabalho não foi de pouca importância a sua experiência nos Estados Unidos, onde pôde assistir à atuação da AFL (American Federation of Labor) e às práticas do "business unionism”. Sobre isso, cf. o trecho entre as páginas 97 e 98.

${ }^{690}$ Cf. Max Horkheimer, "Zur Soziologie der Klassenverhältnisse”, op. cit., pp. 77-79, pp. 87-90. Adorno escreveu à mesma época um texto dedicado também a esse problema, mas infelizmente não é possível reconstituir aqui os elementos de sua argumentação. Cf. Theodor Adorno, "Reflexionen zur Klassentheorie", Gesammelte Schriften, vol. 8. Berlim: Suhrkamp, 1997. pp. 373-391.
} 
seus produtos, quanto pelas oposições em nível nacional e internacional de cliques de dirigentes (Führercliquen) nos diversos escalões da economia e do Estado" ${ }^{691}$.

Em 1942, o autor dava um passo adiante ao recorrer à noção de racket para designar as associações constituídas com vistas à monopolização de setores específicos da economia (dentre eles, o setor da oferta de força de trabalho, monopolizado pelos sindicatos). A partir de 1942, no curto texto sobre "Os rackets e o espírito" e em seu ensaio sobre "Razão e autoconservação" ${ }^{692}$, Horkheimer empregaria o termo ao lado de "clique" (às vezes vertido ao português como "camarilha"), "bando", "grupo" e "gangue", e dessa maneira o conceito ingressaria também na Dialética do Esclarecimento ${ }^{693}$. Como esclarecido por Kai Lindemann ${ }^{694}$, o termo racket provém da linguagem coloquial norte-americana e teria surgido na Chicago dos anos vinte para designar as atividades de extorsão (racketeering) praticadas por gângsteres que exigiam dinheiro em troca de proteção. Eles seriam, entretanto, apenas a ponta de lança de organizações mais amplas, com estrutura e práticas semelhantes aos famigerados clãs mafiosos do sul da Itália, e compostas por empresários, líderes sindicais, políticos, advogados e criminosos comuns encarregados de roubo, assassinato e extorsão. Essa estrutura permitia que, no âmbito do racket, a atividade econômica se beneficiasse de ramificações no Estado e na justiça, assim como de uma força de trabalho controlada e fornecida em condições favoráveis. De seu uso original, a noção de racket foi estendida por Horkheimer a qualquer forma de organização que pretendesse deter o monopólio sobre determinada atividade econômica e o fizesse por meio de relações pessoais de dependência, caracterizadas por lealdade, proteção e controle sobre os membros da organização (um controle também de caráter ideológico) $)^{695}$.

Os rackets seriam, segundo Horkheimer, "a forma básica da dominação”, e na fase do capitalismo monopolista a integração em seu âmbito se tornava um imperativo universal:

\footnotetext{
${ }^{691}$ Max Horkheimer, "Traditionelle und kritische Theorie", op. cit., pp. 178-179.

${ }^{692}$ Trata-se do já citado "Vernunft und Selbsterhaltung", publicado originalmente no volume dedicado à memória de Walter Benjamin, e aqui citado segundo a edição das obras de Horkheimer publicadas pela editora Fischer. Sobre os rackets, cf. especialmente pp. 332-334.

${ }^{693}$ A esse respeito, cf. Kai Lindemann, "Der Racketbegriff als Herrschaftskritilk". In: Ulrich Ruschig; Hans-Ernst Schiller (Orgs.) Staat und Politik bei Adorno und Horkheimer, op. cit., p. 105; e também a tese de doutorado de Ricardo P. Regatieri, Do capitalismo monopolista ao processo civilizatório, op. cit., p. 83, na qual o autor assinala que o texto "Die Rackets und der Geist", não datado na edição das obras de Horkheimer organizada por Alfred Schmidt e Gunzelin Schmid Noerr para a editora Fischer, traz na versão encontrada no Arquivo Horkheimer da Universidade de Frankfurt a datação de julho de 1942, a mesma época da publicação dos ensaios sobre o "Estado autoritário" e sobre "Razão e autoconservação".

${ }^{647}$ Cf. Kai Lindemann, "Der Racketbegriff als Gesellschaftskritik", op. cit., p. 105.

${ }^{695}$ Como notou Ricardo P. Regatieri, na tradução brasileira da Dialética do Esclarecimento o termo racket foi vertido por "gangue", "quadrilha", "bando" e outros, assim como, racketeer, por "bandido", "gângster" e similares. Cf. Ricardo P. Regatieri, Do capitalismo monopolista ao processo civilizatório, op. cit., p. 136.
} 
“ninguém deve escapar à sua proteção, está perdido quem é proscrito por suas agências" ${ }^{696}$. No caso dos "rackets do trabalho", a proteção oferecida pelos líderes sindicais aos trabalhadores incluía o esforço dos sindicatos por manter em um padrão elevado o preço da força de trabalho e era paga com uma parcela dos salários dos trabalhadores ${ }^{697}$. Quanto aos rackets que constituíam os monopólios industriais, se à época do capitalismo liberal a dominação se servia primordialmente (embora não apenas) de processos anônimos (as leis do mercado) para justificar a decadência dos concorrentes e os baixos salários pagos aos trabalhadores, no período do capitalismo de Estado os grupos dominantes decidiam abertamente sobre o destino de seus opositores, das minorias ou de nações inteiras ${ }^{698}$ :

"Os métodos ardilosos dos líderes políticos de hoje são tão privados e particularistas, e por isso talvez até mais cegos em relação às necessidades reais da sociedade do que as tendências automáticas que outrora regulavam o mercado. Ainda é a irracionalidade que configura o destino dos homens" ${ }^{\prime 699}$.

No racket, o critério exclusivamente "econômico", relativo ao exercício das funções diretamente pertinentes à produção, perderia a primazia em favor das relações extraeconômicas, daquilo que pode ser considerado grosso modo como "violência": nessas organizações, segundo Horkheimer, "a eficiência constitui em certas situações um estímulo, mas nunca um título de direito capaz de impor ao racket a aceitação do outsider" ${ }^{\text {700 }}$. A base histórica para essa perda da importância do critério "econômico" eram as transformações dos processos de trabalho na fase taylorista-fordista: a racionalização extrema da produção, com a transferência do conhecimento especializado dos operários às gerências e a automatização dos processos, tornara relativamente dispensável a posse de habilidades específicas para o exercício de funções na indústria, e isso constituía uma tendência abrangente de diversos setores da produção, que passavam a se assemelhar uns aos outros na medida em que os trabalhadores se tornavam cada vez mais executores de funções pré-determinadas ${ }^{701}$. Na indústria, o nível de conhecimento a separar os trabalhadores manuais dos engenheiros se constituía como uma distância facilmente de ser superada por meio da educação, e o ajustamento dos trabalhadores

\footnotetext{
${ }^{696}$ Cf. Max Horkheimer, “Die Rackets und der Geist”, Gesammelte Schriften, vol. 12, p. 287 e p. 289, respectivamente.

${ }^{697}$ Cf. Max Horkheimer, “Zur Soziologie der Klassenverhältnisse”, op. cit., pp. 87-90.

${ }^{698}$ Cf. Max Horkheimer, "Zur Soziologie der Klassenverhältnisse”, op. cit., pp. 78-79.

${ }^{699}$ Cf. Max Horkheimer, "Zur Soziologie der Klassenverhältnisse”, op. cit., p. 101.

${ }^{700}$ Cf. Max Horkheimer, "Die Rackets und der Geist”, op. cit., pp. 288-289.

${ }^{701}$ Marcuse também chamava a atenção para essas mudanças, como veremos adiante.
} 
às relações de poder se tornava por isso incomensuravelmente mais importante do que quaisquer habilidades técnicas que eles pudessem ter ${ }^{702}$.

A participação no racket garantiria o privilégio do acesso a determinados bens e ao mesmo tempo exigiria a lealdade dos membros às normas do grupo: esse seria o caso não apenas dos monopólios industriais e sindicais, mas também das associações de médicos, advogados, acadêmicos e outros grupos profissionais ${ }^{703}$. O ingresso dos indivíduos nessas organizações teria algo de semelhante aos rituais de iniciação que, nas tribos primitivas, condicionavam o ingresso dos jovens na vida adulta a humilhações e provações que certificassem a sua submissão à lei dos adultos: para se tornar seja um trabalhador industrial, seja um membro do corpo diretor de uma grande empresa, o indivíduo teria não apenas de cumprir as funções relativas à atividade concreta de trabalho, mas deixar de lado os aspectos de sua vida privada ou de sua personalidade que contradissessem as exigências do racket, assim como demonstrar ser confiável e estar permanentemente disponível a elas:

\begin{abstract}
"Assumem traços peculiarmente masoquistas a gesticulação do Führer diante da massa, do amante diante da pretendida, o comportamento do indivíduo em relação ao racket, seja ele um negócio, uma profissão ou um partido, seja antes ou depois da admissão. A postura à qual cada um é obrigado para comprovar sempre e mais uma vez a sua adequação moral a essa sociedade lembra os meninos que, ao serem aceitos na tribo sob as pancadas do sacerdote, movimentam-se em círculos e sorrindo de modo estereotipado. A existência no capitalismo tardio é um permanente rito de iniciação. Todos têm de mostrar que se identificam completamente com o poder do qual não cessam de receber pancadas" $" 704$.
\end{abstract}

A teoria dos rackets também contribuía para especificar o conceito de "massa", tal qual vinha sendo usado por Horkheimer e outros membros do Instituto em seus textos do período. A massa não seria uma mera soma de indivíduos destituídos de autonomia, e sim coletivos que dariam forma aos rackets e se organizariam de maneira semelhante à horda primordial, atuando nessa constituição como um dos elementos de reforço da dominação. Essa poderia ser exercida seja por meio da dominação direta dos líderes dos rackets sobre os seus membros, seja por meio da mobilização dos impulsos sadomasoquistas das massas contra os indivíduos não pertencentes ao grupo, notadamente os membros das minorias:

\footnotetext{
${ }^{702}$ Cf. Max Horkheimer, "Zur Soziologie der Klassenverhältnisse”, op. cit., pp. 95-96.

${ }^{703}$ Cf. "Die Rackets und der Geist", op. cit., p. 289. Sobre o racket dos médicos, cf. outros textos de Horkheimer não publicados em vida, contidos no volume 14 das Gesammelte Schriften.

${ }^{704}$ Max Horkheimer, Theodor Adorno. Dialektik der Aufklärung. Frankfurt am Main: Fischer, 1986.
} 
"A brutalidade dos de baixo, da qual é preciso ocultar o segredo do governo, não é primária, e sim produzida socialmente. $O$ coletivo sedento de sangue que perpassa terrivelmente a história da humanidade é apenas a outra face dos rackets excludentes, produzida de maneira consciente ou inconsciente por eles. A indumentária já gasta da aristocracia sobrevive sob a forma de trajes populares, os rackets da classe dominante sob a forma da brutalidade dos mais fortes contra os mais fracos, como a maldade indescritível da populaça contra a impotência. Ela é o racket do homem comum, um bem cultural degradado. Como fundamento de sua própria necessidade, os rackets sempre mencionaram o caráter terrível do coletivo por eles próprios produzido e dirigido, e a ingenuidade (não tão santa) dos historiadores tomou a cicatriz desfigurada em que consiste a massa como mera natureza" ${ }^{705}$.

O racket tornaria problemática a ideia, válida para o capitalismo liberal, de um funcionamento do capitalismo por meio basicamente da "coerção muda das relações econômicas", e apenas excepcionalmente por meio das formas "extra-econômicas" de violência $^{706}$. Isso não nos deve levar, contudo, à ideia de que Horkheimer teria substituído a crítica do capitalismo por uma crítica da civilização em geral ou do progresso técnico. Por serem uma forma de dominação pessoal, direta, os rackets, é verdade, aparentemente constituiriam uma regressão a formas pré-burguesas de dominação, como a medieval (a relação entre senhores e servos, não mediada pela mercadoria) e também, de maneira mais extrema, como lembrava o autor, à horda primordial, com sua divisão entre o tirano no topo da hierarquia, os homens mais fortes logo abaixo dele e os mais fracos, idosos, mulheres e crianças na base. Mas não se tratava de uma regressão, e sim de um desenvolvimento promovido pelo próprio capitalismo - a conversão dos sindicatos em vendedores da força de trabalho, aliás, tornava os rackets do capitalismo monopolista inconfundíveis com formas pretéritas de dominação. A ordem totalitária representaria uma continuação da dominação burguesa, agora convertida em dominação não mediada pela mercadoria: "não foram gângsteres invasores que se arrogaram o domínio sobre a sociedade na Alemanha, mas a dominação social transita a partir de seu próprio princípio econômico à dominação exercida pelos gângsteres"707.

\footnotetext{
${ }^{705}$ Cf. Max Horkheimer, “Die Rackets und der Geist”, op. cit., p. 291.

${ }^{706}$ Cf. Karl Marx, O Capital - crítica da Economia Política. Tradução de Regis Barbosa e Flávio Kothe. São Paulo: Abril Cultural, 1983, volume 1 - tomo 2, p. 277 (capítulo sobre a "acumulação primitiva de capital"). Sobre o surgimento dos rackets nos Estados Unidos do início do século XX, cf. a literatura norte-americana da época consultada por Ricardo P. Regatieri em Do capitalismo monopolista ao processo civilizatório, op. cit., pp. 77-79. 707 Max Horkheimer, "Vernunft und Selbsterhaltung", op. cit., p. 332. Cf. também Max Horkheimer, "Zur Soziologie der Klassenverhätnisse", op. cit., p. 81.
} 
Os rackets conjugavam a relação mercantil e uma dominação de caráter direto. $\mathrm{O}$ cancelamento da autonomia da esfera da circulação acrescentava à aparência de racionalidade do contrato, embora essa não desaparecesse, a dominação direta:

\begin{abstract}
"Seria um grave erro teórico desprezar esse contrato, sob as condições da moderna dominação totalitária, como uma mera formalidade, e por sua vez enfatizar a sua autenticidade sob as condições do liberalismo. Em ambos os casos, a finalidade do contrato pode ser plenamente vista na cimentação justamente daquela desigualdade básica, oculta quando ele é apresentado em linguagem democrática"708.
\end{abstract}

Era como se, na passagem do capitalismo liberal ao capitalismo monopolista, as relações mercantis revelassem abertamente a sua dependência de relações de dominação direta ${ }^{709}$. Horkheimer propunha, então, uma "sociologia dos rackets", a ser desenvolvida em conjunto pelos membros do Instituto e que investigasse a presença constante dessa forma de dominação em diversos âmbitos, como a grande indústria, os sindicatos e os partidos políticos. Ao fazê-lo, ela contribuiria para fortalecer a ideia da possibilidade de uma "sociedade sem rackets"710. Não se tratava, nessa "sociologia dos rackets" meramente esboçada, de investigar em que medida poderes "ilegais" atuam sobre instituições "legais" e de conceber os rackets como elementos externos a uma sociedade que existiria sem eles, e sim de conceber a sociedade burguesa como uma contínua acumulação primitiva de capital, que não seria apenas uma fase pretérita no início do capitalismo, e sim constituiria o cerne de seu funcionamento: a mais-valia seria extorquida diretamente pelos grupos dominantes em $\operatorname{disputa}^{711}$.

\footnotetext{
${ }^{708}$ Cf. Max Horkheimer, "Zur Soziologie der Klassenverhältnisse”, op. cit., pp. 79-80.

${ }^{709}$ Como lembrou Kai Lindemann, o conceito de racket e a teorização de Horkheimer a respeito são bastante proveitosos para se refletir sobre a prática de lobbies, a corrupção em nível internacional e também sobre aquilo que a sociologia contemporânea chama de "redes", constituídas por mecanismos informais de influência sobre processos políticos e econômicos. cf. Kai Lindemann, "Der Racketbegriff als Herrschaftskritilk", op. cit., p. 123. ${ }^{710}$ Cf. Max Horkheimer, "Zur Soziologie der Klassenverhältnisse”, op. cit., pp. 103-104. A esse respeito, cf. também a carta de Horkheimer a Leo Löwenthal de 14 de outubro de 1942 no vol. 17 das Gesammelte Schriften, pp. 342-343.

${ }^{711}$ Essa ideia parece muito próxima das teses de Rosa Luxemburgo sobre o caráter da acumulação na fase imperialista, assim como do desenvolvimento contemporâneo dessas teses, feito por David Harvey com recurso à noção de "acumulação por espoliação". Sobre essa permanente acumulação primitiva, cf. a carta de Horkheimer a Grossmann de 20 de janeiro de 1943: Max Horkheimer, Gesammelte Schriften, vol. 17, p. 399. A teoria dos rackets elaborada por Horkheimer era, contudo, pouco compatível com alguns dos elementos das teses tanto de Pollock quanto de Neumann que Horkheimer havia abandonado, e isso pode ter contribuído para o malogro do projeto: no caso do primeiro, porque em sua concepção de "capitalismo de Estado" o "grupo dominante" formado pelos industriais, o partido, o exército e a burocracia civil seria relativamente coeso e capaz de fazer do Estado a instância máxima de organização dos processos econômicos; no caso do segundo, porque a teoria dos rackets tomava os sindicatos meramente por organizações interessadas na perpetuação da exploração (Neumann, como vimos, ainda em meio ao nazismo considerava a possibilidade de as organizações coletivas dos trabalhadores desempenharem um papel revolucionário). A esse respeito, cf. Kai Lindemann, "Der Racketbegriff als Gesellschaftskritik", op. cit., pp. 113-115. Como se depreende da leitura das cartas seguintes àquela de 14 de outubro de 1942 em que o projeto fora proposto, ele terminou por não ser executado, e Horkheimer passou a partir daquela época a se dedicar em
} 
Essa compreensão revela a nítida diferença entre a teoria dos rackets e a tese de Pollock de um "primado da política" sobre a economia, que sugeria a perda de importância de conceitos como "valor" e "mercadoria", e também suas diferenças com relação à tese de Neumann sobre a permanência, no capitalismo monopolista, dos traços fundamentais que a concorrência havia assumido no período liberal. Concorrentes entre si pela monopolização, os rackets tornavam clara a imbricação estreita entre o poder político e a concorrência, e por isso é possível ver nessa teoria a incorporação, por Horkheimer, de aspectos da compreensão de Neumann do capitalismo monopolista: como vimos anteriormente, para o autor os grupos de poder representados na grande indústria, no partido, na burocracia e no exército controlariam diretamente a população em um suposto "não-Estado"712.

Horkheimer, por sua vez, conceberia esses grupos como rackets dentre outros, e o caráter centrífugo e instável da dominação exercida pelos rackets afastava essa teoria da ideia de uma dominação estável e duradoura, tal qual presente na tese de Pollock. Ao mesmo tempo, porém, a elaboração da teoria dos rackets não deve iludir, entretanto, quanto a um possível abandono por Horkheimer de aspectos centrais da tese do capitalismo de Estado, na versão que o autor lhes dera sob o conceito de "Estado autoritário". A teoria dos rackets representou, ao que tudo indica, a integração dos elementos de concorrência e instabilidade ressaltados por Neumann àqueles relativos ao controle e planejamento estatal examinados por Pollock, e que em suas linhas gerais não desapareceriam da obra de Horkheimer. Em texto escrito em 1947, o autor afirmaria, ainda em consonância com suas formulações anteriores, que "o Terceiro Reich foi a única ditadura da época moderna que tentou sistematicamente se libertar de qualquer instância mediadora entre o indivíduo e o Estado (...)"713. Isso pode nos levar à hipótese de que, ao mesmo tempo em que os rackets seriam, como escrevera Horkheimer, "a forma básica da dominação", a combinação (que os caracterizava) entre processos de concorrência e o exercício da dominação direta se apresentaria em sua forma mais complexa no Estado autoritário,

conjunto com Adorno e Löwenthal à escrita da Dialética do Esclarecimento, na qual a teoria dos rackets não obstante haveria de ser incorporada, como já indicamos acima.

712 Como sugeriu Ricardo P. Regatieri, a teoria dos rackets pode ser considerada uma continuidade, na obra de Horkheimer, das reflexões de Neumann sobre os conflitos entre as frações do grupo dominante em uma época em que a dominação seria caracterizada pelo "não-Estado". Cf., do autor, Do capitalismo monopolista ao processo civilizatório, op. cit. p. 89 e, especialmente sobre a teoria dos rackets, o capítulo 3. É como se a teoria de Neumann do não-Estado tivesse sido conservada na teoria dos rackets, forma de dominação de tendências anárquicas que seria, entretanto, uma parte constitutiva do Estado autoritário (note-se, a fim de evitar um mal-entendido, que no ensaio de Horkheimer de mesmo nome essa teoria ainda não tinha sido desenvolvida, e só começaria a ser esboçada por volta de 1942, em seu ensaio "Razão e autoconservação"). Cf. Max Horkheimer, "Vernunft und Selbsterhaltung", Gesammelte Schriften, vol. 5, pp. 332-334.

${ }^{713}$ Cf. Max Horkheimer, “Autorität und Familie in der Gegenwart”, Gesammelte Schriften, vol. 5, p. 380. 
responsável pelo planejamento da vida nacional. Referindo-se aos monopólios sindicais e à sua integração ao Estado, Horkheimer afirmava:

\begin{abstract}
"A integração de elementos corporativos na administração [pública] avançou durante a guerra. A sociedade se torna um processo planejado e regulado, mas não em relação aos grandes acontecimentos (esses continuam a repousar sobre poderes cegos que resultam da luta entre as classes e os diversos grupos dominantes), e sim em relação àquilo que tange a vida do indivíduo; não no sentido da autoadministração (as decisões são tomadas como compromissos entre os proeminentes, cujos interesses não correspondem àqueles do restante da sociedade), mas tendo em vista o aumento do desempenho do aparato material e humano" $" 714$.
\end{abstract}

Vimos acima que o Estado autoritário significou para Horkheimer a extensão ao âmbito da política da irracionalidade intrínseca ao controle sobre os meios de produção. Na teoria dos rackets, era como se esse raciocínio fosse estendido para se pensar as demais formas de socialização além do Estado, pois incluía os sindicatos, as empresas, as corporações de profissões liberais, as universidades, a família e outros âmbitos. Ao pôr a descoberto o fato de que, sob o capitalismo monopolista, a universalidade do mercado, do direito e do Estado submergia sob formas diretas de dominação, a teoria dos rackets terminava por ampliar a crítica da economia política à crítica da dominação em geral: "essa crença", afirmava Horkheimer em relação ao convívio do fetichismo da mercadoria com formas diretas de dominação, "estende a crítica da realidade da troca livre e justa por fim àquele inteiro setor que a ciência burguesa chama de 'sociologia', ou seja, a todas as formas sociais sob as quais os homens têm de viver" ${ }^{\prime 715}$.

Ao mesmo tempo, o predomínio dos rackets iluminava a história pregressa, pois a racionalidade particularista que neles aparecia de forma aberta e livre do disfarce da concorrência sempre esteve presente ao longo dos diversos modos de produção. Vista a partir deles, a concorrência típica do capitalismo liberal se tornava um meio de dominação entre outros prevalecentes ao longo da história, ao lado do roubo, da fraude e da guerra ${ }^{716}$. Os rackets

\footnotetext{
${ }^{714}$ Cf. Max Horkheimer, "Zur Soziologie der Klassenverhältnisse”, op. cit., p.98. Discordamos, portanto, de Kai Lindemann, que ao defender que os rackets seriam "para-Estados" parece identificar a teoria de Horkheimer à ideia de Neumann do "não-Estado". Cf. Kai Lindemann, "Der Racketbegriff als Gesellschaftskritik", op. cit., p. 110. De maneira semelhante, Michael Greven sugeriu que a teoria dos rackets ficaria "lado a lado" com a teoria do "capitalismo de Estado" compartilhada por Horkheimer e Pollock. Cf. do autor, "Zur Kontinuität der Rackettheorie. Max Horkheimers politisches Denken nach 1945”. In: Michael Greven, Kritische Theorie und historische Politik. Theoriegeschichtliche Beiträge zur gegenwärtigen Gesellschaft. Opladen: Leske e Budrich, 1994, pp. 170-172.

${ }^{715}$ Carta de Horkheimer a Grosmann de 20 de janeiro de 1943. Gesammelte Schriften, vol. 17, p. 399.

${ }^{716}$ Cf. Max Horkheimer, "Zur Soziologie der Klassenverhältnisse”, op. cit., pp. 80-81 e p. 97.
} 
denunciavam a total irracionalidade da dominação (que no capitalismo liberal ainda era justificada ideologicamente pelo mercado), e como ela se funda não em supostas (e inexistentes) qualidades dos dominantes, mas na mera violência. Ressoava aqui, portanto, aquela ideia de Lukács de uma "mudança de função do materialismo histórico", segundo a qual as formas extraeconômicas de dominação deveriam receber uma atenção que até então não lhes havia sido dispensada pelo marxismo ${ }^{717}$. A partir da fase contemporânea do capitalismo, segundo Horkheimer, a história poderia ser vista como uma história da dominação: recorrendo à frase de Marx segunda a qual "a anatomia do homem é a chave da anatomia do macaco", o autor indicava a necessidade de uma teoria da história que fosse pensada como uma história da dominação exercida por meio dos rackets ${ }^{718}$.

A dominação sem disfarces exercida pelos rackets prepararia a superação do capitalismo:

"O capitalismo tem um prazo de validade, mesmo depois de ter passado a sua fase liberal. (...) Não é, digamos, a impossibilidade de fechar as contas, e sim a crise internacional, perpetuada pelo Estado autoritário, o que não deixa mais escolhas à humanidade que se arruína sob suas formas. O sistema eterno do Estado autoritário, por mais terrível que seja sua maneira de intimidar, não é mais real do que a harmonia eterna da economia de mercado. Se a troca de equivalentes ainda era um invólucro da desigualdade, o planejamento fascista já é o roubo aberto"719.

\section{$\underline{6.4 \text { - Os novos rumos da crítica: do indivíduo isolado ao indivíduo não-idêntico }}$}

Em um regime baseado na produção e no consumo de massas, a subordinação dos indivíduos aos imperativos das burocracias econômico-políticas seria conseguida também por meio de sua "mobilização permanente": as necessidades individuais seriam instrumentalizadas para os fins da dominação, de maneira a aplainar a oposição entre as esferas pública e privada. Uma racionalidade técnica reiteraria o isolamento dos indivíduos e tanto mais os reduziria a

\footnotetext{
${ }^{717}$ Cf. Lukács, História e consciência de classe, op. cit., p. 449.

718 Cf. Max Horkheimer, "Zur Soziologie der Klassenverhältnisse”., op. cit., p. 104. Em carta de 13 de janeiro de 1943 a Felix Weil, Horkheimer afirmava: “depois de o fascismo ter se desenvolvido na sociedade européia, somos capazes agora de encontrar seus traços principais em fases anteriores da história humana, mas seria um erro afirmar que, em virtude daqueles traços, o desenvolvimento foi um desenvolvimento necessário". Cf. o volume 17 das Gesammelte Schriften de Max Horkheimer, p. 397. Segundo Ricardo P. Regatieri, essa consideração da história humana como uma história dos rackets teria sido um passo decisivo rumo à escrita da Dialética do Esclarecimento. Cf. o capítulo 4 de sua tese Do capitalismo monopolista ao processo civilizatório, op. cit.

${ }^{719}$ Max Horkheimer, “Autoritärer Staat”, op. cit., p. 311.
} 
"manadas" quanto mais os punha em contato uns com os outros, da mesma maneira que como tanto mais os tornaria impotentes quanto mais os dotava de uma espécie de atividade que, embora incessante e abrangente, tinha um caráter meramente contemplativo:

“(...) pertence ao catecismo da arte do governo autoritário o fato de o isolamento dos indivíduos uns dos outros dever ser empreendido por meio de todos os meios de transporte, por meio do jornal, do cinema, do rádio. Eles devem ouvir com atenção a todos, do Führer ao chefe do quarteirão, mas não uns aos outros, eles devem estar orientados sobre tudo, da política nacional de paz à lâmpada de luminosidade regulável, mas não orientar-se a si mesmos, eles devem pôr as mãos sobre tudo, mas não sobre a dominação. Por todos os lados, a humanidade é instruída e mutilada" ${ }^{\text {"720 }}$.

A subordinação de potencialmente todas as esferas sociais à racionalidade meramente técnica da fábrica teria, no fim, conduzido à liquidação do papel de mediação exercido pela mercadoria. Nas palavras de Horkheimer, um "véu tecnológico" mais espesso do que aquele encarnado no dinheiro (o qual ainda pressupunha um certo grau de autonomia individual) seria a nova forma de mediação entre os indivíduos, deixando para trás as esferas anteriormente cumpridoras dessa função, como o mercado, a família e a escola. O capitalismo, ao se desenvolver, conduziu à crescente insignificância daquelas esferas mediadoras entre o indivíduo e a sociedade e dotou a dominação de um caráter cada vez menos mediado. No período do capitalismo de Estado a "autoridade dos fatos" se apresentava aos indivíduos também, constatava Horkheimer, sob a forma de uma racionalidade técnica ${ }^{721}$.

Foi principalmente Marcuse quem analisou o modo como a dominação se serve da tecnologia, e é provável que Horkheimer ao tratar desse assunto (como na passagem citada) tenha se inspirado em um texto de seu colega sobre "Algumas implicações sociais da tecnologia moderna", publicado assim como o de Pollock no volume de 1941 da Revista ${ }^{722}$. Segundo Marcuse, o processo histórico de aplainamento das oposições entre os indivíduos e a sociedade teria conduzido a uma racionalização tal dos processos da vida social que se tornara possível subordiná-los a um aparato tecnológico, caracterizado pela extensão às diversas esferas sociais do tipo de racionalidade necessária ao manuseio de meras máquinas. $\mathrm{O}$ funcionamento desse aparato tecnológico teria se autonomizado frente aos indivíduos ao fazer deles pontos de apoio capazes de garantir a eficiência de processos dotados de um curso próprio, e se faria presente, portanto, não apenas na racionalização dos processos de trabalho das fábricas, escritórios e da administração pública, mas também, dentre outros, na redução da autonomia da atividade

\footnotetext{
${ }^{720}$ Max Horkheimer, “Autoritärer Staat”, op. cit., p. 302.

${ }^{721}$ Max Horkheimer, "Vernunft und Selbsterhaltung”, op. cit., p. 339 e p. 345.

${ }^{722}$ Herbert Marcuse, "Some social implications of modern technology", op. cit. pp. 414-439.
} 
científica e na conversão da ciência a uma mera extensão das necessidades da indústria, na instrumentalização do tempo livre e da libido para fins de dominação (por meio do entretenimento e do consumo promotores do comportamento conformista), e também, mas não menos importante, na crescente abstração dos critérios orientadores da educação, de maneira a promover um tipo de conhecimento baseado em habilidades intercambiáveis e quantificáveis, capazes de tornar a força de trabalho adaptável às necessidades cambiantes do processo de produção ${ }^{723}$. Como resumia Horkheimer, "no lugar da investigação do significado, surge por toda a parte a constatação da função"724.

A racionalização dos processos de trabalho, ela própria correspondente à aplicação, no âmbito da fábrica, da racionalidade formal da troca de equivalentes, se estendia a diversas esferas até então relativamente independentes da indústria. No período específico do nazismo, como já observamos acima, cumpriram um papel importante a instrumentalização das relações sexuais para os fins da expansão imperialista e a mobilização do sadismo das massas contra as minorias $^{725}$. O fordismo, de uma maneira geral, significou a extensão do caráter de "apêndice da máquina" do trabalhador do chão-de-fábrica para a sociedade inteira, incluindo-se aí a esfera privada da vida: enquanto no período do capitalismo liberal a espontaneidade do trabalhador industrial sofreria limitações principalmente no âmbito da produção, prevalecendo na esfera da circulação a mediação exercida pela mercadoria e a aparente racionalidade da troca, na fase do Estado autoritário, por sua vez, a supressão da espontaneidade do trabalhador se estendia às demais esferas, reduzindo o seu grau anterior de autonomia e transformando a ação política pautada por fins e ideias em mera obediência e adaptação às estruturas burocráticas dos partidos, fazendo da linguagem da conversação uma extensão da linguagem dos filmes e do rádio, reduzindo o flerte e a atração sexual a uma coisa que se poderia converter em fonte de prestígio social, à maneira da mercadoria ${ }^{726}$. De apêndice da máquina durante o tempo passado na fábrica, o indivíduo passava a apêndice de um aparato produtivo que se estendia ao consumo, à educação, ao tempo livre e às relações privadas, que deixavam de o $\operatorname{ser}^{727}$.

\footnotetext{
${ }^{723}$ Cf. Herbert Marcuse, "Some social implications of modern technology", op. cit., p. 415-422.

${ }^{724}$ Max Horkheimer, "Vernunft und Selbsterhaltung", op. cit., p. 340.

${ }^{725}$ Como indicamos no capítulo 5, Pollock se deteve sobre esse assunto em seu artigo "Is National Socialism a New Order?", op. cit., p. 448-449. A esse respeito, cf. também Max Horkheimer, "Vernunft und Selbsterhaltung", op. cit., p. 344.

${ }^{726}$ Cf. Max Horkheimer, "Vernunft und Selbsterhaltung”, op. cit., p. 334, p. 337 e p. 342.

${ }^{727}$ Assim Marx descrevera a transformação do trabalhador em um "apêndice" da máquina, na fase do capitalismo concorrencial: "Na manufatura e no artesanato, o trabalhador se serve da ferramenta; na fábrica, ele serve à máquina. Lá, é dele que parte o movimento do meio de trabalho; aqui ele precisa acompanhar o movimento. Na manufatura, os trabalhadores constituem mebros de um mecanismo vivo. Na fábrica, há um mecanismo morto, independente deles, ao qual são incorporados como um apêndice vivo”. Cf. Karl Marx, O Capital, op. cit., vol. 1, tomo 2, capítulo XIII, p. 43.
} 
A família, a escola e a religião perderiam suas funções socializadoras. Instâncias que tradicionalmente haviam exercido o papel de transmissão da autoridade, elas haviam sido também, ao mesmo tempo, esferas nas quais o indivíduo se formava em oposição à sociedade e sua ordem dominante. O caráter repressor dessas instituições havia convivido, por isso, com o fomento no indivíduo de elementos críticos que o resguardavam de uma identificação direta com a sociedade. À era do Estado autoritário, porém, tais instituições perdem sua relevância frente ao poder avassalador da socialização promovida pela racionalidade técnica e pelo "coletivo" social mais amplo. Correlatamente, a puberdade e a juventude deixariam progressivamente de ser fases da vida caracterizadas pelo conflito, para serem absorvidas por uma integração social que se sobrepunha à autoridade familiar e destituía as autoridades tradicionais de seu papel: “a educação não é mais um processo que transcorreria entre indivíduos, tal qual à época em que o pai preparava o filho para assumir a sua propriedade, e nisso era seguido pelo professor. Ela é praticada diretamente pela sociedade e se impõe às costas da família" ${ }^{728}$.

A esfera da circulação seria cada vez mais subordinada a uma mera racionalidade instrumental: a mediação exercida pela mercadoria teria desaparecido e em seu lugar surgido algo próximo a uma "imediaticidade", pois o papel mediador da tecnologia consistiria, no fim das contas, em uma subordinação pouco refletida à autoridade da técnica. Isso levava Marcuse a caracterizar o regime nazista como uma "tecnocracia", na qual o uso bruto da força seria apenas um complemento à dominação exercida pelos imperativos de eficiência e racionalidade $^{729}$. Do ponto de vista individual, a requisição de capacidades intelectuais e morais meramente adaptativas teria promovido uma atitude chamada pelo autor, em sequência ao escritor norte-americano Lewis Rumford, de matter-of-factness, a disposição a considerar a realidade como algo dado, como uma simples "questão de fato". A capacidade de intervenção dos indivíduos se restringiria aos fatos dotados da "forma opaca" a eles conferida pela sociedade, fatos cotidianos cujo domínio e transformação serviriam em primeiro lugar à reprodução da própria sociedade - em uma sociedade alienada, os fatos relativos ao todo social permaneceriam intocados, e os indivíduos não se sentiriam impelidos a relacionar a racionalidade intrínseca aos fatos a ideias de razão ou de liberdade, capazes de serem vinculadas

\footnotetext{
728 Max Horkheimer, "Vernunft und Selbsterhaltung", op. cit., p. 340. Nos dias de hoje, essa integração é representada principalmente pelo consumo e pelas "novas" tecnologias.

${ }^{729}$ Cf. Herbert Marcuse, "Some social implications of modern technology", op. cit., p. 414.
} 
a uma crítica do mundo existente ${ }^{730}$. No que dizia respeito à integração dos trabalhadores, Horkheimer ressaltava que

\begin{abstract}
“eles aprenderam a aceitar a injustiça social - mesmo a injustiça no âmbito de seu próprio grupo - como um fato poderoso, e a considerar os fatos poderosos como a única coisa a se respeitar. Sua consciência está fechada aos sonhos de um mundo fundamentalmente diferente, assim como aos conceitos que, em vez de serem uma mera classificação de fatos, são orientados por um cumprimento real desses sonhos" ${ }^{\text {"731. }}$.
\end{abstract}

A universalização da racionalidade da troca teria enfraquecido a tal ponto as mediações representadas pelas esferas sociais que os indivíduos teriam sido reduzidos a meros objetos de dominação: isolados uns dos outros, cada um deles estaria entregue à autoridade anônima da sociedade de massas, uma autoridade baseada na racionalidade com relação a fins e que converteria tudo em objeto de cálculo e dominação ${ }^{732}$. O indivíduo se encontraria, portanto, em estado de dissolução, e o processo de reificação igualaria os indivíduos, retirando-lhes de antemão as qualidades singulares que eles poderiam vir a desenvolver ${ }^{733}$.

O enfraquecimento da família como instância de mediação entre o indivíduo e a sociedade também significou, por extensão, o declínio da moral burguesa: ela, que no período do capitalismo liberal se afirmara como uma instância dotada de relativa autonomia frente às necessidades da produção, no capitalismo de Estado perdia sua função crítica e em lugar do imperativo categórico se firmava o interesse imediato, reduzido à forma da "autoconservação". O conceito de interesse individual passava, então, por uma mudança de função: na época de ascensão da burguesia, ele exprimira uma oposição às autoridades constituídas (do Antigo Regime) e continha uma racionalidade impossível de ser reduzida à reprodução social. De maneira semelhante, à época em que o proletariado ainda não estava integrado seus interesses de classe apontavam para além do capitalismo, e não se confundiam, portanto, com o interesse imediato, funcional à reprodução da sociedade. No período da dominação totalitária, ao agir em conformidade a seus próprios interesses os indivíduos atuariam no interesse da reprodução da sociedade e a forma do interesse individual passava a exprimir a mera heteronomia ${ }^{734}$. Isso não

\footnotetext{
${ }^{730}$ Cf. Herbert Marcuse, "Some social implications of modern technology”, op. cit., pp. 417-421.

${ }^{731}$ Cf. Max Horkheimer, "Zur Soziologie der Klassenverhältnisse”, op. cit., p. 89.

732 Cf. Max Horkheimer, "Vernunft und Selbsterhaltung", op. cit., p. 339.

${ }^{733} \mathrm{Na}$ Dialética do Esclarecimento, Horkheimer e Adorno associariam ao fascismo, época histórica da máxima integração, a realização do ideal de igualdade do esclarecimento, na medida em que o indivíduo é negado naquilo que ele tem de singular, para se converter em mero membro da "horda" reprimida. Cf. Adorno e Horkheimer, Dialética do Esclarecimento. Tradução de Guido A. de Almeida. Rio de janeiro: Jorge Zahar Editor, 1985, pp. 2627.

${ }^{734}$ Cf. Max Horkheimer, "Vernunft und Selbsterhaltung", op. cit., p. 332.
} 
impediria os indivíduos de crer que a persecução do interesse imediato seria a ação racional por excelência: nas palavras de Marcuse, "o comportamento racional se torna idêntico à matter-offactness que ensina a submissão razoável e assim garante a acomodação à ordem prevalecente". Ao fazê-lo, a equivalência entre a persecução do próprio interesse e a razão se revelaria como a forma mais eficaz possível de dominação, pois os homens identificariam a sujeição à sociedade como a própria liberdade: “(...) os homens não experimentam essa perda de sua liberdade como obra de uma força hostil e estranha; eles abandonam sua liberdade como se isso fosse ditado pela própria razão" 735 .

Esse estado de coisas tornava necessária uma reconceitualização da noção de "massa". Como chamamos à atenção mais acima, ao analisar a obra de Fromm, essa seria para Freud uma associação caracterizada pela dissolução das características individuais, pela vinda à tona do inconsciente e seus impulsos reprimidos, assim como pela tendência dos indivíduos a pensarem por imagens em vez de conceitos ${ }^{736}$. Nas formulações de Psicologia das massas e análise do eu, é como se indivíduos dotados de um aparelho psíquico autônomo perdessem-no ao ingressar na massa. Horkheimer argumentava, porém, que a psicanálise havia "alçado seu voo" no crepúsculo da era da circulação, uma era cujo fim ela, a psicanálise, prenunciava ao desmascarar o papel repressor da autoridade paterna. Na época contemporânea, a oposição entre o eu da criança e o supereu constituído à imagem paterna estaria aplainada pela autoridade dos "fatos" que a criança deveria reproduzir" ${ }^{737}$. Marcuse, por sua vez, esclarecia ser errada a suposição de que a massa destituiria os indivíduos de uma suposta autonomia anterior: pelo contrário, a massa é uma associação de indivíduos que foram reduzidos, em sua socialização, à expressão abstrata de sua individualidade, a uma individualidade "impessoal" destituída de qualidades distintivas e caracterizada basicamente pela busca do interesse próprio. Capaz de convencer os membros da massa que eles, ao agirem segundo seus interesses imediatos, agiriam também em conformidade à razão, o Estado autoritário asseguraria uma base estável para sua dominação ${ }^{738}$.

A noção de "experiência" e de integração existencial entre as vivências passadas e a perspectiva projetada para o futuro estaria em vias de desaparecer, em favor da “autoconservação", reduzida à adaptação ao presente imediato. O "eu” capaz de conferir uma

\footnotetext{
${ }^{735}$ Cf. Herbert Marcuse, "Some social implications of modern technology", op. cit., p. 421. Sobre a mudança de função do interesse individual, cf. ainda p. 428 e também Max Horkheimer, "Vernunft und Selbsterhaltung", op. cit., p. 335.

${ }^{736}$ Sigmund Freud, "Massenpsychologie und Ich-Analyse". In: Sigmund Freud, Gesammelte Werke. Vol. XIII. Fischer: Frankfurt am Main, 1987. p. 74.

${ }^{737}$ Max Horkheimer, "Vernunft und Selbsterhaltung", op. cit., p. 335.

${ }^{738}$ Cf. Herbert Marcuse, "Some social implications of modern technology", op. cit. p. 426.
} 
unidade à realidade circundante havia se constituído em meio à ordem burguesa, e desde seu início dependera da esfera da concorrência e da propriedade privada individual. Na fase da dominação totalitária, em que o Estado havia se encarregado do planejamento e da organização da realidade, reduzida a um conjunto de máquinas em que se transformaram, enfim, não apenas a produção fabril, mas a política, a educação e as relações amorosas, as características exigidas dos indivíduos seriam a presença de espírito, a capacidade de rápida orientação cotidiana e de resposta aos estímulos provindos de um aparato produtivo que abarca todas as esferas da vida:

"O indivíduo se retrai. Ele está sempre vigilante e disposto, sempre e por toda a parte com a mesma vigilância e a mesma disposição, sempre e por toda a parte direcionado para o que há de imediatamente prático, aplicando seus ouvidos à linguagem meramente como se ouvisse informações, orientação, comandos, sem sonho e sem história"739.

A atomização dos indivíduos pelo Estado autoritário, sua redução a mônadas isoladas orientadas pelo cálculo e pela autoconservação, conteria não obstante elementos que apontavam para a superação dessa forma de dominação ${ }^{740}$. A reificação da consciência do trabalhador, sua redução a mera peça do processo de produção e a separação de sua força de trabalho de sua personalidade não promoveu a consciência de classe e a passagem da contemplação à ação por outro lado, ela teria tornado os operários "refratários, ranzinzas e desobedientes" $" 741$. A adaptação dos indivíduos aos padrões materiais e culturais do capitalismo monopolista conviveria com uma insatisfação crescente diante das possibilidades não realizadas da ordem social, uma insatisfação recalcada com força cada vez maior. À essa época Horkheimer incursionava pelo tema da mimese, que iria ocupar o primeiro plano das análises da Dialética do Esclarecimento e de Eclipse da Razão. O domínio da natureza e da sociedade, ao longo do processo da civilização, conduziria à formação de uma segunda natureza, que imitaria os traços da natureza dominada. A fase contemporânea do capitalismo, caracterizada pela extensão da reificação às mais diversas esferas sociais, seria atravessada por práticas miméticas e por um tipo de comportamento adaptado e irrefletido, que lembra as primeiras etapas do processo de socialização: "assim como uma criança repete as palavras de sua mãe, e o jovem as maneiras brutais dos mais velhos nas mãos dos quais sofreu tanto, o alto-falante gigante da indústria cultural duplica a realidade de modo infinito e entediante" ${ } 742$.

\footnotetext{
${ }^{739}$ Max Horkheimer, "Vernunft und Selbsterhaltung”, op. cit., p. 337. Cf. também as passagens às pp. 335-338 e p. 342.

${ }^{740}$ Cf. Max Horkheimer, “Autoritärer Staat”, op. cit., pp. 316-317.

${ }^{741}$ Cf. Max Horkheimer, "Zur Soziologie der Klassenverhältnisse”, op. cit., p. 99.

${ }^{742}$ Cf. Max Horkheimer, "Zur Soziologie der Klassenverhältnisse”, op . cit., p. 91.
} 
Os indivíduos, quanto mais se integrassem ao meio circundante, mais teriam de empreender contra si uma ação repressora: a redução das formas individuais de expressão a funções do sistema econômico levaria os homens a reprimir desesperadamente, neles e nos outros, quaisquer impulsos em contrário, o eu fraco dirigindo seus impulsos agressivos para vítimas nas quais reconhece sua própria impotência. Surgido da consciência da impotência do próprio eu e da violência à qual ele foi submetido no processo de socialização, o ódio dos indivíduos é projetado em todos aqueles que representam uma diferença não integrada. A contenção do desejo e sua substituição pela identificação com o coletivo (encarnação da ideia de uma realização mais abrangente do que o desejo pontual) seria a fonte de um mal-estar profundo a perpassar as relações sociais, pois o sofrimento ao qual os indivíduos são submetidos em sua socialização viria à tona e desencadearia o ódio repressor da natureza que não se deixou dominar e em cuja matéria contrariada "aflora irresistivelmente a liberdade"743. O ódio contra o impulso divergente das tendências socializadoras seria representativo, portanto, de uma brecha no processo da cultura, e reveladora de um limite da dominação: "o homem reprime em si e nos outros, desesperadamente, todo outro impulso. (...) Precisamente essa odiosidade [Gehässigkeit] mostra que a humanidade não foi totalmente abarcada pela coletivização repressiva dos homens" ${ }^{\prime 74}$.

Esse comportamento, ele próprio elemento fundamental da dominação, seria ao mesmo tempo um "fator inquietante" que obrigaria os dominantes a recorrerem às formas fascistas de governo e a modelos pseudo-coletivistas de socialização, expressões superficiais de uma coletivização mais profunda que operaria por meio da dissolução dos indivíduos e cuja eficácia seria garantida por aqueles modelos, pelo terror e pela propaganda. A plasticidade das vítimas do Estado autoritário (aqui incluindo-se as minorias perseguidas e os seus carrascos), sua capacidade de se submeter à violência da socialização, seria um fator de inquietação para os dominantes porque a mudança necessária à construção de uma sociedade na qual os homens "regulem solidariamente as suas questões" seria muito inferior à modificação já induzida neles pela sociedade atual. Por baixo das meras "caretas" às quais foram reduzidos os indivíduos se esconderia a possibilidade de uma realidade melhor $^{745}$, e um das tarefas do pensamento crítico seria tornar os homens conscientes de sua própria deformação. Esse seria, segundo Horkheimer, o "método em meio à loucura":

\footnotetext{
743 Adorno e Horkheimer, Dialética do Esclarecimento, op. cit., p. 171.

${ }^{744}$ Cf. Max Horkheimer, "Zur Soziologie der Klassenverhältnisse”, op. cit., p. 99. A esse respeito, cf. também, do autor, "Die Rackets und der Geist", op. cit., p. 291.

${ }^{745}$ Cf. Max Horkheimer, “”'Autoritärer Staat”, op. cit., p. 317 e também “Zur Soziologie der

Klassenverhältnisse", op. cit., p. 392.
} 
"A não-identidade de quase cada indivíduo consigo mesmo, sendo simultaneamente e sem pretender consistência - nazista e antinazista, convicto e cético, corajoso e covarde, estúpido e inteligente, é o único modo de comportamento que verdadeiramente faz jus a uma realidade que não é definida por planos desmentidos, mas sim pelo campo de concentração. Mostrar aos homens que eles próprios não são diferentes daqueles que foram arrebentados pelos campos é o método em meio à loucura" 746 .

${ }^{746}$ Max Horkheimer, "Vernunft und Selbsterhaltung", op. cit., p. 346. Essas ideias seriam desenvolvidas posteriormente, principalmente por Adorno, por exemplo, no ensaio sobre "Educação após Auschwitz", op. cit.. 


\section{Bibliografia}

$\underline{\text { Obras de Max Horkheimer e dos autores do Instituto de Pesquisa Social de Frankfurt }}^{747}$ :

ADORNO, Theodor W.; HORKHEIMER, Max. Dialética do Esclarecimento. Tradução de Guido A. de Almeida. Rio de Janeiro: Jorge Zahar Editor, 1985.

FROMM, Erich. Gesamtausgabe. Stuttgart: DVA (Deutsche Verlags-Anstalt), 1999.

HORKHEIMER, Max (ed.). Zeitschrift für Sozialforschung. volumes 1 a 9 (1932-1941). Munique: DTV (Deutscher Taschenbuch Verlag), 1980.

HORKHEIMER, Max (ed.). Studies in Philosophy and Social Sciences, vol. 8 de 1939/40 e vol. 9 de 1941. Munique: DTV, 1980 (trata-se dos dois últimos números da Revista de Pesquisa Social, publicados em inglês - o penúltimo, parcialmente, o último, totalmente).

HORKHEIMER, Max. "Teoria tradicional e teoria crítica". In: Walter Benjamin; Max Horkheimer; Theodor W. Adorno; Jürgen Habermas. Textos Escolhidos. Traduções de José Lino Grünewald et al. São Paulo: Abril Cultural, 1980 (Coleção Os Pensadores).

HORKHEIMER, Max. Gesammelte Schriften. Alfred Schmidt; Gunzelin Schmid Noerr (Orgs.). 19 volumes. Frankfurt am Main: Fischer, 1985-1996.

HORKHEIMER, Max. Teoria Crítica I - uma documentação. Tradução de Hilde Cohn. São Paulo: Perspectiva, 1990. pp. 175-236.

HORKHEIMER, Max. “A Presente Situação da Filosofia Social e as Tarefas de um Instituto de Pesquisas Sociais". Vários tradutores. Revista praga, n. 7. São Paulo: Hucitec, 1999, pp. 121-132.

HORKHEIMER, Max; FROMM, Erich; MARCUSE, Herbert et alii. Studien über Autorität und Familie - Forschungsberichte aus dem Institut für Sozialforschung. Lüneburg: Dietrich zu Kampen Verlag, 1987 (1936).

NEUMANN, Franz. Behemoth: The Structure and Practice of National Socialism, 1933-1944. Oxford: University Press, 1944.

\footnotetext{
747 Observação: às vezes, ao longo do mesmo capítulo, recorri ora à tradução disponível, ora ao texto original, dado ser frequente que um esclareça o outro. A fim de evitar uma leitura sobrecarregada de referências por vezes confusas, tentei reduzir ao máximo esse expediente, o que infelizmente nem sempre foi possível. Peço desculpas pelo inconveniente.
} 
Referências:

ABROMEIT, John. Max Horkheimer and the foundations of the Frankfurt School. Nova York: Cambridge University Press, 2011.

ADORNO, Theodor; DIRKS, Walter (Orgs.). Betriebsklima - eine industriesoziologische Untersuchung aus dem Ruhrgebiet. Coleção "Frankfurter Beiträge zur Soziologie”. Frankfurt am Main: Europäische Verlagsanstalt, 1955.

ADORNO, Theodor W. "Zum Verhältnis von Soziologie und Psychologie”. In: Soziologische Schriften I. Frankfurt am Main: Suhrkamp, 1997 [1955].

ADORNO, Theodor W. "Die revidierte Psychonalyse”. In: Max Horkheimer; Theodor Adorno. Sociologica II. Reden und Vorträge. 1962.

ADORNO, Theodor W.. "Reflexionen zur Klassentheorie". In: Theodor W. Adorno, Gesammelte Schriften, vol. 8. Rolf Tiedemann (Org.). Berlim: Suhrkamp, 1997.

ADORNO, Theodor W. Prismas - crítica cultural e sociedade. Tradução de Augustin Wernet e Jorge Mattos Brito de Almeida. São Paulo: Editora Ática, 1998.

ADORNO, Theodor W. "Educação após Auschwitz". In: Theodor W. Adorno, Educação e Emancipação. $3^{a}$ edição. Tradução de Wolfgang Leo Maar. São Paulo: Paz e Terra, 2003, pp. 119-138.

ANTUNES, Deborah Christina Antunes. Por um conhecimento sincero no mundo falso teoria crítica, pesquisa social empírica e The Authoritarian Personality. Jundiaí: Paco Editorial, 2014.

BENHABIB, Seyla; BONß, Wolfgang; McCOLE, John;. "Introduction - Max Horkheimer: Between Philosophy and Social Science". BENHABIB, Seyla; BONß, Wolfgang; McCOLE, John. On Max Horkheimer - new perspectives. Cambridge, Massachussets: The MIT Press, 1993.

BENHABIB, Seyla. “A crítica da razão instrumental”. In: Slavoj Zizek (Org.). Um Mapa da Ideologia. Tradução de Vera Ribeiro. Rio de Janeiro: Contraponto, 1996.

BENJAMIN, Walter. "Sobre o conceito de história”. In: Walter Benjamin, Obras escolhidas vol. 1: Magia e técnica; arte política - ensaios sobre literatura e história da cultura. Tradução de Sérgio Paulo Rouanet. São Paulo: Brasiliense, 1987. 
BONEFELD, Werner. Critical Theory and the Critique of Policital Economy - On Subversion and Negative Reason. Londres: Bloomsbury Academic, 2014

BONß, Wolfgang; SCHINDLER, Norbert. "Kritische Theorie als interdisziplinärer Materialismus“, in Wolfgang Bonß; Axel Honneth (Org.), Sozialforschung als Kritik - zum sozialwissenschaftlichen Potential der kritischen Theorie. Frankfurt am Main: Suhrkamp, 1982.

BONß, Wolfgang, "Psychoanalyse als Wissenschaft und Kritik. Zur Freudrezeption der Frankfurter Schule". In: Wolfgang Bonß; Axel Honneth (Orgs.). Sozialforschung als Kritik: zum sozialwissenschaftlichen Potential der kritischen Theorie. Frankfurt am Main: Suhrkamp, 1982

BRANDT, Gerhard. "Max Horkheimer und das Projekt einer materialistischen Gesellschaftstheorie". In: Alfred Schmidt; Norbert Altwicker (Orgs.). Max Horkheimer heute: Werk und Wirkung. Frankfurt am Main: Fischer, 1986.

BRAVERMAN, Harry. Trabalho e Capital Monopolista - a degradação do trabalho no século XX. Tradução de Nathanael C. Caixeiro. Rio de Janeiro: LTC, 1987.

BRUNKHORST, Hauke. "Dialektischer Positivismus des Glücks - Max Horkheimers materialistische Dekonstruktion der Philosophie". Zeitschrift für philosophische Forschung. Bd. 39, Heft 3, Jul-Sept 1985. Frankfurt am Main: Vittorio Klostermann.

CARNAP, Rudolf. "Überwindung der Metaphysik durch logische Analyse der Sprache”. In: Erkenntnis. Holanda: Springer, vol. 2, 1931-32, pp. 219-241.

CHAUÍ, Marilena. “Apresentação”, In: CHAUÍ, Marilena; CARVALHO FRANCO, Maria Sylvia. Ideologia e mobilização popular. Rio de Janeiro: Paz e Terra; CEDEC, 1978, pp. 9-16. CHIARELLO, Maurício Garcia. Das lágrimas das coisas - estudo sobre o conceito de natureza em Max Horkheimer. Campinas: Editora da Unicamp, 2001.

COHEN, Yves., "Por que chamar o século XX de o ' século dos chefes' ?”. Sociologia e antropologia, vol. 5, número 3. Rio de Janeiro, set-dez. de 2015.

CROCHIK, José Leon. Preconceito, Indivíduo e Cultura. São Paulo: Casa do Psicólogo, 2006. DAMBÖCK, Christian. "Nachwort”. In: Christian Damböck (Org.). Der Wiener Kreis Ausgewählte Texte. Stuttgart: Reclam, 2013. 
DEMIROVIĆ, Alex. Der nonkonformistische Intellektuelle - die Entwicklung der kritischen Theorie zur Frankfurter Schule. Frankfurt am Main: Suhrkamp, 1999.

DEMIROVIĆ, Alex. "Rekrutierung von Intellektuellen im Fordismus. Vergleichende Anmerkungen zu Horkheimers und Adornos Analyse der Kulturindustrie und Gramscis Analyse der Zivilgesellschaft”. In: Oliver Brüchert; Christine Resch (Orgs.). Zwischen Herrschaft und Befreiung - kulturelle, politische und wissenschaftliche Strategien. Münster: Westfälisches Dampfboot, 2002.

DUBIEL, Helmut. Wissenschaftsorganisation und politische Erfahrung - Studien zur frühen Kritischen Theorie. Frankfurt am Main: Suhrkamp, 1978.

ELBE, Ingo. Marx im Westen - die neue Marx-Lektüre in der Bundesrepublik seit 1965. $2^{\mathrm{a}}$ edição. Berlim: Akademie Verlag, 2010.

ELBE, Ingo. "Zwischen Marx, Marxismus und Marxismen - Lesarten der kritischen Theorie". Disponível em www.rote-ruhr-uni.com. Último acesso em 11 de agosto de 2017.

ENGELS, Friedrich. "Karl Marx, 'Zur Kritik der Politischen Ökonomie' ” [resenha da "Contribuição à crítica da Economia Política" de 1859]. In: Karl Marx; Friedrich Engels. Werke. vol. 13. Berlim: Dietz, 1971. pp. 468-477.

ENGELS, Friedrich. Anti-Dühring. Tradução: Grupo Acrópolis. Disponível em: www.marxists.org

FAUSTO, Ruy. Marx: Lógica e Política - Investigações para uma reconstituição do sentido da dialética. Tomo III. 1ª edição. São Paulo: Editora 34, 2002.

FREYBERG, Thomas von. Industrielle Rationalisierung in der Weimarer Republik untersucht an Beispielen aus dem Maschinenbau und der Elektroindustrie. Frankfurt am Main: Campus Verlag, 1989.

FREUD, Sigmund. "Charakter und Analerotik". In: Sigmund Freud, Gesammelte Werke - vol. VII. Frankfurt am Main: Fischer, 1987.

FREUD, Sigmund. "Massenpsychologie und Ich-Analyse”. In: Sigmund Freud, Gesammelte Werke. Vol. XIII. Fischer: Frankfurt am Main, 1987.

FREUD, Sigmund. "O Recalque”. In: Sigmund Freud, Escritos sobre a Psicologia do Inconsciente. Vol. 1. Coordenação da tradução: Luiz Alberto Hanns. Rio de Janeiro: Imago, 2004.

FREUD, Sigmund. O Mal Estar na Cultura. Tradução de Renato Zwick. Porto Alegre: L\&PM Pocket, 2010. 
FREUD, Sigmund. O Futuro de uma Ilusão. Tradução de Renato Zwick. Porto Alegre: L\&PM, 2010.

FRIEDEBURG, Ludwig von. "Begrüßung im Namen des Instituts für Sozialforschung”. In: Alfred Schmidt; Norbert Altwicker. Max Horkheimer heute: Werk und Wirkung. Frankfurt am Main: Fischer, 1986.

FROMM, Erich. Análise do Homem. 9a edição. Tradução de Octavio Alves Velho. Rio de Janeiro: Zahar Editores, 1974.

GENEL, Katia. Autorité et emancipation: Horkheimer et la théorie critique. Paris: Payot, 2013. GABRIEL, GOTTFRIED. “Carnap und Heidegger”. In: Deutsche Zeitschrift für Philosophie, vol. 48. Berlim, De Gruyter, 2000, pp. 487-497.

GRAMSCI, Antonio. Americanismo e Fordismo. Tradução de Gabriel Bogossian. São Paulo: Hedra, 2008 [1928-1935].

GREVEN, Michael. Kritische Theorie und historische Politik. Theoriegeschichtliche Beiträge zur gegenwärtigen Gesellschaft. Opladen: Leske e Budrich, 1994.

GÖRLICH, Bernard. Individuum und Gesellschaft - zum Versuch der Synthese von Freud und Marx im Frommschen Gesamtwerk. Tese de doutorado. Universidade de Frankfurt, 1979.

HABERMAS, Jürgen. "Nachwort”. In: Max Horkheimer; Theodor W. Adorno, Dialektik der Aufklärung - Philosophische Fragmente. Frankfurt am Main: Fischer, 1986.

HABERMAS, Jürgen. “Max Horkheimer - Die Frankfurter Schule in New York”. In: Derselbe. Philosophisch-politische Profile. Frankfurt am Main: Suhrkamp, 1991.

HABERMAS, Jürgen. "Remarks on the Development of Horkheimer's Work". In: Seyla Benhabib; Wolfgang Bonß; John McCole. On Max Horkheimer - new perspectives. Cambridge, Massachussets und London, 1993.

HABERMAS, Jürgen. O Discurso Filosófico da Modernidade. Tradução de Luiz Sérgio Repa e Rodnei Nascimento. São Paulo: Martins Fontes, 2000.

HABERMAS, Jürgen. Teoria do Agir Comunicativo - vol. 2: sobre a crítica da razão funcionalista. Tradução de Paulo Astor Soethe. São Paulo: WMF Martins Fontes, 2012.

HACHTMANN, Rüdiger; SALDERN, Adelheid von, “' 'Gesellschaft am Fliessband' Fordistische Produktion und Herrschaftspraxis in Deutschland" [A sociedade na linha de montagem - produção fordista e práticas de dominação na Alemanha]. Zeithistorische Forschungen/Studies in Contemporary History, edição online, vol. 6 (2009), caderno 2. Disponível em:

URL: http://www.zeithistorische-forschungen.de/2-2009/id=4509. 
HEIDEGGER, Martin. “O que é metafísica?”. In: Martin Heidegger, Marcas do caminho. Tradução de Enio Paulo Giachini e Ernildo Stein. Petrópolis: Vozes, 2008, pp. 113-133.

HIRSCH, Joachim. em "Staatskapitalismus? Zur Kontroverse zwischen Friedrich Pollock, Max Horkheimer und Franz Neumann in Bezug auf den Charakter des nationalsozialistischen Systems”. In: Ulrich Ruschig; Hans-Ernst Schiller (Orgs.) Staat und Politik bei Adorno und Horkheimer. Baden-Baden: Nomos, 2014.

HOBSBAWM, Eric J. "Costumes, Salários e Carga do Trabalho na Indústria do Século Dezenove". In: Eric J. Hobsbawm, Os Trabalhadores - Estudos sobre a História do Operariado. Tradução de Maria Leão Teixeira Viriato de Medeiros. Rio de Janeiro, São Paulo: Paz e Terra, 1981.

HONNETH, Axel. Kritik der Macht - Reflexionsstufen einer kritischen Gesellschaftstheorie. Frankfurt am Main: Suhrkamp, 1985.

HONNETH, Axel. “Teoria Crítica”. In: Anthony Giddens; Jonathan Turner (Orgs.). Teoria Social Hoje. Tradução de Gilson César Cardoso de Sousa. São Paulo: Unesp 1996.

HORKHEIMER, Max. "Prólogo” a Martin Jay, A Imaginação Dialética. - História da Escola de Frankfurt e do Instituto de Pesquisas Sociais. 1923-1950. Tradução de Vera Ribeiro. Rio de Janeiro: Contraponto, 2008.

JAY, Martin. A Imaginação Dialética - História da Escola de Frankfurt e do Instituto de Pesquisas Sociais. 1923-1950. Tradução de Vera Ribeiro. Rio de Janeiro: Contraponto, 2008. JAY, Martin. Dialectical Imagination - a History of the Frankfurt School and the Institue of Social research. Londres: Heinemann, 1973.

KLEIN, Stefan Fornos. A universidade e a sociologia sergundo Max Horkheimer: teoria, pesquisa e crítica. Tese de doutorado. FFLCH-USP. São Paulo, 2012.

KORTHALS, Michiel. "Die kritische Gesellschaftstheorie des frühen Horkheimer Missverständnisse über das Verhältnis von Horkheimer, Lukács und dem Positivismus". Zeischrift für Soziologie, ano 14, número 4, agosto de 1985, pp. 315-329.

LENINE, Vladimir I.. O Imperialismo, Fase Superior do Capitalismo. $3^{\text {a }}$ edição. Tomo 1. São Paulo: Editora Alfa-Ômega, 1980.

LENK, Kurt. "Ideologie und Ideologiekritik im Werk Max Horkheimers". In: Alfred Schmidt; Norbert Altwickler (Orgs.). Max Horkheimer heute: Werk und Wirkung. Frankfurt am Main: Fischer, 1986, pp. 244-258.

LEOPOLDO E SILVA, Franklin. "Martin Heidegger e a técnica”. Scientiae Studia. São Paulo, vol. 5, número 3, 2007, pp. 369-374. 
LINDEMANN, Kai. "Der Racketbegriff als Herrschaftskritilk”. In: Ulrich Ruschig; Hans-Ernst Schiller (Orgs.) Staat und Politik bei Adorno und Horkheimer. Baden-Baden: Nomos, 2014. LYND, Robert S.; LYND, Helen M.. Middletown - a Study in Modern American Culture. Nova York: Harvest, HBJ, 1959 [1929].

LÖWY, Michel. As Aventuras de Karl Marx contra o Barão de Münchhausen: marxismo e positivismo na sociologia do conhecimento. 9a edição. São Paulo: Cortez, 2009.

LUKÁCS, Georg. História e Consciência de Classe - estudos sobre a dialética marxista. Tradução de Rodnei do Nascimento. São Paulo: Martins Fontes, 2003.

MARCUSE, Herbert. Eros e Civilização - uma interpretação filosófica do pensamento de Freud. Tradução de Álvaro Cabral. $8^{\text {a }}$ edição. Rio de Janeiro: LTC, 2009 [1955].

MASON, Tim. “The Workers' Opposition in Nazi Germany”. History Workshop Journal, vol. 11, 1981, pp. 120-137. Disponível em libcom.org.

MATOS, Olgária Chain Feres. "Introdução". In: Max Horkheimer, Teoria Crítica I - uma documentação. Tradução de Hilde Cohn. São Paulo: Perspectiva, 1990.

MATOS, Olgária Chain Feres. Os arcanos do inteiramente outro: a Escola de Frankfurt, a melancolia e a revolução. $2^{\mathrm{a}}$ edição. São Paulo: Brasiliense, 1995.

MARX, Karl. Manuscritos Econômico-Filosóficos. Tradução, apresentação e notas de Jesus Ranieri. São Paulo: Boitempo, 2004 [1844].

MARX, Karl; ENGELS, Friedrich. A Ideologia Alemã. Tradução: Luiz Claudio de Castro e Costa. São Paulo: Martins Fontes, 2001 [1845/46].

MARX, Karl. O Capital - Crítica da Economia Política. Vol. 1 - O Processo de Produção do Capital. Tradução de Regis Barbosa e Flávio Kothe. Coleção “Os Economistas”. São Paulo: Abril Cultural, 1983 [1867].

McCARTHY, Thomas. "The Idea of a Critical Theory and Its Relation to Philosophy". In: Seyla Benhabib; Wolfgang Bonß; John McCole. On Max Horkheimer - new perspectives. Cambridge, Massachussets, Londres: MIT Press, 1993.

MESZÁROS, István. Para Além do Capital: rumo a uma teoria da transição. Tradução de Paulo Cesar Castanheira e Sérgio Lessa. São Paulo: Boitempo Editorial, 2002.

MUSSE, Ricardo. O duplo giro copernicano - Adorno e Kant. Dissertação de mestrado. UFGRS. Porto Alegre, 1991.

MUSSE, Ricardo. Do Socialismo Científico à Teoria Crítica - modificações na autocompreensão do marxismo entre 1878 e 1937. Tese de doutorado. FFLCH-USP. São Paulo, 1997. 
MUSSE, Ricardo. “A dialética como discurso do método". Tempo Social. São Paulo, vol. 17, número 1, junho de 2005.

NEURATH, Otto; HAHN, Hans; CARNAP, Rudolf. Wissenschaftliche Weltauffassung - der Wiener Kreis. Moritz Schlick gewidmet. Viena: Artur Wolf Verlag, 1929.

NOBRE, Marcos. "Max Horkheimer: a teoria crítica entre o nazismo e o capitalismo tardio". In: Marcos Nobre (Org.). Curso Livre de Teoria Crítica. Campinas: Papirus, 2008.

NOERR, Gunzelin Schmied. "Nachwort des Herausgebers". In: Max Horkheimer, Gesammelte Schriften. Alfred Schmidt; Gunzelin Schmid Noerr (Orgs.). Vol. 11: Nachgelassene Schriften 1914-1931. Frankfurt am Main: Fischer, 1987.

NUNES, Benedito. Heidegger \& Ser e Tempo. Rio de Janeiro: Jorge Zahar Editor, 2004.

O’NEILL, John; UEBLE, Thomas. "Horkheimer and Neurath: Restarting a Disrupted debate". European Journal of Philosophy, vol. 12, n. 1. Oxford: Blackwell, 2004. pp. 75-105.

PAULANI, Leda Maria. "Acumulação e rentismo: resgatando a teoria da renda de Marx para pensar o capitalismo contemporâneo". Revista de Economia Política. São Paulo, vol. 36, número 3, (144), pp. 514-535, jul-set de 2016.

PEDROSO, Gustavo. "Entre o capitalismo de Estado e o Behemoth: o Instituto de Pesquisa Social e o fenômeno do fascismo". São Paulo, Cadernos de ética e filosofia política, vol. 15, n. 2, 2009, pp. 151-179.

POSTONE, Moishe. Time, work and social domination: a reinterpretation of Marx' critical theory. Londres: Cambridge University Press, 1993.

PUZONE, Vladimir Ferrari. Capitalismo perene: reflexões sobre a estabilização do capitalismo a partir de Lukács e da teoria crítica. Tese de doutorado. FFLCH-USP. São Paulo, 2014.

PUZONE, Vladimir. "Filosofia da história ou reprodução da vida dos indivíduos? A crítica de Max Horkheimer a Georg Lukács e a reformulação do marxismo”. Rio de Janeiro, Sociologia e antropologia. Vol. 7, número 1, abril de 2017, pp. 239-265.

REGATIERI, Ricardo Pagliuso. Do capitalismo monopolista ao processo civilizatório - a crítica da dominação nos debates no instituto de Pesquisa Social na década de 1940 e na elaboração da Dialética do Esclarecimento. Tese de doutorado. FFLCH-USP. São Paulo, 2015. REICH, Wilhelm. Psicologia de Massas do Fascismo. $2^{\mathrm{a}}$ edição. Tradução de Maria da Graça Macedo. São Paulo: Martins Fontes, 1988.

RITSERT, Jürgen. Dialektische Argumentationsfiguren in Philosophie und Soziologie - Hegels Logik und die Sozialwissenschaften. Münster: MV-Verlag, 2008.

RITSERT, Jürgen. Materialien zur kritischen Theorie der Gesellschaft - Dialektik, caderno 8. Frankfurt am Main: Goethe Universität/Karl-Marx-Buchhandlung, 2011. 
RODRIGUEZ, José Rodrigo. "Franz Neumann, o direito e a teoria crítica". Lua Nova. São Paulo, n. 61, 2004, pp. 53-73.

ROUANET, Sérgio Paulo. Teoria Crítica e Psicanálise. Rio de Janeiro: Tempo Brasileiro, 1983.

RUGITSKY, Fernando. "Friedrich Pollock - Limites e Possibilidades". In: Marcos Nobre (Org.). Curso Livre de Teoria Crítica. Campinas: Papirus, 2008.

RUSCHIG, Ulrich. "Weiterdenken in marxistischer Tradition: die Lehre vom autoritären Staat". Ulrich Ruschig; Hans-Ernst Schiller (Orgs.) Staat und Politik bei Adorno und Horkheimer. Baden-Baden: Nomos, 2014.

SCHMIDT, Alfred. “Zum Erkenntnisbegriff der Kritik der politischen Ökonomie”. In: Walter Euchner; Alfred Schmidt (Orgs.). Kritik der politischen Ökonomie heute - 100 Jahre Kapital. Europäische Verlagsanstalt, 1968. pp. 30-57.

SCHMIDT, Alfred. “Die 'Zeitschrift für Sozialforschung' - Geschichte und Gegenwärtige Bedeutung”. In: Max Horkheimer (ed.) Zeitschrift für Sozialforschung. Munique: DTV, 1980, vol. 1, pp. 5-63.

SCHMIDT, Alfred. “Aufklärung und Mythos im Werk Max Horkheimers”. In: Alfred Schmidt; Norbert Altwicker (Orgs.). Max Horkheimer heute: Werk und Wirkung. Frankfurt am Main: Fischer, 1986.

SCHMIDT, Alfred. "Nachwort des Herausgebers - Horkheimer als Historiker des deutschen Idealismus und der philosophischen Renaissance der zwanziger Jahre". In: Gesammelte Schriften. Alfred Schmidt; Gunzelin Schmid Noerr (Orgs.). Vol. 10. Frankfurt am Main: Fischer, 1990.

SCHMIDT, Alfred. “Max Horkheimer's Intelllectual Physiognomy”. In Seyla Benhabib; Wolfgang Bonß; John McCole. On Max Horkheimer - new perspectives. Cambridge, Massachussets, Londres: 1993.

SCHNÄDELBACH, Herbert. "Max Horkheimer und die Moralphilosophie des deutschen Idealismus". In: Alfred Schmidt; Norbert Altwickler (Orgs.). Max Horkheimer heute: Werk und Wirkung. Frankfurt am Main: Fischer, 1986.

SILVA, Rafael Codeiro. Max Horkheimer: teoria crítica e barbárie. Uberlândia: EDUFU, 2011.

SÖLLNER, Alfons. Geschichte und Herrschaft - Studien zur materialistischen Sozialwissenschaft. 1929-1942. Frankfurt am Main: Suhrkamp, 1979. 
TAYLOR, Frederick Winston. Princípios da Administração Científica. Tradução de Arlindo Vieira Ramos. São Paulo: Atlas, 1982.

TEDEIA, Gilberto. Materialismo em Horkheimer nos anos 30. Dissertação de mestrado. FFLCH-USP. São Paulo, 2001.

WEBER, Max. A Ética Protestante e o "Espírito" do Capitalismo. Edição de Antônio Flávio Pierucci. Tradução de José Marcos Mariani de Macedo. São Paulo: Companhia das Letras, 2004.

WIGGERSHAUS, Rolf. A Escola de Frankfurt - história, desenvolvimento teórico, significação política. Tradução de Lilyane Deroche-Gurcel e Vera de Azambuja Harvey. São Paulo: Difel, 2006. 